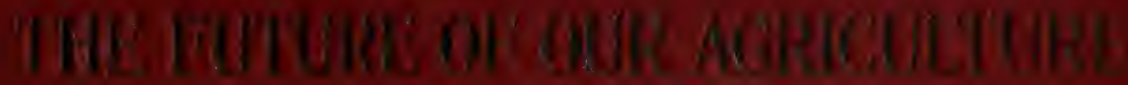

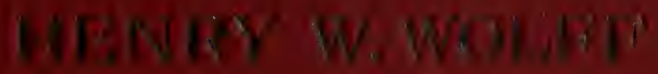



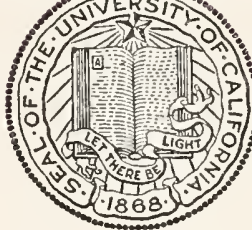

THE LIBRARY

$\mathrm{OF}$

THE UNIVERSITY

OF CALIFORNIA

LOS ANGELES 
Digitized by the Internet Archive in 2008 with funding from Microsoft Corporation 



\title{
THE FUTURE OF OUR AGRICULTURE
}

BY

HENRY W. WOLFF

Author of "Co-Operation in Agriculture"

Honorary Adviser to the Irish Agricultural Organization Society, one of the Founders of the British Agricultural Organizatton Society, 1899, and of the Agricultural Organization Society, 1900

\author{
LONDON \\ P. S. KING \& SON, LTD. \\ ORCHARD HOUSE, WESTMINSTER
}

1918 



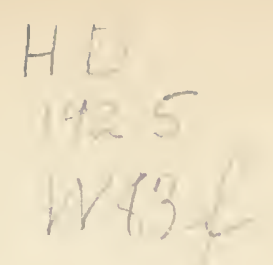

\section{PREFACE}

$\&$ DURING the sixty-one years which have passed w since the author first became practically interested in Agriculture as a farm pupil, great changes have taken place in the craft to which Aristotle in his - day assigned the premier rank among callings.

In spite of the rare skill and remarkable command of resource exhibited by our leading farmers, recent inquiries prompted by war troubles have made it clear that British Agriculture has lost something of that "pride of place" which it held at the beginning of the period spoken of, when it was * recognized as the teacher in Agriculture of all nations. Apart from peculiar features in our land system, $\rightarrow$ which appear opposed to progress, the main reason 㟒 of this is seen to be that the bulk of our farming community have failed to follow the good lead given.

However there has also been some progress among our whilom pupils which has made them eclipse their erewhile masters on some not unimportant points. Just as in matters of constitutional government some of our daughter nations, accepting the principles of the British Constitution, have in 울 their freer atmosphere learnt to graft improved new practices upon the old stock, which we now gladly 
accept as being better suited to altered circumstances, so Agriculturists beyond the seas, emulating our own, have devised new and improved methods, from which we may learn.

It has been the author's lot to see a good deal of such modern methods, which are more particularly interesting in that part of the subject which applies to that important social and economic problem interlaced with the agricultural, namely, that of settling more people on the land and so increasing agricultural production, while providing a larger supply of labour, and creating ampler contentment, happiness and prosperity.

The subject matter having been systematically divided under distinct heads, some recurrence to the same practices under different aspects has proved inevitable.

January, I9ז8.

H. W. W. 


\section{CONTENTS}

CHAP.

I'AGE

I ShortComings of OUR Agriculturl . . . I

II Remiedies Suggested . . . . . 49

III EdUCATION . . . . . . . 97

IV ORGANISATION . . . . . . . . I58

V WORKING CREdit FOR FARHERS . . . . 2 I7

VI LABOUR . . . . . . . . . 274

VII SMall Holdings . . . . . 313

VIII A Full Reward for the Tiller . . . 364

IX Reclamation of Waste Land . . . . 409

X CONClusion . . . . . . . . 456

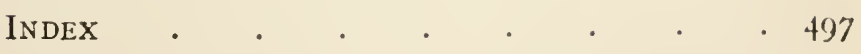





\title{
The Future of our Agriculture
}

\author{
CHAPTER I \\ Shortcomings of our Agriculture
}

THE demand for "Agricultural Reform" is at present on nearly every one's lips. And at all points of the country are minds concentrating their attention upon the question: "In what way may the position of our Agriculture be effectively improved ?" The war has found out our "heel of Achilles," at which even the well-equipped warrior is vulnerable. It has meant a rude awakening for us. For, just as the Germans did with their "Hindenburg Line," we in our self-complacency cherished the fond belief, nurtured by long-continued peace at sea, that our position with regard to the supply of food was impregnable. A disappointing morning came to our dream. Germany had challenged us at arms. And we responded, so to put it, by challenging her "at food." But-lo and behold! Germany retaliated in kind and caused us at any rate some severely troubled three or four years. In our sense of security we had reckoned without the submarines.

It is only characteristic of human nature that, so disillusioned, we should have at once jumped overreadily to the opposite extreme, forgetting in our anxiety-after a hopeful rejoicing over "a century of peace" with our most powerful sister nation, heralding, as we are still bound to hope, a coming reign of world peace-that the world war was, after all, only a passing episode, one of- 
" those momentary starts from Nature's laws, Which, like the pestilence and earthquake, smite But for a time, then pass, and leave the earth With all her seasons to repair the blight In a few summers,"

and that the very motive for our own and America's interfering was, to ensure that there should be no " next time" and to secure peace and freedom at sea as an abiding blessing for the world.

The French have a proverb which says, La paix se conserve enfin par la guerre, that is, there are cases in which peace is best secured by war. Evidently the present is such a case. The hour is trying. But its length is irrevocably measured, and beyond it lies, so we must hope, an era of " peace and concord among nations," in which the submarine will cease from troubling and our commerce at sea will once more be at rest.

But, however uncalled for may be a dread of the future with its submarine nightmare, the discovery that our Agriculture is below par-much below that point-and, as we have recently ascertained, quite unequal to the requirements of the Nation, is no less disconcerting. Providence has meted out to us our cultivable land with a sparing hand. Of that land, war or no war, we ought in reason, and in duty to the Giver of it, to make the most, putting it to the best possible use, seeing what our teeming population is in proportion to our narrow territory. Should it come to war again and should others once more set up for us a Chinese Wall, we shall have to produce what food we possibly can, so as to preserve our population from starving. While war is in abeyance, while the temple of Janus remains closed, we shall be failing in our duty, not only if we do not produce upon our soil what value we can, for the sake of national prosperity and-besides making proper provision for any fresh emergency - to keep our own money at home, but also if we fail to use our land for the purpose of giving healthy productive employment to a maximum number of persons, and provide a maximum number of persons with appropriate rural homes and rural happiness. 
On this point the inquiries which the war has prompted have shown us to be miserably unprepared. Indeed, the discovery is of much older date than the war and than the institution of Departmental inquiries begun in I9I5. Really the evil has stared us in the face for many years back. All the world knew that our Agriculture had long passed its zenith and was struggling through trying times. Ever since the close of what Mr. Prothero has styled "the golden age of English Farming" the realm of Ceres had been troubled. Some of us still remember the dire scourge of rinderpest, carrying ruin for thousands in its train. That being done with, a period of agricultural unrest set in, in all grades of the calling. Tenant right claimed its own. There were spirited debates between spokesmen of the landlords and of the farmers, the echoes of which still ring in aged ears. Landlords' supremacy was held to signify tenants' wrong. There was then no compensation for improvements. Game had a free run across farmers' fields. The rabbit pest was rampant and accounts of its depredations filled columns of our agricultural and provincial papers with tales of woe. Time after time were legislative remedies asked for and denied, till the tenants mustered in the ranks of their "Alliance" and, like the French revolutionaries, "forming their battalions," extorted redress. The result was a series of Agricultural Holdings Acts (which do not even yet set all things right) the first of which was that passed by Mr. Disraeli in I875. By that time labourers had likewise risen in not unprovoked revolt and, once united-for too brief a time to serve their own purpose-they succeeded in obtaining at any rate some measure of improvement of their condition. Shortly after, the first period of Agricultural Depression set ina severe visitation, only too soon to be followed by a second, as ruinous. Every one who chose to open his eyes could see then that British Agriculture was losing ground. Millions of acres passed out of arable cultivation, the national wheat crop shrank; the profits from newly laid down grass did not approximately make up for the loss; labour deserted and became scarce. Marning voices were lieard, 
but were disregarded-at the very time, as it happened, when, unobserved by ourselves, speaking collectively, the country which was destined to become our deadliest enemy, fighting us in the food war as well as with military weapons, was rapidly mending its pace, systematically and remarkably improving its husbandry, in order to overtop us. Some years ago a loud warning note was sounded, unfortunately in a decidedly sensational way, such as never produces the desired effect, recalling rather a novelist's vision than an agricultural expert's sober judgment. Agriculture was reported to be "going to the dogs." The picture drawn was, of course, true up to a point; but it was overdrawn and contained not a few exaggerations. And the overdrawing defeated its effect. We had had a similar Cassandra's call only a few years before, with regard to our Trade' and Commerce-a call easily refuted by reference to facts. What were we to think of the progressing ruin of Agriculture, when so undoubtedly eminent an authority as Mr. A. D. Hall wrote, in I9I3, in his " Pilgrimage of British Farming " about the "pre-eminence" which " our farming still enjoys" and of our getting " more out of the land and getting better crops and stock than by any other existing system" ? The dismal tale of failure was, however, taken up abroad as gospel, sympathetically or else gloatingly, as the case might be. A distinguished Italian statesman, who had in the Nuova Antologia re-echoed Mr. Chamberlain's doleful cry about ruined British trade and commerce, and described our country as living, like a hibernating bear, upon its own accumulated fat, took up a similar parable again in the same Review, about our ruined Agriculture, which he represented as bankrupt. And when in the German Parliament, a well-meaning, hapless deputy, Herr Gothein, referred commendingly to some feature of British farming, which he held up as a model, the Chamber resounded with the derisive cry, "British Agriculture is bankrupt" (Die ist ja pleite) from the Conservative benches. Unfortunately that delusion helped not a little to strengthen the German Government in its warlike determination, in the belief that there was 
really a good prospect of the submarines starving us, so that that sensational cry was proved to have done harm, rather than good. "Il ne faut jamais défier un fou de mal faire."

But even without such excessive apprehensiveness we were warned since a very long time. We are beholden to the proprietors of the Times newspaper for most illuminating and instructive reports on inquiries of a less sensational but far more useful character, conducted periodically by agriculturists of the first rank, commissioned to take stock of the condition of our Agriculture, such as Sir James Caird (whom not a few of us remember in St. James's Square) nearly sixty years ago, and Mr. A. D. Hall only a few summers back. Mr. A. D. Hall's letters tell their own tale-of brilliant light, coupled with creditable variety, and disclosing much masterly skill and command of resource, but also of very, very dark shade, which shade unfortunately greatly predominates. However, practically precisely the same tale was told under both aspects-suited to the period, in I850-5I, by Sir James Caird-down to the really shaming particular of splendid light prevailing "on one side of the hedge," with the darkest of "shades, to set it off, oppressing the view, "on the other," only a few inches off-on the same soil in the same climate, probably under the same landlord, and conceivably under the same terms as to rent. The little light, however brilliant in brightness, unfortunately will not redeem the darkness of the shade. Taking it as a whole, our Agriculture is not at present a matter really to be proud of.

"It was manifest from the evidence laid before us," so reports the Departmental Food Committee presided over by Lord Milner, and composed, among others, of such unquestionably highly competent and experienced men as the present President of the Board of Agriculture and Fisheries, Mr. R. E. Prothero, and Mr. E. Strutt and Mr. A. D. Hall, " that, speaking generally, the land of England is being kept at a comparatively low level of cultivation and that it might be made to produce a greater amount of " "A Pilgrimage of British Farming," p. 432. 
food without the withdrawal of labour from more profitable industries." Average yields are low-considerably lower than those of Belgium, Denmark, and Germany. The very same acreage might very well produce twice or three times the present quantity, very likely more. Cultivation is backward. There is much land out of heart. And wide stretches which ought to bear corn for food are left for the most part under unprofitable pasture-3,700,000 acres having been added to the extent of grassland, in sheer penny wisdom, to keep down the labour bill, within the past forty years. The picture is one to shame our agriculturists of the present day, whatever section of their own particular calling they may belong to, whether landlords or farmers. They hold the valuable national possession of our cultivable land in keeping-unquestionably, as we now discernthough up to now we would not realise it-as something of " a trust," on behalf of the Nation. The war has taught us that it is a trust. And how have they administered it ? Previously the burden of every pronouncement on land and agriculture was " property, property, property." So the planters of the Southern States had argued when they were reproached for illtreating their negro slaves, whom they regarded as simply " property." Our landlords made the same mistake with regard to their land. A time has come when that contention will no longer pass. Everything else has been placed at our disposal without limit or measure. We can multiply manufactured goods and money value at pleasure. Our land alone is narrowly restricted, and the limit obviously imposes a duty, which the clamours and complaints of the poorer classes, threatened with famine, or something very closely approaching to it, has at length during the war made us to realise. The Nation's land is not " property" in the sense of money or chattels.

Our discovery of our backwardness, or retrogression, has been made much more striking than it otherwise would have been by the foil of German achievements, in juxtaposition to which it is placed and which is glaringly set off by it, possibly beyond its actual desert. While we 
have been lazily resting upon our oars-it is Mr. Hall who has called pasture farming "lazy farming"-Ciermany by our side has been pulling vigorously ahead. "If Agriculture," so stated Lord Selborne, when still at the head of the Board of Agriculture, in July, Igr6, while addressing a gathering of farmers in Lincoln, " had made no more progress in Germany than it has in the United Kingdom, during the period I895 to I9I5, the German Empire would have been at the end of its food resources long before the end of the second year of the war," adding that the war was, as a matter of fact, " being fought just as much on an agricultural as on a military organisation of the Nation." The statement is probably correct, and Lord Selborne was right in laying particular stress upon the word "Organisation."

Very opportunely then has the Board of Agriculturestill acting under Lord Selborne's judicious and timely instructions, published a masterly memorandum, written by Mr. T. H. Middleton, on the condition of Agriculture in the country of our great enemy rival, Germany, with whose position in the matter we are naturally led to compare our own. Mr. Middleton's inquiry has revealed some highly disconcerting facts. On every point, except one, in the comparison of average yields of crops per acre, do we come out below the German figure. The main result is perhaps best summed up in the statement, made upon the ground of official statistics, that Germany manages to feed from seventy to seventy-five persons per roo acres of cultivated land, as contrasted with our only forty-five to fifty, notwithstanding the fact that the German cultivated area includes wide sweeps-about two-fifths of the whole area-of soil of unquestionable inferior quality-sand of the diluvium, descending from the point of still fair productiveness to that of almost absolute barrenness-even below that of the Belgian "Campine," which Lavelege styled "the worst in Europe" - which, with an allusion to the antiquated custom, still adhered to in many a German rovernment office, of using sand in the place of blotting paper for absorbing ink, passes popularly by the name of 
"His Majesty's sandbox." There is also less moisture in the German atmosphere, less recuperative power such as our own climate has shown in I9I7, and there is a considerably longer winter.

Here is the comparison: On an average, an acre of wheat yields us $3 \mathrm{I} \cdot 2$ bushels, Germany $3 \mathrm{I} \cdot 6$ bushels; an acre of barley respectively 32.7 and 36.7 bushels; an acre of oats 39 and 44.6 bushels; an acre of potatoes (that is our one good point) 6.2 and 5.4 bushels; an acre of meadow hay $25 . \mathrm{I}$ and 33.7 tons. The figures for milk are even more against us per Ioo acres, namely I7.I tons to ourselves and $28 \cdot I$ tons to Germany.

The figures quoted by Mr. Middleton are of course in themselves incontestable, being taken from official returns. In view of the large proportion of inferior land, and a good deal of bad farming still surviving-as witness the late German Chancellor's, Herr Michaelis, complaint about the unsatisfactory condition of German Agriculture-they represent even greater achievements than would appear at first glance for the land that is well tilled. However, they claim a few words of comment and explanation calculated to give us heart of grace.

To begin with, Germany is a country sacred in respect of Agriculture to the use of the plough and the harrow, whereas Great Britain has become a land mainly of pasture. Now tillage yields incomparably more produce per acre than does pasture, whatever agricultural lights of past ages may have said in defence of the latter, "which saves you the expense of carting off your produce to market, making it walk there instead on its own legs." We have $40 \cdot 35$ per cent. of our land under pasture, to the German $3 \cdot 23$ per cent. That alone accounts for a great deal. Next, as for cereals, Germany has 45.97 per cent. sown with them; we have only I9.50 per cent. And the contrast becomes particularly glaring when we come to the useful and highly remunerative crop of potatoes, which Germany rightly favours, and which we very wrongly neglect. There the German figure is 10.44 per cent., and ours only I.59 per cent. No wonder Germany outlasts a war famine better than 
we had expected. With regard to meadow hay Mr. Middleton has necessarily had to compare a poor quinquennium on our side with an exceptionally favourable one in Germany. Also, it should be borne in mind that the German figure includes the aftermath-in some rare cases even also a third cut-as against our generally only one cut, after which stock is as a rule turned out on the grass. Wheat, once more, is in Germany a crop reserved only for very good soil, which is invariably manured. The popular breadcorn crop in Germany is rye, which, under proper cultivation, has proved anything but the " miser, grudging rent and tithe," for which it is given out in the well-known song of "John Barleycorn." Mr. Middleton does not give the figure for rye. That cereal is so much cultivated in Germany, not only because in Germany inferior soil preponderates-soil which will not bear wheat-but also because it is reckoned the safer crop, among other things in view of the severe winter-which kills our English breeds of wheat -and as admitting, in Germany, of later sowing, up to Christmas (Christkindelkorn), which is a liberty that you could not there take with wheat. Spring wheat is but little cultivated. A further point in favour of rye in German eyes is the superiority of its straw and its bran. Therefore in comparing wheat crop with wheat crop we pit our omnium gatherum against the German élite.

After all that has been said and written in this country about rye as an inferior breadcorn, to which Germans have replied with the assurance that they prefer ryebreadwhich is not quite strictly correct; for the preference is to a great extent utilitarian-it may be worth mentioning that rye is in Germany much valued as breadcorn on account of its keeping quality, which, however, is in great part attributable to its being, as a common practice, baked with leaven instead of with yeast. I have never heard of wheaten bread baked with leaven. Probably that would make it, likewise, keep better. Rye bread, baked with yeast, is more palatable than that baked with leaven; but it soon gets dry and stale. Of course, rye is in ordinary times cheaper than wheat (the proportion used to be as 
2 to 3), especially since in Germany land of any description will bear rye, and only the best will bear wheat. "Weizenboden" admittedly ranks first among classified soils, also above "Gerstenboden." And the long straw, keeping straight better, and the more nourishing bran, are advantages which tell in the balance. Rye, now undeservedly despised in this country, so it may not be amiss to remind farmers, used at one time, as Mr. Prothero reminds us in his book, to be "the breadstuff of the English peasantry." And it would not be amiss if English farmers, farming on poor soil, were to follow the example recently opportunely set by their Irish comrades, of cultivating it again on land which produces but poor crops of wheat. The heavier yield of (better) straw alone might serve as an argument in favour of this. When thrashing machines first came in, German farmers would not use them, because, taking the sheaves only lengthways, they broke up and spoilt the straw, which is greatly valued for its straightness and its length. The wider machines of later make avoid such spoiling. In Germany, by the way, rye does not ripen later than wheat, but rather earlier. Probably the time of sowing and our practice of soiling or cutting in spring in part accounts for the difference. In Germany the rye harvest is generally at least lialf over when the wheat harvest begins. And on fields sown with the two cereals together, next year you will find more rye growing in the new crop from cast grains than wheat.

The yield of potatoes, on the other hand, is in Germany not by so much inferior to our own, as would appear from Mr. Middleton's figures. Rightly, potatoes constitute in Germany the favourite crop, which may be grown anywhere, even on the lightest sand, and accordingly is so grown, not only because it gives the best return among crops, but also because its use for industrial purposes has become quite general, and in this way it is made to yield money first, and valuable winter fodder after. Therefore, as a reversed case to that of wheat, our good yield compares with a yield in Germany which includes very much poor stuff, including "strings of pearls" not worth the lifting. 
All the more unwise for us to miss so excellent and tempting an opportunity of turning the plant food contained in our soil into money. After Mr. Prothero's promising reference to the very great utility of potatoes for remunerative industrial purposes we may hope that a very much larger quantity of potatoes will be grown in this country in the future. Our Agriculture will gain by the changes. The greater equableness of our climate, ensuring a longer period of vegetation than in Germany, and our practical freedom from the danger of early frosts in the autumn-stand decidedly in our favour.

Over and besides all this, it ought to be borne in mind that in Germany practically there is no raising of rent. For the most part the occupier is also owner of his land and secure of a return for all his improvements, in the shape either of annual yield or else of selling value. So far as he is a tenant, he as a general rule farms under a pretty long lease, which enables him to manure freely and till well without fear of being dispossessed of his rightful reward. In such cases also, as a rule, he has a good landlord, that is, the State, some municipality or foundation, or a very large landowner, all of whom are likely to deal fairly by him. And, furthermore, it ought to be borne in mind that Germany lias no game preserving to speak of. It is only in few districts that there is sufficient game to do any serious damage. And there the landlord meets his tenants in a very fair way, permitting them to scare the big game off their fields at night with the help of dogs and trumpets and torches, though of course they must not kill any. The consequence is that bags are less heavy, but game is " game," and there is really more genuine sport in shooting it. Hunting is relegated to very few regions of large estates, as for instance Pomerania and Mecklenburg, in which squires are very much in the ascendant. All this helps to produce a difference.

Unquestionably Germany has stolen a substantial march upon us and left us for the moment behind in the race. Her land, under a different land system, more appropriate to the present age, yields considerably more than does 
ours, and to that extent her superiority has baffled our measures of food-war by means of a blockade. However superior the best of our farming may be, as a nation we shall have to admit that for the moment we are beaten.

That fact is bound to give rise to bitter reflection. How are the mighty fallen! Fifty and sixty years ago we were the observed of all observers as leaders in Agriculture. Great Britain was the farming Mecca for agriculturists to journey to in quest of knowledge. It was we who had held up the light of agricultural learning which had illuminated the world. It was from us that France, Germany, Switzerland-every country of the Continent, in fact-had learnt superior farming, as " Turnip Townshend," " Coke of Norfolk," Lord Somerville and their coetaneans and successors had perfected and taught it. In France it was Saussure who had acted as our apostle. The important Société Nationale d'Agriculture de France was set up in imitation of the Agricultural Society of Dublin. In Switzerland the chosen prophet of modern Agriculture, the founder-in company with Pestalozzi-of the first farm-school, and in this way the "father" of Agricultural Education as a whole, Emmanuel von Fellenberg, had preached from English texts, laying stress, more particularly, upon the merits of our system of rotation. In Germany "Father Thaer "-born, as a Hanoverian, a subject of King George the Third-who is the reputed "father " of modern German Agriculture, held up our Agriculture as the model to follow - just as did many years after, in the same country, in the period here spoken of-which was the German agricultural rinascimento-Stöckhardt and his fellow pioneersStöckhardt having learnt, as he himself owned, mainly from Rothamsted.

It is with our own weapons that the Germans have for the time being vanquished us, with our own heifer that they have been ploughing their field. The application is theirs, past masters as they are in the art of borrowing and adapting; the principle is ours. And what they have grafted upon our native stock, it must be a comfort to 
reflect that we ought, mutatis mutandis, to be able to graft back again to our profit.

Then let us see how Germany has done to reach her present vantage point. The study cannot be unprofitable. For Mr. Middleton has sufficiently shown that we may find lessons to profit us in the inquiry, which may result to our benefit. I approach the subject with some confidence since, by a ruling of Providence, which I did not relish at the time, I was fated to spend a good part of my youth in Germany, being there engaged mainly with Agriculture, to the study of which, comparing it all the time with British, I devoted about twelve years of my life, observing everywhere and farming for myself-a property of my own of $\mathrm{I}, 000$ acres, in Prussian Upper Lusatia-during six years. My father having, on his retirement from business in Leeds, gone to live at Dresden, it was natural that, during my early years, he should have wished to keep me near him. And, once interested in the matter, it is surely needless to say that I have never lost touch with German Agriculture, nor ceased watchfully to observe its progress.

We must not conceive of German Agriculture as of one homogeneous whole of unvarying quality throughout, "without spot or wrinkle." There is not a little bad farming still in Germany, as Herr Michaelis has confessed. Nor must we conceive of it as affording to ourselves a model to follow on all points. Indifferent husbandry apart, there are many things in German farming, even successful points, which would do anything but suit ourselves in our very different circumstances. And there are points also in respect of which we are the more advanced of the two. But there are some outstanding points distinctly deserving of attention and study.

The principles of German Agriculture, as we see it now, being borrowed from our own, by the way, is no exceptional or solitary feature in German economy. For, admirable adapters and perfecters as Germans unquestionably are, their originating power seems limited. Their boasted aniline industry came from our Perkins. And their applied chemistry generally, which, with peculiar aptitude for that 
science and exceptional capacity for entering into minutix, and with their own peculiar heirloom of characteristically persevering labour, they have carried to a high point of perfection and profitableness, they owe in like manner to our Muspratt and Graham, who were the accepted standard authorities on the subject some fifty and sixty years ago, when I studied chemistry in the laboratories of Bonn and Heidelberg, and when the great German advance began to take place, with which Germany has lately dazzled the world. Our Johnstone was also appreciated and studied. Again, those famous "social" measures which we have recently been studying and adapting-not altogether on improved lines-namely, Workmen's Accident Assurance, Old Age Pensions, Health Insurance, and so on, are distinct developments and a State socialised reflex of our Friendly Societies' practices, made general and compulsory. It is a fixed belief in high quarters in Germany, submissively accepted and sliared by the oi $\pi \circ \lambda \lambda o i$, that every popular movement must be under Government leading, lest it go astray and lest there be not sufficient inducement to fill its ranks. That is the secret of the German reputation for exceptional aptitude for " organisation." In the same way that Co-operative Credit, which we are now rightly longing to graft upon our Agriculture after German example, and do so little effectually to acclimatise, is another direct offshoot from our Friendly Socicties' provident practice. It was on Friendly Society lines that both Raiffeisen and Schulze began their beneficent work, perfecting the system as they went along. In the province of Agriculture there is little enough indeed in Germany which is not copied from us, although, of course, there are some interesting racy features brought forth by special circumstances -such as the reclamation of peatmoss, "dry farming" on the Brandenburg and Pomeranian sand, the impressment of industrial undertakings to better utilise agricultural produce such as potatoes and sugarbeet, and the intimate interconnection of Agriculture with forestry. However, in their adaptation of our "Townshend and Coke" Agriculture Germans have with remarkable ingenuity and 
rare application achieved signal success. The reason is that, having written Education topmost upon their banner, and enjoying an enviable freedom from-to put it in Sir James Caird's words-our disease of having " a very prevalent dislike to learn," they have painstakingly analysed processes and results, in order to arrive at the discovery of the operating causes and push those which answer to the utmost, while discarding those that do not. It was the same "schoolmaster" who, as was said at the time, vanquished at Sadowa, who has also triumphed on the cultivated ager. To these causes must be added another, which we in our insular isolation often enough lose sight of. Germany was poor-very poor; and it was a necessity for it to strain every nerve to improve its condition. Besoin fait la vieille trotter. For some centuries German soil had been the chosen battle-ground of hostile armies, the prize disputed for among foreign potentates. And the invading armies had known how to destroy and rob. Turenne and Créqui had wrecked castles, as Demetrius had wrecked "cities." Then came the first Napoleon with all his host and their " indemnities " and pilferings from palaces and museums, which have served the Germans as a pretext for organised brigandage-a thousand times aggravated, of course-such as Germans may be said to have been the first to set an example for-"oir les rêtres ont passé on ne doit point de dimes." 1 Anyhow the result was that Germany was impoverished and its people were backward and cowed, a ready prey to autocratic usurpation, as well as a people condemned to cheeseparing. Our humorists have frequently ridiculed German parsimony and penury. That was a ready subject for cheap wit, which not unnaturally has left its sting behind. But with the Germans parsimony was not a matter of choice. The country was impoverished, and the "groschen " was to Germans valuable as the "penny" of the Bible. Parsimony and cheese-

${ }^{1}$ In the days of the rettres and lansquenets there was a saying current in France that these German mercenaries having, for their misdeeds, been refused an entrance into Paradise by Saint Peter, the devil equally refused to receive them in hell, because he considered them too bad to mix with his host. 
paring extended up to the Throne. In the Thiergarten of Berlin stands a statue of Frederick William III, the king of Napoleon's time, showing a patched boot. That was put there on purpose to commemorate his parsimony at a time when parsimony was a distinct necessity and a virtue.

Agriculture necessarily shared in the effects of general impoverishment. It had to be conducted-and was soon skinflint lines. What impressive warnings addressed to German farmers I remember reading, in my days of German residence fifty and sixty years ago, against underfeeding-with chopped straw-and undermanuring! However, Hobson had no choice then. Needs must when the devil drives.

To Agriculture long so situated British high farming came as a revelation - at a time when, it should be remarked, the most pressing necessity for economising farthings had already passed away. Germany was just beginning to breathe afresh, emerging from her long period of need. Under the "Zollverein" and a liberal tariff policy, the consequences of a long continuance of administratively good government and rigid economy began to make themselves felt and cheeseparing was, although a revered tradition, no longer a necessity of quite the same imperativeness as before.

A brief sketch of the advance of German Agriculture may here be in place. It is not quite correct to say, as has been done, that the present perfection of German Agriculture as a whole was the work "of the last forty years." The real and most substantial improvement began earlier, the latest intensification of the process-for political purposes-which at the present time mainly fixes our attention, more than twenty years later.

However, before beginning to tell the tale of gradual development, in view of very erroneous impressions freely prevailing in this country, it may be well, in order to guard against misapprehension, to call attention to Mr. Middleton's well founded-and in his pen assuredly unbiased-judgment, which says: "It cannot be alleged that the extra 
money which tariffs brought to Agriculture is the sole, or even the main, cause of the increase in production. If other, and quite different, causes had not been operating, German Agriculture must have been bankrupt ere now. ... An examination of prices shows that, if world prices had not favoured the agriculturist, the protective tariffs of Germany could not have removed his financial embarrassment." That is really to some cxtent understating facts as they are. The matter was thoroughly threshed out in Germany itself during the heated tariff controversy of Igo3, when a new, higher tariff was under consideration. And the facts brought forward in the perfect library of publications, issuing from the highest authorities on either side, have made it convincingly clear that Protection has had nothing whatever to do with the happy development of German Agriculture-if indeed it has not actually checked and retarded it. The tariff policy began in I879, as a purely political move-although the fact that by its Constitution the Empire was debarred from raising money for its growing wants by direct taxation, when it wanted money badly for its ambitious military measures, of course, served as a pretext. That hindrance might at the time spoken of have been got over without serious difficulty. However, to serve those "vast ambitions" of which Lord Beaconsfield pointedly spoke at a Guildhall Banquet during his last Premiership, the leading classes concerned-agriculturists on the one hand and commercial men and industrialists on the other-were to be won over, bound to the Thronewhich still, as in the 'sixties, distinguishes between " king's friends" and others-by the golden chains of apparent benefits coming out of other people's pockets. Agriculturists, like industrialists, required a gread deal of persuasion to make them accept the boon, because they had been well enough off before. In truth, barring the recent war, prices for cereals were higher under comparative Free Trade than after, although at the earlier clate Germany was still a meat and grain exporting country. I have then heard our maintaining that shilling registration duty upon wheat denounced in Germany as a piece of "Protection" 
telling against her Agriculture. It may be worth reminding people that, as Huskisson's speech delivered in Parliament in I823 shows, ${ }^{1}$ it was Prussia which first forced a policy of Free Trade upon us, by threatening retaliatory measures in the matter of coasting trade. I was witness to the great rejoicings among agriculturists in I864 over the conclusion of the Anglo-Prussian-or rather Anglo-Zollverein-commercial treaty, which was considered a distinct step towards Free Trade, and was certainly hailed as a great gain for German Agriculture. "You may now order whatever you please," so said to me the late Consul Hesse, of Dresden, from whom I was in the habit of buying English implements ; "the duty is a mere nothing." I remember that it was just half a crown on a Ransome and Sims plough. English implements were then badly needed in Germany, because German implement making was still lamentably backward. But that was not the only point. It so happened that immediately after the proclamation of the commercial treaty referred to the periodical "All German " Agricultural Congress and Exhibition took place at Dresden. There were representative leading agriculturists present from all parts of Germany and Austria (which then still formed an integral part of Germany, and was indeed the leading power). And so one could therehear genuineopinions of all sections of the agricultural community. There was no dissonant note in the chorus of rejoicing. Bismarck's secession to Protection indeed cost him the services of the highest agricultural authority in the land, his colleague, Dr. Friedenthal, a most capable Minister of Agriculture, who resigned at once, deprecating Protection as directly detrimental to Agriculture, in which opinion Prince Bismarck's " right-hand man " of long years, the "Deputy-Chan-

1 Sce "Huskisson's Speeches," vol. I, p. 205 ss. Prussia had threatened us with retaliation for the dues which we still levied on Prussian bottoms. The Prussian Minister announced that "His Prussian Majesty desired to substitute a policy of "reciprocal facilities " for that of "reciprocal prohibition." Huskisson seized the point with great eagerness. The Editor of his "Speeches" compares the result of Prussian "facilities" with that of "French Prohibition" in $18_{31}$. 
cellor " as he was popularly called, Dr. Delbrück, joined him, likewise resigning on this particular issue.

The new policy entered upon in I894-when incidentally Protection was aggravated-undoubtedly made a difference in the output of German Agriculture. But that increased output was not earned, but dearly paid for with public money in a serious crisis.

However, coming back to "our muttons," the decisive step, the step which really initiated progress and laid down the lines upon which German Agriculture has since grown up as a lusty tree, sending its root downward and spreading its branches upward, bearing fruit richly, was taken in the late 'fifties and the early 'sixties, as I can testify from personal observation. It was then that the "new era" set in, following closely upon our own "golden age," as Mr. Prothero has called it, and obviously stimulated by that. As will still be shown, the Germans saw in the remarkabie advance of our British Agriculture at that time a direct consequence of our new policy of Free Trade, which had put our farmers " upon their mettle." Such was the interpretation given in Germany by all the leading authorities to our advance. And German observation of this fact became the turning point in the development of German Agriculture. It was our Free Trade Agriculture which fecundated German soil.

Protection, on the other hand, when it came, had in truth in Germany this decidedly adverse effect upon Agriculture, that it made the principal raw material of that industry - that is, land-appreciably dearer. The expected higher price to be obtained for produce was at once clapped on to the price of the land. And accordingly the price of land shot up. That benefited the owners of land at the particular time, to the detriment of those who were to follow after. And what gain there arose from that, German landowners were foolish enough to fritter away most recklessly. The nominal advance in the price of land encouraged borrowing. And debt incurred fostered improvident and extravagant living. It is the consequences of that, that all too many German landed proprietors are now suffering 
2 from. Agriculture did not benefit. Together with land, everything else connected with Agriculture went up in price at a giant pace. "You have no idea how much we now have to pay." That is what my whilom neighbours, and other agriculturists in other parts of Germany, told me on my subsequent visits. The prices of my day had become a matter of ancient history. Above all things, labour became alarmingly dearer. And it was just at the point of labour that the shoe pinched most. The veritable fortunes made out of sugar beet growing and potato distilling were made in earlier days. The halcyon time was beginning to wane, by reason of competition and higher duties, when I was in Germany. The competition following in the wake of Protection-which was to make every one rich-nipped them still further. Protection had produced the delusive belief among agriculturists of their being favoured by a paternal Government. Such matters as what seemed preferential tariffs on railways (which had become Government property)-although French private railway companies do just as much for agricultural produce in their country-served to confirm that belief, which the junker squires-who, as junkers, certainly were, and continue to be, richly befriended by Government for political purposes -did not allow to evaporate. But agricultural production, the business of Agriculture, has not been benefited by the value of a stiver.

The history of modern German Agriculture is popularly supposed to have begun with "Father Thaer's " publication of his "Principles of English Agriculture" in I795 to IS04. Thaer was-like Scharnhorst, whom we likewise allowed to become a most useful servant of the Prussian Crown - a Hanoverian, and, being one of King George the Third's physicians in ordinary at Hanover, in that way learnt about English farming. Starting his College at Celle, removing it afterwards, on his receiving a call to a University chair at Berlin, to Prussian Möglin, he certainly became the "father" of distinctly German agricultural education. However, his teaching did not really exercise widespread influence on practical Agriculture. A new impulse was 
given in the 'fifties of the past century, the driving force of which-very potent force it was-once morc came from our shores: this time not from England alone; for at that time Scotland, and more particularly the Lothians, received their full meed of recognition on the other side of the North Sea. There was still plenty of "three-field farming " in Germany at the time, and terrible stinting alike of live stock and of the soil-more than farmers in this country would believe to be possible. ${ }^{1}$ It was really Chemistrythe despised science of British farmers even in the august quarters of the Agricultural Organisation Society, but that same "Chymistry" of which some fifty years previously Francis Home had written in recognition of Humphry Davy's memorable work, that "without a knowledge of that science Agriculture could not be reduced to principles," and which had under such leading raised British Agriculture to its eminence of those days - which mainly served to bring about the change. People in the main still swore by " humus," which was Jethro Tull's " MIother Bountiful," the worship of which Saussure had carried across to the Continent. In I840 Liebig, then a professor at the University of Giessen, but a professor not specifically of agricultural chemistry, electrified the world by pressing upon the public the importance of a supply of mineral fertilising constituents. This new doctrine took the world by surprise and subsequently by storm. By a curious coincidence the very same year saw practically the first shipment of Peruvian guano arriving in Europe. Guano was already known to the Incas, whose kings, appreciating its value, strictly "protected " it by prohibiting export. Vega had explained its fertilising properties at Lisbon in 1602. Thus in the

1 Reading the chapter on Agriculture in the Georgian and early Victorian days in Mr. Prothero's masterly " English Farming, Past and Present," has vividly brought back to my memory what I saw in Germany in the 'fifties and 'sixties. There was the old lumbering plough, often with a wooden mould board, harrows still often made of wood, wagons often with wooden axletrees, sowing by hand, thrashing with the flail, "throwing " and winnowing by hand, reaping and mowing with the scythe, binding sheaves with bands of straw, aye, there were the old "clotting beetles" still in use for breaking up clods of heavy clay. 
very same year the new "mineral" theory and the new " nitrogen " theory took birth, in the place of the thenceforth discredited "humus" theory. However, German farmers, moving on in their old humdrum way and, like most of our own in the present day, recking little of chemistry, for a long time took no notice of the epoch-making discoveries. Late in the 'fifties their agricultural chemists still publicly scolded them for permitting their valuable German bones - that is, the bones of their animals-to be unpatriotically exported wholesale to our shores, there to enrich British fields. German oilcake likewise came over to us by shiploads. If the late Colonel Sampson, of Buxshalls Park in Sussex, told us true-which I do not for a moment doubt: only I want to name my authority for the gruesome story-at one of our agricultural dinners, our farmers in their appreciation of superphosphate did 1 ot even disdain to employ the bones of departed heroes--I hope they were not all our own-brought home from the Crimea, as manure. With the employment of these two classes of fertilisers-nitrogen and phosphates, for potash salts were then not yet unearthed-began our " golden age " of high farming, which at once showed capital results, and rumours of which rapidly spread into Germany.

However, what "fetched" German agriculturists most was the fact-clearly demonstrated by Professor J. A. Stöckhardt, a very eminent agricultural chemist, whom I have seen, in $I S_{5} 6$, anticipating in his laboratory at Tharand the experiments with which, many years afterwards, the Frenchman M. Ville gained great renown in this country-that, as Mr. Prothero has since likewise shown in his admirable "English Farming, Past and Present," it was after the repeal of the Corn Laws-which, it had been feared, would wreck our Agriculture-that our Agriculture had, on the contrary, taken its great bound upward. It was our farmers being put upon their mettle by what seemed to them a severe visitation which led them into their "golden age." That was, in truth, but a repetition, in principle, of an earlier experience, when, as Mr. Prothero relates, Lord Townshend and " Coke of 
Norfolk" had made imitation of their own high farming by their hesitating tenants "compulsory " by raising their rents. England was then to some extent already the 'Tom Tiddler's ground, deserving of imitation, of Germans. Hence in the main the impulse accepted from us was received and welcomed on economic grounds. British farming became the special model for German agriculturists. To be an Englishman and an agriculturist then meant to be received with open arms everywhere among the German farming community, and to be credited with an intuitive knowledge of the mysteries of high farming. Professor Stöckhardt, who, as the friend of our Lawes and Gilbert, had learnt much at Rothamsted-which he exerted himself to apply with profit at the first experimental station known in Germany, founded by himself at Möckern-was foremost in extolling British ways of farming. However, you might then hear the praises of our farmers and their judicious and businesslike ways sung at every agricultural college and every agricultural meeting. It was then that Shorthorns, and Southdowns, and Yorkshire pigs became popular in Germany. And so did English implements, a very complete catalogue of which, elucidated by admirable illustrations and explanations, Dr. Löbe, of the Agricultural College of Lützschena, brought out. German implement making was still a thing to be rather laughed at, and machinery was practically non-existent. It brings an involuntary smile to my face to think of the early German thrashing machines and reapers-resembling a Googe's " reaping car" -which I then saw. Also our pedigree seed breeding attracted marked attention. There were two points in our farming-only the best of it-which greatly impressed Germans. One was our " high" farming-which they translated by the word " intensive." They had, as observed, up to that time deliberately starved their soil. The other was the "businesslike" view which our farmers were supposed to take of farming, which to the routine-bound Germans came as a revelation-calculating what paid and what did not. Their enthusiasm for this way of looking at their calling carried them even into admiration of what 
we have since discovered to have been an error, and partially discarded-namely, the preference given to pasturage over tilling, on the supposition that it was cheaper to let little produce "walk off the land to market on its own legs " than to "cart " very much more substantial produce off in wagons. And the other assumption was, that the interest to be paid on barns, in the place of spending much money annually on the building up of stacks, must be regarded as most uneconomical. But the pith of the matter was Townshend's and Coke's system of "rotation," which got rid of the everlasting "rye, spring corn, fallow" of the three-field shift and ushered in what has become to Germany a golden era of the cultivation of roots and leguminous plants-more specifically roots, which have proved a treasure to the country. ${ }^{1}$ There were first-rate agricultural chemists in Germany then. Germans have always had a marked liking for chemistry. Stöckhardt stood at the head. And he spared no pains and no labour to proclaim-in the place of Liebig, who had little contact with the agricultural world-that savant's "mineral theory," heartily adopted by himself, and also his own " nitrogen theory." Assiduous preaching of specifically chemical truths to the farming world greatly stimulated the national fancy for chemistry. Stöckhardt had in his " Chemischer Ackersmann" and his "Chemische Feldpredigten" with great skill put chemical truths into a light, attractive, easily comprehensible shape. And German agriculturists pounced with delight upon such teaching. Agricultural chemistry came to be everywhere pushed. The peculiar organisation of the German rural community made what the more favoured had learnt readily accessible in a popular way also to the more horny-handed practitioners. And, as observed, it was mainly chemistry which won the battle. Improved practical processes, the use of modern implements and machinery followed after. In the 'sixties my English

1 Roots, that is, sugar beet and potatoes (for distillery purposes), had been grown and utilised, at a great profit, before, but in a comparatively small number of cases. The benefit to the country came with the extension of their cultivation, which naturally reduced individual profits, but benefited the fields of the entire country. 
implements were laughed at even by agriculturists of the superior order, although the merits of my English breeds of live stock were done justice to. Since then the derided implements have one and all become popular, common and appreciated. High farming was pushed. So was careful tillage. So was the study of seed. And fertilisers were carefully selected for their relative value. The Germans were the first to publish tables giving the analysis of feeding stuffs and manures. On this point the Germans beat us. They calculated closely. It was just in the 'sixties that potash salts came in-in the first stage as mere cheap refuse. Up to that time potash had been scarce, and little thought of. I remember that a man was particularly commended for collecting the water in which sheep had been washed, in order to extract from it and utilise the potash contained in the dirt of the wool. The opening of the Stassfurt potash deposits brought about something of a revolution. Roots and clover more particularly require potash. But also on sand-barren sand, of which Germany possesses a vast area-it was found that potash stiffens the straw-presumably by dissolving some of the silica. The more general adoption of sugar beet and potato growing for industrial purposes became a turning point in agricultural development. However, at all points heavy manuring became a common practice. Judicious employment of artificial fertilisers made even the erst barren sand of "His Majesty's Sandbox" bear very respectable crops. The Government encouraged all this. There was no one to manure more heavily than did Dr. Friedenthal, the Prussian Minister of Agriculture from I875 to I879, on his own little property in Silesia. In this way our " high farming," originally the model, came to be outstripped and intensified in the shape of what we now know as "intensive farming."

At an opportune moment " organisation" came in. The philanthropist F. W. Raiffeisen had been "organising" since about $\mathrm{I} 85^{\circ}$ in his distinctly philanthropic and quite humble way for the poorest of the poor among the rural population in Rhineland. Schulze Delitzsch had through his co-operative credit associations raised substantially 
larger sums of money; however, his organisation for agricultural purposes did not extend farther than to credit. The fame of Raiffeisen, which has since filled the worldamong other countries also Ireland and India-penetrated into the palace of Berlin. And in 1874 the late Emperor William nominated a Royal Commission-consisting of three very eminent men, namely, the two professors of political economy, Nasse and Held, and Professor K. G. Siemens (who first introduced beet-sugar making into Germany) - to inquire into his system. Their Report was most favourable-not at all like that of the three gentlemen of Gotham of our Central Chamber of Argiculture just twenty years later, who found that it represented simply our system of overdraft " already sufficiently practised in this country." The Raiffeisen organisation, which extended, in its small way, to all branches of Co-operation, was accordingly approved and befriended, and began to spread. 'The year I883 saw the first farmers' co-operative supply society-a very humble institution-established in Hesse. In this matter we had really forestalled the Germans. For on my return from Germany in 1869 I learnt, on inquiry, from the late Dr. Voelcker, that we then already possessed nine County Associations-almost entirely for the collective purchase of phosphates, of bones and coprolites-besides, so Mr. E. O. Greening informed me, an unknown number of unregistered little farmers' clubs for the same purposeand two more ambitious societies, severally in London and in Leith, which aimed at covering the whole field of at any rate co-operative supply in connection with Agriculture in their several countries. However, at that point we practically stood still-indeed, we retrograded from it-until the year IS99, when under the chairmanship of the late Lord Wenlock we formed the " British Agricultural Organisation Society," avowedly in imitation of Sir Horace Plunkett's "Trish Agricultural Organisation Society," formed in IS94. Our " British "Society eventually coalesced with the "rump " of Lord Winchilsea's abortive " National Agricultural Union," to become the "Agricultural Organisation Society." Germany, on the other hand, pushed on. 
New uses were every day found for co-operative organisation. Farmers were busier still in Jenmark and in the Netherlands. And that naturally reacted upon Germany as a further stimulus. Thus the movement sped on, conquering and to conquer.

A great change came over the entire situation in $\mathrm{I} S 94$. Emperor William had just had an ugly reminder that onesided Protection is not all the "beer and skittles" for which Bismarck and his junker following-insisting that Germany should be absolute " mistress in her own house" -had represented it. Bismarck had shot his protectionist bolt, and Russia had retaliated by stopping her own exportation of rye, upon which Germany was in a great measure dependent. There was general dismay. Famine seemed to stare the people in the face. Count Caprivi, the new Chancellor-very characteristically nominated on the advice, not of responsible statesmen, but of " generals commanding the several army corps," whom the Emperor had hastily summoned to a conference to advise him-had saved the situation by a bold stroke which the Emperor himself with a sigh of relief publicly spoke of as " the saving deed." That staved off famine, but it got the back up fiercely of the junkers, who forthwith leagued themselves together in an anti-governmental "Bund der Landwirthe" (Federation of Agriculturists-really of Landowners), which was to fight the Government and insist upon the restoration of extreme Protection, and which came to exercise an enormous power and has practically held the political helm ever since. Now the Emperor was well aware that, if he was to remain emperor and king on his own terms, he could afford to quarrel with any one except the junkers, whose motto has ever been :

" Unser König absolut, Wenn er unsern Willen thut."

(Our king shall be absolute ruler, so long as he carries out our wishes.) He might dismiss Chancellors at a moment's notice, take up and drop again at his pleasure NationalLiberals, Ultramontanes-during the war even Socialists. 
But the junkers were the bodyguard of his Throne and the guardians of his militarist policy. Accordingly he needs must propitiate them, though it cost him the dismissal of a trusty servant like Caprivi, as Bismarck's Protectionism had cost him the services of able ministers such as Delbrück and Friedenthal.

There were special considerations which made a strengthening of the Emperor's traditional alliance with the junkers imperative, particularly if they could manage, as they have actually done, to bring the entire rural population under their sway by deceptive allurements. There is no doubt-evidence is too conclusive on the point-that it was then that the Emperor formed his ambitious great war plan. He had been six years on the throne. He had plentifully advertised himself abroad in his rôle of what his people called the " Reisekaiser." He had taken soundings everywhere. He had dropped his "pilot." He had discovered that Germany's future "lay on the water," and he was vigorously forging his maritime weapons for use. But he had not forgotten the traditional belief of the Hohenzollerns in their army. That army had been energetically reared up ever since Wiliiam the First became Regent. The first William harboured no idea of conquest, at any rate outside Germany. That must have appeared altogether " out of character" in his time. Prussia had cut only a very humble figure at the Paris Congress. It was Bismarck who pioneered the great wars which in systematic and logical order led up to I9I4, to be followed in the Emperor's intention by a crushing blow against ourselves, whose prosperity, unity and general enjoyment of comparative peace had since a long time-as any one who then lived in Germany could tell-filled the Germans with not inexplicable envy, at the same time that our habitual independent bearing was strongly resented by them as arguing " arrogance" and an overbearing mind. However, the first William could not suppress-his published letters show that-his bitter resentment of his brother's "weakness" evidenced by his condescending to parley with the rebels of $I 848$, who had made the then "Prince of Prussia " 
(subsequently Emperor William) fly the country for personal safety. ${ }^{1}$ He would be better prepared. Newly acceded to the Throne as Prince Regent, already as early as in $I 856$, he ordered all that, it seems, he was constitutionally empowered to enforce, namely, a considerable increase of the staff of army officers, beyond the number budgeted for. The sham mobilisation of 1859 , which made the Austrians indignant, ${ }^{2}$ afforded a further opportunity for inflating the corps of officers. Officers of the reserve were pressed into the standing army in great numbers. Then came the Army Bill of I86I, which exactly doubled the old military establishment, and which was carried out in open defiance of the opposing Chamber. Vi et armis Bismarck carried his measure, and at once set the new instrument for fighting to work in Slesvick-Holstein in I864. Queen Victoria prevented our interfering, and the result was, among other things, the digging of the great canal connecting the Baltic with the North Sea, the benefit of which we are now in a position to appreciate. It has greatly added to Germany's naval power. Notwithstanding the vigorous protest raised by constitutionalists, standing up for Federation rights against Prussia and Austria overriding the decision of the "Bund," the ousting of Denmark from the German provinces and the acquisition of new territory -and not least the successful flouting of England-made the war retrospectively popular in Prussia and dug the grave of the old Liberalism of Waldeck and Schulze, who aimed at a Constitution like the British. Present-day German Liberalism, though our newspaper correspondents will persist in dubbing it "Radical "-which it decidedly is not-is

1 It had been proposed that he should take refuge in Stettin. However, the Stettiners promptly started a doggerel rhyme, set to a popular polka tune, which said:

\footnotetext{
" Komme doch, komme doch, Prinz von Preussen, Komme doch, komme doch nach Stettin!

Woll'n wir dich mit Steinen schmeissen,

Wie die Leute in Berlin."
}

${ }^{2}$ A few years after I heard Austrians singing freely the doggerel rhyme :

\footnotetext{
"Preussen hat uns zugesagt

Uns zu helfen in der Schlacht-

Mausefalle! Mausefalle!"
} 
not a patch of the faintest sort upon the sturdy Constitutionalism of the 'sixties. It was not pleasant at that time to be an Englishman in Germany and to find oneself taunted with references to Earl Russell's "Notes." The " Fratricidal " war of I866-so called in protest in Germany-by its successful ending finally won over the Nation and made military rule absolute. Scarcely was the ink dry on the Nikolsburg treaty but I heard my junker neighbours "in the know"-there were great political magnates among them, from Princes downward-significantly hinting at a " coming " war with France. Since then, by the time that I894 came about, the army had been further strengthened, by a good deal. And after IS94, when the lines were cast for I9I4, and the preparations, military and financialto which the President of the Imperial Bank, Dr. Havenstein, confessed, at the sitting of his Board on September 29, I9I4, as dating back from "many years ago" (seit langen Jahren ${ }^{1}$ ) —was begun; increases of the army followed in rapid and calculated succession. In I87 I Germans had written to me boastingly about their " two millions of men in the field." In IgI4 there were ten millions.

For such a war as that proposed the Emperor wanted two things. In the first place he must make sure of his Commissariat. In the second, he must make sure of adequate political support at home. That support he had not got in I894. The commercial classes were up still against his excessive protectionist policy. They did not ask for Free Trade. But they wanted Tariffs regulated by Treaties; and on that point they put up a brave fight even in I903. And the working classes were most discontented. That pretentious "Labour Conference" of I890, which Prince Bismarck strongly objected to, had proved a dead failure. And that Social Insurance Legislation, from which so much had been expected, and which we have come so warmly to admire and to imitate, had set the working classes altogether against the Govermment-all the more

${ }^{1}$ Dr. Havenstein's words were as follows: "Die seit langen Jahren von allen beteiligten Instanzen churchdachte und bis zur letzten Ausführung vorbereitete finanzielle Mobilmachung." 
that there had been repressive anti-socialist legislation accompanying it. President Bödicker, at the head of the Insurance Department-who had really liberal viewsdid his best to conciliate the Socialists. But his superior, Minister von Bötticher, stood obstructively in the way. (Bödicker was by birth a Hanoverian and not a martinet; Bötticher was a Prussian and a martinet to the core.) In the course of my studies of the effects of those measures I was brought into contact with a good many representative Labour men and Socialist deputies from all parts. And I found them strongly anti-Government. They admitted that the new measures gave them something; but they contended that they took away more. They were up in arms against the orthopædic treatment, which they called "torture" - the object of which was to restore disabled limbs to useful pliancy and strength, so as to get the men off the pensions list. And, generally, they held that the employers got the best of the Government bargain and abused their privileges. They also seriously resented the all but suppression of their " free" Friendly Societies. What finally reconciled public opinion to these "largehearted " measures, as they are called, was the employment of the enormous sums collected, not as they would have been used among ourselves, for the "appreciation of Consols," but for purposes socially and economically benefiting the working classes, more particularly for housing purposes.

Against such opposition the Emperor must have his " Swiss Guard," such as only the rural population, officered by the junkers, could supply. While the "Bund der Landwirthe" was forming, breathing forth "threatenings and slaughter " against the Government-though distinctly not against the Emperor's person-the Emperor went down to the "Agricultural Society of Germany," a very powerful body with great political influence, to announce that it was his " firm will " (das ist mein IVille) that Germany should be made absolutely independent of foreign supply of foodstuffs. Nothing could have been more after the mind and heart of the junkers. They received the message with enthusiastic acclamations. And being pitched in the 
patriotic key, that message did not offend any one else. For people were slow to detect that it might mean needlessly dear bread and also dear everything else.

There were two great measures then taken-bracketed with smaller ones-designed really or ostensibly to benefit Agriculture. One was the creation of provincial " Chambers of Agriculture," which are a different thing altogether from our debating "Chambers," and really a type of body that, unused as we are to the same discipline and organisation "from above," we could scarcely hope to establish among ourselves. Those Chambers have served the Emperor well in a manner that we could not altogether approve. They have proved admirable recruiting centres for what Mr. Gompers has aptly dubbed "Kaiserism." But they have at the same time also done very much indeed for Agriculture. Officers of the Prussian Ministry of Agriculture, who had before I 866 held similar offices under electoral and ducal Crowns, since "amalgamated" with the Prussian, just about that time owned to me that it was quite a different thing administering Agriculture in a district which they could overlook, like Hesse or Nassau, and in such wide districts as Prussia, with her extended territory, necessarily must assign to them. Here was a means of better localising administration. But the new policy meant a good deal more. The Chambers, composed of bona-fide agriculturists interested in Agriculture, knowing their district well and endowed with ample administrative and rate-levying powers, might do a great deal for Agriculture in the officially right sense, since they were continually under the direction and supervision of the Central Ministry, whose orders they were directed to carry out, though their counsel and information were gladly sought and taken on local and technical matters ; but also in a thoroughly genuine way designed and adapted to bring benefit to the calling and to those who practise it. Inquirers will find that in matters of general policy there is complete harmony of views between the members of those bodies and the Ministry. But in technical matters they are given a free hand, and their capacity and local knowledge make them of 
inestimable value on such ground. They have proved more particularly useful in pushing organisation and education. But they also fix the Government bit effectively in the rural population's mouth.

Agricultural Education was at that time already a well established fact, which had proved its merit, and merely required wider application to make it fully effective. But organisation was new. The story of its development up to I894 has already been told. The Raiffeisen system was held to be the trump card with which to win. But there were elements in it which were rather calculated to attain the moralist's end than to secure political support. That altruism, that peculiar consideration for small folk, must be cast off. The prize held out must be "loaves and fishes." Here was a weapon to conjure with, if it could be made to awaken the sense of "value received." Looking for "loaves and fishes," Dr. Haas, a Hessian with a great admiration for Berlin, had formally seceded from his leader Raiffeisen, to form a Union which meant "business" rather than the pursuit of high ideals, and which could be joined by junkers expecting personal benefit. That Union was in I894 plodding on, slowly extending its sway. Indeed, it could scarcely be said to be properly organised. And not without reason were its officers very close in communicating, or, rather in failing to communicate, particulars even to persons standing very near to them. Things would not move on very rapidly. The turn which events took in I894 altered the situation altogether. Government saw their chance in impressing Co-operation of a particular type into their service for the purpose of winning over the support of the entire rural community by gifts-the value of which we have seen coming back to the givers with huge increase during the war in the shape of magnificent subscriptions to the various War Loans. Herr Haas and his friends were, like Barkis, "willing." They had conspired with Schulze against Raiffeisen ; they were ready to conspire again. Under Government patronage the "General" Union, whose names had been selected to please Schulze, became the "Imperial Union "-Reichsverband, a name to 
conjure with at the time, with Government favours showered upon it everywhere. Presidents of Provinces were instructed to befriend it at all points ; and so were Chambers of Agriculture, the leading men of which-many of them extremely able-became also the leading men of the Union in its various local sections. Co-operation, so it was plausibly urged, to succeed, "must have money," though it had done pretty well thus far upon its own resources. Well, money it should have! The Prussian Government forthwith, in I895, started the State endowed Central Bank for Co-operative Societies (which, by the way, nets its profits out of business less with co-operative than with non-cooperative bodies), liberally endowed-the endowment now stands at $f 3,750,000$, according, as the Times puts it, to "the pre-war value of the mark." That Bank would open credits freely. In the movement nothing was spoken of but benevolent intentions cherished by a paternally interested Government. However, speaking-it may be unadvisedly-on a public occasion, its President, Dr. Heiligenstadt, has frankly explained that the motive which led to the formation of that Bank was " to give an official head " to the Co-operative Movement, which, without such head, it was argued, might " mean danger to the community." Here is the old official belief in the "limited understanding of subjects " and in the Government being the sole qualified leader for " movements," which private persons must not presume to set their hand to! However, there was the money, and German agriculturists-especially junkers, whose heart beat wholly in sympathy with official guidance, if they could only get the money-had not yet learnt the truth which Sterne has taught that "all is not gain that is got into the purse." The Government laid out money "benevolently" in other ways. Thus, to state only one instance, it lavished $£ 250,000$ on an altogether illadvised project to establish "co-operative" elevators. The " elevators" came to grief, of course, and the money was lost-while other, truly co-operative, elevators established on sounder though humbler lines, did well and came to render extremely useful service. Befriended by the 
Central Bank and political authorities, and, once more, by public offices directed by the Government, more particularly of the army-which were instructed to patronise the Organisation by purchasing produce directly from its societies in large quantities and at good prices-the societies of the new "Union" had no reason to complain of neglect. And there was help given in other ways, not to mention the galaxy of decorations showered upon leaders. With such help from all the High Mightinesses of the Empire, Herr Haas's Union shot up like a Jonah's gourd, covering much ground and doing well in the ordinary business of organisation, which is joint buying and selling. I have found very bad societies by the side of exceedingly good ones, which shows that principle was freely sacrificed to expediency, for the sake of enlisting " big battalions." And in matters of finance, the disastrous collapse of a whole big cluster of banks in Hesse about I9II, under Herr Haas's own personal presidential guidance, shows that there were very weak spots in the system. The financial supremacy of the Central Bank, specious as had been the promises made, was not altogether an easy burden to bear. I have found Herr Haas himself and his fellow-Committeemen extremely irate at the manner in which subjection was enforced, and resolved, if it could only be done, to shake off the yoke.

From an economic point of view, all this State spoonfeeding proved quite unnecessary - as unnecessary as it was irksome and hampering. Progress would have been slower without it, but far more solid and enduring. The great Schulze Delitzsch Union, turning over very much more money than Herr Haas's Union, never took one single stiver from that State institution. And the Raiffeisen Union, which in a weak moment allowed itself to be drawn into the spider's web, after promptly breaking off relations - the moment that it discovered Dr. Heiligenstadt, in his over-confidence in his power, revealing his cloven foot of intended dictation-found that it did very much better without the State bank's aid, depositing with, and borrowing from, a great Joint Stock bank on pure business lines. However, the political service rendered to the Throne, by 
bringing all this large part of the rural population into subjection to it, was great.

Before drawing a conclusion from what as a main result the Emperor and his Government have achieved by the new policy of $\mathrm{r} 894$, let us briefly review the specific features distinguishing the position of their agricultural department and agricultural community from ours, which have favoured, as they may on the other hand have obstructed, German agricultural progress. Those features, as it happens, stand out so plainly that there is no mistaking them.

Germany began, let it be repeated, on our ground, with our seed. The implements employed were hers. But the principle was ours. She accepted our rotation and our high farming. That was the seed. It fell on good ground - carefully prepared and tilled where it was not naturally favourable. And its germination and growth were stimulated by particular conditions.

In the first place, German farmers distinctly are " a reading class of people "-which we have Lord Somerville's testimony, and that of other authorities as well in other terms-that ours are not; and "reading" in this application of the word, of course, means more than mere perusing books. Pushed on by the sense of their backwardness, they were determined to exert themselves so as, if possible, to outstrip us, their teachers, on our own ground. We might be content to sit still like lazy Issachar between his two burdens. Persuaded, as they were, that they were the "coming" Nation, they would go farther. They thoroughly believed in Education and made the most of it - pedantic and over-meticulous about minutiæ, as it might be, but in any case teaching. Their chemists, their physiologists, all their army of scientific men, and all the best among their practical men, set to work a-thinking and dissecting, analysing and experimenting, tracing effects minutely to their immediate causes, and determined, in the stockbroker's phrase, to " run profits and cut losses" -while our farmers were quite content to go on in their humdrum routine way, retaining the bad along with the good. For that work of analysis and research the Germans 
are a chosen people. Nature has gifted them with a searching and discriminating mind. And they have this advantage standing to their credit. Their gregariousness and ready imitativeness help to animate the whole body. Our best farmers are every bit as good as theirs, if not better. But they possess no leavening power. They do not seem to care about leavening. And they have no mass of men to follow them. The bad farmer "on the other sicle of the hedge" looks on indifferently and callously as his better skilled neighbour produces wonders of high farming, and goes on growing his stringy couch and his exuberant "kelk" the same as before. In Germany-where, as among the Athenians every one habitually looks out "for some new thing "once the leader leads, the army follows in close formation and so covers the land in little time. The national addiction to Education-more mechanical and more pedantic than ours, but for the present purpose particularly useful as being searching-prompted the effect. Farmers were "out" for improving Agriculture. And so they asked themselves the question: If one cwt. of a certain fertiliser produces a certain result, where previously nothing was bestowed, will not two ewts. double that improvement? Chemistry helped them to seleet the right fertilisers, and experience showed them that not only would the second cwt.- within certain-limits-double the effect of the first, but under some conditions it would do more still. Combination with other fertilising elements would add to its efficacy. In this way from our " high " farming they rose to the higher level of "intensive" farming which, accompanied by that careful tilling in which the division of land and the previous abundance of labour, leaving behind it a tradition of careful hand cultivation, assisted them, has yielded those admirable results which Mr. Middleton has placed on record. In this practice their official leader in a time of specific progress, the Minister Dr. Friedenthal, set them an encouraging and magnetic example. So assisted by Chemistry, the Germans came to discover that even their erst barren sand-the " sandy sand," as one of their leaders farming upon it, Herr von Wangenheim, has expressly called it-is not the 
hopelessly barren material that it used to be considered, but may be turned into something of a gold mine. This same process also led to an enormous extension of the practice of what may be termed "industrial" farming, or rather farming for industrial purposes, that is, pressing industries into the service of Agriculture, such as beetroot-sugar making, potato distilling, syrup and starch making from potatoes and so on. These industries, by their very multiplication, lost their " profiteering " character. There were no more great fortunes to be made out of them by favoured individuals in advance of the rest. But they became all the more valuable an asset to Agriculture as a national interest. For they meant, after the extraction of the money value from the produce, in the shape of an industrial product, the supply of the land, through well-fed animals, with a mass of valuable manure. And the scientific dissection, analysing and starting on the new lines spoken of, furthermore did much to intensify that valuable feature of "diversification," as Secretaries Wilson and Houston of the United States Department of Agriculture have commendingly called it, which now forms such a striking and laudable feature in German Agriculture. The Germans were routineers when we were specialists. They are now specialists where-with some brilliant exceptions-we are the routineers. This is one of the most notable characteristics of German Agriculture, altogether at variance with our recommended cast-iron idea of "wheat, wheat, wheat!' The object pursued was to find out what produce would, in every particular district, and in that district, if possible, on every particular field, thrive best and yield the best money results. The farmer was "out " for moneymaking. Should an emergency occur-as it occurred in I9I4-the field which had borne tobacco, or sugarbeet, or chicory, or teazle, would produce wheat, all the better for not having been worn out with it before. However, until the emergency came, money was to remain the determining factor. That practice has benefited not districts of small husbandry only. But for them it has proved a true godsend. Another feature markedly differentiating German Agri- 
culture-and indeed all forcign Agriculture; only its effect is most marked in German-from ours is this, that the leaders of the agricultural movement had not, like our own, a country filled with latifundia to deal with-such as, according to Pliny's account, perdidere Italiam et provincias (proved the ruin of Italy and its provinces), and, according to the same authority, led landowners to rely upon pasturage-but with one largely subdivided into holdings of comparatively small, in some instances very small, size. That has made a very decided difference in favour of German prosperity. Students of German Agriculture must be aware that it is not the districts of large landed possessions, or at any rate large exploitations, which affix to that Agriculture the stamp of superiority, but the districts in which land is divided and therefore receives more minute care and more liberal feeding with fertilisers and dressings with labour. The difference becomes all the more striking when we observe that it was just in the time when Germany went on subdividing and guarding carefully against reagglomeration that we, on our side, showed ourselves resolutely bent upon laying field to field and-worse than thatenclosing common after common-" stealing the common from the goose." It was while Professor Seeley's hero Stein and his colleague Hardenberg were overcoming great obstacles in creating an independent peasant proprietary -which work of theirs was zealously continued by their successors in office, down to our days, and is still in progress - that we were most active bringing in Enclosure Bills which ousted the peasantry from their possessions. Germany, as it happens, had not over-many of such precious common lands - which have, in olden days, proved such a support to our peasant population-except in the most equivocal shape, that of common forests, which under good management indeed prove a horn of plenty to communes, but which also very easily fall into a state of mismanagement, in which they are a loss to the community. Where common lands exist in Germany in another form-mainly in the South - they are valued and preserved. And Switzerland-the country par excellence of the Allmend, with its 
alpage-could not do without them and has religiously preserved this heirloom of Teuton descent, together with other valued bequests from Burgundian and Allemannian ancestors, the preservation of which so greatly delighted Freeman! Our enclosure of commons of course gave the finishing blow to small husbandry of the old form among ourselves and saddled us with the task which is now so exactingly taxing our wits, of creating in a new form what we ought never to have destroyed in the old. Germany went on the opposite tack. She continued favouring small property-by various Auseinandersetzungen (separation of dual rights) and eventually by the promotion of Rentengüter, that is, amall holdings created with the assistance (not in money, but in land bonds) of the State, in a form which ensures enduring separation. For the results once more I would refer to Mr. Middleton's Report, unless people will pay me the compliment of reading an article by me entitled, "A Practical Justification of Peasant Properties," which appeared in the May number of the Contemporary Review of ISgI.

The great assistance which German natural inclination to Co-operation has rendered the cause of National Agriculture has already been spoken of. As a point of detail that may indeed be looked upon as the most potent factor which has helped backward Agriculture forward to its present price of place--more specifically in the casc of Co-operative Organisation for the obtainment of money. For without money-much money, too-there was nothing to be accomplished. Indeed, all Co-operative Organisation remained in abeyance until Co-operation for Credit had been organised. You cannot make bread without flour. What huge, what enormous sums of money Cooperation has furnished to the German farmer, large and small-and thereby to the Nation-it would be difficult to make British farmers understand. The amount is so prodigious. When, twenty-three years ago, I put the figure for that time in a prospectus for our Agricultural Banks Association at about two hundred million sterling, the Committee behind my back reduced that figure by half 
in order not to make their public incredulous. However, the figures are there, in that country of systematic entry of everything, where everything is tested, tabulated and rubricated. And the result is patent in the wonderfully improved condition of Agriculture.

However, there is one point still to be mentioned, strongly in favour of Germany, which in a manner embraces all the subsidiary items enumerated. German Governments had throughout a " National Agricultural Policy," whereas we had none. "We have no national agricultural policy," that is what Lord Selborne is reported to have said in the course of his address to a meeting of farmers at Lincoln on July 9, I9r6. And at that very moment he was manfully labouring to remove that blot, evidently with a more or less clear view before him of what it became his Department to aim at. So hopeful a sign, such as we had waited for in vain for twenty-seven years, made one seriously regret the noble lord's early retirement from his office. It was not only his deputing Mr. Middleton to prepare this Report about Germany which warrants the opinion just given expression to, that Lord Selborne saw his selected goal clear before him. But that was one proof. For diagnosis is the first step towards cure. Fate has dealt kindly with the country in clevising the official inheritance to Mr. Prothero, the first homme du métier appointed to the office. A state of war is not a time in which to unfold a settled plan of permanent policy. It is a time for quickness of eye, understanding of situations and prompt resolves. And of these qualities Mr. Prothero has shown himself fully possessed. What he has done in Maulden-avowedly as a means of showing the Government what in its own turn it might do (far in advance of Lord Chaplin's abortive policy of I892) on a much larger scale towards the creation of successful small holdings-his obiter dictum anent the high value of potatoes as a most utilisable agricultural crop, and his vigorous encouragement of the employment of labour-saving machinery, when labour was scarcely to be had-are calculated to prepare one for something solid and promising in the nature of a national policy, which 
cannot fail to improve our agricultural position greatly. However, up to the time of Lord Selborne's accession we cannot be said to have possessed anything in the shape of a national agricultural policy. We have had excellent men labouring at the Board of Agriculture. And they have accomplished much valuable sectional work. Their publicist activity, among other things, though not nearly as substantial and as varied as that of the sister Department at Washington, must have proved highly stimulating. But there was no one idea, no settled programme running through the Board's work, governing the whole, no indication of any fixed, clearly visualised aim, and there have been times when one felt strongly tempted to agree with the late Duke of Richmond and Gordon who, as President of the Privy Council, publicly observed, with reference to the demand then grown popular for a Ninistry of Agriculture, on the very eve of its creation, that no such change was needed. "There is a Minister of Agriculture; $I$ am the Minister of Agriculture."' I was privileged to hear the annual statements of the Clerk of the Privy Council, the late Sir C. L. Peel, to the farmers of his district in Sussex. And taking together what he told us and what Sir J. Caird and his colleagues were doing in St. James' Square, it really seemed as if-barring the "muzzling of dogs," of which Mr. Chaplin, on explaining in the House of Commons the intended functions of his new office, made so great a feature -quite as much, or nearly as much was likely to be proved to have been done without the new Board as with it. Mr. Hanbury subsequently owned himself warmly in sympathy with Co-operative Organisation. (Mr. Chaplin had walked out briskly the moment that that subject came to be taken by the Royal Commission of I894.) But that did not forward matters much. His successor, Lord Lincolnshire, manifested his love for Co-operation by bodily swallowing up the Society formed to organise it and incorporate it-

1 This was said at one of the semi-annual meetings of the Royal Agricultural Society, in response to a vote of thanks to the Duke as President of that body, which had been placed in my hands. 
the professed champion of pure self-help that it was-in his office.

The German Departments acted in a markedly different manner. Their "policy" did not spring ready panoplied out of the head of any Zeus afflicted with a headache. No Hephaestos carved it out of a god's brain with his hatchet. It had to be sought after and laboured for. It was so. But, once discovered, it was steadily adhered to and systematically followed up. There was no "fishing " about, no haphazard movement. German Ministers of Agriculture knew as surely where they were going as did Sir Douglas Haig at the head of our armies. They had rather more work to begin upon than their colleagues in this country, because German Crowns possess considerably more substantial material in the shape of crownlands to administer than does ours. And there were drainage and irrigation associations to look after in the public interest, entailed estates to watch over in the interest of coming heirs, moreover general surface drainage by ditches and rivers to supervise in the interest of private owners on the higher levels, and there were more things of the kind to look after. There were also public studs and forests. But all this was after all mere routine work involving no policy. It was Adminstration rather than Agriculture. The adoption of "a policy" grafted upon the top of all this was greatly helped by the fact that in the foreign countries spoken of Agriculture-or let us say, the rural population, as a matter of fact engaged in Agriculture, and having that industry for its main calling-played a far more conspicuous part in public economy and political life than among ourselves, who had in early days already become pronouncedly industrial. And a further stimulus to it still was the division of the country into so many different states at the time spoken of, still eyeing one another with jealousy, and perpetually on the watch for opportunities to go, if possible " one better" in what was considered good government. "Paternal Government" was a tradition in Germany. "The State" was already expected to take the lead in all things. The proper rôle for subjects was 
supposed to be to follow. In such a matter as the practice of Agriculture the Government could not compel. But it could suggest and encourage, and there were a good many things in respect of which it could afford effective, though it were not yet in a large sense material, assistance. There were railway and market authorities to influence. There was road-making to stimulate and regulate, to provide means of transport. And there were other things. Tariff policy, as observed, did not come in till much later, when the battle was already won. And a war emergency was not thought of in those days of division and State rivalry, when the sleepy "Bund" presided over the destinies of the future Empire, and you might on a day's ride cross half a dozen frontiers and be challenged at every one of them.

It was science and research, it was the discovery of our practical superiority and its causes, the revelation of new secrets of chemistry, biology and the rest of it, which ininspired the idea. Governments, like the devil, render no service without the promise of a personal reward. But up to a certain point the interest of the governed was found to jump with that of the seekers after what Lord Randolph has expressively called "votes, votes, votes!" The first foundation was, as it happened, already laid in the shape of education, at institutions (under this particular head) in advance of ours, laboratories, and the first germs pushing forth of organisation. These promising points were turned to account, and on them a "National Agricultural Policy" was reared up, which it has been found not only possible but also most desirable to follow up to the present day and the results of which proclaim themselves in the account given by Mr. Middleton of German Agriculture.

By this new policy of I 894 - which was a totally different thing from the old-the Emperor did not attain what he had made his main aim. Even within the space of twenty years of continued assiduous labour he did not make his country independent of foreign supply-though he came nearer to that point than has been pleasant to ourselves. He cer- 
tainly did a measured amount of good to Agriculture, greatly extending above all things organisation, but good rather in respect of quantity than of quality. His organisation, unlike competing organisations, is altogether dependent upon State aid and could not continue without it. But there is no denying the utility of Provincial Chambers of Agriculture. However, all the good practically accomplished was only the outcome of foundations previously laid. It was Education and Organisation which carried German Agriculture to the high point which it now occupies.

But the Emperor's policy of stimulating with palm oil has accomplished one great thing which must be precious indeed in its author's eyes. It has put the entire rural community -with very few exceptions-into Prussian uniform, standing at attention, awaiting his command, with a spiked helmet on its head and a sword, ready to be drawn, at its side-ready for battle with "John Bull and the Frenchman." as Herr Haas's Union lias elegantly and suggestively put it in a song rendered "with deafening applause" under the Presidency of the son of our Princess Alice, at a Jubilee Congress-a song in which " mad staggers" in despair at German greatness and prosperity are imputed to us, and the declaration is added that Germany can snap her fingers at us angry neighbours, since she has the unconquerable Hohenzollern as her head. ${ }^{1}$ With the help of

1 This occurred at the Jubilee Congress of the " Imperial Union," at Mayence in I908, when the Grand Duke of Hesse was in the chair. The precise words of the song are these:

"Zum Kampf nach draussen mögen drum

John Bull und Franzmann liollern;

Das ficht uns nichts so lang regiert

Wilhelm von Hohenzollern.

"Den Hahn in Ruh'! Die Flinte blank!

Lasst nie die Schwerter rosten.

Kein Kampfgeschrei! Doch wenn es gilt,

Seid Alle auf dem Posten!"

This doggerel and the manner in which it was used are thoroughly characteristic of the way in which the population of Germany has been for years back systematically worked up, under Government inspiration, into a settled hatred of England and France, but more particularly of England, in the belief-confirmed by frequent repetition, on all, even the most unsuitable, occasions-that those two countries, being bitterly envious of Germany on account of her 
that persuasive "bullock," as Demosthenes called itbeing at that time a Macedonian piece of money bearing the image of a bullock, and freely bestowed upon " pacifist" Greeks as a convincing argument in favour of submission-and plenty of blandishments and preferences, rural Germany was brought into a condition to support "patriotically" the Emperor's warlike designs, and to cheer the smashing of Sir E. Goschen's windows and the studied ill-treatment of British wounded and prisoners. It was Bernhardied and Treitschked all over.

The Emperor and his Government have therefore abused the names of Co-operation and of Agriculture, as they have abused the names and forms of other things under their control-justice, and not least so the nondescript LutheroCalvinist, supererastian State-made Church of their country, whose ministers read a chapter out of Holy Writ and make the sign of the Cross, and then solemnly tell their congregations from out of the pulpit that their supreme duty is in all things to obey the "Kaiser" and do his will."

All this Government befriending hocus-pocus after 1894 was a purely political move. In acting on Mr. Middleton's timely invitation to "learn from Germany," there is, indeed, not a little to be learnt, but Mr. Middleton is fully justified in making his reserves. We shall accordingly have to be careful to distinguish between what was done genuinely for Agriculture and what was done for the Kaiser's autocracy under the mask of Agriculture.

There are other grounds upon which, though certainly we should do wrong not to take German example to heart, we shall have to be careful to accept German example in

supposed unique prosperity and power, were plotting mischief against an innocent and peaceable victim. Herr Haas and his great junker Union, though professedly co-operative, but really to a much greater extent political, had advisedly declined to become members of the "International Co-operative Alliance "-which the German non-junker Unions had readily joined-on the ground, frankly owned to on a public occasion at Vienna, that the Executive Committee of the Alliance was (for reasons of practical convenience, the seat of the Alliance being in London) for the time composed of "Englishmen."

1 I have heard this done. 
the Pauline sense of "proving all things and holding fast only that which is good." Germany's recipe is our original recipe, strengthened and invigorated. Therewith she has scored signal success. It would be anticipating to go now into details. But it will be well at once to point out that there are substantial differences of circumstances, of temperament and of habits in the two cases, which argue that one nation's meat is not necessarily fit meat for another nation. We want a powerful educational apparatus, such as Germany possesses. But it may well be argued that we want it on different lines from hers. We are in a sense less painstaking. But we are better at seizing main points. If it was the German "schoolmaster" who triumphed at Sadowa, we know that it was the football and cricket fields of Eton and Harrow which "won Waterloo." Even in military proficiency, in which Germans profess to exercise supremacy above all nations, we have managed to hold our own pretty well, because our soldiers, although less drilled into machine-like action, have more ready resourcefulness to rely upon. It is the same in Education. Our Education is far more shaped to bring out character than the German and to instil that " mother-wit " of which, according to the proverb, an ounce is worth more than a ton of "learning." In this matter it will be safer to go with Professor Mahaffy than with Lord Haldane. Both, I believe, have drawn their impressions about German Education from the same alma mater. And we shall have to bear in mind that, if German Agriculture makes a good schoolmaster for us at some points, there are other schoolmasters in the field-from some of whom she has herself first learnt-as in the matter of Education from Switzerland, in the matter of organisation from Denmark. The youngest of all "cooperatively organised" countries, Russia, has in Siberia set us an admirable example in the co-ordination of huge masses of egg and milk production. And the United States have already more than one highly useful lesson to teach us, inaugurated either by the active and ever wideawake " Department," or else by such strenuously pushful institutions as the University of Madison. And do not let us 
forget Canada, which operates fruitfully on its own original lines! All round, in fact, we see push and movement, realised settled aim, and accordingly steady advance. We practically alone-among leading countries-have rested aimlessly upon our oars. Under such inertness and inability to make up our minds, adhering to old routine practices and letting things slide, our Agriculture, thus fallen into decay, the war has found us out as being as unprepared as were the foolish virgins of the parable, not thinking of their oil until the moment had come when they badly wanted it. However, people appear now to have pretty well made up their minds that this state of things cannot be allowed to continue; that, the lesson, once learnt, is to be well taken to heart. The iron wants to be forged while it is in a glow. Putting things off is likely to mean dropping them altogether and relapsing into our old loppaty-loppaty crawl. Such national misfortune should be guarded against. The body being found to be sick, there is one thing that we might well adopt from the German practice, now held up so much as a model to follow, and that is, to diagnose the illness discovered and analyse the causes of our agricultural decumbiture. That done, we shall be able to form a "National Agricultural Policy," and to pursue it methodically and steadfastly-let us hope with vigour as well as with judgment-and finally with success. 


\section{CHAPTER II}

\section{Renedies Suggested}

THE present condition of British Agriculture having, as already observed, been condemned by common judgment, and a determination having been unanimously expressed that something better should be put in its place, as a matter of course appropriate remedies have been sought after in diverse quarters and a variety of suggestions have been placed before the public.

Diverse as these suggestions are, there is one common feature running through them all, which one cannot help noticing with regret. Agriculture, so it appears to be assumed, is no longer able to help itself by its own force. Some one else is to step in to do the job for it. The public must be taxed to make it produce-not better, nor more, but at a dearer price. Agriculture in fact appears to have lost all confidence in itself. Agriculture, which raised itself to at the time unheard-of greatness by means of its own efforts, which triumphed over all hinđrances, reaching its "golden age" under the very withdrawal of outside aid, rising - to the admiration of its neighbours-more prosperous out of the ruins of a discarded policy of having things done for it, is henceforth to return for its well-being to its reliance upon the assistance of others and to attain supposed prosperity by being enabled to sell its produce above its market value, taking alms from its customers. Agriculturists appear to have lost all confidence in themselves. Whether by Protection, or by spoon-feeding with money, or otherwise-there are a variety of proposals--at all points it is some one else who is expected to step in to bring 
relief. This is a sad and humiliating pass for British Agriculture to have come to. Britons used to take a pride in doing things for themselves. It is doubly disappointing, since Mr. Middleton's analysis of German farming has made it clear beyond the possibility of a doubt, that German agricultural improvement has been the result, not of State aid, but of self-help-above all things of self-instruction and co-operative organisation by farmers' own efforts.

The creation of the Board of Agriculture has undoubtedly not a little to answer for in connection with this relapse. "Up to I889" - the year of its creation-so Mr. Prothero points out, "all the improvements in English farming, which at one time had gained for their country an undisputed supremacy in the art and practice of agriculture, were effected by private capital, by individual enterprise, by personal initiative." Landlords were the pioneers of improvement. "The creation of the Board of Agriculture altered all this. It constituted " an important reversal of the old ideal . . . a transference of responsibility from private persons to the public department." People looked to " the State," which, " for good or for evil, itself undertakes much of the control and expenditure, which formerly fell to the landowning class."

Human nature being what it is, it is indeed scarcely surprising that men of the very old school interested in "Agriculture "-economic " Bourbons," who neither learn nor forget--should have taken advantage of the opportunity to trot out once more their long stabled stalking horse of "Protection," calling out-as Sir James Caird, with a good knowledge of Agriculture and its wants, put it, in the 'fifties (when it had just been boxed up, as all the world thought, for good): "Give me back my crutch!" But, in truth, the proposal does little credit to human reasoning or to an even only dim recollection of historical facts. For, more particularly in its aspect of putting a duty upon wheat, the old policy has anything but a good record either in this country or elsewhere. "It was the war, and not the Corn Laws," so testifies Mr. Prothero, "which had given agricultural production the monopoly of the home markets." 
Therefore if our " high-pricers" want to be consistent, it is a continuance of the war that they should ask for, not Protection.

The weakness of the plea put forward is emphasized by the fact that it is based upon an assumption that war-time arrangement-which clearly constitutes emergericy measures -should be made permanent. The invalid of to-day is to be kept in bed all his life, coddled and fed upon titbits, having a nurse to look after him, and being physicked with medicine. His own right hand seems to have permanently lost its cunning.

Mr. Middleton has shown how very little-indeed, less than nothing-Protection has done for German Agriculture. And there is other evidence in plenty to corroborate his statement. The matter was thoroughly threshed out in Germany in Igo3. In a country in which reigning potentates and their entourage are the most broad-acred among a numerous and powerful host of broad-acred men, the interest of lords of many fields and forests is of course sure to be well looked after. In Germany, where the Emperor owns 250,000 acres, his cousin the Prince of HohenzollernSigmaringen and Prince Pless, I50,000 acres each, the King of Saxony 75,000 acres, Prince Bismarck 30,000 acres, and so on through a long list of reigning or else mediatised potentates and wealthy Standesherren, and where there is a vast number of landed proprietors below that supreme caste, all waiting to be bribed, in order that their loyal support may be assured to the ruling dynasties, it is quite natural that a measure which necessarily appreciates landed property, however much it may damage other interests, should be stoutly fought for and allowed to prevail. Had German Agriculture, however, not been assisted by other favourable adjunct occurrences, as Mir. Middleton has shown, such policy would have led those very beneficiaries into something approaching to bankruptcy, even if they had not, as this appreciating measure tempted them to do, promptly carried the benefit received to the mortgage pawnbroker, who now feasts upon the spoils.

Protection certainly has not made Germany independent 
of foreign foodstuffs. For, as we have seen, German Agriculture is still painfully dependent upon them, and nothing has hit her so sorely as our blockade. In the words of the Times of August 3, I9I6, " had the Central Powers been forced to rely strictly upon their own resources during the last year, there is a great probability that they would have known starvation before this time." They were very keen upon seizing the grain stores of Roumania.

And what has Protection done for France? It is in full swing there. There is a duty upon wheat which, for its heaviness, the late Paul Leroy Beaulieu-not by any means a Free Trader, as his Traité d'Économie Politique testifies -condemns as insensé. But that has not brought about a wheat growing self-sufficiency of the country. No more has it added to the number of believers in its doctrine. By its actual results it has set those who had first chosen it as their serving policy, against itself, as appears from what Miss Spedding writes in her very interesting article on "The Rural Prosperity of France," which appeared in the Quarterly Review of April, I9I7. "With regard to the part which Protection has played in the agricultural prosperity of France," so she says, " undoubtedly it helped to keep her poorer soil under cultivation during the latter half of the nineteenth century. To-day it is an open question whether it is any longer a benefit. Owing to the great improvement of agricultural methods during the last fifteen years many people in France are now of opinion that the protective tariff is retarding progress by making it unnecessary for farmers to obtain the highest yield from the soil."

That agrees thoroughly with what Mr. Prothero writes about our Agriculture in the bygone time of Protection. "Prosperous years had brought wealth to slovens, and sluggards had amassed riches in their sleep."

And how, in France, has Protection affected the yield, the improvement of which we are most anxious to bring about and for the effecting of which we are actually recommended Protection? The yield per acre is less than in this country, less by a good deal than in equally Free Trade 
Belgium, less also than in Germany, viz., I3. 8 quintals per hectare to the German 22. M. Albert Dulac, a farming landowner in Normandy, who has visited this country on purpose to study our Agriculture, in a little book published not long ago, draws an instructive comparison, very much in disfavour of France, between our two countries, and distinctly attributes French comparative backwardness to the fact that among ourselves, where there are no artificial aids to wheat growing, farmers are put upon their mettle and compelled to exert themselves, whereas in France the protective duty leads them to depend mainly upon that, and makes them pro tanto indolent. They do not put their best leg forward.

And to what extent has Italy benefited by a duty equally cxcessive, to the serious prejudice of its half-starved labouring population? Its yield ranks among the lowest average yields in Europe. Not long ago it was officially recorded that, as in the days of Columella, it reaped only four grains to one grain sown, in some cases only two. And whenever hard times come it has perforce to suspend its tariff.

How different are these results from those presented in high-farming Belgium, in educationally active Denmark, and in the pushing and calculating Netherlands, all of them Free Trade countries, which spurn Protection! Their yields stand at the top of the list, that of Belgium, thanks to an enlightened Government policy in the matter of means of transport, highest; that of Denmark, thanks to its highly developed co-operative organisation-as Mr. Prothero has recorded-about fifty per cent. above our own (he says that our average crop equals two-thirds of the Danish). And with regard to the Dutch farmer, who beats ours in dairying and cheesemaking, Mr. Robertson Scott writes :

"It would be a mistake to imagine that the natural man in Queen Wilhelmina's dominions was much more eager than the countryman of other nations to leave behind him the ways of his fathers and exert himself to manage his holding on new lines. . . . What set the farmer to use his wits and to seek and value science and commercial instruction was the gracious pinch of competition." 
Townshend and " Coke of Norfolk," when they wanted to induce their tenants to adopt their own more advanced methods of cultivation, putting more back and brains into their work, so as to produce more food, did not offer them a monopoly of their land or other preferential terms, but, on the contrary, raised their rent, so as to compel them to farm better. And that remedy had the desired effect. Now, is there not a lesson in all this?

And now let us look at home! We have had Protection. And we have had guaranteed prices. And how have they worked?

No one surely will quarrel with emergency measures such as have had to be taken during war-time. War-time is an altogether exceptional period. The dominating factor, while it lasts, is, not general principle but momentary expediency. The country is in the case of a besieged city in which, figuratively speaking, " an ass's head is sold for fourscore pieces of silver." The people must be fed. We are not mad enough under present circumstances to talk of Protection for foodstuffs. Rather should we be glad to pay a good fat bounty upon imported corn. However, to stimulate our farmers, beginning, as it were, afresh, we have rightly guaranteed prices. Aux grands maux les grands remedes. But that is one of the exceptions which proverbially prove the rule. We have had guaranteed prices before, when there was no war and no emergency. And they have done anything but answer. We have also had Protection before-at a time when it was not, as it must be under present conditions, complicated with necessary consideration for friendly neutrals and our corn-exporting Colonies, whose bottoms submarines respect as little as they do our own, and who have had a sort of promise given them by Mr. Chamberlain that they are to form our granaries. Are such friendly bottoms to be ruled out, or are we by a discriminating tariff to make their importation needlessly costly to ourselves-without even being asked for such a favour? And, in view of all such considerations, one feels inclined to ask: is the submarine danger after all really only a pretext? Is it only a mask put on by an 
old friend of dear food, in order to catch the public's favour for what is distinctly opposed to public interest? If not, we shall have to place Colonial corn, like hostile, on the Index.

Let us reflect for one moment! We are "out " to punish Germany. Be it so! She richly deserves it. But, for the sake of punishing her, are we at the same time also to punish ourselves even more severely? Other articles of course do not at present concern us. But nevertheless let us ask: by boycotting German and Austrian goodswhich ex hypothesi we must assume pro hac vice to be cheaper than our own, or they would not come into account, and in the shape of which Germany and Austria are eventually to pay us our indemnity, if they are to pay it at all-are we forcibly to compel those two Empires to form their redoubtable " Central European Union," a greatly magnified "Customs Union, as it would ke, to which the Balkan states, the Scandinavian kingdoms and Switzerland necessarily must gravitate, and from which we cannot reasonably expect Russia and Italy, geographically situated as they are, long to hold aloof-necessarily animated with a distinct hostile and retaliatory animus against us? We should be like the snake of the fable which rasped her own gums upon the attacked file. However, that affects us here only indirectly-although indirectly not a little. But how is our protecting wheat, whether it be by a bounty or a tariff, to injure either Germany or Austria? Certainly not Germany. For we should only be handing over neutral wheat markets to the undisputed possession of the enemy country, which would not be slow to take advantage of the monopoly so pressed upon it.

However, let us for a moment look at the history of the Protection of corn in this country and see what is its record!

There is no occasion to recapitulate the story of the "Hungry 'Forties," and the general miseries of that period, more specifically those of the industrial and labouring population. The industrial and labouring population had little to say in the affairs of State then and could do little more than voice its discontent by riots, and buckle its 
stomach belt more tightly. At the present time it is the most powerful factor in the State, and we may be sure that it will not sit still in face of a modern Pacte de Famine. It has shown determination and spirit enough in the matter of "profiteering." And it has been successful in its protests. It carries its suspicion of " profiteering" so far as to suspect even our landed proprietors of the offence. It may accordingly be trusted not to permit the hyperappreciation of corn and of bread at its expense.

We began taxing corn, under the modern aspect, in I804. The result was distress. Time after time were new inquiries into the presence and causes of such distress called fordistress so unmistakably pronounced that, speaking in Parliament, Lord Brougham declined so much as to enter into the discussion of its existence, since that was " now universally admitted to prevail over almost every part of the Empire." That was in I8I6, after the Corn Laws had been in operation in their new form just twelve years, and when a fresh sharp turn had just been given to the screw, raising the price of wheat, regarded as normal-that is, as precluding power to import under the law-from sixtyfour to eighty shillings, and when landlords' and tenants' fortunes kept tumbling down right and left, leaving erstwhile wealthy men dependent upon charity, and condemning the labourer, whose wages did not rise till he took to rioting and rick-burning, to abject poverty. In ISoI the price of wheat had stood at IIgs. $6 d$.; in ISI2 it rose to I23s. There had been an inquiry in I802-3, there was another in ISI4, a third in IS2I, a fourth in I833, a fifth was called for in I842. By that time, however, reason had begun to assert itself, and statesmen had almost arrived at a determination to abandon the deceptive benefit. The inquiries referred to had shown that Agriculture was retrograding, that land was going out of cultivation, harvests were shrinking, rents were being paid out of capital, capital was gone or going, and bankruptcy was taking the place of affluence. It would be worth while studying the Records of those Inquiries now. Somewhat later the Times Commissioner reported from Wales that small farmers, if they could live at 
all, could afford to live only on " duffery " or " flummery "that is, oatmeal and water boiled "-and mashed potatoes, never seeing meat once in a ycar. It was, in Mr. Prothero's words, "one of the blackest periods of English history." Farms were thrown up, notices to quit poured in, numbers of tenants absconded-many large farmers lost everything and became applicants for pauper allowance. ${ }^{1}$ Relief never came till $\mathrm{I} \$ 36$, when more propitious conditions, unaffected by the Corn Laws, ushered in a period of recovery. "The truth is," says Mr. Prout, who knew something of corn growing, having made a wheat-after-wheat shift to pay, " that yield and expenditure have a greater influence upon profit than the price of corn has."

The distress which extravagant appreciation of corn brought upon the industrial population, and thereby upon industry and commerce, as a matter of course reacted powerfully upon Agriculture in depriving it of its market. Summing up the general effect of the Corn Laws, in the latest edition (I9I2) of the "Encyclopædia Britannica," Dr. Ingram puts it this way:

"The corn statutes (from I8I5 to I836), though occupying an enormous amount of time and attention in the Houses of Parliament, may be briefly treated, for they are simply a record of the impotence of legislation to maintain the price of a commodity at a high point, when all the natural economic causes in operation are opposed to it."

And so it was to the end of the chapter. Real relief, which Mr. Prothero calls " the golden age of English Agriculture," never came till I853, when the Corn Laws had been finally repealed and when Free Trade had had time and opportunity to produce its inevitable results. The Nation had by that time adopted Sir J. Caird's wise advice to take to "High Farming as the best Substitute for Protection," and it prospered upon it. And it had found that Sir James was right also in his declaration that the previously dreaded Free Trade was not " an enemy bent on mischief, but a kind and judicious friend," stimulating to increased production which carried profit with it. The Germans who,

2 R. E. Prothero, "English Farming, Past and Present," p. 319. 
not being interested parties, but only vigilantly observant onlookers, and willing learners, have long since-about the middle of the past century-discerned in the progress of our Agriculture the welcome stimulating effect of Free Trade. "It was high farming and the liberal use of fertilisers," so wrote, among others of high authority, the late Professor J. A. Stöckhardt in the days of his greatest influence, " which raised British Agriculture to its enviable height and carried it triumphantly over the crisis of the Repeal of the Corn Larvs." And such high farming and liberal manuring were directly provoked by the advent of Free Trade. "During the era of Protection," so writes Mr. Prothero with respect to this matter, "landlords and farmers had learnt to rely too entirely upon Parliamentary help in difficulties. They had been prone to expect that alterations in the protective duties would turn the balance between the success and failure of their harvests. Now, disappointment after disappointment had taught them the useful lesson that they could expect no immediate assistance from legislative interference and that, if they wanted aid, they must help themselves." Just the same as had happened during the preceding great war, once more to quote Mr. Prothero, "the struggle in which the country was engaged quickened the activity and industry of the population, stimulated agricultural improvements, sharpened the inventive faculties to economise both in money and in labour."

Farmers learnt to put their best leg forward. They thought out economic improvements, methods to increase yield. It was then that we took to the liberal use of fertilisers, which a bountiful Providence had mercifully placed at our disposal in new forms, at the same time that Science had, through her students-foremost among them Professor Liebig, whose epoch-making book appeared in I840-taught us how best to apply them. And in this way, under the powerful stimulation of need, fecundating our natural resources of inventiveness and practical sense, we produced the prosperous Agriculture of which Sir James Caird sang the praises in I850-as did a whole chorus of German pro- 
fessors and practical men not long after-and at which we have practically stood still, as Mr. Prothero in his book admits, and as is, in truth, evident to all observers.

Let us, for a moment, look a little farther afield, for new experiences! The experiences of a distinctively agricultural country, while under Protection, ought to some extent to serve us as a guide in the consideration of the matter. Here is what the Canadian Council of Agriculture in representing the organized farmers of Canada, voted December, IgI6, and what has been formally endorsed by the Manitoba Graingrowers' Association, the Saskatchewan Graingrowers' Association, and the United Farmers of Alberta, organisations composed of from $\mathrm{I} 2,000$ to $\mathrm{I} 5,000$ members each:

"Whereas agriculture-the basic industry upon which the success of all other industries primarily depends-is almost stagnant throughout Canada, as shown by the declining rural population in both Eastern and Western Canada, due largely to the increased cost of agricultural implements and machinery, clothing, boots and shoes, building material, and practically everything the farmer has to buy, caused by the protective tariff, so that it is becoming impossible for farmers generally to carry on farming operations profitably ... this Council urges that, as a means of bringing about these much needed reforms, and at the same time reducing the high cost of living, now proving such a burden on the people of Canada, our tariff laws should be amended as follows:-

I. By reducing the customs duty on goods imported from Great Britain to one-half the rates charged under the general tariff, and that further gradual, uniform reductions be made in the remaining tariff on British imports that will ensure complete free trade between Great Britain and Canada in five years.

2. That the Reciprocity Agreement of IgII, which still remains on the United States statute books, be accepted by the Parliament of Canada. (This has in the meanwhile been done.)

3. That all foodstuffs not included in the Reciprocity Agreement be placed on the free list.

4. That agricultural implements, farm machinery, vehicles, fertilisers, coal, lumber, cement, illuminating fuel and lubricating oils be placed on the free list.

5. That the customs tariff on all the necessaries of life be materially reduced.

6. That all tariff concessions granted to other countries be immediately extended to Great Britain. 
Expertis crede! The Canadian farmers know what Protection means to Agriculture. They are recognised as cute men who know their mind. Are we indeed going to be blind to the teaching of their experience?

" Progress in Agriculture," so writes Mr. Prothero," may be summed up in increasing the yield and lowering the cost of production." Now what can Protection do towards achieving either of these ends?

And the same high authority writes:

"It is not easy to decide whether consumers gained most by the laws which kept corn in the country, or lost most by those which kept it out. In the twentieth century, when there is a large addition or alternative supply of grain, produced under different climatic conditions to our own, there could be no question that the loss inflicted by the prohibition of imports would be incomparably the greatest.'

It is urged on behalf of Protection that it will enable us to make ourselves independent of foreign supplies of corn. Well, let us see what is the prospect of our accomplishing such end. We have examples close at hand. If there is any one country more favoured than others under the aspect of producing breadcorn for itself, that country is France. France has attempted the task. And how has she fared? She has imposed a duty of 7.50 francs per quintal upon wheat. Farmers chucklingly congratulated themselves that they would keep out foreign wheat. But scarcely was the war note sounded from Berlin, that is, on July 3I, IgI4, but her rulers found it necessary, on the very same day, to suspend all import duties on foodstuffs, opening the gates of the country wide to foreign imports. And within the first five months of the war the country was very happy to find that it had imported 8,397,593 quintals of wheat. After that it strained every nerve to get from Manitoba what it could.

Germany likewise has-since more than twenty yearsstrenuously tried to make herself economically independent. And now we hear through the complaints that come to us from all parts of that country, and from the charges levelled against us, that we are making war on her women and 
children by starving them, how little she has succeeded.

Where France and Germany have failed, under so much more favourable conditions, how are we, with our limited acreage and our tecming population-and our larger wants in respect of other foodstuffs besides corn-to succeed? Our protectionist friends are shooting at the moon.

But, if we cannot make ourselves absolutely independent, at any rate, so it is argued, we shall be able to stimulate the cultivation of wheat by a duty or a bounty, and so make our land produce more than it did before. That effect must appear extremely problematic. For in ordinary times the sensible farmer is "out" for making money. It will take a high duty indeed to make wheat growing in ordinary times more profitable than other forms of husbandry. Between I874 and I885, writes Mr. Prothero, landlords and tenants became " convinced that Protection of food produce can never be revived on a scale which can really help corn growers." And then, what will the consumers say? It is they who rule the roast.

But, so it is urged, Protection will "steady" the market. Will it ? "Now, in times of scarcity," so writes Nr. Prothero, "they (that is, the Corn Laws) only increased the range of fuctuation in rise and fall by excluding alternative supplies." That was our experience in England. Now look at Germany! At the time of its Fiscal Controvery-which coincided with our own-a chart was circulated among our Members of Parliament showing the difference in the price of wheat as between our free trade country and protectionist Germany. That chart was telling in its way. But, as it happened, it only told half the tale, which was at the same time placed before the German public by Professor Conrad-not a Free Trader-in his well-known "Jahrbücher für Nationalökonomie und Statisch." Iis chart showed how very great were the fluctuations and also the variations of price in Germany herself as between one part of the country and others. We in Great Britain have practically one price at all places. At any rate differences are only slight. Mark Lane rules the market. Under 
German Protection that is not so. Interfere with the natural movement of the market, and you cannot tell to what extent the whole machinery will become dislocated and disjointed. The difference of price as between cornproducing districts, in which the consumers' demands are small, and industrial centres, where those demands for the labouring population are naturally large, was truly staggering. Corn, which, in spite of high Protection, sold cheap enough in Pomerania or East Prussia, commanded a veritable famine price in industrial towns in Rhineland and Westphalia. There was no "steadying" effect whatever about Protection. The co-operative granaries subsequently constituted, so far as they were conducted in a businesslike way, had a far more steadying effect. The Irish are wise in deciding to acclimatise them.

What has made our " old school" agriculturists revert so readily to their pet idea of Protection is of course the present obsession of the public with regard to the importance of growing wheat. Now wheat, of course, there must be. And in war-time there cannot be too much of it. However, please God, we shall not always be at war. The very object of our present fighting is to lay the sure foundation of a lasting peace, in which there will be no danger from submarines, and sea traffic will once more be open and safe. In Mr. Lloyd George's words, "we are fighting to eliminate war from the tragedies of human life." Morte la bete, mort le venin. There will be no need then to exorcise the devil, when he is banned and laid to rest. It may be argued that, in spite of all our precautions, he might conceivably return. Well, and for such contingency we want to be prepared. And that we shall not be by growing a maximum quantity of wheat at all times. Quite the reverse. Wheat is an exhausting crop. And it is crop which requires a clean soil, but, growing on it, fouls it. We want at any rate a " cleaning" crop sandwiched between it. Mr. Prothero dwells upon "the useful rule of never taking two corn crops in succession." "Wheat, wheat, wheat," moreover, means bringing us back to the happily abandoned, wasteful and exhansting, earlier style of farming of the " three-field 
system," which requires a bare fallow to clean the land. Of course, wheat can be grown continuously, and, as Mr. Prout has shown at Sawbridgeworth-and others elsewhere; it can even be so grown at a profit. But why labour for a second or third best, when we can have the very best in an even more profitable way? Wheat requires some other crop-clover, or roots, or some leguminous plant-as a " preparation," and the interposed crop makes husbandry all the more profitable. "Greater reliance on green crops, grass and forage, as contradistinguished from corn, but not to the exclusion of corn," is what Sir J. Caird warmly recommends as a "substitute for Protection." And there can be no better advice given. "We need be under no apprehension," so he continues, "of thereby unduly diminishing the growth of corn; for the more stock an arable farm maintains, the more productive will be its yield of corn." It is "rotation cropping," which has raised modern Agriculture to its actual height, from which it may very well, with intelligence and application, rise to a higher point still. Mr. T. Wibberley has opportunely shown us the way of carrying Sir J. Caird's maxim of "The more fodder, the more grain " very much farther than its own author can ever lave thought possible. In rS86 people spoke of "Three Acres and a Cow." Mr. Wibberley now speaks of "A Cow to the Acre." By means of his "Continuous Cropping" - the practice of which has lately extended into England (on a farm in Surrey)-under which the land is practically never left idle (hardy fodder plants occupying it in winter), so much fodder is raised, in the most convenient and economic way, that a third, or at most half, the land will produce in fodder what now the entire area produces, leaving accordingly a considerable portion free for extended corn growing, should such be deemed necessary. The system has other advantages. It greatly economises labour, and allots it in such manner to the various seasons that it comes to be equally distributed over the whole length of the year. There is no special " rush" in spring. Fewer hands suffice. And, mucl of the plough work being relegated to summer time, whereas 
the wet seasons bring rest to the teams, that same rain which now so often is the tiller's foe, becomes his beneficent friend. For field work is timed so as to fall into the time when rain is a help. This green cropping likewise, with its perpetual covering, keeps the land clean, and by its vegetation evaporates much moisture in the season when moisture in the soil is a nuisance, while keeping the land shaded in summer. And it enables the farmer greatly to reduce his purchases of both artificial fertilisers and, even more, of nitrogenous feeding stuffs. On a farm occupied by Lady Coghill and Miss S. Oer Somerville, in Ireland, under " Continuous Cropping " the yield of milk was found to have become trebled in comparison with what it had been under grass. Elsewhere similar results have been observed ; and the output of beef and mutton has likewise been found to have doubled or trebled. On a farm in the North of Ireland occupied jointly by Lady Francis Hope and Mr. Wibberley, where four years ago the farm staff could cultivate only thirty-five acres, besides looking after sheep, cows and other live stock, now, the head of dairy cattle having been doubled, the same staff suffices for the cultivation of IIo acres. On one of Mr. Wibberley's own farms of 360 acres, under " Continuous Cropping," in I9I6, $£ 5,200$ worth of beef and mutton were sold, the expenditure on feeding stuffs amounting to only $f 80$. The nitrogenous "fleshformers" previously given in that form had been provided without cost in the crops of leguminous plants raised. Since we import annually 20-30,000,000 tons of cake and meal, representing a collective value of about $f_{1} 60,000,000$ in ordinary times, the latter point is worthy of consideration. " Continuous Cropping " ought to become a feature in our farming. There is a good deal more money in it for the farmer than in Protection.

What we want, in fact, in view of possible future wars, is not an actual maximum cultivation of wheat, but a capacity for growing a maximum quantity when the pinch does come. Now to that desirable point the way lies, not across permanent maximum wheat cropping. Quite the reverse. It lies across very careful preparation of all the soil that we 
can press into our service for growing wheat, when the critical time comes. Now in view of such contingency, in the presence of which all other considerations must necessarily go by the board, we are potentially-unless the human factor in the problem should fall into default-quite sufficiently prepared. Under Mr. Lloyd George's, Mr. Prothero's and Sir T. W. Russell's driving we have in IgI7 made ready a round million of acres beyond what we had before (only 300,000 acres in England)-which is after all a fairly substantial addition to the earlier I,900,000 acres-for autumn sowing. That is a gain for which Mr. Lloyd George rightly took credit-but not nearly sufficient gain. And it has a warning for us of which, while talking of "pushing" the cultivation of wheat, we might do well to take note. After Sir T. W. Russell had scored his great success in Ireland with the ploughing up of pasture for tillage, it was discovered that milk was running dangerously short, and the trouble was, how to make good the deficiency. As much as 650,000 acres had been ploughed up. But, as a consequence, no less than $45^{\circ}, 000$ head of live stock had had to be got rid of, among them 2 I,000 dairy cows. And the question was, whether, for food production, the last state of the country was not, as a result, worse than the first-especially as no one knew what sort of crops would actually grow upon the ploughed-up land, whereas everybody was well aware what was the practical value of $2 I, 000$ dairy cows and 450,000 head of live stock, for the production and maintenance of which Irish soil and Irish climate seemed especially made. "There is many a man," says a French proverb, "who has exchanged his one-eyed horse for a blind one." And when the matter came to be looked further into, it was discovered that, supposing that the 650,000 acres were to produce good crops, there was no space available in which to garner those crops! The clever men at the head of Irish Agriculture had reversed Swift's famous judgment of "Irish sense" "and "Irish wit "--when there was something maturing that was "worth defence," there was no "magazine" to put it into. However, Mr. Prothero has since spoken of "three million acres" that we may make 
ready. And Mr. A. D. Hall has shown in his book, "British Agriculture after the War," that, if we only have warning given us by a declaration of war in August-which is late in the year; the earlier European wars, of I864, I866, and 1870 , were declared in June, allowing more time-we can get ready "seven million acres" in all. That in all conscience ought to be enough for an emergency. And that calculation takes no account of waste lands which may meanwhile be reclaimed. Having such area to depend upon, our care evidently must be, to get it into fit condition for producing a maximum yield of wheat when the time comes. For it is not merely acreage that produces wheat. The Romans had a proverb: ammus producit, non ager. Under our present aspect we might put it: stercus et labor producunt, non ager. It is the fertilising matter, the labour and care, the cleaning, digging and ploughing, harrowing and hoeing, which make the good crop. Now for such fertilising and cleaning and preparing for a coming wheat crop the cultivation of other crops-overshadowing leguminous plants, which by their roots put the soil into good condition, and kill weeds ; roots, which stand a great deal of manuring and require careful working of the soil, which means cleaning; and clover, which gets the soil into good heart and good condition-in fact every crop other than cereal-provide the best means. Cultivating them you must cultivate carefully. And, if properly looked after, they leave the land in good condition and clean. And, as it happens, there is not one such crop-with the exception of fruit trees, shrubs and hops-the land under which may not on the occasion arising be at once employed for sowing wheat that same autumn.

Wheat, moreover, is, as observed, not the most paying crop at our disposal. Under normal conditions we have heard it called "ruinously cheap," which, of course, cannot mean that it is highly profitable to grow. And is it not to the interest of the Nation that we should turn the little land that Providence has given us to the best money account, when there is no force majeure to compel us to concentrate our efforts on one particular point? In his 
early days Sir J. Caird gave farmers the very reasonable advice to grow that which would pay them best. "Tenants should cultivate as much as possible that description of produce which has a tendency to increase in value." And there is no gainsaying the good sense of that.

Are we in time of peace to keep our men and women munition making? Are we in time of peace to keep up our emergency army, because there may be a fresh war? Are we to deprive ourselves of the profitable production of factories and workshops, of trade, banking and commerce, in order to keep all our people under arms? But that is just what it is proposed that we should do in matters of Agriculture-forgo the profitable, in order to push emergency work.

We are spending thousands of millions to purchase abiding peace. Having paid that insurance, are we not to profit by it? Are we to go on as if we were uninsured? That does not seem worthy of a "Nation of Shopkeepers,"which, put into less uncomplimentary language, means "a Nation of Businessmen."

Wheat is not the most paying crop, among other reasons, because we cannot produce it of premier quality. It is in our country an exotic. We grow it, and produce quantity, but not quality. For baking purposes it has to be mixed with grain from some more sun-warmed climeHungary, or India, or, best of all, Manitoba. Cambridge is hopeful of "breeding" a new type of wheat which is to pass muster by itself with the baker, just as Pusa has produced its famous "Pusa No. I2." However, Pusa is operating in the wheat's own native land, or at any rate very near it. For it seems likely that the original home of wheat was Miesopotamia. Cambridge is doing very clever and very useful things. But it cannot produce sunshine and sun warmth. And that is what wheat wants. It likes a dry climate and warmth-Amée sêchen'a jamais fait pauvre son maitrc. Our wheat is greatly deficient in gluten. Its gluten is described as "soft, moist, of great extensibility and lacking in tenacity," which makes it indifferent for baling purposes. The Germans have in their 
"Kornhaus" devised a means of rendering their own wheat "bakeable" by artificial desiccation. But that will not produce gluten. German farmers grow our wheat, as French vine-growers of the humbler sort grow what the late M. Foëx, when Principal of the Montpellier College, termed " democratic" wines, for the sake of a big yield. But the one makes inferior bread, as the other makes insipid " Aramon."

Why not, in ordinary times of peace and security, leave wheat growing, beyond what naturally fits into our rotation, to those who can produce it both much more cheaply and of decidedly better quality, and employ our acres to produce what will bring in more money at the same time that, instead of exhausting and fouling, it improves the soil in its condition and heart?

Archdeacon Paley's famous argument about a watch is generally considered a good one. It was to this effect, that, if he were to find a watch, composed of so many different parts, each of which was manifestly designed to perform a certain and distinct function, he would with confidence conclude that the watch was made advisedly to accomplish a certain object, and that, being so designed, it could not be a fortuitous production, but must have a maker. And this reasoning he applied to the world composed, as it is, of so many different parts, each evidently designed to perform some function peculiar to itself. Those different parts obviously includes those remarkable differences in climate, soil and geographical position which qualify one country to produce cotton, another tea, a third good bakeable wheat, and a fourth luxuriant green crops and roots. To turn their various functions topsy-turvy, to want to produce early potatoes in Aberdeenshire rather than in Cornwall and the Channel Islands, and plant St. Dunstan's famous fig tree, which produced tasty beccaficos to Charles Lamb's delight, in the Shetlands, instead of in West Tarring, and so on, manifestly would be acting very foolishly and in opposition to what both Menenius Agrippa and Saint Paul have laid down as plain common sense. That applies a fortiori to the produce of different countries such as Manitoba, Argentina, and our own. The big wheel in the watch cannot do the work of the small, nor the chain the 
work of the spring. Why then attempt to fly in the face of Providence and force the growth of wheat where obviously long neglected potatoes, green crops and beet are intended to be grown as main produce, because they grow there most lustily? Last August with its rains and storms has given us a reminder - which may have been intended to be providential - in view of our disposition to swim against the streamthat if we insist upon relying upon our own cultivation of wheat, we may at times find ourselves reduced to very short commons. We cannot successfully fight against climatic influences. "If the experience were to become common," so writes the Agricultural Correspondent of the Times, " it would be necessary to devise some means of securing the crops, which is not yet adopted in this country." And he goes on: "Wet harvests are not rare in our climate, especially in the North, where the dripping corn is sometimes carried into drying racks, heating being obviated by the use of wires, on which the sheaves are suspended and can remain to dry as the season permits." Then why attempt to be unreasonable and set, in Lord Macaulay's phrase, "piano makers to bake our bread and bakers to make our pianos "? The same wet seasons have no terrors for green crops. In fact the wheat's poison is the green crop's meat. With our climate, such as it is, are we to fight the French vine growers with our hothouse grapes? In wheat growing we cannot compete with Manitoba or Argentina, or even Hungary.

That is not all that is to be said in favour of making green and root produce our " pivot crops." Professor Wood, of Cambridge, has calculated what great waste there is in our production of meat and milk by feeding with corn -at any rate in hard times, such as we are now proposing to guard against, when corn is urgently required for human food. It takes $\mathrm{I} 2 \mathrm{lb}$. of dry grain to produce I lb. of dry human food in the shape of pork; I4 $\mathrm{lb}$. in the shape of poultry, much more in the shape of beef and mutton. "No animal returns in meat anything like the food value that it absorbs in the shape of corn." Meat food for man is, indeed, more valuable pound for pound than animal folder. 
As much as 9,250,000 tons of corn now goes into live stocks' bellies in the year, apart from offal, as compared with about 5,000,000 tons consumed by human beings. We can produce the same quantities of live stock food, containing the same flesh- and fat-forming constituents, in the shape of green crops, which laugh at rain and storm, far more cheaply and with less trouble and risk. Our leguminous crops are full of nitrogenous matter. Then why must we labour and spend, and run the risk of wet harvests and other mishaps, just for the sake of remaining true to our old exploded tradition?

With their accustomed Lancashire shrewdness the Cooperative Wholesale Societies give us a very good lead in this matter. They have recently acquired I0,240 acres of excellent wheatland in Canada, specifically for wheat growing, to supply their corn-mills, which provide their stores with flour. The English Co-operative Wholesale Society alone owns besides in this country something like I4,000 acres (independently of what the Scottish Society possesses). On that land it grows wheat only occasionally, as the rotation requires, reserving that land in the main for very much better paying produce. Here we have the proper use indicated severally for colonial land and land at home.

There is new produce becoming essential to our nourishment every day-produce which is not as easily and cheaply transported, produce in the quality of which freshness, such as we can ensure by home production, is an important factor, and produce which yields a much better return in money. It is variety, "diversification," as they call it, that Secretaries of the Department of Agriculture of the United States are, after the example of Ciermany, most urgently calling for among their farmers-variety which will tell off to every soil and every climate the most suitable and most paying crop, and so bring about the most profitable utilisation of the land and produce the best value alike for the cultivator and the Nation.

Do not let us, then, make the decay of our Agriculture worse by going back to the obsolete methods of husbandry! Iian does not live by bread alone. There is other food 
which we want as urgently, which we can produce at a good profit and much of which we could not with advantage import from abroad. Every day new wants arc making themselves felt. And every day also, fortunately, Agriculture is showing its capacity-though still on all too small a scale-of rising to the occasion and meeting those wants. Our lovers of old ways will have to recognise that times have changed and still change. The old order has given way to a new, in every country marching onward to perfect civilisation. A country in the natural order of things, according to what has been called "von Thünen's law," begins with forest and pasture. Pasturage gains on forest. In course of time comes reclamation. Then enclosure. Then comes extensive cultivation of cereals. As town populations increase and spread out cereal fields recede. Market gardens take their place. A belt of such gardens, and grass fields of better quality, is formed round cities, producing much more in the shape both of food and of money than the cereal fields. That belt deepens as time goes on. It keeps encroaching upon what remains of cereal culture. We are in that stage now. Cereal cultivation must give place to higher husbandry, as the Red Indian has given place to the white man. We do not in the present day (outside war-time) eat less bread. But we consume more other articles. And, especially, as they pay better, and are less fit for transport, they must be allowed the preferential claim. Milk, above all things, we cannot import in its fresh state. But it pays to produce it. And milk-mainly by the light of foreign teaching-we are learning to produce more scientifically and therefore of more marketable quality. What with cow testing, analysing, bacteriological examination and improved processes, it is becoming better and better worth producing. It wants pushing. Milk and dairying pay so well that Danes and Dutch have given up wheat growing in their favour and beat us with them in our own markets while, crying out for the "wheat" which they have discarded as unprofitable, we foolishly neglect the gold for the dross. British meat will always be appreciated above other meat. We are 
finding out now also about the more profitable production of eggs, large quantities of which come to us, as " new laid," from Italy and far Siberia. We have begun to cultivate tobacco, and find that, instead of the stuff " that would not even answer for fumigating plants," as one high agricultural authority (the late Mr. Warren) described it to me some thirty years ago, it makes a very " smokeable" as well as remunerative product. We are growing sugar beet and making sugar out of it, without compunction -in spite of the West Indies and Queensland, whom we were erst accused by super-patriots to be robbing by using beetroot sugar at all-which sugar was to be taxed up to prohibition point in order to save the cane growers. We know better now. And we are to have potatoes for industrial purposes-the great stand-by of German Agriculture. Our cultivation of fruit is making prodigious progress-and is paying. There are, then, a considerable number of uses that we can put land to, calculated to extract from it a higher return than wheat, and in ordinary times, of even greater importance, keeping the land which they occupy in excellent "preparation" for wheat, when the time for pushing that crop comes. When are we going to begin to treat Agriculture as a "business"?

The true causes of the shortcomings of our Agriculture evidently are to be sought in an entirely different quarter from that in which we have been looking for them. Sowing more land with wheat will not necessarily ensure a sufficient or even corresponding addition to our national outputmore particularly if by means of a bounty or Protection in any form a direct inducement is given to the grower to grow more carelessly, since he may in this manner pocket the same amount of money as before with less cash paid out or labour bestowed. What tells against our Agriculture, in comparison with others-as, under Mr. Middleton's showing, in comparison with German-is not so much deficient acreage — though no doubt our acreage is lamentably small-as deficient yield. It is not the "roo acres" of Mr. Middleton's Report, so much that we fall short in, as the seventy to "seventy-five persons" nourished by their 
produce (in Germany) for which we can muster only fortyfive to fifty. Now one would like to put the question: Is a bonus to be given in respect of wheat growing-no matter whether it takes the form of a bounty or of a protective import duty-at all calculated to increase the average yield per acre? If you have a workman "ca'ing canny," do you tell him: My dear fellow, you are doing badly; I will give you a better day wage? Or do you put him " on the piece"? We have known some working men who, when they were too well off, would work only three days a week instead of five and a half, because they earned enough in those three days to keep them comfortably for a whole week. Will not our backward farmer, "out" for no more than a "living," as Mr. Hall has put it, do in substance the same thing? He produces, say, three quarters to the acre. You want him to produce five. Will you tell him : You shall have more money for every quarter? "Well and good," he is likely to answer, "then I can take things easy; I will only produce two in future." The West Indian planter, when he found that his free negro worked poorly on day wages, did not add to those wages, but put his man on "cane farming "- unfortunately not without in some cases grievously oppressing the labourer. But there can be no doubt that the principle adopted was right, and the remedy has answered, so far as growing goes. Antiquated milling of cane is another matter.

Will not something analogous to " the piece" be more to the point in our case?

Landlords, by the way, who plead, as has been done in the public Press, that the "ruinously cheap price of wheat" has compelled them to put their land under grass," to save them from bankruptcy," practically give not only their own case but incidentally the whole case for Protection away. For, as regards themselves, we know that properly tilled land pays a better profit than grass, while at the same time also doing better for the Nation. And as regards Protection, they admit that we are to be seriously out of pocket, and tax the working men heavily, in order to abet them in "ploughing the sands" of unprofitableness, when 
it is profitableness that the Nation certainly looks for. The fault really lies with such landlords occupying a position for which they do not possess the necessary capital, such as tillage undoubtedly in the present day requires. That being so, they ought in justice to the Nation, which has a right to ask that it should be fed by the land, to get out of their possessions, or else to reduce them so as to make them proportionate to their capital. Land in England is not a ranch. You can scarcely in fairness make the consumer answerable for the landlord engaging in a landlord's business with insufficient capital.

"Landlords," so writes Mr. Prothero, " have no money to make the necessary changes. To say this, however, is only to say that the modern system of farming has broken down in one of its most essential features."

The condition of our Agriculture, portrayed as it has been by master pens, some of whose writings have been here quoted, make it quite clear where really the shoe pinches. One point which people writing about a paying price for wheat appear to be constantly losing out of sight is this, that the more intensive the farming, the larger accordingly the number of bushels reaped to the acre, the smaller is the cost of every bushel, the wider the margin of profit. An industrial factory turns out more cheaply than a single worker, because it turns out much more to the same implement and the same horse power. The ton of coal stands us in more at the rate of 248 tons turned out by one man, as compared with 472 tons turned out by one man in Canada, 542 in Australia, and 600 in the United States. So do our shoes stand the shoe manufacturers in more, whose men turn out, with $I_{72}$ horse power, I7I per man, to $5 \mathrm{I} 6$, which a man turns out in the United States with 486 horse power. It is the same in farming. It is intensiveness which makes things cheap. The "law of diminishing returns " as distinguishing Agriculture from Industry, has been pushed too far. That on well tilled, long cultivated soil, as at Rothamsted, there is a limit to remunerative manuring is perfectly true. However, the bulk of our cultivated land does not stand in the same 
position. It requires manuring heavier than that which it has hitherto received. And for some time to come the limit at which " increasing returns" give place to " diminishing returns "-although in every case of course there is such-may reasonably be left out of account--certainly in those fields distinguished by the backward farming whicl the Departmental Committee and other high authorities have singled out as answerable for our deficient production. Time was when we produced wheat that was then called "fivefold." There may be farms now where we do so still. But, generally speaking, we now produce " fourteenfold." That makes all the difference to the producing price of the bushel.

The story of our Agriculture of the past half-century is not a particularly bright one. It has, as $\mathbb{\text { r }}$. A. D. Hall puts it, been " one of continuous decline." We began well. We were the vanguard of the Agricultures of civilisation. All the world came to us to learn. However, the time of trying arrived. And under our present system we were not found equal to the probation. The time of trial found out our weak spots. Tenants discovered that they were being wronged. Being Britons they would not take it "lying down," but combined to obtain redress. It was a stirring time, agriculturally, the time of the Farmers' Alliance. We were as forward in it in Sussex as farmers anywhere. The Alliance fought and secured some reliefwithout, however, exterminating what is considered to be amiss. We still in the present day hear echoes of once familiar battle cries and complaints-about covenants, about rent raising, about excessive interference, about failure to pay full compensation, and so on. During the depression much, very much money was lost-and with it heart and elasticity of enterprise. One notable consequence, as observed, was the wholesale conversion of arable land into pasture and the taking up what Mr. A. D. Hall has appropriately called "lazy" farming-a warning symptom of a widely diffused proclivity in the farming class. The object was to save outgoings, above all things, Labour; If it be argued that it was a necessary policy, 
it certainly was a wasteful one-killing the hen which was to lay the eggs. Attempts to reduce the labour bill were carried to an extravagant length. It was a melancholy thing to see-as I did in company with two well-known Sussex land-agents-the experiment which-purely as an experiment-Mr. Faunce de Laune carried out on his property of Sharsted Court in Kent, of leaving a field of grass - good grass, too-to rot on the stem, merely to see how the account would stand, supposing that, for the sake of saving labour, grass were not cut, but allowed to decay into mud, so as to manure the ground. The conversion of $3,700,000$ acres of arable into pasture certainly meant a tremendous loss in annual output-all the more as we know things now, and the many have at length learnt, how very much more, even food for their live stock, arable land will produce than pasture. And letting labour go meant depriving Agriculture of the best instrument for productive working. Saving outgoings also must needs mean letting even what arable land remains fall into a deteriorated state. And that is what has come about. Rightly enough did Lord Crawford, when President of the Board of Agriculture, observe: "Shortage of Labour means bad cultivation, and bad cultivation means bad yield. It also means that it will take two or three years, and in some cases four years, before the quality of the soil can be re-hearted." In the same sense Mr. Prothero has since said at Exeter: "Labour is the key to the whole trouble."

In this way our Agriculture has sunk into the proverbial " slough of Despond." There was no need for it. "There is still a very substantial profit in arable land," so wrote Mr. A. D. Hall as late as in I9I6, with wheat and barley at the prices assumed-viz., severally wheat at 36 s., and barley at $32 s$. And again :

"In every part of the country we may see instances of the way a really knowledgeable farmer on the look out for opportunities makes successful departures from the ordinary routine of his business and obtains general average of profit far higher than that set out in the typical case quoted." 
And the profit "quoted" was not bad. However, the "really knowledgeable farmer" is not forthcoming in anything like sufficient numbers. He distinguishes himself " on one side of the hedge." And on the other side and all round there is backward old " leather jacket " farming, as "grandfather " practised it in times when, as Lord Beaconsfield put it, there were still really " three livings" to be got out of the land. In truth, the "really knowledgeable farmer" does not exist in anything like adequate number to answer the requirements of the Nation.

"The real limitation," once more to quote Mr. Hall, "lies in the lack of skill and enterprise among the farmers of the country taken collectively." "The ordinary farmer," so he goes on, "is a pretty good master of his craft. He knows how to manage his land. He has an instinct for stock, and he gives very little away in the practical day-to-day management of his business. He is, however, very closely bound inside the routine of his district; he has little acquaintance with the methods by which other people attain the same ends, and is impatient of even attempting to think whether he cannot introduce modifications in his own system. He is apt to regard his style of farming as inevitable, something that Nature imposes upon him and that he ought not to attempt to alter. It is just this lack of flexibility of mind, of the power to look abroad and consider his business in a detached fashion as a whole, putting aside for the time details which are otherwise essential, that marlis the imperfection of the education of the farmer to-day." And again : "What the ordinary farmer needs above all things is better education. And by this we mean not so much additional knowledge of a technical sort, but a more flexible habit of mind and the susceptibility to ideas that is acquired from acquaintance with a different atmosphere." And once more : "We feel justified in concluding that the average British farmer is not educated up to his position or his opportunities; but it is not so much technical education that is lacking as an awakening to ideas that is acquired from acquaintance with a different atmosphere."

The excessive preference given to grazing, which, barring Mr. Prothero's temporary, very timely interference, landlords will not consent to have reduced-because, as Mr. Hall shows in another place of his book quoted, they are afraid that they might eventually have to pay over again for a second laying down-is answerable for a good deal 
of present deterioration. Taken collectively, that has produced little, not only because any soil capable of being treated as arable land will yield considerably more under arable tillage than under grass, but even more, because among the 3,700,000 acres laid down to grass within the past four decades there is a large proportion of land which is really not fit for pasturing. During the Napoleonic wars, when wheat was dear, we ploughed up much land which was really not fit for wheat growing - as we may see-for instance, on the Sussex Downs-in disused whilom wheatfields still showing the furrows overgrown with indifferent, wiry grass-which is rather a warning for the present advocates of wheat growing quand même. Now, during depression, we have gone to the other extreme, laying down to grass land which is not fit for such use. However, "grazing farming" is "lazy farming." And the average farmer prefers easy going to business. "As long as considerable areas of grazing land are to be hired cheaply, the farmer considers that he obtains an easier and safer return on his available capital by grazing than by putting the land under the plough. His personal profit does not coincide with the national interest." He does not consider that the higher profit which he would earn by arable farming would make up "for the greater capital required and the constant labour, anxiety and risk attending arable farming." If the truth be told, he is also short of such capital. "Speaking generally," so wrote Mr. Hall, " it is not too much to say that they (farmers on an average) are insufficiently educated and short of capital for the business they have in hand. Putting aside a substantial minority and many brilliant exceptions, they have not been touched by the revival of agricultural education that has taken place during the past twenty years" (and in the promotion of which we must allow the Board of Agriculture to have shown creditable zeal), " and do not take advantage of the technical assistance that is now at their service. Most of all, their business training is at fault; they often enough are capable enough craftsmen, but they are bound within a narrow routine and show no adaptability either in their management or in their 
buying and selling." There is more. Evidently the present time is a time for intensive farming - the more intensive the better. However, we have still a considerable quantity of poor extensive husbandry. "In many parts of the country" -it is still Mr. Hall speaking-" it is clear that the farmer is occupying more land than he can properly manage with the capital at his disposal. During the depression men who could in any way make a living by farming got hold of comparatively large tracts of land, after putting several holdings together; by cutting down expenses they succeeded in obtaining a working profit" (much of our land being under-rented) "off their extended areas, and though prices have latterly justified a more intensive policy, they still continue to let the land go to waste with a minimum of effort on their part." Clearly in this case also " their personal profit does not coincide with the national interest." We have it on the authority of the Food Production Committee that our land, if properly farmed, might produce two or three times what it does now. However, giving a bonus per bushel is not the way to make it do so.

Evidently the point at which we fail is not, in ordinary times, the price of corn-which Mr. Hall found sufficient in ordinary times at $36 \mathrm{~s}$. for wheat-but the farmer who grows too little of it to the acre. And our reforming policy will have to be addressed to him and to his deficient capacity, rather than to the product of his indifferent labour-at the cost of others who in their own vocations and callings do their work sufficiently well and do not deserve to be penalised.

Seeing our Agriculture in such bad plight, one feels tempted to ask, though I do not remember having ever heard the question put forward in any other quarter: How is it that our Agriculture has sunk down into this sad state of decay, at the very time when Agriculture elsewhere all round has forged ahead as if by miraculous propulsion? For it is not a question merely between ourselves and fortunate Germany. Mr. Middleton has told the story of Germany's rapid and wholesale uprising, altering the condition of her Agriculture really beyond recognition. Whoever be the 
author of the saying, it has become a current observation among us that German Agriculture has risen to its present height "within the past forty years." Well, those "forty years" are the very same period in which our Agriculture has gone down to the point over which Sir Rider Haggard has shed tears and which the Milner Committee has found to be discreditable-the same period in which we have had $3,700,000$ açres of our whilom 5,400,000 acres of tilled land laid down, in a sort of composition with bankruptcy, to very much less profitable grass; in which our landlords and tenants have lost enormous sums of money and heart; and in which Labour has been forced off the land, by distress, by the hundred thousand. Germany has had her bad times during those forty years just as well as we. It was during those "forty years" that Baden and the adjoining countries had those "ten years of distress," one bad harvest following upon another, which made the Badenese Minister of Agriculture of the time, Dr. Buchenberger, own to me (in I889) that he was puzzled to explain how the small farmers-all small and nearly all of them owners-had been able to hold on. But the bad period did not appear to affect them. North Germany as well has had its bad seasons. The year I 893 was to all Germany a season of severe trial, owing to the long-continued drought, which drove German farmers wellnigh to despair. It was then that the remarkable resources of Organisation so brilliantly disclosed themselves and Co-operation brought such almost marvellous relief. There have been other untoward seasons. Nevertheless, in spite of it all, Mr. Middleton's "Memorandum" shows that Germany has marched on, going from strength to strength, till it has come, agriculturally, to beat us.

And Germany is not the only country which has prospered in this way. The advance made in the Netherlands and in Belgium is enormous. Denmark has gone prodigiously ahead. Italy has done the same. Spain has begun its own upbuilding of Agriculture. In the Scandinavian kingdoms progress has been very marked. Russia, likewise, has benefited by the change-even before the late 
Emperor's seisachtheia brought unexpected relief to the land-owning peasantry. So have Roumania, Serbia and Bulgaria-Serbia very much. And he must be blind who does not see the great progress made in France. I can speak as an ocular witness, having been a frequent traveller in the rural parts of France, always comparing notes with local agriculturists, taking stock of the condition of Agriculture and attending, as a guest become familiar by repetition of visits, agricultural congresses. The advance made, thanks, on the whole, to an enlightened policy pursued, is very considerable.

Why have we all alone stood still and, indeed, gone backward?

When we have an exceptionally severe winter we hear voices complaining that the Americans " must have turned off the Gulf Stream." However, the superhuman beings -Pandora and others-who direct human destinies can scarcely have been so partial, and to ourselves so malevolent, as to have sent all the good things of the celestial Gulf Stream to our neighbours, all round about, leaving Pandora to endow us all alone with her fateful godmother's present.

Besides, it is not the Continent only that we see pitted against ourselves. Things have moved on satisfactorily in America-on both sides of the Anglo-United States frontier, as Mr. Wilson's latest Reports and those of his colleagues at the Agricultural Department in Canada show. And we may look still nearer home. Ireland has not yet had "forty years " of the curative treatment, as one might call it, of the favoured continental countries, that is, of well-aimed organisation and a judicious agricultural policy. But it has had a small dose and pro tanto it has advanced at the same rate.

Clearly there must be something in our agricultural system which is in fault, which keeps us back and makes adverse seasons tell with twofold gravity. If our landlords, as Mr. Hall complains, will not " take the lead " in a movement which so nearly concerns them; if our tenants remain unaffected by the brilliant examples set them by the 
best among their own class and go on farming badly, and if our villages become more and more depleted of their once ample population of sturdy, intelligent labourers, who leave only the dregs of their class behind-we shall have to bear in mind that they are but the wave-driven "bubbles" of the Greek sage, not self-generated, but produced by a force stronger than themselves, that is, by the system under which they have been born, and have grown and worked, and which has formed the habits which in their turn have moulded their character. Our system, as Lord Beaconsfield made it a boast on its behalf, used to yield " three livings." In Mr. Prothero's words, that system " has broken down." 1 The system practised elsewhere-since recently also in Ireland-yields only one. But that one evidently is worth more in practice now than our " three" of past times. It takes, as Dr. Johnson ill-naturedly put it to Oliver Goldsmith, "two hundred and forty pennies to make one sovereign." There is no one surely to deny that Ireland does all the better now for having only one living to be yielded by the land. The other two meant distress and want.

The first supposed " living " of Lord Beaconsfield's boast is, of course, that of the landlord, who owns the soil and lets it cheaply-as Mr. A. D. Hall suggests, quoting some Lothian authorities of the first order in support of his thesis, in many enough cases too cheaply, so as to make things too easy for the tenant who, under such circumstances, sees no object in exerting himself while the "living " comes to him of its own accord. Lord Townshend and Coke, when raising their rents, drew a logical conclusion from that. In a good-humoured way Mr. Hall takes landlords to task for not "taking the lead" in a movement for agricultural revival. Landlords have as a class, or let us rather say as an institution, failings enough to answer for, in all conscience; and as an old Farmers' Alliance man, a member whilom of the Executive of that body in my own county, I am not likely to underrate their shortcomings. But how can we expect them to " take the lead " when we are daily encroaching upon that which alone enables them to take 1 "English Farming, Past and Present," p. 40I. 
it, and endeavouring to divorce them more and more from practical Agriculture, and deprive them of all voice in agricultural business on their own land? The demands put forward on behalf of the tenant as the operating factor in Agriculture are just enough in themselves. The farmer wants to-day, not only those "more liberal covenants" which Sir J. Caird demanded on his behalf nearly seventy years ago as an essential condition to success, and which in all too many cases he has not yet had conceded to him, but greater freedom still, or he will never be able to develop that "diversified" and "intensive" system of husbandry for which not only American Secretaries of the Department of Agriculture clamour, but which a well-versed British agriculturist like Mr. Hall likewise insists on. He wants that security for money laid out in improvements which in all too many cases he is still not certain to obtain. $\mathrm{He}$ wants that security of tenure-whatever be the precise form of his agreement. There is actual security under yearly holdings-which enables him to take long views and think years ahead. But, on the other hand, how is a modern landlord to play the " Coke of Norfolk," to place himself at the head of a movement which threatens to leave him with less and less hold upon his own land and upon its employment, while the tendency of the time, steadily pushed forward, is, to reduce him to the position of a mere rent-charger-with the sword of Damocles of a long bill for compensation for changes - in the execution of which he is not even to be allowed to have a voice, and cxecuted in a form which he may absolutely condemn-perpetually dangling over him; while the spectre of Land Nationalisation, which to him means confiscation, keeps grinning at him over the wall? It is not altogether reasonable to expect that. Our heart-so we know on the best authority -is there where our treasure happens to be. A Coke of Norfolk, a Somerville, a Townshend, could "take the lead," because the improvement of their land was their own work, from which they were sure personally to reap the benefit. We reckon it a national benefit that Coke within forty years nearly decupled his rent roll. That 
advantage has now become doubtful on both points entering into it.

And if it were otherwise, if landlords were not popularly classed with the branches of the condemned "Upas-tree," are our landlords of the present day as a class altogether fitted for the work for which Mr. Hall has designed them? And are they likely to be accepted as leaders by those who really stand for the agricultural interest? Times have changed. The squire of olden times, the Squire Western or Squire Crawley, made his property his home and his workshop. He played the master a little more than would be consistent with the spirit of the present age. But he was the soul of the local agricultural community, the pivot around which local life turned. He was a bona-fide agriculturist. His farming might be backward. But he was keen in his interest about the "shipses" and the beeves. Every one knew him and he knew every one. He knew every inch of his land and was intent upon the management of his property. And there was not a move made in his parish in which he did not take an active part. He was anything but a squire fainéant. But we have long since done with men of that type-at any rate, as a class. If squires of that old sort had continued in any number, who knows but there might never have been a Farmers' Alliance, never an "Agricultural Question" to trouble us. Land to-day is for a good part only an investment-possibly a speculative one-or else a foil to a jewel of riches acquired in other callings-beaucoup de montre et peu de rapport, meaning a fine country house, in which to receive friends en grand seigneur, good shooting and a privileged position in local society, but not personal interest in Agriculture. Of course there is to be an income. But the getting of that is a matter for the agent. There is scarcely any link except the cash nexus between the "new man " and the "old acres." Such a condition does not favour the "taking a lead" in an agricultural movement-in which, moreover, the new man would probably not at all be accepted as leader, because the mass of the agricultural body would have no confidence in his knowledge of Agriculture and perception of its wants. 
Once more, it is different in Ireland. We have landlords there who do trouble-agriculturally-about their estates, and who do take the lead in agricultural organisation and progress. And we can trace the benefit resulting from this in Foynes and Randlestown.

And the landlords' agents would not be in a position to help their " clients" much. For they are for the most part themselves not agriculturists at all, but surveyors, it may be solicitors, often enough auctioneers, in other words $e x$ hypothesi men well versed in a very valuable part of estate management-though even that does not hold good in all cases-but not agriculturists in the full sense of the term. They may be full of genuine interest in Agriculture. But they are not of the caste itself, not men du métier. And of all people in the world farmers are the least disposed to place confidence in men whom they do not know as good practitioners in their own craft.

Lord Beaconsfield's second "living" is that of the tenant. Now here we touch the core of the matter. Agriculture is the work of the tenant. The landlord may help him or he may hinder him. He more generally now does the latter, because for his own security he feels compelled to set limits to the tenant's freedom of action and reserves to himself a veto on his enterprise. It is the tenant who tills, the tenant who manures, the tenant who sows, the tenant who makes good or bad Agriculture. Now one would like to ask, under our present system, what security has the Nation, on whose behalf the soil is tilled, or has in fact any one, that the tenant selected to work the soil will be capable and equal to his task, and that his farming will be of the kind that can be approved? We cannot of course ask that the tenant should be made to pass a qualifying examination, or secure a diploma of fitness ; nor would such test of capability, if it could be enforced, afford any guarantee for the attainment of the desired end, even in the smallest degree. But what do we actually do in the matter? The tenant is, if not selected-for there are times when there are too few offering for selection to be practicable-but at any rate accepted and installed by the landlord. Such 
occasional slumps as happen do something to explain the frequent presence of decidedly indifferent farmers on decent farms. Mr. Hall puts it in this way: "Landlords were hard hit in the depression, and they learnt to stick to any tenant who would continue to make the land earn something. They had no prospect of getting superior tenants ; the business was not attracting new men with capital and brains." Such explanation may be satisfactory for the landlord; but it does not give the Nation much of a prospect of securing the coveted addition to its food.

On what principle does the landlord accept his tenant, and what does he do to employ his own influence in furtherance of good farming, such as the Nation wants? It is his interest, of course, that the tenant should do well, so as to be able to pay his rent in full and regularly, and put the land in good heart. There are peculiar features about land letting which do not square with those of any other kind of hiring out of an object of value and which place such land letting in a position all by itself. We cannot, of course, conceive of any other kind of business being let out as is a farm, with covenants, prohibitions, and undertakings to restrain the hirer. And the letting of a house, or a ship, presents far fewer points susceptible of so much difference of opinion and of interest as does a farm. There are features about the letting of a farm which recall the ancient medietas, the modern inétayage or mezzadria. The tenant hires his land at a certain rent-which, as Sir J. Caird points out, does not in every instance correspond to the real value, being often enough determined simply by "custom." And often enough it is so much under the real value as to act as a direct incitement to poor farming.

"One very real objection to granting security of tenure," so writes Mr. Hall, " now without qualification is that rents are, speaking generally, below their true economic level in England." And again : "An indictment might be framed against landlords for not insisting upon higher farming on the part of their tenants, even for not raising rents to the pitch that would force men to a better use of the land they occupy." And once more: "The Lothian farmer has been heard to argue that the poor farming 
which is but too common in the South of England has been encouraged by the low scale of rents prevailing, and that higher rents are desirable to force men to make the land produce more.'

The landlord and his agent as a rule have no other test to apply than the offers made to them. When Agriculture is prosperous and applicants accordingly are many, rents go up. And even when they were previously fixed on the tacit understanding of that being for a long time, a notice to quit will bring about the effect of determining the agreement. Under an old Danish law, which goes too far in the other direction, notice is permissible on the part of the tenant, but not of the landlord, and the rent is fixed almost as under Lord Cornwallis's ordinance for Bengal. However, hard times supervene. The tenant finds that under the circumstances he has made a bad bargain and that he is losing money. Now the landlord is expected to share in the loss. He may refuse and break his tenant. Or he may remit rent due. Prudential considerations in favour of the latter alternative, which is the more commonly resorted to, cannot fail to act as somewhat of a restraint upon the tenant, when disposed to fight for his own supposed rights on other points. In view of a possible evil day he will want to keep " on the right side" of the landlord. When depression is long continued and becomes a heavy burden to bear, landlords' remissions are not always appreciated at the value which the landlord himself-who has his own burden to bear in the shape of "charges," on which there is no remission-places upon them. I have heard very angry references to the " semblance of landlords' sympathy " coming from highly responsible tenants' lips. But all this by the way. It is only meant to indicate the peculiar features of this bargain, which places the latter on quite an exceptional footing in comparison with bargains in other lines of business. The point at present is: What precautions are taken to ensure good farming such as the Milner Committee and men of the authority of Mr. Hall have pronounced to be lamentably absent? The landlord deals with his own "property" according to his own pleasure. He has his interests as an investor; but he also has his crotchets. 
He wants a man to please him and to fall in with his own views. For security he has his landlord's distress. I know a landlord-landlord in two counties-who is otherwise a most estimable and liberal-minded man, but who takes credit for it that he never will accept a Dissenter as a tenant. His tenants are all Churchmen. I knew a great landlord, a noble marquess, now dead, who would not have a tenant who did not vote his own way in politics. There may be men on the other side of the party line who are equally intolerant. There may be blue ribbon landlords who will not have a tenant who will not take the pledge. Now, what has all this to do with good or bad farming? And how does it represent the interest of the Nation, which looks for the production of food? A Dissenter's five quarters of wheat will be worth more to the Nation than a Churchman's three -be he ever so orthodox. A red ribbon man's good farming will be worth more to it than a blue ribbon man's bad -be he ever so temperate. The thing shows how very far our accepted land system has forced the regulation of national Agriculture away from its true lines, allowed that which is really a trusteeship for the Nation to degenerate into irresponsible patronage, to please private fancy. The evil is aggravated by the fact that so very much of our Agriculture is small. Not the small Agriculture of the small holder, which distinctly stimulates intellect and energy; but the small Agriculture of the tenant, say, of $5^{\circ}$ or 200 acres, which acreage under ordinary circumstances will not suffice for a man of such position as would suggest superior education and refined power of mind, a man with business ambition and sufficient capital to permit him to give scope to it. We have excellent farmers upon our land, men whose example ought so to influence our Agriculture as to raise it to the highest possible level. Unfortunately amid the torpor and routine-bound inertia surrounding them, their splendid leaven will not work. But these men are for the most part farmers of the larger sort, men with sufficient capital, and occupying a position, which enables them to meet their landlord on terms of equality and bargain freely with him. And these men in truth form a class 
by themselves, a superior class. There are also splendid craftsmen-specialists, say, in fruit culture, vegetable growing, and other select branches of farming, among our smaller farmers. But they, too, form something of a class apart. They are in truth industrialists rather than agriculturists. And they likewise fail to react upon the grcat inert mass of backward farmers, who go on in their unprofitable old humdrum way. It is the host of our small farmers, craftsmen with no ideas in their head beyond their accustomed daily job, who form the drag upon our farming machine. They are "idlc bellies," like the Cretans of old, and want -that is the point to be operated upon-to be either " shaken out," as Mr. Hall has called it, or else raised. Now raising them is a tough job. But it must be tried. The way to improvement lies across Education-Education in its widest sense, as applying both to old and young, to every one after his sort. Now on no point telling against the host of our farmers as a class are people whose judgment is entitled to count so fully agreed as upon this, that there is a lamentable want of Education noticeable among them, just for this class of people. I have seen a good deal of this, even among men of the highest local position-men universally looked up to as skilful as well as successful farmers-who all the same were decidedly ignorant on very important matters concerning their calling, more particularly on matters relating to ancillary sciences. They were perfect masters of ploughing, or disc-harrowing, or breeding. But their knowledge of agricultural chemistry was a total blank. Their familiarity with grasses was nil. Of course they were cheated by their dealers. Of course, in spite of their practical proficiency, they failed to do justice to their opportunities. Of course their "light" and example to others burnt only dimly, in comparison with what it might have done. And if these things happen in the green tree of agricultural eminence, what are we to look for in the dry of humble position of the 50 and 200 acre craft?

Under such circumstances is it surprising that Agriculture languishes and will not develop? Evidently this is 
the crucial point of the system, to which we shall have to apply either a healing salve or else the operating knife.

In all other callings we have got beyond the old humdrum plodding of the mere craftsman. The old weaver, the old spinner, the old nailer, the old engineer are gone-superseded by more instructed, better equipped men. Successfully to carry on any calling to-day we need men with brightness of intellect, quickness of apprehension, keen power of distinguishing between what is good and what is bad, in one word, men of complete education. No professional man, no manufacturer, or other industrialist, no merchant or trader could to-day get on in the world on such humdrum knowledge as the average farmer brings to his work in his own calling. Only in Agriculture have we stood still. And when landlords, already too insistent upon their right of dealing with their "property" according to their own fancy, persist in entrusting their broad acres-which they hold under the supreme ownership of the Nation-to men so little qualified as these, is it surprising that remueurs of the very new school cry out for "Land Nationalisation" as a means of ensuring that land shall be turned to account for the national benefit-or, as the powerful Co-operative Community has put it, that the direction of National Agriculture should be placed in the hands, not of producers, but of consumers, who would stand on no etiquette with incapable husbandmen, but promptly get rid of whosoever was not equal to his job, in a rougher way than is now usual? We shall have to recognise that the present war has given a powerful push to Socialism at almost all points of the economic compass, but more particularly at this. What is the Government management of important branches of trade on behalf of the Nation, to the elimination of profit and placing goods on the market at no more than cost price, other than a form of collectivist handling of the "instruments of production," which Socialists have made their main objective? And the fact that, notwithstanding such interference, " profiteering " remains, is calculated to impart a still further stimulus, because it suggests that even a Coalition Government, formed in the main on bourgeois lines, is not fully equal 
to its task, and that more drastic methods deriving their motive power from a broader and more popular stratum are called for. We sec this tendency of opinion pointedly expressed in the suggestion put forward-among many others, as already remarked-that the Community, that is, the State, should take, not the brewing industry alone, nor the trade in corn, in potatoes, in wool, alone, but the important practice of Agriculture as a whole out of the hands of private adventurers and manage, as well as own, our national acres for itself. That is manifestly, as invariably happens in such cases, overshooting the mark. A wealthy body like the Co-operative Wholesale Society, disposing of millions and having a market with more than three millions of "well-to-do artisans," as the late J. C. Gray has described them, at their back, may do great things in the farming of tens of thousands of acres-be it remembered, for its own supply. Its farming is still, on a greatly enlarged scale, the husbandry only of the self-contained landowner of the old Roman age, catering with his fundus instructus for himself and his household alone. The idea of course is, that the whole Nation is to be gathered together into this co-operative commonwealth, directed by one central authority. However that is not National Agriculture. You could not press the Agriculture of the entire Nation into so narrow a frame. The conceivers of the idea overlook, in their keenness for one laudable interest and ideal, that there are other interests and ideals, of as great importance, conflicting with it and forming important obstacles to be reckoned with. The fact that not only have our landowners, as Mr. Hall explains, as a class failed to make management of their own land by paid servants a success-which seems to indicate a sad falling off since the days of "Coke of Norfolk," and shows our landlords at a disadvantage in comparison with the French, many of whom make their faire valoir pay very respectably, as do also German landownersbut that countries much better endowed than ours with Crown lands, have long since found it greatly to their advantage to farm such out-except public forests and land attached to public studs-rather than manage them them- 
selves, and that even the declaredly Socialist Italian affittanze collettive, although renting in common, for the most part make a practice of farming scparately-a conduzione divisa -disregarding the classical but not precisely encouraging examples of Ralahine, Orbiston, Radbourne, and the early Assingtons - seems to show pretty conclusively that salvation does not lie altogether in that direction.

However, our Socialists and Co-operators deserve credit for having pretty clearly discovered the point at which our machine grates. It is the duality of interest, such as for so long a time hinderingly stopped the progress of Agriculture in Ireland, which keeps us back in our turn. We see how our Agriculture has broken down under the trial of war in its rôle of a provider of food. In the two collaborating parties, with often conflicting interests-the conflict of which is needlessly aggravated by adherence to old pretensions and crotchets out of keeping with the present day-these advocates of " thoroughness" believe that they see the two rival attorneys of the fable who share the disputed oyster between them and hand only the empty shells back to their clients. The position which the Cooperative Community has taken up in the matter is of decided significance. Those Co-operators may be wrong in even main points. However, they represent over three millions of thinking and resolute persons, well organised and brigaded together for action, who have a curious knack of heralding coming changes in public opinion and success in whatever they take up.

It is quite evident that our present land system, which suited our youthful condition as well as does an Eton jacket the slim figure of a boy, and which has rendered us admirable service in the past, no longer suffices for our fuller form. It does not sufficiently cover our nakedness. Agriculture has become a totally different calling from what it was when tenants were simply the landlord's retainers, when there really was something of a "living " in tenancy, that was "given" in truth as a matter of patronage. It has become a business like other businesses, requiring special aptitude, particular training, general intelligence, initiative 
and enterprise, and as a necessary condition to all these, more working capital and full freedom. "As farming became a trade, agricultural progress demanded less personal dependence, a freer hand, a larger scope for individual enterprise." So Mr. Prothero puts it. Our traditional fondness for super antiquas vias stare, however admirable in matters of constitutionalism, is wholly out of place in such a matter as this. We want, in Léon Say's words, efficient and active operators as well as a good machine. ${ }^{1}$ And to ensure that we have them we want some machinery which will of a certainty produce them. Other nations, which look not for "three livings" in each agricultural enterprise, but for only one-but that a good one-have prospered and developed largely, while we have retrograded. Their " one" interest, like the one lion's cub of the fable, has proved worth more than the whole litter of less valuable fry to which other animals give birth. It has made them think, learn, act. It has led them to " organise," which our old-fashioned farmers still will not do. It is disheartening to see men of this class, who ought to be men " of light and leading " to their humbler brethren, so determinately close their eyes to patent facts, and distinctly warn farmers against that which above all things is calculated to bring them deliverance from troubles which they never cease to complain of, that is, Organisation. Fortunately the world is moving on, in spite of such men. Where is the isolated large farmer's power by the side of those giant Co-operative Unions which we see at work abroad, cutting us out and giving their country the lead of us? It is Co-operative Organisation which has secured to those neighbours of ours a dependable supply of credit, absolutely indispensable to modern farming, on the only lines upon which such supply is possible, that is, by self-help. Do not we observe precisely the same effect in Ireland? The abolition of dual interest, made to give place to only one, but that an effective one, has-as is shown by Mr. Hall, who has severe enough criticism to bestow upon some points of Irish land

1 "Il ne suffit pas d'avoir une bonne machine; il faut aussi aroir un bon mécanicien." 
legislation-produced in Ireland, where its consequences could be followed up, markedly better farming. It has, in addition, taught the Irish farmer to co-operate, which means placing better machinery for buying and selling, such as Mr. Hall misses in this country, at his command, but means also a great deal more, among other things that standing together for common interests, that readiness for receiving education, which our farmers lack, but which they need and which leads up to " better farming, better business, better living." Lord Selborne has spoken of the necessity of a veritable " revolution " in Agriculture. There is scope for it in good sooth. And there is much to be thrown into the melting pot which is not likely to issue out in its old form. It is our system that requires altering. It is not the tools that we constantly complain of that want scrapping and replacing-unhindered commerce, free supply from the cheapest markets, an open field for development-but others which hinder action where action, on the contrary, requires to be stimulated. We want a new system for the disposal of land. We want the concentration of interest in profitable farming in one responsible, one unfettered hand. We want, for the most part, a new class of farmers -evolved from the old or else newly introduced. We want organised common action among those who carry on our national husbandry. We want competent Labour made fully available in its best quality. In one word, we want a new agricultural whole.

However, we cannot afford at once to take too long views. Le mioux est l'emmemi du bien. Our land system, such as it is, with all its ponderousness and cumbrousness, with its dual and triple interest, with its arbitrariness in the selection of those who are to produce our food, is there and is pretty firmly rooted in the soil. It is an unicum in the world's Agriculture, and will certainly have to be made to give way to something more in harmony with the spirit of the age and better meeting the matcrial wants of a growing population. And the country will be all the better for such change. However, such change will require decades. It will mean progress if we take only one step at a time. 
Meanwhile we cannot leave things as they are. It may be said that the first want of our Agriculture among those indicated is better Education for farmers-farmers and all connected with the exploitation of the soil, farmers grown up and farmers growing; farmers of the future as of the present generation; farmers, it may be, in occupation of much land, and farmers plodding on their small holdings.

Next in order of succession necessarily must come Organisation, as a means of concentrating efforts and placing Agriculture on a par with other callings, all of which are organised and do the better for it-Organisation in producing and in marketing; Organisation for enforcing by the gentle but efficacious force of self-interest larger production of more marketable produce; Organisation for creating new markets, in which the farmer will stand on an equality with the organised buyer and may himself dictate forms of business conformable to his requirements: Organisation also to give becoming weight and power to his collective voice in the contest becoming more keen, as section after section of the community arms and mobilises for championing its own one-sided interests in the battle of popular forces. More in particular is Organisation needed for the obtainment of the funds required to do justice to existing opportunities by means of Credit provided on soundly economic lines. For without adequate money there can be no production. And there is no one else to provide it on conditions appropriate to the case but the farmer himself.

A further great need to be provided is an adequate supply of Labour-Labour adequate in quality as well as in quantity-Labour which may be depended upon to fail neither in its attendance nor in its efficiency. And such Labour will have to be paid for in more ways than that of increased wages, to which thus far our attention has in the main been restricted. The provision of Labour under this aspect naturally includes that of perfected implements and machinery, the instrumenta muta, to supplement the instrumenta vocalia-the latter of which will after the war have a conspicuous part to play in agricultural economy. 
To this must be added the certainty of having a full reward for outlay and effort to the tiller of the soil-even while the desired unification of interest remains in abeyance-as a stimulus to enterprise, such as under present conditions is not assured to him.

And, however slow may be the desired transformation of Agriculture into a single-interest Industry, judged from a national point of view, Agriculture wants a substantial multiplication of small farming enterprises, to bring the land under more intensive, more minutely prosecuted cultivation, while at the same time providing a useful outlet for population and support to the supply of Labour, a more fully populated and more prosperous and happier countryside.

All these things are virtually on Sir J. Caird's lines, when seeking for "A Substitute for Protection," and promise -as results elsewhere have shown-to prove infinitely more effective than even the heaviest bounty upon corn or any other venal stimulus to its production.

In the succeeding pages a discussion of the several points more in detail will be attempted. 


\section{CHAPTER III}

\section{EDUCATION}

THE very first need to be satisfied, if we are in future to have our Agriculture in harmony with the wishes and requirements of the Nation, is a revision of our educational apparatus, so far as it relates to Agriculture and country life. For without Education carried up to the full height of modern knowledge we can have no successful husbandry. We are planning educational reforms in other quarters. We appear to have a period of vigorous educational action before us. At more points than one has it been found that our educational system needs recasting. However, in this matter Agriculture stands on a different footing from all other studies. Inquiry all round-also special inquiry by a Departmental Committee in Igo7-8-has shown educational reform to be nowhere more urgent. And yet on this very point the wants of Agriculture appear in danger of being scarcely done justice to. We complain of the rural population turning away from Agriculture. To make it take to it once more we shall have to begin by employing our efforts upon the rural child, so as to attune it to the conditions of its intended life. The child is proverbially the father of the man. And if we want to have a good stable country population, we shall have to begin by training country children to country habits and country pursuits.

Hitherto our action has been all the other way. We have had education for the young-scarcely any for the adult. But, if anything, that education has been shaped on too general lines, with a strongly urban flavour about it. In has in truth tended to train children away from a 
fancy for country life and agricultural pursuits, suggesting rather clerkships and commercial or industrial occupations. The inquiry by a Departmental Committee (Lord Reay's) already referred to, producing most interesting and instructive evidence-upon which a thoroughly illuminating Report has been based-has made the defects and deficiencies of the present system perfectly plain. The pith of the judgment there pronounced is summed up in the words spoken by Lord Barnard when acting as President: "There is no system." There has been piecemeal action-not a little of it-at this point and that, here a little and there a little. But that has been without clearness of aim, or a settled, comprehensive plan-perhaps it is not too much to say, without any plan whatever. It has been like the Irish jarvey of the anecdote, who upon being told that he must be quick, lashed his horse into a gallop before he had so much as been told where he was to go.

Evidently there has been a great deal of goodwill. The Board of Agriculture and Fisheries has shown itself most laudably active and zealous-more particularly after Lord Reay's Committee had reported, after which it promptly elaborated the outlines of a new plan, moulded so much on the lines of the Prussian regulations that one cannot help concluding that the Prussian was advisedly selected as a model. That means no blame to the Board. For the Prussian system has been found to be sound and effective, and had previously already served as a pattern, among other nations, for our keen-eyed cousins across the Atlantic, who are with reason very well satisfied with what they have now got. No doubt that system has been very judiciously adapted. However, our new system is still " new." We are, as Mr. Middleton points out, in this matter full thirty years behind Prussia. And our system is not by any means complete in itself, more particularly inasmuch as it lacks the essential feature of which Prussians have readily discovered the value-as has also Sir Horace Plunkett when devising his system for the Irish Department of Agriculture and Technical Instruction-that is, effective machinery for applying the principle laid down. The Prussian Government does not 
trust itself to County Councils, whose record, we shall do well to remember, as initiators of reforms of any sort is in this country not immaculate, and who, it may be added - especially after the admission has been frankly made in Reports of the Board of Agriculture-do not always pull well together with the latter. A recent Report tells us that after various clashings of opinions on this particular subject, at length a modus vivendi between the two authorities has been established. But modus vivendi scarcely indicate anything thorough, anything directed by a master idea and a single aim. They are invariably the result of compromise, which means giving and taking. The Prussian Government has nothing to do in this matter with modus vivendi. It retains the initiative as well as the superior guidance warily in its own hands, committing the local execution to specially appointed provincial Chambers of Agriculture; whose attention is not diverted by care for other interests; which have only the welfare of Agriculture to think of ; and which are composed of specially qualified members, exercising large powers of administration and rating, and necessarily, by reason of their composition and their brief, inspired by a singleness of purpose. And apart from the rate-levying powers entrusted to these Chambers, the Prussian Government by no means stints Agricultural Education in the matter of funds, as unfortunately we have done in this country. In very truth we had scarcely any Government grants for Agricultural Education worth speaking of until Mr. Lloyd George created his Development Fund. Even so we do not give much beyond $f 60,000$ a ycar. And that is after a quite recent considerable augmentation of the grant. In I 9 IO the Prussian grant in support of higher agricultural education alone amounted to more than five times what in that year we spent upon Agriculture altogether, viz., fI9,265. The United States Department spends about $£ 2,000,000$ a year upon research and education. You cannot have a good article without paying for it.

Some of our County Councils indeed have, like the Board of Agriculture itself, shown very commendable zeal for the 
cause of Agricultural Education, and in giving scope to it have done unquestionable good. But many of them have evinced little sympathy enough with the object of their task. " Some of them," so Mr. Brooke Hunt, the Inspector of our Board of Agriculture and Fisheries, deposed before Lord Reay's Committee, " give little or nothing towards Agricultural Education." And, put the action of the County Councils at its best, there is this to be said against it, which stands in the way of success, that, in the first place, there is no uniformity about it, possibly no distinctly recognised aim at all; and, in the second, that the members of those Councils have other things to think of as well, and other interests to serve, to which often enough precedence is allowed. It is humiliating to read-in the evidence given before Lord Reay's Committee-of a witness obtaining, by hook and crook, a miserable grant of $f_{3} 0$ for a journey to Switzerland, to study there the important subject of dairy organisation (which is, in Switzerland, carried to a high point), when, as the same witness learnt on arriving at Berne, the Government of the little Republic devotes annually $£ 4,000$ to dairying research.

Although our Treasury has been niggardly, the cause for our doing things amiss, so it will be well to point out and to bear in mind, does not lie with any lack of money, in this country. "The total amount of money available for Agricultural Education in England," so deposed Professor J. R. Campbell before the Departmental Commission on Agricultural Education sitting in I907-8, " is infinitely greater than that available in Ireland (where the amount spent on the subject per annum at that time amounted to about fI46,000), because the County Councils of England get very large sums of money, which they may apply as they choose." The fault committed is that "you can put no compulsion upon them. They do what they like with the money, and the central authority has no control over them at all." Questioned by Lord Barnard, sitting as chairman-who remarked that he could hardly call the arrangement practised in England "a system"; he would call it "the want of a system "-whether to make the arrangements in England 
more efficient would not make them "much more costly," Professor Campbell replied that he did not think so. It was a matter of system. He instanced the work done in the matter of agricultural experiments. "There has been a vast amount of excellent work done in Great Britain in that direction; I myself took part in it and attempted to use the results of other institutions for educational purposes; but it was almost impossible to do so because of the want of co-ordination between the work of the different institutions." We know what that refers to.

In Ireland, under Sir Horace Plunkett's scheme, so the same Professor Campbell, working under the Irish Department of Agriculture and Technical Instruction, went on to show, thanks to clear insight into the matter and sound judgment practised, things are strikingly different. There the initiative is jealously reserved to the central body, whereas in England the central body contents itself with supervising what the County Councils are expected to initiate, and often enough do not, having powers to stimulate or restrain reserved to itself, which clearly do not go far enough. In Ireland it is the central body, that is, the Department "which initiates, directs and compels." There the money annually raised for the purpose of agricultural education " is not given to the County Council to administer, as is the case in this country, but it is given to the central Department, to be administered through the County Councils in accordance with schemes approved by the Department itself; and it is given on the condition that each county participating must raise a rate for the same purpose. No money is given to any county unless a rate is raised." "In Ireland all the money goes through the central authority, who has the power to withhold it from them (the County Councils) or give it to them according to the way they make use of it." In respect of teaching arrangements, the central authority has plainly put it this way: "You shall have no college until you have trained teachers; you shall have no agricultural school until you have had itinerant instructors. .. We have got into serious difficulty with County Councils through refusing to sanction the appointment of 
certain classes of instructors, but we have stood firm, and nothing but the most rigid examination will satisfy us. . . And now we have come to the brick-and-mortar stage." Throughout, the central authority is supreme. And the result is a settled plan, perseveringly pursued, and uniformity, co-ordination-in one word: a system.

Such arrangement, which has worked exceedingly well, approving itself by its results, wherever it has been tried, was originally devised in Switzerland, as between the directing Federation and the executing Cantons. It has subsequently been adopted both in the United States and in Canada, as between the Federation, or else the Dominion, on one side, and the several States or Provinces, on the other. Under all these arrangements it is the central body which directs and exacts compliance with its regulations, as well as contributions of funds. The result is not only a general uniformity, but also efficiency and vigorous work.

Evidently we have been "boring with the wrong tool." Afraid of over-centralising, we have in our decentralisation missed our aim, because shooting at it with a favourite but faulty shaft. The consequence is that our arrangement spells "Chaos." And from such seed you cannot reasonably look for satisfactory fruit.

What has been said does not mean that we have not very bright points indeed to exhibit in our attainments, in truth burning and shining lights, which are well worth following up further. Quite the reverse. We possess some first-rate educational institutions, reaching up to the topmost grade, and most proficient teachers, just as in practical Agriculture we have very highly skilled practical farmers. However, these are comparatively few in number and possess little power of communicating their brilliancy to the surrounding mass of fog and darkness. The Board of Agriculture and Fisheries itself has in a recent Report confessed that "Agricultural Education is a difficult thing, in which there have been many failures and some successes." Unfortunately, as observed, the influence of such admirable examples as we possess does not go very far. There is, 
once more, a good deal of difference between what is done " on one side of the hedge and what is done on the other." The leading points are bright. But they shine amid an irresponsive atmosphere. They exercise but little diffusive, propagating, leavening force. They dispel but little darkness. We can trace the barrenness of the effort in all, let us say three, grades of the agricultural or rural community, the lowest, the middle, and the higher. We find it even among farmers of the very highest local standing-men who shine in practical farming, but who show themselves perfectly indifferent to Education and to the value of scientific knowledge. The average smaller farmer, used to his "leather jacket" husbandry, inherited from his father and grandfather, not only does not "believe in education," as Mr. Middleton puts it, but he actually nourishes something approaching to contempt for it, and meets the tidings of progress with hermetically closed ears. As the late Mr. Buckmaster, of the Education Department, was wont to put it, in his homely way, his answer to invitations to learn is: "What I know, I know; and what I don't know, I don't want you to teach me."

And, stepping down to the lowest grade, the depleted state of our villages, the general scarcity of, and the avowedly poor quality of much of the work done, the backwardness of the labouring population of our rural districts, in comparison with that of industrial centres, and our poverty in qualified men to occupy the small holdings which we are eager to create, and for the occupation of which we are now impressing discharged soldiers, bear ample witness to the prevailing defects in education in that quarter. Suitable education-supplemented by other appropriate arrangements-we may be sure, would keep much of the rural population where it was reared, and faithful to its country occupations. We shall have to "educate our masters" in the country as we have done in towns, if we are to have our countryside once more the little world that we should like it to be, the "Sweet Auburn" of the past. We shall have to open to "Hodge" the same path on which his industrial brother has walked to knowledge, to the enjoy- 


\section{I04 THE FUTURE OF OUR AGRICULTURE.}

ment of respect, to better social and economic conditions, to political power and distinction.

Our rural educational arrangements compare badly indeed with those of our neighbours all round. And even our system of purely technical agricultural education shows a want of breadth, of diffusiveness and of the power of permeation.

Such want is, of course, attributable to special causes which do not exist elsewhere, but which are among ourselves not by any means hopelessly irremovable. In Germany, whose system our authorities appear to be bent upon following, the agricultural population are on the whole more favourably situated. The large number of their "squires" -owning properties generally of considerably smaller extent than those of our average landlords-supplies highest agricultural education with a crowd of willing students, who see nothing derogatory in the study of "clodhopping," but rather carrying their heads high as constituting a privileged, powerful class, whose position makes Agriculture a fashionable study, equal in prestige to any pursued at a University. And the even larger number of those who aim at making a living out of Agriculture as superior employés — " under-managers," Mir. Middleton calls them-with a tenancy or well remunerated place as what we should call " agent" for some very large landlord, a Prince or Duke, or else a small property of their own, in prospect-some also on the look out for land-owning partners for life-greatly swells the ranks of those who gladly flock to agricultural colleges or Agricultural Departments of Universities, there to acquire knowledge more varied than that which we ourselves are contented with at similar institutions, owing to the many industrial developments attached to Agriculture in Germany. Such knowledge in their position they have power, and indeed can scarcely fail, to impart, almost automatically, to a much wider circle of rural denizens-in the very same way that Mr. Robertson-Scott has told us that Dutch farmers of a higher station impart it to their humbler neighbours, with whom they mix and discuss things freely. On the other hand, the division of 
German territory into a multitude of freehold holdings opens a prospect of independent competency to every peasant labourer who carries a head upon his shoulders and chooses to learn. Contact with others, in military service and otherwise-not least in those thousands of co-operative and other societies which overspread the country and place instructive companionship within reach of even the most humble-the comparatively most isolated cultivator-serves to whet his ambition to rise upon the "ladder " in Germany placed effectively before him.

Conditions are different in France. But still, owing in the main to the large division of the soil, its accessibility to purchase and-at present, when a diminishing population has so greatly reduced competition and so considerably lowered the current price of land, thus improving greatly the prospect of making a good living out of it - the number of earnest seekers after instruction adds not a little to the fruitfulness of the work of those able and willing teachers -at Colleges, in the offices of departmental "Directors of Agriculture," and among lecturers employed by the numerous "Agricultural Syndicates "- which, as Lord Reay has attested, have worked "wonders" in the matter of rural and agricultural education, and which also make it their particular task to extend agricultural education. At the same time local conditions maintain that love of land which has long been a traditional characteristic of the French peasantry, so painstaking in its pursuit of special branches of husbandry.

The most pervasive systems of Agricultural Education, tending to keep people true to their agricultural calling, faithful to the land on which they were born, expert, more in particular, in the various methods of husbandry which make up small and medium farming, and eager to perfect themselves in agricultural knowledge, are those of Denmark and Switzerland. Both countries are particularly favoured by the dependence of the community specifically upon the smaller kind of husbandry, which lends prestige to the agricultural calling, as representing the premier industry of the land. Belgium and the Netherlands are likewise 
careful nourishers of agricultural education-and, as we shall see, more particularly of the kind which at the present time specially interests ourselves. And the results obtained show that their systems are good and effective. And Sweden-the "father" of whose Agriculture, Nonnen, learnt a good deal from our country-has likewise a good show of rural and agricultural education to produce. If the effects resulting from careful agricultural education are not everywhere as imposing by their magnitude as they present themselves in Germany, in respect of distinct points, they are unquestionably superior in some other of the countries named. And the "Agricultural Atmosphere" pervading countries like Switzerland and Denmark is a matter that we may well envy and the cause of which we should do well to study, so as to be able to produce it among ourselves. The fact that, in spite of great educational efforts made in countries like France and Germany, nevertheless there should be a tendency observable among the rural population to desert its old sphere and seek more remunerative or else more congenial employment in other quarters, is not altogether to be wondered at. From time immemorial it is the country with its prolific generation of men which has served as the nursery for towns. The urban population needs renewing by healthier blood, bringing with it more robust constitutions, such as only the country has to supply. And the glitter of town life and the apparently more liberal remuneration of labour there exercise a powerfully alluring influence upon the plain and not always over-wise rustic, whose family is, as a rule, larger than that of the townsman and must seek a fresh outlet. Besides, there is the military service, which is a great seducer of country simplicity, making arduous labour distasteful, and, in France, disposing people to the quest of a place as "fonctionnaire."

What in our case stands in the way of an equal attunedness to country life and to the study which makes Agriculture perfect, is our land system which, utterly wanting in the levelling-up conditions prevailing in towns, separates the rural population in three strictly bulkheaded classes, 
of which the lowest has, by reason of its hopeless dependence -so long as it remains on the land-not been able to march abreast, in its social and intellectual advance, with its sister class in towns, whereas the uppermost is in number as nothing compared with the foreign squirearchies. Although of course dependent upon Agriculture, the youth of this select class of ours appears "above" making a regular professional study of that calling. If a young man of the "squire" class goes to Oxford or Cambridge, he does not go as a student in the agricultural department, but as a student of letters. That is altogether different from what prevails abroad and from what would prevail in this country had "S. G. O." (the late Lord Sydney Godolphin Osborne) had his way of seeing the country parcelled out among " $£ 2,000$ a year (in Ireland $£ \mathrm{I}, 000$ a year) squires," to whom their properties would have been not mere investments or country residences, but real bread-winning workshops, to be treated seriously, like a "business." There being no upper stratum to "set the tune," the middle stratum, that of intending tenant farmers, naturally gravitates even more than it would do in any case to pure practice -all the more since the large majority of our tenant holdings are comparatively small. In that stratum accordingly the rule of thumb necessarily dominates over the rule of brains, and tradition prevails over new discovery. We have more difficulties besides to contend with. But those other difficulties are not insurmountable. And in spite of them Agricultural Education will somehow, in the interest of the Nation, have to be done justice to. The remarkable upshooting of industries in Germany, which has been one of the wonders of the age, calling for hands and offering tempting terms, while at the same time there are foreign populations in close contiguity which have more hands to offer for the rural employment to be given than their own countries provide work for, fully explains rural depopulation in Germany. In France it is the sparkle of the town, with its estaminets and cafés and the national addiction to fonctionnarisme (which yields a certain income at a very modest expenditure of labour), which act as causes. However, 
it will be observed that in both countries it is not the number of small and very small occupiers of land that diminishes. It is the main d'ceuvre, the staff of landless or all but landless labourers which suffers diminution. That clearly shows that the fault in the matter lies not with Agriculture but with the conditions offered to Labour. In all countries there are, as a matter of fact, at present labour difficulties. Germany has raised its agricultural labourer's wages relatively far more than we have. There is absolutely no comparison. And in Germany also the road is far more open for Labour to independent occupation than among ourselves. Nevertheless difficulties will arise, as they have arisen for centuries back. For we read that one of the causes suggesting the formation of the Société Nationale d'Agriculture de France, about I660, was "labour difficulties." However, the maintenance, and even increase, of the number of small farmers and small holders, which is purposely stimulated by facilities given in both countries named, shows that although human beings are withdrawn, it is not really Agriculture that suffers inroads. Thanks to a system of rural education adapted to local circumstances there is in both countries - as any one can see who inquires carefully into the matter-far more " rural-mindedness," so to call it, among the rural population than among our own.

It may afford some interest to trace here briefly the course of development of methodised Agricultural Education from its first beginnings. We shall have to look abroad for that. For our first Board of Agriculture did not leave a brilliant record behind it under that aspect.

The merit of the first efforts made to methodise Agricultural Education appears to be due to Emmanuel von Fellenberg in Switzerland and "Father Thaer" in Germany. It was in $\mathrm{ISO}_{4}$ that Fellenberg, in company with the well-known Swiss pedagogue Pestalozzi, prompted rather by humane motives than professional, opened the first farm-school at Hofwyl in Switzerland. A few years earlier "Father Thaer" had begun teaching agricultural science (as learnt in his position of physician ordinary to the Elector of Hanover, our George III, from British Agriculture) on his little 
property near Celle in Hanover, to a select number of students. Berlin quickly detected Thaer's ability and the importance of his subject and, after Hardenberg had, as Prime Minister, called him to a professorial chair at Berlin, he-about I804-removed his infant agricultural college to Möglin in the Prussian province of Brandenburg, which became the first recognised agricultural educational institution in Germany. (Bishop Grundtvig's organisation of the noted Folks Hoejskoler (People's High Schools) and "Peasant Schools" in Denmark took place at a much later period.) However, Thaer's action was more on academical lines than on practical. Fellenberg's activity was directed towards practical work, supplemented by science, and the influence of his teaching proved on the whole far more stimulating and expansive and became in fact the practical starting point for agricultural education in all countries. For the "Farm-schools" (Ackerbauschulcn), which set practical education a-going in Germany-not Prussia aloneand have been so largely imitated elsewhere, were avowedly imitations of Fellenberg's Swiss Wehrlischulen. And the French fermes écoles appear likewise to have taken the Swiss institution for their model. In his organising work Fellenberg showed himself thoroughly public-spirited, endeavouring to attract even very poor young folk, for whose education no payment could be exacted from empty pockets. His wish was, if possible, to establish a farm school in every village or parish-“" civil " parish, that is, such as in Switzerland often enough embraces several ecclesiastical parishes -in the Federated Cantons. Of course, there had been research and discussion previously in agricultural societies. The Agricultural Society of Dublin, among others, had a distinguished record to show, and it had proved, as the late F. Passy had recently related, the direct inspirer to the formation of the Société Nationale d'Agriculture de France, which numbered Turgot, Buffon, Lavoisier, Malesherbes and Gournay (the coiner of the familiar phrase, "laissez faire et laissez passer") among its members. But that was not schooling.

Since Fellenberg and Thaer set their hands experimentally 
to the useful work, we have by practice and experience learnt not a little about the requirements of Agricultural Education-much of which, however, appears to have escaped the notice of authorities in this country.

In the first place, and above all things, we have learnt that Agricultural Education, to prove successful, must be altogether differently shaped and handled from ordinary Education, training to other callings, and carried on on its own lines. Agriculture is a different thing altogether from classics, mechanics, languages, or science. And it is addressed to a different and quite distinct public, bred up amid different surroundings, in a sphere of active labour - a public less patient than town children to undergo dry, wearisome class teaching. The country child lacks what the Germans call " sitzfleisch," the flesh that is content to sit long hours on forms. It feels the pain of this, as did the Xanthias of Aristophanes. It has physically more quicksilver in its blood. It is quick enough to seize what is carried to its mind through the channel of its eyes and what it can readily understand, but it wants its mental pabulum to be handed to it in its own way, just as the stork of the fable required a different receptacle for its food than did the fox. The aim of the teaching addressed to it is avowedly practical. There must, accordingly, be a practical ring about it, instruction tempered by demonstration, with life in it, to keep attention fixed. Slavishly imitating town teaching is like serving pap with a hatchet, calculated rather to frighten the child than to feed it.

Next, we have learnt that, however, practical and distinctly rural must be the tone of the education given for instruction in Agriculture, it is in the majority of cases, certainly in the higher forms of teaching, a mistake to mix up theoretical and practical instruction in the same institution. It has taken us a long time to find that out. But it is now accepted as a general rule. The first shape given to agricultural teaching was as a matter of course composite. Naturally enough it was thought that pupils must be taught the two things pari passu, and that the one would readily blend with and supplement the other. That was the way 
in which Fellenberg began, and Thaer as well. That was the method adopted in Agricultural Colleges, which were at first kept carefully separated from Universities, although made abroad, where every institution has its distinctive rank, in respect of authority accorded and regard paid to them, to rank on the same level. It was once more Liebig who, with keen perception, detected and pointed out the mistake and by his protest, uttered in IS6I, and readily accepted by others in authority, first of all in Germany, caused an end to be put to this. Doubtless Liebig was to some extent influenced by his great appreciation of the value of science, and more particularly of his own science, chemistry, in alliance with Agriculture-although he was not specifically an agricultural chemist. As Colleges were originally organised, there was danger of science being inadequately taught. For Colleges could not, for their limited amount of science teaching, secure, or pay for, the very best instruction, which nevertheless was desirable. At a University such teaching might easily be provided by means of the specialists attached to the institution being told off for such duty. Also, being attached to a University was sure to maintain a higher tone among both teaching staff and pupils, and secure to Agriculture its full recognition as

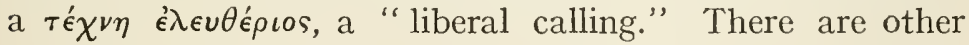
advantages accruing from the combination. There are other studies besides pure science taught at Universities, in which agricultural students may wish to be instructedas they only can be, thoroughly, at such a high school. Some such sciences are political economy, law relating to property in land, and more besides. "Attach your Colleges to Universities," so Liebig advised, " and you will have the most competent teachers of science at your disposal." His advice was followed in his own country. And the Agricultural Departments of Oxford and Cambridge show that we have appreciated it. The change has proved a decided improvement. In Germany distinct Colleges, like that of Tharand, have been given up and converted into "Departments" of Universities. And the result has proved all the better in every way. There is better teaching, the link 
with practical work during the period of academical study has been broken, and Agriculture has gained even a better position as a subject of study. There are at present among the academical institutions for Agriculture in Germany only three or four in which practical teaching is retained. Practice is generally taught-very thoroughly, as we shall see-on the farm. Science is taught in the class-room.

The idea has been pretty generally adopted. With regard to India, Mr. Wynne Sayer, Assistant to the Agricultural Adviser to the Government of India, writes:

"We think that in India also for the general widening of Education affiliation to a University is desirable. So long as agricultural colleges are not affiliated to a University they will not attract boys from the higher classes of Indian socicty connected with the land. These classes require a true collegiate education centring round Agriculture, not mere training in the details of agricultural work. Where these facilities are provided a fair number of pupils from these classes will be forthcoming, and the men thus trained will take their places as leaders of rural society with a thorough knowledge of what to aim at in the development of their estates."

This tallies pretty well with what is done in the two great American Commonwealths, from whose educational arrangements in the matter of Agriculture we have something to learn. It seems natural that in the United States Agricultural Colleges should have been attached to Universities, or, where this is not possible, given University rank, because the entire United States system of Agricultural Education is admittedly moulded on the German model. It is so, as is frankly confessed, owing to " the apprehension caused by industrial progress in Germany arising from the application to " industry" (a point for ourselves to note)," a fact brought home by the influx into America of scientifically formed men from Europe," especially from Germany. ${ }^{1}$ The Americans desired to make themselves independent of their German masters by training their own scientific men. In the adoption of the German system they have exercised great and creditable freedom and judgment,

1 Mr. Gerald Lightfoot's "Report on Agricultural Education in the United States." 
so as to give their educational system, in spite of its foreign origin, an independent and indigenous impress. In Canada, once more, which has an excellent educational system for Agriculture, producing good results, the leading Agricultural Colleges are advisedly attached to Universities, that of Ontario, which is the senior of them all, to the University of Toronto, that of Quebec to the McGill University. Both are entitled to confer University degrees. But without question University education for Agriculture is most widely diffused and pursued with most visible vigour in Germany, where, as Professor Campbell, speaking of what he has himself seen, owns that in science " they are ahead of us." Such College education is also most fashionable there, which accounts for the number of pupils who flock to it. And it is that really which gives to German Agriculture that superior tone which Nir. Middleton recognises. For, although there is not a little "addle" fruit produced in College nurseries,-more in Germany than where there is less fashionableness but more general earnestness about the study-College education may in general be said to supply the "brains " to national Agriculture. College and University tuition, in this matter, is, of course, designed for the highest grades of $c d u c a n d i$ - socially and economically the highest - and those aiming at the most perfect, or, at any rate, proposing to themselves the most extensive, practice of their calling. Issued from their Universities, these men should, as they do in Germany, set the tone for Agriculture in their country, serving as exemplars and, by their practice, as teachers for the lower grades, who cannot be expected to devote the same amount of time, money, and application to higher agricultural study.

Separation of theory from practice has also been found distinctly advisable in agricultural training institutions on the second plane, known in Germany as "Landwirtschaftliche Mittelschulen." The corresponding institutions in the United States may be taken to be the "Special County Agricultural High Schools " and the "Congressional Schools." "Colleges" are intended for the education of agriculturists of the higher grade, intended to own or manage fairly large 
properties. "Middle schools" are designed for what we should call the larger yeomanry, that very comprehensive class of fairly substantial " peasant" owners, who make up the bulk of the agricultural population of Germany, and also a large part of it in France.

In the lowest grade of instruction, in Farm-schools, no doubt, a certain combination of theory with practice has to be maintained, the scientific part of the curriculum there being very elementary. Farm-schools (Ackerbauschulen) are intended for small folk. But then experience has taught us that Farm-schools, once the hold-by in agricultural instruction for all the world, have only a very limited utility, and are serviceable really only as a first stepping-stone. They answer exceedingly well in the earliest stage. But even there unquestionably drawbacks make themselves felt. It is a serious sacrifice to a small farmer-and it is for children of small farmers mainly that Farm-schools are intended - to have to part with the nimble young arms and the quick young wits of his son or sons, when there is work to be done on his own holding. The teaching of manual work given at the Farm-school may be superior to that which the father himself can give at home. However, at the rate of sacrificing his son's labour, it seems dearly bought. Also, there is no telling whether, superior as it is assumed to be, it will quite meet the case to be provided for. A new patch will proverbially not hold on an old garment. And soil and other circumstances may be too strikingly different in the locality of the Farm-school and the scene of the pupil's intended future labour, to make what he has learnt in one place quite appropriate to the other. For the better use of new and perfected implements and machinery other teaching institutions are possible and, indeed, preferable. In this respect Belgium has, with its special schools reserved exclusively for such purposes, to which in seemingly bona-fide cases admission is free, set a good example.

Partly under the influence of such considerations, partly owing to the advance in knowledge of the young public to be taught, made in course of time, "Farm-schools " have 
everywhere-except to a limited extent in Switzerlandgone down and seen their place virtually taken by a less exacting institution, in which manual work, work on the teaching farm, is not demanded, but all instruction given is theoretical and scientific. Such institutions are generally known as "winter schools," or "winter courses." The name denotes the season in which they are held-purposely so, as not to interfere with practical farm labour. However, their teaching is supplemented by visits to demonstration plots, combined with lectures, on convenient days also in summer. Such winter teaching has proved decidedly popular and successful. The difference between "winter schools " and "winter courses" is this, that in the former there is residence and a general, so to call it, encyclopædic curriculum, whereas the latter are considerably freer in form, and deal for the most part somewhat empirically with selected subjects judged to be of practical interest for the pupils to be taught. They are found to enlist more lively interest and to put less strain upon the faculties. Obviously for adults, even only of recent maturity, the " courses " are preferable. Both forms have been found attractive, and the "winter schools" have tempted many a youth on to higher teaching and so gained recruits for up-to-date farming. To what extent the change has affected agricultural teaching may be judged from the fact that, as between I875-6 and Igo8-9, in Prussia the number of "Farmschools " has gone down from I26 to I7, whereas the number of "winter schools" has increased from I2 to I84. There has been a corresponding movement throughout the Continent. Even in Switzerland, where Fellenberg's Wchrlischulen still best hold their ground, "winter schools " gain conspicuously upon them. In France the modern écoles d'agriculture pratique are steadily crowding out the old-fashioned fermes écoles (apprentice schools). The change is particularly marked in the Netherlands and in Belgium, both which countries have laboured assiduously and with excellent results in the province of Agricultural Education. In the Netherlands there were in I9I2, I26 mainly agricultural "winter courses," with 8,875 pupils, as contrasting 


\section{II6 THE FUTURE OF OUR AGRICULTURE.}

with 208 "winter schools," of which I30 dealt witl agricultural subjects, being attended by 3,487 pupils, and 78 with horticultural, commanding a pupils' roll of 1,747 .

In the two great countries of North America the combination of practice with science in the lowest class of schools has still been maintained, under conditions differing from those of European countries-conditions which plainly justify such course. And a great feature is there maderather in contrast with what is now done in Europe- of teaching elementary Agriculture in rural elementary schools. The position of Agriculture is in both these countries rather different from what it is in Europe, and it is thought to be to the advantage of national Agriculture if, even on this lowest grade, Agriculture is pushed, though that should be to the exclusion or curtailment of teaching of some other subjects, which are considered more pressing among ourselves.

In the more democratic countries of the European Continent, such as Switzerland, it is found that-just as has been noticed in this country, as shown by the evidence given before Lord.Reay's Committee-the three grades, or at any rate two of them, have not infrequently lent themselves to service as consecutive rungs in the " ladder," the instruction received in the lower grade stimulating the pupil to go up to the higher. In the United States pupils climb up the same ladder in virtue of advancing age, the social gradation of the old countries not being there recognised. Originally " middle schools " were, like Colleges and Farm-schools, organised as institutions for mixed teaching, theoretical and practical. They were started by individuals as private venture schools. About I860, however, in Germany, Government took the matter in hand, eliminating the practical teaching and confining instruction to theory. The practice is considered a success.

Since more particularly under the effect of Mr. Middleton's Report, Germany has for the moment become our principal exemplar, it may be not without interest to explain what is the usual curriculum there for a young man preparing for the calling of Agriculture, whether with an early prospect 
of possession of a property in view, or as intending to serve for some time as Verwalter-_." under-manager," as Mr. Niddleton has called it. The curriculum is in both cases the same, and there are numbers of well-to-do young men who prefer going for some years as "Vevwalter," before acquiring a property of their own, or renting one, in order to run less risk of mistakes, and to accumulate more learning and experience, not at their own expense. The young man will certainly go for two years as " farm pupil," generally remaining on the same property. There he is put through the whole course of practical learning, not as a matter for his own benefit only, but chiefly in his teacher's service, looking after the mien and women at work, so as to keep them up to the mark, while being himself made to lend an occasional hand in the work done. There is nothing done on a farm in which he is not expected to take part. After that he may go straight to a University Department or a College, where he will probably spend another two years passing through the conventional studies, analysing in the chemical laboratory and so on. In any case, whether he go to the College at once or later, he will devote several years more to learning as "volunteer," paying his way, but not expected to take a hand at work more than he pleases, or else as "Verwalter," working for a salary under a skilled employer. In doing this, in whichever of the two capacities our man be engaged, he will try to shift his ground as much as possible, in order to cover a wide field of knowledge and avoid remaining one-sided. Apart from the difference in farming distinctive of various districts, varying as soil, climate and habits suggest, there are in Germany many special branches of applied Agriculture or agricultural industries to be learnt, such as potato distillery, sugar making, the management of fish ponds, forestry and the like. Our man is supposed to graduate in all or most of these. Such variety of studies undoubtedly serves to open the mind and helps to make our man think-to which must be added that there is a great deal of agricultural and cognate literature produced and also attentively studied in Germany-where agriculturists are great readers-so 
that our man, when he has passed through the regular curriculum, may be taken to be fairly well grounded in agricultural knowledge.

However, in dealing specifically with technical agricultural education, - which seems the natural and most convenient course-we have really been anticipating. For one of the most valued and weighty lessons that experience has taught us in the matter during the past century is this, that agricultural education, that is, the fitting of the man for rural life and agricultural pursuits, is really best served, not by technical, but by general education, cast in an agricultural mould, so as to make it suggestive of, and preparatory for, the learning of superior Agriculture, as contrasted with what Mr. Prothero has called "the vulgar methods of Agriculture," by observation, practice and reading, out of school. Such education must, as a matter of course, be applied before technical education can be thought of. It must, in fact, take a specific, suitable shape. Its object must be, as in all education, to prepare and capacitate the young mind for the assimilation of and the spontaneous search for further knowledge and at the same time to create in the mind what Mr. Brooke Hunt has well called a " rural atmosphere," distinctly and powerfully disposing the young person taught for agricultural pursuits and rural life, with all its own peculiar pleasures, trials, prospects and occupations markedly differentiating it from life in towns and occupation in factories. This is the point on which we more particularly fail; and we see the result. Under the teaching dealt out under Whitehall rules our rural population grows up with an instinctive, involuntary, but powerful bent for the choice of other than rural or home occupations. That effect is reinforced by the more or less degrading, or at any rate shackling, condition under which rural Labour has up to now found itself employed-utter dependence, poor remuneration, want of dwelling accommodation producing a "sense of inferiority," as Mr. Prothero has called it. However, education has played its part in the process. Except where an innate love of Agricultureunder more equitable conditions than prevail here-prompts 
young men to emigrate into some new country, that education strongly tempts those who receive it to seek a better position than agricultural labour can afford them, as clerks or factory hands. That is what our elementary education, measured with a procrustean rule, prepares them for, and certainly not for rural life and agricultural work. We observe the difference in the contrasting effect which the education of "our masters" has had severally upon town and country population. Our industrial working classes have grown to be a different race from what they were fifty years ago-far more intellectual, more independent, much better versed in business, conducting their magnificent co-operative stores and other undertakings with remarkable ability, holding their heads high, taking a leading part in politics, supplying the Treasury Bench with distinctly capable occupants, who help to shape the destinies of the Empire, and respected by other classes. Where are all these attainments among the rural population? Where are their Burts and Barneses, their G. H. Robertses and Hodges? We have had one Joseph Arch. But even he was not remotely fitted for the tasks very properly assigned to the men named. What disposed him to lead a revolt was simply an instinctive yearning for liberty and independence on behalf of his class. You can tell the tree by its fruits. The rural population, decidedly skilled in its own way, is still looked down upon and held in light esteem, because it has been educated upon wrong lines, aiming at roundness where the hole to be filled is square. It is as if you were trying to train a man for a sailor's life by giving him a solicitor's education.

In this respect Continentals understand the nature of their task better than we. They impart elementary education to the rural population with the same care as to the urban, but they impart it on different lines, in a rural way. In Denmark-in some respects the master country for Agriculture-whose peasantry, in Bjoernson's words, is " the most enlightened in the world," education stands higher in rural districts than in urban. In Switzerland, in the country education is distinctly elementary, but it 
is as distinctively rural. And you see the effect in the bearing of the agricultural calling and agricultural Labour. There is no suggestion there of social or intellectual inferiority. If anything there is the reverse. The rural population stick to their rural pursuits, are proud of them and carry their heads high. And they exhibit distinct eagerness for further learning. They do not require to be coaxed and almost inveigled into more learning like our labourers and farmers, who " do not believe in education." With some difference, due to local surroundings, it is the same in France and in Germany. With regard to France I can only speak from the observation of results. But with regard to Germany I can speak with some confidence, as having been, during the six years of my residence in Germany as a landed proprietor, patron of a village school, for the passing of whose annual report my " discharge" was required. Hence I could not avoid looking into the doings in it with some little care. It is not that in those countries essentially different matter is taught. The teaching is not of Agriculture but of Alderman Curtis's famous "Three R's" and what pertains to them. But all is put into a rural and agricultural garb. All through the children are taught to understand and realise that they are ruval children, growing up amid nural surroundings and destined prima facic for callings more or less connected with Agriculture. They are not led to look down upon their parents' position and occupation. They are as much led to look forward to agricultural pursuits as an English boy is taught to look forward to his living upon British soil. For purposes of illustration rural subjects and rural occupations are called in, so that the child grows up breathing, as it were, in its education a rural and agricultural air.

And with very marked effect is such practice carried higher up. In Belgium, in Germany, in Denmark, it is in great part to rural continuation schools, existing there under different names, - still for general teaching - that the high standing of national Agriculture is attributable. The rightly famed Danish Folkshoejskoler are schools for general education. Only a few teach Agriculture as an additional by- 
subject. Germany has more than four times the number of continuation schools (Ländliche Fortbildungsanstalten) that it has of Mittelschulen, because it finds them so useful. And their number keeps steadily increasing. It instituted them originally with a non-agricultural object. Once more, it wanted to catch its fry young-make sure of young folk who still had the habits of school discipline upon them, before they had grown into ways of independence, tending on the one hand to idleness and loafing, and on the other to the falling into the widely spread net of hated Socialist propaganda. They were to be kept " in hand," so as to grow up good, obedient Prussians and submissive soldiers. They have done that. But they have grown up at the same time also superior agriculturists in their various grades.

In Belgium the same service is, very effectively, rendered by the sections agricoles-which, in truth, are agricoles only in the effect which they produce-(in contradistinction to the agricultural schools proper, the écoles agricoles), but to which much of the forward condition in which Agriculture normally finds itself in the "Little England of the Continent" is distinctly due. In the Netherlands it is the "courses of winter lectures"-which, like the Danish Folkshoejskoler, admit also adults, for whom they were really mainly intended-which discharge the same duty. Throughout we find it recognised, and strongly recognised, that, apart from technical education-which teaches the handling of implements, of crops and of live stock-it is most essential that the mind of future agriculturists should be carefully trained for a receptivity for further learning, but trained with a distinctly agricultural spirit flavouring the teaching. The results have proved such theory to be correct. Why, then, should not we be able to apply it in something like the same way?

Although the general teaching ruralised is effectively supplemented by scientific and technical training, that is, however, abroad not considered sufficient to produce good agriculturists, either of the self-employing or of the employed class-the latter of which has, where land is easily obtain- 
able, always the prospect of future self-employment before it. There must be practical training as well, though it be not in a school. We know the value of "school-gardens" and endeavour to increase their number. But the schooling there given is little in comparison with that obtained where parents at home have their own free garden and allotment or small holding, in which the child may exercise its head and hand at all free hours, under a parent's tuition, with the lively interest evoked by working for itself, or for its family to stimulate it.

"In the house and on the soil belonging to their parents," so writes Mr. Prothero, "children might gain that love of country pursuits which is rarely acquired in later years, and that practical handiness in all details of management of land, without which they cannot become effective workers." It is a thousand pities that we have not more such gardens and such small holdings, independent of an employer's capricious notice, in our country. It is not " the" garden, generally speaking, which creates the liveliest interest, apt to shape intellect and to incite to good thinking work, but " our" garden, "our" field-something that is our own, that will remain our own, on which the work of future years may be bestowed, and in which the effects of continued good work may be watched in the progress made. Such work is in itself more than half an agricultural education. And it does not strain the child. One cannot help thinking, in this connection, that the jealous solicitude exhibited by our urban educationalists for nonemployment of children in paid work is, in respect of the country, carried a little too far. Such work, practised in moderation, may temporarily fatigue, but it does not wear. It is a form of exercise-educating exercise. It affords enjoyment, as well as toil, by the interest which it evokes, and a sense of pride in what infant faculty sees that it may accomplish. The children whom I employed every autumn, as did every landowner in the country, in Germany, in " helping mother " to lift potatoes, tumbled about merrily, like hoppickers in Kent. There was fun in the thing. It always happened at the time of the kirmess (fête patronale), 
deliberately so fixed by the authorities, when the schools were closed. The children were proud of the few shillings that they earned. And they learnt something. We train sailors young: why not agricultural labourers in a halfpaying way? Grown up men in towns find some work on their allotments a welcome recreation. During the war we have seen schoolboys making hay, out of which performance no doubt they managed to extract some fun. If only the ne quid nimis is observed, and sufficient change from one occupation to another is studied, there is no reason to fear that a little paid field work would, in the country, interfere with children's learning.

In the United States American inventiveness has devised a peculiarly attractive form of practical educational work for children, which has proved exceedingly effective, and overflowed, with the same results, into Canada.

This work is called "Club work." It was begun in the Southern States about eleven years ago, and in the Northern about six years ago. The object of the work is, by means of Clubs to instruct boys and girls in practical agriculture and home economics, bringing to them the latest results of research by the Department. To the promotion of this activity the Department has given considerable attention, especially through the States Relation Service and the Bureau of Animal Industry. The number of boys and girls enrolled in the clubwork has grown rapidly, until, in r9r5, it approximated 250,000. The number has grown further in volume since. A Report recently issued says :-

"And the activities of the members, which were at first confined to corn, now include the following projects : Corn, potatoes, home garden and canning (without artificial preservatives), 'mother-daughter home canning,' alfalfa growing, poultry, market garden, farm and home handicraft, forage, home management, farm management, sewing and sugar-beet clubs. The Office of Extension Work in the South has a large corps of workers in Washington and a still larger force in the field, who give their entire time to boys' and girls' club work in the Southern States, and a similar organisation in the Office of Extension Work in the Northern and Western States promotes club work among the boys and girls in its territory.

"In the organisation of boys' and girls' clubs the Department 
works in close co-operation with the State Colleges of Agriculture, through their extension departments. Arrangements are made for the appointments of State leaders in club work who are paid partly from Federal and partly from State funds. The State leaders are thus the employees of both the Department of Agriculture and the State Colleges, and are responsible to both. Working usually through the county agents and the county superintendents of schools and local teachers, the State leader directs the organisation of boys' and girls' clubs in communities which show sufficient interest in this movement. He travels throughout the State, explaining the work to boys and girls, to gatherings of teachers, and to various organisations interested, such as chambers of commerce, business men's associations, bankers' associations, women's clubs, and granges. Whenever possible, he is present at the first meeting of a group of prospective club members, to explain the work and assist at the organisation of the club. In many states the State leader has one or more assistants, who devote their entire time to giving out instructions, visiting club leaders, looking after the details of organisation, and keeping in touch with all the projects in the field. The county agricultural agent also is ready to assist in the organisation of clubs within his territory and to follow up their later efforts with expert advice and assistance.

" Once every year, at Washington, or at some other central place, a conference of State district club leaders is held, at which the general policies and the general methods to be followed in the conduct of the work are determined for the ensuing year, and special instruction is given in extension work.

"In addition to the direct advice and help of the local leader, the county agent, or the State leader and his assistants, members of the clubs receive complete instructions by post both from the Department and from their State Colleges. Thus the corn club boys learn from the authorities of the Department and the College the best way of fertilising their plot of ground, preparing the sced-bed, selecting their seed, planting and cultivating. The canning club girls are told how to cultivate their tenth of an acre of tomatoes or other vegetables, and are given full instructions for the work of canning. During the canning season demonstrations are given in as many localities as possible by the State agent or her assistants. The State leader furnishes all club members with blanks, on which they are to report from time to time their method of procedure in growing their crops. At the end of the season a fair, festival or contest is usually held, and prizes are given for the best exhibits or the best essays on the growing of the crop. The boy who has raised the most corn at the lowest cost becomes the club champion and competes with other club champions for the State championship. Prizes are 
given by local residents and by the State Colleges, and diplomas are given to the State champions by the Secretary of Agriculture.

"Another form of organisation among farm boys which the Department has promoted is the pig club, which is under the direction of the Bureau of Animal Industry, co-operating with the State College. This work was taken up by the Department in I9I2, in co-operation with the State of Louisiana, the work having been previously started in that state under the direction of the State University. It has been gradually enlarged and extended until in I9I5 (the year of the Report) there were pig clubs in thirteen states, with a total membership of over 9,000. The Federal Department and the State Colleges co-operate in this work in the same way as in the boys' and girls' club work under the States Relation Service, a State club leader being appointed jointly by the Department and the extension division of the State College. The State leader sends out complete information on how to organise clubs, forms for reporting on the work, advertising posters and other material. In each county or community there is a local leader, who directly supervises the work of the members. The State leader, with the assistance of the offices in Washington, prepares circular letters on the care and management of pigs, and sends them, either direct to the members or to the local club leaders. Each member of a club must secure at least one pig to feed during the season, according to instructions from the State leader. The boys are encouraged to get pure-bred sows, if possible, and raise litters of pigs ; or they raise their pigs for meat and become members of the ham-and-bacon clubs. The Department of Agriculture, through the State leader, furnishes instructions on slaughtering and curing the meat to the members of these clubs.

"The Burean of Animal Industry, in co-operation with the State Colleges, also has charge of the boys' and girls' poultry club work in the Southern States. In each of the six states which co-operate with the Department in this work there is a State poultry club leader who directs the organisation of the poultry clubs. He travels throughout the state, explaining, both to the members and to their parents, the proper methods of poultry raising. Personal supervision is given by a local leader, who is usually the local school teacher. The object of this type of organisation is the improvement of farm-poultry and the placing of the industry on a more profitable basis. A great increase of interest in poultry raising has been noticed in the states where this work has been conducted. There were in I9I5 326 boys' and girls' poultry clubs in the six states where this work has been undertaken, with a total membership of 3,722 .

"The success of the boys' corn clubs and pig clubs," so the 
official Report concludes, " in the South has led those in charge of the work to plan for the extension of the movement through the formation of boys' farm clubs. In these clubs the boys who have already learnt to produce large yields of corn and how to feed pigs, in the earlier organisations, are taught the elementary principles of crop rotation, of the cconomical feeding of live stock, and of soil building."

Under the patronage of the American Bankers' Association, which has betokened a lively interest in the promotion of agricultural education, the boy and girl competitions have recently been extended to cow keeping. The Association advances the money for buying a cow, in each case, which is to be paid for out of the profits realised out of the keeping and the sale of the animal itself, or of its yield in milk or a calf. The competition is not as extensive as in the other cases. But the Association appears to have recovered all its advances, and boys and girls have been much encouraged by the profits made. One boy last year had netted a round \$Ioo. Under the auspices of the same Bankers' Association the method of stimulating competition has recently been still further extended, to adult farmers occupying their own holdings in respect of corn growing. It is the Bankers' Association which gives the prizes and, at the end of the competition, provides a public luncheon, which appears to be exceedingly popular, because it " brings farmers together to talk over their own affairs one with another." The prize-takers find a ready market for their corn as seed. In Canada the same practice-begun, of course, in Ontario-is now reported to be spreading over all provinces. And the children are said to be taking to it "with enthusiasm."

The method of teaching by prizes has of late been still further extended in Canada, namely to the collection of good seed-corn. Boys and girls are invited to collect a sufficient quantity of the best ears in their fathers' fields to breed from, say, enough to yield two pounds of clean seed - of one kind, directions being given for the collectionto thrash and clean by hand and deliver. There is a graduated scale of prizes. The highest prize for wheat is 
£5. And there seems to be a lively competition. The method has many advantages. In the present case it familiarises the growing generation with the proper qualities of the varieties of grain commonly produced and infuses into them a keen interest in the subject, which is bound to be of profit to them in their subsequent agricultural career. Needless to say, it also helps to improve grain growing in the country, even though the qualities so produced should not equal the best outturn of Cambridge and Pusa. The competition being open to children of both sexes from ten to eighteen, there is reason to suppose that, before they have done with the thing, they will have gathered a good idea of what good cereals ought to be.

The American practice in respect of these matters is very much better than that which some of our own benevolent capitalists have adopted, in which there is too much patronage and " benefaction." That makes the institution miss half its aim. The American banker advances money, in order to assist the young experimenters. But he claims that money back, putting each of his protégés upon his or her own personal responsibility. And, large as has been, comparatively speaking, the cash lent out, the bankers maintain that they have got all their lendings back. That is the only way in which such an institution can be made to do good.

Instruction, as it happens, even of a less specific kind, is necessary not for the up-growing generation only. Agriculture is an ever advancing calling, for the perfecting of which practice, science, mechanics, engineering and sundry other ancillary occupations every year provide new material for instruction. Accordingly in every civilised country provision has had to be, and is, made for instruction among adults. In our country, with a large number of admittedly backward medium and small farmers, there appears to be special need for this. Nor has it been altogether neglected. But it cannot be said that anything like full justice has been done to the existing want.

Accordingly it may be well to look round and see how these things are managed elsewhere. It is all the more 
important, since education given to adults, in addition, to improving actual farming, unfailingly reacts sensibly upon the disposition for receiving education among the young, whom, of course, we are now anxious to educate up to the mark. Lord Reay's Committee clearly discerned this when it wrote in its Report, under the head referring to "winter schools "- the value of which it found to have as yet not been fully appreciated: "Before the children of the agricultural classes will fill schools, the paren.ts must be convinced that the instructors have information worth securing." Nothing will convince them more effectively than the acquisition of useful information by themselves.

In all countries where instruction has been given to the adult we find that the State has taken an active hand in the work. All the same, barring one essential item, on which State action is indeed essential, it is rather associative than official action which has conquered the ground. Lord Reay recognised this when, as Chairman of his Committee, he spoke in high praise of the veritable "wonders" which in this respect the syndicats agricoles of France have brought forth. Their work has indeed been fruitful. However, on the whole, German associations have done better still. And one important point in syndicat agricole tuition was learnt from the Italian cattedre ambulanti, promoted in the first instance by a public-spirited independent Savings Bank, tlat of Parma. The striking difference between the two kinds of initiative-by the State and by Associations-is perhaps best observed in Belgium, where the State was indeed the first to occupy the ground, reaping, however, but a scanty and indeed disappointing harvest from its labours. The associative spirit came in and struck root, and the whole face of things became changed. The effect is all the more remarkable because, in Belgium, in country districts, Co-operation was practically unknown. There were no Raiffeisen societies, no syndicats agricoles-at any rate, none to speak of. And those few were organised on faulty lines. Two of M. Lêon d'Andrimont's banques populaires styled themselves " agricultural." But they did little business. The rural socicties of the Bocrenbond, formed 
ostensibly in imitation of German Raiffeisen societies, were all pronouncedly Roman Catholic societies, governed by priests, and designed, by assisting the poorer rural population, to keep it clear of the Socialist propaganda reputed highly dangerous. Non-denominational, specifically agricultural associations were formed, not practising Co-operation; and agricultural education started into life. There were in I9II in the little country of II,57I,387 inhabitants, and II,373 square miles of territory, no fewer than 6,770 societies connected with Agriculture, 3,468 of which may be classed as societies for the improvement of Agriculture and specifically of agricultural teaching. The remainder consisted in the main of co-operative dairies, mutual insurance societies (666) and common purchase syndicates. And it is these societies which do the main work for the instruction of adults-except on one point. That is a smashing reply to the hyper-étatistes of Germany and France, who attribute all the merit of instruction to State action.

On one point, as observed, it is true that State action has been found indispensable, or at any rate of very great value. We shall have to bear in mind that the adult agricultural population wants to be studiously coaxed into the acceptance of instruction. It will not itself seek for it. For it the world seems good enough without it. It will not receive it under pressure, like compulsory military service. The hook may be made to catch, but it wants to be first baited. Direct interest must be aroused and direct gain must be held in prospect. Now there is nothing so calculated to attract and arouse interest as a prospect of individual gain. In the inquiry about Agricultural Education already referred to Mr. J. Fitzherbert Brockholes, who knows his way about English Agriculture, deposed that what has been found most effective in spreading instruction is individual teaching of the farmer in his own lingo, about his own concern, upon his own farm. It is precisely the same elsewhere. What has excited farmers' interest and brought them round to the acceptance of, and even delight in, instruction is the instructor getting hold of the individual farmer, talking over matters familiarly with him, explaining, 
giving his services for testing, meeting doubts and objections, and becoming a "guide, philosopher and friend." That is to a great extent-but not solely-in respect of dairying, the work of the zuivelconsulenten, in respect of breeding of the fokking consulenten, of the Netherlands, of the agronomes de l'Etat of Belgium, of the Directeurs départmentaux of France, and of the numerous "control societies " of Germany, Switzerland and the Scandinavian kingdoms-in Germany and Switzerland also of the itinerant lecturers sent about by the Governments or else by agricultural societies. It is the work of the " County Agricultural Representatives " in Canada, whose number keeps increasing, because there is a steadily growing demand for their services; and of the "County Agricultural Agents" of the United States, the service of which officers in both American countries are highly esteemed and considered indispensable. In all countries named the work of such instruction has proved blessed with good results. It means money spent upon a large staff of teachers. But it yields a return. And the outlay is not likely to prove permanent. For once a certain number of farmers have been converted, the ground is sure to be found to have been cleared for schools and "courses." There will still be plenty of work left for the consulenten and agronomes, such as testing, inspecting, advising and controlling. But there is not likely to be much need left for beating up recruits.

Outside the province of individual influencing, societies of farmers, independently formed, ought at least fully to share the work with the Government officers. It would be ungracious indeed to fail to recognise the excellent work which many of the men sent out by public Departments accomplish-for instance, the active and well-skilled " Directors of Agriculture" (as they are now styled, of France; a few years ago their title was "Professors"). There is one of them stationed, with his modest staff, in every Department - as the Canadians and Americans have their Agricultural Representatives or Agents in each county, where he is called upon to serve as teacher and controller of things agricultural. The change which he has helped 
to bring about in the condition of French Agriculture is exceedingly noticeable. We must not judge the French Agriculture solely by the results of that excellent market gardening and fruit and flower growing which extorts admiration, not only in respect of cultivation, but also of marketing, including large co-operative cold storage depôts for fruit and vegetables, and special fast railway and boat services which carry train and boat loads of perishable fruit and other produce safely and expeditiously from the Côte d'Azur to Paris and to our shores. There is still backward ordinary husbandry in France. And twenty and thirty years ago there was a great deal more. Travelling-for the most part on foot-twenty-four years ago through the famed Lauragais, the original pays de cocagne, ${ }^{1}$ or " Cockaigne," as we have called it, I could not help being struck with the very backward aspect of Agriculture in that chosen paradise of fertility and a genuinely favourable climate. " You are still rather backward here," so I timidly remarked to the departmental professor at Toulouse. "Oh, we are still in the age of the ancient Roman plough," was his reply. Such things have been altered, thanks, in a great measure, to the devoted labours of the "Directors of Agriculture." However, one may be thankful that there have been other influences at work by their side. For, as one cannot help remarking at the annual Congresses-unfortunately interrupted by the war-of the Fédération Nationale de la Mutualité et de la Co-opération Agricoles, the Directors are willy-nilly kept very much under their master's thumb, and not allowed to exercise much will or initiative of their own. There is far greater freedom, and therefore more genuine and representative expression of opinion, at the Congresses of the Agricultural Syndicates, to whose good work and teaching, as observed, Lord Reay specially alluded at the head of his Committee. In Government quarters their leaders are taxed with being " Royal-

1 So called from the coques de pastel (cocks of woad) which were to be seen at harvest time on this fertile bit of land-woad being a very remunerative, but also a very exacting plant in respect of soil, and therefore accepted as a test of fertility. 
ists." They may be so. But you do not find any trace of Royalist politics in their proceedings. There is in truth no greater foe to professional progress than political suspicion. Agrarians, lookers after their own class interests, the members of the Agricultural Syndicates certainly are. But they have given French Agriculture a new and better face in the thirty odd years of their existence. ${ }^{1}$ Under a curious misapprehension of the meaning of the word " $\mathrm{Co}$ operation," they pride themselves upon not being "mere co-operative societies." "We are not mere co-operative societies," so insisted the late M. Duport, one of the leading men in the movement, at the last Congress that he attended ; "we aim at the raising of the moral, intellectural and social status of those whom we lead." That necessarily includes teaching. However, we ought to bear in mind that all Co-operation is education. Men cannot buy or sell things in common without thinking, talking and exchanging their opinions about the several values of the articles bought and of the best way of making a marketable commodity out of the produce to be sold. Things must be talked over and thought out, notes must be compared, opinions exchanged. The co-operative society automatically becomes an agricultural discussion forum, stirring up minds and diffusing knowledge. Really, co-operative societies, agricultural syndicates and agricultural societies proper do very much more in a didactic way than this. Some of them, while doing it, indeed, have politics in their mind, some think of denominationalism, some are genuinely agricultural. Nevertheless, for all of them alike the perfecting of agricultural practice is either the aim made for, or else the main means employed. And so by their action, whatever ultimate aim they may pursue, Agriculture is improved. That is now done in the main by itinerant lecturers, sent to scour the country, deliver lectures and hold private discourses, and by organising discussions in the winter months, to lead farmers to think and study for themselves.

1 The first "Agricultural Syndicate" was formed in I 883 (one year before the passing of the law which authorises them) at Blois, by Professor Tanviray. 
The lectures want to be supported by demonstrations. the cattcdre ambulanti of Italy, which have been copied in other countries, carry their entire teaching apparatus, so far as it is required, about with them. How much such teaching, simultaneously to the ear and to the eye, will effect we have seen when running our "Egg Demonstration Train " from London to the West. Such " Demonstration trains " have become a standing and recognised feature of Agricultural Education in Ontario. In Germany teachers at "winter schools" are required under their agreement to hold demonstration lectures in the open in the summer months, to which both youths and adults are invited. In the United States-when once interest is roused, quite remarkable zeal is exhibited-gatherings which have been named "Farmers' Institutes" have proved exceedingly successful. Mr. Wilson, the late Secretary (that is, Minister) of Agriculture, explains their object in this way:

"The absence of agricultural instruction in the scliools, and the coming on to the farms of millions of people from foreign lands, together with the widespread interest in the results of agricultural research, have made it necessary that means be devised for giving agricultural people instruction by word of mouth, which will enable them to understand and utilise the information so largely given out in the publications of this department and the stations. For this purpose the 'Farmers' Institutes' established under public authority in the states and territories furnish an agency of great usefulness. It has, therefore, seemed highly desirable that this department should ally itself closely with the 'Farmers' Institutes' and make them efficient instruments for the wide diffusion of the knowledge gained by the Department and other agencies for agricultural research."

Such Institutions, which some ten years ago had in all about a million people inscribed as hearers, are held in convenient centres, where fields for demonstration are available, and are attended by hundreds of people, many of whom travel long distances. In some cases the number of those present is known to have exceeded a thousand. There may be one gathering only, or the proceedings may be spread over the better part of a week. According to 


\section{I34 THE FUTURE OF OUR AGRICULTURE.}

Mr. Secretary Wilson there can be no question as to the utility of these gatherings.

In several countries of the Continent, more particularly in Germany-where, according to Heine, the fancy for forming associations is so pronounced that if two Germans, being strangers to one another, were by chance to meet on the top of Chimborazo, they would forthwith proceed to form a "Verein"-discussion, more in particular of a conversational sort, at local association gatherings, is very much turned to account for the diffusion of agricultural knowledge. We too have, of course, our agricultural discussions, which are generally more or less of a full-dress character, dealing rather with questions of agricultural policy, of grievances and the like, than with matters of pure Agriculture; but all these debates assume rather a front-bench character, failing to drive the information imparted fully home, at any rate to the less prepared minds. All these things have among ourselves assumed a very formal, unpractical character, from the Chambers of Agriculture downward, which farmers for the most part distrust, holding them to be " landlords' institutions." " As a rule," remarks Mr. A. D. Hall, " the Chambers of Agriculture and Farmers' Unions only draw in a small proportion of the farmers in each district; their action is often confused and unenlightened and they by no means carry the weight that the agricultural party ought to possess." In Germany, where there are some thousands of purely agricultural associations-not counting co-operative societies - the gatherings are more of a local and undress character and what Frenchmen call "familial," often enough seasoned with lectures or didactic discourses from local or cosmic lights, but as to discussion of an infinitely more free and easy and conversational sort. No one there need shrink from expressing his own opinion freely, and accordingly no one who has anything to say or to inquire about hesitates to come forward and air his views. At these gatherings large farmers and small meet, and accordingly the spoken word, being duly challenged and vindicated, goes home well to even the less erudite. It is such influence exerted con- 
versationally by the knowing upon the less cultured, which has done so much to raise German Agriculture to its present high average level. Men of the same class as the humbler farmers attending such meetings among ourselves would for the most part either shyly hold back, being too timid to take active part in the discussion, or else would condemn the whole discussion as unpractical "rot."

The mention of demonstration stations naturally suggests the thought: Is it not a mistake that in the teaching of Agriculture the appeal to the ear is not far more fully supported by appeals to the eye, in the shape of demonstration? That was one main point in Pestalozzi's peculiar system of instruction, which has proved so successful in Switzerland. The eye takes in knowledge far more readily, and more effectually too, than the ear. The word addressed to the ear-or else to the eye merely in print-only too often among our "not-reading" farmers falls upon a nonreceptive tympanum or retina. The eye grasps the pith of a matter at a glance. That is why in the early 'seventies I tried to set the example of eye-teaching in chemistry by preparing coloured tables ${ }^{1}$ to indicate the chemical composition of feeding stuffs, manures and crops-quantitative as well as qualitative-under three heads: flesh-forming, fat-forming and collective, in feeding stuffs: nitrogen, phosphates and potash in crops and manures. The idea governing the publication was, to make farmers understand what in respect of the main chemical constituents they take out of the soil by an average crop and in what form they may restore it in the shape of fertilisers, so as to make them appreciate the respective value of various fertilisers, and keep their land in good heart. The table showing the proportions of flesh-forming and fat-forming constituents in feeding stuffs was supplemented by another, indicating,

1 Those tables were first published in the Agricultural Economist in $187 \mathrm{I}$ to $\mathrm{I} 873$, under the title of "A Handy Chemistry of Farm Crops," "A Handy Chemistry of Manures," and "The Proportionate Fattening Qualities, etc., of Feeding Substances." They were subsequently issued collectively in a little volume entitled "Agricultural Economy," published by the "Agricultural and Horticultural (Co-operative) Association," now of Long Acre, London. 
according to such calculations as were then attainable, the inoney value of the residue of the feeding stuff used, after passing through the animal. All these tables had a certain anount of success. The most successful was the last mentioned, owing to the accident that not long after its appearance, in I875, Mr. Disraeli brought in his Agricultural Holdings Bill, the first of a series which have occupied the attention of Parliament. To arrive at the amount of compensation due to an improving, generously feeding tenant, of course, some such guide as that supplied in my tables was a help. Accordingly a good number of those tables found their way into Westminster Palace, as well as into the laboratories of agricultural chemists. The values shown in those tables no longer hold good. We have learnt a good deal more since they were published about chemical constituents and also about manurial values. Some years ago I prepared a new set of tables, on the same lines, but brought up to date, hoping thereby to render a service to the Agricultural Organisation Society, of the Committee of which I was then still a member. However, evidently my colleagues on the Committee did not share my high appreciation of the value of a knowledge of chemistry, and after a refusal from my colleagues the tables remained unpublished. I cannot, however, help thinking that it is just such ocular tuition as would be given by coloured diagrams, the lines of which tell their own tale at a glance, and the teaching of which is accordingly readily assimilated, that is most urgently wanted among our agricultural population, a large part of whom are likely to remain unmoved by the droning of a lecturer, who may be found to be talking over their heads, and to whom chemical formulas are worse than Greek.

It is the same with demonstration plots or farms. We have such, and very excellent ones, too. It is in fact we who set the example of them. Rothamsted was the inspirer, not of Thaer's Möglin only, but of all the host of experimental stations now scattered over the German Empire and beyond, the results of which have since about fifty years been eagerly scanned and studied by minds 
anxious for more knowledge. As long as about fifty years ago there was a distinct publication issued in Germany, to record the collected results obtained by experiments. It bore the title of "Die Versuchsstation." Probably it is published still. We have Rothamsted, Woburn, and some more-but mairly for research. America has experimental stations in at least fifty-one states of the Union. Research ought indeed, as a matter of course, to dominate as it must precede demonstration. However, without demonstration research would be doomed to remain barren. Where the bulk of the farming population is known to be backward, demonstration certainly seems urgently needed. I endeavoured to press the matter-gently, as was all that I could presume to do-at the semi-annual meetings of the Royal Agricultural Society some thirty years ago. I then had the late Dr. Voelcker altogether on my side in this. But as only an ordinary member, with only these rare occasions at my command for advocacy, I could not expect that my pleading would have much effect. I was then living in Sussex, where through the medium of the "Sussex Association for the Improvement of Agriculture," formed by the late Major Warden Sergison, of Cuckfield Park, we did our best to work upon the local agricultural population by such means. There can be no doubt that we did some goodalthough the experiments undertaken were not in every instance shaped upon the most scientific or judicious lines. Among other things we actually then introduced those " manurial experimental stations" which a few years ago, before the Agricultural Education Inquiry Committee, Mr. Brooke Hunt so warmly recommended. Unfortunately, the Association proved short-lived. It came to an end upon Major Sergison's death. Our experiments were not highly technical. We found on our annual visits to the several stations-which visits were well attended-that highly technical experiments would have been above the heads of most of our public, even of men of position in the agricultural world. But they were designed to bring home established scientific facts-partly chemical, partly botanical-to a public still unacquainted with them and their 
meaning. We occupied sites in different typical parts of the country, in order not only to make the stations accessible to the largest possible number, but also to test our various problems under the most varying conditions of soil and climate. There was manifest reason for such distribution. It is sometimes objected-just as in the case of farm-schools, where practical farming is taughtthat experimenting, and in the farm-schools ${ }^{1}$ teaching, on one particular soil, can have no general value, inasmuch as soil and climate vary. What is ascertained on clay may be of no use on sand, or loam, or peat. A practice very much in vogue on the Continent and also in the United States -far more than here-is, to enlist the support of farmers in various localities for either concurrent experiments, undertaken on precisely the same lines, the several plots being generally small, or else, for independent experiments by individual farmers, considered to possess sufficient capacity and being willing to give their services for the purpose. The first class of experiments are mainly for research, the second for demonstration, the several plots being intended, with the help of their owners' explanations, to bring instructive facts home to farmers in the district and to stimulate them to imitation. "If you can get down and show a man how to do his job better than himself," so writes Mr. J. McKenna, the Agricultural Adviser to the Government of India, " he has plain evidence that you can teach him something." And accordingly he is prepared to learn. "You cannot," so the American Senator Mr. Lever has put it, " make the farmer change the methods, which have been sufficient to earn a livelihood for himself and his family for many years, unless you show him under his own vine and fig tree, as it were, that you have a system better than the system which he himself is following." And that is the object of demonstration plots. In Mr. S. H Young's words, spoken in the American Chamber of Representatives, demonstration "makes every field a class-room." The practice above referred to is a good practice, because it forcibly enlists individual and local interest and promotes thinking. Whether it be further extended in this country 
or not, there can be little doubt that a great deal more of demonstrational teaching would be likely to do much good, by opening minds and filtering knowledge into them, which for the time remains in abeyance. In the United States and in Canada demonstrational experiments are highly appreciated. In Prussia, as observed, there are about eighty experimental stations. And all over Germany experiments for research or demonstration form the very kernel of agricultural education.

Experiments for research stand on a different footing. There is no need for urging those now engaged in them to greater activity or to any modification of their practice. However, those experiments might well be extended and multiplied. In the United States there is no province of instruction more systematically pushed. The Department's research work is said to " cover the whole field of scientific agriculture." There are about 2,000 persons engaged on demonstration and research work. And the United States Department of Agriculture expresses itself most satisfied with the results.

Assuredly a claim for close affinity between experimental stations and institutions or "courses" of special studies will not be judged excessively far fetched. We have some such institutions in our country. More particularly the educational establishments connected with the cultivation of fruit and garden produce have attracted much attention. However, it can scarcely be contended that we have enough for the requirements which the need of the country imposes upon us, if we would bring our Agriculture up to the desired point. Specialising has become the ruling practice in all forms of production. It means concentration of attention and effort. We cannot in Agriculture carry it to an extreme length. It would, for instance, be a mistake to abandon our approved system of rotation for one-crop cultivation. In the Southern States of the North American Union exclusive reliance on the remunerative cotton crop has led to an acute crisis. And Egypt has had a taste of the same visitation. But we cannot expect the average farmer to excel in more than one or two specialities. Evidently 
those specialities in which he does excel he ought to push, selecting his farm accordingly, and in so doing he is likely to fare well. There is no fcature more noteworthy in the recent development of German Agriculture, or more clearly indicative of the causes of the success attained, than the striking variety of cultures, adapting cultivation to local conditions. And with regard to the advance made in Agriculture in the United States, the present Secretary of Agriculture, the Hon. D. F. Houston, remarks explicitly : " The progress of Agriculture reveals itself more particularly in its diversification, in the rise of minor crops to larger proportions, than in the increased production of staple products." In the United States there are institutions for special subjects, such as dairying, fruit culture-and, again, veterinary schools for farmers and the like in all states. However, the system is probably most developed in Germany, in part because German appetite for knowledge is, sometimes to its detriment, most comprehensive; in part also because in Germany Agriculture has become most blended with industrial by-pursuits which, to be carried to success, require to be carefully learnt and studied. Such by-pursuits are distillery (both of potatoes and of grain), sugar refinery, converting potatoes into starch-much practised also in France-or else into syrup and the like. It would surprise our farmers to learn how many different "special " studies the German teaching programme recognises. However, there are very useful specialities also to be found elsewhere, for instance in the United States and in vigorously active little Belgium.

There is a special institution in Belgium for the study of Belgian soils and climates, a study which to many in this country may present itself as superfluous, but which has nevertheless been found to possess its distinct value. There is also an institution already referred to in Belgium for instructing farmers and farm pupils in the use of modern implements and modern machinery, making them understand the mechanism and so training them at once for better knowledge and better use of such articles. Implement making and the manufacturing of machinery have 
made great strides already and keep steadily undergoing further perfecting processes. To the farmer in the country the article may be worth much and it may save him much labour, which is a consideration of daily increasing importance. But how is he to know about and learn how to employ it? In Italy the cattedre ambulanti serve, as far as is possible, the purpose of familiarising him with such new things. The teacher shows them and explains their use. And, by a curious arrangement-which of course is not suitable for our country-the society providing the cattedra leaves an officer in some central locality, to exhibit permanently, teach, and at the same time to take orders for the implements exhibited and supply parts requiring renewal. In Belgium more is shown and more is taught. And, rightly, the use of the institution is made free to any one who can show a fair title to study there.

If demonstration suggests "special" studies, "special studies" in their turn suggest what every one who knows our country life will admit to be a matter of the very first importance, namely, teaching for girls and women. The war has made us appreciate women's labour, the value of which, but for the Studley and the Swanley Colleges, and one or two more similar establishments, we had wellnigh been brought to forget. We have nothing as yet to compare with the hundred or so Ländliche Haushalinngsschulen of Germany, the host of Cercles de Fermières and Ecoles ménagères ambulantes of Belgium, and the 600 or so Women's Institutes of Ontario with their thousands of members, and the numerous and active "Associations of Domestic Science" of the United States, with their host of institutions and courses of lectures and demonstrations. And yet there is no question connected with rural life of greater importance, either economically or socially.

"We have evidence," so writes Mr. Geo. A. Putnam, Superintendent of Toronto, " from the husband, the son, the daughter and the neighbour, that the (Ontario) Institute has been an uplifting force in the life of the home and the community. The husband notices that the mother performs her work in a more systematic manner, with less labour, while the family is better nourished with plain, wholesome food, placed before them in an 
attractive, varied form. A few well-chosen plants are artistically grouped in the house during the winter months, while the garden contains a judicious selection of vegetables, small fruits and a sprinkling of flowers. More attention is paid to the selection and care of the fowls, with the result that this part of the farming operations has produced an increased income, and has been the source of a constant supply of fresh eggs and poultry for the farmer's table. With less manual labour and a little more study, thought and planning, the family is accomplishing more - producing more in dollars and cents on the old farm-has more time for recreation and social intercourse, enjoys better health, as a result of better selected and properly prepared food, and is appreciating the advantages of rural life under modern conditions.... The growing interest of each in the work of the other members of the family is apparent. The daughter notices that mother has a great interest in the everyday routine, which has lost some of the monotony in the variety and simplicity of methods introduced through the Institute. She has a renewed interest in her regular household duties and has come to more fully appreciate her responsibilities and opportunities as mistress of the homestead. She is able through the simplifying and perfecting of methods, and by inducing greater co-operation among the various members of the household, to give greater attention to those things which make towards contentment and perfect liappiness in the home. She shows the children how to prepare the flower-bed, the children doing most of the work; she shows them how to take care of the vegetable and flower garden, and takes a keener interest in the school work of the child. ... In furnishing the women of Ontario with a means whereby they can develop their talents and make the best use of standard works and periodicals bearing upon matters dealing with home topics, we believe that we are rendering a service which will do much to better conditions surrounding home and community life in the rural districts, as well as in many of the larger towns, of the Province. The Institutes have been established long enough to demonstrate that they will be permanent; and while much good work has been accomplished, those in close touch with the organisation realise that the future presents many opportunities which have not yet been taken advantage of by the mothers and daughters."

An Alsatian proverb has it that "a farmer's wife can bring into the farm, in her apron, more than her husband can carry out (to sell) in a four-horse wagon." And a memorial presented to the Economic Society of Berne in I764 lays it down that a woman well educated for rural life brings her 
husband " a better marriage portion by far than ordinary marriage portions" (" une dot plus précicuse que les dots ordinaires").

One may hope that the present generation of country women will find their way back to certain appropriate branches of field and farm, as well as house, work such as their grandmothers were far from despising. But that is not the question here. The question here is this, to provide teaching facilities for women upgrowing and adult-for our adult generation possess none too much of the requisite knowledge-in what may be recognised as the special provinces of woman's activity in the management of a farm, that is, poultry keeping and dairying, and the like, and, above all, improved housekeeping and cooking. What an entirely different world would our rural community be if women of the humbler class only knew how to cook well, how to render dishes tasty, economise material and make the home thoroughly comfortable! The unfortunate uncertainty of their tenure of their cottage, and all the restrictions imposed upon their humble families by our confining system place serious difficulties in the way. However, such obstacles, we may now be confident, will be made to give way under the spirited denunciation and the long stored up but distinctly growing discontent of the great bulk of the Nation. It is the want of knowing how to do things that makes country women wasteful and negligent and inefficient in what they perform. Only instruction can remedy this; but it can do so effectively. We want a regiment of "Lady Barkers" for the country, as well as a good many more "Lady Warwicks." But we want much more. Government attention is now given to this matter abroad, practically in all countries. For, if Germany boasts about its roo Ländliche Haushaltungsschulen, and a special service for women teachers, and Switzerland probably about as many, the Scandinavian countries are not idle, being chronologically in advance, and the instruction given in the Danish "High Schools "-which receive alike young men and young women-is of the best.

France likewise has a good record in the matter. For 
it began the organisation of domestic and agricultural instruction for women-the attainment of which strikes every foreign visitor as adding so much to the charm of French country life-some twenty-five years before either Germany or Belgium, which are now so prominent under this head. It set hand to this work in I880, in Brittany, at Kerléon and Cöetlogon. The Agricultural Syndicates once established, the most active Union of the body, that of the Sud-Est, led by such energetic men as MM. Duport, de Fontgalland and Guinand, took the lead in promoting domestic and agricultural instruction for women in private educational establishments, which form of education has been carried very far in all parts of France, other Unions following suit. However, such action of necessity presents a want of uniformity. Later, accordingly, to remedy this defect, both the Société des Agricultcurs de France (corresponding to our "Royal Agricultural Society") and the Government took the matter in hand. So now there are in France, by the side of such distinctively " catholic" societies as the Institut Jeanne d'Arc, purely educational women's schools under the supervision of the Syndicats, and such Government-directed Institutions as that of Monastir and a number more (more particularly in the north of the country) and, moreover, a special school for women's school teachers at Avaux in the much tried Ardennes. And there is more coming. For at the instance of many leading statesmen connected with husbandry, including past Ministers of Agriculture, the French Parliament has sanctioned the opening of the "Institut National Agronomique" to women students, on precisely the same terms as to men, and without any limitation as to numbers, from the spring season of I9I8 forwards. Women have, in fact, during the war made good their standing in France in matters of Agriculture, by the devoted and generally judicious management of agricultural properties in the absence of their men folk. Without doubt other agricultural educational establishments will be opened in the same way. In fact, France seems thoroughly awake to the educational necessities of the great national calling. "We want a 
full million of male students, and another million of women students, in the place of the 2,000 or so male and the few hundreds of female students that we have at present." So says a Memorial recently handed in to Parliament by a Committee of leading men interested in Agriculture, including late Ministers of Agriculture. Is there not a roı $i$ opoi $\omega$; for ourselves in that Memorial?

By the side of these countries Italy also has its own housekeeping schools, Spain has some beginnings, as at San Ferdinando, and even Russian Poland has a "Ziemianki " (women landowners) society to show. Everywhere the recognition of the great social and economic regulation of the subject has forced it to the front. Organisation and comparative extension seem most perfected in Belgium. There are the écoles ménagères and above all things the most useful Cercles de Fermières, which gather in pupil recruits. In 1909 the number of cercles-the formation of which was only begun in Igo6,- -was sixty-five, with 6,162 members. However, the parent country of all, probably, in the United States, from which Mi. de Vuyst, the originator of the Belgian movement, admits that he brought over the idea as a Promethean spark abstracted from a transatlantic Olympus. In Europe, apart from France, the movement as an organised movement is accordingly only about ten years old. In America it began earlier. And what matured it more rapidly there than happened in Europe probably was the marked preponderance of women teachers among the instructing staffs of rural schools. Women naturally think of their own sex and, thanks to their initiative and their keen perception of the necessity of agricultural education, in a country of farmers, rudimentary lessons upon Agriculture and rural life, which latter Mr. Roosevelt, while President, tried so hard to improve (appointing a Commission of Inquiry on the subject), have become a standing feature in a large number of rural elementary schools. In the United States women's gatherings-seeking generally at their local centres the support and shelter of established and recognised male organisations-are organising female education by counties. Their organisation is practically 
the same as in men's Colleges. But the subjects are different. And the teaching is markedly different, in order to suit the feminine temperament. There are schools and "courses" of the kind in Colorado, Indiana, Iowa, Maryland, Minnesota, Michigan, Missouri, Montana, Nebraska, New York, North Carolina, North and South Dakota, Pennsylvania, Tennessee, Western Virginia, Wisconsin, and Wyoming. And the movement is reported to be spreading in other states, several of which have begun with the formation of local centres.

The United States had in I9Io rural women's schools in eighteen different states-by this time probably in more-with the Illinois "State Association of Domestic Science," as the originator of the movement, at their head. And Ontario, as observed, has at least 600 Women's Institutes. In Ontario the movement is assisted by the Provincial Department of Agriculture, which sends lecturers to meetings, and contributes $£ I, 500$ to $£ 2,000$ annually towards the expense. However, the main cost is defrayed from the shilling contribution of women members. The effect of the teaching upon the conduct of farmers is said to be very marked. Hence "we have benefited very largely in a social way," so writes Mr. Putnam, already quoted.

"In all communities there were societies of women, more especially in connection with church work, but each denomination worked apart, and it has been the work of the Women's Institutes to bring them all together as one harmonious whole on common ground, the good of the home. The Women's Institute cannot measure success by dollars and cents, nor yet by numbers, but by the spirit of helpfulness, sociability, sympathy and sisterhood, which it has engendered throughout the entire township. To fully grasp the effect upon the individual members, the families and the community, it is necessary to have been a member of a branch and to have noted carefully from month to month and from year to year the improvement on the individual, the home and the community, brought about by the regular monthly meetings of this congress of women, with politics and religion brushed aside, and with one object only in view, the betterment and uplifting of the home and the country in which we live." 
There is promise in this for the improvement of country life and the repopulation of the half-deserted village.

In Belgium the Women's Education movement is seenbarring the war-on a smaller scale, with, accordingly, very much more attention paid to details. As in the societies of the Boerenbond, there is a pronounced flavour of " the Church " about a good many of the centres formed, which are supported by fixed and also by travelling écoles ménagères. The number of the fixed écoles is to be increased. One object pursued is to keep country folk " rural," uncontaminated by the vices and demoralising failings of the town, one of which failings of course is held to be "rampant Socialism." With the help of her Cercles de Fermières Belgium has carried rural instruction for women to a high point of efficiency. At the International Exhibition held at Brussels in 19I0 one of the exhibits most noticed and most freely visited was the Pavillon de la Femme, which showed on what a great variety of female occupations Education has laid its hand, and what excellent results it has secured. There can be no doubt that to the proficiency in occupations of their calling, by means of the instruction imparted in Cercles, and otherwise, and the careful attention bestowed upon the giving of such instruction by the authorities, Belgium is indebted for much of that rural prosperity and rural contentedness and happiness which it enjoyed before the war. The object of the leaders of the movement is, in due course, to establish a Cercle de Fermières, with its école ménagère attached to it, in every parish. That aim has not nearly yet been attained. There were probably about Ioo Cercles before the war. They are organised like men's societies with a minimum subscription. The gatherings take place in the afternoons in winter, and it is said to be curious what enthusiasm for attendance and learning women and girls give proof of by their appearance in large numbers, many having trudged long distances to do so.

Widely extended as the movement in favour of women's instruction is, authorities do not yet appear to be quite at one as to which is the best shape for female education 


\section{I4 8 THE FUTURE OF OUR AGRICULTURE.}

for farming life to take. In Germany, Austria, and Switzerland the movement was started by the formation of household schools (Ländliche Haushaltungsschulen), which are really "winter schools" occupying from three to four months for a course of teaching. Germany, as observed, numbers about Ioo of such-schools-apart from a considerable number of itinerant cooking-schools moving from place to place like our Egg Demonstration Train. These are found to be more expensive than the fixed institutions. But they do a great amount of good, reaching a humbler stratum of women folk, who could not be expected to attend household schools. The organisers, alike of schools and of itinerant lectures, are Chambers of Agriculture, Agricultural Societies, and religious foundations. In Roman Catholic Bavaria the local clergy direct these establishments. Among the countries here referred to it is Germany which has paid greatest attention to the training of efficient teachers. It maintains a special Seminary for the purpose, Austria also makes a fair show in the matter. In Switzerland the movement is only about ten years old. The number of schools is small. But the schools are excellent, maintained by the several Cantons, with the usual equivalent grant from the Federation. The teaching is gratuitous, but there is a charge for board. The variety of subjects taught is considerable. And on this ground theory and practice march abreast, the one supplementing and elucidating the other. However, both in Germany and in Austria a new departure has been made by extending the " courses," and it is proposed to have regular schooling of from one to two years, which latter term would serve also to train teachers for such schools.

By the side of all this it cannot be said that we have overmuch to show of a similar nature, although the cooking and domestic arrangements of our humble country folk appear to call for a good deal. It may be hoped that, as from Mr. Middleton's Report a desire has sprung up to emulate Germany in the production of food, from what is going on elsewhere in respect of female education a corresponding desire may arise to rival our neighbours and our American cousins also in this matter. 
Returning for a moment to the point of special subjects, it may be questioned whether that Amcrican speciality, an " Office of Farm Management," would not be worth adopting in this country also. The reproach of backwardness, as compared with other callings, in a knowledge and practice of business methods among farmers, which in the United States suggested the formation of such Office, with its special schools, applies to our British farming quite as much as it does to American. Indeed, it may be doubted if, once farmers had got hold in their heads of the "business end " of farming, having learnt to calculate what pays and what does not, what pays better and what worse, a desire for scientific and technical instruction would not spring up of its own self. Our farmers have the reputation of possessing an observant eye to the main chance. Once they came to understand that there is "money" in Education, they would surely not be slow to covet the latter. It is, in the words of the Hon. D. F. Houston, Secretary of Agriculture in the United States, the object of the Office of Farm Management to teach a farmer " to know at all times just how his business stands, what parts are profitable, what unprofitable, and how he should direct his activities to ensure success." A young man rarely learns that in private apprenticeship, because that is just the part of the business which the principal is careful to keep scrupulously to himself. Farming, as most of our farmers do, after a routine fashion, the ordinary man cannot readily find his way to such knowledge. He sees a maze before him, to which he lacks the key.

"The business of the student," so writes Mr. Houston, " is to make an analysis of the operations of the farmer, to study the proposed adaptation of the types of farming to local conditions, such as soil and climate, the size of the market, market demand, and transportation, the quality of the farmer's business, its organisation, the distribution of farm enterprises, and the costs of each sort of product. The investigations of the Office of Farm Management are as yet in their infancy, and there is much to learn in this branch of agricultural science; but the inquiries thus far pursued furnish a deeper insight into the causes of success and failure in farming and give promise 
of helpful results in the increase of production on a profitable basis."

And that, as a matter of necessity, carries with it instruction in that particular item of farm management in which our farmers are notoriously most deficient, namely, account keeping. In Germany, even in advanced Rhineland, organisers of co-operative societies have found it advisable to form a special department for teaching their societies correct account keeping. That has nothing to do with either audit or inspection. The Department simply receives the societies' rough data and puts them into book-keeping shape, so as to instruct the Committees how after a time to do the work for themselves. Such service could not of course be offered to individual farmers, because it would be considered prying. Farmers would be naturally shy to disclose the facts. However, the substance of the matter necessarily finds a place in "Farm Management."

Another "special" subject deserving at any rate of mention, although relating rather to Research than to Education, is that committed in the United States to the "Bureau of Soils," and in Belgium to that of "Soils and Climates," occupying stations in different parts of the kingdom. The work to be done is not merely one of chemical analysis of soils, although that must inevitably form part of it. A collocation of the same constituents in the soil may, as we know, coexist with quite distinct qualifications for practical treatment. The observations made by experts in a scientific way are said in both countries to have been found exceedingly useful.

There is one point more which requires to be noticed. That is the point of teachers, be it at Colleges or schools, or be it at movable lectures, or in the buttonhole talk with individual farmers, which has been referred to as the most effective first stage of Education. From what one has seen in this country it is to be feared that those responsible for the organisation of Education are not yet fully alive to all the requirements to be met for really effective teaching. We have seen men sent about by societies which have set themselves the task of teaching and organising, about 
whose qualifications for teaching their hearers knew nothing and who have accordingly altogether failed to command their confidence, meeting with an irresponsive reception like that described by Mr. Buckmaster. We have even seen men sent about as " organising secretaries" of societies, officered by men of note, who knew practically nothing of their subject-say, in respect of co-operative credit. One of these gentlemen, who had previously been employed as organiser of boys' clubs, admitted his ignorance to me, but self-consciously declared that "on the platform" he would " not give way to any one." Under such circumstances what practical results can there be looked for? Things are better abroad now. But, as a hopeful solace to ourselves, it may be mentioned that they have previously passed through the very same stages of development. Let us hope that we likewise may emerge triumphantly from this phase of infant malady.

What the Latin proverb says about the " rustic orator," 1 who is not to be despised, applies fully as much to the " rustic " who is to be educated. It is the greatest mistake in the world to think that a little declaration about some learned subject that he does not understand, or is supposed not to understand-accompanied, it may be, in Mr. J. McKenna's words, by a little "waving of degrees in their face "-will in a lecturer's mouth be accepted as teaching deserving to be respected by his hearers. Though your rustic does not know about chemical formulæ and scientific farrago, or rural credit and co-operation, none is shrewder to detect whether his would-be teacher is deserving of attention or not. Above all things, he is acutely alive to the fact that as " the proof of the pudding is in the eating," so is the proof of science in practice. On any practical subject it is essential that the teacher should be a bonafide practical man, with a creditable practical record at his back. Even a teacher of science, if he wants to be understood, will be required to be able to talk to farmers in their own practical lingo. A man giving instruction on practical subjects must be known to have been himself

1 Rusticanum oratorem quamvis humilem, non contemseris. 
creditably engaged in practice, upon which he has subsequently grafted science as an addition, without accepting it as a substitute. In Switzerland in the lower grades that restriction, originally jealously observed, has had to be broken through, because the demand for teachers became excessive. However, there, as it happens, the limitation may well be set aside. For there is sufficient " rural atmosphere" there to correct the want. But everywhere else the condition is still rigorously necessary. In Prussia the authorities will absolutely not allow a teacher on a practical subject to be admitted to teaching, unless he can show creditable practice of his own. And that is a commendable limitation. In Prussia also-and not in Prussia aloneteachers are made to pass through a special course of education, with examinations and a diploma at the end of it. If you cannot secure instructors who, in addition to knowing their own subject thoroughly, know also how to gain the confidence of their rural hearers-which is a special gift -your instruction will be vain.

If there is to be an advance in Agricultural Educationand on that really all further progress depends-in addition to a guarantee of competency there will also have to be an ample number of teachers. For we have what may be termed an entire world to conquer, under circumstances of not inconsiderable difficulty. Many of our people to be taught we can hope to convert only by quasi-private talk, such as Mr. Fitzherbert Brockholes has shown to have been particularly effective in Lancashire, on their own farms and about their own affairs. If such method has proved necessary in the "brains of the country," we may be sure that it is wanted also elsewhere. When the Bank of Egypt first established its Agricultural Department, which subsequently developed into Lord Cromer's "Agricultural Bank," in the first years it was found that, to obtain custom, the Bank's cmissaries must go out into the highways and byways of the country, carrying bags of gold coin on their backs and plying the fellaheen with arguments in favour of their accepting loans. The employment of the gold so pressed upon them taught them-while at the same time unfortu- 
nately developing some very undesirable propensities and habits - the use of credit, and so fitted them for the introduction of that co-operative credit, for the practice of which Lord Cromer has owned to me that he did not in his day consider the country population yet fully ripe, but which is now, as I understand, to be introduced. In the same way Indian Government officers have had to press their takkavi loans upon scarcely willing rayats, so preparing them, by a practice which in itself is far from perfect, for the more educating employment of co-operative credit, which is now working such wonders in our great Eastern dependency. It is the same thing with our education. We are pressing upon our rural population a commodity in which they " do not believe." We are asking them to take our goods " on approval." We know that what is wanted is what an expert American of authority, Mr. H. J. Waters, President of the Kansas State College of Agriculture, has called " a veritable campaign of Education." And so, if we would have the result, we must not grudge the means required to produce it. We spend from $£$ I9,000 to $£ 95$,000 (the latter sum includes $£ 6$ I,699 from the Development Fund for the particular year) of public money a year upon our Agricultural Education. The figure for I9Io was $£ 19,265$. Prussia in that year spent five times that amount on its agricultural High Colleges alone. The United States spendon Education and Research-fully $£ 2,000,000(\$ 10,000,000){ }^{1}$ The money is not thrown away. A canny Scot from Ayrshire was, about I896, placed at the head of the Department, to set the "campaign" a-going. Listen to what he reported in I9o8, after twelve years of hard work-which has since been as energetically continued by himself and his successor:

"The period has developed an amazing and unexampled prosperity for the farmer. His improving financial condition has been both an effect and a cause-an effect partly of his own efforts, joined to those of public agencies; and also the means of making his life and the lives of his wife and children better

1 The total vote for the Federal Department of Agriculture in the past year was $\$ 138,180,030$ (over $£^{2} 7,000,000$ ). 


\section{I54 THE FUTURE OF OUR AGRICULTURE.}

worth living. More wealth has been invested in improving the farm-house and in the current expenses of farm life. With better houses, filled with modern conveniences, the family life has developed in strength and in enjoyable living. . . . Child life on the farm is entering upon a realm of favouring conditions in the home, at school, and in farming ; and home-making apprenticeship is rising to a higher level.'

There are numbers of particulars given referring to improvement in seed breeding, in research, in marketing, and so on. Referring specifically to Education, the Report says :

"The students at our Agricultural Colleges, in I897, were 4,000; they are now (in Ig08) I0,000 (in I9I4 there were sixtynine Colleges with 6,370 instructors, and 69,132 students) ; one Agricultural High School existed in 1897 ; there are now fiftyfive; not one normal school taught Agriculture in 1897, but now II5 do so, besides many privately endowed schools (practically all elementary rural schools teach it now); about half of the Agricultural Colleges now give training courses for teachers in Agriculture ; forty-four states and territories give some instruction in elementary principles of Agriculture in the lower schools; the number of sessions of Farmers' Institutes held in 1908 was I4,000, with an attendance of about $2,000,000$ persons; in I897 the number of publications issued by the Department was 424, of which 6,54I,200 copies were distributed; in I908 the $\mathrm{I}, 522$ publications issued by the Department were distributed to the number of $16,875,5 I 6$ (in I9I4 the Office of Information communicated with the public by $250,000,000$ printed papers monthly). In respect of production per acre of the principal crops, there has been an increase in the last ten years (notwithstanding much backward farming not yet affected) in the yield of cotton by about 20 per cent. ; the yield of wheat has increased by 14.5 to 45.9 per cent. ; of corn (maize) by 17.5 per cent. ; of barley by 13.5 per cent. ; of rye by 4.4 per cent. ; of buckwheat by I 4.7 per cent. to $2 I \cdot 9$ per cent. ; of potatoes by $22 \cdot I$ to $39 \cdot I$ per cent.; of hay by I9.5 to 30.8 per cent. "The percentage of increase," so adds Mr. Wilson, "now has a new significance-no one need fear that the farmer of this country will ever be unable to provide for the population."

That last-named object is that which we now have most at heart: provide the population with food. And the road by which such goal may be reached is perfectly plain-Mr. 
Wilson has shown it to us. It is above all things Education that we want.

"The farmer will not fail the Nation," so wrote Mr. Wilson a few years previously, in I906, when the raising of public expenditure upon agricultural Education and Research to $£ 2,000$, 000 a year had just been decided upon, " if the Nation does not fail the farmer. He will need Education, to know the powers of the soil which are now hidden to him. The prospective yearly expenditure of $\$ 10,000,000$ for Education and Research must have enormous effects." It has had them. We are willing to tax ourselves heavily to make up for the deficiency in the output issuing from a faulty machine. Would it not be better policy to remedy the fault at its source, in the machine, and then let the output take care of itself? What do we do in the way of Education for Agriculture and for rural life in comparison with Belgium, with Switzerland, with Prussia, with the United States? In a Report on Agricultural Education in Germany delivered to the International Institute of Agriculture, Professor Rümke, of the Agricultural High School of Berne, says:

"The great progress which Agriculture has achieved in Germany during the last quarter of a century is the result of the union of Practice with Science, and proves that money spent on research and on education to every class brings in a high rate of interest and is compensated by the increase of returns of land taxes and of revenue from railways."

Prussia, with a population one-ninth smaller than our own, provides 5,564 teachers of various kinds for the service of Agriculture, in I,227 distinct establishments. These are the official figures for Igr4. That figure counts some men twice over, but it does not include the considerable number of teachers sent out by co-operative and kindred societies (includung many "Peasants' Unions"), nor teachers employed at veterinary colleges and forest schools; nor the University Professors borrowed for specific courses of lectures; nor yet the teachers at about 4,000 rural continuation schools; nor yet the instructors and instructresses supplied by various societies and corporations without 
distinct persons being named. There were I,7I9 teachers at farm-schools and "winter courses," and 395 itinerant lecturers. ${ }^{1}$ The result of the teaching so provided is recorded in Mr. Middleton's Report. What have we to show against that? Prussia superintends its agricultural educational machinery from headquarters, with the provincial Chambers of Agriculture-that is, bodies composed of skilled agriculturists, with no object to keep in view except the improvement of Agriculture-to apply its Act. We still act through our County Councils, which have many other things to give their attention to and the exacting argumentum ad crumenam to limit their liberality-as if Agricultural Education were not a national but merely a local interest, in the pursuit of which no settled plan, no uniformity were called for and in which supply must be kept down. In the United States, so long as the matter was left to the several states-just as it was in Switzerland while the matter was there left to the Cantons-Agricultural Education would not advance; the supply of money was stinted. In both Republics the Federation stepped in, providing State money and claiming supervision by the Federal Departments. And in both countries the wagon henceforth went forward at a rattling pace. In the United States not only did the Federation money prove a direct benefit; it also disposed the states on their account to vote considerably larger sums. And Education produced fertility out of barrenness. Our problems of Agricultural Education and systematic training to rural life require tackling afresh. There can be no real advance till that need is supplied. It is the backward farmer who holds back our Agriculture. If he

1 I take the following list of educational establishments concerning Agriculture from the official Report of the Department for rgo8, which was kindly supplied to me at the time by the Prussian Minister of Agriculture, Baron von Schorlemer-Lieser: 8 Agricultural Colleges, 2 Forestry Colleges, 2 Veterinary Colleges, 3 superior gardening schools, 18 middle and 201 lower agricultural schools (farm-schools and winter schools), I 7 schools for gardening, forest cultivation and meadow cultivation, I4 dairy schools, 4 schools for agricultural by-industries, 3 agicultural schools, 65 horse-shoeing schools (for farmers) ; 7 poultry schools, 4 schools for forestry pupils, 98 rural householding schools; $3,78 \mathrm{I}$ rural continuation schools, 
were taught how to do things, he might produce twice and three times what he produces now and, if war were to break out again, we should be able to snap our fingers at submarines. We complain of having only an insufficient number of pupils. An earnest effort to provide more teachers and to train such specially at our educational establishments would of itself swell the number of agricultural students to be taught and so help to make agricultural education more popular, by opening up a road to a new calling to a generation among which such would assuredly be appreciated. The Board of Agriculture is worried by farmers who find themselves cheated by dealers, more particularly in the purchase of fertilisers, and who ask the Board to take up their quarrel and publicly pillory the guilty parties. The time ought to be near when farmers will know how to deal with such cases themselves, providing for analyses on their own account. In the meantime, in the kingdom of Saxony the Agricultural Department offers to analyse goods for farmers indifferently and gratuitously and to place all firms which submit to such analysis upon a published list. For reasons easy to divine, firms eagerly agree to such a test, and the farmer is safeguarded from fraud. There are other similar services to render; of which a public department might temporarily take charge until farmers are educated enough-for organisation, if for nothing else-to be able to look after their own interests. But the greatest want at present is plenty of officers, corresponding to the Dutch advising consulenten and the Belgian agronomes de l'Etat, the Canadian "County Representatives," and the United States " County Agents," and attractive machinery to gather together farmers, upgrowing and adult, in well-mastered schools, " Institutes," permanent associations, and periodical gatherings. 


\section{CHAPTER IV}

\section{ORGANISATION}

Next to Education probably the most urgent want of our national Agriculture at present is Organisation. Practically speaking our Agriculture lacks all such. And what feeble beginnings there are, scattered thinly over a wide area, are the result purely of a quite new movement (copied from the Irish), which has not yet made nearly the headway which it is desirable should have been made. And yet, never was there a business interest which by its very nature was more dependent upon Organisation. Never also was there a business interest confronted by such a serried army of thoroughly organised other interests, against which it is called upon to try its strength in daily strivings. In the American Senator Mr. Gronna's words, " there is no industry except farming in which a man has to accept the price offered by the buyer." And never was there a business interest to which better examples were set, all round, of organisation accompanied by convincing proofs of its success. It is not only Germany, the constantly quoted, with its close upon thirty thousand agricultural co-operative societies, which instructively points the way. There is France, with its imposing phalanx of "Agricultural Syndicates" ; Denmark, premier country that it is in respect of Co-operation for agricultural purposes, with its multitude of local societies, carefully adapted to every particular need, and its great Egg export and Butter and Bacon centres; and Russia, in which the emancipation lately completed has conjured a whole host of co-operative societies, so to speak, out of the earth, so as to give it first rank in Europe in 
respect of the number of societies existing; and Austria and Hungary, with their subsidised societies doing a large business--it is true, on something like a spoon-feeding planSwitzerland, with very active and well-organised agricultural Co-operation ; Italy, with its sindacati, its comizi, its affittanze collettive, and so on. Sweden and Norway have come in in some force and are satisfied with the results of their Organisation. In Bulgaria, Serbia and Roumania co-operative organisation had, before the war, transformed the face of the country-far more beneficently than the subsequent tramp of battalions. And America is heaving with agricultural organising work, bristling with societies which, although their Co-operation is of rather a different stamp from that which we in Europe accept as ideal, more on jointstock lines, exercise even greater power, disputing the primacy of business with the mighty rings and trusts and grouped railway interests in wide districts-to state one instance, almost monopolising agricultural insurance in the Middle West-providing machinery and telephone service for their members, and altogether governing the enormous Western fruit trade, all of it with remarkable success. Canada is reported to have at least 2,000 societies of the sort. The United States boast more than I0,000.

Everywhere have Governments, bent upon promoting the prosperity of their countries, and more specifically of Agriculture, given what encouragment they could to the introduction, and subsequent more and more perfect organisation, of Agricultural Co-operation-in some cases more than was useful. But in any case they may claim the merit of having recognised the importance, not to say indispensability, of the establishment of Organisation on co-operative lines and shown their goodwill-as did also, in this country, more explicitly, the late Mr. Hanbury, during his brief tenure of office in Whitehall Place, telling us, of the Agricultural Organisation Society, that he did not consider himself entitled to the gratitude which we expressed to him, since it plainly was his "duty" to encourage Cooperation in Agriculture-for which " encouragement" unfortunately not overmuch scope was allowed him. In the 
United States so impressed is the Federal Department of Agriculture at Washington with the great value of Co-operative Organisation to farmers, large and small alike, that it has instituted a special "Section of Markets and Rural Organisation," the Specialist of which, Mr. C. W. Thompson, writes in an official Report of I9I5:

"In the farming processes, from the first stage to the last, from the selection of the seed to the marketing of the product, as well as in the promotion of social well-being in farm life, Organisation has proved its value, and, as this fact is being realised, more and more fully organised methods are being employed in increasing measure."

And everywhere, without exception, Co-operative Organisation has proved Agriculture's best friend.

It is curious-and interesting - to note how everywhere, in sore trouble, agriculturists have, as if by instinct, turned to Co-operation when their country suffered. In Denmark it was the crushing defeat of I864-when, as the pun ran after our desertion of the Turkish fleet at Sinope, we left our friends " sine ope" - which first suggested Agricultural Co-operation. And Agricultural Co-operation has proved an efficient solace. In Finland it was the same cause-political oppression and deprivation of liberty under the Plehwes and Bobrinskys, which gave Agricultural Co-operation the start. And the effect was as brilliant and even more rapid. In Russia it was-just as in India-the bloodsucking of the usurer (nicknamed "benefactor") and usurious trader which drove peasants to Agricultural Co-operation. In Germany it was, in the early 'eighties, after agricultural disappointment caused by the failure of Prince Bismarck's Protection of $\mathrm{I} 879$ to perform what had been promised, that farmers resorted to Co-operation. In similar manner in France it was the protective tariff which stamped rural co-operative bakeries out of the ground as Pompey did legions. In the United States it was depression and the cruel exactions of "Trusts" and "Rings" which led to the formation of the great Farmers' Educational and Cooperative Union, a body now with more than two million members and some thousands of associations, which has 
grown to be a veritable economic power in the land. There was no other resource to turn to. For there would have been no use in crying out for Protection, the grida di dolores of our farmers in England: because the United States had Protection already; and, like the Germans, had found that it did not help Agriculture a bit, however magnificent had been its promises. So, in their need, they must turn to Co-operation. Here is what one of the officers of that Union reported on the subject to the Marketing and Farm Credits Congress of I9I5 :

“ Before the Farmers' Union came into existence, as an organisation, the average farmer of the South was very much dissatisfied with his condition in life. He realised that he had not been getting the value of what he produced. He felt that he was not responsible for this condition and was much inclined to lay the blame at some one else's door. He realised that he and his family would have to labour the entire year to grow a crop of cotton, and that he would have to sell this cotton crop immediately upon gathering, and often at a very low price. In fact this type of man was unable to supply himself and family with their necessary wants and comforts. His children were not being educated as they should be, and their prospects in life were none too good. Such a condition led to a deep-seated discontent. The great majority of the farmers realised, however, that they needed some form of co-operation, and they began to realise that in order to do what they would have to do, they must organise themselves. This led to the birth of the Farmers' Union. After this organisation came into existence we began to study the real condition of the farmer. We found that the farmer himself is perhaps as much to blame as any other individual. So the organisation of the farmers was begun, to protect them. We have undertaken not only to conduct ourselves as members of that organisation along the better lines of using better methods in preparing our products for market, but we have undertaken to do something that would affect the market itself."

And they have done it. Under the spell of Co-operation the face of things has become materially changed. In truth, the movement began before then. For it was in 1867 , when depression was great and rival interests were pressing Agriculture sorely, that the society of "The Patrons of Husbandry," better known as "The Grange," was 
formed, as a means of combating the all too cute cornerers and groups of railway companies which kept farmers forcibly in subjection. The "corners" and railway harpies were fought by the Elevator Companies, of which there are at present more than 2,900 in the States, and have found that such could give a good account of themselves.

Thus practically the entire civilised world shows its Agriculture organised and profits thereby. We alone remain unorganised. By our very side is Ireland, with its goodly array of societies of various kinds, the result of a movement which sprung up little more than twenty years ago, strengthening the feeble, providing markets where previously there were none, and thoroughly uniting -as the one thing which has ever succeeded in doing soin the common interest, for the good of one common country-literally all the otherwise conflicting and ever wrangling parties of the green and orange, the Roman and Presbyterian, the Gaelic and Sassenagh kingdom.

In all the countries named it is a touch of necessity which has brought farmers together to work-and, if necessary, to fight-in unison. Agriculture was poor. Or, as has happened in Denmark, German closing of one market necessitated to searching for another, which, it turned out, could only be secured by united action, so as to furnish uniform standard goods in sufficient quantity. Or else, and for the most part, it was the other business interests, the usurer, the trader, in one word, the middleman, who, very naturally, tries to make a profit at either end of his bargain, and who has an ugly knack of getting the unsuspecting, weakly yielding farmer into his toils, and place him by degrees in abject subjection, who became the moving cause. Now the middleman is a most useful institution, where he is wanted -that is, where the two factors of supply and demand cannot otherwise be brought into touch with one another. But wherever they can be so brought, he becomes a decided nuisance, very much de trop, and a very leech and octopus for sucking blood out of, or fastening his tentacles upon, hapless victims, and drawing them down into the deep-the unfathomable deep of peonage and ruin. In India, where the 
"bania" has his paradise, rayats in borrowing pawn the ungotten child of the daughter for whose wedding they borrow money. And the child, come to maturity, recognises the debt. So the fetters of debt come to be handed down from father to son and grandson, and descendants beyond that, as a permanent burden. In Ireland "gombeening " has no better record, favoured as it is, politically, by parliamentary electors, and also higher up. In German Rhineland it was the extortions of the wily usurer which drove Raiffeisen into inventing rural Co-operation, with which weapon he went to battle-and so far as he could do so, has gloriously conquered. In France it was the exorbitant charges of the middleman dealing in agricultural necessaries. In the United States, as already stated, it was the all too cute cornerers and groups of railway companies which practically forced farmers to try to do the work required for themselves. The cornerers and railway harpies were successfully fought by the Elevator Companies, acting under the name of Co-operation, which in a good many cases really means only Combination. However, for business purposes even pure Combination is effective. It emancipates the producer. It secures to him his own market, in which he is master. In Germany and the Netherlands he has got it even for his live stock. We ourselves have our beginnings. We sell some live stock co-operatively, to manifest advantage, through skilled agents. And we have other co-operative societies for various purposes, dairies, egg-selling societies and others, which do well. In Germany corn is freely sold on co-operative lines, and, by a curious coincidence, such sale is realising the very same 2s. per quarter which Mr. Chamberlain promised as a reward for the acceptance of his Tariff Reform. In Hanover the co-operative trade in live stock, as organised by cooperative societies, has been perfected to such a point, that beasts are bought and sold unseen, as we buy and sell inanimate commodities of known quality. It is some years since the President of the "Farmers' Educational and Co-operative Union," already mentioned, in the United States publicly stated: 
"We have I,628 warehouses, mainly for storing cotton; Mississippi leads the warehouse movement with a million-dollar corporation. We own and operate a large number of elevators and terminal agencies for the handling of grain. We own and operate 245 packing houses. We own and operate dozens of newspapers. We own and operate coal-mines. We own and operate several banks, flour mills, creameries, pickle factories, several hundred stores, an implement factory, a phosphate plant, a phosphate mine. We own and operate tobacco factories and warehouses, produce exchanges, fertiliser factories, peanut warehouses, a peanut reclean, many cotton grading schools, cooperative life and fire insurance companies."

The country beyond the Atlantic is accordingly all astir with Co-operation of a sort and, with the help of its Department of Agriculture, its State Legislatures, its Universities -such as Madison--and its Bankers' Association, scenting profit for banking in the advance of Agriculture, the national farming interest is developing much further.

Now one would like to ask: Have we in this busy country of ours no need of a bridge to span the space which still separates the producer and the consumer so as to bring them into direct touch with one another and do away with unnecessary toll taking-repeated as it is at more points than one? Are our agriculturists so prosperous that they can afford going on doing as they do now, that is, buying in the dearest market and selling in the cheapest--even supposing that there is no fraudulent rigging of the market by means of disloyal combination or conspiracy on the other side? And that at a time when all the business world has settled it that the proper business principle is, to buy in the cheapest and sell in the dearest market, and has organised its forces accordingly, so as to avoid loss where it can be avoided and ensure profit by appropriate distribution. Listen to what Mr. A. D. Hall says on the point: "The uneconomic nature of the present system may be gauged by the number of dealers, auctioneers, agents, etc., that even the smallest country market supports. Undoubtedly by Co-operation something might be knocked off the cost of materials bought, and in the end a more stable market might be found for produce." Those hosts of middlemen 
are eating the marrow out of our bones-not necessarily malevolently, but by reason of a costly arrangement of business, which multiplies transactions, swells the amount of transport charges, and quite unnecessarily causes additional expense.

But that is not all. Organisation is not merely an effective weapon for defence against overreaching and waste. It is, besides, an admirable, extremely useful implement for business, even where there is no visible attack made, where the enemy to be defeated is merely waste of time, failure to produce at cheapest rates and in best quality, and in quantities which perforce command a market.

There is more still, as we now understand Co-operation. But let us stick for the moment to the pure business aspect as a regulator of transactions and as a preventer of waste.

There is not another productive business in the world the transactions of which are so much subdivided, made up of so many distinct units, as Agriculture. And not only is the business divided up into small, and often infinitesimal fractions, but time and space, sorting and guarantee of quality (where different degrees of quality make a considerable difference in the determination of the value) play so leading a part in it. Goods are perishable, or at any rate lose much of their value if not brought upon the market fresh. And to produce anything like the bulk which will take a place in which to hold its own, the produce may have to be collected, in small quotas, from a wide area.

"For the marketing of perishable products," so says Mr. R. W. Hockaday, General Industrial and Agricultural Agent to the Missouri, Kansas and Texas Railway Company, who has laboured hard in the United States in the interest of farmers' better marketing, " an organisation is absolutely necessary; for the many questions arising in community shipping (i.e., transport) of such products can only be handled satisfactorily through an organisation."

This reference at once explains why Co-operationwithout which of course Organisation is impossible-has taken a different shape in Agriculture from that which is 
common to it in that successful Store business which has become so familiar to us. It also secms-but only seemsat first glance to confirm the grounds of the objections raised by some large farmers, who hold Co-operation to be valuable, if at all, only for small cultivators-the number of whom of course we are now eager to increase greatly-but quite unnecessary for the large farmer who, in the words of the late Clare Sewell Reade, a typical large farmer of his time, should be (the phrase is not altogether happy) "his own co-operator." No doubt Co-operation is above all things valuable for the small farmer, who in the present day would find it impossible to do without it. He wants the acquisition, or the use, of things which he is not in a position to obtain singly for himself, and he also wants to sell on better terms than in marketing for himself, with his small output, he has a chance of obtaining. However, business has generally assumed so gigantic proportions that the large farmer has no reason to contemn collective action. Large as he may be, the market is infinitely larger. And the question to be taken into account is not purely one of price, nor even of the purchase of goods only, but of guarantee and of common use of articles such as electric power, which require very large participation, of common work and of sale. The German agricultural co-operative societies of the Haas type, which has produced the largest Union, that is, the societies now so freely held up to us as objects for study, being greatly favoured by their several Governments on the ground of their political value as a support for junkerdom and the Crown, are made up to a very great extent of large farmers, that is, cultivating squires, who distinctly find it profitable and amply worth supporting. Among the members of the thousands and tens of thousands of American " co-operative" associations you may find a vast number of large farmers. In Austria and Hungary their number is very great. The host of French agricultural co-operators-and also the host of Italian-includes a substantial portion of owners and tenants of considerable properties, who are all very well satisfied with the results of their Co-operation. The large farmers of the Lodigiano, 
in Italy, farming their Soo and I, ooo acres each, consider themselves every bit as good as their landlords. And our very successful Eastern Counties Farmers' Co-operative Association is for the most part composed of large farmers in those counties. From what will still be said it will, I think, appear that large farmers, like small, are likely to find their account in Co-operation. Indeed, there are cases in which simple Co-operation, in one Union, is scarcely found sufficient. That was so when the farmers of Germany felt it to be their interest to combine in overwhelming numbers to defeat the unfairly profit-seeking scheme of the associated owners of potash deposits. To vanquish them-as they eventually did-the existing specifically "co-operative" unions, with their millions of members, found it advisable to combine, not only among themselves, but also to call in the aid of other great associations of farmers, the great Agricultural Society, and the powerful Federation of Farmers.

As already indicated, Co-operation-which is Organisation-has taken a somewhat different shape in its development among industrial workers from what is required in the service of Agriculture. The industrial worker buys. He produces nothing except the work which is paid for according to arrangement. The aim of his Co-operation is, to buy cheaply and to buy genuine goods, in order to be able to lay by and so attain economic independence. Among those labouring men who make up the mass of our industrial Co-operation it is, accordingly, the distributive side which has claimed first attention and for the time carried the field. At the outset it was not so. When the late J. M. Ludlow brought the doctrine of working men's Co-operation, engendered by the spirit of the French Revolution, across to our country, the great aim of the movement was proudly owned to be the emancipation of the workman, the raising of the wage earner to the position of a self-employer, the liberation of Labour, not as a consuming but as a producing force. The new doctrine was enthusiastically taken up by Denison Maurice, Kingsley, Vansittart Neale, Fughes, and some more, who succeeded- 
more or less forgotten as they are nowadays by the sons and grandsons of their former pupils and beneficiaries-in starting that Co-operative Union, which has now grown so mighty and such an incalculable benefit to the working population as an active force. It was not so much supply that was thought of as production, emancipation of the labourer, the recognition of Labour as a calling equal in status to any other, the placing of the direction of Labour in the workmen's own hands and securing to them the full profit due. Robert Owen, who is commonly reckoned as the "father " of Cooperation in this country, likewise started with the aim of emancipating the workman. That is, however, a slow process, which requires time, patience, and dauntless resolution, in the face of serious difficulties. Meanwhile the abuses of overcharging and adulteration were felt terribly oppressive by the poor, and indeed as formidable obstacles to the emancipation aimed at. Accordingly, and very rightly, combination was resorted to, at first in the smallest of waysbecause the task of removing so great a mountain by trifling efforts and merely nascent faith presented itself as nearly hopeless-with a view to the cheapening of the cost of necessaries of life and ensuring that they were genuine -as a first necessary step to emancipation. The attempt to do so-ridiculed as it was in its first stages, and puny as were the forces which at the outset could be enrolled for the pioneer service (for the twenty-eight Toad Lane weavers, with their small wants, began with only $£ 28$, the ten founders of the great Plymouth Stores with only $£ 3$ ) has in the result proved magnificently successful. The explanation is simple enough. You begin by creating a market that you can absolutely rely upon. There is no need of canvassing for a clientèle. Practically, accordingly, risk is excluded-excluded alike in actual marketing, and excluded also in the matter of payment, since credit is (theoretically, at any rate) strictly forbidden. There must be payment in cash. Apart from excluding risk, that at the same time cheapens management, for there is no need of advertising ; and, so long as the society is small, necessary outlay on the shop is of the smallest. In this way the middleman comes 
to be superseded. Economically the explanation of the process is simple enough. The homely illustration of the bag of raisins which our humble housewife buys for her Christmas pudding, and for which she pays, let us say, eightpence, is familiar. Those raisins cost only fourpence in producing. They are to be bought for that in Spain, where they are produced. The freight to this country is a mere nothing. However, there are four or five toll-takings upon it by intermediaries, each of whom naturally claims to be paid for his pains. There is the agent in Spain, the wholesale house, the shipper, the wholesale house in England, and there are one or two more through whose hands the little bag passes-of course as contained in a large consignment. Now that the great Co-operative Wholesale Society has stepped in-buying the raisins through its agents on the spot, shipping them in its own vessels, and then passing them on, all at cost-price only, to the local store, the price comes to be reduced to the purchasing housewife, let us say, to five pence, for what used to cost her eightpence. Here is a proof of what consumers may do for themselves, once they organise such supply-which, in its perfected state, includes independent production, in the place of purchase only--for sale by the society. Supply or Distribution accordingly became the main point in the co-operative programme of to-day. Its success is practically certain. And its benefits are very apparent in the surplus accumulating to the co-operators' profit. Except for the comparatively small section of the co-operative community which still places the conversion of the wage-earner into a selfemployer and the corresponding raising of the status of Labour to an equality with other callings foremost, and production for the consumers' own use, as an alternative to purchase, Production is put aside. Let the wage-earner remain a wage-earner! That appears to have been accepted as an unchanging ruling of Providence. Even in the employment in the productive departments of the great co-operative organisations-which have grown to erst undreamt of magnificence-the workers remain wage-earners still-wageearners well paid, well accommodated, well considered, but 
liable to dismissal, without a voice in the management and with interests distinct from those of their employers. Hence we have had friction, the formation of a special trade union, and even strikes. The growing idea is that " commerce and industry and exchange" are to be taken over by the consumers, as a collective community, all intermediate profits being eliminated, and the goods passing from the producer straight, and at little more than cost price, to the consumer. When the Chairman of a recent Co-operative Congress spoke of the co-operative aim being " supremacy," he did not mean that the three million British Co-operators now enrolled should rule the commerce and industry of the entire Nation, as William of Hohenzollern proposed to rule the world, but that the consumers of the Nation should all co-operate in order so to dominate production and distribution and so get rid of what foreigners call the unproductive "agio." There is much talk of abolishing "Capitalism." However, so long as co-operative societies make high dividends, which necessarily raise the store price of goods, so as to exclude the poor-for whom Co-operation was primarily intended, as the Women's Guild has rightly again and again called to remembrance at Sunderland and in one or two other places-and practically tell the working man that his road to emancipation lies, not across the raising of the status of Labour, by recognition of the labourer as a co-employer, but across the accumulation of capital in the society's deposit department, so long the boast of "abolishing Capitalism" cannot seriously be upheld. Distributive Co-operation by itself may with its "dividends" help to emancipate the labourer, but that will be by enabling him to turn away from Labour to some other occupation and make of him what specifically distributive co-operators are pleased to call, rather reproachfully, an "individualist." It is self-employment which emancipates Labour.

The farmer also buys, however his buying is mainly for business purposes, as a means to production. His main aim in Co-operation is, after having purchased his raw material cheaply, to sell his finished material to best 
advantage. He is in the main a producer. Evidently the farmer's Co-operation, although still the same beneficent institution as the industrial worker's, resting upon the same foundation-a foundation that cannot be shaken-accordingly presents itself with rather a different face. There is no question here, it is true, of emancipating the working man. And the purely consumptive side of present-day industrial Co-operation drops into the background. The mass of industrial co-operators are mainly consumers. On the farmer's side domestic consumption is of considerable importance, but not as a question of the technical calling. It certainly makes an appeal to him. He may greatly benefit by it-benefit, among other things, for the organisation of other Co-operation which professionally concerns him. And in very deed we find that farmers enrolling themselves under the banner of the Agricultural Organisation Society, not only small ones, but also the substantial farmers of the Eastern Counties Association, were particularly keen upon profiting by the rapprochement between agricultural and industrial co-operative societies, of which I made myself the successful advocate at the Birmingham Congress in 1905, in the way of obtaining cheap goods for domestic consumption. To very small farmers and agricultural labourers the services of a co-operative distributive society, cheapening their grocer's and draper's goods, making them independent of the gombeen man and the scarcely less rapacious village shopkeeper in some parts of our country, would be a very substantial boon. It ought to be systematically striven for. There are parishes in Switzeiland in which the shopkeeper has been entirely crowded out by the farmers' own co-operative stores. And the rural community is the more prosperous for it, laying by out of its business with the stores, instead of running into debt with the grocer-draper. In Eastern Switzerland, so it may be to the point to mention, the transaction of such business in combination with purely agricultural Co-operation, such as we now claim the right of doing in Ireland, has proved not only a benefit but a necessity, and in truth the salvation of agricultural Co-operation, which was on the point of 
becoming bankrupt without it, from insufficiency of business, but which has since shot up rapidly into remarkable prosperity with it.

It is very much to be hoped that in this country likewise, in one shape or another, combination between agricultural and domestic store business may be brought about. The sale of household requisites may not be quite as pressing here as it is in Ireland, where the gombeen man simply bleeds the poor farmer white. But it is wanted, and for reasons already explained will be a distinct benefit, as producing money by overplus where money is wanted, and as training to Co-operation, quite apart from its immediate benefit in cheapening the supply of goods. The very successful practice of the Lincoln Society, spoken of elsewhere, supplies conclusive proof of the practicableness and recommendations of such service.

The action recently, very rightly, taken by the United Board of the Co-operative Union is of good augury for such development. The Board has decided to enter into communication with the newly formed "Allotments Association " which desires to procure for its members the very benefits which Distributive Co-operation assures, and to link up with it for common action. Of course, the Cooperative Union is, very rightly, actuated in making such proposal by a desire to prevent possible friction by overlapping and, not badly meant, but all the same detrimental competition between its own societies and those of the Agricultural Organisation Society. Such friction may very well be avoided - and should be-by a very close connection between the Co-operative Union and agricultural societies. As one move towards bringing this about one might have wished that the Co-operative Wholesale Society, having a very well-equipped and well-managed Agricultural Department, which already does a considerable business in agricultural requisites, had been accepted as the wholesale organisation for the gradually forming agricultural societies. All division and separation means waste of power. And waste of power retards growth and restricts business. An arrangement similar to that which the "Dresdner Bank" 
has adopted when entering upon its new rôle of central society for two great co-operative organisations, and for that purpose instituting a distinct co-operative department, accepting delegates selected by the Co-operative Unions as ex-officio members of the Board of that department, might have proved convenient for the purpose. The Bank of France has set a rather similar example, placing a distinctly agricultural "Regent" on its Board, as a tribute to and recognition of Agriculture, with which it has a very large amount of business doing.

However, in the main, what the farmer buys, or is at present thinking of buying, he buys for business purposes. And his object is cheapness and the obtainment of a genuine article. Those among us who still look at Co-operation askance, as a help only for the small man and the poorjust as Credit, now the mainspring of all business, used to be reckoned a matter only for the embarrassed-will do well to have regard to the latter point-of genuine quality. It is not price so much which serves as an occasion for dishonest enrichment-or, let us say, ostensible price. To a certain extent the markets regulate the figure. Looking at the mere nominal price, the large farmer who despises Co-operation may affirm that he buys his goods just as cheaply from his local dealer "Smith" or "Brown "Tas does the co-operative society from its own purveyor. But are his goods worth the money? There is a terrible amount of cheating going on by adulteration. Our Board of Agriculture is at times besieged by applications to take the matter in its hand, testing the goods and pillorying the wrongdoer. We have had a leading seedsman of a Northern county confessing, under examination before a Parliamentary Committee, that he must adulterate, since that had become a recognised custom of his trade. In Sussex we (the "Sussex Association for the Improvement of Agriculture ") put the matter to a practical test in the case of grass seeds, and the late Mr. Faunce de Laune, who was a special student of the subject, owned himself struck with the large amount of fraud that we had in this way detected. On this ground he pronounced our experiment (which was faultily 
designed otherwise) one of our most valuable achievements. As regards the utility of Co-operation, the Danes have practically settled that point. When their small men first set up their co-operative dairies, the large farmers at the outset, as a matter of course, looked rather contemptuously upon the new movement, and smiled at the small men's attempts to compete with themselves. However, their competitor got the best of the competition. And the consequence is that private sales are steadily diminishing, and co-operative sales increasing, the large farmers now willingly joining in with small in their co-operative dairies and finding themselves doing well thereby.

So, again, it has been in Siberia. In the words of M. A. N. Balakshin, quoted by M. J. V. Bubnoff, in his excellent little book "The Co-operative Movement in Russia":

"Fifteen years ago nobody would have thought that the Creameries belonging to private, and very often rich, people could pass into the hands of the peasants working in artels. At the present moment the position is radically changed and the artels are rapidly ousting private enterprise in the butter industry from Siberia."

The wealthy creamery men have sought and claimed their place among the co-operators.

It was consideration for genuineness, quite as much as for price, which set the Toad Lane weavers in motion. It is not surprising that some of our farmers, at any rate, should have begun rather early imitating their practice and following their example. In the 'sixties, when manuring with superphosphate became general, something near a dozen co-operative societies for the collective purchase of that article were formed in as many counties, acting each for its county, in addition to an unascertainable number of irregularly formed unregistered little local clubs. A decided step forward - still only on this one line of collective buyingwas taken in 1868 when, under the inspiration mainly of the late E. Vansittart Neale and Mr. E. O. Greening, an Agricultural Supply Society was formed in London (the " Agricultural and Horticultural (Co-operative) Association ") for the collective purchase of all varieties of agricultural 
necessaries-and others as well; for the business rapidly extended. Fertilisers, seeds, implements, feeding-stuffs, and sundry other things found their way into the Society's price list. About the same time a similar society was formed at Leith, for Scotland. At that point, unfortunately, having taken the lead among European countries, after our accustomed manner, we stood still. The Continent took the same business up only at later dates. (For the Co-operative Society formed in I866 at Thisted in Denmark was a Store.) In Germany Raiffeisen had planned the way, with his little parish societies, catering for all the wants of his humble little protégés, which of course included agricultural requirements, among them "the poor man's cow." In the early 'eighties things took a bolder shape. By a curious coincidence the same year, I883, saw the late Professor Tanviray forming the first French Agricultural Syndicate at Blois, and Dr. Haas starting his little Hessian co-operative union of only a handful of little local societies-both for the same purpose, that of collectively purchasing goods.

So far is it from wonderful that this movement should have grown rapidly and greatly extended, that one may rather feel surprise at the fact that it failed to be taken up among ourselves with the same readiness which had been long evinced among our neighbours. However, the British farmer loves plodding on in the same old beaten track, like those East African natives who still will recognise no other money except the familiar " thaler " of the Empress Maria Theresa, who died about I40 years ago. ${ }^{1}$ It is rather curious to note the effect which the remarkable spread of agricultural co-operative supply has had upon the trades purveying the articles in which the new societies dealt, after the first shock of surprise and annoyance had been got over. If they did not exactly welcome them afterwards, at any rate they learnt to contemplate them with a distinctly smiling face, because they found that, although their deliveries to the persons concerned decreased, and their profits on a given quantity grew less, yet on the other hand their collective sales generally went up considerably in volume.

1 See M. M. Fischel— "Le Thaler de Marie Thérèse." Giard et Brière, Paris, 1912. 


\section{I76 THE FUTURE OF OUR AGRICULTURE.}

The explanation is this, that Co-operation, with its usual educating effect, had taught farmers how profitable it is to expend money upon artificial fertilisers, feeding stuffs, and perfected implements benefiting them, whereby the sales of these articles became in the aggregate greatly increased and the trade, at any rate at its central points, did appreciably better for Co-operation. It was the smaller fry, the middlemen of whose number Mr. Hall complains, the local dealers who had fattened upon the small business, as flies fatten upon an exposed joint of meat or some sweet dish, who were hit. The productive army was relieved of its host of marauding camp followers.

However, the farmer's main interest in Co-operation lies, as already stated, in its utility for productive and working purposes. The goods which he has produced out of, let us assume, his co-operatively purchased fertilisers, seeds, feeding-stuffs and so on, and which, if he is a small manso far as they are cereals-he has thrashed with his co-operatively owned machine, want to be brought upon the market, and very possibly first turned into marketable shape. His milk wants to be sold in some near town, or else converted into butter or cheese. His eggs want to be carried fresh to a market which is not prepared for very small lots but deals gladly with quantities. It is the same with fruit, potatoes and the like. They all want to be put into a shape to suit the market and disposed of so as to cause least outlay and ensure largest returns. Live stock, once more, wants to find its proper outlet; for the same animal is not of the same value everywhere.

For all these things to be done to the best advantage, organisation-by means of Co-operation, which can produce bulk, grade and sort, and pack, according to the taste of the market-is wanted. And Co-operation can do them most satisfactorily-far more satisfactorily than an individual, by his farming on ever so large a scale. There is no occasion to smile condescendingly at the mention of butter and eggs, as if the consideration of these things applied only to small people. There is of course most proportional saving in the collection of the produce for sale, or else for 
the manufacturing of marketable commodities out of them, wherever that is called for, in the case of small cultivators. The woman carrying her basketful of eggs to market, and the milkmaid trudging long distances to dispose of a diminutive quantity of milk or of butter, in which cases the marketing costs almost more in time and labour than the goods sold will fetch, is an anachronism to-day, thanks to the help which at any rate elementary Co-operation has brought. However, business is to-day conducted on so large a scale that the producer of fair quantities stands to profit nearly, if not quite, as much by collective dealing. The larger the number of cows, to stick to that point for the moment, the more uniform will be the quality of milk for butter, or cheese turned out. And uniformity counts for a great deal in the market. Latte di vacca, pessima, latte di vacche ottima, say the Italian peasants. And when you have very large quantities to deal with, you can fit up an installation and adopt practices adding to the value of the output which are, on economic lines, beyond the power of the individual farmer, even if he be a large one. One of the great benefits resulting from Co-operation is, that it can surround the individual farmer, who to-day, if he is to be successful, wants to be a whole number of experts rolled into onefarmer, live stock expert, engineer, chemist, physiologist, botanist, entomologist, bacteriologist, and what not-with a staff of experts, whose expert services come to him individually for a song. On this point the large farmer, who cannot be a master of all trades-non omnia possumus omnes -stands to benefit practically even more than the small one. For in view of his larger operations, more depends for him upon the good expert advice which the co-operative society secures to him. But, to go back to our co-operative dairy, you can do a good many things there, when operating on a very large scale, that are quite impossible even in a large private dairy. You can, for instance, keep your own bacteriologist to examine and check, which nowadays helps not a little in the sale. Also a large establishment means a proportionally reduced staff, and therefore economy, such as is well worth considering. You have the opportunity 
of larger contracts and greater provision for the disposal of unsold material. When it comes to other articles, having large quantities to deal with, you can grade ever so much better and in more different classes, keeping the "select" - " extra fancy " and " fancy," as the Americans call themin greatest perfection, and pack and dispatch better likewise. Mr. Hockaday, already mentioned as a great practical expert in the sale of agricultural produce, urges farmers rather to employ an expert packer at five dollars a day than an ordinary man at one dollar. "Highly graded produce," so he adds, "in proper packing, sells itself; the trouble lies with culls, low-graded, and mixed shipments." It is the standardised article, supplied in quantities which can be relied upon, in a stream which it is known will not fail, which commands the market. And that means operating with large masses.

And there is more. Often enough it depends upon Cooperation whether there shall be a market at all. The Danes, forbidden to sell their corn-which was at that time their staple product-on their accustomed German market, were compelled to seek for another market for whatever produce they could advantageously raise. They did not cry out for State help, like our own farmers, and maintain that without it Danish Agriculture, the mainstay of the little kingdom, must infallibly "go to the dogs." They looked about them. There was butter-subsequently there were eggs and there was bacon-wanted in England, where these things would, under certain conditions, fetch high prices. But they would fetch them only so long as they could be fully trusted to be up to the mark in respect of quality, and supplied in very large quantities of the same type. The Danes created a market for themselves. Our Irish dairy co-operators have had to operate some time before they could come up to the Danish standard of a uniform article. They have not yet equalled the Danes in establishing a fairly uniform delivery throughout the year. They fall short in winter-which makes a considerable difference in the command of the market. Now, to be able to supply butter-and also eggs-in winter as in summer, you must 
needs have " bulk" to deal with. And that you can secure by co-operating in fairly large numbers. Following the example of the Dutch, the Germans, and the Americans, we have succeeded in going farther still at some points. The Dutch Co-operative Markets-for live stock and also for other produce-have been found a most valuable institution, which not only really creates a most willing and highly appreciated market, but in addition make the seller the regulator of sales. In Germany the business is considerably larger. The co-operative live stock markets there-and also some in Austria-are really grand institutions, taking rank among other markets like the world-famed Leipzig fair among other fairs. And not only are the producing farmers masters there, but on several occasions the cooperators have been able to ward off the suspension, dreaded by them, of the prohibition to import live stock from abroad, by undertaking to supply, themselves, of homegrown live stock, all that would be required. And they have carried out their undertaking fully, purely by Cooperation, and have accordingly reaped a splendid reward.

We have lately taken-late enough in the day-to cooperation in the sale of wool, and those joining in the undertaking have found their account in it. The French have been beforehand with us in the matter, and so have the Americans. Collecting large quantities of wool, you can get an approved expert, who knows the market well, to have all the wool sorted according to the several parts of the body, and collectivelybrought up to the market in a shape thoroughly acceptable to buyers and therefore fetching a considerably higher price. For sorting and sending backwards and forwards costs money, and the buyer always makes quite sufficient allowance for what he might conceivably lose in overestimating the proportion of the good parts. That, of course, presupposes that all the wool brought together is of the same breed of sheep. And here we come upon a new recommendation of organised Cooperation, which applies not only to wool. In order to secure the best possible market as a trustworthy and permanent possession, a Co-operative Organisation can, by 
economic argument, and does well to, induce its members, for whom it is expected to sell their produce, to produce such of a certain, the most marketable, species, consistent with the conditions of the soil, climate, etc., of the locality. It cannot, of course, compel members to produce such. However, any one of experience-say, our fruit growers in Worcestershire-knows well how great a difference uniformity of article makes in the dependable marketableness of produce. It applies to wool. It applies, above all things, to fruit; and accordingly, wherever we have fruit culture largely developed, as a business undertaking, we see growers in one district sticking to the same description of produce. There may be more than one. And there may be more than one species of fruit cultivated. But of whatever there is every one species wants to be produced in large and uniform masses. The day of the old farm orchard with its one tree of one sort, one of another-dear as it is to the owner consuming the fruit himself-is, for business purposes, gone by. The fruit trade of America is something truly enormous. An official "Bulletin," issued in I9I5, estimates the annual sales of fruit (and vegetables) executed on co-operative lines at about $\$ I, 000,000,000(£ 200,000,000)$. More than fifty per cent., so it is stated, of the deciduous fruits of the North-west and Middle Rockies, and the larger portion of Californian fruit ports are distributed and marketed by co-operative organisations of growers. That indicates the magnitude of the organisations and operations, which dwarf anything that we can show in Europe, though our own co-operative fruit growers, alike in this kingdom and abroad, know well enough what advantages Co-operation and co-operative selling bring them after they have learnt to standardise, to grade and to pack, and generally to consult the markets and adapt themselves to their requirements. Our co-operative fruit growers do pretty well in this country. The French fruit, flower and vegetable growers have turned Co-operation to even better use. Collecting their produce, more specifically the early varieties-in the cultivation of which, of course, the South beats us-they have obtained sufficient command 
of supply to be able to run special fast trains from the Côte d'Azur to Channel ports, where special steamers await their arrival, to ship the goods to our shores. The Rapide des Fleurs has become a well-known institution. In addition they maintain special cold-storage depôts. The fruit and vegetable trade from Normandy and Brittany is likewise brisk. And Brittany sends us many potatoes and other vegetables, likewise by special boats. In America the "Peninsular Products Exchange of Maryland" spends something like $£ 2,000$ a year on nothing but the collection of information concerning the trade in such fruit as it deals in. The "California Fruit Growers " have more than I2,000 members, cultivating among them about I20,000 acres, and dispatching annually about $\mathrm{I} 5,000,000$ boxes of fruit. The "Wathen Fruit Growers' Association" in Igro (being then five years old) disposed of about 40,000,000 boxes, equal to about Ioo railway truckloads, of strawberries alone, in addition to 35,000 boxes (among 50,000 sent in all by the district) of grapes, I0,000 boxes of raspberries, 20,000 of blackberries, 62,500 of cherries, currants and gooseberries, and 326 truckloads of apples, to the collective value (apples alone) of $£ 35,000$. America and France have distinguished themselves by particularly careful grading, making minute differences as between " Extra Fancy," "Fancy," "Extra Choice," "Choice," and so on. In France a leading expert, M. Gavoty, has laid it down that "The most important part out of all the matter is the very careful grading of goods, the offer of them in a presentable condition, and the steady delivery of goods of good quality and strictly uniform." ("La question qui prime tout c'est le triage sévère de la marchandise, la bonne présentation et la régularité d'expédition de produits très uniformes et de bonne qualité.")

The same care in the selection and treatment of the article produced, as in respect of fruit and eggs and butter, tells in the production of grain, whether wheat, or barley, or rye, or oats, or-in America-maize. It has been mentioned that in parts of Germany through the interposition of co-operative granaries-which collect, store, dress, and eventually sell, the grain at convenient times-being 
in a position in the meantime to make an advance in money to the producer, should he require it-the local price of grain has come to be raised by about 2s. a quarter. That has occurred in Saxony. These granaries promise, after the Government has sown its wild oats in their promotion, with public money, five million marks of such (the loss of which it may have seen reason to regret when milliards were required for the various war loans) to become a decidedly valuable asset to the country. And one of their distinct self-set tasks is to promote the cultivation of what is in each particular district the most prized and marketable species of grain. In America-alike Canada and the United States- "elevators," as they are there called, have long been a fully recognised institution, full of value to the 400,000 or so farmers who support them as stockholders in the United States and probably I00,00o in Canada. In Canada the three chief Grain Growers' Associations-in Manitoba, Saskatchewan and Alberta-alone muster about 60,000 members strong.

All this shows the great commercial value of Co-operation, as meaning money in the farmer's pocket. It may be of interest to note how American farmers were first led to co-operate in their grain business, and how the movement, approved by results, came to grow.

The Elevator movement took its rise in the United States late in the 'eighties, when, as Mr. H. W. Danforth, President of the National Council of Farmers' Co-operative Agriculture, has related, " the farmer first began to realise that he was being robbed of his just profits through the exactions of the Grain Trust, the Lumber Trust, the Coal Trust, and other combinations with which he has to transact business."

“For a century," so he adds, " the United States Government had fostered, nursed, and granted special privileges to the manufacturing interests, with practically no concession to the agricultural interests of the country. Accordingly, farmers came to the conclusion that they must help themselves. Therefore, in March, I889, about a hundred farmers met at Rockwell, Iowa, to discuss the question and decided to become their own grain sellers. Very little experience sufficed to show the great advantage which Co-operation would bring them. The newly formed 
elevators succeeded in raising the price of corn-to the dealer, not the consumer, who had gained nothing by the dealer's underbidding-by about four or five cents. per bushel. The dealers at once took to boycotting the co-operating farmers. However, the farmers stood firm. The movement accordingly spread rapidly. Joint Stock companies were acquired by the farmers and transformed into co-operative societies. There are no figures availablc to show the actual magnitude of the trade as it stands at present. But not long ago, the Farmers' Grain Dealers' Association of Iowa, the state in which the movement took its birth, handled II5,500,000 bushels in the year, in which it gained the farmer members three cents per bushel, a matter of $\$ 3,465,000$ $\left(f_{6} 693,000\right)$. Besides financially benefiting the seller of grain, the movement was shown to have a decidedly beneficial effect in improving the grading to the advantage of the public. All in all there are understood to be now in the United States about 2,900 elevator societies, with about 375,000 stockholder members, whose investment amounts to about $\$ 30,000,000 \quad(£ 6,000,000)$, and which do an annual trade of more than $\$ 600,000,000$ ( $f_{\mathrm{I}} 20,000,000$ ). How large is the financial benefit accruing to the co-operating farmers it is impossible to say with precision. However, the farmer members of the Middle West alone, a fow years ago, computed their profits at $\$ 50,000,000$. Supposing that it is only half," says Mr. Danforth, "that is $\$ 25,000,000$, the benefit is still sufficiently large to make the undertaking attractive."

In Canada the movement, copied from what had been done in the United States, was taken up only later. It was, of course, the signal success achieved in the United States which prompted it. The "Manitoba Grain Growers' Association," which has now about I2,000 members, with about 300 local associations, was formed in I899. It handles about 30,000,000 bushels of grain each year, has paid a Io per cent. dividend, and in that year disposed of a realised surplus of $\$ 183,000$. The "Saskatchewan Co-operative Elevator Company" was launched in I9II. It numbers 25,000 members, with more than 600 local associations. The "Alberta Farmers' Co-operative Elevator Company" was formed in I9I2. It has now I5,000 members and 500 local associations, and is said to realise an annual profit of $\$ 400,000$. One most encouraging feature attaching to American elevator trading is this, that-in marked contrast with what has 
happened in Germany, where Governments have wastefully opened the public purse to afford deceptive "help" to "co-operative" granaries, which soon collapsed-" there is a smaller percentage of failures among these companies than there is in any other business organisation or profession." And the financial gain is not all. "Everybody," so reports Mr. W. M. Stickney, who is a student of the matter, "is becoming a student of Co-operation. We think this spirit is of far more benefit than the twentyfive or fifty million dollars (in the Middle West)." The Elevator movement has also exercised a distinct effect upon the social side.

"During the summer and early fall," so writes Mr. Stickney, " hundreds of farmers' elevator picnics are held. ... It is these thousands of gatherings every year, together with the business experience acquired in conducting the affairs of a corporation, that are making the farmer a leader in the progress of the West. In fact, so progressive has he become, that he now owns his own trade paper, The American Co-operative Journal, which is the official organ of the farmers' movement in all the grain-belt states."

That also means, what Mr. Stickney does not expressly mention, that the Elevator movement, both in the United States and in Canada, has actively exercised the same educational propagating power that is peculiar to Co-operation of all sorts. It has not belied its co-operative character. The Elevator Societies do a great deal for Education, both in respect of their own peculiar interest and with regard to Agriculture generally. And it may be worth mentioning that they have not in every instance confined their action to their own special business, that is, grain selling. Many of them have tacked on supply of various articles with distinct benefit to their members.

It may be granted that the call for grain stores is not quite equally pressing in this country as it has been in the United States and in Germany, where, with greater variety ranging among local prices, there is freer play for dealers' tricks Grain stores of the old pharaohnic type 
have within the last few years been advocated as a preparation for war-which advocacies the great war itself, with its gigantic demands, must have shown to have been illusory. India has its dharma golas - very few of themfor other purposes. But one cannot help thinking that at any rate a little might be gained by farmers who might choose to co-operate in grain selling after the American fashion. And that the Irish are probably right in setting up grain stores in their own country, such as, if properly handled, bid fair to do much-since they have done so in Germanyto accomplish the objects for which Protection was particularly recommended, far better than Protection, of " steadying the price of corn," while at the same time securing a better profit to the farmer, paying him money at the precise time when he most needs it.

Referring back to what has been said about specialising in produce, there is some corn "breeding" likewise going on in America. However, this is not a special task of Elevators. There are other institutions to attend to this, alike in the United States and in Canada. And, still more to further seed breeding, prizes are offered in special boys' and girls' clubs for the best lots of wheat or other grain fit for breeding from, picked from their fathers' standing crops, as has already been explained.

In Germany, where co-operative dealing in grain is done on a smaller scale, it is otherwise. It is just the co-operative granaries which experiment and recommend it, so as to produce a maximum production of the variety of grain best suited for their district. In this work they have achieved some success. The American Elevator Societies cover too wide an area to make such "breeding" or selection practicable. Also, the quantity of grain that they deal in is so enormous that there is plenty of room for variety. The corn dealt in is also mainly for milling purposes. Accordingly the point of "breeding" scarcely arises.

In the co-operative sale of live stock there is no occasion for favouring or pushing any distinct breed. That matter it is for a different class of societies to occupy themselves 
with. The points to be kept in view are different. Above all things it is desirable to know which will prove the most appreciative market for any given class of animal, or a particular specimen of it, whatever be its species. There are few farmers, not specialists, whose knowledge in this respect extends very far. The Co-operative Society can, by acting together for many, provide itself with experts fully up to the mark in this respect. Another point is, to determine the best time for selling a beast. You do not want to sell it before it is ripe; but you do not want to keep it after, unless the conditions of the market really require it. And then there is the organisation of transport, and the actual selling on the market. For their sale of eggs, bacon and the like the Danish co-operators have arrangements, such as some of our agricultural co-operators have likewise established (for instance the Blairgowrie fruit growers), for maintaining telegraphic and telephonic intercourse, on the one hand, with their members, and, on the other, with the various markets. The Danish societies receive telegraphic advices from the British markets, which tell them every day what is the position of each particular market; and according to their import they direct the sales of their members, telephoning to these, so as to regulate supply, avoiding glut in one place and emptiness in another. Such arrangement has an advantageous effect not only in contenting buyers, but also in maintaining prices, steadiness in which is really of greater practical value to the producer than an occasional spasmodic boom. In dealing with live stock, time is not equally precious. But it is essential to be well and promptly informed. And the heads of the Society, knowing-let us say, at Ipswich-what beasts there are maturing or ready for sale, and what are the requirements of the several markets-with the specialist's opinion given as to the proper market for each one, to secure the best price-can well regulate the supply, sending animals at the right time to the right place and assigning full truckloads to every dispatch-all which benefits the vendor, while at the same time contenting the consumer. 
Live stock is dealt with, on co-operative lines, with advantage, for other purposes than the sale of fat beasts. Reference has already been made to cow testing, which is gradually spreading in this country, after having for a long time back proved a most valuable adjunct to dairying in Switzerland, in Germany and, above all, in the Scandinavian countries. Sweden, more in particular, has a distinguished record in cow testing, and has benefited by it to a remarkable degree. On the Continent cow testing is much combined with general supervision and advice on most agricultural practices or questions, under the title of "Control." Specifically to the province of dairying it has rendered excellent services, not only in teaching farmers to "weed out" poorly yielding cows-of which class of animals there is an alarmingly great number-and study the composition of their herds of good milkers; helping thereby to improve national cattle breeding by directing breeders' attention, long after this should have been done, from the one-sided worship of "form " and "points," to the more practical consideration of "yield," but also in inculcating better notions and knowledge on cow keeping and feeding. Not a little economy has been introduced into feeding on the advice of "Control " officers, by the substitution of cheaper rations, possessing the same nutritive value, for dearer ones. Also the health of cattle has been improved, by more careful attention, under good advice, to the sanitary requirements of animals. Although other methods than Co-operation may be made useful for such purpose, if there is a kind fairy godmother present to provide the necessary cash, Co-operation, placing the direction of the matter in the hands of those who are to benefit by it, is by far the most recommendable. In this country and in America the "Control" system-to give it its Continental namehas been limited to simple cow testing. After a period of hesitancy, it has been taken up with some zeal in Scotland. And in England it is spreading. The United States, three years ago counted about 200 cow-testing associations within their borders, with a membership of more than 5,500 farmers and applying to more than I00,000 cows. 
In Canada cow testing is a well-established practice. And it is practised to some purpose. Thus in Ontario farmers report that, thanks to it, their output per cow has within eight years been raised from 800 dollars to over $I, 700$ dollars. Elsewhere the milk yield, which in IgI2 stood at $5,405 \mathrm{lb}$., had gone up to $792 \mathrm{lb}$. By dint of useful breeding, by the way, also the yield of wool had gone up from only $\mathrm{I} \cdot 85 \mathrm{lb}$. per sheep, in I840, and within the last twenty years, from $5.5 \mathrm{lb}$., to $684 \mathrm{lb}$.

The improvement of live stock is carried on co-operatively, with advantage, in other ways than this. Governments do so much in the way of encouraging improvement of local breeds by mating female animals with better stallions, bulls, boars and tups, that one might almost be led to consider this work as: one marked out for patronage rather than self-help. However, Government or other assistance is generally given in the shape of encouragement to form co-operative live stock improvement societies under the direction of their own members, not as a matter to be kept permanently under outside direction. And the co-operative method is really the most recommendable. For one thing, it promises to attract greater attention than has thus far been given to the female side of the pedigree. The sire does not answer for all. Its influence generally addresses itself rather to form than to the more practical qualities of animals, such as milking. And co-operative organisation also creates a warmer interest in members. Co-operative breeding societies are organised in a variety of ways, which this is not quite the place to discuss.

Live stock improvement with the help of Co-operation is carried further, as a rule with good effect, in Switzerland, by the organisation of pedigree breeding societies. ${ }^{1}$ Switzerland is happy in the possession of three breeds of cattle which command a world-wide market, to wit, the brown Zug breed, the speckled Berne or Simmenthal breed, and the black Fribourg breed-which last named in all qualities except coat closely resembles the second. Bulls

1 For particulars consult " Co-operation in Agriculture," pp. I99 to 221 . 
and heifers of these breeds have a large sale on both sides of the Atlantic.

However, to keep the herd up to the mark, it is found necessary from time to time to renew the blood by importation of fresh beasts coming from the healthy Swiss home, where Alpage, and mountain air and mountain herbage, maintain the old qualities.

That indicates a further valuable use still to which Co-operation is put for the utilisation of live stock. Alpage - the annual pasturing of Swiss cattle during the summer months on the mountain tops-is really a co-operative practice, which is now spreading fast-though without the use of any Alps-in Germany. And Mr. Prothero may be said to have set the example of something like it in our country, by the creation of a common pasture for collective use by the eighteen occupiers of land bought from the Duke of Bedford at Maulden. Common pastures, co-operatively acquired and co-operatively held, are becoming rather general in Germany, where, in the midst of a general practice of stall feeding, it is found that growing beasts require movement and fresh air. Co-operative societies have accordingly been formed for the pasturing of stock on what may be looked upon as regulated "commons," on which both overstocking and oppression of the small man by the big are safely guarded against.

But, to return to the Swiss cattle-breeding societies, the invention of M. de Wattenwiel, of Elfenau, near Berne. The difference in price between stock bought for breeding purposes and for the butcher's knife is so considerable that it is not unnatural that owners of cows should have turned their attention to herdbook breeding. Animals qualified for sale as breeding stock fetch about five times the price that animals intended for slaughtering do. The start having been made, there are now some $\$_{50}$ societies in Switzerland which breed. There are also some similar societies in the United States, which country has been quicker than our own to adopt the Swiss practice. And the question may be asked: whether in our country, noted as it is for its excellent breeds, in request all the world over, 
there is not likewise room for such beneficent democratisation of cattle breeding. The cows admitted to these herds-or let us rather say, to the inner herd; for the same man often enough keeps other cows besides, which find no place in the herdbook-are carefully tested and have to prove their descent. They are mated with pure herdbook bulls. There are periodical inspections, and annual shows, at which prizes are awarded, more particularly to "families," bred of the same parents, with records furnished of their milk yields. In any case the herds are kept pure. The local societies are grouped together in Unions, according to the various breeds. And it is of course the Union in each case which keeps the herdbook, entry in which entitles to sale as a herdbook beast. Of course, the business is subject to fluctuations according as demand increases or declines. But on the whole the system has answered well.

There is probably no occasion to carry specialisation of the various uses of Co-operation in the service of agricultural buying and selling any further here. I have given plenty of instances to the point in "Co-operation in Agriculture." 1

However, buying and selling is not all for which Organisation is with advantage impressed in the service of Agriculture. Co-operation can effect more, even in a purely material way.

How readily Co-operation will lend itself to the business of Insurance need scarcely be pointed out. The very basis upon which Insurance rests is the co-operation of many. And the larger the number of insurers, the safer and the cheaper as a consequence will be the insurance. Accordingly Co-operation appears clearly marked out by the features of the case as the proper method for insurance. Our Insurance Companies bring about a certain kind of co-operation or " mutualism" by the method which they practise. But they bring it about in an extravagant way,

1"Co-operation in Agriculture." Second Impression, I9I4. P.S. King \& Son, Ltd. 
so as to ensure a profit to the shareholder, for which the insurer is made to pay a heavy tax. There is no wrong in this. For, since capitalists take the risk, it is only fair that they should receive a recompense for such service. Only it makes insurance costly. As much as 30 and 50 per cent. of the premium income is often enough swallowed up to provide administration expenses and dividend. This is not only wasteful, but it is quite unnecessary-becausc the principles and practice of provident insurance are now so generally understood that there is no difficulty in insurers organising the service for themselves. They stand to save very much in money. Even the German Social Insurance Corporations, which stand under Government, lose no more on their business expenses than about ro per cent. And our Co-operative Insurance Society, now amalgamated with the Co-operative Wholesale Society, has ingeniously devised a scheme of collective life insurance which whittles down the loss to only 5 per cent. Quite apart from the point of economy, specifically in the application of Insurance to Agriculture, there are services to be rendered which, by reason of the smallness of the operations in each separate instance, appear unsuited to management by large commercial bodies, and for which, on the other hand, Co-operation appears to afford the proper method, by reason of the immediate oversight by expert neighbours directly interested in the matter, which Co-operation not only permits but actually necessitates, and which acts as an effective safeguard against fraud on the one hand, or any kind of overreaching, and as a very substantial assistance to cheapness. Take, as an instance, the insurance of small cottagers' cows or pigs. The insurance of a single pig is a small object indeed for a capitalist insurance body to handle. And in case of a casualty it is difficult for such a corporation to establish the precise facts by inquiry at a moment's notice-which, however, is very essential. A co-operative society, on the other hand, can do so easily through its appointed officers without cost. Accordingly it is not surprising that insurance has been early marked out among agriculturists for co-operative management. Such co- 
operative insurance is well established on the European Continent. However, the country in which-it is true, in a capitalist " co-operative" way-it has become by far the most extended is the United States, which set us a most stimulating example. On the European Continent Governments and provincial administrations have to a great extent forestalled Co-operation by prescribing compulsory insurance directed by themselves. In the United States co-operative insurance has become a great power. In the Middle West it all but monopolises insurance business. In this country the Agricultural Organisation Society has adopted a very useful scheme of Co-operative Insurance, which, it is satisfactory to see, is now gaining fresh adherents every year. Whether it might not have been quite as well for the Society to join for insurance purposes the Co-operative Insurance Society must remain an open question. The Co-operative Insurance Society has worked well and satisfactorily, and its Collective Life Insurance scheme is a veritable boon to small folk. It is, however, only applicable where there is a considerable distributive business. The Cow and Pig Insurance schemes devised by our Board of Agriculture are likewise good. On this ground the country has a good deal of leeway to make up. And one may well hope that the wave of co-operative enthusiasm which we are now looking for may carry provident insurance of live stock-the small holder's most precious possession, but a possession exposed to great risk-far and wide into small farmsteads. Once more, for detailed discussion of the subject, I must refer to "Co-operation in Agriculture."

The useful services which it has in its power to render in the matter of land settlement have already been alluded to. Collective settlements for collective cultivation are now in one sense a thing of the past, and in another a communist fad waiting for its true fulfilment in the dim and distant future. But Co-operation in the securing of land wholesale, be it by hiring or be it by purchase, accordingly at wholesale prices, in order to retail it once more, either by sale or by letting-at cost price only to members of the co-operating host-is an operation full of practical 
benefit, which should, now that we are anxious to settle small folk upon the land, prove of considerable practical value in the future. Tenants or purchasers of small parcels of land quite naturally have to pay a proportionately higher price for what they buy or rent than the man who takes the whole piece. There is more trouble about the transaction, more expense, and also more risk. However, landlords and vendors do not invariably stop at that natural and legitimate limit. They are apt to "stick it on," simply because they can get a longer price. Earth hunger is keener in the small man coveting a small piece of land -or wishing to hire it-than in the large man. I have quoted one instance of an irregularly shaped bit of land of fair quality in the East Riding, which I found a small tenant renting at three pounds an acre, after a large farmer had failed to make it pay at nineteen shillings. Very much worse instances might be quoted from abroad. I have already quoted the late Baden Minister, Dr. Buchenberger's, branding of small letting-at exorbitant rents it was-as. "legalised usury." In Italy contadini have been very badly bled. And what has furthered the movement of collective land renting so much in Roumania is the fact that, not only were the small farmers badly overcharged, but that they were systematically exploited by middlemen of an alien and greatly disliked race, who made a regular trade of such extortion, reducing their tenants to the position of mere peons, working for them, besides paying an exorbitant rent. Abroad, in Italy, and more particularly in Sicily and Emilia, and in Roumania and Serbia, the movement of collective renting has spread fast and wide and has done a great deal of good, both to the small husbandmen and to the nation. In Germany, its benefits-in buying-are to a not inconsiderable extent practically secured by the operations of the "General Commissions" and the "Rentenbank" already spoken of. Where purely renting takes place, the landlord finds his account quite as much in collective renting as does the tenant. For the saving to him in trouble and risk-dealing with a host of small men of unascertained financial standing, by the substi- 


\section{I94 THE FUTURE OF OUR AGRICULTURE.}

tution of a body collectively answerable for the rent and taking all the dealing with the single tenants in detail off his hands-is to him amply worth the reduction in aggregate rent. In our own country we have already some few instances of collective renting. And they seem to answer well. However, as has been explained elsewhere, these instances do not altogether square with those observable abroad, inasmuch as only to an infinitesimal extent do they represent the creation of new homes or holdings, applying, as they do, mainly to the mere acquisition of land by tenants who have a home already. One method which appears particularly deserving of recommendation is that devised by Mr. W. L. Charleton, in imitation of what Mr. Vivian has with so great success introduced into the urban housing movement-namely, of a co-operative society buying the land, and then letting it out in small holdings to its members, who farm separately and independently, but share jointly in the proceeds of the entire estate, the overplus belonging collectively to them. There is real community building in this. And it secures the additional advantage, that tenants-renting their land, of course, subject to the right of giving notice only on their own side, so long as they fulfil their engagements to the society-who may wish to surrender their holdings can easily and without lossprobably more easily than would be otherwise possibleget out of them, through the society, by transfer to a new member.

However, there are a good many other things still, which especially small farmers and petty cultivators find that they can with advantage accomplish in common by Cooperation. And it should all along be borne in mind that we at present particularly desire to increase the number of such type of farmers.

One thing for which Co-operation helps smaller folk greatly is the common acquisition of implements and machinery, the expense of which would be too great for a single small man, and for which the small holding could not afford adequate employment, although the use of it must be of appreciable practical value. This is, by the 
present time, rather an old employment abroad. I wrote about it, urging to imitation, when it appeared to be still quite unknown to our agricultural world, in the Contemporary Review, in 1895 . But it has lately found its way into this country as well, and the war has given it a sensible, though for the most part still prospective, impetus. Invaded France, with its great needs, owing to German devastations, has forestalled us, and with a very large employment given to collectively owned machinery, set us a splendid example. Germany is far ahead of us in the matter. And in the first edition of "People's Banks" I showed, in I893, how already in the 'eighties Raiffeisen societies had, by means of their credit facilities, brought costly machinery such as steam thrashing machines-the one that I saw there was a Clay, Shuttleworth \& Co. of a large size, with the engine-without putting their hand into their pocket, raising the money by loan and paying it off out of the hire which it fetched, a little more being charged to non-members. However, such collective ownership is abroad applied to every species of implement or machinery, for which a single holding does not furnish adequate employment, whether it be large or small. For instance, grubbingup tools are frequently owned in common. Before electric power came in, co-operative steam thrashing machines had for a period a good time. In France their use was actively promoted by the late Count de Bouillerie. Steam and electric ploughs have not covered quite as much ground laterally. However, in Germany and France, wherever they have been used, they have given great satisfaction. And the war has given an additional fillip to their employment, more particularly in France, where also tractors, for the supply of which after the war our agricultural authorities, administrative and co-operative, have made ample provision, have come into very extended application. That is for the supply of power. Motors are also coming increasingly into use for the forwarding of goods, where there are no more convenient means handy, say, from a secluded country district to the nearest railway station. For all these things, alike for the steam plough and the motor wagon, somewhat 
more elaborate arrangements are necessary than for other co-operative work. Motor wagons have previously had rather a chequered career. We have not much to show of that sort. Alike in the United States and in Germany electric power and light and co-operative telephone service are very much in vogue, and very large electric enterprises, covering wide areas and supplying, in addition to a wide country district, also small towns, have been very successfully set on foot and worked satisfactorily. However, even in populous districts, where small towns are served-such as Prussian Saxony, and of course even more in the American West-it has been found that agricultural customers supply the main support to these societies. We have facilitiesand I should say, occasion-for the employment of telephones in connection with farming which do not seem half enough severally recognised and put to use. The employment of co-operatively owned electric plants has not only proved a remarkable convenience and an appreciable economy, but has in Germany to some extent also revolutionised agricultural labour relations. Men and women alike who left the country in disgust, because the hard work expected of them when working with hand-power only tried them too severely-like those heavy sacks, handed down by tradition, which break down our farm boys' health, causing ruptures-have willingly returned to their agricultural occupations now that collar work has been lightened for them by the introduction of the electric machine. And electric lighting, permitting of the use of light in close proximity to inflammable material, has been hailed as a great convenience indeed. Electric power has become so manageable a servant that it can readily be used for the smallest as well as for the largest implements, working a liquid manure pump or a chaff-cutter or corn crusher as well as a big thrashing machine.

Among our own nascent rural co-operative societies grist mills have become great favourites. However, implements of all kinds, mowers, reapers, drills, binders and what not are already co-operatively owned and used. In Ireland there is an enterprising and thrifty society which began 
with a simple binder. Investing the money saved by its use in new machinery, it has by degrees accumulated an entire equipment of all that is required on a modernised farm, and does decidedly well with such outfit. At Stotfold, in Hertfordshire, the local Small Holdings Society own even their horses in common and find it answer. All those inconveniences and frictions, the fear of which was so freely expressed before this form of Co-operation came into use, have in practice been found easily avoidable. There can be little doubt that the same form of Co-operation will also in the post-war development of our Agriculture be very much resorted to. And there can be no doubt whatever that it will prove a boon.

There are other objects still for which Co-operation in the form of common work has been, and may with advantage be, employed. We are not likely to require those co-operative fumigating installations to keep the frost off the fields at night, which are much used in French vine-growing districts, and also in the United States; nor yet, and even less, those co-operative sky-bombers which either truly or only in imagination disperse hailclouds, either chasing them away altogether, or else bringing down the hail in them in the innocuous shape of something resembling soft snow. But we have already found Co-operation useful in the matter of water supply-for instance, in the North Riding. In America Co-operation is freely impressed for purposes of irrigation. In France the associations syndicales-meaning thereby those not of the official orderwhich group together neighbours in some more or less wide district for a variety of common work, are at times found very serviceable indeed. In Germany such special association is not necessary, because farmers are already sufficiently associated together for all kinds of common work, more particularly in the Raiffeisen societies, which make a point of providing co-operatively for all the wants of their members.

Attention has already been called to the remarkably stimulating effect which Co-operation is generally found to exercise upon the pursuit of Education. But the matter 
is worth a second mention here. Because it is one of the brightest jewels in the crown of Co-operation. Everywhere, without exception, wherever Co-operation has been practised, on anything like genuinely co-operative lines, it has been found to exercise the same power. And that power is forcing. And that is one of Co-operation's best claims to consideration among ourselves, in connection with the proposed improvement of national Agriculture, by means of better Education.

Give us Co-operation, and Education may almost be left to take care of itself!

Even in India this stimulating effect is already making itself clearly and powerfully felt. The natives enrolled in co-operative societies-for the most part still for credit purposes only-ask to be educated-educated in Agriculture, educated generally-and to have their children educated. In one district in the United Provinces they have made their society secretaries hold regular classes for the children, as part of their duties. And our industrial co-operators spend more than $£$ I00,000 annually upon Education, it is true, understanding that Education in rather a wide sense. They award prizes and scholarships, and send successful students to a University. In France the Agricultural Syndicates, as Lord Reay has testified, "work wonders" in Education. In Switzerland and Italy similar societies do a great deal for Education. Danish Agricultural Organisation is in very truth built up upon Education. In German Co-operation the Wanderlehrer (itinerant teacher) plays a conspicuous part-let alone that of course society officers, inspectors, and so on, are very carefully and specially trained.

However, Co-operation in itself teaches. It brings people together to discuss matters of common-more particularly practical-interest, and to study them in common. It is not every co-operative organisation that takes its backward members in hand like the Raiffeisen societies, by careful sifting of candidates for admission, by the threat of expulsion held warningly over them, should they be found to have made themselves unworthy, and otherwise by the 
force of contact, example, and the recognition of high moral ideas, influences which are found to make thieves honest, drunkards sober and ne'er-do-weels creditable members of society. (I have quoted instances and evidences in " People's Banks.") M. Luzzatti impresses upon his Italian societies that " the best security of a society is the quality of its members." In Italy, where among the peasantry illiteracy abounds, many whilom illiterates, who are good enough in character, are beholden to the Raiffeisen (or in that country "Wollemborg ") societies for their modest mastership of the pen and familiarity with printed characters. However, the mere bringing together of members of such a society, in which contact becomes close, interests are common, and in which character is valued, quite naturally has its elevating effect. But add to that the consideration in common of matters that interest every one concerned, matters of technical interest, such as the relative value and the composition of fertilisers and feeding stuffs, the proper handling of crops, the meaning and object of farming operations, where the arguments of Reason are powerfully supported, not merely by the argument of Example, but also by that most convincing plea, the argument of the Pocket, and it cannot fail to be understood what powerful educational agency is here at work. In any case the results are in evidence. In Germany, according to the evidence of high authorities of undoubted knowledge, thanks to Co-operation the bauer has become a totally different creature from what he used to be-more intelligent, more businesslike, a better farmer, a better conducted citizen.

In Russia we see the moujik developing fast, since, under newly acquired freedom, he has been able freely to organise Co-operation, which in his country has expanded marvellously under the new régime. And with regard to the United States, Mr. W. M. Stickney, referring to a pertinent declaration by President Roosevelt: "It is only through such combinations that American farmers can develop to the full their social and economic power" ; stated before a recent Congress: "No one would think of belittling the 
great work of our agricultural colleges and experiment stations. They have performed a marvellous service to mankind. And yet the Co-operative Movement among the fruit and grain growers of the West, and the cotton planters of the South, has done as much to make Agriculture a science and a profession as all other forces combined." And Mr. Charles A. Lyman, Chairman of the Legislative Committee of the Wisconsin Society of Equity, very suggestively remarks: "I believe that it will repay an agricultural college many fold to understand that farmers will be quicker to apply scientific methods to their industry after they have learnt the value of science in the conduct of their own business activiiies, such as in co-operative societies, creameries and cheese factories, and in associations organised for the purchase of their agricultural requirements." On this ground alone, although denounced, lock, stock and barrel, by old fogies like Mr. Kidner, late President of the Central Chamber of Agriculture, Co-operation deserves to be practised in our national Agriculture.

However, there is a further object still to serve, a wider horizon to look to. "True Co-operation," so with great truth observes Mr. Clarence Henry, one of the leaders of the national agricultural movement in the United States, " does not consist of combinations, built on greed or prejudice, to destroy any cogs in our business world, but in organisation based on mutual understanding, to further community interests." That still rather points the way only, instead if indicating the full aim. Mr. Roosevelt, as President of the United States, grasped the meaning of the further aim when, at the instance of Sir Horace Plunkett, he appointed his Country Life Commission, to inquire into the most advisable methods for improving country life on the social as well as on the economic and technical sides. The Commission included elements too widely differing among themselves to enable it to arrive at any very clear conclusion. The recommendations made by it represent a compromise, which in such matters is never satisfactory, and may be taken really to meet the wishes of neither side. It should be borne in mind that 
the United States are in a different stage of development from any old country like our own, and, for the purpose of the creation of genuinely heart-linked country communities, are in a less favourable position even than our colonies of the latest planting, in which after all people of one race, one language, one set of habits, and one way of seeing things predominate. Our own position is more favourable still. We are, after all, one people, virtually one race, one community of like-habited and like-thinking persons, at any rate in each of the several countries composing the United Kingdom. And we have had prosperous, comparatively well-peopled, contented and happy country communities once. "Sweet Auburn" is there-although for a time it has lost its "sweetness" and a good part of its population, and much of its former prosperity and contentedness. It wants to be repeopled, to be made prosperous, contented and happy and "merrie" once more. Purely economic means do not suffice for that. A patronised village hall and village club will not do it. Nor yet a village library or a temperance public-house. Co-operation has ever aimed high, more particularly that intended for agricultural and rural life. Owen aimed high. So did Vansittart Neale and his friends. So did Raiffeisen ; so did Holyoake. Our industrial co-operators make a boast of it that they aim, as in truth they do, not only at making men wealthier, but also at making them better. There is a good deal of combination for business purposes in the world which styles itself " co-operative" without at all being so. Holyoake used to complain that, numerous as are each year the recruits for co-operative societies, the number of genuine co-operators among them is only small. And Mr. James Wilson (a native of Ayrshire), at the time United States Secretary of Agriculture, unrolling before my wondering eyes in I9I2 an account of the numerical strength of Agricultural Co-operation in his country, added the suggestive qualification: "It is possible that the form of organisation and of operation is not co-operative in all cases "; and he added : "There is considerable confusion in this country, not merely in the mind of the general public, but in the 
trained minds of university professors, as to what economic Co-operation is. What is the definition that will place this organisation in the class with those that are engaged in economic Co-operation, and will place that organisation outside? You will confer a favour on this department if you will communicate your formula which will establish a test for including and excluding associations as co-operative or not." Unfortunately a "formula " will not do it. It is a matter of Spirit.

We stand in great need of Co-operation for economic purposes in its relations to rural life and Agriculture. I think I have shown, in however brief and summary manner it has had to be done, to how many different but in every instance practical uses Co-operation can be most profitably put in Agriculture. Surely in the future, when we propose to lay ourselves out for heavier production, production of crops and animal produce of increased value, and for radically democratising our Agriculture and Land-holding by opening the gates wide to small holders and farming labourers, we need the help of Co-operation greatly. In truth one cannot conceive how democratised Agriculture can live without it. Past failures in the promotion of Small Holdings policy are clearly attributable to the absence in it of Co-operation; to the attempt made-often enough under very kindly, and even generous patronage-to breast the waves of competition with other men, more favourably situated, alone. In cases similar to these, wherever the help of Co-operation has been enlisted, Co-operation has brought substantial support, and it has it in its power to do so still.

But surely it is not only beeves and sheaves that we are thinking of in proposing to recast our rural arrangements, but men and women. "True Co-operation," once more to quote Mr. Henry, " consists in organisation based on mutual understanding, to further community interests. Being a good neighbour is the first essential for being a good American "- -and a good Englishman, too, so one may add, or a good Christian. And Mr. C. IV. Thompson, of the American Department of Agriculture, writes; "In the 
farming processes, from the first stage to the last, from the selection of the seed to the marketing of the product, as well as for the promotion of general social well-being in farm life, Organisation has proved its value, and, as this field is being reclaimed more and more fully, organised methods are being employed in increasing measure." So be it! We see in the past and present what Pliny saw only in the dim and distant future, namely, that "caring for wheat more than for men" must needs lead to disaster and ruin-in his case the conversion of the smiling, fertile plain, such as was the Agro Romano in his time one of the granaries of Rome, into a barren, unproductive, desolate, ruin-stricken, miasma-poisoned, scarcely habitable desert. Italian statesmen are now labouring to repair what has been done amiss. The results of a similar policy could not be equally serious among ourselves, for obvious reasons. But the care for men and women should certainly stand first, if we really want to make our country the wealthier and the happier.

Co-operation applied to Agriculture has shown that it can do much more than cheapen fertilisers and feeding stuffs - just as Industrial Co-operation has shown that it can do more than cheapen groceries and hardware. Rural Cooperation can do even more than industrial, more in respect of social and moral results, because with reference to them it stands, under our present aspect, at any rate, on more favouring ground, inasmuch as it has, in every single case, a smaller community to deal with, upon which its efforts can the better tell. Our Industrial Co-operation, being on the look out for "bigness," has run away from that condition. Rural co-operative work is, as a late German Chancellor has very properly put it, addressing more specifically the beneficent Raiffeisen societies, whose great aim is what Mr. Gladstone happily called " man-making," in the main " detail work" -work applying in each several instance to only small things - the "little things" which "are great to little men." The Raiffeisen society is a parish society. Its units have combined to a large Union, professing and practising the same principle throughout and trying to 
make it effective over a large area, in fact now in the whole world. But cach society works for one particular small district only, in which there is-or, thanks to other ministrations, there may be-close touch among all members, a common understanding readily ripening into confidence, true neighbourly feeling and a readiness of each to assist the other. In this way it is that communities are built up-small in each case, but of great worth, and helping greatly to keep the country populated, Agriculture prosperous, and rural society united in a brotherly spirit, and therefore well conducted and happy.

These things want to be seen. I have elsewhere told the story of Frankenheim, a God-forsaken parish if there was one, in which each inhabitant, indebted up to the ears, inhabiting a ramshackle cottage, with that and his famished cow or cows all pledged to " the Jew," was as a matter of course credited with being a thief and a robber. There was extreme poverty-poverty so great and so pinching that in mercy the princess of the land, the late Grand Duchess of Saxe Weimar, felt moved to set up cottages with gardens for the population, to be let at a purely nominal rent. Those cottages would not fill. At the same time the morals of the parish did not mend. Every misdeed committed in the neighbourhood was as a matter of course set down to the debit of the Frankenheimers. An energetic and judicious parson coming into the living set up a Raiffeisen society. That society built cottages which were let at an economic rent. There was no charity, no patronage in this. It was all the people's own self-help. But the cottages filled. People came to be humanised and educated. They became industrious and moral. They would and did pay off the usurers. Thefts and robberies ceased. And the parish is now one of the best conducted in all Thuringia.

There are hundreds of cases like this-not in Germany only. Under my friend M. Michael Avramovitch's guidance the system has been introduced into Serbia. It has taken root there. And so far as it extends it has transformed the face of the country. Public-houses have lost the majority of their whilom customers, and a good many have had to 
close their doors. Card-players are cold-shouldered. Evillivers are tabooed. Old bad habits have been dropped. And were it not for the devilishly devastating work of the Austrians, rural Serbia would now be, as it was before the war, the wealthier, socially the better and the happier. Italy has similar tales of improvement to tell. I have. spoken of them elsewhere. ${ }^{1}$ In India patriots hope by means of the Raiffeisen society-of which there are already thousands in that country - to reconstitute a replica of the ancient dearly cherished Indian "village community," with its close touch and friendly feeling, making for happiness among neighbours.

Dr. J. A. Ryan, Professor of Political Economy at the Great Seminary of St. Paul at Minnesota, a recognised authority in the United States on questions of social economy to which he has devoted much study, writes:

" The transformation in the rural life of more than one European community through Co-operation has amounted to little less than a revolution. Higher standards of agricultural products and production have been set up and maintained, better methods of farming have been inculcated and enforced, and the whole social, moral and civil life of the people has been raised to a higher level. From the view-point of material gain, the chief benefits of agricultural co-operation have been the elimination of unnecessary middlemen, and the economies of buying in large quantities, and selling in the best markets, and employing the most efficient implements. . . . Co-operation," so he concludes, " is a golden mean between individualism and socialism. It includes all the good features of both. On the one hand, it demands and develops individual initiative and self-reliance, makes the rewards of the individual depend upon his own efforts and efficiency, and gives him full ownership of specific pieces of property. On the other hand, it compcls him to submerge much of the selfishness and indifference to the welfare of his fellows, which characterises our individual economy. It embraces all the good that is claimed for socialism, because it induces men to consider and to work earnestly for the common good, eliminates much of the waste of competitive industry, reduces and redistributes the burdens of profits and interest and puts the workers in control of capital and industry. At the same time it avoids the evils of an Ltd.

IIn "People's Banks," Third Edition, I910. P. S. King \& Son, 
industrial despotism, or bureaucratic inefficiency, of individual indifference and of an all-pervading collective ownership."

It we want to repeople our own countryside and restore the "Sweet Auburn" of happier days, surely here we have an apt instrument for doing so ready to our hand-the most effective that has ever been invented and that human ingenuity could think of. Let us cultivate and promote Co-operation, not merely for its economical attainments - great as they are-but even more, in our depopulated, deserted, impoverished and dreary rural districts, for social and moral blessings which it has it in its power to bring, the drawing together of neighbours to mutual helpfulness and mutual confidence, to the gilding of the humiliated and despised agricultural labourer's home with a touch, not only of justified hope for a better economic future, but also of that happiness which true neighbourly contact with others brings about, a little community in which class distinctions do not mean a separating wall, but in which rich and poor, employer and employed, can without forgetfulness of what is due to each, but still on a footing of equality, as man and man, meet on common ground, united by the bond of common humanity! At the end of the lane along which co-operative effort pushes its way, dropping material blessings as it goes, should stand a happier country life, enriching the deserted fields with renewed fertility, and at the same time repeopling the depleted villages with contented, hopeful human beings bound together by mutual consideration for one another.

It may be asked: If Co-operation is so advantageous to Agriculture and to rural folk generally, in both an economic and a social sense, how is it to be organised?

The question has of course attracted the attention of Governments claiming to be " paternally" interested in the welfare of those whom they govern. Governments, appreciating its value, have tried their hand at promoting agricultural Co-operation, and have in some cases managed to set up imposing structures of organisation, bearing the title "Co-operation" conspicuously on their façade; but they have never yet succeeded in producing quite the right 
article. It is indeed difficult to see how they could produce it. For Co-operation, to be worth anything, requires to be the production of those who participate in it, being based upon pure self-help and self-reliance, which qualities evidently the Government, be it ever so powerful, cannot produce for and in others. Apart from that, the mere fact that Co-operation, which consists in persons doing for themselves what otherwise necessarily others would have to do for them, of necessity involves competition with other established interests, and so from the very outset in justice places a bar in the way of Government assistance. For Governments cannot with fairness interfere between competing legitimate interests, nor take the people's money, in order with it to subsidise one single interest. Governments may, indeed, do a great deal for Co-operation; but not in the way of direct interference of assistance with money for trading purposes. Their attempting to do so has necessarily led to difficulties. Of course they have given grave offence to the interests with which Co-operation is led into competition. Nevertheless Governments have persisted in their attempts. But even in doing so they have not been able to maintain even a semblance of fairness. For in the distribution of their favours they have exercised curious discrimination. Very generally thcy have set the claims of purveyors of specifically agricultural requirements - that is, makers of and dealers in agricultural machinery, implements, fertilisers, feeding stuffs, and the like-aside with very little ceremony. These people must take their chance. In Ireland the Government is even reported to have gone so far as to set up a direct competition with these Cinderellas by selling the articles in which they deal directly itself to its favourites at less than market price. But, on the other hand, Governments have shown quite peculiar tenderness for traders in general and in domestic articles, the "banias" and "gombeen men" of their several countries, whom they have selected as their " anointed," who must not be "touched." An explanation of this fact presumably is this, that the traders have a larger number of votes, which must not be estranged, as 
long as the patient agriculturist, being deliberately kept out of the useful self-purveying trade--which has been the making of our industrial working classes-allows himself to be put off with specious but transparently false excuses. Abroad that consideration is freely avowed, and it has led to very marked discrimination indeed-but only in countries whose institutions we profess ourselves distinctly unwilling to copy-always with the exception of Ireland. Abroad, alike in Austria and Hungary, and France, agricultural co-operative societies have been distinctly forbidden, in consideration of money help rendered and preferential buying of their produce directly by Government departments, to set up any business in domestic requirements - the right which they are made to forgo being worth very much more than the ostensible quid pro quo given in return, even materially, to say nothing of the all but total sacrifice of the educational value of their organisation. In Germany Governments have not gone quite the same length. Agricultural co-operative societies may there deal in household articles. But they have received a plain hint that it is not desired that they should do so. Distributive societies are in Germany-as also in Austria-distinctly under a Government ban, half of them being suspected of being tainted with Liberalism, whereas the other half are known to be at least in sympathy with Socialist ideas. And, obedient to Government hints, even Raiffeisen societies have thus far abstained from encroaching upon the tradesmen's reserve, though holding the threat in terrorcm over the traders that, should they carry fraud or overcharge too far, they will be met by rivalry.

There are other Governments, really far more favourable to agricultural Co-operation, which have gone on an entirely different tack, and whose action has been marked by signal success. In Denmark farmers are ahead of all others in co-operative distribution. In Switzerland there are not a few villages in which the farmers' co-operative society has effectively crowded out the private trader. And the community, all being members, experiences the advantage of obtaining cheaper and better goods. Notwithstanding 
this, the Governments of those countries assist co-operative societies freely-in a legitimate way, by teaching, by instituting a better and closer control, and so on-without claiming anything like that redoubtable part $d u$ diable, the right of interference in management; and there is none of that systematic spoon-feeding and coddling assistance which to such an extent spoils matters in Germany, Austria, and France, producing what Holyoake has called " members of co-operative societies, but not co-operators."

All such German-Austrian coddling is wrong. But since there evidently is a disposition in high quartersin spite of the excellent example which Lord Curzon has set in India-to consider it as a practice worth following, it may be well to look to the other side. Our industrial co-operators have never received a single stiver of help from the Government. Mr. Gladstone distinctly laid it down that they must not. They might, so he contended, be allowed remissions of fees and similar little encouragements. But they must not be subsidised or receive illegitimate protection. And to this it should be added, that they should not be interfered with in the exercise of their rights, but should be allowed to develop in full liberty, with absolute freedom of action left to them. Our industrial co-operators have enjoyed such perfectly justifiable freedom and have prospered under it as no other co-operative organisations have done. Looking abroad, there are no better nor more prosperous co-operators than those of the Schulze Delitzsch connection, who not only have never received any Government aid-on the contrary, they have been incessantly frowned upon for political reasons-but who would scornfully refuse it if it were tendered-no Government advances, no preferential arrangements of any sort, no purchasing of their goods or other favouring of business. Relying purely upon self-help, Schulze Delitzsch's followers have, like our own industrial co-operators, worked their way up to most brilliant success.

Agricultural Co-operation, no doubt, stands upon a rather different footing from that which we know as industrial. The industrial co-operator builds up his society 
only to a very trifling extent upon money originally put into shares, but in the main upon purchases, which he is in any case bound to make. He becomes his own middleman, and, putting his middleman's profits into the society's funds, he in due course becomes a shareholder and to that extent a capitalist. The agricultural co-operator begins with larger requirements and smaller available resources. Even for mere supply, the collective purchase of requirements, he wants a little money at starting. And his main aim in co-operative supply, perhaps, is not simply to get what he now gets more cheaply, but to get it more cheaply for the purpose of enabling him to get more of it and so improve his farming. It is therefore not only arguable, but appears quite reasonable, that in very backward and poor countries, such as India and Egypt, for instance, some little State aid may be given in the earliest stages. The proper qualification to this is, that it should be limited to what is absolutely necessary, and made distinctly a temporary business only. That has been done both in India, according to what Lord Curzon as Viceroy laid down, and -in matters of supply of goods-in Egypt, where the Khedivial Agricultural Society found after a few years that, in view of the considerable proportions which the business in agricultural requirements-which it had saddled itself with temporarily for the benefit of the fellaheenassumed, it could not go on supplying such goods, but must look to the fellaheen to help themselves.

In our own country it cannot be pretended that farmers or small holders are in anything like such an equally helpless position as Indian rayats or Egyptian fellaheen. Even our very small folk have sufficient material stamina to work out their own salvation, if only led in the proper way. Our two Governments-the English and the Irish-have gratuitously dabbled in State help, in Pauline phrase, with "zeal, but not according to knowledge." In Ireland, which has preceded England in the movement, the Government has for a time provided money in aid of slowly growing agricultural Co-operation. Circumstances seemed to necessitate that. However, when all was over, one of the chief 
leaders of the movement frankly owned to me, that the money given might just as well have been " chucked into the sea." It certainly caused great inconvenience when a new " king, which knew not Joseph," summarily called the money in. And how hinderingly it acts, even in the best cases, under the most legitimate conditions, may be judged at the present time, when the Development Fund Commissioners-no doubt under pressure from the gombeen men, making such pressure felt through the Irish Government, which apparently has a very tender place in its heart for these gentry - has made its otherwise welcome subvention conditional, not only upon the Irish Agricultural Organisation Society undertaking not to employ it in support of trading societies-which is perfectly fair-but even upon not employing it in aid of teaching given to co-operators for buying and selling-which is preposterous. For the very first object for Co-operation to serve is just buying and selling. Irish small farmers need a schooling in Cooperation. They moreover need liberation from the claws of the gombeen man. And they need a practice of Cooperation which will secure immediate saving of money, so as to supply them with the wherewithal to go on. Accordingly, since co-operative buying and selling is to the benefit of Agriculture, and therefore of the country, one would think that the Government's direct duty must be to promote the teaching of Co-operation for such purpose. How well the supply of household articles works in with purely agricultural Co-operation for small talk is shown, among other instances, in the practice of the Lincoln Cooperative Society, an excellent society of, at the outset, industrial working men, which, however, has cast out its net over the surrounding rural districts, 23 miles wide, maintaining now about a score of rural branches, which distribute domestic requirements among their rural adherents, securing to them the same benefits that industrial adherents enjoy, and taking home from them in return their agricultural produce, which the society employs in its own trade or else sells for them to advantage.

On the English side of St. George's Channel there is no 
such prohibition in connection with the employment of Development Fund money, which makes the Irish prohibition only the more unfair. But there the Government has considered it to be its duty to come to the assistance of the nascent co-operative movement-which, it is true, for want of proper guidance by people not only well intentioned but at the same time also acquainted with co-operative practice, made little progress, and enlisted but meagre material support-in a distinctly prejudicial way. There should have been no occasion for this. We have wealthy men enough in the country, interested in the matter, to be able to finance the movement in its early stages, till it should become self-supporting. And those people would probably have come forward if there had been plain evidence that the direction given was in expert hands, not of patrons, but of experienced co-operators. At the outset it was not. The Government, having paid the piper, as a matter of course claims to call the tune. One of its representatives has frankly urged this. And the "tune" called is not in every instance a co-operative one. The Society has practically become an annexe to the Board of Agriculture, doing its will. One would like to know in what manner our industrial co-operative movement would accept such an arrangement. The Government has even gone so far as to nominate the Society's " Board " of "Governors." The concession made to co-operative feeling in asking for representatives of the Co-operative Union is mere dust in the balance. We cannot expect to see genuine Co-operation -which is the only Co-operation which will last-grow up under such conditions.

And our would-be agricultural co-operators had so much better and more promising a way open to them! We actually have among us the most brilliantly successful co-operative movement that the world has ever seen-a movement of which, after looking into its working, the American David Lubin, United States Delegate to the International Institute of Agriculture at Rome, remarked, in I913, that that was the thing of all that he had seen which came nearest a "miracle." That movement has 
much to give to Agricultural Co-operation, in a perfectly legitimate way, without pretending to any right of dictation, without setting up any claim to interference. Above all things, it has a knowledge of co-operative principles and practice to impart, which is the first thing that our would-be agricultural co-operators stand in need of, and which Whitehall Place cannot give. But our Co-operative Union can give very much more. Next to sound co-operative principle, the great need of a starting agricultural cooperative movement is a market. That our Co-operative Union has ready for us-on a grand scale-and willing to take our produce on fair terms. That market is worth a good deal more than all the Government favouring by State purchases that we see practised abroad. Beyond this, the industrial Co-operative Movement has a most successful Wholesale Organisation ready to hand, such an organisation as we have been groping for-at first, at any rate, it must be admitted, with anything but success, on most curiously erratic lines-an organisation all ready made, with all the necessary machinery, all the trade, all the agencies ready provided, doing already a considerable agricultural business. Our proper policy evidently would have been to join hands with that other co-operative movement on an understanding of give and take. The return which the industrial movement would get would simply be an expansion, such as it desires, of its movement-its distributive movement-into rural parts, where it is very much wanted, and where we are at present endeavouring to organise something of the same sort at the risk of coming into direct conflict with our should-be ally on the dangerous point of overlapping. The Nation would stand to gain much more. For combination of the two movements, which ought to be made to grow into one, like the prophet Ezekiel's " two sticks," must of necessity impart a powerful impetus, that should be welcome, to the Small Holdings movement. Small Holdings are a thing which stands almost foremost on the early co-operative programme-the country to be filled with small cultivators, thriving with moderate and healthy 
labour, under their own "vine and fig tree." That aim has been temporarily lost sight of over the more ambitious political and socialist aims taken up. But it is on the programme still. It cannot be erased. When the Small Holdings Act of 1908 was passed, the United Board of the Co-operative Union, realising the importance of the question and the favourableness of the opportunity offering, issued appeals to societies to take up the cause of Small Holdings and form special organisations for securing them. To that appeal, so the late Mr. J. C. Gray, at that time General Secretary of the Union, advised me, only a very disappointing response was made. Quite naturally so. On co-operative ground Industry and Agriculture still stand too far apart from one another for the one to be able fully to understand the other. It is not so very long ago that industrial co-operators owned that they had no faith in the Agricultural Organisation Society. Why not? With the one exception of my humble self, so it was pointed out to me, all the members of the Committee were pronounced Conservative politicians. Now Co-operation can have nothing to do with party politics. In the province of Agriculture unfortunately in this country still things have a natural tendency, not yet overcome, to become "besquired." However, Co-operation is a democratic movement, which does not want to be "befathered" or " bemastered." Union with Industrial Co-operation can keep us clear of that; it can instil a spirit of real Co-operation, which scorns favours, and makes its way by sturdy resolution and unbending self-reliance. And it can infuse enthusiasm for the cause of "Repeopling the Land" with willing, selfreliant, pushing cultivators, such as we want to see upon the land.

In this matter Italian Co-operators have quite recently set us an admirable example. The various forms of Cooperation there have all along maintained a very close and friendly touch among themselves. Their Agriculture is not either "bejunkered " or " besquired." Accordingly it was in a position readily to hold out the right hand of brotherhood both to the distributive and productive and 
to the co-operative Labour movement, which latter more particularly is in a peculiarly favourable position, and ready also, to pour recruits into the agricultural ranks for the purpose of repeopling and cultivating the long neglected land, by means of small holdings. Now the three movements have rightly resolved to become one. And each of them promises to benefit by the Union. But most of all benefit is likely to accrue to the Nation, which bids fair to have a reproach of generations wiped off it, and see its land, which has been running ruinously to waste, turned to good use by a thrifty and laborious rural population.

If our agricultural co-operative movement is to succeed, we shall have to do something of the same kind, taking the industrial co-operative movement for a model, and evincing a readiness to join with it-not merely as a safeguard for the avoidance of friction by overlapping, but as a means of bringing about heart-union, and getting up the steam which is now wanting, to carry us forward on the way to success. "Bejunkering" and "besquiring" will not do it. It is the cultivators themselves who must build up their Co-operation.

There is another point in organisation which deserves a word of mention. Do not, for goodness' sake, let us be pedantic! Co-operation, to be suitable to different occupations and different localities, wants to be flexible and elastic. Rules are good. But principles stand above rules ; and rules must be pliant. We have all but drummed out of our ranks what was, from a business point of view, at the time our out and out most successful society of farmers, simply because it would not submit to a rigid formula of formation in parish units, but from the outset covered a wide district, which gave it that "bulk" which of course Co-operation needs to achieve success. No doubt in ordinary circumstances the most advisable and the most natural form of organisation is by parishes or small districts, such small district societies afterwards combining to as powerful unions as can be got together, even were it only for the education imparted to small men by making them manage their own affairs in a little district society, and the closer 
touch engendered by the meeting of small district committees. Those benefits would be worth insisting upon. However, we are not all moulded on one block. Circumstances differ greatly in different localities. The test of good Co-operation is not its measure of extension, but its spirit and its practice. Co-operation above all things ought to be elastic. We have with advantage adopted, on the foundation of the same principle, different methods of practice in this country, and again in India. The Germans, the Italians, the French, all have different methods, raised up upon the same principle. We want to be adaptable also within our own narrow frontiers in the matter of Agriculture. Wherever people themselves show a preference for a larger society, for goodness' sake let them have it! So long as the small man is admitted to equal rights and the resulting society is a society, not of capitals but of persons, what the people themselves like best is likely to prove the most successful. 


\section{CHAPTER V}

\section{WORKING CREDIT FOR FARMERS}

THE first requisite for successful Agriculture under maximum production per acre-given, of course, the land upon which it is to be produced-is Money. The days of skimming the natural fertility off, with little labour, rude implements and haphazard cropping, the plant food so removed to be replaced by one or more years of unprofitable fallow, are past. We want more out of the soil now than the scanty harvests of those days. Farming has become a business. And in every business money, not only fixed, but for working purposes, becomes the most necessary factor. In our native Agriculture we are notoriously short of such capital. Our landlord has his funds tied up in his land. Mr.' Prothero frankly admits that "Landlords have no money to make the necessary changes.... Unless impoverished landlords can obtain State aid" (query: Is that the only credit obtainable?) "their only resource is to sell their land." Our tenant measures his holding-often rather optimistically, and on an already obsolete scaleaccording to his means, cutting his coat big, so as to leave him little margin. However, to-day it is " money which makes the mare to go." And such money need not necessarily be the tiller's own property. It goes in and comes out, as manure goes into the soil and comes out in the shape of crops, like the rain which descends from heaven, giving "bread to the eater and seed to the sower," returning " not void," but with profit. It is, according to the French term, the "rolling fund"-fonds de roulementwhich is wanting and which may be borrowed, just as may 
be the steam plough or electric thrasher, so long as it is judiciously borrowed and applied.

The fact is now acknowledged everywhere-outside our own country. And nowhere is it more so recognised than among our kinsmen and cousins beyond the seas-although relief is there sought by a different application of the principle to what prevails in Europe. In Europe and India it is co-operative credit societies which supply the need, in veritable floods of money. Beyond the Atlantic, in Canada as well as in the United States, it is the welldeveloped banks-numbered in the United States by the legion-which are trying to meet the requirement universally felt. In Canada banks have come to a special tentative arrangement with farmers, which is now on its trial. In the United States the various Bankers' Associations have to a considerable extent openly identified themselves with the cause of Agriculture-more particularly in its aspect of small farming. Examination of prevailing conditions has taught them that their own interest is wrapt up with that of the farmers, that, on a national scale, successful farming means successful banking. And accordingly we see them, corporatively, pushing the interest of Agriculture, more particularly in the matter of Education, and of financial assistance, for the formation and furthering of educationaleconomic young folks' societies, - cow and calf, and pig and poultry and "canning" clubs-and scoring, for the present in a small way, considerable successes. Not only so, but it has come to be recognised that a competent, pushing man, laying himself out for the agricultural calling, should have ready means placed within his reach for purchasing a holding entirely with borrowed money, to secure him a comfortable existence in later age, when there will no longer be the same amount of "go" in him, and when credit will come too late.

And if there is one fact which the various inquiries into the condition of Agriculture instituted in this country during the last few decades have made incontrovertibly clear, it is this, that, if we are to have more highly productive Agriculture, such as the Nation at present seems resolutely 
bent upon, there must be more working capital at the disposal of the agriculturist - whether his holding be large or small.

The fact was already plainly recognised, by the Royal Commission of 1894 , at any rate at the close of its inquiry, which took place at a period when this peculiar aspect of the agricultural question irresistibly forced itself upon the attention of inquirers. For in $\mathrm{I} 894$ the prolonged depression, which is said to have cost British landlords and tenants between them more then $£ 800,000,000$ (making, it is true, no allowance for earlier appreciations), still weighed heavily upon the calling, although at that time drawing to its close. Of such approaching change, however, at the time no one could be sure. The depression had upset all older notions respecting the alternation of seasons and the quantity of working capital necessary for carrying on farming successfully. Nobody yet dreamt of the lesson which under Mr. Middleton's competent guidance German Agriculture, with its high-pressure working, was destined to teach us. But we knew that under the effect of a succession of bad harvests, coupled with low prices for leading cereals, many farmers had been ruined, and that the old allowance of $f$ ro an acre -in many cases only a counsel of perfection--which would stand one bad harvest, could not be made to weather two or more.

Accordingly the Report of the Commission called pointed attention to the desirableness of providing for a better equipment of farmers with funds. And newspapers, echoing that demand, evidently without much familiarity with the matter, move solito called upon the Government to step in and provide what was wanted out of its assumedly inexhaustible store without overmuch regard for certainty of recovery. The Government was to make inquiry as to which farmers could turn credit to good account and on the strength of that to let them have whatever might be considered necessary.

To one cause of prevailing insufficiency of farmers' working capital some writers deserving a hearing had already called attention It was decades before that the 
Farmer's Magazine related that possibly hypothetical tale of the farmer who had thrce daughters and I,000 acres of land and who, for want of cash, handed over successively to each of his daughters, on her marriage, 250 acres as a marriage portion, and who, to his surprise, found after parting with each lot that, instead of having to pinch, as he had anticipated, he did better-and best of all on the 250 acres ultimately left. In his "Pilgrimage" Mr. A. D. Hall rightly lays some stress upon the mistaken policy of some farmers who hold land in excess of what their working capital will adequately finance, and upon the indifferent farming resulting from such practice. For to-day it is money-to be coupled, of course, with brains-which determines success in farming. It is money which "fetches" the maximum production, as well as the maximum profit, out of the soil.

As a case in point I should like to quote that of our great Co-operative Societies going into farming. A question has recently been raised, more specifically in Ireland, as to the propriety of their occupying land-which Nature appears to have intended rather for the local farmer-for the benefit of their distant consumers. Whatever be the objections, from a farmer's point of view, those well-endowed societies, bent upon business, have certainly shown us how greatly production may be intensified and rendered remunerative by farming with a full pocket, which need not stick at expense. That in itself shows how much beyond its proper limit the theory of "diminishing returns" has of late been pushed among our writers. No doubt there is a point at which fertilisers cease to yield a proportionate returneven if well chosen. And in Woburn and Rothamstedthe places quoted to press the principle-that point is not likely to be very far off. However, on the bulk of our land there is a good distance still which separates us from that critical limit. And there, the more heavily you manure, the more profit you are likely to secure. When I took the agricultural delegates from various European countries attending our first International Co-operative Congress, in I895, over the Borstal Farm in Woolwich, belonging to 
the Royal Arsenal Co-operative Society-but now no longer agriculturally employed-those gentlemen seemed thoroughly aghast at the enormous quantities of fertilising matter that had been put into the land, and the heavy outlay which had been incurred for deep digging, etc. The cost appeared to them excessive. However, the return fully tallied with it. Societies such as this are under no necessity of asking themselves-as an ordinary farmer would have to do-whether they can afford so much outlay or not. Whatever money is required will be forthcoming. The object is to produce as much as is possible. The only question for occupiers to ask themselves accordingly is, whether the outlay will pay. It turned out that it will. If the Nation requires a maximum of production, it will be for it to see that farmers "go and do likewise."

The need having been established, the problem to be dealt with came to be this: How is the money needed to be supplied?

Obviously it must be by Credit. There is no other source available, out of which to take it. And, as it happens, credit-given in cash, of course-also constitutes the very best possible form for equipment with money. For by reason of the fact that it imposes the duty of repayment, of a necessity it demands careful calculation, in order that misemployment may be avoided, and waste kept at a minimum. Every other trade in the world is now financed by credit. The merchant, the manufacturer, above all things the banker, who is sometimes supposed to be " made of money," all of them operate with borrowed capital, the attracting of which is in truth the most valuable service that their own cash can be made to render. In such application the use of credit is fully legitimate and proper, because the money employed will reproduce itself, and more than that. And there is so much money in the world, specifically in this country, waiting and seeking for employment, that the question of ultimate supply need trouble no one. All that is required is to show that the money will be well and safely laid out. Agriculture is the only calling which thus far has dispensed with a large use of credit in 
the accepted sense-meaning free borrowing of cash for free employment, as a productive factor, to be returned after it has rendered its service-just as it is the only calling which has dispensed with methodical organisation-and has suffered accordingly. Where-to instance only two forms of brief investment already referred to-moneylaid out on deep digging and heavy fertilising is known to produce a proportionate return, leaving a profit over, there not only is it perfectly legitimate to borrow the requisite cash for the purpose, but on reflection it would really be difficult to understand why it has not been so borrowed freely long ago-if one did not know of the obstacles hitherto standing hinderingly in the way.

One of those obstacles is engrained habit and characteristic indisposition to move out of the accustomed groove. And another is the absence of a congenial market for the obtainment of the money wanted-which latter obstacle is at the present time a peculiarity altogether of our own country, inasmuch as everywhere else, all round, in Europe and beyond it, a more or less favourable, but distinctly credit-yielding, market has been created and tapped. And hence in great part what superiority other countries-more particularly Germany-have gained over us in respect of productive Agriculture. There may be other hindrances there, but want of money for remunerative purposes does not stand in the way.

For want of such favourable market our farmers have been driven to the use of credit of a totally different and distinctly uneconomic, illegitimate and impoverishing kind, given in very equivocal forms. Even the credit openly obtained from bankers-a much reduced quantity now, since the private banker has disappeared from the scene, to give place to the big Joint Stock bank-which is financially certainly legitimate, is in the vast majority of cases resorted to, not-as it would be in the case of a merchant or a manufacturer-to produce more new value, but to help to tide over a temporary embarrassment, in other words to fill up some hole that has been created. Credit afforded pretty freely to farmers by bankers has recently been made 
a boast of by the latter, when the Board of Agriculture very unnecessarily approached them to obtain a promise of their willingness to loan money to agricultural credit societies still to be formed. The bankers questioned reported that they had never before had so many farmers on their books as borrowers. That, however, so far from proving a command of a vailable productive credit, indicates rather the exact reverse. For that money is not likely to have been borrowed for productive purposes. And it was no part of the bargain that it should be. It was given not for what it would produce but for what the borrower was supposed to be still worth. What is satisfactory about the matter is that it shows that bankers have once more taken to practising such credit rather more freely. For it had become very scarce. But it deserves mention that it is not stated what is the security demanded in such cases, which is of course a factor of importance. There is no reproach to be levelled against our great banking corporations for not supplying farmers with personal credit as freely as did the private bankers. Obviously the Board of a great Joint Stock bank, sitting in London, has not anything like the same power of appraising the credit value of a customer in the country that the whilom private banker possessed; and together with the accumulation of large masses of money its aim in business had also taken a rather different turn.

Generally speaking, of course, it may be assumed that a substantial man, whether he be a farmer or belong to some other calling, will always be able to obtain credit, which in his case is given on the strength of the knowledge that he is substantial and also trustworthy. That is however not altogether the sort of credit that other callings are in enjoyment of, that we are now in quest of and that we need to put Agriculture upon its legs. It does not correspond to the business credit upon which men in commerce and manufacture build up their business, the credit obtained, not as the result of possessions previously secured, but as a means of enabling the borrower to earn those possessions by its use. In any case it cannot help the small and struggling 
farmer, who is just the man most needing financial assistance ; and it leaves the host of small holders whom we hope to settle on the land altogether out in the cold. The merchant or the manufacturer borrows when he has a business in view which, if only he can provide himself with the money required, will bring him in a gain. The farmer thus far has borrowed only when he found himself in straits, to make good a loss already sustained, or to tide over a difficult season. That may prevent further loss. But it does not earn a profit. It does not produce new value. The money obtained for such purpose is not, properly speaking, working capital.

To what cxtent farmers' credit, as thus far practised, is salving rather than enterprising credit, is to be judged from the methods by which it has been procured. The favourite supply for it is dealer's credit. It is useless to belittle the extent of such borrowing. On this point Mr. A. D. Hall remarks :

"The greatest source of loss to our farmers is their bad credit and indebtedness to dealers. In all parts of the country, when one gets below the surface, one nearly always finds a large proportion, even a majority, of the farmers entirely tied to some trading intermediary who has advanced them money. In some districts it is the cattle salesman, in others the corn and cake dealer, but with one or other of these traders the farmer has to deal, and dares not grumble at either the quality of what he buys or the price of what he sells."

Indebtedness to dealers is very general. And it is so in part because farmers do not realise how extortionate and wasteful it is, and to what extent it cripples a farmer's freedom of action. In the United States, being a new country, where fresh settlement is still in progress and where the future is liberally discounted in business, such credit is more openly practised and more methodised. And it culminates in what Americans themselves confess to be pure " peonage," the borrower being bound to do business only with the man who gives him credit on his own terms, which to the borrower are impoverishing. It is no less crippling, though less openly carried on, in this country. 
One case in point I may give from my own experience. Being an old co-operator, since many years in touch with the first promoters of agricultural supply co-operationwhich was at the time all in the way of agricultural cooperation that was known-that is, Vansittart Neale, E. O. Greening, Thomas Hughes, Ludlow, and their friends, I in I883, while living in Lewes, convened a meeting of persons interested in Agriculture, with a view to inducing them to form a co-operative society for common purchase. The long spell of depression had already made its effects felt and common purchase would, I knew, if practicable, tend to lessen its rigour. I had a capital meeting, both of landlords and of the most prominent tenant farmers. Everybody approved the scheme. Nobody offered to join. Why not? My friend the late William Mannington, of Laughton, the foremost tenant farmer in East Sussex at the time, supplied me with the answer. "You will never get these men to join," so he said; "they are all on their dealers' books." They were tied by the leg.

Where the dealer's credit gives out, the moneylender's comes in. A farmer having a banking account will of course in case of need go to his banker-first, at any rate. The fact of his coming proclaims that he is embarrassed. But if he is a substantial man, he will still obtain credit on the usual easy terms. That is, however, only the élite. After the bank comes the usurer. And to what extent smaller farmers are in the usurer's hands Mr. T. Farrow has told in his rather sensational books, based upon evidence which as Secretary of the Agricultural Banks Association (of which the late R. A. Yerburgh, whose private secretary he then was, was President) he had collected in the course of a special inquiry.

All this is sheer ruin. It sucks the life-blood out of farming, instead of infusing new strength into it. Instead of preparing the ground for better credit, it has laid serious obstacles in the way of credit at all, by giving credit a bad name and making men ashamed to own to it. "The merchant and the manufacturer," so said the late $M$. Graux, at the time Belgian Minister of Agriculture in the 
Chamber, "glory in their credit ; the farmer, if he has any, is ashamed of it." And, although throwing a straw to the drowning farmer of moderate position, the credit actually practised leaves the small holder, upon whom now we stake so large a part of our hopes, wholly unprovided for. For it is not for him that Mr. Cent-per-cent carries on his business.

The question then arises: What are we to put in the place of present uneconomic forms of credit? What source of credit can we open to the farmer, large or small, from which he may, like the pushing merchant or manufacturer, draw the working capital which it is admitted that he very urgently needs?

As a matter of course, in these days of waning self-reliance, the State has been appealed to. The State is to-day expected to do everything. People seem to forget that all the money that the State itself disposes of is necessarily taken out of their own and other people's pockets, and that State help merely means making the persons not interested in a matter pay for the benefit of those who are. People also often enough forget that it is not everything that the State can do. Among other things, it positively cannot discriminate between deserving and undeserving borrowers. It has citizens to deal with, every one of whom must be considered as good as the other. It may fertilise a barren spot. It may drop a shower of gold upon a desert. But wherever it interferes, it unfailingly destroys confidence in people's own power and paralyses self-help. Look at the poor figure that the Indian takkavi loans cut by the side of Co-operative Credit! Again, look at the utter breakdown of the Agricultural Bank of Egypt's intended main business-the other is right enough-that is, the supply of working credit to small cultivators! As Lord Cromer has explained to me, he did not-although a thorough believer in Co-operation-at the time of starting the Bank resort to Co-operative Credit, because he did not consider the fellaheen yet quite ripe for it. That was an excusable mistake. But a mistake it was. For a small man is sooner ripe for co-operative than for other credit, as we now see 
in India. The Agricultural Department of the Bank of Egypt had, in its tentative efforts, before the Agricultural Bank was in existence, to send men about with bags of gold upon their backs, to persuade fellaheen to take loans. And eventually (even before the passing of the Five-Feddan Act, which places the credit originally intended altogether out of the question) its successor found itself with about forty thousand unpaid claims on its hands, the mere number of which made recourse to the Law Courts impracticable.

There is no instance on record of direct State interference in this matter bearing good fruit. Rather has it been found to act demoralisingly. And there is very plain evidence of its being often abused for political purposes.

Evidently from a desire to keep the conduct of the matter in its own hands, our Board of Agriculture has lately come to an arrangement with County Councils, offering on the State's behalf to become guarantor for any overdraft demanded by a farmer which may be first approved by the County Council. It is the latter that the farmer is told to look to for sanction. The County Council is, through its District Committee, to inquire into the merits of the case. And if it pronounces its placet, the State will, so to put it, "back the bill." It will be interesting to watch the result of that experiment. It appears to have come like something resembling a godsend in the trying times of war, which, of course, is altogether exceptional-though, to make it really useful, the terms for which under the original scheme loans are to be granted have had to be lengthened. American bankers have not been slow to seize the fact that nothing under a year can be sufficient, with renewals in sight. However, if the arrangement is to help Agriculture on a broad scale, it is evidently not cast on the right lines, let alone that it is bound in general to benefit, not the poor, whose security under the scheme must prove problematical but who need help most, but the wealthy. The seeking of security is all on the old lines of what a man has got. Co-operative credit, as practised abroad, is based upon what a man may be relied upon to earn with his borrowed money. Our scheme is not likely 
to do much for the small holder. In truth, ample experience gathered abroad has shown with great conclusiveness that there is really only one way in which the great want of working credit, generally recognised as it is, can at all be satisfactorily or adequately supplied. And that way is by Co-operation among those standing in need of credit themselves. That method has not only provided very adequate, really astonishingly large assistance, but it has in addition done very much needed good besides, of the very nature that we now admit that we want. It has proved a most useful preparative for other Co-operation in Agriculture, and a most potent stimulus to the advancement of Agriculture and of rural well-being. Alike in Germany, Austria, Hungary, France, Switzerland, the Low Countries, Italy, Russia, and the minor Balkan States, Agriculture thrives visibly upon it and, although its beginnings have in the earliest cases been beset with some difficulties, it has in general proved so easy of application that, to state one instance, British India has within the first twelve years of its existence in that country (up to July, I9I6), by an unintended tour de force-because it is rather the drag of caution than the whip of stimulation that has been employed-seen its organs, that is, credit societies, multiplying to the number of nearly twenty thousand, with nearly a million members, $£ 5$ I0,000 paid-up share capital and $f_{\mathrm{x}}, 600,000$ business. Our fellow-citizens in Ireland have profited by it to a degree which has evoked expressions of admiration from the late King Edward on his visit to the island. In truth it is only England and Scotland which have thus far remained unaffected by the gilding Midas touch which has extended its sway all over Europe, carrying it eastwards beyond its ancient home into far India, and which now promises to bring fresh wealth also to our cousins in the United States, to the mixed population of the Hawaii Islands and to the Spaniards of Mexico.

It may occasion surprise that among ourselves, where under another form Co-operation has stood all tests so magnificently and achieved greater successes than in any other country, and where certainly the golden sovereign 
is held in high estimation, this particular form of Co-operation should so long have remained unused. We have talked a good deal about it. It is nearly fifty years since Sir R. Morier, then our Minister at Darmstadt-where he had seen a good deal of the success of Co-operative Credit - sent a glowing account of its triumphs and utility to the first National Co-operative Congress held in this country, in I869. Since then the late Lord Avebury has warmly recommended it in the House of Commons, in I889. In November, I893, we formed the Agricultural Banks Association, to promote specifically agricultural co-operative credit societies. In the succeeding year, as a sequel to my reading a paper upon the subject before the Central Chamber of Agriculture, a committee of that body was appointed to investigate the subject. In the same year Sir Horace Plunkett invited me over to Ireland to explain the system to his Irish Agricultural Organisation Committee. About the same time, in the same month, we formed the first English village bank at Scawby in Lincolnshire, thanks to Captain Sutton Nelthorpe, the squire.

Twice has the matter been brought before Parliament, in the shape of a Bill which, on the second occasion, passed the House of Lords with flying colours, a peculiarly competent Select Committee under Lord Miersey reporting strongly in its favour. After that the Board of Agriculture has professed a keen desire to acclimatise Co-operative Credit. It has begged for a Memorandum on the subject from me, and has tried its own hand at a Bill. The Small Holdings movement has imparted a fresh fillip to the desire to establish Co-operation banking. For everybody recognises that small holdings without easily obtainable and cheap credit have no chance of success.

And yet at this moment we stand, with regard to practical co-operative credit for Agriculture, only precisely where we did before Sir R. Morier entered the lists as spokesman, and Lord Avebury, as a banker, pronounced his benison upon it! Ireland never heard of such credit till I894. But, buckling to its task at once in good earnest, it has, without in any way forcing the pace, achieved a very satisfactory 
success and knows since a long time now that in co-operative credit it possesses a very valuable national asset. India only began in I904-and late in that year. The incidental points which so much trouble our wise men were promptly and, it may be said, instinctively, grasped by the Hindoo and the Mahommedan. No doubt in either case the consciousness of poverty and indebtedness has hastened the success. For poor people make the readiest co-operators. However, an unprejudiced mind brought to the problem has greatly helped.

It may be admitted that, as a country, we stand in a decidedly different position from what Germany and Italy -also Belgium and Austria-did when Co-operative Credit was there first introduced. We possess a first-rate organisation of credit, spread out over the entire country, with its tentacles, in the shape of branch offices, penetrating into pretty small local centres. None of the Continental countries named could at the time boast of anything like that. However, that credit organisation of ours manifestly does not reach those particular points upon which our territory most requires fertilising with money. Either it does not touch them; or else, in consequence of the incompatibility of usages, it cannot connect itself with them. That difference indeed may account for the fact that we do not set up such powerful business banks on co-operative lines, in towns, as Germany and Italy possess at Leipzig, Milan, and at some other places. It may be granted that we do not here want such giant co-operative establishments. But what credit organisation do we possess for Agriculture? The Joint Stock bankers whom a year or two ago the Board of Agriculture summoned to an interview, to say if they would grant credits to co-operative banks-which it was hoped would be formed-made a boast of it that they had never had more farmers on their books than at that precise moment. But that, as observed, is not for productive purposes, and only proves prevailing embarrassment. People point to the United States and plead that there there are many farmers shareholders and even directors of National Banks and in such capacity obtain easy credit. Quite so-" in such 
capacity." That assists individuals in difficulties. It does nothing for Agriculture. It helps the wealthy. It could not possibly benefit that large host of coming small holders of whom we are now thinking. It shuts out all the financially weak men-a very large number-whom in Germany Raiffeisen made it his particular aim to help on their legs, others imitating him elsewhere. And even for financially stronger men it does not represent the everready, ever-available, easy, matter-of-course credit which merchants and manufacturers trade upon and of which farmers stand in no less urgent need. It makes wealth the foundation of credit, not its prize. In spite of the credit given to substantial men who happen to be farmers, in the United States-after looking into the specifically agricultural business done by the Bank of France-millions and millions-Mr. Myron Herrick, a banker himself, and at that time United States Ambassador at Paris, had to say to himself: "We possess nothing like it." Here were not overdrafts merely, such as Mr. Leroy Lewis's Committee of the Central Chamber of Agriculture has contended that co-operative credit consists of. Here was agricultural " paper" in millions, down to drafts for five francs, which came in and went out as regularly and as currently as bills of exchange at a commercial bill-broker's. And French Agriculture feels the benefit.

The excuse sometimes put forward, that we possess sufficient credit for our agricultural requirements, will not stand the test of examination.

Unquestionally there is a certain amount of contrariety to the ways of Co-operative Credit in the nature and the long engrained habits of our farmers. We have a Cappadocian for our patron saint, and with his guardianship we seem to have accepted also his Cappadocian skin, which does not readily take in new "wrinkles." Sir Horace Plunkett puts it in a different way when comparing our English slow-coaches (in this matter) with his more quickly moving Irishmen, who have adopted the new practice promptly and successfully. Irishmen, so he says, are quicker to receive a message in one ear; but the trouble is that it 
will almost as rapidly fly out at the other. Englishmen boggle badly over taking it in with their one ear. But once it gets in, it sticks. Let us hope that such will prove the case in this connection. For up to the present the message does not appear to have passed even into the first ear.

There appears to be a very unfounded apprehension among bankers that Co-operative Credit might interfere with their business and damage their interest. It is odd how timid bankers, armed as they are with their panoply of gold, are in such matters. Twenty-four years ago they offered such stout resistance to a valuable Bill amending our Savings Banks legislation that they succeeded in extracting a concession which does them no good, but for a long time diminished the utility of the measure by cutting down the amount allowed to be paid in in one year on one account. Now they appear to be obstructing progress in co-operative banking in something of the same spirit. And yet their market is unassailably theirs. In the present case nobody is so much as contemplating any inroad upon it. Rather would co-operative banking prepare new ground for their conquest by training new recruits for service in the army of their customers and creating new business which must ultimately infallibly come to them. What the co-operative banks contemplated are to do is what ordinary bankers in their own interest absolutely cannot do ; and the business that ordinary banks do in the same way lies altogether beyond the reach of the humble little credit socicties projected. A very apt comparison is that with the relations existing between Collecting Banks-very meritorious institutions that they are-and Savings Banks. Collecting Banks collect deposits like the Savings Banks. But they do not compete with them. Their emissaries collect the pence coming in on pay-days in working men's homes, before there is a chance of their being wasted, and keep them for a time. But as soon as the money collected from one person reaches the sum of $£ 5$, they hand it over to the Savings Bank, and from that moment only does the deposit begin to bear interest. We want thousands of these modest little institutions. Many crumbs proverbially malie a loaf. 
In the same way Co-operative Banks whip up new customers for banking in the wide, neglected plains on which banking would without them not be thought of, train them to banking ways, teach them how to lay by out of their earnings, to form capital. And when a certain point of accumulation is reached they necessarily-for their cloth will then admit of the cutting of a moderate-sized coathand them over, with money and banking habits formed, to their bigger, non-co-operative colleagues.

Abroad ordinary banks are only too glad to do business with and for co-operative banks. It is so very notably in Italy. And in Germany the wealthy Dresdner Bank acts to its own and to its customers' satisfaction, as Central Bank, or bank at the back of the Central Bank-apex bank, as they call it in India-both for the powerful SchulzeDelitzsch Union and the more strictly agricultural Union adopting the principles of Raiffeisen. Its own officers have assured me that they are satisfied. The Bank maintains a separate Co-operative Section. Not a. few of our most intelligent bankers have readily perceived and freely owned that co-operative banking rather promises to favour than threatens to damage their own interest. The late Lord Avebury, having spoken for co-operative banks in the House of Commons, expressed to me his views in that sense by a special letter. And another member of a wellknown and prominent banker's family wrote to me unsolicitedly at about the same time (in I894) to bid me "Godspeed " and say that in his opinion I was advocating just what was urgently wanted and certainly ought to be done. But there are more clear-sighted bankers even in this country. And abroad we have the best of them on our side. In Italy Comm. Ettore Levi, being one of the tip-top bankers -he was Vice-President of the National Bank of Italyhas written a very valuable handbook on Co-operative Banking. We have had bankers taking the chair at our Co-operative Banking Congresses. And a recent German Bankers' Congress, meeting at Münich, passed a special resolution declaring that the work which co-operative banks are doing in that country wants to be done and that those 


\section{THE FUTURE OF OUR AGRICULTURE.}

banks deserve to be supported. In 1894 , when in Ireland, on Sir H. Plunkett's invitation, to explain the system to his fellow co-operators, I explained it also to the late Colonel Dease, at that time Governor of the Bank of Ireland, and to the Manager of the Country Business of that Bank. And they were both fully satisfied and declared their perfect willingness to enter into business relations with societies formed as I suggested-which is just what Joint Stock banks in Ireland, and also in India, have done, without any introduction by a public Department, such as our Board of Agriculture has considered called for when approaching bankers. Good wine needs no bush. It is about time that English bankers gave up their bogy fears.

However, suspicions entertained by bankers have not been the only obstacle. Somehow those people in high quarters who took any sort of interest-only languid thus far-in the matter seem to have been determined to take the matter up at the wrong end.

The Central Chamber of Agriculture, as a matter of course, bungled hopelessly. Having heard a paper on Co-operative Banking read by me, on the invitation of its chairman at the time, the present Lord Channing of Wellingboroughin which paper I, of course, had to treat the subject most summarily, since my time was limited to fifteen minutesit in I894 appointed a Committee to inquire into the question. The members of that Committee who really acted were, so far as I heard, the chairman (Mr. Channing's successor), the Secretary of the Chamber and a learned Professor. Their Report was to the effect that this new kind of banking-which had raised millions and millions abroad for people who had no banking account, as we understand it, down to the humblest peasantry, thousands and thousands of them-was nothing but the practice of " overdraft " already " sufficiently" provided for in this country. Considering that only a very small portion of that business is even now, and scarcely any was at the time, done by overdraft, and that, moreover, complaints were rife in this country about the insufficiency of credit thus practised for farmers, that must be set down as a rather 
bold departure from fact. Conclusively to prove their qualifications for acting as judges on such a matter, the Committee went out of their way to affirm, what would certainly have surprised Messrs Byles and Chalmers, the well-known text writers on bills of exchange, that "the main difference between ordinary mercantile credit and agricultural credit is that, while the former is given against specific securities, the latter, when given at all " (please note the admission), "is purely personal." "The Committee could not see their way to recommend anything of the kind." When challenged upon their verdict-of which by this time the three wise men of Gotham must be heartily ashamedthe chairman wrote that it had been " unanimously " adopted by the Chamber, and rode off on a cheap jeer-he himself being an American naturalised in England-at " highly intelligent foreigners." None of Schulze-Delitzsch, Luzzatti or Raiffeisen Co-operation for him! Let "Mr. Yerburgh, Mr. Channing, Mrr. Jeffreys, and Professor Long" -these are the gentlemen named in his letter-devise something "English"! Well, they have not done so. And, seeing that Mr. Yerburgh, as President of the Agricultural Banks Association, was pledged to the furtherance of that "foreign" credit banking, and that Mr. Channing numbered among its most fervent supporters, it was not likely that either of them would attempt the task. The other two gentlemen appear to have been content to leave the matter alone. The Secretary, more discreetly, deprecated further discussion, which would, he said, "not be convenient." Doubtless it would not. And the Professor, most discreet of all, held his learned tongue.

However, the Government in its turn bungled just as badly. One would have thought that in the course of the inquiry by Royal Commission in I894 the subject would have interested the founder of the Board of Agriculture. Nevertheless, he promptly walked out, seemingly in great haste, as soon as the first witness on it was called. The late Lord Wenlock's Bill of I908, having been assented to by the Government in second reading, was fiercely assailed in Committee by Lord Denman, then a Junior 
Lord of the Treasury, who pronounced it terribly dangerous, likening these little village banks, with, it may be, their score or five or tenscore of members, dealing with only trivial sums, to the ill-fated "City of Glasgow Bank," which plunged thousands into ruin; and with Rouher-like emphasis declared that never would the Treasury agree to-what in point of fact it had formally agreed to fourteen years before, when sanctioning the registration of village banks as " specially authorised societies " under the Friendly Societies Act. Lord Denman, who in the same speech severely censured a well-known parliamentary draftsmanwho is also a member of the House of Commons--on the score of his bad draftsmanship, may be a very high authority on banking. However, seeing that Sir George Murray, at that time Permanent Secretary of the Treasury, accepted my explanation of the case as fully satisfactory, and that his predecessor, the late Lord Welby, was one of the Select Committee of the House of Lords which subsequently inquired with great care into the provisions of practically the same Bill brought in in Igro by Lord Shaftesbury, and approved the Bill without a dissentient voice, and that he afterwards wrote to me expressly declaring that he would be glad to give any assistance that he could to the promotion of such banks as I proposed, it will be just possible to bear Lord Denman's censure with something like equanimity. The stumblingblock to him evidently was the form of liability implied in the case of one type only of the banks recommended, which is technically unlimited. A word or two will be due presently to that point, since the name " unlimited liability" has raised a perfect epidemic of apprehension. Lord Denman's official opposition temporarily gave a quietus to the Bill. For, although Lord Crewe had warded off a division, which was likely to go against the Government, by the promise of a "Conference," once that offer had been accepted and had served its purpose, no more was heard of the proposed "Conference."

Brought before the same House in a slightly altered shape in rgro by Lord Shaftesbury, the Bill was referred for examination to a singularly competent Select Committee, 
presided over by Lord Mersey. That Committee reported strongly in favour of its acceptance. And in due course the Bill was passed by the House without a dissentient voice. A very curious Bill, dealing with the same subject, prepared by the Board of Agriculture during the same session, met with so poor a reception in the House of Commons that it was voluntarily withdrawn.

And there the matter remains. The only sequel is the arrangement actually put in force, under which, as already explained, the Government undertakes to guarantee loans made to individuals, which secure the approval of the County Council Committee.

Even that is not all that has stood in the way of the adoption of Co-operative Banking in this country. There seemed to be a perfect conspiracy of hostile forces arrayed against it. There are many honest well-wishers to the cause. However, most of them do not appear to be able to approach the question from the right side. They start with the truism that "if there is to be credit, there must first be money"; and, building in a wrong way on that premiss, practically putting the cart before the horse, they address themselves above all things to the search for funds, upon which they have fruitlessly bestowed great pains. That practically means not seeing the wood for trees. As it happens, there is plenty of money in the country, money "overflowing in the coffers of the bankers," as the late Lord Salisbury put it-money waiting, eager for employment. To borrow such money on the mere chance of being able to do business with it in lending it out to farmers, means making straight for bankruptcy. For you cannot have money without paying money for it. Having money in hand means an almost irresistible temptation to look for employment, instead of waiting for a demand for employment to come to you; and to judge such demands as come over-benevolently, when, on the contrary, in the interest of safety you want to be absolutely strict in dealing with them. It was the presence of cash, for which there was no demand, which wrecked Napoleon the Third's wellendowed and pretentious Crédit Agricole. The expected 
legitimate applications from farmers not being forthcoming -because the Government, which cannot do credit business otherwise than mechanically, had prescribed quite unsuitable terms-the Crédit loaned millions away to the Khedive Ismail, from whom of course it never received a penny back. It was, again, the presence of cash for which there was no demand which compelled Gambetta's well-intended Caisse Centrale to abandon its intended popular business and convert itself into an ordinary profit-mongering business bank. There is surely no need to support the thesis by further examples. Res ipsa loquitur. But I may add that there is a whole host of credit institutions formed under the " co-operative" sign that apply it in the manner now so freely advocated in England, of looking out for " money" and for "business "-instead of making sure of " security" -which have come to grief. Shall we not take warning?

The general apathy in respect of Co-operative Credit for farmers shown in this country, its contemptuous poohpoohing by officers of the Board of Agriculture, by gentlemen like Mr. Leroy Lewis and, under his inspiration, of the Central Chamber of Agriculture, and by the banking interest and writers on finance, contrasts strangely with the keen interest evinced-for good reasons, too-by men and bodies of corresponding position among our kinsmen across the Atlantic, alike in Canada and in the United States. In modern days, it appears, the "wise men," the men of action and initiative, come, not from the East, but from the West. In the United States the interest is most noticeable. The Bankers' Association has taken up the question with great spirit, and the "Banker-Farmer" has become a recognised institution. The "Department of Agriculture," corresponding to our " Board of Agriculture," is moving actively in the matter. The late United States Ambassador at Paris, Mr. Myron T. Herrick, himself at the head of an important banking establishment, owned to me, while still at Paris, that one of his reasons for accepting the ambassadorship had been the wish to have a good opportunity of studying the practice of co-operative credit for Agriculture established in Europe on the spot, in order 
to be able to influence the adoption of something similar in his own country. He was simply astounded at the enormous amount of agricultural " paper" held in discounts by the Bank of France. In Canada the bankers are equally busy endeavouring to solve the problem, the great national importance of which they, with their keener Western insight - as compared with our own-perceive clearly. And in July, I9I6, at a "Banker-Farmer" Conference held at Winnipeg for the special purpose of considering the matter, they made specific offers of enlarged credit-and more particularly for credit extended in point of time-to the farmers of the three great grain-growing provinces of Manitoba, Saskatchewan and Alberta. In both countries bankers and farmers are now manfully pulling together for the purpose of establishing cheap and convenient agricultural credit-let alone that banker minds are also busy over plans for providing easy and more accessible mortgage credit.

If you want to build up a sound system of co-operative banking, what you have to look for first obviously is security. Everything hinges upon that. Provide security and you will find the money coming in of its own accord-not at once, perhaps: because the method is new and unfamiliar to ourselves; but after very little hesitation certainly. That is the common experience of co-operative banks all over Europe. There may be some rough ground to be got over first. Ardua quae pulchra. But the money will come in. The Banca Popolare of Milan, which now has more than half a million of share capital and deals out millions across its counter, catering, among other things, for more than three hundred smaller co-operative banks, began in a little room in a back street with $£ 28$ share capital. Sound business brought in the rest. There are many other similar examples.

Now, in the case of Agriculture, more particularly of small Agriculture, the provision of security, such as will satisfy lenders, entails rather considerable difficulties. There is no calling which-even without bringing the freehold into account, which should have nothing to do with 
this sort of credit-contains better elements of security. Experience has shown that more particularly small farmers make excellent repayers. However, those elements are not present, without further licking into shape in a marketable form, current with the banker.

For one thing, a farmer can never quite tell by what time he will be able to repay his loan. He may state a minimum period, which in any case is likely to be longer than that for which the merchant or the manufacturer needs his money. For he turns over his cash very much more slowly -in most cases (except in dairies and similar industrial undertakings) only once a year. However, that one year may not suffice. For the harvest may fail. And the humbler is the scale of the borrower's agricultural business, the less certain will be the time that will suffice for repayment. The substantial farmer may be able, in the event of one source of income failing him, to repay the debt from some other source. Or he may take his loan in the shape of an overdraft-which in his case would be perfectly legitimate. However, our practice of overdraft is not as convenient as that in force abroad, and also in Scotland, in the shape of Cash Credit-the form of credit from which our overdraft is copied, but, as the late $H$. Dunning Nacleod has rightly pointed out-pace the Central Chamber of Agriculture-not with the same method and completeness. We regard an overdraft as an exceptional resource, for a "special, temporary purpose," a matter almost of emergency. Bankers do not like to have too many overdrafts running, because they leave them in doubt as to what money may be required to meet calls. And, such as they grant, they do not like to have running for very long. Abroad the overdraft is taken for a year at a time, to be renewed as a matter of course if all is satisfactory. So it is in Scotland, where Cash Credit has worked veritable wonders, " raising the country," as Mr. Macleod has put it, "in the space of a hundred and fifty years, from the lowest state of barbarism up to its present proud position." Our bankers could not possibly be expected to provide overdrafts for the entire mass of credit required 
by our farmers, stimulated into intensivism, more paticularly that host of small holders whom we hope to see, with the help of borrowed money, turning our countryside into a garden of Eden. It was a different matter in the case of the Scotch banks, which could issue paper money ad libitum. And the question of security would be a very difficult one to solve. In the absence of other materials for such-for farmers as a rule have all their money locked up in their farms, not in specific securities which might be pledged-the security given would have to be personal. In industrial and mercantile centres the question of personal security raises no insuperable difficulty. For there is no scarcity of acceptable sureties there, and the status of both borrowers and their bailsmen is readily ascertainable. In the country this is not so, especially with the bank a large bank at a distance. A farmer, large or small, may be deep in debt to his dealer, or else in arrear in his rent, without the banker being able to ascertain it. We have seen men reputed substantial "cut up" in some cases very poorly indeed. And letting alone shyness in pledging themselves, the number of available men and their bailsmen is small. You cannot have Brown backing Smith, and Smith returning the compliment to Brown. Besides, an overdraft is by no means the most desirable form of credit in agricultural business. It provides the same temptation for the small borrower that the presence of a large fund of cash does, as already pointed out, for a credit society. It tempts to careless use. And our agricultural public still needs very much training to banking business. So training it, compelling every borrower to calculate carefully beforehand whether an outlay will repay itself with interest or not, is one of the main functions of co-operative credit societies, in which they have admirably succeeded. Therefore in the great majority of cases it is a specific loan for a stated object, rather than an overdraft, that will most benefit the borrower. And that same course is certainly desirable, if not downright necessary, in the interest of those who pledge themselves for repayment of the loan. To a not inconsiderable extent, under Co-operation, the 
dormant security of the agricultural borrower is made marketable by his pledging himself to a certain approved employment of his loan, out of which employment-carcfully considered and scrutinised and made obligatory upon the borrower by the lender - the loan is in truth to be repaid. No tolerably certain prospect of repayment, no loan! Even so, additional grace may have to be granted. For, apart from bad seasons, there may be other causes of delay. And to make the borrower who has borrowed money, let us say, for the buying of a cow, or a pig, or the draining of a field, or the sinking of a well, repay out of other sources of income, would be a hardship upon him rather than a help.

Such considerations in themselves will show how greatly different is the financial atmosphere in agricultural credit and in ordinary banking; and, incidentally, how unsuitable in the majority of cases is an overdraft as a method of borrowing. It is because longer time is in almost any case required in agricultural credit than in ordinary, that cooperative banks in Italy habitually allow a longer term than the three months usual for commercial credit, namely six months and in some cases nine, after which period the loan is, on approval, renewable, on condition of a certain proportion of the original sum being paid off. It is the uncertainty of repayment, as regards time, which practically justifies the particular method adopted by Raiffeisen, of which more will presently have to be said, which designedly operates more with liability than with ready cash, such as would " eat its head off " while waiting for employment. The liability pledged is turned into cash by means of a central institution, expressly formed to deal with it.

The point of time is, however, not the only difficulty to be overcome. Persons engaged in agriculture are, as a matter of fact, generally honest and trustworthy-down to the humblest-and more specifically so when they are liable to men of their own class and their own neighbourhood. In the little peasant banks of Italy poor people who had had to emigrate have most scrupulously repaid from transatlantic countries what they owed. They would 
not play their classmates false. That is another argument in favour of Co-operation. Co-operative banking, according to M. Luzzatti, means " the capitalisation of honesty." The honesty is there. But without such capitalisation it is not readily convertible. To make it marketable, it has had to be surrounded with some strong safeguards. In many cases-where poor people are concerned, not substantial men-what is called " unlimited liability" has had to be resorted to, and it is difficult to see how in such cases it could be dispensed with. There are plenty of other cases, of fairly substantial farmers, in which it is quite unnecessary and therefore not advisable. But the poor man has, practically, nothing else to pledge. What he possesses is worth very little to others, but very much to himself. The difference between the two values is one of the points which come prominently into play.

We ought not to make the mistake of assuming that the freehold, so usual abroad, has anything to do with this peasant credit. That is assumed by many in this country and put forward as an argument against the practicability of such credit amongst ourselves. It is also urged even by some leading personages abroad, who employ it, intending to prove the superiority of the German freehold system. However, the freehold stands absolutely by itself and is subject to its own form of credit, which is a mortgage. In truth all authorities are fully agreed that the less the freehold is brought into account under what is distinctly intended as a system of personal credit, the better will it be. There is not much tenant land which comes into account under the present aspect in Germany. But in Italy, where the same class of co-operative credit institutions exist, there is a great deal. And there accordingly the point of making co-operative credit purely personal, and safeguarding the personal undertaking to repay by effective protective methods, has been given special attention to. So it is in the Lodigiano, the Cremonese, and the district of Rovigo, in all of which Co-operative Credit is highly developed and working admirably.

One such protective method, only partially resorted to, 
is what has been called-and really miscalled-unlimited liability, the label on the article which has become such a bogy to Lord Denman and a good many uninformed persons besides. In Ireland and in India, where unlimited liability has been put to a test, nobody is afraid of it. In India really natives almost universally, if not quite so when given a choice, decide unhesitatingly in favour of unlimited liablity - even though they at the same time make a decided point of the collection of fairly ample share capital, which under such circumstances might be considered dispensable.

In truth there are more misnomers than one connected with Co-operative Credit. Even talking of these humble little organisations as "banks" is really giving them a wrong name. In preparing the Bill which Lord Shaftesbury brought in in I9I0, we advisedly altered the title to "Thrift and Credit Societies." Since I dedicated my first book on the subject to my eminent friend Ir. Luzzatti, I considered it becoming to adopt the title which in his own country, that is, in Italy, he has given to co-operative credit societies, and which is also commonly employed in Belgium and in France, that is "People's Banks." " Creait Societies," the name employed in Germany, where the institution had its birth, would have been more correct. The business to be transacted is by no means " banking," such as we understand that to be-certainly not in agricultural societies. Therefore it is giving a Roland for an Oliver to apply to "bankers" for advice on the matter as is frequently done. Agricultural banking and ordinary banking are as markedly dissimilar as, say, Old Bailey pleading and conveyancing. It is very right to take bankers' opinion, and abide by it, in respect of the link to be created between co-operative banks and ordinary-the security of the former of which is, for bankers, only latent in the agricultural credit society, but is to be so put into marketable shape--most conveniently by the interposition of a Central Bank-as to make it available for raising money in the great money market. That feat has been most effectively accomplished, as not only the opinion pronounced by Colonel Dease and his Manager, and the active business in progress between ordinary and 
agricultural banks in Ireland and in India, but also the very large business done between German agricultural banks and the great Dresdner Bank, conclusively show. But it is a great mistake to go for advice as to the management of agricultural banks to ordinary bankers, who know, qua bankers, as little about it as does a fiddler about architecture or philosophy. The two different classes of institutions were created for essentially different purposes; they have different sets of customers to deal with; and different kinds of security to operate with. The ordinary bank is there to earn a profit for its shareholders out of deposited money belonging to others. The co-operative bank must of course keep on the right side in its reckoning, but it distinctly must not make a profit, or as little of such as can be, beyond what is necessary to enable it to accumulate a sufficient reserve fund and provide for contingencies. It is there to provide credit for its members at the lowest possible cost of production. If it makes a profit, that shows that it is overcharging; and its first care must in that case be to reduce its charges-except where a special effort is decmed advisable as a means of rapidly building up a substantial reserve fund. The ordinary bank shapes its terms of credit to suit itself. The co-operative credit society has as much as possible to adapt its practice to its members' requirements, that is, it has to give credit under circumstances and for periods that would not suit an ordinary bank. The ordinary bank takes as security for a loan or an overdraft some readily realisable effects, or else a lien upon some saleable object, or else, once more, suretyship from substantial backers. The co-operative bank, so far as it is agricultural, has practically neither the first nor the second of these convenient forms of security at its command, at any rate exclusively for its purpose. The two institutions move on different planes, like two planets revolving in distinct orbits, and for that reason have to employ different methods and aim at different objects.

The one common feature of the two classes of banks is that they must have security of some sort--such as is available-for the credit which they give. However, 


\section{THE FUTURE OF OUR AGRICULTURE.}

"security" does not necessarily mean a certificate for Consols or railway shares. It means the certainty that repayment will be made at the proper time. Consols, certificates and railway shares our intended beneficiaries -small cultivators and the like-have none. But they know one another, they can gauge one another's honesty and means of repaying, and they can watch one another effectively in an inoffensive way. The originators of the famous Scotch "Cash Credit," which, in the words of H. Dunning Macleod, may claim " the far-famed agriculture of the Lothians, the manufactures of Glasgow and Paisley, and the unrivalled steamships of the Clyde for its own proper children," understood this well.

"There is one part of this system," so says the Report of the Lords and Commons Committees appointed to investigate the matter in I826, "which is stated by all witnesses (and, in the opinion of the Committee is very justly stated) to have had the best effects upon the people of Scotland, and particularly upon the people of the middle and poorer classes of society, in producing and encouraging habits of frugality and industry.... From the facility which these cash credits give to all the small transactions of the country, and from the opportunities which they offer to persons who begin business with little or no capital but their character, to employ profitably the minutest products of their industry, it cannot be doubted that the most important advantages are derived to the whole community." "The witnesses whose evidence we have quoted," so the Report goes on, "stated that they calculated that the number of persons who had cash credits granted to them amounted to about IO,000 or II,000 and, as the average number of securities to each bond might be taken at three, there were about 30,000 persons interested as securities; so that the total number of persons at that period interested in the system was at least 40,000 . . . This system has a great effect upon the moral habits of the people, because those who are securities feel an interest in watching over their conduct; and if they find that they are misconducting themselves, they withdraw the security." " The practical effect of which is," so says the witness quoted, " that the sureties do in a greater or less degree keep an attentive eye upon the future transactions and character of the person for whom they have thus pledged themselves; and it is perhaps difficult for those who are not intimately acquainted with it to conceive the moral check which is afforded upon the conduct of the members of a great 
trading community, who are thus directly interested in the integrity, prudence and success of each other. It rarely indeed, if ever, happens that banks suffer loss by small cash accounts."

The Scotch banks practising cash credit do not tie themselves down to fixed mechanical rules. They estimate the credit (or repaying) value of their borrowers, and according to their valuation of them they require few or more sureties, one or two, or as many as ten.

Scotch Cash credit has proved a magnificent success. It has made banking common in its own country, raised Scotch banks to their present high position, made them considerably more liberal in their grantings of credit in small sums than their sister institutions on this side of the Tweed, and set a most valuable example to the entire world, by making personal credit, which is now the driving wheel of all business, available for business transactions. However, it is not nearly popular enough for our purpose. We have to dive very much lower than the overdraft for $£ 500$ or $£ 2,000$, which Scotch Cash credit allows-very few under $£ 200$ and none under $£ 50$-and the method of overdrafts does not, as already pointed out, in the great majority of cases that we have to consider, constitute the most advisable form of credit. Also, we require some further security for repayment.

That security is the pledging of the employment of the loan itself. In some instances, among the wealthier persons to be catered for, who command a fairly steady flow of business, overdrafts may be permissible. But as a common rule the loan will have to be granted for some distinct purpose commending itself to the lending institution as promising a certain profit or economy, so as to repay itself " with usury," out of its own employment. And to that employment the borrower wants to be rigidly tied down.

Now here it is that the liability commonly termed " unlimited" comes in, not as a source of danger, but, on the contrary, as an element of strength. It may readily be admitted that in a good many co-operative banks-however, only in Germany and Austria-unlimited liability is freely imposed, where it is by no means necessary-for an entirely 
different purpose, and where none of us in this country would think of, or be wise in, employing it. That is because such banks were formed before limited liability was recognised at law-which in Germany took place only in 1889 ; and, having been so employed, it has been found extremely serviceable for raising funds more freely. (In Germany, as in the United States also, it is quite common to fix the limit of limited liability at a higher point, a multiple, of the value of the share paid up, as intended additional security for the lender? Therefore excess liability, beyond the value of the share, comes to Germans with a familiar face. Hence many Germans and some Austrians have retained a strong preference for unlimited liability. And it may be owned that as a rule their co-operative banks with unlimited liability number among the strongest, doing the best business-just for this reason, that unlimited liability imposes upon managers the greatest vigilance, the most careful weighing of probabilities and testing of sureties, and the greatest strictness in insistence upon observance of rules.

However, in agricultural credit societies the matter wears an entirely different aspect. And in truth their " unlimited liability " is no more unlimited than is Lord Denman's own engagement to answer with all that he possesses for the price of a motor-car, which he may buy, or an estate, or a horse, or a dinner. He answers for what he buys with all that he is worth; but he wisely limits such liability himself by limiting its application. And that is precisely what the humble agricultural banks-his supposed compeers of the "City of Glasgow Bank"-do, being composed, as they designedly are, of only a small number of members, because it is essential that there should be very close touch among them. They have no large estates, no holdings in Consols or the like to pledge, which might be foreclosed upon. But they all of them possess something that is as dear to themselves as are his Consols to the rich man, and his manor to the squire, and which they will take a good deal of trouble to prevent seeing taken from them. The danger of this happening sharpens their wits, whets their vigilance, and imparts keenness to their vision. 
Let us look at the matter in detail!

These people all want the use of credit, or they would not combine to obtain it. But their first care is to keep themselves safe, to lose nothing over the business. Accordingly they will want to make sure that they have none but trustworthy fellow-members to work with, men faithful and true. They will want to make sure also that their society is administered by capable persons having security at heart. They will want to make sure that no loans will be granted except for employment in which they will repay themselves with interest. And they will want to make sure also that the purpose for which the loan is granted is adhered to, and that the terms of the loan are scrupulously observed.

Now, how are all these objects to be attained, among more or less poor people, under limited liability? People will elect Tom, Dick and Harry as members, as a matter of neighbourly courtesy; they will be careless about the election of their Committee men, wink at improper purposes, and not want to be hard upon borrowers in the matter of repayment. Should things go badly they will comfort themselves with the reflection that they stand to lose only their $£ I$ or whatever the value of the share may be. It may be below $f I$. That is not worth the trouble of serious bother. A legal gentleman officially connected with the supervision of societies in this country has ventured the opinion that a liability of $£ 200$ would be fully as effective as unlimited liability and answer all purposes. However, what small holder will make himself liable for $£ 200$ ? The figure will simply frighten him away. His whole possessions may not be worth the $£ 200$. But they are extremely valuable to himself. The collective unlimited liability of all members will fully suffice a lender as security for the credit likely to be demanded. And it may enable societies, if they are so minded, to dispense altogether with shares and even with entrance fees. That was the very object which Raiffeisen, the founder of such societies, had warmly at heart. He was not thinking of Agriculture proper. $\mathrm{He}$ was thinking of the poor in the country. And he wanted to help even the beggar upon the dunghill, if he could only 
find neighbours to vouch for his honesty and good conduct. Unlimited liability enabled him to do that. A £200 liability would have left his labour barren. And unlimited liability, the knowledge that every member is liable up to the hilt for any default which may occur in the account of any other member, makes every one careful to scrutinise newcomers searchingly, to elect only trustworthy persons, to select Committee men with discrimination, to limit credit to the right sort of purposes and to insist upon proper repayment. And that is really the main object for which such liability has been resorted to.

One cannot see how in any other way the object aimed at could have been attained.

A curious hybrid institution in Germany has attracted the favourable attention of one writer on the subject in this country. In Pomerania and in the Prussian province of Saxony there are a limited number of agricultural credit societies, nominally of the Raiffeisen type, which after a fashion limit liability. That was done to propitiate the junker squires who-wrongly-desired to appear to be favouring the societies without being put to any trouble or risk. Ordinarily men of some wealth, of status, and of business experience are most welcome in such societies, although they are not indispensable. But that is not so much on account of their better command of credit as on account of the useful counsel and vigilance which, with their larger experience, they may contribute. If they really desire to help the society, they ought to give their service (which is not exacting) as well as their credit. If that is too much for them they had best content themselves with making a deposit. It is quite true, as is urged in praise of these "limited" societies, that they have managed to attract a satisfactory amount of deposits. But that is not the sole test of the value of a credit society. In other respects the result of their labours exposes the faultiness of their system. Above all things they are not "co-operative " in character. The "co-operative spirit," as Raiffeisen complained, is wanting in them. Herr Haas himself, the chief of the Union to which these societies are attached, has expressed 
to me his disapproval of their principle. And quite apart from that, their system is wholly inapplicable outside Prussia, because nowhere else do the conditions exist upon which it is reared up. The determining factor in them is the assessment of each member to income tax. Income tax in Prussia is levied down to incomes of $£ 45$ a year. And below that point there are several grades of "assumed" income, on which a tax, supposed to be proportionate, is levied. The heads of the societies have free access to the income tax register. And they rate their members in liability according to such assessment. None of these means of appraisement exist among ourselves. And we possess nothing that could take their place.

Under unlimited liability the system has worked very successfully, and claims on the score of liability there have been very few indeed, and those few have only been for trivial amounts. The form of liability employed has in truth proved effective without involving, as M. Louis Durand, the Raiffeisen of France, has put it, " the slightest element of danger." And the liability has been further fortified by the protective measure of narrowing liability in application, under which treatment not only has it lost all its terrors, but from a danger it has been converted into a source of security.

What constitutes the danger inherent in unlimited liability, as we know it, is not its want of a limit, but the severance of liability in the majority of cases from its employment, the entrustment of its employment to persons other than those who are answerable for it. Thus in the ill-fated City of Glasgow Bank the body of shareholders knew nothing whatever about the commitments entered into on their behalf by the Board. In co-operative credit societies, on the other hand, nothing of the sort occurs. Every fact in the business of the society is accessible to every member under that "maximum of publicity" the merits of which Sir R. Morier extols. The only fact not made known to members, and indeed kept scrupulously secret, is the amount of deposits standing to each man's name. Everything else is within the reach of every member's ken and is, in so 
small a society, with such close touch among members and so much care for publicity, sure to become known. That is why each society is limited to so small a district, by preference a parish. That is why, even if it did not follow as a necessary consequence from the smallness of the district the number of members is very eclectically kept down. That is why credit is only permitted to members. That is why the monthly or fortnightly balance sheet is hung up to public view (for members) wherever the Committee meets. That is also why it is made a rule that wherever there are wealthier members among the poorer, the wealthier members must certainly be represented on the Committee, with freedom, of course, to go out of the society should they consider any undue risk to be about to be incurredafter which all liability for future commitments would automatically cease for them. And that is one reason why, for greater security still, there is a Supervising Council placed above the Committee, to pass in review periodically -as a rule every quarter-whatever the Committee has done, and express an opinion upon it. Even that is not enough. The society is required every year to fix, for the year, the maximum amount of credit to be granted to an individual, and also the maximum of all lending, which must not be exceeded, except it be by decision of a general meeting to be called for the purpose.

Thus fenced in, unlimited liability ceases in effect to be unlimited. It is unlimited to the lender of money and to the depositor, who both have the entire number of members to answer with all that they possess for whatever they themselves may entrust to the society. It is unlimited, as a safeguard, inside the society, to compel every one to do his duty in the giving of that vigilance and labour which serve as a substitute for the tangible possessions which are not present. But as regards the liability incurred by any one member, it is altogether limited-limited by himself.

In this way is that " minimum of risk," which is a standing precept to every co-operative bank, whatever its type, and which Sir R. Morier held to have proved so effective, usefully combined with the "maximum of publicity" and 
" maximum of responsibility" which Sir Robert Morier likewise commends as ruling principles of these banks. And, pace Lord Denman, Sir R. Morier, who had seen co-operative banks at work in Germany, is likely to have known what he was writing about.

The aim, then, which these little banks set themselves, and which they have very successfully attained in tens of thousands of cases, with the best of results, is: to serve as a lending institution within easy reach of even the smallest cultivator, and open to the poorest, levying no tax whatever upon his pocket on joining, which joining is conditional upon his being known to his neighbours and fellow--members as being honest and trustworthy-in order, with the help of money to be obtained, as far as possible, from local deposits, and also by loans made to it direct, or to be secured by the intervention of a Central Bank (being a union of local banks), to deal out credit to its members, and to them only, through their own neighbours, men of the borrower's own class, who speak his own language and understand his position, for any approved purpose promising to more than repay the outlay by production or economy, in fully sufficient amount for such purpose, and for as long as the work undertaken may require to reproduce the loan - the credit to be given at cost price, only so as to yield a small surplus, out of which gradually a common fund is to be raised up, indivisible among members, belonging only to the bank as a whole, designed to unite members permanently by a bond of common interest and eventually to replace borrowed capital.

It would be a fatal mistake among these objects to lose sight of the promotion of thirft and to restrict the services of the society only to lending. For, in the first place, lending is impossible without the collection of funds, for which local deposits supply the best source, as not only fixing surplus income for fructifying employment in the district in which it was raised, and at the same time constituting the cheapest and best "lying" money, but also because the inculcation and propagation of principles of thrift is one of the chief objects of the institution, which is to 
increase the well-being of its members, not merely by enabling them to engage in profitable productive enterprises, but also to raise funds themselves by thrift. Borrowing to lend without providing funds of its own would make of the banks institutions from which no permanent good could be expected. "It is self-help which makes the man," so Mr. Gladstone has written; "and man-making is the aim which the Almighty has everywhere impressed upon Creation. It is Thrift by which self-help for the masses is principally made effective. In them Thrift is the symbol and instrument of independence and liberty, indispensable conditions of permanent good."

Thrift must therefore be the groundwork of the institution. But the encouragement of Thrift should be carried beyond the narrow limits of the society itself. The society cannot lend to others besides its own members, because others have not the same security to offer. But it can collect money from any one. And in Schulze Delitzsch's words, the co-operative bank, being strongly localised, ought to make it its endeavour to collect every spare shilling to be met with in its district.

The stability and strength of each bank will be greatly added to by union with other banks governed by the same principles, and combination with them for the formation of a central bank, which will, however, have to be formed with scrupulous care taken, not to entangle liabilities. Each bank must remain answerable only for itself, though giving support to, and receiving support from, sister banks, by means of a central institution which alone can make sure of obtaining money, when wanted, from outside sources. The principle which M. Luzzatti has laid down for cooperative banks is a good one: independenti sempre, isolati mai.

It will be seen that the societies here spoken of, "the humbleness of which," wrote the late Eugène Rostand, a leading organiser of co-operative credit in France, "constitutes their beauty "-are institutions of a quite peculiar kind, designed for humble members, down to the very humblest, who are otherwise debarred access to cheap 
and easy credit, and who might have difficulty in raising a sufficient capital by shares.

Wherever other conditions prevail-therefore mainly among medium and larger farmers, but not necessarily among them only-where there is less straitness of ready cash, and the levying of shares presents no insuperable difficulty, where, moreover, there is greater familiarity with business, and probably a brisker flow of transactions, evidently a different kind of institution is called for, which will still have to be co-operative-that is, working without a profit, only to render a service, under the management of its own members. The formation and working of such a society, of members and for members only, offers no difficulty. In a society of this description, as M. Luzzatti has justly urged, unlimited liability is in nowise called for. Rather does it there become a danger, as even its stoutest advocate, Schulze Delitzsch, has admitted. The number of members may here be larger, the working district wider, the amount of business much more considerable. Touch will be less close, and the power of supervision more feeble. Liability limited to the value of the share subscribed alone will be quite sufficient. Such a bank, if it confines itself to its own distinctive work-which means avoidance of competition with ordinary banks-will be able to render very useful services indeed. It has been an invaluable support to Agriculture, alike in Germany and in Italy. It cannot do all the work that ordinary banks accomplish; but whatever it does-once more through its own members, who are likely to be quite equal to the not very exacting task-it will be able to do in a better way, because it is familiar with the persons to be dealt with and with their condition, and can watch them. Quite the same eclecticism in the election of members, and surveillance of the employment of the loan as in the other form of society will not be called for. But care will still have to be taken that no black sheep are admitted and that the borrowing taking place is for reproductive or economising purposes only. Our legislation makes it easy for such banks to be formed under the Industrial and Provident Societies Acts. And it 
is very desirable that there should be such. They cannot dive quite so low among the strata of society as the others; but they can go fairly low down. There are plenty of such banks abroad, composed of small cultivators, and doing well. What members gain by them is this: they secure a lending and depositing institution of their own, from which so long as there is money, and provided that they comply with the conditions laid down, they have a right to claim credit-credit which, once more, may in respect of time and otherwise be more fully adjusted to their own requirements than would be that conceded by an ordinary bank; an institution working without taking toll from its customers in the shape of profit, endowed with permanence, so long as the members decide to maintain it, and a very great help to other Co-operation, all of which requires money for carrying on. That institution is within their easiest possible reach.

Between the two types our farmers ought to be able to find one to suit their own case.

It would carry me too far to go in detail into the subject of their organisation. I have dealt with that matter elsewhere. ${ }^{1}$ But it may be in place, by way of further recommendation, to call attention to the fact that all that imposing fabric of German Agricultural Education, all that technical knowledge and technical proficiency, bearing such magnificent fruit, which Mr. Middleton has described in his masterly Report, took their rise in the creation of cooperative credit institutions. Before such became general, Co-operation in Agriculture there was none in Germany -absolutely none. Co-operation for Credit placed its Midas' hand upon the land, and former dross became turned into gold. Education in technical institutions undoubtedly did much. But Co-operation-by far the most precious component part of which is Education-did more. It made the education given outside its own limits effective,

"See "People's Banks : a Record of Social and Economic Success," Third Edition, I910. "Co-operative Banking: Its Principles and Practice," I907. "A Co-operative Banks Handbook, with Rules," I 909. All published by P. S. King \& Son, Orchard House, Westminster. 
and supplemented it very liberally by its own. Accordingly, with Léon Say, we may say, looking at the brilliant picture which Mr. Middleton has limned for us: La mutualité (and specifically co-operative credit) a tout créé.

However, those brilliant results have not been achieved exclusively by Co-operative Credit practised in its original purity, such as has been here described. In either of the two shapes here spoken of it has been reshaped so as to serve distinct by-ends-which are not altogether consistent with genuine co-operative principle. However, so useful a weapon, so serviceable as a means of enlisting popular support, was not likely to be left to be used only for ideal purposes. The adaptations made, favoured as they are by principalities and powers, come before the public with so much dazzling authoritative commendation and have to such an extent captured the public ear, that it will be well here to add a few words in explanation of them, were it only to call attention to their weak points and to sound a timely note of warning against their overready acceptance. For being patronised-as a matter of what M. Luzzatti has not inaptly styled "egotistic altruism "-by Governments and other high authorities, they find themselves very well advertised and eulogised.

Economic conditions being in some respects more or less the same all the world over, the particular obstacles which we complain of at home have very accountably been encountered in other countries as well. There is that difficulty about the beginning. Those first funds required are very slow in coming by pure self-help. In general estimation they appear more reluctant still than they really are-as we have recently seen in India. However, in the earliest stages every trifling untoward incident is apt to produce an awkward setback. And unquestionably on new ground the first progress is laborious. A tree fit to stand storms is slow in growing.

Beyond this, specifically in the Raiffeisen societies, those " ideal " objects, the creation of a sort of brotherhood, the aim of making members better, more trustworthy, more loyal, more God-fearing, as well as better-to-do, appear 


\section{THE FUTURE OF OUR AGRICULTURE.}

purely gratuitous to the strictly economic-minded man. To many not of the least worthy among mortals, on the other hand, those ideal ends constitute the best part of Raiffeisenism. And we have seen with what eagerness Mother Church has taken hold of these societies to make Co-operative Credit serve its own purposes. It is in these "ideal" ends that Indian registrars avowedly see a prospect of providing a precious substitute for the practically extinct ancient "village community," so dear to the Indian mind. It was in consideration of them, mainly, that our late Princess Royal, the Empress Frederick-as well as her husband and her father-in-law-particularly favoured the Raiffeisen societies. However, all men are not so shaped as to value ideal ends and the strict eclecticism, the narrow limitations on which the Raiffeisen system is bound to insist. We all, on the other hand, have a keen eye for "business."

Raiffeisen's rather angular manner and extreme rigour, and his insistence upon uniformity and strict central control, which unquestionably to some extent retarded progress, gave rise early in the career of his movement to a secession. His whilom lieutenant, Dr. Haas, being intent upon " business," set up his own movement, which was "Raiffeisen minus its very pronounced ends." Being a first-rate organiser, and holding out a prospect of benefit to large farmersmainly squires-as well as to humble folk, who came, in contrast with what they do in the Raiffeisen Union, to play only a secondary part in his movement led by junkershe managed to attract a fair number of followers. The Prussian Government, being then-some twenty-three years ago-very much on the look out for popular support of the ambitious policy which it had framed, was not slow to discern the advantage which such a movement as that of Dr. Haas might secure to it, if enlisted in its favour. To make sure of the bulk of the rural population, led by junkers, and held in leash by the Government itself, by assistance with money given to a movement ostensibly designed for the public benefit, was too tempting an opportunity to be allowed to pass unused. Accordingly the Government 
struck up readily an alliance with Dr. Haas's Union and, to support it in a particularly showy and impressive way, founded, in I895, its State-endowed " Central Bank for Cooperative Societies "- - the endowment of which out of State funds, after various increases, now stands at $£ 3,75^{0}, 000$. That State Bank was to give ready assistance to acceptable societies with funds which, it was argued, would not be otherwise forthcoming. It would of course be in a good position to help, seeing that it was given power to engage in other banking business as well, which in point of fact proved to be the business which made the chimney to smoke, the co-operative business being at first scarcely remunerative. The political aim pursued by the Government in the formation of this Bank was really far more ambitious. The Bank was-as has since been frankly owned-to link all co-operative organisations-not agricultural aloneto itself and become the mistress, the "official head," as its able President, Dr. Heiligenstadt, has called it, of the movement, which, if left to itself, so he added, was held to involve "danger to the State." Other Unions were accordingly to be attracted to its counters. Scenting mischief, they proved slow in coming. However, on nonagricultural ground, a distinct Union of "Trade societies" "Gewerbegenossenschaftsverband") was promoted, to pit against, on the one hand, the Schulze Delitzsch societies, the majority of whose members were declared Liberals, and, on the other, to hold the balance against the everadvancing, hated Socialists.

The linking up of the two organisations-the State Bank and the new co-operative Union, which has since taken the attractive title of " Imperial Union "-was effected with judicious skill. The internal organisation of the Union was not interfered with. The societies were left self-governing. And advances were to be made to them only through their provincial Central Banks-which meant no concession, inasmuch as it provided more ample security for the State Bank. The sacrifice made-unbelnown to themselveswas on the side of the societies.

In this way very large sums have been made available 
for "co-operative" credit societies under Dr. Haas, and the movement, becoming more and more squire-led, and more and more "imperial," in the sense of cultivating devotion to the Emperor, came to flourish like a green bay tree, and to spread out its branches like the tree of King Nebuchadnezzar's dream-more especially while the "Silesian Bismarck," Herr von Huene, an Agrarian and "Emperor's friend" to the core, remained President of the State Bank. He was very " kind " to Co-operation and did not stumble at bank dividends of $\mathrm{I}$ and $\mathrm{I} \frac{1}{2}$ per cent. However, Herr von Huene came to be replaced in his office by a new chief who, being more of an official than of a politician, for his own protection saw reason to make the existing arrangement more businesslike, which meant less " kindness " to the societies. As early as in I 898 accordingly the Haas Union came to rise in open revolt against the State Bank, and in confidence Dr. Haas owned to me, at the Congress of his Union held at Carlsruhe in that year, his impatience to throw off the galling fetters. "We hold $£ I, 500,000$ in deposits!" Alas, that was not nearly enough. And it did not "lie" firm. Our South African war-in consideration of which we called in our foreign loans-depleted German hoards. Deposits were withdrawn in large amounts from savings banks, co-operative banks, and all kinds of financial institutions. And the Haas Union had to creep at heel and accept the State Bank's conditions--which, barring its aiming at dominion, were reasonable enough, in the interest of security and self-supporting business. The State's Bank's aim of becoming absolute mistress of of Co-operative Organisations, as its imperial chief was, in politics, master of his empire, came to be more clearly confessed in I9II, when an attempt was openly made by the State Bank to break up the great Raiffeisen Unionwhich, weakly, had late in the day consented, after much persuasion, to become a client of the State Bank-in order to make its provincial sections individually dependent upon the State Institution alone, which was to have an absolutely free hand in directing them. In this move the State Bank had reckoned without its host. For the Raiffeisen 
Union, which it had supposed to be abjectly at its mercy, turned out to be strong enough to resist the pressure and promptly to break off all relations with the State bankafter which connecting itself on pure business lines with the great "Dresdner Bank," it found that it did considerably better than under the patronage of Dr. Heiligenstadt and his institution. The Union of Trade societies likewise by that time had found out that the Government loans, however sweet they might have been in the mouth, developed a decidedly bitter taste in the belly, and its most trusted advisers urged it to break loose as soon as might be practicable and attach itself to the un-State-aided SchulzeDelitzsch Union.

Therefore all "co-operative" connection with the State Bank has now come to be reduced to that with the Haas Union. But, to make up for the defection, it has, like its Court at Berlin, extended its sway all over Germany. The Haas Union has likewise grown greatly, by absorbing several erst independent Unions, previously maintaining themselves distinct for local reasons. It is accordingly now a very powerful, and also in most matters an extremely well-organised Union, but, if the truth be told, attached to its Stateendowed banking spouse rather as in a mariage de convenance than in a real union of hearts. IWhile Dr. Haas lived, he did not, in private, conceal his impatience at the State Bank's overmastery and his wish to get away from it.

Now in matters of Co-operation of other forms-buying, selling, production, and the like-which are really matters of business only, the Haas Union has done exceedingly well. Its leader laid himself out for " bulk," which is in such things very essential, and, to secure that, let not a little "principle" go uncared for by the board. As long ago as in I895 I found decidedly bad and faulty societies side by side with exceedingly good ones. It was all the same. The principle followed was: the more the merrier. The toleration of those "limited liability" village banks, which Dr. Haas avowedly-as a letter written to me shows -disapproved of, for the sake of having them in his Union, in itself shows how lax has been his own and his successor's 
adherence to principle. In Co-operation for purposes of credit, on the other hand, laxity-which has been greathas led to a veritable catastrophe, a crash of banks which has astonished all Germany. The Secretary of the Union has tried to explain the serious character of the collapse away. That was like the owner of the horse that died protesting that it was not his system of training the horse to do without food that killed it, but the unfortunate accident of its dying just when he had succeeded in pressing home his lesson. The facts of the case are in themselves too plain and too well known in Germany. Other Unions, no doubt, have likewise had their setbacks. But such arose from totally different causes. The collapse of so many Haas banks, involving criminal prosecutions against a leading officer in the Union, plainly showed that sound business principles has been recklessly set aside. I may say that I foresaw something of the kind as long ago as in I895, on my first personal acquaintance with those banks. And I am afraid that the matter is not yet wholly done with. For instance, that wholesale practice of giving credit on overdraft, which avowedly is adopted to save the trouble in inquiry into the object of each loan and considering the title of the applicant to it, is, under the circumstances of these societies, distinctly dangerous. In short, credit has been made easy, but at the cost of principle and security. Progress and extension have been forced, where "more haste " must mean "worse speed." And the nobler ideal ends of Co-operation have been placed in the lumber-room. It is all business and-from the Government's point of view that is the main achievement, and one well worth paying for-faithful adherence to the cause of the absolute Crown on the part of the rural population, led, like a flock of sheep, by the junkers onward towards the war of I9I4.

France likewise has made the State minister to the cause of Co-operation for purposes of Agricultural Credit-with a very large sum. Its system, very ably administered, is of course designedly different from the German. But it is equally open to abuse. And it has proved so little ideal that it is now to be recast. The Government has made large 
sums, paid by the Bank of France, upon two several renewals of its charter, available for purposes of Agricultural Credit, the disposal of which it has kept securely in its own hands. Hence the complaint of "manna " dropping into the lap of favoured societies, to the loss of less favoured, but generally more deserving ones. But the main objections are these, that, of course, being so freely favoured with advances-repayment of which, as the Chairman of one Regional Bank openly declared at the annual meeting of his Union, "we do not suppose that the Government will look for "--members have refused to take upon themselves any of that liability which the Government fully intended them to take, or, indeed, to make any serious efforts for the sake of building up economic prosperity. It is all "take," no "do" whatever. In the intention of the Government the societies assisted were, with the assistance rendered out of State funds, to make themselves strong enough to become self-supporting and self-governing. That aim has been in the main defeated, as it was bound to be by gifts. "Ce que le poulain prend en dompture, il le maintient tant qu'il dure." The banks remain parasites. And many of them also have shown very little desire to accumulate the necessary reserve funds. Their reserve lies in the Crédit Agricole.

Just as in Germany, all the Government action has been found to be prompted by very much of a political object. The Syndicats Agricoles, whose action has attracted the admiration of Lord Reay, are, of course, officered in the main by agriculturists of the superior class. And these gentlemen were suspected by the Government of harbouring pronouncedly Royalist sentiments. The aim of the Republican Government accordingly was, by means of a finely forged golden chain, to bind the rural population to its own car. However, the Syndicats are now trying to establish a credit system of their own, in independence of the State. As in Germany, the true object of State banks has been found out and is resented.

Things are different in Hungary, the fruitful "Co-operation" in Agriculture of which has attracted much notice 
and excited not over well grounded admiration. Great things are indeed being done there. And on the part of many of the leaders and givers of gifts-such as the late Count Alexander Károlyi-with the purest and most benevolent of intentions. However, the "Co-operation" there practised is not Co-operation in our sense. It is in no sense self-governing or emancipating, raising character and "manmaking." On the contrary, the money assistance afforded by Crown and Magnates is distinctly given to keep the peasantry in subjection to the Throne and to its leaders of the very large squire class. It is Patronage, not Co-operation, brigading the peasantry under the Crown or Magnate chiefs.

State assistance in Austria is of much the same stamp. In the words, uttered with unmistakable pride, of one of its chief administrators-who contributed a paper on the subject to the International Co-operative Alliance, for its Budapest Congress held in Ig04-there is no country in which the State does so much in proportion to its size for Co-operation in Agriculture as Austria. However, outside the non-German Unions, which, spurred on by nationalist sentiment-just as are the Poles in Prussiathrow a most creditable amount of spirit into their Cooperation, all self-governed as it is, for economic purposes, there is a very notable want of stability in the fabrics set up. Provincial officers exert themselves to start " cooperative" societies, for the sake of getting promotion. Then they go, and the societies collapse. Very much money contributed to "co-operative undertakings" by the State or by provincial Diets has also been lost owing to unbusinesslike management naturally resulting from such organisation. The movement cannot be pronounced remarkable for its success.

Of the action of the Church of Rome in the province of Co-operative Credit there is scarcely any occasion to speak here, since there is nothing like the same likelihood of denominational ecclesiastical bodies fastening upon this otherwise convenient means of bringing populations under their influence. The "Catholic" object of Church patronage and interference is very pronounced in the "Catholic" 
movement of Italy, Belgium, and parts of Germany (mainly in "Peasants' Associations"), and to some cxtent in France and in the Netherlands.

All these types of "Co-operation" make a very proud show. With the aid of influential patronage, kept very much in evidence by liberal supplies of money, the various movements have advanced rapidly, and spread out, and the business done is considerable. But at bottom it is not "Co-operation." It provides pence-and pounds. But it does not raise the man. It does not educate and emancipate. It leaves him dependent upon the sunshine of his patron's favour-which sunshine may be succeeded by a sunset. It creates nothing with a prospect of permanence about it. And it abets-certainly tolerates-bad practices, which may lead to disaster, as they have done in Hesse.

And the outside help given to co-operative societies has been proved to be quite unnecessary. There is no Cooperative Union which has raised more money-in truth there is none which has raised anything like as much-as has the Schulze Delitzsch Union, which has acted throughout without a stiver received from either State or any outside source. M. Luzzatti's banche popolari likewise, doing a prodigious business, have never received a farthing from the State or from any one else. All that they have required they have been able to produce out of their own resources. The Raiffeisen Union likewise has been reared up upon self-help-save not quite willingly accepted advances from the State Bank while the short-lived relations with that body lasted. And that connection was, as has already been shown, discovered to mean a loss rather than a gain. Hence it was promptly broken off.

We are much pressed to follow the example of the Stateaided institutions. The reasons pleaded are the same that have been put forward elsewhere-dislike of irksome restrictions, impatience for results, a wish to have things made easy for us. The peas for walking on which the pilgrim is promised his pardon are to be first boiled. Things may indeed be made easier by that, but they are not made 
better-not anything like as good. They provide moneywhich, being easily got, is apt to be injudiciously and unprofitably employed. Raiffeisen's principle was to make borrowing difficult, in order under the circumstances, such as they are, to make it possible. However these institutions leave "the man" untouched. They do not fit him the better to stand by himself, to be a better citizen or a more inquiring student of things affecting him.

We have not, fortunately, the same inducements that people have abroad to put Co-operative Organisations into Government harness, to dress them up either in Prussian blue, or else in Republican tricolour. For we have not, like the Germans, a Government distinct from the people, and partially in opposition to it. And we have no reason to dread a Royalist movement, like the Republicans of France. Indeed, we rightly do not trouble about the political complexion of any economic movement. In India, we should welcome Swadeshi co-operative societies. We have difficulties to contend with in Ireland. But what opposes us there is not a Government self-seeking on its own account, but decidedly self-seeking gombeen men, basking for a while in official sunshine. That difficulty is likely to be got over.

Having the choice open to us between two systems, I do not think we can be doubtful, upon knowing the facts and upon due consideration, in favour of which to decide. We have, on the one hand, rapid extension, possibly a brilliant early show to look forward to. However, the timber so produced is not the tough, weathered British oak which only gets the more firmly rooted with the "loud blast that rends the sky "--such as must sooner or later come to any financial institution-but oak of the American type, which shoots up like a poplar, but the wood of which has as little strength. On the other hand, we have an institution which grows slowly, it may be, but produces what will stand by itself, an institution devoted to that " man-making " which, in Mr. Gladstone's words, Providence has impressed as an aim upon Creation and so made it our duty to pursue. Its gold, even though it should come tardily, is not " rainbow gold," but the real metal which will last. We have good 
proof of the several merits of the two types of Co-operative Credit here presented and, aiming at something that is to do real good and to last, we cannot be at a loss which to choose.

Quite apart from what has here already been referred to as having happened under other flags, we have quite sufficiently illuminating examples to turn to nearer home, showing how utterly uncalled for is that reliance upon State or any other adventitious help, the insistent looking for which has thus far formed an insuperable obstacle in the way of the establishment of that Co-operative Credit in this country without which certainly we cannot look forward to any extensive and successful creation of small holdings, and without which, beyond this, the outlook for the wishedfor improvement of our Agriculture must remain doubtful.

There are good workable systems of " Co-operative Credit" in operation, both in Ireland and in India, both of which can boast of success. The one was begun in 1894 , the other in Ig04. In both cases-as happens in England at present -at the outset "State help" was eagerly clamoured for. How should a credit movement start without "money" ? In both cases State help was given, but in both cases in a form restricting it within very narrow limits. In Ireland there were very special reasons which made it at first acceptable. However, the result showed not only the instability of such external support, but also its needlessness. What a Plunkett had given a Russell might withdraw-and did withdraw-at a moment when withdrawal meant serious inconvenience to a most useful movement, against which to all appearance the right honourable gentleman acting for the State had set his face, in favour of an abortive intended institution of his own. That affords one more proof of the fact, the truth of which clamourers for State help are so reluctant to see, but which is attested by hundreds of examples elsewhere in economic history, namely, that the State never gives anything but it expects a return, which often enough is out of all proportion to the benefit which it has bestowed. Even Mr. Gladstone has freely confessed - after the event, as recorded in Lord Morley's Life of him 
- that he introduced his Savings Banks legislation with the view-to which he was afraid to own openly-of obtaining money for the Exchequer and making the Exchequer to some extent " independent of the bankers." However, that momentary inconvenience being overpast, Government aid proved in Ireland altogether dispensable-which means, seeing that the State has no business to spend public money in support of private enterprise, that it could not be economically justified.

In India, among the poverty-stricken and economically untrained rayats some little State help was required, for a time-to serve, like that pailful of water, which in the olden days of sucking pumps we used to pour into the newly made pump, to enable the sucker to work. That pailful being supplied, the pump took care of itself. There was, of course, in India, a great cry for liberal State help, as well as for summary powers to collect debts. The poverty of the rayat and his helplessness turned out to have been exaggerated-also his aptness to disregard the duty of repayment. As one Registrar assured me in I904, when the movement began, it was utterly useless to look for any deposits from rayats. These were too poor. Lord Curzon, being Viceroy, gave way on neither point. And in his speech on the new Bill, on March 23, I904, he gave his reason in the following words: ${ }^{1}$

"There is one point upon which there seems to have been some misconception, and which it is desirable to make clear. I have seen it complained, and at an earlier date I have heard the complaint from the lips of an Honourable Member of the Council, that Government might have been a good deal more liberal in initiating so great an experiment, and that part of what we take from the people in land revenues we might very appropriately give back in capital for these societies. These views, plausible as they may seem, rest upon a complete misconception, both of the co-operative system and of the policy of the Government with regard to this particular scheme ; and I desire to supplement what fell from the Finance Minister on this point. It is not primarily because the financial contributions that might have been required to assist any new institution would be great, or

1 See "Lord Curzon of Kedleston's Speeches," Vol. III. 
because we grudge the money, that so little is said about grantsin-aid by the State, but because the best advice and the teaching of experience are at one in the conclusion that unrestricted Government assistance is a dangerous, and may be a fatal, gift. 'Prolonged and indiscriminate State aid,' says Mr. Henry Wolff, who is an unrivalled authority on the matter, 'is destructive of self-help...' For similar reasons no special powers of recovery of debt have been given to the societies. The object is to foster a spirit of responsibility and self-reliance; and it is because the societies must be dependent for their success on their own care and caution in the disbursement of their funds that it has been possible to dispense with restrictions on their powers in the Bill that would otherwise have been necessary. Government aid will be forthcoming when necessary, and there is more danger to be apprehended from excessive liberality than from the withholding of assistance where there is a prospect of its proving advantageous.'

The "further help" here spoken of has proved quite unnecessary. Quite on the contrary, even the small help given very soon proved superfluous. A certain proportion has been retained, because the Government loans were offered free of interest for three years. But the amount has shrunk to a comparatively paltry sum, $£ 87,000$ at midsummer, I9I6-in comparison, be it noted, with $£ 235$,000 deposits from members only, that is, from those "poor rayats" whose practice of thrift in such form had been pronounced hopeless. ${ }^{\text {I }}$ In addition to that, the first offerings from that vast concealed hoard of savings in precious metals, so uselessly and unprofitably stowed away, to the dismay of financiers, have come forth from their hiding places, in aid of what is felt to be a "national" cause. And what State money there still is in the coffers of the banks has been since some years declared unnecessary by the very people who first clamoured for it.

The result has shown that in refusing larger State aid and summary powers of collection Lord Curzon acted altogether judiciously. The Co-operative Credit movement

1 Members have besides subscribed and paid up $£ 5 \mathrm{IO}, 000$ in share capital and accumulated reserve funds to the amount of $\delta_{4402,000}$. The societies hold $£ 235,000$ in deposits from non-members and $£ \mathrm{r}, 980,000$ in loans from banks and other institutions, which shows that they are not wanting in well-established credit. 
could not have prospered in India as it has done under State spoon-feeding. It is not nearly yet all that it should become. You cannot teach uncultured men to handle so delicate an instrument as personal credit, in which every case has its own peculiar distinctive features and wants to be dealt with accordingly, as you can to drive a furrow or the groom a horse. To a certain extent the same thing may be said of Ireland. But at any rate in either case the main object has unswervingly been kept in sight, not of merely raising money, but of producing men who could raise it for themselves, to provide the instrument which will turn out the valuable goods, rather than begging for the ready goods turned out elsewhere.

That, evidently, is the more precious object. At the same time it must be said that the State, which rightly buttons up its pocket on the one side, has very needlessly and prejudicially buttoned it up on the other as well. The State ought not to help in business, not to subsidise economic undertakings. But it is right in teaching a business which, where properly practised, has been shown to confer great benefits upon the Nation. Teaching does not mean mere lecturing. The infant movement wants to be kept on the right lines. In India we are successfully employing State-appointed and State-paid Registrars to set the machine going and supervise it when started-not as a permanent arrangement, but as "guides, philosophers and friends" to the infant movement. It is quite understood that that arrangement is to give place to self-management when the time comes. And Registrars have rightly understood their task. However, how many public officers are there in India employed upon the job, exercising proper surveillance and control? I have figures before me, which, it is true, are distinctly stated to be incomplete, but which rise to only $\mathrm{I}_{5} 6$ for the whole vast empire-figures including auditors. That is nothing for such a huge business. What Co-operative Credit above all things requires, and cannot do without, is proper inspection and control-control beyond mere actuarial audit. Everything depends upon that. In this country it was the point of points upon 
which the late Lord Welby was doubtful, until I completely reassured him by explaining that the more searching control there is, the better shall we co-operators be pleased. For control is the soul of the thing. It was want of proper control which wrecked those ill-fated Hessian banks of the Haas Union. Such control necessarily must be carried out by the movement itself, through its properly selected and appointed men; because no one else possesses a sufficient knowledge of the facts and principles coming into account, or the same interest in keeping things safe. A Government officer or an auditor or clerk from an ordinary bank would be wholly out of place in undertaking the task. Control ought also to be actually paid for by the movement itself. It is worth the money to those in the movement. However, the child sent to school cannot pay for its own schooling. Alike in India and in Ireland the movement is still too reak to be able to bear the entire cost of inspection, such as there should be, out of its own means. In Ireland, to provide it with such means, we have tried to secure for it the power to practise distributive Co-operation such as Raiffeisen societies abroad enjoy and practise, so far as it is required, with excellent results. There is no danger whatever in the exercise of such powers by small, strictly localised societies such as the Irish. The House of Lords unanimously and enthusiastically endorsed our demand. But that demand was resisted in Dublin in the interest of gombeen men, whose profitable "trade" - I should feel inclined to call it " blood-sucking "- was not to be taken from them. The questions constantly put to me, when giving evidence before a Departmental Committee about the effect of Co-operative Credit, sufficiently prove this. And it was also resisted in the interests of a new-fangled "non-controversial" scheme of "Co-operation," which has been explained as meaning "Co-operation" without actual business-"Hamlet" without the Prince-which has failed to bear fruit. Probably in deference to such resistance the demand was frowned upon at Whitehall and momentarily stopped by the refusal of facilities for proceeding with the Bill in the Commons by the Government of the day. 
However, in such matter as this Governments should help, as it is perfectly legitimate for them to do. They cannot conduct the supervision themselves. 'That is a technical matter requiring special qualifications. The wellfounded opposition raised to State interference in the matter of control abroad-where such interference is quite unnecessary, and is, as results have shown, very inefficiently handled -is directed against the actual conducting of the inspection by Government officers, who are necessarily quite unfitted for the work, possessing no interest in the well-being of the banks and apt to perform their work-as in a good many cases they have actually done-either in a perfunctory and therefore wholly useless manner, or else autocratically, with needless and profitless worrying. I have been questioned on behalf of the Agricultural Department of the United States whether there is any objection to the mere verification of the actual facts, the entries on the balance sheet and the data supplied in the Annual Report by officers of the State, and have of course at once answered that there is none. The more facts are verified the better it will be for the bank.

Checking and control there must be and it must be efficiently conducted, or the societies may easily come to grief. And for such work an adequate personnel is required. A full-grown movement can well provide for the necessary expense. An infant movement cannot. The movement is for the national benefit. And inspection in the early stages is "teaching." Therefore a Government may well for a few years put its hand into its pocket to contribute to the expense. That assistance, if it is efficiently given, will not be required for long. For its security the Government may demand that it be kept in full cognisance of facts, that the scheme of supervision be communicated to it and that results be reported to it. But it must not undertake the inspection itself, just as little as it employs its office clerks and assistants to set up its buildings, the erection of which is a matter for builders.

With this exception the less State aid there is, the more co-operators are compelled to rely upon themselves, managing 
their own affairs and making themselves fully responsible for them, the better will it be. Without a real will on the part of the participants it is useless to attempt to establish Co-operative Credit, whatever its form. There are unquestionably difficulties about its creation-which are not to be got over by spoon-feeding or giving of sugar-plums. You cannot establish Co-operative Credit for others. That is what our Board of Agriculture and the many clamourers for "Credit for Farmers" appear to fail to understand. It is only "will" which will conquer the ground. But "will" can do so easily. Our national Agriculture cannot develop as it should without very much larger facilities being given it for the obtainment of working credit. Hidebound as we have shown ourselves to be in our notions, afraid of what is new as the cow in the field is afraid of the newly painted gate, we have waited far too long for it. We cannot pretend that there are no examples and precedents to instruct us-nor yet "bishops" wanting to point out the right way to take. So, please God, though it is late in the day, we shall at last proceed from words to deeds. 


\section{CHAPTER VI}

\section{LABOUR}

THE war has placed the much debated question of the position of Labour upon an essentially different footing from that which it occupied before. In every country, even in Kaiser- and junker-ridden Germany, the war has exercised a truly remarkable, really obtrusively perceptible general emancipating efiect. Even where the result has been temporary dictatorship, such dictatorship plainly has been the result of the emancipation of the masses composing the community, and has therefore represented only the force of popular emancipation. In its action upon the long and bitterly disputed question of the relation of sexes the effect has been startling. Women have, for good or for evil, received a ready, almost eager, recognition of their " rights" from their very whilom most determined opponents. As for Labour, it has, as a whole, simply commanded the situation. It depended upon Labour whether there should be war. It was Labour which during the war made inroads upon the privileges of Capital, forbade profiteering, in the public interest commanded interference to regulate prices and direct the distribution of the necessaries of life. And never before has Labour made its power so much felt in the determination of the opinion and will of the country, in Parliament, in the Cabinet. And the effect has been world-wide. Even the German Crown has been unable to resist the demands of Liberal opinion and the masses-giving promises, it is true, forbiddingly like those freely made in I8r3, only to be boldly broken afterwards. In Italy, in France, Labour has extended its sway. To Russia it has given its Revolution. In the United States it has decided 
the question of heartily joining in the fight against absolutism. Nowhere, however, has that emancipating effect been more marked then among ourselves. Among ourselves Labour has gained positions which we may be sure that it will never surrender-rather, that will be made to serve as steps for fresh conquests. That is, Labour collectively.

Agricultural Labour stands upon a distinct footing. It has likewise gained, although-barring an improvement in the rate of wages which might conceivably prove only temporary - as yet really only to the extent of the admission of an indisputable claim to further consideration. However, that claim is weighty and commanding. In the war Agricultural Labour has been put to a searching test as a national interest, and it has stood the test most creditably. TVe have appealed to the country for recruits. And from the ranks of Agricultural Labour recruits have come forward freely-sturdy, efficient recruits, even at a time when, under a regrettable misconception as to the danger really threatening the country, a portion of Industrial Labour still hung back.

That brave muster from the countryside has proved a decisive factor in our warfare. Country physique, country resource, and country endurance have helped materially to win many a battle. But at home, while impressing a very necessary but very much neglected lesson upon us, concerning the high value and, indeed, indispensableness of the agricultural labourer, the effect has been to place the community in imminent danger of distressing shortage of food, by a still further thinning of the already attenuated ranks of available labour to till the ground and harvest the crops.

The lesson is not likely to be forgotten. We have conceived an interest in Agriculture which, in Mr. Prothero's words, "has come to stay." And that interest is likely not to be least directed towards the point of the agricultural labourer, on the twofold ground of his utility as an instrume'ntum vocale and of his rights as a citizen.

People interested in Agriculture talk glibly and with pecu- 


\section{THE FUTURE OF OUR AGRICULTURE.}

liar emphasis of our long neglect of that calling, meaning thereby that the community should have done something by means of special concessions and sacrifices, more particularly by taxing itself, for the benefit of those who at the time produce foodstuffs, to give additional encouragement to Agriculture, as represented by the landlord and the farmer. The point, however, at which there has undoubtedly been gravest neglect-neglect which was long in producing its Nemesis, but which has in the end brought down serious retribution upon offenders-is that of Agriculture Labour. For many decades back-one may say since grasping " laying field to field "deprived him of the use of the commonthe agricultural labourer has had a sorry time of it. There was no deliberate ill-will harboured against him. But he was so helpless, so utterly dependent upon employment, without any other standby to support him, so broken in by the curb of need to abject submission, that almost any treatment of him seemed possible and economically, at any rate, legitimate. There was no power of resistence. The agricultural labourer could not, like his industrial brother, "form his battalions" to fight for his own emancipation. Local dispersion and a certain slowness of mind generally accompanying agricultural employment stood in the way of this. Joseph Arch for a short span of time roused his class to action and achieved a certain success. But it was all short-lived. And even the most combative leaders of the trade union movement have had to admit that "organisation " among agricultural labourers is not seriously to be counted upon-at any rate, under present circumstances. Tenant farmers have in their hour of need stood together, forming their "Alliance," which in the end brought them a very fair amount of gain. Agricultural labourers could not do the same thing. Hence they came to be set light by and treated practically like those instrumenta vocalia-implements of labour endowed with speech-as which Roman capitalists knew their predecessors. There was, as observed, no intentional unkindness in this. Agricultural employers generally, without question, intended to be fair to their labourers. Many enough among them desired to be kind. However, 
there is kindness and kindness. And things move slowly in the country. The force of habit is great. "I have never paid more than that; that is a good wage," seems a conclusive argument to the employer who has the whiphand-all the more when other commodities besides labour become dear and corn is cheap. Also, the farmer's fairness was generally of a condescending kind. His kindness was often marked by a haughty patronisingness, which lost it much of its grace. It was all yielded as a concession which might be withheld, a matter of goodwill, not a matter of bargaining. Labour had held its head up once. And it remembered the day. The man who worked, who clipped the farmer's hedge, who reaped his corn, had had his own little home, with a garden to it, and it might be, a field and a right of common, upon which he kept his cow and a few geese. He felt a free man then-free to bargain for his labour, a man poorer than his employer, but of the same flesh and blood, and having the same interests. And in such position he did not feel degraded. However, with the enclosure of the common and the resulting necessity to sell his house and field, a change had come over our man's position. Labourers had come to be looked upon as a distinct, inferior caste, almost as made of different clay, born to a Gibeonite lot, called upon by Providence to toil toil, toil, like horses walking their rounds in their gear, with nothing to look for beyond-no rise, no independence, no comfortable old age-doomed to pinch and toil on to the bitter end.

In Mr. Prothero's words, the treatment accorded to him had "impressed the labourer with the feeling that he is not regarded as a member of the community, but only as its helot." The author of the old familiar Latin doggerel seemed to have reflected the sense of the great mass of employers when he described rustic folk as best-that is, most convenient to be dealt with-when they have cause to "weep," and worst when they have cause to "smile," 1

1 Rustica gens

Optima flens,

Pessima ridens. 


\section{THE FUTURE OF OUR AGRICULTURE.}

Such treatment in course of time naturally brought about its own revenge. The agricultural labourer could not stand up against it and stand out for better treatment. He had not sufficiently heavy guns for that. But he could run away from his profitless treadmill. And he did. Villages became depopulated, hands scarce. There was "wealth for honest labour," as the poet Thomson has it, elsewhere. Employers in their unwisdom aggravated the evil, binding thereby a scourge for their own back. Wages had all along been poor. It seemed, as Mr. A. D. Hall has explained it, a point of honour with the farmers as a class to keep them so. The wages bill is an ugly item in any business account. When, as a natural consequence of resistance to a fair demand, the road to better things-be it in town factories, be it on the land in Colonies, which had been meanwhile discovered-the ranks of labour began to "thin "the best men, as being the men best fitted for other work, being of course the first to go-the shrewder among farmers discerned the coming danger and showed themselves willing in self-defence to guard against it, doing some justice, at any rate in the matter of wages, to the men who were literally their " hands," the instruments wherewith to carry on their business. They admitted, says Mr. A. D. Hall, that conditions "would allow of increased wages." However, " there has always existed a strong personal feeling and even a certain amount of social pressure on the side of the maintenance of the local standard rate of wages, until the farmer felt it almost a duty to his fellows to let a discontented man go rather than meet his demand for higher pay." The time of depression came. And not only did agricultural employers in their blindness contentedly permit " hands" to leave them and their old occupation without any attempt to stop the current, but they actually bundled them off, as the Egyptians at the critical moment did the Israelites -but without pressing gifts upon them-deliberately discontinuing tillage so as to attain the one great end of cutting down the labour bill. The penny so saved proved anything but the proverbial " penny got." However, that was a revelation reserved for the future. For the moment things 
went on swimmingly. While the depression lasted, without any regard paid to further consequences, land was laid down to grass by the million of acres, for the avored purpose of avoiding payment for labour, until we arrived at that non plus ultra of Sharsted Court, where even good grass was deliberately allowed to rot on the stem, in order to test to what extent the manurial value of the rotting crop would in the next crop make up for the present sacrifice, set off by a saving in labour.

People who are disposed to find fault with the labourer for running away from the station to which he seemed born would do well to consider this. A false inference has been drawn from it, that he objects to country life and agricultural work. That is a great mistake, as also is that ascribing the loss of public consideration and comparative independence to those frequently remarked upon defects in the labourer's present condition, which, as Mr. Prothero has shown, are not the cause, but the effect of his social and economic degradation. ${ }^{1}$ Our man did not by any means go willingly, we may be sure. There is no one more conservative in his habits and his attachment to his native clod of ground than the agricultural labourer. The blame for deserted "Auburn," for the abandoned countryside, with its reduced production and profits resulting from such desertion, falls almost entirely to the account of those who drove the labourer away, however much they might after the event, with an Esau-like repentance, regret their own foolish action.

The war has shown us how serious is the mistake that has been made, and has happily knocked a good many old prejudices and misconceptions out of people's heads. The mistake made was all the more serious since it is by no means difficult to manufacture an industrial labourer out of an agricultural, but extremely difficult to reverse the process and manufacture an agricultural labourer out of an industrial -as a soldier not to the manner born. The war has taught us that in stinting labour we have starved Agriculture itself, killing the goose for the sake of a poor addle egg. It ought 1 "English Farming, Past and Present," page $30 \%$. 
not to have "passed the wit of man" to discover this without such painful teaching.

But the war has taught us more besides. In its ignorance the world had in the past set down the agricultural labourer as a "yokel," an unskilled " hand," whose labour could not be highly appraised. However, when the critical time came and people offered indiscriminately to come forward and lend a hand, the question was promptly asked: "Can you do the job ?" When soldiers were pretty freely offered, in I9I7, for putting the harvest into ricks, farmers cried out: "But send us skilled thatchers with them, to direct them, or their labour will be thrown away. There was great waste in this way in I9I6." And for want of skilled hands the question was put: Where are ploughmen? Where are skilled sowers-since it was a question whether the drill could be worked on the wet land? Where are this, that, and the other? Townsmen had foolishly set down the agricultural labourer, standing before them in a garb absolutely demanded by his calling, in his billycock hat, his red neckerchief, his smock, his tied-up corduroys, and his hobnailed boots, as an ignorant beefwitted clown, with no wits about him, no power of observation in his eyes, no power of reflection in his brain. And by their treatment of the "yokel" agricultural employers had helped to confirm the prejudice. The demands made upon Agricultural Labour in the hour of trial have shown that fact is altogether different from assumption. The agricultural labourer is in many respects as different from the townsman as is, say, the Englishman from the Italian or the Greek. He lives and moves in a different world; he is called upon to do essentially different work; his powers of observation and of reflection are necessarily directed to different objects. But he has his wits about him all the same. The very complaint now so often given expression to, that Agricultural Labour is no longer what it used to be-evidently because the best labourers have fled into factories or to the Colonies-shows that labour in agricultural employment, to be useful, must be highly skilled and of such an order that it cannot be readily replaced. He is 
as fully skilled as are industrial workmen and, as the event has shown, perhaps even more difficult to replace. What he sees in his daily round, and in his own appointed work, and what is essential for his employment and the perfecting of his skill, would escape the observation of the industrial labourer; but in agricultural employment it is of great importance. The difference between the two is one not of degree but of kind, as great as that between Lord Macaulay's "baker" and his " pianomaker." The degree of skillattained differs between individual and individual. But skill there is in all of the calling.

Unfortunately there is one great, most regrettable feature in our agricultural organisation which has, as by design, kept the value of the agricultural labourer at a lower point than was necessary-by withholding from him his coveted little field and garden at home, and, beyond this, making him as much of a "one job" man as was possible. Nevertheless in many cases high skill there is undoubtedly in our man's knowledge of his work, and the belittlement to which he has been exposed is wholly misplaced.

It is natural that at the moment when the high value of the agricultural labourer has come to be once more appreciated, a comparison should have been drawn between his present position and that of his industrial brother. A hundred years ago-and less-there was not much to choose between the two. They started even. The one was as little thought of qua labourer as the other, as much held in leash under employment and as freely made a mere convenience of. In truth at that time the industrial labourer was really worse off than the agricultural, who still possessed his own little home and his common rights. Distress, overwork, dependence, oppression were more rife among industrial ranks than agricultural. And education simply was not. Greater need in this case brought about prompter action. Humane men forced the recognition of human rights-to use M. Thiers' words, " the necessary liberties of life "-from Parliament. Fifty years ago brought political emancipation to our factory toilers, who became, in Mr. Lowe's words, " our masters," importunately claiming 
by their very masterhood to be " educated." They have amply shown by their after-conduct that such " education " was not thrown away, that the seed then sown did not fall upon barren ground. The entire position of Industrial Labour has become changed. And the country is the better, the richer, the stronger for it. It is thirty-three years since the same political emancipation was extended to the agricultural labourer. However, in contrast with what we did with his industrial comrade, we have thus far failed to " educate " him as we did his town brother. Or, at any rate, if we gave him some elementary education-unfortunately far too much moulded on the urban pattern-we took care to neutralise its effects by other retarding influences. Accordingly he remained in dependence. Thirty-three years after receiving the vote the industrial labourer had made good his position in practically every walk of life. He was powerful in Parliament. His co-operative societies did almost the largest business in the country. He dominated at the polls. Where is now similar power wielded by the agricultural labourer? Where are the agricultural Burts and Barneses, G. H. Robertses, and Hodges? Joseph Arch's day was a brief one. And yet, in spite of his rustic appearance-the necessity and utility of which in his own circumstances the urban observer fails to understand, and which is so often caricatured-the agricultural labourer carries as shrewd a head upon his shoulders as does his industrial brother. He has as good raw material in him for making a statesman, or a captain of business, as the distinguished industrial labourers named. The merits of that raw material want to be brought out by a better position, ripened by the sunshine of Freedom. "The majority of our great men in the States," so remarked to me, a year or two ago, Mr. Myron Herrick, when discussing with me at Paris the necessity of agricultural credit as a means of benefiting the agricultural classes, " were drawn from agricultural ranks." How many good men, deserving well of their several countries, have not been drawn from the ranks of Labour? "How many are there among us," so asked the late M. Beernaerts, the well-known Belgian statesman, when 
presiding over our International Industrial Insurance Congress at Brussels in 1897 , "whose forbears only a few generations ago had not their places in the ranks of working men?" When men in good position interested in Agriculture clamour for it that Agriculture should at length " come by its own," will they not include the claims of Agricultural Labour, as compared with industrial, in their demand ?

The difficulty which stands in the way of the supply of Agriculture with an adequate amount of labour and of the agricultural labourer working out his own salvation, as the industrial workman has done his, is not purely one of larger wages. Wages stand for a good deal in the problem. But there is very much more besides. And the point of what constitutes sufficient wages has long been misunderstood. It is not so very long since a leading statesman, now defunct, himself a land owner in a distinctly agricultural county, astonished members of the House of Commons by informing them, quite seriously, that in his district, where the current rate of wages was I3s. or I3s. $6 d$. a wcek, labourers' families manage on such wage to eat meat freely. Whether the same optimistic assumption was shared in other quarters or not, wages have undoubtedly been far too low. The war, with its many needs, has given them a fillip, and Mr. Chamberlain's 25s. a week has settled the point for the moment. That is, by the way, nothing to what has had to be accorded in France, where labourers' and farm servants' wages have risen to the double of their ordinary rate, and in some cases to the treble. And where board is supplied, labourers' and farm servants' demands have become exacting. M. Zolla tells of cases in which meat twice a day has been insisted on, with cider or wine to match, and coffee after the meal. But how about afterwards? All the world clamours for higher wages. But how is this payment to be enforced? A minimum may be fixed. But in the country, even more than in towns, there will have to be many exceptions from it, or the aged, infirm and juvenile will be cruelly deprived of what to them and their families is a welcome godsend. There are to be 
Wages Boards. Those Boards will be able to see to it that no labourer actually employed is paid less than the regulation minimum. But they cannot answer for it that such employers as grudge the regulation payment will employ the number of men that are really required to make their farms as productive as the Nation has a right to expect them to be. And in peace time we shall not be able to compel tillage in place of pasture, supposing that both landlord and tenant are content to leave the land under grass.

For the Nation at large the higher wages now generally clamoured for on the ground of patent justice constitute after all in the main only a means to an end. The Nation's interest is, that there should be sufficiency of labour, in order that what land there is should be made thoroughly productive. In the hour of need-of scarcity of labourfortunately the weaker sex have once more come forward to fill the depleted ranks of working folk. One may be thankful for this on the country's behalf, as well as on that of the women themselves, and labourer's families. And one may furthermore hope that, although, of course, the "ladies " grown up in the lap of luxury or of well-to-doness, who have in their enthusiasm offered themselves patriotically as recruits of the "Land Army" for what to them certainly is rough and trying work, will drop out, once normal conditions return, our muscular women of the peasant class will remain faithful to the calling-which was their grandmothers', and which was certainly not thought amiss by their ancestresses, but which for some reason or. other they, like their mothers, have discarded. Why on earth rural women, of all classes, should have run away from wage labour, when times were notoriously not altogether good, when labour was much needed on the farm, as were shillings in the cottage, and when their sexmates of all other classes were importunately clamouring for even subordinate employment and agitating with truly revolutionary ardour for the concession to them of all " Rights of Man" in respect of remunerative occupation, it is not quite easy to understand. Had they offered themselves, 
it is likely that, under the effect of a lack of male labour, they would have been welcomed. But there are also many things in agricultural occupation proper that, in spite of a deficiency of physical strength, women can under all circumstances do as well as men. They would have undertaken such at a proportionately lower remuneration-which circumstance to the narrowly calculating among our farmers, who grudge a shilling, would have been an inducement. There are things that women can do even better than men. For one thing, it is less trying to them to stoop. Therefore they are exceedingly useful at planting and gathering up fruit or roots. They are good at singling and hand-hoeing, and first rate at haymaking. They make better milkers than men. They are good about cattle, and in the unsavoury occupation of spreading manure they are more careful in the matter of equal distribution. In the German peasant world I have often heard the cadenced fall of the flail wielded by women. Generally on German peasant farms women take a very active part in the labour done, and their position is by no means a sinecure. And on large farms there are generally about four or five women employed to one man. And labourers who have no wife or daughter to take employment with the farmer habitually hire a maid to do double duty, at home and in employment. In France, where peasant folk know admirably how to accommodate themselves to circumstances, women have in the absence of their menfolk held the stilts of the plough. So they have among ourselves. But this is rather overstepping the proper line of demarcation of their province. It should be rather judged an emergency measure. Among ourselves, more even before the war than now, money was wanted in peasant dwellings, and the shillings brought home on pay-days by a stalwart daughter of a rural labourer would have made an acceptable addition to his scanty week's earnings. All the world knows that agricultural occupation is healthy. It fatigues, but it does not wear. People have remarked during the war how, with country work, roses came to the cheeks of our town ladies and women so employed, and how their health and strength improved. There are no 
women more hard worked, agriculturally speaking, than the Wends (a genuinely Slav race, but for the most part now Germanised) among whom I spent six years, five decades ago. They are hard worked still. But nowhere do you meet with more healthy women. Their young mothers are eagerly sought after as nurses all over Central Germany. And, as for derogatoriness of farm labour, the notion is absurd. We are every one of us called to the work peculiar to our station. During the fit of enthusiasm which took hold of the country, when it was known that labour was wanted, some grotesque mistakes were committed. Delicate ladies of gentle up-bringing patriotically volunteered for rough country work, far too trying for their constitutions and conflicting with their habits. One of these ladies related her experiences humorously in the August number of Blackwood in IgI6. Here evidently was misdirected zeal. However, to country women to the manner born there is absolutely nothing unbefitting in farm work. One may indeed hope that country women will stay on at agricultural work on economic grounds when the sentimental inducement of patriotic enthusiasm will have spent its force. After the Maidstone test nothing seems too hard for them.

However, wages are, as observed, not everything. There is a good deal more. And that "more" is not likely to be satisfactorily determined by the method which some of the agricultural labourers' most ardent well-wishers in towns have adopted of incontinently urging the application of approved town remedies to rural ills. It is perfectly natural that the position of the neglected rural labourer should have been compared with that of the more favoured townsman. Under one aspect that has been done here. The contrast is indeed striking. But it by no means follows that what has proved successful in towns, and in industrial centres, will prove equally effective in the country and in agricultural occupation, which is a different thing altogether from industrial. It is therefore idle to press town methods upon Parliament. Our Agriculture wants "industrialising " badly; but it does not want " urbanising." Aliter cum aliis agendum. We have had one telling proof of 
the inappropriateness of town methods to country life in the matter of elementary education. None of those familiar with the conditions of rural life can be satisfied with the results of a system of education which, modelled on that given in towns, fits the upgrowing children of country folk possibly for clerkships, shop-assistantships and the like, in fact for anything rather than for agricultural occupation, and so naturally predisposes country folk to think of town employment and to migrate into towns. We have not even taken a leaf out of the United States' book in making lessons on agricultural subjects common in rural elementary schools, much less have we sought to give our rural schooling a distinctly rural tone. In fact, in Mr. Prothero's words, " unfortunately, for the children of agricultural labourers little or nothing is done which does not unfit them for their fathers' industry."

Without question our Education for labourers wants tuning up, and that considerably, upon more points than one, and in quite a new sense. The subject has been generally discussed under the head of "Education." But it bears a special aspect as applying specifically to Labour. What our educational authorities seem, let us say, not quite fully to realise, is this, that classes grow as well as individuals. Whether our rural system of education was in former times fully suited to the class and conditions of rural labourers, it is bootless now to inquire into. But in spite of persistent neglect-and more than neglect, that is, social and economic pressing backward--the class which supplies our agricultural labourers has grown in its mentality and its aspirations. It wants different food set before it to-day, food suggestive of further knowledge, of a destiny to rise to higher things, among other such, to independence. The blank created by what actually exists is rendered all the more perceptible and painful by the sight of what is going on around. Our general system of Education is not all that it might be. We acknowledge that in earnestly trying to improve it. But it has advanced upon what used to exist. And being so, it has produced better results. And rural folk observe those results and detect the cause. They 
know that they have been made a Cinderella of. They feel the progressive widening of the chasm which divides them from others. But they observe no efforts made to bridge over that chasm. Is not that calculated to breed depression and discontent?

No doubt the main work of improvement now to be accomplished is that in the rural elementary schools, in which the future agricultural labourer-provided that he sticks to "father's" calling-is taught the " three R's," and a little besides, unfortunately without any reference to his agricultural environment, which ought to be the dominating note and "leitmotiv" in all his education. But it is not specific teaching that, above all things, he needs, but rather the systematic opening of his intellect, the infusing of a greater receptivity for further knowledge and desire to acquire it in an after-life, out of school, in a variety of ways, coupled with a capacity for taking it in. You see the man dull, irreceptive-in Oliver Goldsmith's words, "solitary, slow." Often enough it is your method of teaching that makes him so. He wants, not the "three $R$ 's" so much as a stimulating influence to vivify his mind, which is not without capacity for learning.

And our man does not want to be left alone when emerging from school. It is by their well-organized, methodically treated continuation courses that the Germans have scored so great successes in the matter of popular rural education. It is the same thing in Belgium and the Netherlands. Mr. Prothero expresses a fear that with small holdings increasing in number, there will be a scarcity of winter employment. Well, some such employment may readily be found in educational classes and courses, to which we may be sure that growing labourers will take, if their minds are sufficiently awakened and prepared for them. But the courses want to be tuned to the tonic of the intended learner's faculties. The teaching wants to be made attractive and stimulating. There is a special gift required for this. But there are people who possess that gift. Once more, there is technical instruction. Do not, to take one instance, those Belgian implement classes appeal to our sense of what is appropriate 
for the labourer who is about to be called upon to yield work of a higher order than heretofore? The labour which we require for " intensified " Agriculture is likely to become progressively of a higher and higher type. Men may be trained to that. But it presupposes learning. If our employers would encourage capacity by offering better wages for that which is worth more money, as they pay a higher price for superphosphate which is richer in the constituent which gives it its name, the higher price accorded to more efficient labour would be likely to produce greater efficiency.

Apart from what may be accomplished in school, given a more distinctly "agricultural" tone, there is probably a good deal that may be done in after-school days, if the right note can there be struck. And the national gain in prospect is worth the sacrifice of working for it.

Our would-be reformers ask for better wages, shorter and fixed hours, and for fixed holidays or half-holidays for recreation and rest. Our rural labourers themselves understand their own case very much better, and any one acquainted with the conditions of agricultural work cannot be at a loss how to judge in the matter. Rural labourers are the last to be so unreasonable as to expect that agricultural employment, with all the uncertainties of weather and seasons to contend with, should be regulated by the stroke of the clock. In no occupation is it more necessary to take the tide of opportunity when it offers " at the full." And if there be, as there should be, kindly and sympathetic relations established between employers and employed, to make the latter realise that they are not regarded as mere machines, but as fellow-workers, to whom respect and consideration are due, the employed will show themselves as anxious not to jeopardise the employer's interest as they would be to sacrifice their own. I remember the harvest of 1858 . I happened to spend just that time with a landowner in Germany who farmed his own land, as is usual in his district. It was a nor-. mal year up to a point, and everything went smoothly, until the corn was cut and stooked. Then my host's barometric instinct somehow told him that a change in the weather 
was coming. He put all his hands and all his teams on the carrying, and two nights running we carried up to eleven o'clock at night. As the last wagon rumbled into the barn -for there are barns there-the first drops of rain came down " pop, pop." And it rained on at a stretch for forty-eight hours together, after which a wet season followed. Nearly all the corn in a wide district was sprouted, and it came to be a year of bad bread. So far, however, from grudging the extra labour that my friend's men and women had been put to, they rejoiced heartily with their master over the saved harvest. Agricultural labour is not wearing, like industrial or other urban labour. It is fatiguing and serves to give you healthy sleep. But it does not weaken the nerves or vital organs. On the contrary, if you only abstain from making young folk carry too heavy weights, it strengthens them. More opportunities for recreation and for the cultivation of the intellect and the graces of life, and greater freedom in respect of hours, there certainly ought to be. And these things may be provided without forcing the free child of Nature into the strait-waistcoat of hard and fast factory regulations, to be timed by the stroke of the clock. Such modification is possible without undue interference with the natural flow and ebb tides of rural occupation. But while seed time and harvest remain you cannot put a farm under a rainproof roof or provide sunshine at pleasure by electric lighting. The country requires its own horarium, the ruling feature of which must be elasticity.

Looking at the matter with a view to improving it, let us ask: What was it that enabled the industrial labourer so materially to improve his position, once he was constitutionally lifted into equality with other citizens, while his agricultural brother continued to lag helplessly behind, in bondage practically - unless he desert his calling-on to the great day?

The answer is simple. It consists of the one word: Freedom. The industrial labourer had been given-and given fully-M. Thiers' " necessary liberties." Bound he might still be at the outset. But even then his bondage 
ended at the walls of the factory. He had his own home in which-to apply Blackstone's saying about "the possessor of sixpence being ling to the extent of sixpence" -in respect of relations with his employer he was king. He was king of his doings and of his own time. His employer had nothing whatever to say there. Even if by some odd chance he were to be also the man's landlord, his relations to the tenant as such were entirely different from those as the tenant's employer. The working man's dwelling might be mean, poor, leaky, dismal, unsanitary. The man might be compelled to leave it on account of want of funds when earnings fell short. But so long as he occupied it, it was his castle and, like the famous charbonnier of the proverb, he was absolute master in it. That gave our man the Archimedean $\pi \circ \hat{v} \sigma \epsilon \hat{\omega}$, the little speck of firm ground upon which to take his stand, from which, in the words of Archimedes, he might proceed to "move the earth "-as, in fact, he has done. Domestic freedom secured to him some independence in labour, sufficient to enable him to treat with his employer as a contracting party, not as a mere dependant-cautiously at first, later firmly, and sometimes exactingly. It was not proximity to others of his class alone which enabled him to take up the cudgels of Trade Unionist resistance. Of course the presence of numbers of men similarly situated in close neighbourhood made such joint action all the easier. But union would not have been possible if the industrial labourer had not first possessed his complete freedom in the matter of his dwelling, of off hours and of absenting himself from work on occasions of his own choosing.

The agricultural labourer is in no such position. Scattered and dispersed his class necessarily is, and that in itself makes combination difficult. However dependence for a dwelling, a practical absence of off hours and the impossibility of free movement, unless he is prepared to give up his employment altogether, are even more serious hindrances. Joseph Arch broke through the ring fence and produced united action, which led to a moderate and short-lived success. But that was, under present conditions, an excep- 
tion. Our agricultural labourer cannot, while things remain as they are, escape from his bondage-except by abandoning his home and deserting to some different occupation abroad or at home, because his class is still as a general rule dependent for its dwellings upon those to whom it has to look for employment, cap in hand, not as a matter of free bargaining but as a matter of almost necessity. Employers may be fair and even kind enough, but up to the present time they have utterly failed to grasp the conditions of the man's case from his own point of viewhis legitimate desire to rise to something better, his just title to such aspirations and, one might add, his common humanity and his position as a political equal.

Now let us for a moment imagine a state of things in which the desiderata here suggested in outline have come to be fulfilled. There stands the old farm with its broad fields-no matter whether the occupier be one of "S. G. O." 's fancied "squire-farmers" or a tenant still. Scattered round it or near it are labourers' cottages, with their well-kept gardens and their diminutive little fields yielding potatoes and parsnips and similar produce. Those cottages are rented or owned by their occupants in absolute independence of the employer, who has no voice in their letting or selling, and can give no tenant notice. No matter whether rented or owned, the cottage is, for use, the labourer's own. He may lay out care and pains upon it, to make it neat and spruce, comfortable and cosy, so as to fix upon it the wife's and children's affections. His children will grow up in that little home-of which they know every corner, as they do every bed of the garden, both of which they have helped to make trim and attractive with grateful labour, with the right results-and expect to see father and mother one day sitting restfully by the cheery fireside-no longer in the "house" - with memories crowding in upon them suggested by their surroundings-the home possibly to go on from generation to generation. Our man, if he is to be kept true to his calling and then to be enabled to render his best work possible to Agriculture-as it is the Nation's warm wish and interest that he should be-if he is to be 
given a fair chance, by industry, application and skill, to better his position-will have to begin by having justice done to himself and his family in the securing to them of a free home - a free home in which he will be absolute master, in which his children may grow up with a sense that it is "home," which will remain theirs. There should be some land with it, on which our man may expend his energy and affection, such as Providence has endowed every one of us with, on which to teach his children their first lessons in husbandry, so as to rivet their affections to rural conditions and rural surroundings, instead of leaving them by the contemplation of his own hard lot to yearn for other employment; and in which he may train them up to be useful all-round workers, with a love for their work. This is the "Rhodus," where the decisive first leap will have to be taken. One little speck of freedom will make of a peon a man capable of becoming fully free in course of time, of contracting equitably for his labour.

What are the conditions now ? The dwelling goes with the employment. It is given in part remuneration of the employment. People may contend that it is given, as a matter of kindness, not to say charity, below cost price. That is bunkum. If the house is given below fair market price, so is the labour. There is a per contra account, in which the balance is not invariably held fairly. But the main point is, that the occupation of a dwelling is inseparably linked to the employment. Even so, there are far too few dwellings. Even so, many a willing man finds the greatest difficulty in securing the mere apology for a decent home, even at the price of abject surrender. He would gladly remain on the land, he is anxious to labour there and to make the land produce the Nation's food. But there are no houses. There are not even in every case occupants of houses who will take our man in as an overcrowded lodger, without sufficient elbow room. If he is fortunate enough to secure a dwelling, his occupation of it is at the pleasure of his employer, who is employer and landlord in one. Supposing that any difficulty arises in his employment, out he must go, without the power of appeal. If that is not a 
nudum pactum, a "leonine society," one would like to ask what is. Our man cannot even call upon his landlord to carry out the necessary repairs or alterations, unless the local authority befriends him. He is tied by the leg and has a convict's cannon ball locked to his ankle. A " home" so secured is not a home at all. There is no feeling of a " home" about it. , There are no laves and penates to hallow it. There is no sentimental halo encircling it, nothing that the man's children could look upon with affection and confidence in its permanency. It cannot inspire our man or his family with any love for his position and his dwellingplace-more especially with the dismal prospect of a helpless, impoverished and painful old age before him.

There is outside our own country no part of civilised Europe in which a similar state of things prevails-except it be in the far north-east corner of Prussia and in Mecklenburg, where oppressive junker rule has, under what is appropriately termed " englische Zustände," that is, " conditions similar to those prevailing in England," established something of the same sort, with the express object of tying down the labourer in absolute subjection. There landed proprietors -generally farming their own land-have set up labourers' dwellings which go inseparably with the employment. One reason was, that in those thinly peopled provinces, where immense breaks of broad acres prevail, villages are few and far between and there is accordingly a dearth of labour. However, a distinct object of the move was also to bring the men and women under an iron yoke. But even there housing is at any rate not scarce. There is enough for all labour that is wanted. Labour need not go about seeking and begging. And there is furthermore some land to cultivate attached to the house, however little it be-some land on which children may learn how to raise useful or ornamental plants and on which young and old may expend their surplus labour and bestow their affection. Such dwellings are generally grouped together and so provide something of society and fellowship at the same time.

EIsewhere throughout on the Continent the agricultural labourer has his own house, owned, or held independently, 
with its valued lopu de terre going with it - in France, in the Low Countries, in Austria, in Germany. In Lusatia, on my whilom property, every labourer that I employed had his own little house. And he was none the worse a labourer for that, rather a beiter. For-leaving questions of strife and malice prepense out of consideration, for which there should be no room-emplcyment on his own land naturally makes the labourer more careful in his work, more disposed to reffect, more conscious of his responsibility. He knows better what things should be and instinctively applies the care which he bestows upon his own cultivation on that executed for his employer. It also makes him a more capable labourer. For he learns more different things than he does in his paid employment - at any rate among ourselves. Writing about small holders, Mr. T. Wibberley, who has a good deal of experience, says that he would at any time rather plant the son of a small holder upon a new small holding than the son of a labourer, because he is more of an all-round man and therefore better fitted for his new task. The labourer's son has been trained to do " father's job," and has mastered that-well or indifferently, as the case may be--and nothing more. Occupation of a garden and a little land also makes a more cheerful, contented man, willing to give and take and be a good neighbour. His temper is in better tune, because he has something to occupy his thoughts and his hopes, something to yield him a direct reward, something to interest him.

Our man is a labourer still. He comes to his employer regularly for work. But he comes as a free man. The employer fixes the hours of work and assigns to every one his task. The man is not likely to quarrel with his necessary bread and butter. However, he has now a voice in the matter as well. There will be occasions when he will want to stay away. On the other hand, when there is pressure of work, he will be willing to give freely of his extra time. Freedom and an approach to equality have banished the sense of distance. There is less patronising and more neighbourly feeling. Under such circumstances rural life assumes a far more cheerful colouring. The foundation 
comes to be laid for that better " country life" which, under Sir Horace Plunkett's inspiration, President Roosevelt made it his aim to introduce in the United States. Both sides understand that theirs is a bargain of give and takefavoured, as it must be, by mutual goodwill and mutual consideration. Employer's work is now sweeter to the labourer, who understands the employer's position better than he did before, just as does the employer his. To some extent at any rate both have individually the same interest and they have now learnt that that is so and come to share that interest in common. Something of that "brotherhood " spoken of recently in this connection by the Bishop of London, and the breaking down of class barriers, has been brought about. Our man is no longer a machine but a fellow-worker.

Such were the relations between my labourers and myself. And such they are in all similar cases where there is goodwill and a liking for fairness. Fairness on one side begets fairness on the other.

Here is a picture full of promise of happiness and contentment for work satisfactory and beneficial to the Nation as well as to those taking part in it, and full of promise also for the repeopling of the countryside, and the production of happiness and contentment upon it. The men's own farming at home may indeed mean a draft upon their time otherwise given to the employer. But the employer will receive in quality what he sacrifices in quantity. It is another form of the application of "the economy of good wages." And repeopling the countryside with contented denizens may be expected to bring back some of the sunshine of the old "Merrie England," with its humble place for the labourer, secure in his home and his common rights. There was considerable waste in the use of those common rights. And one would not think of re-establishing them as they were. But under the circumstances they gave the small man what he wanted, a position of comparative freedom, with a home of his own to pass on to his children. The new garden and the well-kept field will do the same thing now in a way more in harmony with the spirit of the present time. 
And see how this arrangement naturally regulates problems about which intending reformers now bootlessly rack their brains! The man-and probably his lads and girls, when they are sufficiently grown up-will want to go to the farm for employment, for subsistence's sake. It is not supposed that his diminutive holding will be sufficient to support him and his family. If it should be capable of doing so, he would have taken a second step already on the social and economic ladder that we keep talking of setting up, without ever arriving even at the setting up of the lowest rung. But that cannot in the first stage be general. Making the most of his holding, our man may have become only a casual labourer. As such he will still be a distinct asset to the rural community and also to his casual employer. There will be times when his work will be greatly appreciated. However, we are here in the first instance thinking of a man to whom paid labour is a regular occupation, and cultivation of his own land merely by-employment. There is room, time and strength for both.

We must not allow ourselves to be frightened by the apprehensions of narrow-minded employers, who contend that the man could not possibly cultivate land of his own except at a loss to his employer, with strength and time of which his employer is robbed. That assumption presupposes the recognition of a principle abhorrent to the sense of the present generation, namely, that the labourer, in engaging himself to work for his employer, contracts-thus far it has been at a miserable wage-for absolutely his whole time and for every atom of strength that is in him, by a sort of labour rackrent. Whoever would think of propounding such a theory to an industrial labourer? The industrial labourer knows-and his employer knows it likewisethat he contracts for a certain quantity of work, which, being honestly yielded, he is free to do with what remains of his time and of his strength whatever he pleases. And it is the opportunity for such by-employment-additional earning, cultivation of an allotment, study, intercourse with others better skilled in social, political, technical or general knowledge-which, so far as it has gone, has enabled 
lim to raise himself to the higher position which to the good of the Nation he now occupies.

And that is not all. With increasing knowledge, with increasing inducement to put more head and heart into his work, with the satisfaction in his mind of a knowledge that he possesses his comfortable free home, and that, in working, he is working also for himself, our man has, where these things apply, grown a superior workman, yielding a better output and better profit to his employer in the same time. Let no one pretend that "work" is " work," any more than that "food" is "food." The epicure whose appetite-and with the appetite his power of digestiongrows over the "capon of Barbezieux" "truffé a tout rompre," raved about by Brillat Savarin, would make wry faces enough over a mess of paddy or polenta, and " ort" such food, however nourishing and "good for the wholesomes " he might be assured that it was. Let him, figuratively speaking, have his Barbezieux capon at home, promising him a toothsome bite after work-and at the end of the year-and the appetising flavour of its truffles will make his millet or his groats a good deal more endurable.

From Roman days downward, when the proverb was coined about the unsatisfactory job of "reaping another man's harvest," it has generally been realised--by those who can see two sides of a question-that working for another man, without any direct interest in or about the work, is wearying drudgery. The interest required it has been sought to impart by assigning to the workman a proportionate share in the profits. "Profit-sharing" has its difficulties to contend with in its application to all callings, but probably most in its application to Agriculture. But so far from being impracticable, it was to employment in Agriculture that Profit-sharing was first of all appliedin Germany in the case, become historically rather famous in economic and social history, of Herr von Thünen, in Ireland in the less widely known but equally memorable case of the late Lord Wallscourt. And it is its application to employment in Agriculture that Mr. E. Strutt has in the present day made a success of it. There are such faulty 
conceptions about what Profit-sharing means current in the world-as is, to quote one instance, shown by the late Lord Goschen, who ought to have known better, denouncing it with indignation as "a socialist abomination" (when in truth it is rather anti-socialist in its tendency) - that a word or two respecting its meaning may be in place. Profitsharing means that a well-defined share, fixed beforehand, of the net profit resulting in an enterprise as a whole shall be handed over to the workmen employed, over and above their ordinary wages. The wages should be fixed to start with and should be of the ordinary level. For Profit-sharing is not designed as a substitute for part of them-as you place a traveller on fixed pay and on commission-but as an inducement for work of head, hand and eye beyond that which is paid for in the regular wage. The labourer should receive his honest pay first. Profit-sharing pays well. "You see me a wealthy man," so observed to me, more than twenty years ago, M. Goffinon, a notable industrial profit-sharer in Paris. "Well, it is profit-sharing which has made me so." And his workers-in the well-known establishment of MM. Tassart, Balas et Barbas-were satisfied also. They had profited as well as he. "If my workmen would only be thoroughly careful in the handling of slabs," so remarked a large employer using stone slabs to the late G. J. Holyoake, " they might save me $£ 4,000$ a year which now goes in breakages." "Then why do you not offer them $£ 2$,ooo out of it?" was Mr. Holyoake's reply. ${ }^{1}$ There is a great deal-in Agriculture, perhaps more than in any other calling - that extra exertion of intelligence, of vigilance and carefulness will effect. That is worth buying. The main object of profit-sharing of course is to be found in a loftier sphere. Profit-sharing is to raise the workman to a higher level, by making of him to some extent a fully interested self-employer. In the last talk which I had with our great profit-sharer, the late Sir George Livesey, shortly before his death, that gentleman remarked to me that he would not now approve of any scheme of profit-

1 The late Earl Grey, who was a thorough profit-sharer, was greatly struck with this argument. 
sharing which did not include the provision that the extra profit earned by the workmen, or at any rate the larger part of such gain, must go into the employing concern, to buy shares in it. In his early days Sir George was not so much of a purist. In Agriculture it would scarcely be possible to apply such a provision with full stringency, more specifically under tenancy. But in Agriculture also there is infinitely less need for it than in industrial employment. For the agricultural labourer has less temptation to fritter his extra earnings away in improvident expenditure; he is in truth by nature too thrifty to do so; he lives in a different atmosphere from his industrial brother, which discourages that. The extra profits which he earns are likely to be laid by. It would be a good thing if Mr. Strutt's example, and his brother's, Lord Rayleigh's, of sharing profits with agricultural labourers were to be more widely followed.

Mr. Strutt, however, is not the only agricultural profitsharer in this country, not counting Ireland, where Mr. Dermond O'Brien has trod in Lord Wallscourt's footsteps. During the period of scantiness of labour caused by the war several witnesses have come forward in the Timesa paper which has for some years back shown its sympathy with profit-sharing-to report their successful experiences. Thus Mr. Alfred Amos writes from Wye in Kent:

"I am satisfied with the result. Whereas I often hear complaints from farmers that their men are now doing much less work than they used to do ten and twenty years ago, I have no fault to find in this respect; my men work freely, often suggest new methods by which economies can be practised, and take greater care with stock and the use of implements."

However, we want something more potent than profitsharing. And indeed profit-sharing may be made to lead up to that, as the first step towards it. Our man must be placed in a position to occupy a little land of his own and till it for his own profit. There lies his self-employment, such as Sir G. Livesey was anxious for in the case of his gas-workers. There should be time and strength left, after his daily work for his employer, for cultivating that bit of land. The labour bestowed upon it will not wear 
him out, nor serve as a means for his defrauding his employer. Rather will it act as a stimulus, sharpening his understanding of the object of labour and sweetening his toil by the prospect of its gain.

From the time of Queen Elizabeth downward-who in I589, the year after our victory over the Spanish Armada, put her signature to the famous statute which ordered (ineffectually, as it proved to be) that "four acres of land should be attached to each cottage let to an agricultural labourer," we have acknowledged the desirability of endowing the agricultural labourer with land for his own private cultivation. The unnamed "Country Gentleman" quoted, in I772 with approval by the first Board of Agriculture, which endorsed his recommendation, demanded that "a sufficient portion of land should be attached to their (the agricultural labourers') cottages, to enable them to keep a cow or two." Arthur Young in I779 suggested that " all labourers should be assigned a garden and grass-land for the keep of a cow"; and in ISOI he particularly urged that all Acts of Parliament for the reclamation of wastes should attach enough land to every cottage to provide summer and winter keep for a cow." Writing a little later he " deplored the loss of the golden opportunity of the remarkable revival of Agriculture in the period of about I783 to I8I3" (when ownership spread in an unprecedented fashion), "of attaching land to the homes of the cottagers." About the same time there was a general complaint that agricultural labourers-like the famous mariner who, with "water, water everywhere," had " not a drop to drink" - -living in the midst of cows, could not obtain any milk, all the country milk going-like the butter to-day in the same districts, where the economy of margarine for home consumption is practised, to the children's detriment-to the towns for money. The Poor Law Commissioners of I834 reported that the holding of an allotment meant, in those days, the equivalent of an addition of two shillings a week to wages, in addition to which there was " money saved." Men spent less at the public-house and were less dependent upon shopkeepers for their nourish- 
ment. Spending less at public-houses, so one would say, is desirable still. Morally there was " an added feeling of independence and self-respect." And the creation of a peasant proprietary was one of the main points called for in the agricultural labourers' interest by Joseph Arch's Union. There is a perfect " cloud of witnesses" in favour of this simple concession, which, in truth, needs no argument to be advanced in its favour, since it quite sufficiently speaks for itself by its plain sensibleness, not to speak of the examples set in other countries.

No doubt, under circumstances, and to a certain extent, the holding might become an inconvenient pledge to the man to remain where he is, such as an unscrupulous employer might exploit for purposes of oppression. The chances of that occurring are, however, decidedly remote. And after all, in such cases as that suggested, the houseless, landless labourer, liable to be turned out into the street, would be worse off still. Even though we should succeed in settling thousands of discharged soldiers on the land, many of them to become labourers, there is not likely to be such a plethora of labour offering as to give the employer the absolute whip hand under essentially altered circumstances. And the more independent position secured by the labourer would more than balance such chances. Meanwhile we may expect other influences to do their humanising work, wiping out old prejudices and misconceptions bred by long habit. With technical education doing its workmore especially if Sir J. Caird's prescription is followed and landlords as well as farmers cut their territorial coat more nearly according to their financial cloth, seeking profit rather than sufficiency of working capital than from exaggeratedly extended acreage-labour, highly skilled labour too, is sure to be in greater demand than it has been. It is money to-day which " makes the mare to go," which produces the paying crop; money which markets it to the best effect. And intensive cultivation means not less but more labour, and labour of the most capable sort, therefore calling for the best remuneration. That, once more, necessarily means more employment and better 
wages. At the same time under the new influences the suggested old caste barrier, which makes it appear-without evil intent- - that the farmer does not consider the labourer as made of the same clay as himself, is sure to crumble to pieces. That done, the question of hours and holidays settles itself. For there is, after that, no more compulsion for the labourer, only free contract. Dependent as he is, in the main, upon his earnings, he is not likely to abuse the newly gotten power of taking a holiday or curtailing his working hours whenever he chooses. That would be quarrelling with his own bread and butter. In point of fact this matter settles itself. In Lusatia I could not compel my labourers and their women-folk to come regularly and keep the full number of hours. Had they missed often, and had I had more labour at my command than I should have known what to do with, I might have given them the sack. But, as a matter of fact, they came regularly, only too glad to earn their wage. However, whenever occasion arose demanding that they should stay away, whether for the day or for several days or for an hour, they would as a matter of course-in order not to jeopardise their employment-inform the person placed above them. And, supposing that their hours were inconvenient, they would be reasonable, and alter them. And in this way all was arranged amicably to mutual satisfaction.

The question of a house and land in truth dominates the question of wages. There can be no real improvement till the agricultural labourer becomes a free householder.

If our employer is to pay better wages, there must be a competitor to compete with him. Hitherto he has been practically the only bidder in his own market. That market has shrunk. The article wanted has been withdrawn. But the employer has been left in command of the market so far as it goes. To the labourer it was a question of taking or leaving-unless he would go away altogether. And those employers who, from a want of understanding of the circumstances have preferred to go on farming in the old loppaty-loppaty style, have had the satisfaction of maintaining low wages-at the cost of the 
Nation, which has seen its land produce much less than it should. The labourer in a town has a choice of firms and of other forms of employment besides his own. The rural labourer, in his comparative isolation, having long distances to count with, and the difficulty about a lodging ever pressing upon him, is in this respect badly off. The only competing form of employment open to him thus far has been such as takes him away, either from his calling and the walk of life to which he was born, or else from the country. He might migrate into a town to become an industrial workman or something else ; or he might emigrate to a colony. There is in the country itself no rival to set up, to pit against employment at unduly low wages. At this point the taking in of landholding as a complement to labour, recommendable on other grounds, promises to prove effective, as giving our man the first foothold on that "ladder" by which it is intended that he may, by means of the occupation of land of his own, rise step by step to a higher position, of which we have so long been talking. And such combination would promise to prove effective also as setting up an incipient form of competition with pure wage labour, bidding fair to gain in competitive force as time went on. For our labourer, with his little holding, may develop into a market gardener, or a fruit farmerlet alone that, as the "ladder" becomes peopled with climbers, some higher up, some still lower down, his hand and head may be found to be useful implements, for the employment of which there is scope on the holdings of those who have risen to a certain height. We have talked a great deal of that "ladder." Everybody seems to be in favour of it. But when are we going to set up the bottom rung, the first rest for the foot of the rising labourer? If he is to have access to that rung, unprovided as he is with all opportunities at present, the community will have to take some steps to place it within his reach. The result to be attained is well worth an effort, even though it be at some public cost.

Once house room and a modicum of land are provided, we may look with confidence for further development, 
for a steady, gradual rise of the labouring population, both social and economic, for the gradual accumulation of some possessions, the acquisition of greater skill and general knowledge, the ascent of "Hodge" into the higher strata of the body politic, in which his industrial brother, more favoured by circumstances, has preceded him by some decades. Then also the wish of our urban rural reformers is likely to be realised, namely, that of seeing the agricultural labourer following the steel worker and the engineer on the track of "combination" and "organisation." For it is his absolute subjection and poverty rather than mere dispersion which stands in the way at present.

Here is another "Rhodus" at which a decisive jump has to be taken, for making which landowners' confidence, such as-coupled with judicious selection of fit men-has been given by the Duke of Bedford to his purchasers of land at Maulden or, more probably-because the scale will have to be much larger-financial advances from the community, will be needed.

For land cannot be acquired by the landless without such assistance. They cannot be expected, as they are now situated, to work up to it, even within the limits set up in Lord Chaplin's Act of I892, at any rate on a large scale. Wherever we look in other lands we find that the acquisition of a holding of their own-and when they have got it, its gradual extension-forms the ideal and settled aim of every one engaged in agricultural labour. The German farm servant-from the day when he engages himself as "bullock boy," which is as a rule the lowest grade to be occupied-lays by carefully out of his scanty wages, to save up a small sum-truly derisory it would appear to ourselves-wherewith to commence his farming for his own account, while still taking employment with others. The maid whom Fate has destined subsequently to become his helpmate-though they neither of them know anything about this at the time-does the same thing. And their two little hoards of savings suffice, in a country where land is frecly saleable and much divided, and where great 
facilities are provided both for the acquisition of land and for the obtainment of credit, to secure some little cottage with a little field attached to it, that figurative " vine and fig tree " under which there is a brilliant promise for wellconducted people to find a restful occupation. The day labourer has his little holding already. But his stcady aim is, either to improve it, so as to make it to yield more, or else, when that has been accomplished, to add to it and in course of time to turn himself into a " peasant." The "ladder " is there. And it does its work. There is a steady rise, while newcomers pour in on the bottom rung. "Even the poorest," so writes Robert von Mohl, an economist of high authority, "can, if he will, lay by in his youth as farm servant, and if he marries an industrious and thrifty girl, begin with the purchase or renting of a plot, and by application, industry and thirft increase his holding, and by degrees work his way up to comparative wealtl." "And this," said the late Dr. Buchenberger, when Yinister of Agriculture in the Crandduchy of Baden, "has happened in thousands and thousands of cases." Minister Buchenberger adds: "The advantage afforded by the fact that every day labourer in the country may acquire a small plot of land, may by industry and thrift add to his modest holding, and eventually raise himself to the position of an independent bauer, cannot be rated too high; for the prospect of making himself economically independent is one of the most potent incentives to the exercise of economic virtues.'

In the words of M. Jules Guyot, a noted writer on rural economics, "the plot purchased or rented by the day labourer "offre à la fois la propriété et lc prix qui doit la payer, l'atelier de travail et la caisse d'épargne immobolière." That is: it provides at the same time the property and the money which pays for it, the workshop and the landed savings bank.

In Germany the State has helped. I am not now talking of that odious land settlement with a political object, which is to replace Poles by Germans, and which, while altogether failing to achieve its desired object, has cost 
the country millions of pounds-which money can now, happily, not go into munitions of war. There is also, by the side of this, a purely economic form of land settlement, which has accomplished much good. And up to a certain point it has cost the State nothing that did not come back into its cashbox in ringing coin. "You will not find," so said to me on one of my early visits, in x894, Privy Councillor Metz, at that time President of the Land Settlement Commission for the Provinces of Brandenburg and Pomerania - a very active Commission - " that my land settlement has cost the State a stiver." After a time Jeshurun waxed fat and kicked. Germany had money to spare and the Government grew keen on land settlement. Those settlers-the majority of whom are small holders in our sense, with fairly large holdings for that description of men ; but some of their holdings, intended for working men, do not amount to more than about three and a half acres-were to be petted. And of late, what with this outfitting and that, fruit trees of selected kinds and other little luxuries, a sum averaging $£ 25$ is lost, so far as cash goes, on each of the larger holdings - no doubt with the hope that it will be scrupulously repaid in the shape of loyal support given at the poll and otherwise to a kindly paternal Government. That State advance covers, as a statutory allowance, threefourths of the appraised value of the property. But it often amounts to more. And so far as the man acquiring the property is known to be deserving of being trusted, he finds further assistance with his co-operative credit bank. The persecuted Poles-who make admirable settlers-have achieved perfect wonders in the matter of such land settlement, their Polish credit bank providing commonly the whole of the last fourth and so placing their land settlement on a par with the Duke of Bedford's at Maulden-with the aid of the same safeguard, of selection of the beneficiaries.

It may be rather easier to accomplish such feat in Germany than it would be here. For land is there, although dearer, more "in the market"-land in more get-at-able small quantities, but readily obtainable in all sizes. Transfer is a matter of almost only nominal cost, and casy as 
the sale of a pig-thanks in great part to compulsory registration of title. And the folk settling are of more modest pretensions, perhaps, to begin with, than our own people. However, if our settlers' demands may be a little superior, so are our means of meeting them. "Is not wealthy England," so President Metz asked me, full of astonishment at our inaction, at our last interview, in IgII, "in a position to find the necessary funds for such an undertaking, which repays its cost over and over again in benefit to the country?"

Supposing that we seriously desire to retain Labour for our Agriculture, or rather call it back to what it ought never to have been permitted to leave, we shall have sooner or later to decide upon something of the same kind. We shall have to throw into the scale something that will make a labourer's life worth living. That will be worth more to the Nation than putting a tax upon the consumer of corn. At present we have nothing in the country to pit against the attraction, on the one hand, of town life with its better paid employment, on the other, of the Colonies. We shall accordingly have to create something. The very number of men and women emigrating to the Colonies, rather than go on living that drudging, dreary, weary, hopeless life at home, shows that it is not country life or agricultural occupation that our country folk object to. The burden of agricultural occupation might indeed be lightened, if we were to go farther in our application of mechanical force and follow the German example in employing more electric power to move our machinery, down to the smallest implements, the corn-crusher, the chaff-cutter and the liquid-manure pump, and to light our barns and stables. That has produced a most striking change in the attitude of German peasantry looking for agricultural service and labour. The work formerly dreaded and shunned, as being too fatiguing and troublesome, has lost its terrors since there is the electric power to lighten the burden. And our facilities for instituting such power are greater than those which Germany possesses. We have the power fairly everywhere within our reach ready for 
impressment. There is much else that we might do to make agricultural labour more attractive.

There is a social side to country life which affects labourers above all men and which wants to be studied as well as the economic.

"Nothing short of a comprehensive attempt to make rural life profitable, healthful, comfortable and attractive," so writes the Hon. D. F. Houston, Secretary of Agriculture in the United States, in one of his most recent Annual Reports, "will solve the problem. It is the only sure way of retaining in the rural districts an adequate number of efficient and contented people. . . While we labour to increase the supply of material things, we cannot neglect the higher things-the intellectual and social sides of rural life. The conservation and development of the people is the greatest problem of conservation confronting us." There is an echo of Mr. Roosevelt's instructions, as President of the United States, to the Rural Life Commission, which he appointed, in this. We are endeavouring to cultivate the social side in a way perfectly appropriate to past times, but out of harmony with the spirit of the present day, namely by patronage. There are plenty of good people willing and anxious to provide for the social wants of rural folk by clubs and entertainments, cricket and other meetings and all that, a sort of rural "going slumming." But there is one feature about this which robs it of more than half its grace, and that is the tone of condescension. Nothing could be better than that classes should be brought freely together and made to mix, more particularly in the country, where population is not excessive and where people billeted side by side instinctively learn to be neighbourly. However that should be, not on the footing of benefactors and beneficiaries, but on that of pro hac vice equals. The great German philanthropist Raiffeisen, who has done so much for the rural poor, not of his country alone, understood this when he organised his little co-operative societies, which have grown to be collectively a large army, benefiting small cultivators by millions, and at the same time alsoand that is their chief merit--generating a spirit and a 
feeling of brotherhood, of mutual interest and mutual helpfulness, by which not only the locality has its inmates and the entire country, but, it may be said, all humanity come to be benefited. In these societies high and low mix, but mix as equals, There are no distinctions. Knowledge will tell, position will tell, experience will tell, judgment will tell, effort will tell, above all things character will tell. There will be leaders and led. But there is no pretension to superiority, no material giving and taking. And that it is which has made these modest little societies such fruitful generators of economic, social and moral good, drawing members together as by bonds of common kinship. The sense of distance has come to be banished, without the humbler abusing the right of equality accorded to them. They have been educated by the new spirit actually infused. And these societies - in the shape of which Indian philanthropists, as observed, hope to revive their valued lost heritage of the "Village Community "- have certainly succeeded in keeping small folk, including labourers, in the village. It is on such lines that our Village Clubs and other social institutions for rural districts want to be developed.

The continuous flow of emigration seems to tell us that the man who goes to seek a new home, to make it for himself, in unknown parts of the world, would require little persuasion to stay in his village, in which he has grown up and has friends, in a locality in which he knows every shrub and every footpath, and to which all his memories are attached, if we could only rival the attractions of those distant lands by offering equivalent benefits. But he wants something to give zest and colour and heart-warmth to his life. The home of his own-maybe an idyllic, picturesque cottage like those over the sight of which Southey grew rapturous, with a garden by it exciting such sentiments as those which the late Poet Laureate owned to in "The Garden that I Love," with a happy and contented family to share the home with him, working, or else playing, in the garden, training the creepers up the trellis wall, tending the flowers, keeping the rooms with their familiar furniture and ornaments tidy, and bright with flowers culled from the garden 
and other little adornments, raising vegetables in the garden which are consumed with a special relish, and minding the fowls which yield the eggs and chicks that bring in money, it may be with a pig contentedly grunting in its sty close by, promising luscious bacon-all these things cannot fail to engender in the workman a feeling of satisfaction and hope, which would more than reconcile him to his lot, raise his intellectual aspirations, and make a better worker of him. There must be a fulfilment of the biblical promise of one's own " vine and fig tree," to which Henry of Navarre's "poule-au-pot," as an occasional treat, would make a most suitable complement.

The war has taught us that we must have agricultural labourers. We had long forgotten it. Other aspects of life had to such an extent forced themselves upon our notice that in the backward state of our rural life, during the progress of that steady decline of our Agriculture which the Food Committee have placed upon record and which we all have lately scen reason seriously to deplore, "Hodge," being out of sight had got "out of mind " too. However, we know now that we must have him.

Soit tôt ou tard, soit près ou loin:

Le riche du pauvre aura besoin.

Now times have changed. Like everything else, Labour commands a different price now from what it did before the war. We must give it that price as we give it for our clothes, our food and other commodities. Give the labourer recognition as a full citizen, as the useful member of civil society that he is, give him recognition of his calling as an honourable calling in which to make a.career, give him the " necessary liberties"-above all things give him a free home to become his castle, with a little holding, in which, like the heir of the legend, by digging deep he will be able to find " a treasure," give him a chance corresponding in civil life to "the marshal's baton in the knapsack" of the Napoleonic soldier, that is, give him a prospect of social and economic betterment, give him education appropriate to his surroundings and his calling, and you may rely upon 
having the same hearty, cheerful, capable, trustworthy labourer back whom some of us old folk remember and regret-and, in addition to that, a working citizen apt to become a source of strength to the State and to contribute by his good sense and judgment to the welfare of the Nation, like the Burts and Barneses, the G. H. Robertses, and Hodges of the present day. Our rural labourer thus raised to a higher status cannot fail to start our Agriculture once more upon an upward path, leading it up to that "pride of place" which in the youth of us old men it occupied, when other nations came to learn from us, and when food was good and plentiful. And with such brighter outlook opened to our rural labouring folk, unfailingly must come back to our country the smile and sunshine of "Sweet Auburn," the happy physiognomy of the lost "Merrie England." 


\section{CHAPTER VII}

\section{Small Holdings}

A German agriculturist of note a few years ago related in succession both in the Times and in the Morning Post the impressions which he had gathered on a journey of inquiry undertaken through our country to ascertain the condition of our Agriculture. His verdict bore a humorous resemblance to that famous chapter in the book about Ireland, headed " Snakes in Ireland," for it practically said, "'There is no 'Agriculture'-no cultivation of the ager, what Suetonious calls agrorum cultivatio-in England." All that he had seen was prata-pasture.

That picture was of course overdrawn. But there was not a little truth in it.

A far more striking difference between our Agriculture, and our rural life generally, and those of the Continentby no means Germany alone-is this, that on our fruitful plains human population practically there is none, whereas on the Continent-be it in smiling France, or in busy Germany, or in sunlit Italy, in bustling Belgium, or in mountainous Switzerland-corresponding plains everywhere teem with humankind. Village there stands by village, cottage by cottage, and multitudes of peasantry greet you with laughing eyes and cheerful countenances, the tokens of contentment and well-to-do-ness.

The contrast is certainly impressive. There are patches of sparseness abroad, of course, just as there are oases of denser population among ourselves-strips by the sunny sea-coast, districts of fruit growing, girdles of market gardens encircling favoured places, little bits of stirring peasant 
life, such as in the Isle of Axholme. But the general character of our country is bareness. Splendid crops there may be in the fields, luscious pastures, luxuriant hedgerows separating them, imposing mansions in the parks -but the happy throng of cheerful people, with whom Goethe says that even at more or less bleak Eastertide Nature fills the German plain, is wanting. Accordingly, wherever in Germany squire rule, or junker rule, as we in rightful reprehension term it, prevails-there is no such thing in France, nor yet in Switzerland, or in Italy--say, in the eastern provinces of Prussia, or in Mecklenburg, where manor farm fields spread out far as eye can see, and peasant holdings there practically are none, natives call this " England in Germany" (Englische Zustände). And German authorities are careful to point out that such districts are those which entered latest into the realm of civilisation. You can, so they contend, tell, as by a scale, by the subdivision or else the agglomeration of land, at what date civilisation fastened its culture-fashioning hold upon that country.

Even where we have people, something of the foreign gaiety seems wanting. "In our 'Arcady,'" so wrote the late Canon Jessop, "one never hears a laugh." The Swiss bauer, the French propriétaire, the German kleingrundbesitzer, stands in off-time before his cottage door, or sits on the bench beside it, with the satisfied air of a little king. His nourishment may be plain, possibly more or less meatless; his clothing may be simple, his air rough. But his looks proclaim contentment and tell you that he knows that he is on his own sod, a full citizen, who needs not doff his cap, otherwise than in neighbourly courtesy, to any one. He may be dependent only upon his little farm; he may be engaged in some trade which brings him pence; he may be a simple agricultural day labourer. However, at home he is master-maitre chez soi. And if you will inquire at the Inland Revenue Office, at the Registrar's, at the Recruiting Bureau, in the Statistical Department, your informants will tell you that his presence means wealth to the country, more live stock 
kept, more produce reaped, more recruits for the army, more taxes for the Crown, and (outside France) more increase of the population. There is distinctly more productionof food and otherwise. "In my recent tour along the front through France," so remarked the Australian statesman Mr. Hughes at the Mansion House not long ago, "I did not see as much land uncultivated as you may see within ten miles of London. The French nation is rooted in the soil of France: that is the secret of its great strength. You must cultivate the lands of Britain ; create such conditions as will induce men to follow agriculture."

The difference in the matter of keeping more live stock is particularly marked in Württemberg, to the agricultural institutions of which Mr. Jesse Collings not undeservedly some time ago called particular attention. A statistical inquiry there made has shown that on very small properties there the ratio of cows to land is as high as one cow to four-ninths of an acre ; on larger properties, from I,000 acres upward, it is only as one cow to the traditional "three acres." In Germany the comparison between agriculture in populous and in sparsely peopled districts is made very easy by the work, that has already proceeded very far, of home colonisation, which has been going on, rather under State direction than with pecuniary State help, in the eastern provinces of Prussia. New population has been settled on whilom desert large estates. New villages have sprung up, with church spires rising up above the cluster of neat tiled roofs. The plain has become chequered with well-tilled fields, like a patchwork quilt. And figures tell a tale of allround improvement. I have no space to go into particulars here. I have given figures elsewhere. ${ }^{1}$

As already stated, with the settlement of these little hosts of freeholders, with the growth of population, everything else that makes for national prosperity has grown too. And the men and women themselves have grown in character. They now have a fuller sense of citizenship, they

"See "A Practical Justification of Peasant Properties" in the Contemporary Review of May, I891, and "Repeopling the Land " in the same print of May, I895. 
realise the responsibility that rests upon them. They have grown in intelligence, in businesslike capacity, in judicious application of their labour. There is more. That important factor in national economy upon which Mr. Chamberlain not without good reason laid so great stress, that is, Home trade, has been brought to feel the benefits of a larger and better-to-do rural population. Your big squire may keep a goodly household, like the Abbot of Canterbury of the ballad, with his "housekeeping of high renown," buy wines from France and costly luxuries and works of art from all foreign climes, which make a brave show, and the expense incurred upon which strikes the plain man with awe. But your village full of small folk nourishes home trade-individually less but collectively much more-buying what comes from home workshops and employs home labour. There is no need in this matter of harping upon the example of Germanyalthough Germany contributes a goodly part to the collective picture. Look down from the top of the Vosges upon smiling Alsace, or from the Drachenfels upon sheltered Rhineland, cycle through the densely-peopled Palatinate, or through laughing Touraine or sunny Languedoc, wend your steps even through comparatively large-farming Normandy, follow the course of one of the happy valleys of Switzerland, pursue your tour through Lombardy or Tuscany-everywhere on the Continent the same attractive picture meets your eye and tells you that you are not at home, not in only whilom " Merrie England." And no one wants to get away from such " congestion," such subdividing by the law of equal inheritance. "Repeal the law of subdivision, of equality of shares in inheritance," so remarked to me upon my inquiry statesmen entrusted with the supervision of Agriculture in practically all countries in apparently excessively subdivided South-western Germany, "why, the thing is inconceivable; there would be a revolution." And it pays the Nation. "How is it that France has suffered so much less from 'agricultural depression' than other countries?" So asked people at the great International Agricultural Congress at Paris in 1889. "Because its land is so largely subdivided," so replied the 
Official Report prepared by M. Bénard. "There are over $5,672,000$ comparatively small farms, about $5,000,000$ of them cultivated by freeholders, 4,800,000 in holdings of less than twenty-five acres." And there is no destroying such division by the action of the big purse. The number of distinct properties is too large. Our wealthy squires could buy up yeomen's properties. But you cannot buy out a numerous population any more than you can "indict a nation." Naboth stands out. Besides, under small cultivation land has grown too precious. Engrossing requires a marvellously well-filled purse. It is almost indispensable in this connection to quote German precedents, because German authorities have dealt most systematically with the matter, keeping a strict account of all that has happened. And they have, in an inquiry instituted some thirty years ago, found that land subdivided into small holdings yields approximately as six to the five of medium holdings and four of large. In owning to this they are speaking against their own predilections. For German authorities fancy and protect and favour the medium proprietor, the bauer, with a holding from 20 to Ioo acres -in the eastern half of Prussia, where subdivision is less prevalent, the average figure is sixty acres. They do that, not to evidence their agreement with Aristotle's considered judgment ö $\tau \iota \dot{\eta} \mu \mu^{\prime} \sigma \eta$ (sc. $\left.\kappa \tau \hat{\eta} \sigma \iota \varsigma\right)$ i $\beta \in \lambda \tau i \sigma \tau \eta \dot{\epsilon} \sigma \tau i \nu$, but because they find the medium bauer the easiest to deal with, the most amenable to official leading, the most given to supporting authority. Some twenty years ago I inquired carefully of the authorities whether in that apparently excessively subdivided district of Germany, the South-west, absolutely no buying up of small properties by the big purse had taken place. And the answer given was that there was only one such instance known. The late Naier von Rothschild had, with his millionaire purse, bought up about 400 acres of land!

It may appear strange that in the policy of the partitioning of land our country and the Continent should have proceeded on such diametrically opposed lines. We had a host of small freehold owners once-in the times of " Nerrie 
England." "Sweet Auburn" was peopled and happy. Abroad grasping feudalism quickly asserted itself. Nulle tcrre sans seigneur rapidly became the rule. From the far East, where the "kniaz" was lord, to the West, where the peasant-as we older men remember from a book very popular in our childhood ("The Peasant and the Prince ") -was made to whip the ponds at night to keep the frogs from disturbing the slumbers of the dwellers in the chateau, the squire was king, the peasants were helots. But on the other side of the Channel and of the North Sea the progress of events absolutely turned the tables. Il n'y a plus de marquis ; il n'y a plus de "de" : il n'y a phus de "saint" ; il n'y a plus de Sire (Cyr). The verdict of the Revolution, which left the Marquis de Saint Cyr nameless claimed its own upon the land and turned ancion régime rural France into the most subdivided, and at the same time the most democratic community in the world. All the samebarring German invasions -it is "la Belle France" still, as merry and cheerful as in the days when Sterne mingled in dance and merriment with its happy peasantry in sunny Languedoc. In Germany a considerable portion of the large estates formed under feudal rule have been cut up into small properties. Until Government interfered with its Home Colonisation scheme, the thing was done in a distinctly mischievous fleecing sort of way. Agriculturally speaking, much harm was done. The estate knacker had no more mercy than the proverbial French sapeur, cutting out the best bits of the property and spoiling many a farm. However in spite of all this there is no gainsaying the fact that the multiplication of holdings, however un-Trypherian may have been the carving out of them, has economically as well as socially benefited the district and the country. I can speak of this feelingly. For my whilom property had been a victim to the knacker's knife-and that knacker one of the most ruthless and inconsiderate of his class. Pieces of land had been sold off that I should have been most happy to repossess myself of had they been in the market-even at a higher price. However, in spite of this damage done to the big farm, the people of the community 
were undoubtedly the better for the operation, and the land, as divided, yielded more produce as well as more happiness. In the south-western corner of Germany, which was the first part of the country to be civilised-Cæsar and Tacitus knew nothing about "Prussia" and "Saxony," which were not "Germany" in their days-the "mailed fist" of the manor has never fastened its choking grip) upon peasant holdings, which are there as old as civilisation. In France mischievous Malthusianism, restricting the family to two children, prevents excessive " pulverisation." There are not many to put forth fresh claims for land. The propriétaire is careful to keep his property intact, as well as his family small. But even there the Government has judged it right to create facilities-by means of advances of money on easy terms (by the law of IgIo)-to very small people-farm servants, landless labourers and very small landowners anxious to increase their holdings-for acquiring new parcels of land. And the measure, due to the initiative of M. Decharme, the devoted Director of the Crédit Agricolc, has proved one of the most successful and most popularly welcomed operations affecting the land ever taken in hand. In Italy, Roumania, and Serbia co-operative tenancy societies, formed independently but subsequently encouraged by their several Governments, have done all in their power to create independent small holdings. (It is interesting to note that such practice of co-operative land-holding-for reclamation-has already spread into Burma.) The success, more particularly in poverty-stricken Sicily-but there has been good success also in Emilia and in other parts of Italy-has been remarkable. Everywhere on the Continent-for Spain, too, is moving in the same direction--the tendency has been since many ages to divide the land and people it with small cultivating folk. Rendered wise by experience, legislators have rebelled against and reversed the disastrous policy of Rome, complained of by Pliny, of thinking-as we seem to be disposed to do at the present moment - in his words, " more of wheat than of men." And, men being raised, there has been a systematic push upward, reaching 
down to the lowest grades. And hence not only those scenes of life and gaiety which we admire and sometimes envy, that romance of garden-like fields and trees festooned with vines, but also a richer yield from Mother Earth. And the further such principle was carried into effect the better has it been held that the national interest has been served.

In our country, and in it alone, the reverse movement has taken place. Like Naomi, our rural population "went out full and returned empty." The big purse bought up everything. Field was laid to field-first to produce food for sheep, which in their turn were to produce our whilom staple commodity of wool; then to ensure show, influence and social and political power. As in ancient Rome, which perished by its latifundia, there was a thirst to be numbered among the potentiores, the principes loci, who alone had a voice in the direction of affairs. And that position was, as in Rome, dependent upon the possession of land. Human nature, as we see, does not change much with the march of ages. Once the bulk of our Commons had becn absorbed by the Manor, by means of Enclosure, what appears to have proved the death-blow had been dealt to independent small cultivation. The countryside wasted away ; country life grew dull; population became sparse and labour scarcc. Wasteful as the established utilisation of Commons was, to the small folk in the country and to the Nation, Commons represented far more than a purely social benefit, or a picturesque feature in rural life. There was economic good in this piece of antiquity, a possibility given to the labouring man to maintain an independent, self-reliant life, and a method of keeping the peasantry attached to the soil. Look at Switzerland with its Allmend and its Alpage in the present day, to see what the Common means to the rural population! That same Allmend is becoming a powerful factor in rural life, as in part rehabilitating the discarded "Common." We cannot, of course, hope, or even desire, to re-establish the Common precisely as it was. There was great waste in it, and it would be out of keeping with the present age. However common land, more specifically for purposes of pasture, as in Alpagc, is felt to 
be greatly needed. The old abuses of overstocking and of " thrusting with side and with shoulder," on the part of the strong, and of bad management, may be effectually guarded against. On his Maulden settlement Mrr. Prothero has advisedly introduced a common pasture. In Germany common pastures are now being provided by means of Co-operation. And in Italy there is a strong movement in favour of Demani collettivi, of which, among other leading men, the late Prime Minister, Signor Tittoni, is a spirited advocate. The Common gone, the independently owned cottage was bound to go too, and with the cottage also the sturdy independence, the manly freedom and the trustful confidence of the rural labouring citizen, who, after feeling that he was an integral, fully righted factor in the body politic, fit to meet his employer-if he had one-without having to tell himself that the other was his master, upon whose favour his miserable livelihood depended, sank down to the position of a mere helot. The change has not been a change for the better in its effect either upon the small man or upon the Nation, nor upon the employer either.

Quite of late a new tendency of feeling has set in, revealing the discovery made in the public mind that such agglomerating, all-engrossing policy has from a national point of view proved a mistake. The effervescence of satisfaction at the conquest gained by enclosure being spent, the Nation has awakened to the painful discernment of the sober truth of the want of labour, and dullness and misery prevailing among the changed rural community. That defect, so it is realised, must be corrected, as Lord Selborne has put it, when Minister of Agriculture, almost at all costs. " There is nothing so urgent as an increase of the number of the people living on the rural land of England." People have been clamouring for small holdings ever since Mir. Jesse Collings upset a Conservative Government with his famous "Three Acres and a Cow." And with advancing time the movement has rather grown than lost in impetus. It began on one side of the political boundary. The active labours of the late Lord Ilkeston's Committee should not now be forgotten. However, the promotion of a Small Holdings 
policy has long since ceased to be a distinctive "plank" in either political platform. Rather has it conquered for itself a recognised place on either side. Both political parties alike now evince equal eagerness in the pursuit of the desired aim. And if there is one point of disagreement severing the serried host into two sections, the line of severance by no means coincides with the political dividing line. The demand for ownership rather than tenancy is not a Conservative monopoly. It would be too much to say that the entire Nation is convinced of the desirableness of a great change in our rural policy. But there certainly is steam enough at the back of the section championing small holdings to carry such policy farther forward.

However thus far, so it must be admitted, not very much of that which was asked for has been actually accomplished. We have bungled, as we usually do, not taking bold views, but advancing timidly and sticking to half-measures. We have had two Acts, but only a paltry output of results. For the time the war with all its many demands upon public money and public attention has put a stop to all further progress. We had, up to December 3I, I9I4, created a certain number of small holdings- $\mathrm{I}_{4}, 085$ in all, including I, 458 let to societies. But neither was that at all enough, nor did it really, so far as it went, achieve the object which had been laboured for, namely, that of " repeopling the land." For the number mentioned represented as good as no new homes set up. A certain number of small folk, being already housed, had obtained land which one may hope that they will be able to turn to good account. That certainly is a gain. But the rural population has not been increased, nor yet much altered in its complexion. And the number of bona-fide labourers whose feet had been so planted upon the first rung of the much-talked-of " ladder " cannot have been large.

Among the causes accounting for the meagreness of the result one is, of course, that the British Ethiopian is not given to readily changing his skin, which out of respect for our Cappadocian patron saint appears to have preserved peculiar hardness. The old policy has become ingrained 
in him. It seemed so much a decree of Nature that things should be as they were, that natural torpor and inertia blocked the way to progress. There was also the familiar "lion in the way." Landlords might or might not object to the new policy. Some did not; more did. The thing was so new and they were by nature so opposed to change of any sort! The creation of small holdings would make the country bright and add new votes to "our side" whichever side that might be. People in the country think of this. Have we not still "Tory Terrace" in old Lewes as a memorial of the attempt to create new faggot votes - on the very eve, as it happened, of the abolition of faggot votes? But it would upset the established order of things, cause trouble, disturb and annoy the farmers already settled, and cost money. For if there were to bc small holdings, there must also be additional buildings upon them. And money is what not every landlord has at his ready disposal. However not a few landlords, including men of the very old school, detected clearly how the change proposed would benefit their estate and also public welfare. And they have owned themselves satisfied with the results obtained. Where the small should-be tenants held back for want of cash, I have even been asked to "go down" and "form a credit bank for them," which request I clearly could not comply with, since it is the beneficiaries themselves who necessarily will have to "form" their own bank.

There is not the slightest ground for setting such indisposition as has prevailed among landlords down to selfish motives. These men may not have discerned, as some of their brethren did, how much the change would benefit themselves. Those who have discerned it, have profited by it and now receive more money and that more punctually. However, the cause of small holdings labours under this disadvantage, that experiments have already been made -on wrong lines-and have accordingly proved disappointing. So it has become a settled belief among the older school of our landlords that small holders cannot make their holdings pay. 
Farmers as a class are decidedly opposed to the innovation. No "Othello" yet has been content to see "his occupation gone." But farmers apprehended worse. They were honestly afraid that the best pieces, what is called " the heart," would be cut out of their holdings, in order that it might be given to the new public favourite, about whose capacity to work the land they quite naturally had their doubts. Using "wood," as the French proverb has it, of all sorts for manufacturing darts to shoot at the new foe, they proclaimed-even before the war drove the fancy for wheat growing up to fever point-that wheat was what we mainly want in our agriculture, and that small holders could not possibly compete with large ones in the production of wheat. The experience of France and Germany, both of them countries pre-eminently of small holdings, but the only ones among countries possessing a considerable industrial development which have reached a point very near that ideal one of producing all the bread corn required for their population within their own borders, and one of which boasts a distinctly better average yield of corn per acre than ourselves, does not appear altogether to bear this out. I myself have seen in Germany peasants' corn, the heavier yield of which was expressly accounted for by the fact that it was peasants'.

However, that was a minor point, which it is needless to contest. In any case farmers were hostile. So here was a decided obstacle in the way.

In the next place we cannot be said to have been particularly happy in the choice of our machinery for creating small holdings. In this respect we have a lesson to learn from our present enemy, Prussia. She has managed her own home colonisation on decidedly better lines. We have committed the task of the creation of small holdings in the main to bodies upon which the opponents of such policy are strongly represented, and the class of the intended beneficiaries are not-to bodies, also, which have many other things to occupy their attention. Some of these bodies, no doubt, recognising the national interest involved, have buckled to their task in good earnest. However, they 
form a decided minority. And even to honest groodwill there are so many difficulties in the way, that progress cannot be rapid. Is land to be purchased "on the chance" ? Or are applicants to be made to wait, as we do in the lift of a Tube, till there are a sufficient number to satisfy? There is more than this. And then there is the question of money. In the first stages of the operation of the measure, Small Holdings Commissioners were greatly astonished at the amount of money produced in ringing cash by some applicants-to all appearance bona-fide agricultural labourers-for full-sized holdings. It appears to have been inferred from this that money was plentiful in all applicants' pockets. But this is distinctly not the case. And when it came to be understood that, like the man of the anecdote, who "of his great bounty built this bridge at the expense of the County," the County Councils were going to grant leases of land of which the lessee was to pay for the freehold rights, which in their turn were to be retained by the County Council-leases being for short terms only, without even a guarantee given to the tenant for renewal-applicants and their friends came distinctly to " smell a rat," and their ardour cooled considerably. The scheme was too little considered, and experience collected was too little taken to heart. We have been used to measures for purchase-like Lord Chaplin's Act - under which the new settler is expected to pay down twenty per cent. of the purchase price, and which for that very reason have failed to prove successful. How the thing may be successfully managed has since been shown on the Duke of Bedford's estate at Maulden, where the offer of freehold holdings attracted veritable hosts of applicants and not a penny has been lost to the vendor.

There is at least one further reason accounting for our disappointment. Those of us who wish to see small holdings established cry out for them in lusty chorus. But we are not in any wise agreed among ourselves as to what it precisely is that each of us wants. So we drift this way and that, and at times, like Jason's warriors in Colchis, fall a-fighting among ourselves. One evidence of this is 
seen in the controversy which has grown rather keen on a point which can scarcely be held to possess all the importance which has been attributed to it, namely, the question of ownership or tenancy. We have become so much accustomed to the practice of tenancy that it has come to appear to us as natural that a cultivating farmer must be a tenant. But it is just this universal application of tenancy, for a great part under inconvenient covenants, which differentiates our system of Agriculture so strikingly from that of continental countries which have at present better results to show. The point will call for fuller consideration. At present we are concerned only with the existence of a marked difference of opinion. The Land Nationalisers, whose influence goes beyond the bounds of their party proper, naturally see their chance in the Small Holdings movement, and hope by insisting upon tenancy only to bring the day nearer when State ownership can be effectively established. In this view they may be right or wrong. According to Nero's theory, who wished that humanity had only one neck to operate upon with his executioner's axe, the present paucity of landowners, with a distinctly anti-democratic character signalising their existence, and not too much public opinion in favour of their monopoly, would appear prima facie the ideal condition for Land Nationalisers to deal with. It is scarcely likely that the County Councils, becoming large landowners, will incline to the side of Nationalisation. However, amid the existing conflict and confusion of opinion not a little consideration has had to be taken, and tender toes which might prove recalcitrant, have had to be spared. Also an idea has curiously spread among Liberals that tenancy is the Liberal solution of the problem and ownership the Conservative. This is about as wrong as anything could be. It is tenancy which keeps men in subjection and hinders their free action. Ownership is the rural Reform Act. The French small propriétaire is conservative in this sense that he dislikes revolution. But he is neither royalist nor imperialist, but genuinely republican. The Swiss small owner, one of the class who, on political grounds, filled Freeman with liber homo admiration, 
is certainly strongly Liberal, though conservative in the non-political sense. And in Germany it is just those parts in which small ownership is largely represented which are the most Liberal, the most free in the formation and utterance of their opinions, and the most independent in their ideas. In I 848 and I 849 it took only a few days to squash revolution in Berlin and Dresden. It took an entire campaign under the leadership of the late Emperor William to stifle it in Baden. There are people who connect small holdings with the "ladder," and would carry that well down, by the creation of even diminutive holdings-among larger ones-to the very ground. The Roman heredium, considered large enough to occupy and support one family, contained only one acre and a quarter. There are other people-the party at the present moment apparently predominating - who would create only holdings big enough to support a family doing all or nearly all the work of its cultivation, but nothing more.

Then there are would-be reformers who appear scarcely familiar with rural conditions. In their view the conditions under which a rural cultivator works correspond exactly to those of an industrial working man or small jobbing tradesman in a town, who can walk into the workshop to-day, do his work, and go out a year hence or at any time, having all his gains to the last penny in his pocket and leaving the workshop just as he found it. There are agricultural men, no doubt, who under appropriate conditions can act in something like that way-make the most of a small holding till they are in a position to move to a larger and so, in course of time, to become wealthy, by changing from place to place. And very useful men such competent cultivators are. However, most of those whom it is now desired and seems desirable to attract see in their proposed holding very much more than a mere temporary workshop. They see in it an abiding home, to be perfected and embellished bit by bit, by their labour, to become dear to their children and go down to those children ; and they also see in it a savings bank, into which all spare efforts and spare pence at their disposal may be put, with a certainty of 
being repaid, "with usury," but not at any time. Those deposits take a. long time maturing; and to abandon the holding beforc they have matured is likely to mean leaving them unrepaid.

With aims and objects going so far apart, it is not surprising that our rather halting and timid measure, designed to be worked with an apparatus which results have shown to be not particularly well suited to the task, should have produced only very moderate results. We show the sense of our disappointment experienced by deciding to take advantage of the war to gain results from our land, enlisting discharged soldiers for the work of "repeopling the land" and carrying on small agriculture, towards the achievement of which two objects our canvassing among the civil population has effected so very little. One could wish that there were a more assured prospect of such proposed policy succeeding. However, ever since the Emperor Probus set his legionaries to work tilling the soil-with rather melancholy consequence to himself-examples have been against such sanguine presumption. Soldiers do not generally take kindly to farming or exhibit particular proficiency in it. The whole Roman history of military settlement is a history of failures. The soldiers' colonies founded by Sylla in Preneste lost all their population within twenty years. The land which Cæesar assigned to his victorious warriors in Campania soon became deserted. The military colonies founded by Augustus fared no better. And the "three jugera" lots allotted to soldiers about Falerno were readily swallowed up into latifundia, their original allottees turning their backs upon them. The Emperor Constantine was no more fortunate in his military colonisation. The soldiers' settlement at Cremona, founded in 222 before Christ, with 6,000 veterans and their families as settlers, had to be wholly resettled in Igo, every one of the original settlers having disappeared. Soldiers' settlements present themselves as a charming picture to the imagination. But somehow Mars will not take enduringly to Ceres. There is insuperable incompatibility of temperament. Roman legionaries, so it was found, and so Professor Salvioli particu- 
larly testifies, settled gladly on conquered territory where they lield land as masters. But they would not settle down to a quiet country life in their own native land. "Les établisscments militaires," so he goes on, "sont toujours voués à la mort ou à unc vie misérable." In the present day it is notorious that in France there is no influence so potent for drawing away people from "La terre qui meurt" as soldiers' service, which makes those who have served settle in towns near their dear estaminets and other amusements and seek for some comfortable position as fonctionnaires. In Germany the continued growth of the population, not yet sufficiently Malthusianised, counteracts this effect. Besides, the "ladder " arrangement is in that country better organised really than anywhere else. Agriculture is a "career," which offers prizes. But service in the army is not found to be the very best preparative for hard-working agricultural country life. The uniform and barrack life suggest other things. The rather successful courses of agricultural lectures for soldiers, organised successively in Germany, France, Austria, and lately also in Italy, are distinctly intended, not to turn non-agriculturists in the army into agriculturists, but to prevent agriculturists becoming non-agriculturists through the influences of military life, which have been found to be strong in that direction. They constitute a defensive measure, a sort of substitute for agricultural college training, not a recruiting one.

Such examples as exist of men combining agricultural pursuits with military, as among the settlers in the whilom "Military Frontier" of Austria, or the Indelta of Sweden, both now improved out of existence, represent rather settlers who were agriculturists first and soldiers by necessity, holding under military tenure, paying a rent in the shape of militia or landwehr service, than soldiers settling down after completed military service, to agriculture. The late Mr. Arnold Forster brought home no particularly glowing account of prospects for settling discharged soldiers in South Africa, whither he had been sent to inquire into the matter. I had the benefit of his opinion privately expressed. Under such circumstances we had better be cautious in the 
hopes that we form of a success of our scheme. "Settling," so we shall do well to remember in the outburst of our kindly feeling towards our retiring warriors, is not the acceptance of a "living," or of the goodwill of a "going " business sure to yield an income, but the entering upon an undertaking which in unskilled hands is certain to miscarry.

In skilled hands it is pretty sure to turn out well. We have, very naturally, been led by the circumstances under which the subject has been brought forward, to regard the question of Small Holdings as pre-eminently a social question - such as indeed it is - that to a very great extent we have lost sight of the very important economic bearing which it has as a question of Agriculture. However, the agricultural side of the question yields very little indeed, if anything, in importance to the social. Upon the point of the agricultural value of Small Holdings all the world which has experience of it - which means practically the whole world with the sole exception of our own country-is completely at one. Small Holdings have brought wealth as well as happiness to the countries accepting them. The small holder's agriculture may not be scientifically as perfect as that of the large farmer. Most improvements in Agriculture have admittedly originated on large farms, or on farms occupied by owners. But the small holder's husbandry is superior in meticulous attention given to small things, in the results of the constant watchfulness, the minute care given to all operations by the cultivator. And naturally so. He has more direct interest in those apparent trifles. And he is in a position to overlook his farming continually, at all moments, and in every detail. He is a much better imitator of the up-to-date agriculturist than the medium farmer, having his wits about him and being continually on the alert. And where his proficiency as an imitator and an adopter of good novel practices is up to the mark, the result is apt to tell very much in his favour.

In the debate in the House of Commons on July Io, I9I6, Mr. Prothero, then not yet Minister of Agriculture, bore witness to the value of small holdings on agricultural grounds, stating that "his experience had convinced him that small 
holders were a very valuable part of the community. The small holder worked harder than the agricultural labourer. In many cases his income was not so large and more precarious. But for all that the condition of the small holder was happier than that of the agricultural labourer, because he worked on his own and called no man master. Small holdings fostered self-reliance, independence and initiative among men who probably would not develop those faculties if they spent all their lives in obeying orders. Besides that, a small holding was a ladder which often enabled its occupier to rise to the rank of farmer."

Just a week previously Lord Selborne had declared in the House of Lords that "there was nothing so urgent as the increase of the number of people living upon the land." By the side of the social aspect of the question, which no doubt is the most weighty, in this country the agricultural aspect is still comparatively neglected, because as yet we have but little experience of the system. In Germany, however, where small holding farming is of long standing, and has stood the test of long experience, the prevalence of small holding husbandry is set down as a very valuable asset indeed to national Agriculture. The nature of its produce is generally rather different from that of large holding husbandry. But it is nearly always larger. And that is not only because, as Mr. Prothero has rightly testified, the small holder works harder than the hired man of the larger farmer, but because, more especially where he is owner of his holding, he works with greater interest, with more brain power and with much less restriction as to hours than the larger farmer's paid man. If he does not precisely rival his negro brother of whom Mr. Booker Washington tells us, who, having lost his donkey, harnessed himself to the plough, of which his wife held the stilts, and dragged the share across his field in moonlight nights-in order not to incur the ridicule of his neighbours (he ended as a wealthy farmer)-he works early and late, at any hour when his interest calls upon him to do so-taking it out at other times. A high German agricultural authority, writing from Silesia, some years ago laid particular stress 
upon such utilisation of all hours at his own discretion. He takes advantage of every hour, every minute, of sunshine or rain. He steps out, when occasion requires, during his time of rest, to perform such or such little act of work which, trivial as it seems in itself, is of decisive importance for the saving or increasing of his produce, making the very most of his land. There is no gainsaying the German contention that small holdings, owned, make not only the happier and more prosperous, but also the more intelligent husbandman. The educating effect of small husbandry, which is a point of considerable national importance-since it means perfecting the large composite machine turning the Nation's land to account-has already been referred to under the head of "Labour." Mr. Wibberley with his great experience has laid it down that for occupying a new holding he would ever so much rather have the son of a small holder, who has become versed in all kinds of agricultural occupations, than the son of a labourer, who merely knows "father's job." A comparison between the large and small farming districts in Germany makes the difference alike in production and in intelligence in favour of the latter perfectly clear. There is much more progress. There is a quicker and prompter response to opportunities offering. There is greater alertness of mind. Also home trade fares by far the best where there is small ownership farming, which, as observed, is a weighty consideration. German statisticians furthermore will have it that in small holding districts longevity is greater. Thus in large-farming Pomerania and Posen the average length of life is fifty-six to fifty-eight years, whereas in small-farming Rhineland and Westphalia it is sixty-eight to sixty-nine. This appears to prove that, however much "harder" petty owners' work may be than paid labourers', it is not nearly as wearing. And the difference between the two districts is really greater than would appear from the figures quoted, inasmuch as Rhineland and Westphalia are strongly industrial provinces, whereas Pomerania and Posen are purely agricultural. Now Industry notoriously claims more victims by mortality than Agriculture, 
In practically all countries of the civilised Continent a deliberate policy of furthering the formation of Small Holdings, and multiplying such as much as is possible, is now being followed. To such policy, as to more others besides, it was Germany, and in Germany specifically Prussia, which by its methodical treatment of the matter gave the first impulse. It may accordingly not be altogether amiss at this point briefly to review what has within the last thirty years been accomplished in Prussia, under a very methodically pursued policy of home colonisation, which since I893 I have had under continued observation, paying repeated visits for the purpose to the operating centres and to the settlements. For, although of course in the two countries to be compared conditions differ materially, nevertheless what has been done abroad may teach us something.

The policy was begun on lines that we can do no other than heartily abominate, namely, a deliberate plan to depolonise Polish districts-inhabited, by the way, by very able cultivators, whom one of the official German colonisers, the late President Beutner, frankly declared to me that economically he preferred to Germans. The scheme was: with State money to buy up estates of large Polish landowners and settle them with German peasantry. That scheme has cost the State an enormous sum of money and proved, from the Government's political point of view, a dead failure. For the estates bought up were for the most part encumbered property, belonging to embarrassed owners, who were not sorry to sell, especially as the price which had to be offered was good-not a few of them with a view to setting up afresh on less encumbered lines elsewhere. The State being the directly operating party, buying up with its own cash-as Mr. Jesse Collings in his scheme proposed that the State should do among ourselves-could not-as the President of the Prussian Colonising Commission of the time, the late Herr von Wittenburg, explained to me-do otherwise than offer handsome prices as well as pay for everything else connected with the matter " througl the nose." The newly created holdings proved comfortable 
enough and remunerative enough to the settlers-but at a long price to the State. And the main point was not achieved. The Poles did not become Germans, but rather did the incoming Germans to a considerable number become Poles. For the single men among them married Polish wives, and it is the mother who determines the nationality of the family. Those who were married already had of necessity to accommodate themselves more or less to their surroundings. And the Poles soon managed to set up colonising societies of their own which-as I have seen for myselfproved to be exceedingly well organised and well supported, and accordingly resulted in success, without State countenance.

To such an extent the settlement scheme failed. But it was found that, although the gold obtained in the result had been paid for too dearly, still gold there was in it. Deserts had been converted into smiling, thriving villages, with fruitful fields spread out around them. Agriculture prospered. There were more taxes, more recruits, more ample crops and produce of every kind, more happiness.

That made the Government bethink itself of the existence of a long disused institution, originally created under Stein and Hardenberg at the time of the enfranchisement of the Prussian peasantry, enabling purchasers of certain descriptions of land to operate with very little cash, through the intervention of the State, given, not in the shape of ringing coin but of instruments of credit. In approved cases the public Rentenbank pays vendors in terminating land bonds, for which the State makes itself liable, running for a very long time, so as to make repayment cheap by sinking fund, and issued at a moderate rate of interest either of 4 or of $4 \frac{1}{2}$ per cent.

With the aid of the "General Commissions" appointed for certain districts - each as a rule for two provinces and assisted by local "Special Commissioners" working under them-this Rentenbank carries on the home colonisation aimed at with very good result. The State, while not assisting with money, interferes very effectively with very carefully conducted supervision. It does not itself colonise. 
It is for the vendor of a property to find purchasers. $\mathrm{He}$ knows best the object with which he is dealing and the people concerned in the matter. It is for him to prepare a scheme of partition of his property, agreeing as to terms with the intending purchasers. There must be purchase. The Germans do not believe in tenancy. They will not have it. Even when I spoke to them of our excellent "Tenant Co-operators" for this purpose, under whose scheme a block of land is purchased collectively, to be let severally in plots, they would not listen to my argument. Under its depolonising scheme, the Government has had to put up with some exceptional letting-very much à contrecœur, as President von Wittenburg admitted to me-simply to proceed with their main aim. The land had been bought and, for want of suitable applicants for purchase, peculiarly conditioned pieces must be disposed of to tenants. Elsewhere, in Germany too, the letting of small holdings had a bad name. The rents paid are made excessive. In Yorkshire I have found small holders renting at $£ 2$ an acre (it had been $f 3$ ) land which had previously been let to a large tenant at Igs. and had not answered. In Southwestern Germany I met with worse cases. I have official authority for saying that plots whose real value was about 48 s. per acre were let at $£ \delta$ to $f$ II per acre. And Dr. Buchenberger, then at the head of the Agricultural Department in Baden, did not hesitate to stigmatise letting of small holdings as "legalised usury" (on account of the excessive rent demanded). Under the "General Commissions " partition is invariably carried out by purchase. The intending vendor is expected to submit his "plan" to the " Commission " of his district, by whom it is carefully scrutinised and dissected. As a rule it is amended at points, in the purchasers' interest. For the Government is determined to enable settlers to make a good start, on a holding well capable of sustaining them-what the French call "viable." It has no procrustean rules as to size or buildings. The settler is to please himself. Indeed, the Government often prefer to see the settler setting up his own buildings in his own way and according to his own ideas, 


\section{THE FUTURE OF OUR AGRICULTURE.}

and is ready to assist him with extra credit for the purpose. Such credit is possible because there is new value to pledge. There are settlers who have begun settling, lodging only in a disused railway car while the house was slowly building. But the holding must be compact, drained, well accessible by a good road, with good water and all else, and a full harvest stored in the barn, to help the newcomer over the first year. Of late the State has provided additional adjuncts, such as a little orchard with selected fruit trees in it. It is these extra luxuries which have led it to put its hand in its pocket and spend about $f_{2} 5$, not to be recovered, on each holding. Previously, under good management incomings and outgoings balanced. In certain cases now, more particularly if the settlement takes place in a Polish district, even a larger sum is spent, not to be recovered.

The "Commission" looking after the settlers' interest means that the vendor not infrequently has to incur some additional expense, or else disgorge some of the promised money. In I894 I found, while visiting one of these settlements in company with President Metz, that the vendor had been made to give up about $f_{I}, 000$ of the sum that the purchasers had already agreed to pay-subject of course to the "Commission's" approval. For all that landowners willing to sell are very glad to avail themselves of the services of the "Commission," taking the price in guaranteed land bonds running for a long time-optionally for $56{ }^{1}, 2$ and $60 \frac{1}{2}$ years-according to the rate of interest agreed upon, up to three-fourths of the value of the property. In respect of the remaining fourth vendors are at liberty to arrange with the purchasers, who according to the governing idea ought to pay it down in cash. Often enough, however, they pay only part of the sum, the vendor debiting them with the balance. Or else the vendor will find private capitalists to take up the amount as a second mortgage. Where there are co-operative credit banks the difficulty about the last fourth is - in the case of settlers with a good character-readily got over by means of personal credit. That has been done on a comparatively large scale, without difficulty and with excellent results, in Prussian Poland, 
where there are admirable co-operative credit societies of the Schulze Delitzsch type, working in the matter in concert with Polish settlement societies. The Poles make first-rate co-operators and as a matter of course co-operate willingly among themselves in the nationalist interest. One of these societies, at Pischin, some years ago finally wound up its affairs after a comparatively brief working period, because the whole of its intended business had been completed, the settlers having paid up their money to the last penny before the time fixed. And the balance sheet was in excellent order. For such settlement the Poles-Poles though they are-are, by a recognition made in a favourable moment, entitled under Rentenbank legislation to receive three-fourths of the purchase price in land bonds. The balance being obtained on personal security from their co-operative banks, the thing now goes on swimmingly.

Vendors, as observed, readily have recourse to the intervention of a "General Commision," because by selling through it in lots they obtain in any case a higher price than they would if selling the estate undivided. And all the trouble of legal business, surveying and the like, is taken off their hands by the Commission at a purely nominal charge. The bonds issued under Government guarantee are as good value as 4 and $4 \frac{1}{2}$ bonds can be. When money is raised by the Government at 6 per cent. and more, of course they are quoted below par. But before the war they held their own well.

In this way a large number of settlements have been established-in compact communities, forming new villages, with a school in every one of them and a church where such was thought to be required. By this time something like a million acres ${ }^{1}$ have been so settled. As a result the face of the country operated in has been completely changed -changed for the better, having life, prosperity, contentment and population brought into it. Where there were twenty or thirty families there are now I30 or I40. Where

2 In IgIt the official figure for settlements formed under the Rentenbank system alone was about 500,000 acres. Other institutions are responsible for the balance. 
there were fifty cows there are now 200; other live stock in proportion. ${ }^{1}$ And the old barns would not hold a tithe of the produce now raised. The productive power of the districts concerned has greatly increased. And the general aspect of things has as greatly improved. Such settlement has decidedly proved a success.

One of the pre-eminently satisfactory effects of small holdings observed elsewhere is, indeed, not to be seen in these particular settlements, for the very plain reason that they were formed, so to speak, in vacuo, on previously scarcely inhabited spots, removed from populous places. For this reason they were formed of varying, but on the whole of a fairly good size, so as to make every holding self-sufficient. Even so, after a time it was found necessary to come down from the high scale to one of smaller settlements designed for persons who had other employment-wherever there was such employment. Thus I found a settlement near Bromberg, intended for railway men, composed of holdings of about $3 \frac{1}{2}$ acres each. That is not nearly as small as holdings are to be met with in Western Germany, where they shade off gradually to mere allotments. Now, judged from a genuincly democratic point of view, combination of agriculture with other employment, whether it be home trade or salaried employment elsewhere in an industrial establishment, is in truth an ideal combination of conditions. For, on the holding itself, much of the produce of which presumably goes to feed the holder and his family, it combines the two great essentials of good business-the cheapest possible production with the dearest disposal at the ultimate market of consumption. Production on the spot is cheap because the labour bestowed can scarcely be put down at any value, being, to a good extent, moreover, merely healthy recreation.

1 On one property the population of 320 increased at a bound to 45: : the number of horses kept went up from 40 to 150 ; the number of cattle from 80 to 400 ; the number of pigs from 100 to 920. For another property the corresponding figures are : $28 \mathrm{I}$ and $307 ; 30$ and $125 ; 80$ and $360 ; 200$ and 1,200 . For a third: 152 and $452 ; 60$ and $100 ; 230$ and 452 ; 126 and 1,102 . 
There is much of such combination of callings in Germany, and the country benefits by it very visibly-whereas, on the other hand, in spite of strenuous Government efforts to develop them and make them prosperous, so-called "cottage industries" steadily yield ground. There is also some in France, where a society, of which the wellknown Abbé Lemire is a prominent member, has effected much relief of poverty by means of Jardins Ouvriers, which indeed begin on the allotment scale, but generating a real interest in and devotion to the work done, lead up automatically to the small holding stage. The idea took birth in the brain of a lady, Madame Hervieu of Sedan, who alone has over 40,000 persons to thank her for a welcome rise given them in life. Instead of helping poor people with money, she would rather afford them an opportunity of helping themselves by labour in the garden or on the land.

This is to some extent on the same lines as the assistance given by means of "Field gardens," by the "Society for the Bettering of the Condition of the Poor," which was formed in this country in I776. Madame Hervieu hired plots of land for them and assisted them with tools, seed, and the like. The result was most satisfactory. Accordingly a society was formed to extend the practice. And other societies in other parts of France have been formed in imitation of hers, doing the same work, philanthropic men and women providing whatever is wanted for the first start. And wherever this system has been put to the test in France it has yielded the same excellent results, turning idlers into good workmen and generating in them a new zeal for industry. We are talking of planting forests out in mountainous districts, with little settlements close by, to provide homes for the people required for the necessary forest work. How well those two occupations may blend may be seen in Major Poore's settlement in Winterslow in Wiltshire, where his "landholder" settlers thrive particularly well, just because they have occupation in the Baring woods to depend upon as a second string to their bow. 
Encouraged by the success of the Government's operations in this matter in Germany societies and public companies, as well as private individuals, have taken up the same work, generally speaking with marked success. Whenever the task has fallen to the share of private individuals, of course, there was a danger of the professedly good and humanitarian work being exploited for "filthy lucre" or else for political purposes. There is such a wide margin between the cost price of the land in a block and its value for productive purposes in small holdings that a very fair toll may reasonably be taken. Where this is not done, funds accumulate with unexpected rapidity. There is a settlement formed in Prussian Saxony, at Steesow, by the late Herr Sombart. He took no profit whatever for himself, and in consequence the settlers were soon found to be so well off that over-prosperity tempted some of them into improvidence and mischief, and there was trouble. Once more, Major Poore, who likewise of course disdained profit for himself, found that on his small settlement in Wiltshire soon a very respectable surplus was accuniulated for the common benefit. It is a long time since he reported it to me as $£ 600$. The entire property extends only over II2 acres. Germany is the chosen hunting ground for professional estate dissecters. Accordingly not a little settlement work with a money-grabbing object has been undertaken there. But even under such conditions, selfish greed notwithstanding, good may be done. President Metz told me of one estate divider, a Jew too, who in the district of Colberg in Pomerania made a business of cutting up properties at a profit, but at the same time looked after his settlers "like a father," assisting them with advice and with other services, even with loans. His reward was, that he never made a bad debt and never had to proceed to foreclosure. He " colonised" tens of thousands of acres and by his action turned the tide of emigration in his district against itself, the population actually increasing at a time when everywhere else in Pomerania it went down. Nevertheless estate knacking has a bad name. And to meet it, here and there societies-some of them co-operative 
or quasi-co-operative-as well as Joint Stock companies, have come into the field. There are several societies in the eastern provinces professing exceedingly altruistic objects, but working, as is generally known, for the crowding out of Polish husbandmen by Germans. ${ }^{1}$ But there are also some genuinely humanitarian societies, which take a moderate profit, but provide equitably for their settlers. The largest of these bodies-whose programme is similar to what is known among ourselves as "philanthropycum-five-per-cent." -is the Joint Stock company Die Landbank, of Berlin, which works with $£ 2,000,000$ of money, half raised by shares, the other half by debentures. ${ }^{1}$ The real profit-yielding business of this company consists in the buying up of neglected estates and improving them thoroughly, after which they will resell bodily, as undivided properties, at a considerable advance, having been made worth so much more. But at the same time the company also cuts up properties suitable for the purpose into small holdings and disposes of them at a moderate profit to small folk under the surveillance of the "Commission " already mentioned, whose help in respect of land bonds is of course in all such cases resorted to as far as is practicable, on the ground of the advantageousness of its terms.

Naturally it could not be suggested that in shaping our own Small Holdings policy we should at all points follow the Prussian precedent. Our adoption, for instance, of one main point, that is, the vendor being expected to find the purchasers and propose a "plan," does not appear altogether to fall in with our accustomed usages. On this point, however, we might to some extent learn a lesson from Italy, Serbia and Roumania. There it is not the vendor who seeks out the purchasers and marshals them in the formation of the "plan"-indeed operations take the shape there of renting, not buying, according to the estab-

1 Some of these, I am sorry to say, have recently been " cracked up " in the British review Press, on the strength of their professions.

2 I have given particulars of the working of this scheme in an article which appeared in the Economic Review of April, I9I2: "Small Holdings and Land Banks." 
lished Jabit of those countries-but the would-be settlers, who under able guidance-at the supreme head of which in Italy now stands the highly meritorious Societa Umanitavia of Milan, whose Director of the particular Section, Signor Samoggia, is peculiarly fitted for the work-organise themselves in co-operative societies for the collective renting of a largish property, which they lay out in small holdings according to their requirements.

Italy is in this matter particularly active-and successfully so. The very public-spirited Societa Umanitaria of Milan, liberally endowed as it is with funds by the benevolence of a wealthy philanthropic Jew, who left it practically his whole substantial estate, and ably officered, has taken up the task of promoting collective co-operative holdings with great energy. Its beneficent action is, as a matter of course, in the main confined to Northern Italy, where it has already produced much good work. However, it is not only co-operative societies that are active in the matter. The public generally appears to be impressed with the conviction that in the creation of small holdings, arrayed in groups so as to enable the holders to act together in all thingsnot in renting, buying and selling only--lies the salvation of generally backward Italian Agriculture. More in particular do Italians hope for the long delayed reclamation and utilisation of the long neglected, dismally barren Agro Romano by such means. Under recent legislation the Government is armed with ample powers for expropriating land of neglectful territorial magnates. And, although it does not employ those powers solely in favour of collective settlements, yet it decidedly favours such. There is a special Department now in the Ministry of Agriculture to take charge of this matter. Among other things such organisation is designed to provide for security of tenure for tenants, which is now distressingly wanting on the latifundia, where the bid of a few lire more will dispose the landlord to give notice to his tenant, who, with such sword of Damocles perpetually dangling over his head, cannot possibly throw much energy, labour, or outlay (his own or borrowed) into the improvement of his holding. 
Apart from the movement for the creation of Dcmani Collcttivi, which incidentally occupies itself with such work, there are several influential public-spirited societies at work, such as the Istituto di Fondi Rustici of Rome, and the Socictà por la Bonifica dci Tcrreni Forrarcsi, of Turin and Ferrara. But there are also other societies moving. And there are wealthy individuals who make the creation of small holdings their pet task. The Ferrareses society has, among other things, reclaimed and successfully "settled" an entire district, in its country, which forty years ago was a hopelessly unprofitable lagoon. In the whilom "Forest" of Montello 4,500 acres of waste have been made to provide settlements for about a thousand families. The small settlement movement is particularly active and successful in Sicily, where need was greatest and where the Credito Agrario, endowed by the State and by public financial institutions, renders ready and substantial financial aid, practising, however, before parting with its money-and also afterwards-very careful and searching supervision, so as to make sure that the money goes into the right pocket and is employed in the right way. So large have the operations of the Credito in this particular work become that the institution has had to create a special Department (Ispettorato) to carry it on. Otherwise, as already stated, co-operative land renting is most largely practised among the socialist peasantry of Emilia. Unfortunately there are no statistics to quote in respect of Italy, the statistical inquiry formally ordered to be carried out by the Lega Nazionale Co-operativa as long ago as in roI2 not yet having been completed, by reason of the war.

Statistics are likewise unobtainable in respect of Serbia, where, under the guidance of the Agricultural Co-operative Union, and its energetic Secretary, M. Michael Avramovitch, the promotion of co-operative settlements was before the war most vigorously prosecuted, with very promising results.

Roumania in I 909 numbered 275 such societies, occupying 276,302 acres of land at a collective rent of $£ 232,980$, the movement having begun only in 1903. Italy a year later numbered about 200 societies, occupying a considerable 
area, the extent of which I cannot tell, since a report long promised has been delayed in the process of publication for some years already. We have something of the same sort, on a very small scale, already in this country since a few years-in Wiltshire, in Northamptonshire, and elsewhere. However, Co-operation there does not go nearly as far as it does in the foreign countries named and is in the main restricted to collective leasing. The members of Italian affitanze collettive become co-operators for good and all. Some of their societies farm the land in common, after the fashion of Ralahine and Assington. The movement, like nearly all working men's movements in Italy, being under Socialist inspiration, the "collectivist" idea is, as a matter of course, strongly supported in them. However, practical considerations have militated against its practical adoption except in a minority of cases. But the settlers rent in common-of course at a great economy of rentand continue to act in common as co-operators, forming part of the great co-operative movement, although parcelling out the collective holding into distinct special holdings (a conduziona divisa), to be separately worked.

The policy pursued seems justified, among other things, by the experience gathered in this country and recorded in the Report of the Poor Law Commissioners of I833, to the effect that " Parish farms " had proved a failure, whereas "allotments" had proved a success.

There is no doubt that if we were to adopt similar means, adapted to our circumstances, whether for renting or for purchasing in common, to partition afterwards, according to demand, we might make things more convenient for the lessor or vendor, and cheaper as well as more convenient for the settlers.

One way of applying such idea is that shaped on $\mathrm{Mr}$. Vivian's method of "Tenant Co-operators," under which a society buys the land in common and then lets it in lots, liable to notice from the occupier, but not, so long as the terms agreed upon are observed, from the landlord, all overplus netted going into a common fund. Under such procedure the parts of offering and preparing a plan would 
of course be reversed in comparison with the German practice; but the underlying idea would be the same.

That detail, however, we may now place out of account. But it may be well to point out what are the main governing points in the Prussian scheme, which have contributed so much to its success. It will be for us then to consider to what extent we may do well to borrow from them.

The first is, that the allotting or partitioning authority is nominated for this one special purpose, with no other duties assigned to it, therefore absolutely no other considerations to interfere with its work. The Prussian "Commissions" are independent of ministerial Departments and, although they are directed to consult local authorities, they are not in any way bound by their advice or objections. Their one task is to see that small holdings suitably laid out and fitted out are provided for the settlers, whose interest, coinciding with that of the Nation, is their supreme care. They are thus placed in a very different position from our County Councils, which have plenty of other things to occupy their thoughts, such as are often enough allowed to take precedence of Small Holdings; also from officers of the Board of Agriculture, which is a political Department, and whose chief might be challenged in Parliament on party grounds for any exercise of his discretion. In the matter of adjusting terms of credit to distinct cases, however, a pretty wide latitude of discretion is indispensable. It does not follow that because " Smith" is allowed Government help, or Government credit beyond-in some cases considerably beyond-the settled limit, therefore "Brown" must in fairness be held entitled to the same consideration. But when a case comes to be challenged in Parliament, to the challenger "Brown", is as good a man as "Smith." The object pursued in Prussia is to make things as easy and convenient as possible-coming down almost to the Maulden level of "no money at all "-to incoming settlers found deserving of such confidence. But Tom is in this respect not necessarily equal to Harry.

Next, there is the very important point of the selection of settlers, which among ourselves-except by Mr. Prothero 
-appears to have passed altogether unheeded, but by which Prussian authorities, after considerable experience, set the greatest possible store. The question to be dealt with is not merely one of finance and credit. In this country we talk of small holdings settlers, as if any one could be planted upon practically any land and be expected to make a good living out of his settling. Indeed, in speaking of settling discharged soldiers on the land, we talk as if we were giving away something that must necessarily spell a living. Prussian authorities have not in their first carelessness gone quite that length of optimism. But they have been careless, and found that it will not pay. Since a considerable time already they will not accept a settler who cannot provide prima-facie evidence of his fitness for his new occupation. At the outset village schoolmasters were readily accepted as presumably well acquainted with country ways and in a fit condition to take to agriculture. However, on trial they failed and have accordingly as a class been placed upon the Index. Genuine town folk the Commissions will likewise not have. But they are glad to take country folk returning to rural pursuits after a period of town life. Their favourites are rural labourers and sons of peasants, that is, what we should term small yeomen. Such eclecticism is perfectly fair and called for. The Commissions are directed to see that the holding is so constituted as to promise to a fit working cultivator and his family a fair subsistence. Having employed their influence and the State's credit for that purpose, it is no more than proper that they should make sure that the human factor employed in the task is likewise fit and suitable. Selection of suitable men is the secret of Mr. Prothero's success in the Maulden experiment, in which purchasers were accepted who paid actually nothing down, but men also who, it was known, could be trusted for fitness and for honesty.

In the third place it is a governing point in the Prussian system that the State should, as already observed, intervene in the matter by careful supervision, charging itself with all the clerical and technical work required, but not-save 
in quite exceptional cases-by advances of money. It employs its credit instead. The Depolonising Commission operated with cash and lost heavily. Certain settling operations in India conducted on similiar lines, with money advanced, have likewise more or less failed. Mr. Jesse Collings's scheme, put forward some six or seven years ago, in which it was proposed that the State should pay the vendor in cash, was openly laughed at, on that very ground, by Prussian " old hands." The State's interference in the province of finance, so it was firmly held, must be limited to credit, made properly secure. Its taking over the legal and technical work facilitates arrangements exceedingly and the demand for restriction of financial interference by credit makes the exercise of patience--such as in the matter of repayment, is to the settler's interestconsiderably easier. We have in this country stickled for comparatively short terms for terminable rent charge. It is only a few years ago that we extended the period in certain cases to eighty years. In France, in respect of the small sums advanced for the acquisition of land under the measure of I9I0, the time is still limited to only twenty-five years. But then, in France, with its provident habits and its Malthusianism, the bas de laine, is a great institution, which provides money freely. In Italy people are content with a term of only twenty-three years.

Prussia began at once with $5^{6} \frac{1}{12}$ and $60 \frac{1}{2}$ years, according to the rate of sinking fund charged, which of course affects the allowable length of time. In truth, wherever the financial help given takes the shape of paper, there is no earthly reason why a very long time should not be permitted. For the critical period, if there is one, is the earliest stage, not the latest. The earliest stage passed, the purchaser has staked quite sufficient to make it his own interest not to make default. In the words of the late Herr Beutner, President of the "General Commission" in Posen and Western Prussia, "once a man stakes his all upon the venture, he is not likely to play me false." That remark applied to the case of a man who had put his life's savings of about $£ 60$ into his little holding. Add to this that the 
settlers themselves see the wisdom of being provident. In the Maulden settlement seventeen of the eighteen settlers took advantage of the option given them, to pay a higher rate of sinking fund than was strictly required under the scheme, during the first twenty years, in order to get the financial collar work as quickly as possible off their necks, and also to make the burden fall as much as possible upon their own shoulders and save their children's withers. In consideration of that they are afterwards allowed to pay less than the normal rate. No one will want to quarrel with this arrangement, which suits both parties. But it cannot be insisted upon by the vendor.

The experiment instituted has made it quite clear that so long as the vendor's interest is safeguarded, it is the best policy to make things easy for qualified settlers. You want people to settle. You select them-as we must now assume, on the ground of their fitness. You see that their holding is all that it should be. Both the human and the physical material being equal to the charge laid upon them, it is for you to further settlement by appropriate provision in finance. We have in previous legislation adopted hard and fast precepts which, instead of encouraging would-be settlers, have in truth frightened them off. Lord Chaplin had required twenty per cent. of money down. Our Public Works finance is troublesome and cumbrous. The Prussian authorities examine each case upon its own merits and make allowance accordingly. In deserving cases they are liberal. There is no fixed rule. However, I am advised that under certain conditions considerable concessions are made. The case of Polish settlers who receive the full remaining fourth of the purchase price on personal security from their co-operative banks has already been mentioned. That gives them considerably more latitude in the use of their own working capital, upon the sufficient presence of which everything depends. The same resource is of course open to people of other nationalities, who are members of co-operative credit societies and have good personal credit. It is on a par with what is done in housing by the General Savings Bank of Belgium, a very deserving institution, 
which advances to housing societies having a fixed capital (therefore not to co-operative societies) a full nine-tenths of the value of the property to be pledged-philanthropical people, who as a rule include in their number the officers of the very Savings Bank concerned, providing the remaining tenth as a separate credit. And in Hanover, so long as money was cheap, therefore up to shortly before the war, Councillor Liebrecht found that out of the large capital amassed under the Social Insurance business (mainly for Old Age Pensions) he could with confidence make advances to co-operative housing societies up to ninety-seven per cent. of the value of the object pledged. This was not done sneakingly, in disregard of existing regulations. It was the President of the Social Insurance Department, the late Dr. Bödicker, who commendingly first called my attention to the practice.

At Maulden Mr. Prothero has proceeded in principle on similar lines. By way of experiment he offered eighteen holdings of various sizes-ten of them over thirty acresof the Duke of Bedford's property for sale without money down. The number of applicants responding was 575 . Here then is convincing proof that small people are not, as is so often alleged, indifferent to the acquisition of small holdings, but on the contrary eager to become possessed, every one, of his own little farm, provided that terms are so arranged as to make them suit their small pockets. The soil at Maulden is good. The land was got into proper trim. A capital road was made to the holdings, the upkeep of which the County has charged itself with. The buildings were such as were required. Tithe had been redeemed. The holdings were priced at their full commercial value according to an impartial valuation, which charged for the cost of the road and the redemption of tithe. So there was nothing given. There are twenty-five acres of pasture attached to the eighteen holdings, held in common, overstocking upon them being guarded against. Absolutely no money was asked down. But five per cent of the value was made payable, to include sinking fund, for thirty-five years. Purchasers may, however, at their option, pay a 
higher rate up to the end of the first twenty years and after that proportionally less. Seventeen of them have, as already mentioned, selected this latter mode of payment. One of the eighteen went bankrupt. But the estate lost not a penny by his bankruptcy: There was another man ready, only too ready, to step into the bankrupt man's place, taking over all his liabilities.

Here we have a practical solution of the small holdings problem, which by its success disposes of all doubts and fears with which that problem has been hitherto thought to be surrounded, so as to bar progress. It shows not only that people are willing to buy, but also that, if you will only be careful to select none but fit men-which cannot be done by Whitehall red tape, in a mechanical way-you may with impunity be bold in your fitting of the transaction to the circumstances of the small buyers. The Maulden transaction was intended as a pioneer experiment to teach the Government how to proceed. The teacher in the case is now master of the situation. So one may hope to see past timidity laid aside and a bolder policy pursued.

There are still, however, various objections raised to the creation of small holdings, of which it will be well to take note.

The first is, that a small holdings policy is supposed not to be compatible with wheat growing, which for the moment is much too exclusively accepted as the test of good husbandry. For normal conditions it is a wrong test altogether. Farming is a business and its object must be, not to produce any one particular article, but, once the sea is open again and freed from the piracy of those who make the "freeing" of it a pretext for free brigandage, the greatest possible value per acre. That was Sir James Caird's advice. And from a national point of view, seeing how great trouble we sometimes have in dealing with the unemployed-in the teeth of the opinion long held among farmers-the requirement of much labour, giving employment to many people, is an advantage to it, and not a drawback. In normal times it will be best business to leave wheat growing to those who can grow it most cheaply- 
very much more cheaply than ourselves-and make the most of our land in the production of other crops and, as Mr. Wibberley rightly urges, of milk. German small holders " make hay" out of the production of industrial crops-not to speak of vines-which pay them so well that they are known to have held out in bad seasons much better than large farmers. Dr. Buchenberger, at the time at the head of the Agricultural Department of Baden, expressed to me his surprise at their extraordinary power of endurance in the time of the great depression. "For ten years," so he said, " these people have had bad harvests. Their losses are estimated at about $£ 2,000,000$. Nevertheless they go on and do not seem much the worse." This was in a vine-growing district. But it is the same where tobacco, or maize (for ripening), or teazle, or sugar-beet, etc., are grown-sugar-beet, out of the cultivation of which, according to the evidence of an expert witness, Herr Gerhard, the " cow peasant "- that is, the peasant on so small a holding that he cannot afford to keep bullocks or a horse, but has to put his one or two cows under the yoke for ploughing purposes-picks relatively the biggest profit. The same thing may be said of small cultivators raising special highpriced crops in France. However, small holdings can grow very good wheat, and rye. And, putting special produce for the moment out of consideration, to show the power of endurance of small men in bad times, it deserves to be mentioned that, alike in France, and even more markedly in Italy, as I have been advised by official experts, during the time of general prolonged depression, it was the districts in which métayage (mezzadria) prevails where, accordingly, holdings are small-in addition to which also, as a further relief, rent is paid in kind-depression made itself least felt. That agrees thoroughly with what our Poor Law Commissioners of 1834 state in their Report, namely, that "small occupiers employing no labour but their own had managed to pull through " the exceptionally trying times which preceded the reform of our Poor Laws. The remarkable "weathering capacity" of small holders is a strong argument in favour of small holdings. In some 
districts abroad they produce better crops of cereals than do the adjoining large estates. With Co-operation to help them, they have the use of perfected machinery, and advantageous arrangements for the employment of machinery, within their reach, the same as large farmers and, if the latter still effect a saving in production by reason of the breadth of their breaks, the small make up for that advantage by the more meticulous care that they can bestow upon the crop in detail. The objection will not hold water.

Another objection raised applies more particularly to the question of small ownership. Accordingly it may be well briefly to consider the point: Shall we go for ownership, or for tenancy? Not that that point possesses anything like the importance that has been attributed to it, or that the one thing necessarily excludes the other. However, my belief is that in practice the advantage will be found to lie so much on the side of ownership that, once we have much small cultivation, we may securely count upon soon also having ownership preponderating. However, let us consider!

The Small Holdings question is, above all things, a social question, a question of creating homes and renewing country life. The renewal of village life, the creation of a fresh rural world, a world pulsating with contented activity, repeopling the deserted country, the formation of new communities instinct with a spirit of their own, but all combining to make a happy and contented countrycommunities in the existence of which every one living within them can take pleasure and by willing and cheerful labour contribute to the common well-being, with a joyful realisation of the sense of citizenship-all of which influences are calculated to bring back people to the country and make them take root there, decentralising society, in the sense of spreading it out over a wider area, so as to counteract unhealthy over-population at one point and wasteful and dismal desert at the other-ought really to be the main aim in our whole Small Holdings policy, because it affects the well-being of the Commonwealth. However, our econo- 
mic and political pre-occupations make us only too often lose sight of it. You cannot have a stable, self-contained, self-sufficing, contentedly working rural community without small holdings. The first thing that the citizen, ready to work for himself and for the country, wants, is a home. And a home requires more to make it than the four bare walls of a cottage. But, beyond a home, he wants touch and relations with neighbours contributing to happiness and wellbeing. We had such life once, even with a much smaller collective population-life in which within the rural parish every one found his own proper place, enjoyed his own rights, was able to contribute to the well-being and happiness of the little country world. It is the loss of that happy state of things evidently which has brought about the desertion of the country and the unhealthy overcrowding in towns. The need of a genuine racy village community is felt in all climes. The Indian, happy in the recollection of his characteristic " village community," mourns its loss, and hopes to re-establish it by means of Co-operation. In the West, again, statesmen like the late President, Mr. Roosevelt, are keenly alive to the need of it, even among a teeming population like that of the United States, among people in one sense only too eager to crowd to the land. Our Canadian kinsmen, in Saskatchewan and elsewhere, are exerting themselves to create it. And in the far Hawaii Islands authorities are busy trying to evolve it, once more by means of Co-operation, out of the curiously mixed chaos of races. Prussian autocracy is bent upon forming it. But we ourselves do not appear to care about the one thing economically and socially needful. "If the attractions of town life are to be counteracted and agricultural labourers lifted from apathy and hopelessness into contentedness and activity of interest, a reality, a purpose, a meaning must be given to village life." So writes Mr. Prothero. And surely his argument speaks for itself. However, such village life cannot be without small holdings, suitably apportioned, as demand may regulate once artificial barriers, running, as one would think, altogether counter to the intentions of Nature, are removed. The man intended to 
be a villager must necessarily have his archimedean standing ground, his $\pi 0 \hat{v} \sigma \tau \hat{\omega}$.

That consideration, as a matter of course, brings the point of ownership to the front. The Small Holdings question is, as observed, above all things a social question, a question of creating homes. Now there can be no doubt about it that ownership makes the best homes-homes that families become attached to, homes in which the man who plants knows that he will of a certainty also reap, on which accordingly he is likely to bestow most pains, constant attention, loving care. "Socially," remarks Mr. Prothero, "the advantages of a class of peasant-owners are indisputably great." And he says elsewhere: "It is only by ownership that the atmosphere can be recreated in which the peasantowner becomes part of the land and the land part of him. The opportunity of buying a freehold cottage and garden appeals to every man." And he adds: "On economic lines, such as these, village lifemight in time be reconstructed, and intellectually placed on a higher level than the old." Read Henri Baudrillart's charming chapters about the French peasant's little owned farm in all different parts of the country and compare what he writes with what you can see on a personal visit, when you will find it fully confirmed. It has been said that to the owning small holder his holding is a workshop, a home, and a sure savings bank. To the tenant it is only a workshop. The house is his to-day; it may be another man's to-morrow. The savings bank contained in the holding goes with the home. Another man may reap what the present man has sown. To the owner it is the three things in one, and more besides. It is, according to Baudrillart's showing, an object of affection and devotion to him, like a "sweetheart," upon which he will readily lavish pains and labour without reckoning the cost. See those little plots high up on the rocks, of which Arthur Young showed himself so much enamoured-see them up on the projecting points of rocks rising up almost perpendicularly in the mountains of Languedoc, Provence and the Dauphiné, where they strike the eyeas a most characteristic feature. One wonders how people could manage to get 
up there at all. But they offer a good face to the sun. All the soil that is up there has been carried up on human backs in hottes. No tenant would take the trouble to do this. The owner does not count the labour. He secures his little field which bears him such and such produce, benefiting at once himself and the country. He works, not for a short term, but for all futurity. And it is such outlay of labour which enriches the Nation, while at the same time it rivets the affection of the owner indestructibly to his holding. "The best kind of man, the strongest and most vigorous kind of man," so says Mrs. Rowland Wilkins-whom her answer to Sir Gilbert Parker's pamphlet, "The Land for the People," has shown to be a pronounced advocate of tenant holdings-in her evidence given before the Small Holdings Committee, "would aim at a freehold," and "you will always get a class of men who will think the freehold is the best thing to aim at." With good reason, too. It is objected that the small holder may want after a time to go away and lay out his labour upon a more promising holding. In that thought, as it happens, you get away from the idea of "home," which in the majority of cases is likely to be the most cherished and also, from a national point of view, the most worthy of consideration. There are however men of this sort, who look only at the business side-taking out of their holding what they can, so as to make the maximum of money out of it, and, having done so, to move farther and continue on a larger scale. These men distinctly have their value and a ready opening should be reserved for them. But they do not improve the land permanently; nor do they yield that which most of us desire to see established, that is, a permanent rural population making the country the richer and the happier. They remind one of the adventurers who go into a far country to exploit there the virgin riches of a fruitful soil and come home to spend the yield upon themselves. That is not precisely what the Nation wants. The number of these men is, as it happens, comparatively small; and there is no reason why for their sake the majority of their class should be deprived of more enduring benefits, of common 
good to the Nation and which really are their due. Besides, our present argument is in nowise opposed to tenancy, but only in favour of giving an easy opening also to ownership. And it deserves to be remarked that wherever land is freely saleable, as it is in France and even more so, with the help of a compulsory land register, in Germany, ownership is by no means a bar to removal. Land which can be bought freely, will also sell freely.

The close connection between agricultural prosperity and occupying ownership, as testified in our own national Agriculture during the period of agricultural revival at the turn of the eighteenth and nineteenth centuries, has already been remarked upon. The occupying owners there concerned were for the most part men of the yeoman class, therefore not precisely "small holders" in our present acceptation of the term. However, their well-being certainly argues in favour of ownership. That ownership, generated by the sunshine of prosperity, disappeared under the clouds of quite exceptional depression. And by the time that prosperity revived, after the Repeal of the Corn Laws, the domination of capital had become so pronounced and capitalists showed themselves so keen upon the acquisition of land for the sake of the social and political advantages which its possession carried with it, that the economically calculating agriculturist was practically kept out of the running. He could not then keep up his competition with the big purse which thought more of possession than of income. Economic conditions of the present day, including the dwindling of the agrements of possession of land, and the gathering weight of taxation, bid fair to bring things back to a proper balance. Meanwhile the movement in favour of really small holdings ownership, a peasant proprietary, has been gaining in force. And it may be worth repeating that Joseph Arch's Union, the only fully representative organisation of the class for whom such small properties are intended, that we have thus far had, distinctly placed the creation of peasant proprietorship upon its accepted programme in the 'seventies.

One argument very freely employed against peasant 
proprietorship-upon which the late Lady Verney in her many writings laid particular stress-is this, that peasant proprietorship means poor housing and poor living-poorer housing and poorer living than among ourselves for paid farm service. Now, letting alone that the whole tendency of the time is not in the direction of service, but in that of emancipation and self-employment, a study of the facts in nowise bears out this allegation. Lady Verney, with all her knowledge of France, has evidently compared things which will not bear comparison. She has judged hardship in the case of the very small French peasant what is by no means hardship to him-any more than the rye bread and chicory coffee habitually consumed in Germany constitute a hardship to the German peasant-or to Germans much above his rank-though our farm servants might make wry faces over these things. She should have seen the grimaces which French and Italian delegates at some of our British Co-operative Congresses made when they were given very good dinners-without wine. Alia vita, alia diaeta. The Indian may be as happy over his paddy as the Briton over his meat. Quite apart from that, recent inquiries do not at all prove that either our farm servants or our farm labourers fare particularly well-even though a recently departed statesman would have it-in Parliament - that in his own county, Gloucestershire, agricultural labourers find means of consuming plenty of meat on their weekly wage of I3s. or I4s. a week. Our "Egyptian fleshpots " are for the most part a creation of the imagination. The French peasant is as happy over his pain percé and his choppe or carafon of Aramon as are men of his class in our country over their pint of beer and their cut of meat. His wife certainly provides him with more tasty pot-au-feu and vegetables. But it is not eating that makes the happy mortal. The continental peasant owner is a free man. His holding gives him what he wants and allows him to fix his own hours of work. It induces him to work hard -no one can deny that; but it does not perforce make him a drudge. It does not place him on a lower grade of humanity than his neighbours. Mr. Prothero's very true 
words have already been quoted: "Small owners in France and Flanders are very poor, respecting money, but very happy respecting their mode of existence."

There is certainly incomparably more stability about the political and economic condition of the small-farming districts. It is large-farming districts which send emigrants abroad. Everywhere also it is only from the large-farming districts that revolutionary Socialism comes. It is so in Germany. The late Dr. Liebknecht, the comrade and coetanean of Bebel, admitted this. It is so in Italy. My socialist friends in the Romagna, which is a socialist stronghold-as a bequest from papal misgovernment-have complained to me bitterly that there was no doing anything with the peasantry of Tuscany who, being comfortably situated on their peasant properties, " are all reactionaries." So would the Romagnoles be if they had the Tuscan peasants' prospering freehold farms. The anti-revolutionary tendency of the French small propriétaire has often been remarked upon.

Again, it is contended that small ownership must needs sooner or later what Frenchmen call "pulverise" the land, cut it up into such diminutive fragments as must be detrimental to good husbandry and good living. All pertinent facts on record conclusively disprove that. In the most " pulverised " part of Germany-that is, in the South-west, where small ownership has been in operation since the early Middle Ages, and where average holdings go down, e.g. in Württemberg, to $\frac{3}{4}$ acre or, more correctly (if the forest area is deducted) to $\frac{1}{3}$ acre-an official inquiry has shown that land is to-day not one whit more subdivided, even to a fractional extent, than it was at the time of the Thirty Years' War, nearly 300 years ago. In electoral Hesse there are actually no fewer holdings than there were in I760. French soil is no more subdivided than it was at the time of the great Revolution. Land being readily saleable, the matter rights itself by corresponding buying up. In Oldenburg it has been observed that subdivision and agglomeration adapt themselves automatically to circumstances. In good times the wealthier men buy 
up more parcels; in bad the small holder sees his chance of buying cheap, and his power of holding out against adversity is called into requisition. The principle of equal inheritance among children is often found fault with in our paradise of the first-born-not that it is not admitted that it is fairer to the younger children, but because it is said to "pulverise" land too much. However, no country which has such "Kentish custom" on its statute book appears at all inclined to give it up. I put the question on my journey of inquiry to the chiefs of Agricultural Departments in the principal countries of southern Germany, whether, in view of the manifestly pronounced popular desire to strengthen the position of the larger peasant owner it was not conceivable that the law would be altered. The reply was: "Why, that is altogether out of the question; there would be a revolution." In France of course the stagnancy of the population acts as a preventive to over-subdivision. But, apart from that, the loophole left in the "Code Napoléon," borrowed from Roman institutions, which excepts properties which cannot be conveniently (commodément) partitioned from the general rule, is much taken advantage of, the Courts giving a liberal interpretation to the word commodement. We ourselves should have no reason to apprehend excessive subdivision in this country. Really, it is not less, but more subdivision that we stand in need of now.

However, it is urged that suitably and judiciously as land might be divided among small owners, there is no guarantee that, as time went on, the ownership so created would not be abused, the balance might not be upset. That has actually occurred in some cases. However, the danger may very well and very effectively be guarded against. In Prussia it is so by two distinct means. Under the depolonising Commission the State retains part of its mortgage on the property-one-tenth-as a permanent charge, which makes every further disposal of the property dependent upon its assent. Under the Rentengüter system advantage is taken of a right claimable under Prussian law, to secure a right of a veto entered upon the register, without a mortgage being actually held. Something similar might well be done 
in our case--possibly under the provision of the Land Transfer Act of I897 permitting a similar claim to " cautioners." Or, if that were not practicable, it should not pass the wit of man to devise some new special law.

Mr. Prothero, as already observed, owns to an apprehension that the "scarcity of winter employment, at times felt in the past, will probably be reproduced under the rule of Small Holdings." That apprehension appears to me excessive. The proposed re-afforestation, though it may help locally - as it has done at Winterslow-cannot indeed count for very much in a national aspect. And cottage industries, which it would be most desirable to introduce, if that were to prove practicable on economically sound lines, have among ourselves, even more than among neighbouring nations, gone the natural way of decay. The well-meant and well-supported attempts made in Ireland, by that deserving body, the United Irishwoman, to introduce them there, although they have led to the discovery of much, and in some cases very original, aptitude-as visitors to the occasional exhibitions of work resulting must have perceived - have not generally led to particularly encouraging results. Abroad artificial assistance, such as might not prove available among ourselves, has in some cases kept them alive beyond what natural conditions would have permitted. Nevertheless those industries, which are attractive by their picturesqueness, are generally on the decline. It wants some special circumstances to make them successful. The lace makers in Lorraine, the embroiderers in Lunéville, under French rule the weavers and spinners of those superior " Articles de Sainte Marie-aux-Mines," and some such skilled men and women as the wood carvers of Bavaria, the clockmakers of the Black Forest, and the meerschaum workers of Thuringia, manage to make a success of their particular industry, while the sunshine of demand lasts. But for the moment, at any rate, cottage industries, opposed as they are, speaking generally, by Trade Unions, are under a cloud. However, the widespread prosperity of small holders in France, Germany, Switzerland, Italy, etc., in districts where there are no cottage industries and 
where there is no special winter employment, scems to prove that small holders can very well do without such extraneous aid. They soon learn to accommodate their summer outgoings to winter needs. And even though winter - even the long winter of the Continent-bring enforced idleness with it, on the balance they find themselves well off with their small holdings.

The dreaded "lions in the way" thus turn out to be for the most part imaginary rather than real, alike as threatening ownership holdings in particular and small holdings generally.

If, on the economic side, there have been difficulties in the way of successful small husbandry, Co-operation has effectually cleared them away. A very telling instance showing the difference which small-ownership husbandry makes to a country, deserving to be quoted is that of the peasant proprietary of the Baltic Provinces of Russia. All over Russia proper the great emancipation of serfs in I86I, which failed to couple the possession of individual freehold with freedom, produced a rural proletariat, the evils of which have long weighed prejudicially upon the empire -until by a munificent blotting out of the figure on the land register a modern seivachtheia, they were remedied. In the Baltic Provinces three laws decreed in I863 made the peasantry-who had not been actual serfs, although bound dependants of the landlords-absolute freeholders, compelling the landlords to turn over their land to them in a very similar way to that applied in Prussia by the memorable act of Stein and Hardenberg. The consequence was that $2,7 \times 6,000$ peasants became at a stroke free owners of their soil. Five years later, in I868, a Baltic economist, Herr Eckhardt, could write as follows:

"Within a very few years the property of the peasants has increased so rapidly that, in the aggregate, the small capitals accumulated in their hands already amount to millions, and the material condition of the small landowners may be described as, on the whole, more satisfactory than that of the owners of ' knights' estates,' more especially in Livonia, where bankruptcies of noble landowners are steadily becoming more frequent." 
It may be added, in connection with the last-named point, that the encumbrances of landed property with mortgage debts in Germany, of which so much has been made-and not without good cause-attach, so far as excessive mortgaging comes into account, preponderatingly to large properties-squires' estates. There are some peasant holdings over-mortgaged; but their number is not large. And the statistical figures given are in places misleading. For I have the late Dr. Buchenberger's authority for it that in many cases the entries made represent uncancelled but actually repaid mortgage loans, the cancelment of which has been advisedly deferred, in order that the same deed might serve, if it should prove necessary, to raise a fresh loan. That will save a few fees.

It is not my business here to give precepts for the establishment and management of small holdings. For such information I would refer readers to the high authority of Mrs. Rowland Wilkins and the very useful publication "The Smallholder," with its instructive "Smallholder Library." As Mr. Prothero rightly urged, you cannot establish small holdings anywhere. There must be precedent favouring conditions, the most important among which is that the site should be accessible and have in its turn ready access to suitable markets. No one in his senses would think of planting small holdings in a wilderness. With the exception of such truly unmanageable soils as very sticky clay or very stony brash, the question of soil presents no serious difficulties, although of course good workable loam is the best. However, under suitable conditions-with the knowledge of fertilisers now at our command-sand will make excellent small holdings-for more besides the cultivation of asparagus.

Careful selection of only suitable settlers, well fitted for the task to be entrusted to them, is a matter of very considerable importance, which cannot be neglected with impunity, whatever the circumstances of the case may otherwise be. And it is just on this point that we are threatened with falling short. Another point on which I should like to lay stress is, that small holders should begin 
on co-operative lines and adhere to them. Co-operation has become the indispensable helpmeet of the small man.

To render its full benefit it should begin with the collective buying or renting of the soil, which of course ensures a great economy. But it should not end there. What we want, and what we have thus far worked for only very half-heartedly, if at all, is to get more people, more households, on the land. And that is best done-as it has been done in Prussia, and also in Italy-in entire settlements. In such there are the greatest opportunities for mutual help, and mutual help is most easy and most useful. And the settlement creates a new tone among the rural population. We want Co-operation everywhere on the land, and we want examples like those of such settlements as have been referred to, to set it going. It is at the point of small holdings, for the purpose of creating a rural population, that the great "revolution in Agriculture" of which Lord Selborne, when still President of the Board of Agriculture and Fisheries, spoke at' the London School of Economics in March, IgI6, must begin. "Statesmen judged rightly when they inscribed the creation of small holdings as a pressing matter upon their programme. In truth public sentiment was forcing them to such course. From the time of the publication of the "Modern Domesday" downward the feeling in that direction has been growing. The Nation has awakened bit by bit to the fact that the land was made for the people, that it is the Nation's, and that it is property of a kind the volume of which cannot be increased ad libitum, which has to meet the wants of a growing population, by being progressively adapted to its necessities, and from which more is to be asked than dividends. It wants to be made "the People's" once more. And the starting point for a new agricultural policy promising greater happiness and contentment, as well as greater productiveness and a new impetus to a great increase of the population, must be "Small Holdings." 


\section{CHAPTER VIII}

\section{A Full REward For the Tiller}

IF the earth is to bring forth the maximum of its increase, for the feeding of the Nation, in addition to being fully qualified for his calling, it is indispensable that the tiller should in his toiling also be assured of a full return for all that he puts into his land-not in the shape of artificial fertilisers and feeding stuffs only, as the various Agricultural Holdings Acts provide, but also in the shape of intelligence, labour, judgment and risk, such as attach to every business. Men never work at their best when there are others to take toll upon their production, possibly to skim the cream off. Under our present system such security is not provided for. We habitually take pride in our long-established landsystem, which has in other times served its purpose exceedingly well and has obtained praise, not from our own countrymen only, but also from those who were destined to become our pupils and eventually our rivals.

The feature in that system for which in modern times it is mainly a custom to take credit, is this, that it separates the provision of fixed capital from the supply of working capital, assigning the former to parties supposed to be possessed of substantial means, and therefore not only in a position without difficulty to undertake any improvement wanted, but also to be content with a very moderate return upon their outlay-such as is indeed consistent with the greater security of their stake; and the latter to the working factor in the concern, who, with a less secured stake, throws into the scale besides his money at the same time also his labour, vigilance, intellect, and risk, and is evidently thereby 
entitled to a higher rate of interest-which, as a rule, when times are normal, and supposing him to be capable, he receives. Under this arrangement, so it is rightly urged in its favour, the raw material for Agriculture, that is, the land, is placed at the tiller's disposal at the lowest possible charge to himself, while at the same time he is left free to devote the whole of his own disposable capital, whatever its amount may be, to working purposes, where it is most needed and where it will yield the highest return. That is, of course, not the motive with which our prevailing land system was originally created. Land was, or else became, accumulated-“"hoarded "-in few hands. A large possession of land meant political power, a high social standing, and more besides. The land was, accordingly, not to be parted with. The occupiers were of an inferior caste and, in truth, originally the landlord's retainers, and the tenant system became established among ourselves, as did more or less modernised forms of the ancient medietas, the métayagc or mezzadria, which sprang from the same root, among our neighbours. In such countries as northern Germany the ancient privileges of the landed class survived to a late day, just as did, among ourselves, our game laws. Owners of manors were still magistrates in right of their possession when I had my property in Prussian Lusatia. These men had exercised petty justice. And I found memory fresh of a predecessor of mine who had run a peasant through with his sword, because he had dared to beat off a dog of his which had assaulted the peasant, without any penalty being exacted from the murderer. And so fully impressed were people still with the extensiveness of the jurisdiction formerly permitted to "rittergutsbesitzer" that a weighing frame which I had had put up close to a pond which served as reservoir for fish after dragging my large fishponds, to have them ready for delivery to the fishmonger-who bundled them off to Hamburg en route for the East End, to feed the Jews-was very frequently mistaken for a gallows dating from the time of squires' jurisdiction, which was then not very distant. The privilege of magistracy came to an end in 1875 . 
Time has in one sense been less considerate to our landlords. However, being, up to some time ago, generally better blessed with funds, and in possession of larger demesnes than their Continental classmates, there has been a greater halo about their position and much greater tenacity in their retention of their land. And the land by which they have held fast they have known how to turn to account in certain ways. Our laws, being for the most part based upon respect for property, have scrupulously -perhaps over-scrupulously-protected their rights in every respect. In this way modern tenancy has grown up with all its rigid reservations, with its covenants, its landlord's distress, and all its other restraints upon free action, which harassing conditions are to a very large extent indeed responsible for the much-complained-of, routinebound backwardness and dullness of our " average " farmer, who enters upon his tenure with his hands tied and has little scope for initiative left to him for striking out new paths, on which the benefit of the land to the Nation might be better consulted. Under such conditions it requires exceptional alertness of mind, and knowledge of what is being done elsewhere, to depart from the beaten track of rule-of-thumb husbandry. Mr. Prothero rightly insists that, on farming becoming a business, there must be "free action." Meanwhile time and democratic institutions have made serious inroads upon landlords' social preserves. The possession of land is no longer, as it was in past centuries, a matter of descent, but of cash. It is "Cash rules the grove," as Byron sang. Accordingly the ranks of landlords have been invaded by newcomers, many of whom have claimed the privileges so eagerly sought, without recognising the accompanying responsibilities. Hence the particular landlords, whom Mr. A. D. Hall chides for " not taking the lead" in the agricultural movement. Their heart is elsewhere than in the land, as a workshop for Agriculture. Tenacious holding fast by the land, as encumbrances grow up like gourds of Jonalı's type, has at the same time eaten fatally into whilom superior wealth, which appeared to entitle landiords to their exacting overlordship-at the 
very time when new demands made upon Agriculture called imperiously for greater outlay on improvements, which the comparatively impoverished landlord was not able to meet. And so came about that deadlock at which we have actually arrived with land running to waste under pasture, tenants failing to do justice to the Nation's soil, improvements being left unexecuted and the land bringing forth much less than the Nation has a right to expect and than in truth it needs. The conditions surviving in the landlord's position are for a good part hopelessly out of tune: Possession and wealth have in the majority of cases parted company.

Under such conditions, which plainly indicate the nature of the prevailing disease and therefore of the remedy needed, it is idle to keep on singing the praises of a land system which has become an anachronism, and which keeps the Nation in want. That system has, as Mr. Prothero has put it, " broken down." It was a palpable exaggeration, to begin with, on the part of Mr. Disraeli, when bringing in his Agricultural Holdings Bill of I875, to boast on behalf of our land system that under it the land yields " three distinct livings "- - to wit, one for the landlord, one for the tenant, and one for the labourer. Such tripartition, between capital, technical direction and manual labour-sometimes carried to still further ramification-by the way, as a matter of fact, is not peculiar to Agriculture, but really exists in all forms of business. In a manufacturing concern the fixed capital is likely to be contributed at a comparatively low rate of interest by preference share and debenture holders. There may indeed be a ground landlord as a further venturer at their back, content with still lower interest. The working capital will be contributed by the ordinary shareholders and the directors, who work the business and draw, according to the profits earned, a higher rate of interest. And the manual labour will be contributed by the " hands," who get what the market rate and the pressure exerted by their unions yield them. And in that case there, is genuine and fair tripartition, with nothing more, unencumbered by hampering restrictions, covenants and the like, which constitute a heavy price to pay for cheaper use of the land. One 
would like to put it to the managers of manufacturing concerns whether they would be content to put up with such restrictions as accompany the renting of a farm; and to factory hands whether they would rest satisfied with such conditions as are habitually imposed upon agricultural labourers, in the matter of dwellings, of wages, of hours, and of general dependence.

However, what Mr. Disraeli evidently intended to convey by his reference to " three livings " was, that the land under our system is made to yield more collectively than it would or could yield under any other system. Now this is in the present day demonstrably the reverse of the fact. Quite necessarily under a system which divides profits among various parties there must be some wastage. There must be bargaining and therefore friction, snipping and tolltaking-let alone that the division may be "leonine"as in fact it often is-and therefore unfair to one party or the other. And not only will there be conflict of interest, also the substance to be divided is likely to become reduced. For there must necessarily be a hampering understanding as to the use to which the land may be put, which means, that not under all circumstances, perhaps under none, will it be made to yield the maximum return. We admit this in our reasoning in favour of small holdings-most fully in the case of the occupying owner-on whose behalf the plea is rightly put forward that urder such arrangements labour will be contributed at lowest cost, whereas part of the produce, at any rate, will be at once placed in the most remunerative market, that is, in that of the ultimate consumer. Our small holder is expected to earn more in proportion out of his land than can the large owner or farmer. And Mr. Middleton's Report shows that in Germany, where the occupier is for the most part also the owner of the land, secure to obtain, ordinarily speaking, the full value of all his improvements, either in increased yield or else in increased selling price for his property, he produces on an average substantially more from the soil than do our farmers under tenancy, while at the same time the fact that the price of land has risen more under the German system than 
under ours-under which it has actually fallen, as Mr. Prothero has shown, by $£ 22$ an acre-indicates that fixed capital fares better under such arrangement.

It may at once be admitted, per contra, that in Germanyand in the matter of that also in France and in the Low Countries and in Austria-just as among ourselves-more money is, generally speaking, earned by actual farmingfarming proper-under the tenancy system-wherever what may be termed ideal conditions prevail, that is, where the land is good, the tenant capable, the tenure secure, and the landlord not only so well endowed with worldly goods as to be able to execute all improvements commending themselves, but also so much at one with his tenant as to make negotiation respecting such improvements easy. Such is the case in Germany in respect of tenants of large Crown lands or municipal demesnes. But even so it does not follow that under such system the Nation is likewise best served. The tenant may receive a good return for his outlay. The landlord is likely to receive what is fair. In any case the fixing of the interest which he draws is his own business. However, the Nation not only wants to reap from the land all that the land can be made to yield, but also wants to see the land maintained in its actual condition of productiveness and, if possible, raised to a higher level. That point is potentially-barring insufficiency of means or of intellect-secured under occupying ownership, but not, otherwise than exceptionally, under tenancy. For the tenant quite naturally thinks not of the land but of his own pocket. When he gives up he wants to take with him quite all that he has put in. Where conditions such as were known to our grandfathers survive, and such as still are common on favoured estates-for instance in the long-famed Lothians - of a hearty understanding and complete mutual good feeling between landlord and tenant, so that written leases or agreements become in fact superfluous - a man's word being still as good as his bond-the Nation's interest in this respect is likely to be practically safeguarded. The tenant, knowing that he may rely upon the landlord's good faith and good will, and that no 
difficulty is likely to supervene in respect of permanent improvements, will not "rob" his land at the close of his occupancy, but hand over the holding to his successor in the same good heart in which he himself received it. However, unfortunately, as has been said, such conditions, so far from being universal, are really only exceptional.

We need not make too much of the alleged " rapacity" of landlords, though undoubtedly some such there is. We know, indeed, from frequent complaints made-since the time of Sir James Caird--that most land in England is, in the reverse sense, actually under-rented. It would probably yield more if the tenant, urged to more strenuous application by a higher rent, such as Lord Townshend and "Coke of Norfolk" imposed, were compelled to put more "back" into his work. However, such under-letting is not due to any conscious generosity on the part of the landlord. Many of his class show this by the claims for higher rent which they put in whenever they can. So common is the disposition to do this that Mr. Prothero, when he endorsed the Premier's plea for a guaranteed minimum price for wheat, oats, and potatoes, deemed it necessary, in virtue of the powers conferred upon him under the Defence of the Realm Act, to prohibit any raising of rent by the landlord on the ground of such guarantee. "Rapacity" of this particular kind is in truth exceedingly common, even where its existence is denied. We had a most popular landlord in Sussex, a noble Earl, the owner of much land, who made it his boast that " he never raised rent." "No," remarked to me one of his principal tenants, a highly respected farmer, whose name was a household word in the county; "he does not raise rent but he gives notice to quit, and then a fresh bargain has to be concluded." There is undoubtedly not a little of this sort of " grabbing." "If a man improved the farm during a lease "-this is what Sir James Caird wrote in $\mathrm{I}_{5} 5^{\mathrm{O}-5 \mathrm{I}}$, and in spite of Agricultural Holdings Acts it still holds good to a considerable extent-." he would be obliged to pay an increased rent for it, in consequence of that improvement, when he renewed it for a second term. If he held from year to 
year, he either made no improvement or, speaking generally, so little that the difference of produce from year to year was so gradual and imperceptible that the farmer kept nearly the whole advantage to himself." Tenants are now entitled to " compensation for improvements." However the year-to-year renting, which for well-known and good reasons has become so common, stands in the way of a settled and continuous plan of improvement, and the value, or even existence, of an "improvement" is not always easy to prove. What the tenant holds to be an "improvement" may in the landlord's eyes be the exact reverse. Speaking of the local custom prevailing in Kent, to compensate for fruit trees planted by the tenant, Mr. A. D. Hall says: "Compensation is sometimes given when death or accident has voided a tenancy before the occupier has obtained a return for the work he has done; but cases are not unknown where the rigour of the law has been enforced and the outgoing tenant has got nothing for the improvements he has made." The tendency of tenancy farming certainly is, in the majority of cases, to discourage continuous improvement and keep the land in its actual condition, if not, indeed, to impoverish it by " robbing." It is like an industrial undertaking failing to increase the value of its goodwill and laying by no reserve.

However, the present is not a question merely of " rapacity." "Rapacity" apart, the generality of landlords, however kindly disposed they may be, are unfortunately not in a position to play a kind Providence to their tenants, to deal sparingly with them and to meet their wishes in the way of improvements. Mr. A. D. Hall has, rightly enough, found fault with tenants for occupying land in excess of the measure for which their means suffice. The same reproach is at least as applicable to a goodly number of landlords, who hold much more land than they have capital for. The true fact is, that the practice of laying together vast areas of land in immense estates, which are to remain in the family-being a relic of feudal and subfeudal times-has caused the larger part of our narrowly limited allowance of land to be held by owners or life tenants 
who, whether they have sufficient knowledge of Agriculture to manage those estates intelligently or not, certainly have not the means to keep them in the best condition, according to the ideas of modern days, and to provide liberally for the many improvements now called for. This is a stumbling-block which has been growing in size for decades past. "In every county where we found an estate more than usually neglected," so wrote Sir James Caird in I850-5I, "the reason assigned was the inability of the proprietor to make improvements, on account of his encumbrances." Only too many lordly estates have in truth become mere imposing shop windows with poverty at the back of them. One could wish that that were all. However, there are other damaging heirlooms left, handed down from feudal times, when our present land system was devised, not on the economic grounds now advanced in its favour, but because the landlord's tenants were his dependants and retainers; and the landlord, being above farming, for himself-Mr. A. D. Hall speaks of the "all but universal failure of rich men and corporations, who take up farming, under the management of paid servants "--strongly desired, nevertheless, to remain in possession of the land, the ownership of which carried with it, along with some economic benefits, many social and political advantages, which are quite unsuitable to the present day. The social and political privileges, one is glad to think, are gradually being swept away by advancing Democracy. But still enough survive to prevent the matter of land hiring and land renting from being put upon the same purely business footing as other business. Very many landlords think not of doing the best economically by their land, but of administering their estate in best accordance with their own personal fancies and likings. There are plenty of landlords-we had one with very large possessions in Sussex (and he was by no means the only one of his sort in the county)-who in the choice of their tenants carefully consult their own personal political predilections. Our Marquess would not have a tenant, large or small, of the other side in politics be he ever so good a farmer. There are others-I know of one in a 
Midland county-who make a boast of it that they will not have Dissenters. Now are these landlords-who are after all in the occupation of their land in a sense trustees under the Nation-really serving the Nation, which looks to them for sufficient bread, well in giving it in the place of such bread only a stone of supposed political or denominational orthodoxy? There are many other fancies, to observe which is part of the contract. There are fields laid out in the most inconvenient and uneconomical way, with angles and corners and many bits of irregularly shaped headland, whose fertility must run to waste. There are hedgerows of quite unnecessary height, which look charming, but which eat up much fertility, cause much harmful shade, shelter many injurious animals and breed much vermin. However, wheat growing must on such properties stand second to the landlord's fancy for high hedges. Sir $\mathrm{J}$. Caird instanced a case in which, on an estate of only 260 acres, a felling of hedge timber produced $£ 3,500$ - in his day of cheaper prices. Tenants were "forbidden to touch the hedges." There are other prohibitions and precepts, which are sport to owners but a sad hindrance to tenants. Many of us remember what the rabbit plague was before Sir W. Harcourt carried his "Hares and Rabbits Act." Mr. A. D. Hall speaks of one landlord in the Lake District who, although potatoes grown on lea have been found the most remunerative crop in his district, will only allow a very limited area to be planted with them; and of another, in Kent, who forbids his tenants to let their poultry go upon the stubbles, holding that the grain there dropped belongs of right to his partridges-as under the Mosaic law gleanings belonged to "the fatherless and widow." In the testing hour of need we have had to allow the shooting of foxes and the thinning of herds of deer and flights of pheasants. However, those animals were as detrimental to farming before the war came on as they are now. The difference is only that the war has brought the loss which they cause vividly before our eyes and reminded us of the responsibilities connected with landowning.

However, there are many and many cases in which the 
difficulty arises merely from the landlord's comparative poverty. Why did we keep so much land under pasture after the tyranny of bad times for wheat growing was overpast? Because landlords made it a covenant that pasture, once laid down, however unsuitable the land might be for pasture, must not be broken. Their fear was that, once broken, it might have to be laid down afresh and then it would be they who would have to pay the cost. So pronounced and so widespread was this disinclination that, to secure what food was possible at all from the wastefully laid down land, Mr. Prothero found himself compelled, by means of the powers conferred upon him under the Defence of the Realm Act, to override that covenant by a temporary absolute annulling of it. We know from the evidence given before the Forestry Committee a few years ago how much forest is allowed to run to waste, the good trees being picked out for present money making, and the rubbishy underwood being left, simply because the landlord has not the will, or else the money, to reafforest scientifically. If we could reckon up the loss caused to the Nation, on the one hand by the selection of inferior tenants, on the other by the landlord's inability or unwillingness to make called-for improvements, the reckoning would mount up to a huge sum, from which it might easily be calculated how much our present land system costs us, how much shortage of food stuffs and timber has accrued to the Nation in time of war, merely through the landlord's unwillingness or inability to lay out the talent entrusted to him by the Nation in the manner of the good servant of the parable.

But what are we to do? Under our land system landlords are for the most part life tenants. They have present needs to think of. The future troubles them as littleotherwise than in barren sentiment-as "Posterity" did the Prince, who would do nothing for it, on the ground that it had done nothing for him. I remember the case of a Scotch Peer-who had inhabited a house in which I afterwards occupied chambers-whose property was entailed in the male line, and who was blessed by Providence with twelve daughters but never a son. He could scarcely be expected 
to do anything else but what he actually did, that is, take all that was possible out of his life tenancy for the benefit of his daughters, who were naturally nearer to his heart than his heir-in-tail, and leave the estate to take care of itself. A considerable estate in Sussex, now highly developed, was during the life of its last owner left with all its splendid opportunities for improvement unused-it is now a popular seaside place-avowedly because the owner preferred, as his agent owned to me, to take all revenue accruing out of it for himself. Whatever he might have laid out in improvements would have come out of his purse, to enrich his heir. These cases are not singular or exceptional. Our land system distinctly invites landowners to be bad managers of their estates. We could not-except in a case of extreme emergency, such as is not likely to occur-dispossess such owners. But we have the right, and one would think also the duty, as a Nation to see that, once the estates are entrusted to such men's keeping under protecting laws of the land, the interest of the estate and of the Nation is not neglected so as to condemn us, when the emergency comes, to meatless days and bread rations, if not worse. That will cost less than the bonus that we are asked to pay on tariff-protected corn.

There are other points on which our land system affects us prejudicially-in a way to react seriously, among other things, upon our production of food. It has made dealing in land needlessly troublesome and costly. It helps to leave our rural labourers houseless. It renders access to the land difficult for small folk, whom it is a gross mistake to suppose to be indifferent to the acquisition of agricultural holdings-as Mr. Prothero's experiment on the Duke of Bedford's Maulden estate has proved. It is the barriers which our land system has erected and which interested parties have studiously strengthened, which keep them off. Indeed the feeling of dissatisfaction with this anachronistic relic of old times - which was serviceable, like a boy's frock to a child, in the Nation's infancy, but which has long since been outgrown-has during late years spread far and wide. 
The first evidence of this was our laborious attempt to provide statutory remedies for the tenant securing-though not fixity of tenure, as in Ireland-at any rate, when dispossessed, equitable compensation for the improvements which he may have effected with his own money, his skill, and his labour. The mere fact that the Acts attempting to accomplish this have had to be so often amended shows how indifferently we have succeeded in solving this problem and how difficult in truth it is to remedy what is amiss by such means. And, after all, compensation is only compensation. It may be insufficient. In the best case it is a matter of arrangement, it may be of arbitration. Often enough it has to be preceded by litigation, which eats into the value ultimately adjudged, thereby diminishing it. And, which is worse, often enough it acts as a distinct deterrent to the effecting of improvements, since there is no telling which way the judgment may go. And it is doubtful whether the correct value of improvements or, let us say, of the changes effected as intended improvements, can in all cases be correctly ascertained. Since the landlord is the compensating party, it is only right that "improvement" should be proved to his satisfaction, especially after the execution of certain improvements has been made independent of his consent. So good a judge as the late Dr. Voelcker on one occasion remarked to me very positively-on one of our visits to the Woburn experimental plots, while the subject of improvements and compensation was under discussion: "I myself would not pay compensation for anything that I could not see." I myself am responsible for a table showing what was at one time the money value of the residue of fecding-stuffs, after passing through the animal and going into the soil. ${ }^{1}$ However, we learn more even about chemistry alone, every day. We know, for instance, now about "amides" what we did not know when those tables were prepared, and "amides" were accordingly wrongly classed. The tenant may have em-

1 " The Proportionate Fattening Qualities, etc., of Feeding Stuffs." Published by the Agricultural and Horticultural (Co-operative) Association, Long Acre. 
ployed such and such fertilisers or such and such feedingstuffs, ostensibly represcnting an improvement, but employed them wrongly. Or he may have paid the money for them honestly enough, but received inferior articles. The fertilising constituents used may have been washed into the subsoil. The animal manure, into which the residue of fertilising constituents had passed, may have been impoverished by bad handling. As a last point, arbitrators are only human and therefore fallible. The whole subject is beset with difficulties. And all this affects only the strictly agricultural side of the question, as between landlord and tenant. But there is a much wider field in which the system unfortunately works damage.

Public expressions of discontent with what exists accordingly have taken different and more demonstrative shapes. Apart from labourers' movements, which became violent in Norfolk, and noisy in Sussex and Kent, we have had a " land campaign," which is not unlikely to be repeated; we have had a boisterous demand for small holdings, to be cut out of larger estates; and the cry for " Land Nationalisation " has become louder and louder. Land Nationalisation, however undesirable it may be in itself, is, in truth, the natural and logical outcome of the feudal land system now still in operation, its direct and legitimate offspring in these days of democratic institutions. For, so far as possession goes, the prerogative of the ancient Crown has virtually passed into the hands of the people, and if there is a feudal overlord, under whose grant lesser lords may hold the Nation's land, that overlord now is the people.

It is not likely, all the same, that the demand for Nationalisation would have arisen if the old order of things had properly served its purpose. But when the shoe begins to pinch, we take to looking at its seams. The causes for the cry have been the neglect of national interests for private. And so long as such neglect continues, the cry is likely to grow louder and louder, and to gain in backing. It is not every one who will hold Land Nationalisation to constitute the most desirable remedy. The practice of Agriculture is so varied, according to locality, climate, markets and 
personal ability; the work of every one who devotes himself to it requires so much of the personal impulse, if the best results are to be obtained, that one would judge that individualism is the proper régime. However, every one recognises that in the Nation's interest the land must be made to yield its proper increase. And if one master will not make it do so, it may be advisable to pass the property on to another. Therefore in their own interest present landlords will be doing wisely to consult the Nation's wants, instead of insisting to an extreme point on the absolute rights of " property." After the war, with its necessities and its shortages, to let in the searchlight on the rights of the national demand for food production, the old protesting cry of " property, property, property," is not likely to avail much longer.

Keen observers of cause and effect, and analysers of operative forces, have long since detected the spot on which the shoe has pinched, and formed a judgment as to the proper means of removing the squeeze. Thus, something like sixty years ago, the once well-known "S. G. O." of the Times, Lord Sydney Godolphin Osborne, careful student of social questions that he was, denounced the practised " hoarding " of land which, by reason of the mass of property in land lumped together in few hands, necessarily estranges the owner from practical Agriculture and creates at least two conflicting interests-under the conflict of which there must be loss. As a remedy he advocated that properties should be reduced in area, so that the owner should become personally interested in the management of an estate which he could overlook and in which-preferably farming it for himself-he could take a direct interest. "S. G. O." accordingly pleaded, in England, for " $£ 2,000-a-y e a r$ squires in Ireland for " $£ \mathrm{I}, 000-\mathrm{a}-\mathrm{year} . "$ Such men, he argued, would be able to manage their own properties and accordingly to answer to the Nation for their management. They would become, from mere agricultural "grandees"--like Captain Marryat's "fine gentlemen" captains of vesselsworking agriculturists, with an object to serve in thoroughly studying their business, acquainting themselves with all 
the latest discoveries and improvements, and giving more thought, more heart, and more back to the management of their properties. From drones consuming their income and looking pretty on the Bench, in Society, and, maybe, in Parliament, they would become active, valuable localised workers for the Nation, laying up, like bees, a treasure far more precious than honey.

It is to the presence of such a class as this that Germany is beholden for the rapid and very substantial advance that it has made in its Agriculture. Members of that class are generally well educated. They are, to use Lord Somerville's term, a "reading class," who " believe in education." Their position and their number-so much larger than that of our squires-secure to them a powerful influence in the Nation. Nevertheless they cannot disregard questions of $E s$. $d$. even in small matters. They are too big to play the Tony Lumpkin, but too small to play the grand seigneur. A few bushels more to the acre, some twenty or thirty gallons more milk to the cow, means something to them, for which they will be content to take a good deal of trouble. And they identify property in land with practical Agriculture. Among ourselves there has frequently been talk about the formation of an "agricultural party" in the political world. Here you have such party self-madedistinctly overdone in Prussia since I894, by royal favouring practised for political purposes, but in existence and exercising legitimate power before. The existence of such a constituency imparts a distinct fillip to the taste for learning the craft of Agriculture at Colleges. German Agricultural Colleges are in ordinary times well filled with studentsthe intending squires making the study popular and fashionable, and acting as bell wethers to others. Accordingly the teaching there received goes out into the world broadcast, to tiller lustily, and communicate its benefits to the humbler strata which, in the country, of course, are in constant touch and exchange of thought with the occupants of the " big house." These German squires do not go to the Riviera for the winter, or to other foreign lands, and to London for the season. Nor do they persuade themselves 
that the country was made only for shooting and foxhunting - though they indulge in and enjoy their less pretentious sport fully as much as do our gatherers of artificially swelled bags. Their country seat is their home and their workshop, where they live and labour, and fully fill their place in the local microcosm. When they make their voice heard in public, it is as bona-fide agriculturists, not as men of some other or of no calling, happening to possess landed property. And their voice reaches the public ear with all the greater force, since there are known to be no necessarily conflicting interests among them as between our landlords and tenants, whose bickerings have for a long time weakened agricultural influence, since it was held to be, not the agriculturist, but either the landlord or else the tenant who was pleading pro domo suo, for his own class only.

No one in his senses assuredly would wish to reduce land tenure and the occupation of Agriculture to one fixed dead level. The present-day advocate of small holdings does not plead for the abolition of large farms. The advocate of ownership would not do away with tenant farming, or the contender for medium-sized estates for the abolition of all large properties. Every form of possession and of occupation has its own peculiar uses in the public, as well as in the private, interest, and should accordingly, within its just limits, be retained. It would be short-sighted policy indeed, for the sake of uniformity, to want to cut up all large properties into small, or to abolish all large farming concerns, up to the very most extensive, for the sake of creating small holdings, for which there would on such a scale be nothing like a sufficient personnel or demand. Those large concerns, whether they be of a thousand acres or of very much more, farmed, as they generally are, on fully businesslike lines, and producing heavily, are a distinct asset to the Nation, the very large ones, highly farmed as they are, constituting a valuable speciality of these islands. But it would be just as short-sighted policy to allow to those larger farming concerns a monopoly or even a supremacy in the field to be occupied. It would be bad 
economy to endeavour to force British Agriculture into a Procrustean bed of any sort. There are different wants to be satisfied, and Nature has, by a difference provided in local conditions, indicated clearly enough in what localities each want will best find its satisfaction. Generally speaking there can be no doubt that our landed properties have been allowed to run into too large areas for agricultural purposes, that the grasping of too much land by one iron hand, which holds it tight, meting it out for what must under the circumstances be inadequate utilisation, has worked mischief and las become an anachronism. One cannot help thinking that a division of the soil, not forced, but made in response to demands such as one hears expressed on all sides, according to the idea of " S. G. O.," with the more modern requirement of many small holdings added, would do away with much of the mischief now complained of - the landlord indifference remarked upon by Mr. A. D. Hall, on one side, and the ignorance and inertness of the majority of our smaller farmers, testified to by the Agricultural Education Committee on the other-and that it would redound great'y to the benefit of Agriculture. Under our present conditions, what the French call the faire valoir, the management of agricultural land by its owner, is stated not to have proved a success. A statement to that effect coming from a high authority has already been quoted. However, the cause of this is patent to all agricultural eyes. It is because, as I have more than once heard landlords themselves admit, landlords do not, let us say in a large number of cases, sufficiently know their own business. Suppose the division of our land into small squire properties become pretty general-with, let us hope, a large number of yeomen's properties and small holdings clustered round them, according as the change brought about in economic conditions might favour and justify such development-the entire position of affairs would be likely to become altered for the better. Yeomen's properties could not in olden time hold their own against the large landlord's big purse, because not only co-operation but also intensive cultivation and even high farming were then not yet known; because credit was 
quite undeveloped; and because the social and political advantages attaching to large possessions in land weighed so heavily in the balance as to be considered worth a fancy price to the big man. All that is altered now. Thanks to intensive farming and Co-operation the yeoman could now certainly put in a good show as against his larger rival, if not, indeed, give him points. Ample legitimate credit, according to his possessions, has been placed within his reach, if he will only grasp it. And democratic advance is whittling away, one by one, the old feudal privileges-as it has whittled them away even in ultraconservative Prussia. Virtually the same thing may be said with regard to small, holdership. In truth the whole rural fabric is assuming an altered shape, in which the old squirearchy, with its strict rule over tenants, stands out of place like a medieval castle in the midst of a peaceful plain cultivated according to modern notions, with no need for portcullises, drawbridges, arrows and spears, or any of the other paraphernalia of knighthood. And to resist the natural movement of progress is only to play the game of extreme Land Reformers and Land Nationalisers. The recent rather considerable purchase of holdings by their tenant occupiers-effected more or less against the grain for a reason still to be considered-and, once more, such wholesale applications for freehold holdings when-without reduction of the price fixed for purchase-conditions of payment were offered in accordance with the convenience of small purchasers, as those already instanced, at Maulden, seem to prove that there is readiness to buy, if only terms can be made to suit buyers. On the other hand, the readiness to sell land on the part of discontented landlords-to all appearance in a not strictly justified pet (which after the outbreak of the war not a few who manifested it are not unlikely to have regretted)-appears to indicate that the general democratisation of things-financial as well as social and political -is beginning to tell on the other side and that landlords with their long rent-rolls and their often correspondingly long schedules of encumbrances, the costliness of their credit, while fresh burdens are being laid upon them, their 
death duties, their threatened land tax, the invasion of their charmed ranks by nouveaux riches, and the like, are in a temper to yield ground.

Let us suppose our rural society reorganised-a large number of squire-like owners living upon their properties and dependent upon the profits which those properties yield, accordingly giving themselves up, from their youth up, to Agriculture as a calling; with smaller owners clustered around them, likewise possessors of their own holdings, and a still smaller peasantry distributed over small holdings -but all this not to the exclusion of a reduced number of large estates and many tenant holdings-is it not likely that agricultural production would sensibly increase, and with it rural happiness and prosperity? We see the result elsewhere. France with its contented and thrifty population, of the well-being of whom Henri Baudrillart has given captivating sketches, has often enough been quoted. And now Mr. Middleton has drawn us a picture of Germany. Rural population would certainly be increased, and with its increase its wealth and intelligence, both of them potent sources of production, would come to be far more equally distributed over the soil. Agricultural education, the root of agricultural improvement, would assuredly benefit, because it would have a larger constituency to address itself to, naturally endowed with a spirit of emulation among its component parts, wit sharpening wit, as steel sharpens steel ; and because that constituency, making Agriculture a real calling, must needs be dependent upon its success. Let it be granted that the intelligent tenant, endowed with adequate working capital, finding a good holding and a good, sympathetic landlord, will do full justice to his opportunities, we cannot get over the fact that by the very nature of his position he can take only short views. He will want to turn his skill and his capital to the best possible account in his own interest-put into the land all that he knows that he will be able to take out again, but not a particle more. At the determination of his lease he will deliver his holding, as the unprofitable servant did his pound, without increase. During his tenancy he will 
be tied right and left by the landlord's interdicts and by his covenants. Hc cannot operate freely on his holding. As owner he would quite naturally be led to take very much longer views, such as could not fail to coincide with the interest of the Nation. He would have noterm of tenancy which would come to an end. Of whatever he put into his land, whether its fruit mature rapidly or tardily, he would in any case be sure of a return. Accordingly his aim would be, while making the land yield to the best of its possibilities, at the same time also to improve his possession and go on further improving it. Now that is precisely what the Nation wants.

We may resent having German and even French examples cast in our teeth, but we meet with precisely the same condemmation of general tenancy farming and preference for ownership among our cousins and kinsmen in the United States. "Tenant farming is undoubtedly the greatest single curse of this country," so writes Mr. Melvin Traylor, President of the Live Stock Exchange National Bank at Chicago. Governor McGovern chimes in with this remark, forming part of his annual message to the Wisconsin Legislature :-

"The evil effects of a general system of tenant farming on the land, to the tenant and the community in which he lives, are too well known to need discussion. . . Whatever may be done, we should not fail to recognise that the increase in the proportion of 'renters' among the farmers of our state is a serious menace not only to the prosperity and welfare of our rural communities but also to the efficient use of the agricultural resources upon which we are all dependent for our food supplies."

Mr. B. H. Hibbard, Professor of Agricultural Economy at the University of Wisconsin-which has cccupied itself greatly, and since a long time, with agricultural and rural problems-distinctly terms the tenant " the weak link in the chain," and points out that in the United States it is tenants specifically who are found opposed to the practice of Co-operation, and who support the middleman. "Wherever the farming population is half tenants, it means strength to the line-elevator and all other private undertakings of 
the kind, and weakness to the tenants, and hence to the whole farming group." He adds that large holdings favour tenancy, whereas small holdings promote proprietorship. No doubt tenant farming takes place in the United States under different circumstances and with a different object in view from what prevails in Europe. The landowner who lets his land there is not the magnate grandee of our country, but the speculator, to whom it does not matter much whether his land produces much or little while he holds it. He is holding on for an eventual substantial rise in capital value. However, from a national point of view the effect is the same. Under the tenant, who deliberately robs his land, that land produces less, in the proportion, as already mentioned, of about two to three. Therefore the Nation loses in food production, which, under our present aspect, is the main consideration.

We find telling proof in support of what has been put forward in the remarkable prosperity which has resulted from the turning of tenants into freeholders in the most advanced parts of Ireland, in Ulster, where farmers carry a head upon their shoulders and know, with canny Scottish cuteness, how to turn favourable conditions to account.

"Everywhere in the County Down," so writes Mr. Hall, "we were surprised by the obvious prosperity and comparative wealth of the small farmers, men holding from 40 to 60 acres. To take an example, we were with one man near the shore of Strangford Lough, whose farm was a trifle over 50 acres, on which he had himself built a good modern house, as the agents would say, with two reception and five bedrooms, and a trim flower garden in front. It was clear that he and his family lived comfortably if plainly; he spoke of hunting, though that was in the way of business, because he bred a light horse or two every year. He spoke, too, as an expert of wild fowling on the Lough ; his style, in fact, was that of the English farmer, not of 50, but of 300 acres. Now it is difficult to compare rents in Ireland with those in England, because in Ireland the landlord has only provided the actual land: the buildings, roads, fences, drains, etc., all the immovables which we know on English estates have often cost the landlord within the last seventy years more than the fee simple of the land, have been provided by the tenant, and long ago in Ulster became his pro- 
perty under the old tenant right custom, which later became legalised all over Ireland. We believe there is only one estate in Ulster, belonging to a City Company, where the English custom prevails of the landlord doing the improvements. The rent on the farm we were considering used to stand at about 20s. an acre. Then came the judicial rent system, perhaps the most demoralising piece of legislation which even Ireland has experienced, and successive revisions lowered the rent by perhaps 20 per cent. Finally, under the Land Act, the farmer bought at twenty years' purchase of his judicial rent spread in annual instalments over sixty-eight years, with the result that he is now paying I $2 s$. to I 45 . an acre instead of $20 s$., and gradually acquiring the land. Without doubt lie has thereby been encouraged to better his farming ; for, though the old tenant right gave lim the improvements, yet he had always one eye on the Commissioners, who might raise-at any rate not reduce-his rent every five years, if the farm looked prosperous. But nowadays as prospective owner he has reformed the drainage, the hedges are taken in hand, and the farming is tuned up as rapidly as the profits permit." And oncc more: "In this district, which, if not so rich as the Ards, still bore every sign of steady prosperity, the farms had all been bought-our host indeed had acquired his nearly twenty years ago under the old Act-so that the flourishing condition of the farming industry might be associated with the fact that ownership had been operating for some time."

Those passages recall Arthur Young's oft-quoted panegyrics of the gilding Midas touch of "property." Outside England it is hard to argue at all in favour of tenancy, so firmly rooted in Continental and Colonial minds is the belief in the superiority of ownership, which gives the tiller an absolutely free hand, such as Mr. Prothero insists that the farmer must have, once farming becomes a "business," and permits him to deal with his property in matters both of sale as of husbandry, without hindrance, in the way that he thinks best, growing whatever pays best, laying out his fields in his own way, setting up buildings or cutting down hedges, wherever such course recommends itself to his judgment and giving his creative mind a free rein.

It deserves to be pointed out that the conditions under which Irish tenants under their Land Act acquire their land, is in substance precisely the same as that under which encumbered owners, wherever there is a Credit Institution 
like the German "landschaft" or " mortgage bank "- - the system of the Crédit Foncior is rather different-giving credit on an "amortisable" plan, are enabled to pay easily for their properties. As land credit has recently been organised in East Prussia, with special provision for second and third mortgages, up to nearly the full value of the property, the owner's payment in cash down for the freehold has become negligible, wherever the purchaser chooses to take advantage of the facilities offered.

Our own Agriculture, like those of foreign countries, furnishes very instructive evidence of the intimate connection between cultivating ownership and agricultural prosperity. During the period of remarkable agricultural advance that this country has seen, in the period from about $\mathrm{I} 780$ to about $\mathrm{I}_{8 \mathrm{I} 3}$, even without the existence of those effective aids to smaller ownership that we in part already possess now, and in part are promised within a measurable distance of time, that is, Co-operation and Rural Credits, owning occupiership spread fast and spread wide over the country, and produced most noteworthy results, in the sense of improved scientific cultivation and substantial production. Mr. Prothero, in his truly admirable " English Farming, Past and Present," remarks upon the "exceptional activity in agricultural progress" which marked that period. And he adds that it was on the properties of farming owners and of larger farmers that the improvements introduced originated. Intelligent farmers were everywhere found purchasing holdings. "The opulent farmer who has purchased the farm he lives on," so says the Shropshire Report of $\mathrm{I} 803$, " is a character that has increased." From Norfolk, William Marshall had reported sixteen years previously that many farmers had prospered enough to buy their holdings and " to add to them numerous small estates of the yeomanry." According to the testimony of Arthur Young, farmers were " freely buying holdings in Essex." In Leicestershire "yeomanry of the higher class abounded." "Men cultivating their own estates of two, three, four and five hundreds a year are thickly scattered over almost every part of the country." This was not 
purely the result of high war prices. "The new race of men," so says Mr. Prothero, "who were beginning to occupy land, were better educated, commanded more capital, were more open to new ideas and more enterprising than their predecessors." They were "strongly marked by a liberality of thinking," says Marshall. "Quite a different sort of men," says the Oxfordshire Report, "quite new men, in point of knowledge and ideas." Passing from the old men to the new, "I seemed to have lost a century in time, or to have moved a thousand miles in a day." They were cultivated men, men of study, and "who had travelled much and mixed constantly with one another." "They made extensive tours for the sole purpose of examining modes of culture, of purchasing or hiring the most improved breeds of stock and seeing the operations of newly invented and most useful implements"-men who "had mixed with what is called the World . . occupying the same position in society as the clergy and the smaller squires." They were, in fact, mutatis mutandis, according to the time passed in the interval, the very class of men whom we must now wish to see back upon the land, cultivating itmen of education, of independent station, of ideas, and men who have been attracted to the land by brighter prospects. The bad times which followed, marked by a decidedly reactionary régime, provoking disturbances which were put down with a merciless hand, which, after the stress of war, brought feudalism, accompanied by the new Corn Laws -up to I8I5 the Corn Laws had, as Mr. Prothero has testified, "exercised little or no influence upon price"-altered matters very much for the worse and ushered in "the blackest period of English Farming," dispossessing once more the rising race of cultivated, intelligent and enterprising owner-farmers, in order to make room for landhoarders and men who preferred " rabbits to forest," game to crops, high hedges and ruinously cramping restraints to free farming. There was no Co-operation then and no ready Credit to protect them. As opposed to the landgreedy rich man, the small owner found himself helpless. The country did not gain by the change. The times of 
ownership and progress are fondly remembered by those who love Agriculture. Will it not be well to bring them back again? There are no insuperable hindrances in the way.

And particular attention wants to be called to one recommendation of the "freeland" system which a writer in the Quarterly Reviere of April, I9I7, dealing with "The Rural Prosperity of France," Miss Spedding, does well to notice and which ought to be of interest to ourselves at the present time, when we complain of our Agriculture remaining in a hidebound state, under a system which has grown altogether out of harmony with present, altered conditions. "The advantages of a free land system," so writes Miss Spedding, "are strikingly displayed in the manner in which it is adapting itself to new conditions. Throughout France, to-day, agricultural decentralisation is taking place at a rapid rate, for the large landowner, unable to obtain sufficient labour to work his land properly, finds it advisable to sell or split up his property into small holdings. The great increase in the number of small holdings does much to counterbalance, in rural France, the loss of labour." That reflects, above all, of course, upon the Small Holdings policy which we ought to be pursuing. But it has, as I know from observation in other countries, where the "free land " system likewise prevails, a most beneficial, furthering effect, favouring progress, also in the case of properties of larger size. It is freedom of land which permits freedom of action. And without freedom of action we cannot get out of our anachronistic old rut.

One reason why a transformation in the sense here sketched has not long since begun to take place among ourselves, undoubtedly is this, that the transfer of land under present conditions presents many difficulties and is costly, and that "rural credits," as the Americans-earnestly bent, under their different conditions, upon securing such -call them, are practically non-existent in this island, in the sense in which Continental countries know and profit by them. "Rural Credits," however, if we are to have occupying owners, we must needs procure for ourselves, or 
the tax upon the pockets of these men will prove excessive. Once we have " rural credits," rendered easy and sufficiently ample, such may well take the place of the landlord's " cheap " tendering of his land which is now made such a point of. It will be immaterial to the farmer's pocket whether he pays toll in the shape of rent or of interest. But having "rural credit" at his command, he will be a gainer by the acquisition of freedom, independence, and security of a return.

Both difficulties referred to spring, in effect, from the same cause. It is the costliness and trouble of proving full possession of a particular piece of land, so as to make it readily transferable and pledgable, which stands in the way. Where such proof is made easy and cheap, land changes hands readily. That is what obtains abroad, where "rural credits" flourish. Land becomes split up according to the demand of the market, and changes hands without difficulty.

We must not-as Sir G. Cornwall Lewis has shown that we are habitually only too prone to do-judge of institutions by the abuses to which, like everything else in this imperfect world, they may conceivably give rise. Much less are we justified in judging them by abuses which are only imaginary. When ready transferableness-which John Bright held up as a most valuable desideratum - and ready divisibility of land come to be spoken of, we instinctively recall to mind all the bad things that have been said, on the one hand, about excessive subdivision of land in France, and of supposed excessive indebtedness of land in Germany. Neither matter, as it happens, has anything to do with the institution here about to be pleaded for, which is, as a first step, Land Registration. For, in the first place, France has no registration of title of land, although very shortly before the outbreak of the war she decided to set us the good example by introducing such, by reason of the great advantages which it secures. And one direct consequence of the absence of such register-very painfully felt for a long time, similarly as in our own case-was, that there was no readily obtainable mortgage credit available for small 
landowners, who, for want of it, had to pay considerably higher interest than their cases warranted, to the notaires and to small capitalists. For the powerful Crédit Foncier, which provides credit liberally for urban and also for large rural properties-barring the very important item of forests - shows itself chary in dealing with small men. The difficulty was, on a very small scale, overcome by M. Louis Durand, at the head of the French Raiffeisen Union, who made co-operative money available, just to teach the grabbers a lesson. In the second place France possesses no machinery for bringing about a readjustment (remembrement) of intermingled pieces of land, such as in Germany has been found extremely useful. A movement is now on foot in France for introducing such correction of boundaries, making remembrement (readjustment of plots) allowable on the application of a considerable majority of votes, in the place of the unanimity which, under the present condition of things, is indispensable. In Germany, on the other hand, in certain districts, particularly appropriate to subdivision, with the help of readjustment, not only is subdivision not felt in the least as a hindrance to production, but on the contrary, as a distinct help. And so far from subdivision proving progressive, as is sometimes alleged in this country, an official inquiry instituted some twenty years ago in South-Western Germany, where subdivision is greatest, has shown that the number of holdings was then practically precisely the same that it was at the close of the Thirty Years' War, two hundred and seventy years ago. Where there is freedom of action, these things regulate themselves according to requirements. As regards over-encumbering, by reason of facilities for borrowing, we shall have to recognise the unfortunate fact that, whether the pledge be land or anything else, improvident running into debt cannot be prevented. Nobody has ever proposed that we should place hindrances in the way of commercial or even private borrowing, apart from actual usury, on the ground that credit is sometimes unfortunately abused. Then why cripple Agriculture alone among all callings by an interdict? However overburdening agricultural estates in Germany 
with debt, although unfortunately there is no denying the fact that it exists, mainly among large landowners-whom we know as junkers, and who make a point of keeping up appearances, even beyond their means-yet, generally speaking, it may be said that in truth it is not nearly as great as appears from published data, inasmuch as mortgage deeds are often advisedly kept uncancelled after the mortgage has been paid off, in order that they may be reissuable without a new entry, so as to save even the small fee, payable on the transfer.

The whole matter of land credit and facility for transfer hinges upon the establishment of a title, made valid in the market-a title making transfer of land as easy, says Sir J. Caird, " as stock in the funds," "as my watch," said John Bright, " as shares or a ship," says Sir C. F. Brickdale-that is, by means of an official register, entries in which vouch for validity. Germany and Austria-also Hungary-have had such register for some time, and its existence is answerable for a degree of cheapness and facilities, alike for purchase and for mortgaging, beyond what people in this country are at all likely to imagine. A second help in those countries is the existence of a land tax, based upon official valuation which, although not absolutely dependable, gives a very fair clue to the value of the property, and in many cases determines, at the owner's option, the degree of its mortgageableness. No one in the countries named would think of suggesting the abolition of such register.

The truly enormous business of the German landschaften, about which so much has lately been said, and of the foreign Joint Stock Mortgage Banks, which are still more in the ascendant and far more businesslike (far more suitable also for our own conditions) - that is, of institutions which provide cheap, long-termed and convenient mortgage credit, which may be "amortisable," for landowners, and is a most welcome and safe investment for capitalists-would be altogether impossible without a land register, as a commonly accepted institution. And the transactions are so expeditious and simple, as well as cheap! A single stroke 
of the pen at a trifling fee will do the business. In $\mathrm{IS6}_{3} \mathrm{I}$ bought, and in I869 I sold, an agricultural estate of just I,000 acres in Prussian Lusatia. The bargaining with the vendor-and subsequently with the purchaser-completed, the transfer was effected and possession was surrendered on the spot. From the entries in the register I knew to an inch what land I had bought, with the boundaries clearly marked out on a map appended to the register, and I knew all the encumbrances, permanent or temporary, which rested on the property. In I879 I sold a little bit of land at Deptford, forming part of the land on which Lawes' Manure Works stand, with a water frontage on the Ravensbourne Canal, which had been in my father's and my own possession ever since I833. But for the truly lucky fact that the agent collecting the rent had collected it for just twenty years, I should have had great difficulty in proving my title, although there was no doubt whatever about its validity. On the strength of the rent-collector's affidavit I could give a " twenty years' title." However, after I had sold the land, it turned out that this man had indicated the wrong boundaries, thereby leading me to sell a wedge of land that did not belong to me; and that wedge was specially valuable, because it provided the only access to a road. The cost of transfer had been considerably heavier than that attaching to either the purchase or the sale of my I,000 acres in Prussia. And on the top of that I was made to disgorge a goodly sum out of the purchase price. That occurrence certainly seems to argue strongly in favour of a register.

The importance for owners of land of easy access at all times to cheap and safe mortgage credit does not require to be proved.

\section{"In terra nummus rex est hòc tempore summus."}

More particularly in Agriculture has the command of sufficient working capital become a matter of prime necessity. Accordingly it is imperative that all means of raising cash upon valid security should be made available, so as to be at command if required. 
Our own country is, like all other civilised countries, already heavily burdened with mortgage debts. $\mathrm{Mr}$. $\mathrm{H}$. de F. Montgomery, of Blessingbourne, in Ireland, who has made a special study of this matter, something more than twenty years ago estimated the collective mortgage debt weighing upon agricultural property in the United Kingdom at something like $£ 900,000,000$. The burden is not likely to have grown any lighter since. If that money had been raised for bona-fide agricultural purposes, that is, to be spent upon judicious agricultural improvements, the benefit to our Agriculture might have been great indeed. Unfortunately the objects for which that huge debt was contracted were, as is common in similar cases all the world over, for the most part of a totally different character. The burden, however, is there and remains, like a dead weight pressing upon him who has to support it. And instead of being a help to Agriculture, it has become a direct hindrance, because it cripples the power of the owner of the land to deal improvingly with his property and make it yield to himself and to the Nation what the Nation, at any rate, has a right to expect. In cases like this it is usual for the overburdened man to look out for some new source of credit which, by an exchange such as the Romans already knew by the name of versura, will make the burden more bearable. This is what is, by means of co-operative credit, being done on a comparatively large scale, although only in respect of small debts, in India, where the mahajan's and sowkar's ruinous claims, turning the borrower into a veritable peon, are being steadily got rid of so far as the institution works. The trouble is that in the case of our British landowners it is not, as in that of the Indian rayat, the heavy rate of interest that makes the debt oppressive, but the improvident manner in which the debt was contracted, and the heavy tax attaching to the act of contracting it. For such an evil as this a versura by co-operative means provides no remedy. The proper remedy-the only one, in fact, of real effectiveness-is that of clearing out of a false position and making room for men with longer purses and more available means. 
However, mortgage credit, of course, there will have to be. And it is perfectly right that the land should itself, in case of need, provide the means for its own improvement. If the owner of past times threw his chances away by raising funds for improper purposes, or else found himself compelled by the exigencies of our land system to rob Agriculture in order to provide out of its yield for his younger children, that is a matter past praying for, the mischief being done. However, many a new owner is sure to require credit for legitimate purposes, the pursuit of which should in the national interest be encouraged. Now the difficulty in our mortgage credit, as observed, is not that the rate of interest charged is exorbitant, but that the raising of it is extremely troublesome and also costly, necessitating the intervention of lawyers of both branches of the profession who find in it a veritable milch cow that, without absolute need, they would not wish to part with. One reason for this is that already referred to, namely, the difficulty of establishing a valid title to satisfy a lender. Another, equally effective and equally hindering, is the want of appropriate machinery for dealing out such credit. Such machinery exists abroad and is found to answer. The question was even more urgent there than among ourselves, because money was scarcer and the owner of the land did not begin as a capitalist of the type of our large landowners of a past day. Necessity acting, as usual, as the mother of invention, has there devised two kinds of most convenient, easy and at the same time cheap credit, available for agricultural purposes, one of which positively ensures legitimate and provident employment. Such two types it is important not to confuse or to mix up with one another, because to do so would infallibly work mischief. They must be kept strictly apart. The type of credit given on personal security, for working purposes is dealt with in a separate chapter. Mortgage credit it may be more advisable to deal with here, because it is so dependent upon title, of which I am now speaking. Attempts, naturally suggested by a false idea of simplicity, have been made to blend the two forms of credit, so as to make them the 
work of one and the same institution. But such attempts have invariably miscarried. And necessarily so. Because in mortgage credit the object aimed at is to tie up capital for a long time--under present-day conditions a very long one. In personal credit the aim pursued must needs be to keep funds fluid. M. Durand's intervention in France in the matter of mortgage credit was quite exceptional, as intended to be temporary only, being embarked upon simply to make provincial capitalists realise that in the country's market the rate of interest for mortgage debts had generally gone down from the old 5 per cent. to 3 per cent. That lesson having been taught, M. Durand's little banks desisted.

For purposes of convenient personal credit under the circumstances coming into consideration Co-operation may be said to be a necessity. For purposes of mortgage credit Co-operation may be a help, and a very effective one, too. It has proved so in Germany, Austria, Hungary, the Scandinavian kingdoms, and to some extent in Russia. But it is not necessary. And on new ground, where its methods are not well understood, it seems preferable to avoid it and to leave the business in the hands of Capital, at any rate in the first stage. Capital is fully in a position to answer requirements.

The chief distinctive features of modernised mortgage credit are these. Apart from cheapness-which is necessarily dependent at all times upon the state of the money market and the value of the security pledged, and upon what may be achieved by means of good managementcredit is given, not for a short term of years-as in other cases appears preferable-but for a very long time, which may, in fact, come to be indefinitely extended and the determination, of which, so long as he complies with the conditions agreed upon, remains at the sole option of the borrower, who by this means secures command of a fixed capital for his free disposal. Coupled with this is the other characteristic, namely, that the mortgage is gradually paid off by means of a terminable annuity, which makes repayment very much easier and less burdensome to the borrower, who, however, is often allowed, after having in this manner 
ridded himself of a portion of his debt, to contract that same portion anew, on the same terms. Another point deserving mention is this, that under the new form of organisation a mortgage debt is converted from a practically untransferable, fixed and very cumbrous security, into a security fully mobilised and readily transferable-as readily tranferable as stock. Without such condition, of course, neither permanency nor gradual " amortisation " would be practicable. The instrument employed for issue is not a lumbering deed, requiring legal aid and long time for its examination and investigation before a transfer can be effected, but a bond readily transferable like a banknote. That innovation has proved a most effective help to rural mortgage credit, all the more that security was so amply provided for that mortgage bonds, fluid as money, were at times reckoned superior in value even to Government paper. The altered form of issue opened the gates of the money market wide to rural borrowers and made the mortgage, which previously had been a drug in the market, one of the most fancied investments even for short holding only.

All the advantages indicated of the new mode of issue may be secured and maintained under co-operative as well as under capitalist organisation. Their first entrance into active employment, effected under a sort of co-operative organisation, or co-ordination, was imperatively necessitated by the paucity of capital available for the enterprise at the time. It consisted in a large number of landed proprietors pooling their liability together without limit, in order by such pooling to be able to offer to the public a most ample guarantee for individual loans. The individual borrower would of course be answerable to the poolers. And equally of course it might be taken that the credit required would be less in amount by a good deal than the pooled security pledged.

It is scarcely necessary to enter in detail into all the minutiæ of the development of this system of raising money from practically a mere issue of mortgages made as a charge upon an individual property to a wholesale issue of seriated bonds, on which only the name of the particular issuing 
body appears, the naming of any distinctive pledge value having been suppressed. ${ }^{1}$ The whole arrangement was an eirenicon offered by Frederick the Great to the landed gentry of his at that time newly conquered province of Silesia, as one of the means resorted to to gain them over to fealty to himself, as a sequel to one of the most decisive chapters in the history of what the Hessian historian, Professor Feder, has uncomplimentarily styled "The History of Brandenburg Usurpation." Another such measure brought into requisition at the time was the wholesale creation of "Counts." The rank of "Count" was readily conferred upon landed proprietors in Silesia, who contributed a certain number of bullocks to the Prussian military Commissariat for conquering their country. These gentlemen came for a time to be known as Ochsengrafen" (bullock counts). As originally conceived, the plan on which a landschaft was organised meant compulsory liability for every landed proprietor in the province, whether he borrowed money from the landschaft or not, for the liabilities of the landschaft. While I had my property in the province, although I had not borrowed a penny from the landschaft, I was at law so liable. However, everybody knew the affairs of the landschaft to be so securely conducted that such nominal liability really amounted to nothing at all. In truth the landschaft then had a substantial balance of assets to its credit. The right of borrowing was restricted to owners of "knights" " properties - rittergïter, as they were then still called. Experience has shown that none of these restrictions and excessive engagements are necessary. Landschaften are now formed for the benefit of landed proprieters of all sorts, down to the very smallest, and with the restriction of liability to actual borrowers only. Indeed, in one case a form of engagement has been devised under which liability has become strictly limited. However, the antiquated, stately, but rather ponderous machinery, rendered effective by pri-

1 I have explained all this and other pertinent matters in the special chapter on " Mortgage Credit" in my book " Co-operative Banking: Its Principles and its Practice," published by Messrs. P. S. King \& Son, London, 1907. 
vileges conferred which recall feudal memories and are scarcely in harmony with the spirit of modern times, at any rate in democratic countries like ours, has survived. What at first glance makes the machinery adopted attractive to observers in other countries is the avowed principle of the organisation not working for profit, which appears to argue cheapness; and, moreover, the promptness and expedition with which execution may be effected in cases of noncompliance with terms or deterioration of the property pledged. The landschaft-which was orginally composed of persons exercising magisterial and indeed judicial authority in their province-possesses powers of summary jurisdiction, that is, seizure of pledged properties without a judgment from a Court. Experience-more particularly in the Scandinavian countries but also in Germany itself - has made it quite clear that such arbitrary powers are not by any means needed. They may easily be replaced by other measures of safety not interfering with the liberty of the subject.

To balance the apparent advantages secured by landschaft procedure, and by the exceptional powers conferred, there are decided drawbacks inherent in the system. For instance, cheap valuation by landesälteste or ritterschaftsräthe-who, in consideration of the "position" conferred upon them, draw no salary, but receive exceedingly moderate day pay while actually valuing-is offset by the very doubtful value of a scarcely expert valuation. The valuers are landed gentlemen of the " circle," elected by their compeers, men who have a general knowledge of the value of land in the neighbourhood, but no thorough training. Theirs is a case on a par with that of the two unskilled members of a society whom our Industrial and Provident Societies Act permits to act as auditors of accounts. As an alternative, the Act permits auditing by one qualified accountant, whose audit is now generally recognised as very much preferable, as being more trustworthy. The valuation of the officers of the landschaft is low-advisedly so, according to an accepted, more or less antiquated scale-in order to keep the landschaft on the safe side. However advantageous this may be for the 
landschaft, it naturally discontents the borrower. And an authoritative admission of the insufficiency of such valuation is to be found in the fact that an additional sixth of the ascertained value, beyond the "three sixths" originally prescribed as the limit of a loan, is now generally granted as a matter almost of course. That practically brings up the loan to about half of the commercial value of the property. Control of the property, to prevent deterioration, is effective under landschaft supervision. However, the original object of the measure, to lead the borrower steadily to get rid of his debt, is effectually defeated by the provision constantly taken advantage of, which permits re-borrowing of what has been " amortised." The very bureaucratic organisation adopted, placing officials on the landschaft on a par with members of the public service, according to a specific " decreet of ranking," and the investing of these men with summary powers of execution, are distinctly out of keeping with modern ideas.

The more recently formed Joint Stock Mortgage Credit Companies-which were at first eyed a little askance by the public as being bound to be inspired by a desire for pelf-now render absolutely the same services in a less antiquated and red-tape, and more businesslike way. These societies-for the practice of which Switzerland is the classical originating country, but which are numerous in Germany and distinctly gaining upon the landschaften-do work for profit. That is quite true. However their profit is only moderate, amounting to from 6 to 7 per cent. per annum upon the share capital employed. They earn it by working on more businesslike lines. For instance, their valuators, being trained men, at work throughout the year, and employed, as occasion may require, in various parts of the empire, not only possess a more thorough and more general knowledge of their subject than the officers of the landschaft, but make their rather higher remuneration worth paying by constant employment and more economic methods. Directors, also, as well as valuers, are selected for their fitness, not because they happen to be landowners in a certain district. There is, under these 
societies, no liability weighing upon borrowers beyond the actual amount of their debt. There are no summary proceedings-which might appear arbitrary-in waiting for them. There is no limitation of district. The various organisations adjust the measure of their work to that of their capital. In landschaften and imitation landschaften, where there is no share capital, notably in Denmark, special arrangements have proved necessary for carrying over liability entered into for one series of loans to another, so as to give the new series a start at non-beneficiaries' risk. Where there is capital, as for instance in the co-operative landwirtschaftlicher Kreditverein in Königreich Sachsen, it has proved possible on an economy effected in the working of the society, to confer a signal benefit upon borrowers by reducing the rate of interest on mortgages already actually issued. That is quite unknown in landschaften. Loans are "amortisable," and readily saleable bonds are issued by Mortgage Credit Companies and Co-operative Mortgage Credit Societies just the same as under the landschaft.

One cannot help thinking that on new ground, especially where Prussian bureaucratic methods are unknown, ordinary Joint Stock Companies, working with their own capital, give better promise of answering their purposes than organisations of landlords, who may know much or know little of the business, pledging their liability.

In the various shapes adopted, the various mortgage credit organisations here spoken of have proved a signal benefit to Agriculture. They have liberated mortgage credit from its ancient hampering shackles, and carried it into the realm of free transactions. Millions and millions of money have been raised by their means in a simple, easy and thoroughly legitimate way, pressing only very lightly -only in the shape of a duty to pay interest and sinking fund-on the shoulders of borrowers, who have no notice to repay to dread, but may, if they choose, themselves give notice at any time and pay off at their own convenience. Enormous sums of money have in this manner been made available for agricultural improvements. And a negotiable security has becn created and set current which is greatly 
appreciated by capitalist buyers, large and small; and true, and richly productive, Co-operation has been made effective between realised capital and advancing Agriculture.

None of this would have been possible without the security provided by Land Registry. Such registry cannot of course indicate or appraise the value of the properties to be pledged. But it guarantees an indefeasible title, for which the Crown makes itself responsible. Valuation has to be provided for by other means. In some countries land tax gives some sort of clue-to such an extent that special valuation can be dispensed with, land tax being optionally accepted in lieu of specific valuation. In the kingdom of Saxony the "taxation unit" (stenereinheit) may serve as a fairindex. From what I have seen of the valuation carried out in Prussia-I was there at the time and my predecessor was one of the valuers-I should not be inclined to accept that unreservedly. However, valuation is a matter that mortgage organisations-whether similar to landschaften or more co-operative-like the Mortgage Societies in Denmark and one in Saxony-or else purely joint-stock organisations may provide for themselves. The foundation upon which the transaction has to be built up is absolute guarantee of the title by registration.

Like our neighbours on the Continent, we likewise have for a long time made attempts to introduce a land register applicable to all kinds of property in this country. Some of us have heard of the admirable way in which that institution works among our Transatlantic cousins, that is, in our Australian Colonies and New Zealand, and in some parts of Canada and all the West Indies, where, as well as in the United States, it passes by the name of the "Torrens system," owing to its having been first advocated and introduced (in South Australia) by Sir Robert Torrens. In truth we may be said to have been "hankering after it" ever since the time of Henry VIII. Both he and Queen Elizabeth issued orders to establish it -which orders failed. Lord Westbury took the matter up in IS62. Since then we have scen strenuous efforts made by succeeding Lords 
Chancellors-Lords Selborne, Halsbury and Herschell-. to place Registration of Title on the Statute Book. All this has resulted only in the adoption of clauses in the Land Transfer Act of $\mathrm{I} 897$, which make registration optional -and compulsory only on the application of a County Council in respect of its own particular county-except in one case, the first of an expected but thus far not forthcoming series, in which the Privy Council was given power to issue the necessary fiat. The County so brought under the Act was that of London, which is not, strictly speaking, an agricultural county. However, Land Registration is useful for all land values, and its progressive, thoroughly timid adoption has in a skeleton way covered a large part of the ground assigned to it. Within that area registration has worked smoothly and satisfactorily, and up to August, I9I6, about I70,00 titles had been entered (since I8g8), the work being done gradually, by districts. ${ }^{1}$

In the United States, where the question of "farm loans" is now very much to the fore, the "Torrens system" is likewise much appreciated, more particularly as a means of facilitating credit. As a first step towards popularised credit "Torrens" registration was recommended. There turned out to be legal difficulties, and registration has thus far been adopted (in a fair number of states; a short time ago the number was thirteen) purely in an optional form, which very greatly reduces its utility.

Optional registration has, as already shown, been resorted to in a fair number of cases in this country, owing to the substantial advantages which it manifestly confers; and the inquiry instituted in IgoS and I909 by a Royal Commission presided over by the late Lord St. Aldwyn has provided conclusive proof that it has given full satisfaction to those who have resorted to it, securing for themselves an absolutely indefeasible title to land, minutely marked out on a map to the very inch, at about half the ordinary cost to the purchaser and about a third only to the vendor, and without any bother and trouble, any preparation of

1 The Counties of Yorkshire and Middlesex have had Optional Registration since some time. 
an "Abstract of Title" and the rest of it. All this work is done, and reliably done, by special experts, under the Registrar, who examines the deeds and has all the points coming into account at his fingers' ends.

None of the difficulties and uncertainties which timid minds at first apprehended and foretold have occurred in practice. In an old country like ours, with a labyrinthine network of laws affecting real property, and with wide ramifications of families, it was naturally dreaded that rival claims might be set up, running counter to the Registrar's entries. Indeed, some people thought that nothing short of a new Solonic seisachtheia-corresponding to the first Napoleon's despotic : Possession vaut titre, which settled the matter in France as by an Alexandrine sword-cut, simply quashing claims-would be able to introduce order into the confusion always threatening. All this has proved a simple nightmare. There has, indeed, been less of any approach to competing claims to ownership in the old country than in Australia, where, as one would have thought, on a tabula rasa of new ground, entanglements by rival claims could scarcely occur. There have been more there than among ourselves. To guard against any loss by such in Australia, a trifling levy has been made upon entries in the register, which some years ago had yielded as a collective result a sum of about $£ 400,000$-against which only about $£$ I 4 ,000 had been adjudged as due. In this country even such precaution-it is $\frac{1}{2} d$. in the $£$ in Australia-was considered-and rightly considered, as the event has shown - superfluous. In truth, our old title deeds have been so carefully inquired into by the parties concerned that the occurrence of doubtful cases is extremely improbable. As security against such, the reserve fund accumulated out of fees appears more than adequate. In fact up to the time of writing only one diminutive case, involving a sum of about $£ 400$, has arisen; and in that the rights of the matter are not by any means clear, although judgment has been pronounced. Our English system really marks an advance upon the Australian, because it provides for the entry of settlements, easements and the like in fact of all charges 
made upon the land. The advantages to be secured by registration are accordingly convincingly manifest. Everything is judicially noted down and kept in its proper place. But it had been doubted if all the information entered on the register could be kept strictly private and protected from prying eyes. That apprehension has likewise been proved to be quite unfounded. The register is kept strictly private and not shown to any one but those establishing a clear right to see it. Once more, it was thought that however cheap subsequent entries might be, the first entry, for which deeds would have to be examined and claims considered, must involve much expense, and that the discretion given to the Registrar whether to accept or to reject an application might carry disappointment with it. However that danger has proved absolutely negligible and would altogether disappear if, as one could wish would happen, registration were made compulsory. In truth everything is made easy to the landowner. The prize to him is an indefeasible title and absolute power to transfer or divide, as if dealing with stock; and in case of such transfer or of the taking up of a mortgage, cheapness of the transaction such as there has not hitherto been at all practicable. Vendors' costs have in the case of values up to $£ 500$ been $£ 2$ I2s. $6 d$., instead of $£ 7$ IOs.; in the case of values up to $£ 5,000, £ 775$., instead of $£ 45$; purchasers' in the same cases respectively being $£ 42 s$. $6 d$., instead of $£ 7$ IOs., and $£ 22$ 7s. in the place of $£ 45$. On the raising of a mortgage of $£ 5,000$ the costs are $£^{2} 2$ I 45 . in the place of $£ g 0$. And business is concluded on the spot, once more in the same easy way and with the same economy of time as in a transfer of stock.

It must indeed strike one as surprising that, with such advantages within their easy reach, landowners should not have long since as a body sought the protection of the register. The reasons probably are, apart from an engrained vis inertice and deficient knowledge of their own interestpossibly also with an inarticulate groundless fear that after all "walls have clocks and some of them have repeaters" -landowners have allowed themselves to be adversely 
influenced, to their own injury, by interested parties-not only solicitors, to whom of course the business of investigating titles and arranging transfers and mortgage loans are richly yielding milch cows, but also habitual lender's upon mortgage, such as, in the shape of insurance companies, stand most hinderingly in the way in the United States - parties who look upon this business as their own private preserve. Obviously it was a mistake on the part of Parliament to entrust the decision as to application for the requisite powers to those habitual inviti canes (unwilling hounds, which will not hunt) the County Councils. They have disappointed public opinion in more matters than one. The establishment of order in our modern Domesday holdings is a matter of too great national importance, too great importance to Agriculture and to country life, to admit of its being left to such resisting hands. The Land Transfer Act has had a twenty years' life and produced no result. It is time that other steps were taken. Parliament has shown that it sets store by the use of the Register. For it has made registration obligatory in the case of land dealt with under the Small Holdings Act of Igo8. Why not make it obligatory for all property throughout the land, or at any rate leave the decision on that point to the Privy Council? General registration would be a boon to the country and it would fit admirably into Mr. Lloyd George's registration of values, with a view to a possible levy of land tax.

Obviously purely optional registration is at best only a half-measure-in truth very much less than that-bringing benefit undoubtedly to individual landowners, but not to Agriculture or the Nation at large. The Nation has expressed its desire to see Agriculture made more productive. That is only to be done with the help of a large command of money. And that money requires to be raised.

Another measure necessary for this purpose is a considerable increase in the number of landowners occupying severally smaller estates with greater freedom in farming, presumably a larger command of working capital, and a promise given them of a full reward for their labour, intelli- 
gence and outlay. We talk much of "commercialising " and "industrialising" Agriculture. That calling in sooth necds such treatment badly. But if it could be placed on a full par with Commerce and Industry, undoubtedly the same skill, inventiveness, energy and outlay in capital, which have stimulated and marvellously developed the rival, according to Aristotle inferior, callings, would be forthcoming and raise it to the same high point of intensive practice and prosperity. To ensure successful business there must be freedom of action and there must be a prospect of a full return. The point here urged is not that the entire face of the country should be changed by a wholesale creation

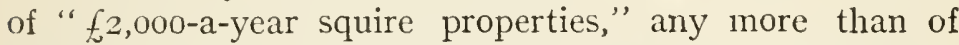
small holdings, nor that tenancies as well as large estates should cease. It is, that the number of rungs composing the "ladder" so currently spoken of should be increased and completed. It is that Sir James Caird's demand should be fulfilled and the landowners who do not possess the means to fill the position which they occupy-who in truth, by reason of their insufficiency of means and of interest, form a heavy drag upon national Agriculture-should not be drastically got rid of, but have a golden bridge built for them, by which to retire gracefully, yielding their places to others better equipped for the purpose. Occupying ownership, supported as it would be by the aes aliemum, not, as heretofore, of the landlord, but of a mortgage institution, would not get rid altogether of tenancy holdings. Nor is it desirable that it should do so. But it would set a new tune to tenancy conditions, by showing what farming can accomplish when freed from hampering restrictions and enforced submission to personal fancies. It is likely that it would create a new love for the land. It is certainly probable that it would, by keeping owners on their land, identifying them with practical Agriculture and associating them closely with local country life, impart a new tone to that life, such as in the more densely peopled Englishspeaking countries people are now in search of -in the United States since Mr. Roosevelt as President appointed the Country Life Commission, in Ireland since Sir Horace 
Plunkett took up the lead of the rural co-operative movement, which aims at far more Co-operation than that merely of the Store and the Market, and in England, where a " Rural Co-operative Society" has taken up the pioneer's work.

The means to be adopted for such transformation present no serious difficulties. The work might easily be accomplished. The result bids fair to prove exceedingly beneficial, lifting our national Agriculture at length, after a long delay, out of the barren rut of unprofitable routine, and breathing new life into what after all is a supremely important national calling. 


\section{CHAPTER IX}

\section{Reclamation of Waste Land}

ONE point in our long catalogue of errors, upon which our self-examination, provoked by the war, has thrown a particularly glaring light, laying bare what now appears a distinctly reprehensible sin of omission, is our quite inexcusable neglect of cultivable or plantable land, which has long been allowed to lie unprofitably idle, and still continues so. Providence has meted out to us our land, in proportion to our population, with a somewhat sparing hand. We have not overmuch room to turn round in and our proportion of acreage to inhabitants is small. When we talk of planting the humble population belonging to rural England back on their native land, in order that they may there enjoy the " beatitude " sung by Horace, to relieve the jostling throng of industrial population in towns and to produce in larger quantity the food required for our people, the cry at once goes up that there is no land to spare from what is wanted for the larger farmers, that to cut up large farms, in order to create small holdings, would simply be robbing farmer Peter to pay small-holder Paul. And yet there are, as is reported, something like twenty-one million acres lying idle within easy reach, almost under our very noses, a very tidy slice out of which is fully capable of being sown with corn, or else planted with trees, providing for us directly or indirectly what is needed, in sheaves or in beeves; and, once more, the timber that we want when an emergency like that of the past few years comes upon us. There are, apart from a considerable number of desert patches scattered sporadically over the surface, wide stretches of bog and 
marsh, of neglected land yielding a miserable rent as sheepwalks, or else only enlivening the landscape with Goldsmith's "unprofitably gay " furze bushes ; and there are square miles and miles of bare hillside and hilltops-more particularly in Scotland-which would bear larch and spruce and pine, it may be beech and oak, all of which yield valuable and needed timber-precisely the type of timber, says the Forestry Committee, that we are in want of-staring us reproachfully in the face in their nakedness, "One-fourth of our $12,000,000$ acres of waste land, and our I2,500,000 acres of mountain and heath land used for light grazing," says Sir W. Schlich, "if put under forest, would produce all the timber now imported, which can be grown in Britain, that is to say, 95\% of the total." And for decades and decades nobody has appeared to trouble about this inexcusable waste. To any one acquainted with the painstaking utilisation of mountain land by our Continental neighbours it is apparent at first glance. And there is no excuse for it, except it be our native indisposition to take trouble to which necessity or the prospect of immediate substantial gain does not impel us. What timber might have been grown upon those bare mountain sides! What employment might have been given in the woods to the local population! How many more healthy homesteads might have been set up! What welcome shelter against destructive winds might have been given to inland plains and valleys! And as if such neglect were not enough to weigh upon our consciences, whatever forests there are-it now turns out, more specifically under the recent inquiry by the Forestry Committee -have been disgracefully mismanaged and half ruined, left to decay because, as Lord Selborne has well put it in his evidence before the Committee just named, "landlords prefer rabbits to trees." There we have one cause of this long and shameful neglect frankly confessed! We have fancied ourselves so rich, sitting like Babylon of old "a queen" amid nations, that we have come to value "ruffles" of luxury more than the "shirt" of necessity, sport more than the production of food, and than the 
employment of labour, and the creation of new habitations for men and their families. The "bridegroom" of the parable has come upon us "foolish virgins" in the shape of war, and now we discover what it is to have lamps in our hands without the necessary oil-which by a little forethought we might so easily have secured! Waste land, with trees neglected, brushwood, bracken, furze, heather and the like, favours game. Some sixty years ago a story was told me of the late Prince Consort, who had by invitation of the owner been shooting over some Derbyshire moors. Inquiring as he was by nature, he had carefully examined the soil and cliscovered that it would bear excellent crops. "What unconscionable waste," so he is said to have remarked to his host, " to leave such good land to lie idle under heather!" "What," so his host is reported to have retorted with amazement, "spoil the moor! That would be vandalism.'

That is one cause. Like the poet Gay in Pope's estimation, we have spent " on silver loops and garments blue," on sheer luxuries, what was entrusted to us for a nobler purpose.

But there is another cause as well, really of a graver complexion. What inducement has a landowner under our present land system to reclaim or to plant, especially if he has no large command of funds? That would mean money out of his pocket, to ensure a benefit to some future successor. He may be on the look out for laying by for the children who do not inherit the land. Or else he may be thinking of his own amusements and enjoyment of life. It is not every landlord that has the public spirit, the intelligence, the enterprise, the money, and the youth, -when he began-of Coke of Norfolk, or of Lord Somerville, Lord Egremont, or the Duke of Bedford of those days. Abroad, in most cases, outlay upon such work ensures a direct return in grist or in meal. The fruit drops into the lap of the man who planted the tree. If the land has not already repaid the outlay, if the trees have not grown up to felling height, while he was the possessor, the increased value will swell the selling and valuing price of the property, even in its only half-matured state, just as a three months' 
bill will be worth more than at the time of its drawing when part of the maturing time has run. The money comes back to the spender. In our case it does not.

There are other causes still. More than once have I asked in the country-more particularly in my whilom county of Sussex-why such or such a patch of land fully capable of cultivation was left uncultivated. "We began digging it up and sowing or planting things; but at once the rate collector "-I think there were several other harpies of the same clan, the kind that the late Lord Salisbury on a memorable occasion in the House of Lords branded as " nuisances" - " came down upon us. Cultivation would not in the first stages have been worth the outgoings. So we gave up." In the grandduchy of Oldenburg, in which very careful attention is paid to land reclamation, more particularly of moor and marsh, and where land settlement is systematically encouraged, settlers reclaiming waste land are allowed ten years' exemption from rates and taxes, besides a certain period of freedom from rent, if the land be the property of the State. Under such conditions reclamation advances apace, to the benefit of the country, which becomes the richer by it. Similar privileges are accorded in other countries, not of the European Continent only, although the measure of exemption may be less-for instance in Italy, but also in Prussia. Where so great a benefit is to be secured for the Nation, cannot we too sacrifice a few years' rates and taxes? As they say in Yorkshire, there is "nowt for nowt." And it is just from the smaller men, whose purses are small too-though they may have abundant fruit-bearing efforts in their bodies-that we may expect most in the matter of reclamation.

It we look abroad we find a different state of things altogether from what obtains among ourselves. In France -apart from some wastes on large estates which take up proportionally little space on the map-you see every square foot of available territory turned to account. The meticulous care of French husbandmen for little plots that they can even only create by carrying the soil up laboriously on their backs in their hottes, hundreds of feet of steep climbing 
has passed into a proverb. You see the same thing in Germany, wherever vines can be cultivated so as to ensure a sufficient return, more particularly on the Rhine and the Moselle. One of the most famous Moselle wines has been given the name of "Treppchen " from the "steps" hewn into the rocksides to enable the cultivator to reach the little plots carefully made cultivable, on which the grapes ripen. In Germany you will find little land that is at all suited for cultivation that is not actually put under the plough or the spade-except in the desert sweeps of the great sparsely peopled sandy plains, poorly provided with roads. And even there cultivation is active on land which it is doubtful whether we on our more happily situated island, and with our very much more easy-going ways, would consider to be worth cultivating. However, the careful bauer labours from early to late to force his family's sustenance out of an unwilling soil. So keen is he upon extracting what he can from even unpromising sand that it has become a saying that soil which produces heather will also produce rye-which in Germany, as we know, forms the staple food of the people. In France the thing is so much more striking and more general, and more remarkable, also, because those mountainside fields which delighted Arthur Young are only rarely put to the lucrative use of growing vintage vines. Whoever has seen those artificially created little plots on the sides of the almost perpendicularly upstanding rocks near Aniane, memorable as the abode of the great reformer of monasteries, on the way to the venerable ruins of the abbey of Saint Guillem, will not fail to give credit to French husbandmen for making the very most of what cultivable land Providence has placed within their reach.

We, for our part, although in our island more people are crowded together in smaller space, have been far more indifferent to waste. We appear to like the " unprofitable gayness" of waste land, we like sport, and we love natural beauty. We separate our fields by hedges which cost us very much more than we appear to be aware of in cropbearing power-because they are so picturesque. The sight of a bare plain of fields, such as we observe in the best 
cultivated parts of Germany, with nothing between them but at most ten inches of grass, not unnaturally palls upon us. God forbid that we should get rid of more commons than we have done already, or destroy the beauty of our smiling English landscape! But it is not commons only that lie waste. And if we want to retain our commons and gentlemen's parks and hedges and the like, we shall have to bear in mind that the indulgence of our æsthetic tastes, to the prejudice of cultivation, has to be paid for. And when the time of pinch comes, the question arises: How much can we afford to pay?

Quite apart from the plenteousness of bad farming that our experts complain of, and the land which would well repay tilling unwisely laid down to pasture, there is plenty of land that we might with great advantage put to agricultural uses-say those veritable nests or " pockets" of fertility studding our East coast, alike of Scotland and of England, which would yield rich meadows and capital arable land, capable of producing crops of great value. We have learnt what drainage of land and warping means on such soil from our early Dutch settlers. There are in truth, for work of this kind, no better teachers than the denizens of the two sections of the Low Countries, whose employment not only of their low-lying land, but also of the dry sandy stretches inland, is something to wonder at. They do not grudge either labour or study. And they secure for that labour handsome rewards. We talk rather disparagingly of the light Belgian "Campine," which Laveleye branded as "the worst soil in Europe." In the sandy marches of Brandenburg-which are nevertheless to a considerable extent well cultivated-I have heard farmers lamenting that their sand will not come up to the quality of that despised "Campine" !

Why cannot we, in spite of the drawbacks already indicated, under the influence of our rather notorious disposition-recently referred to by Sir J. Stirling Maxwell, quoting from a Belgian economist-to measure all things by their capacity only to " pay," husband our land in something of the same way? The war has come upon us and has 
found us unprepared. There is the land! There is the need confessed! But the means for connecting the two are neglected. In his speech at Lincoln in July, IgI6, Lord Selborne gave vent to a longing for the same dictatorial powers which under the law passed in Prussia, specifically for the war, the Prussian Minister of Agriculture is supposed to possess for commandeering land for the service of the nation and dictating to landowners and farmers how to employ their land. The powers conferred do not go altogether as far as Lord Selborne appeared to assume. And practice does not in every case correspond to powers given. The territory is so vast, and conditions vary so greatly, that even the largest powers are often bound to fail in view of opposing practical hindrances. You cannot get blood out of a stone. You cannot force landowners who have no money, few live stock, and but little labour -and who could not under present circumstances, even if they had the money, obtain the requisite fertilisers-grow indefinite crops of wheat, rye, and potatoes. In its practical application the law affects in the main small landowners in the vicinity of populous centres, whose cultivation may be most readily controlled. We are at present still wholly without data to show the success of the measure. And as regards powers of coercion, our Development Commission is likely to be able to do more, at any rate specifically for afforestation, than any such dictatorial powers in the hands of a Minister could accomplish.

We have got into the way of making rather light of the difficulties standing in the way of the reclamation of waste land. Ploughing up and sowing with wheat seems to be considered such a very simple thing, securing a certain harvest, even where the land is not simple pasture, but has stones in it, and brash, or is soured with wet and raw in the extreme! It does not even occur to us that special knowledge is required for the work. It seems such a plausible programme, to propose to assign our wastes to the discharged soldiers, whom we desire to plant upon the land, as a matter of "doing something for them," as if giving i man land to cultivate were equivalent to giving him a 
"living"-in the sense in which Lord Beaconsfield used the term, when bringing in his "Agricultural Holdings Bill " in I875. The proposal now made, namely, to concentrate the work of would-be small holders upon waste land, is of course-admittedly-put forward with a view to protecting present large tenants against disturbance in the use of their holdings of old land for the benefit of the coming small holders. And if the assignment of a holding, to be paid for in rent or else by a terminable rentcharge, really meant the giving of a "living," the plan would be plausible enough. However, farming of every kind, and more specifically this description of it, will yield a "living " only if the farmer knows precisely how to make one out of it. The "piping times" -in this case of warthat is, of abnormally high prices-are, thank God, not likely to last for ever.

We have had some curious instances of false handling of land-even cultivated land-in the course of past experiences. I remember more in particular some in the, now happily defunct, "English Land Colonisation Society," in which settlements undertaken with great hopes turned out miserable failures. What kind of settlers discharged soldiers will make and whether they will take to settlement at all, and stick to it, we do not yet know. Why then set thess inexperienced, untried men to work upon what is really the most difficult task to be set to a cultivator of the soil ? Many of these men are not likely to find much "living " in it. And put them under State direction, supply them with State means, and you destroy all spirit of selfreliance and promise of the land reclaimed by such men becoming an asset to the Nation-rather a white elephant. In truth, reclamation of land is not by any means the easy, self-regulating thing for which it is given out. Ploughing up pasture is one thing and reclaiming waste land another. German discoveries are quoted, about saturating the land to be cultivated with fertilising plant food, inoculating it, and the rest of it. That is not all that is required. And it is not practicable everywhere, as Germans themselves have discovered. On very much of their drift-sand 
heavy doses of manure, whether phosphates or nitrogenous, would be clean thrown away. There is too little retentiveness in the soil. Inoculation has proved valuable. But there is plenty of waste land which requires more even on the top of inoculation after breaking up and treating to heavy dressings of manures, and on which the second year after reclamation will not see the imagined heavy wheat crop grow that we hear talked of. Carting off the soil from the mounds and filling it into the hollows, which is spoken of as so very easy a matter, is likewise a good deal less successful in practice than it appears in theory. There are wastes in which that would mean piling up soil capable of bearing crops in unnecessary thickness on some spots, to leave other bits hopelessly bare and barren. People want to be trained to the work of reclamation, as well as to any other. You may waste a good deal of money and labour in injudicious reclamation.

Our cousins in the United States, although of course disposing of enormous spaces of waste land, afford us no guidance in the matter of reclamation, except in the rough and ready, generally wasteful way of reclamation by individual settlers. In a national capacity they do, perhaps, more than any other nation in respect of reclamation.' But it is all irrigation, to make arid land capable of bearing crops. That means, in the United States, a great deal. For arid land tells up to about a third of the entire Federal area. Under this aspect the Americans have accomplished veritable wonders, such as have astonished our Indian irrigators. The United States Treasury now disposes of a fund to be appropriated to this purpose of about $£ 8,000,000$. On irrigated land as little as five acres, and even less, is found sufficient to maintain a family.

We shall have to lay our account with having not a little inferior land, less grateful in itself, or else more beset with obstacles than that now under plough and spade, to deal with. When that task falls to expert hands, familiar with the quality of the soil and with local conditions, of climate and otherwise, however primitive and elementary may be their handling of the soil, we may count upon more or less 
satisfactory results. Very much of the land now under cultivation in Ireland has in this way been secured for pasturage or tillage by little skilled native labour. And there are many pieces of land on this side of St. George's Channel which might be dealt with in the same way by simple labourers taken from the neighbourhood. But that is not like setting an unskilled soldier fresh from the camp to the task and making a peace-time Cincinnatus of him.

In respect of one particular description of improving work waiting to be taken in hand there will be found a perfect unison of opinion, and there is not likely to be much disagreement with regard to the methods to be adopted in accomplishing it. That task is the reclamation of our alluvial or else marsh-- and bog-covered land, so much of which at present lies reproachfully idle. Acres and acres there are of black alluvial soil in the estuaries of our East Coast, both north and south of the Tweed; and again, distant from the sea, in the river valleys of Wales. And other acres and acres there are of bogland, peat and moss, presenting a picture of miserable desolation, yielding nothing except it be a home for waterfowl or a few blades of innutritious grass for the tooth of hardy stock, but concealing under such uninviting surface the fertility of the best loam.

We know how to deal with soil of the first kind alluded to. For ages ago the Dutchman Vermuyden taught us in what manner to proceed to render it profitable, and though his work was interrupted by a foolishly opposing peasantry, the rich lowlands of Epworth, Thorne Moors and Hatfield Chase now show us what may be effected by draining, unsalting by rain, and also by warping, and careful cultivation. There is luscious grass in the lower parts, with a belt of fertile arable land above it, and the improvement reaches still higher up. Why not improve all our alluvial deposits and promising fenland in the same way?

Then there are the long stretches of coast, over which the sea breeze now blows-the meal-like sand from the shifting sand dunes making them barren. How much of that land is there not to be secured for Agriculture by fixing the dune-sand with vegetation-vegetation, be it what it 
may. There is coarse grass that will grow there, there are hardy shrubs. In the landes of France Brémontier has more than a hundred years ago set us a brilliant example of what may be accomplished with the cluster pine or pinaster, a plant seemingly specially created for the purpose of fixing the sand. For it fastens its penetrating roots in such sand with remarkable tenacity and bends by nature so as to lessen the force of the wind. That example has been systematically followed in other parts of France, with the best results. However, there are other plants which will achieve the same purpose as well-and better, it may be, where trees would be out of place--such as dog's tooth grass. Vegetation of any kind found suitable will do, so long as it fixes the sand and thereby makes the land lying behind it-generally very useful land, if only by reason of the moist state in which it is kept and the ready access of sunshine-valuable for agriculture.

However, there are also considerable stretches of waste -like the Derbyshire moor which occasioned the Prince Consort's astonishment-inland, some very sandy, so as to have hitherto frightened off cultivators, some of better quality. And the consideration of these brings us up to the main cause of the waste which, now that the need has come upon us and that the shoe has begun to pinch severely, we all profoundly deplore. Such need becomes most regrettably apparent in the cause of waste and semi-waste which would bear good forest crops, of which we shall still have to speak. But it makes itself felt to a lesser extent also in respect of much land fitted for the plough. The stubborn hindrance spoken of in our land system, which places the ownership of the bulk of our land in the hands of life tenants, who often enough have little regard for the interests of those who come after, forms a serious stumblingblock. Their circumstances in many enough cases also compel them to make hay while the sun of life shines. Planting a forest would mean sinking money which they would rather spend upon their own pleasures or else leave for their younger children than on an investment which will not mature for decades-beyond their possible limit 
of natural life. Reclaiming land for the plough presents something of the same difficulty in a lesser way. Reclamation and improvement cost money. "Coke of Norfolk" spent a great deal before he got his first return. A late duke, whom I knew as a lad, and who got his affairs rather out of order, when told by a good man of business that all might be set right if he would only consent to economise for a limited number of years, coolly replied: "Why should I ?"

It is to these waste spaces that one would wish to see the principle of the Prussian law, to which Lord Selborne enviously referred, applied, or else the French law which expropriates au nom de l'utilité publique. The difficulty is to make the law work. In theory it seems easy enough. Under the Prussian law the Government is entitled to call upon the owner of any waste land, which is found suitable for cultivation, or, if there should be more than one, all those concerned, to combine to a consortium-formed like one of the French compulsory associations syndicales, the Belgian wateringues or the German deichgenossenschaften -in order conjointly to reclaim and cultivate such land, failing which cultivation may be carried out by the parochial or district authorities at the landowners' expense, so that the Nation be no longer defrauded of the benefits which Providence has prepared for it. Here is an interference with the rights of " property," such as our own landowners would probably never dream of being possible, but which is calculated to recall to their mind the fact that their "property" is not their absolute property at all, but to some extent a value held by them in trust for the Nation. There are occasions conceivable on which they may be called upon to give an account of their stewardship. Unfortunately the matter presents undoubted difficulties in practice. Wherever there is a willing competitor in the field from the outset, the thing is easy enough. In Prussia since a very long time, wherever there are mineral deposits under private property, a person, or a company of persons, is entitled at law to give notice to the authorities that he or they intend to work such deposit. Thereupon the 
authoritics call upon the owner of the land either to work the minerals himself or else to give the applicant access to the land for the purpose of embarking on the work on his own account, allowing the landlord a royalty according to an arrangement to be made. But reclamation of land is a different thing. Since the days of the early Popes Roman Governments have endeavoured by such means to bring the wild stretch of the Agro Romano, at one time the granary of Rome, under cultivation once more. Pope Julius II, who was no mincer of words or shirker of action, issued a particularly stringent decree directed against those highborn dukes and marquesses who share among them the ownership of that immense tract of territory, which is now in its barrenness a disgrace to Italy. No one can drive across that extensive dismal desert without feeling real pain at its utterly neglected condition, while real wild horses running about masterless are pointed out to him as a curiosity in Europe. Whatever Popes might decree, however, the dukes and marquesses invariably discovered means of frustrating. If they could not resist cultivation by settlers, they could put spokes into their wheels very effectually in the matter of getting rid of their produce. The recent law of $\mathrm{I} 88_{3}$, from which great results were looked for, has proved scarcely more effective. But that law marks a turning point in the history of the Agro, which it may be well for us to note. It was passed in the interest of co-operative settlement societies claiming land in the Agro for reclamation or settlement. Co-operative societies, so it was thought, would be better able than single unassisted individuals to form village settlements. Their combination would provide some guarantee for good and permanent settlement work, and for overcoming the obstacles placed in their way by recalcitrant nobles. To such the law was made to apply. Later legislation on the same lines has proved more effective, and the desert is now very slowly beginning to recover the appearance of land in a civilised country, coming to be at any rate thinly studded with little co-operative settlements, designed to become borgate, by means of affitanic collettive. The Government 
is also proceeding independently in this matter of settlement. Realising the importance of the work, the Ministry of Agriculture has appointed a special Uffizio dell' Agro Romano, having power to expropriate upon the report of expert officers, "such land as being suitable for reclamation, is not being reclaimed by its owner." Lord Selborne might well wish for such power as this. However, if we are to proceed in the matter, under our peculiar circumstances, we may require something equally drastic. We ought not to be made to wait for improvement as long as Italy has done.

In passing it may be mentioned that in Burma, as in Italy, the work of reclamation is now being undertaken by co-operative societies. The United States, busy as they are with irrigation, give us no lead whatever under our present aspect. For, although they contain an almost immeasurable extent of what they term "Swamp-land," which has by the Federation been handed over to the several states, under the impression that the States would more readily make it cultivable, all this potentially fertile land has thus far been left, in the main, in its original state of swamp. "States," like County Councils, do little unpushed. But we must deal with our bogland. There are some millions of acres of it in the kingdom, looking bleak and bare, or else sloppy and waterlogged. Nevertheless there are splendid examples to show that that waterlogged, Sodom-like desert might become richly yielding wheat land, like the best of loams. And without excessive trouble or expense too, in some cases-such as have occurred in Prussia-repaying the outlay for the improvement by the very first harvest.

We naturally look to Holland for an example how to effect the work. And Mr. Robertson Scott's book, "A Free Farmer in a Free Country," has told us in the most lucid way how the Dutch proceed in the matter. They drive a canal into the bog, dig off the peat, remove it by boat, dig side canals, go on in the same way and, when the peat is cleared off, they begin to cultivate, section by section, planting new villages on the reclaimed bit, which soon becomes flourishing and prosperous. That is a method 
alike of improving the bog and settling cultivators on new land, which has proved most successful. However, it requires time-long time, in some cases time of which the end seems to lie beyond the reach of the human cye. And there is another drawback. In spite of the recognised utility of moss litter-for which only peat in an early stage of decomposition and with much undestroyed fibre will do-and employment of peat under the "Mond" process, as adapted by Messrs. Frank and Caro, for the manufacture of gas - to say nothing of the employment of peat dust in the manufacture of sugar-before the war peat had by little and little become disappointingly cheap, with scarcely a profitable market left for it. Accordingly in Germany -which is estimated to have about 6,000,000 acres of unreclaimed peat bog within its territory (Prussia alone answering for about 5,000,000 acres)-sufficient, according to Professor Fleischmann, who is esteemed an expert authority, to provide food for 800,000 tons (live weight) of stock and to nourish 70,000 peasant families-other means have been used to turn the latent fertility of the bog to account by simply reclaiming such storehouse of productiveness. (Herr von Wangenheim, by the way, one of the chiefs of the Agricultural Party in Germany, considers Professor Fleischmann's estimate to be too low by half.) Instead of being carried off to be turned into gas by the "Mond" process, the peat has been used for that purpose on the spot, so as to generate the electric power which will raise and remove what peat has to be removed, at very little cost, and in very little time. This process, which is found to answer better, to cheapen the cost and very materially to shorten the period required for reclamation, has recently been tried upon a large scale on a moor of about 25,000 acres, belonging to the State, at Wiesmoor, and has proved successful.

However, there is more still to be said in favour of the Prussian process. In the recent discussion of the question of reclaiming moorland in this country the objection has been raised to the Dutch process, that it will not suit our purpose, inasmuch as most of our bogland to be reclaimed 
lies too high up to lend itself readily to such process. But it is at present precisely in the high "moors "- the word "moor" standing in German for our peat bog-that in Germany most work is being done. And that is because it has been discovered that on such moors the peat does not require to be removed at all, nor to be mixed with the underlying sand, but that, after simply draining, it may with great advantage be at once ploughed up and placed under crops. Such high-lying bog wants as a rule to be rather differently treated from low. There is, of course, bog and bog. Low moor has as a rule more or less mineral constituents, including lime, which form a valuable asset for cultivation. High bog is generally poor in mineral salts and lime, and requires to be manured accordingly. But that may easily be managed. Apart from this, of course, bog has to be dealt with according to its ripeness, that is, the degree of decomposition of its vegetable matter.

The reclamation of bogland-and, in addition, of those extensive and highly fertile "brooks," as we call them in Sussex, corresponding to the German word " bruch," that is, marshes produced by the natural warping process by rivers (in Germany the Oder, Warthe, Netze, and others)is in Prussia a long-established and cherished tradition, dating back to the days of Frederick the Great, or really, as a small beginning, to the reign of his father. However, Frederick the Great-who in agreement with Aristotle pronounced Agriculture " the first of all arts," and declared that he would hold the man who made two blades of grass grow where only one had grown before in higher esteem than the best general or the most adroit statesman-was the real father of the policy, and carried it out with creditable zeal and perseverance. Had his successors-up to the present one, who has once more taken up his ancestor's hobby, as we have seen, for special reasons-continued on the same paths, there would now not be a square foot of bog or "brook" left unreclaimed in the monarchy, and in the opinion of Herr von Wangenheim Germany would be able to nourish another 30,000,000 people "with homegrown meat." Frederick the Great felt so strongly upon 
the point that in his lifetime he devoted the main part of his attention to the work, and caused $£ 6,000,000$ to be spent on the reclamation of moors and "brooks." In the present day that $£ 6,000,000$ may appear a paltry sum. But at the time of Carlyle's hero it meant about eight per cent. of the public revenue, spread over twenty-three years. And when his ministers and administrators in their clumsy red-tape way raised objections, on the score of an. insufficiency of available labour, in respect of a large moor in Friesland-which Frovince had become Prussian in I744the king promptly ordered the release of half the number of prisoners detained in the military prison of Emden, being rural folk, accustomed to agricultural labour, and their settlement upon the moor, with $7 \frac{1}{2}$ acres of land assigned as property to each. For this they were to pay by instalments, presently, after the holdings had been got into good order. In such way arose the new thriving village of Moordorf which exemplifies one specifically valuable feature in the reclamation of bogland, namely, its pronounced utility for settling purposes. Frederick was not the first to discover such aptitude. Reclamation of moorland had even before his day found its way from Holland into the western parts of Germany, of course on Dutch lines. There moorland abounds to such an extent that about thirty per cent. of the entire territory of the grandduchy of Oldenburg is made up of it. The whilom electorate, then kingdom, of Hanover also has plenty of moorland; and the two episcopal sees of Bremen and Verden, holding extensive stretcher land in it, were active promoters of colonisation thus combined with reclamation, setting up in this way no fewer than roo new villages within fifty years.

However, King Frederick's activity in the matter gave a new fillip to the movement. During his reign he had about 625,000 acres of moorland reclaimed.

In recent days reclamation of moorland has made very marked progress in Germany, owing to the attenticn devoted to it under the systematic agricultural policy directed by the State, with the aid of many leading private agriculturists. Perhaps the doings of the Government in the 
matter may be useful as suggesting to our authorities some desirable steps. In the first place, the Ministry of Agriculture some time back instituted a distinct department to deal with this special subject, ably officered and presided over by the particularly capable and active Councillor Thiel, whose name is not altogether unknown in this country. By the side of that public department, there is an independent association of men interested in the subject. And, in fine, to permit of experimental research, there is a well endowed experimental station, specifically for dealing with moorland, established at Bremen. All three institutions, working hand in hand, have proved exceedingly valuable and have stimulated inquiry and activity to a remarkable degree. Under such guidance the science of dealing with moorland has advanced greatly.

One newly introduced process, which has proved most valuable, deserves mention. It concerns low moors. After many varied experiments, which cost him his fortune and even landed him rather deep in debt, Herr Rimpau discovered that by laying out low moor in ridges, by means of trenches, out of which the black soil first dug up, and later the sand-which in Germany almost invariably forms the subsoil under moorland-is placed upon the ridges, producing a layer of sand above the peat about 4 or 5 inches thick, very valuable arable land may be produced, yielding as heavily as the best wheat soil, and suitable for any variety of crops. It is the sand which is cultivated. The black soil underneath is left untouched. Moorland so treated will produce such considerable quantities of good fodder, that most ample farmyard manure becomes available for fertilising the adjoining land, which in Herr Rimpau's instance - as in many others - consists of pure white sand, but which has by such manuring been raised to a pitch of fertility which enables it likewise to bear any variety of crops, including sugar beet. That has now become the favourite process for low moor.

One advantage of high moor, on the other hand, under the German system, is that with the aid of the manure bag it may be cultivated from the very start-once it is drained. 
And it is found to provide first-rate meadow and pasture. That is in Germany, where stall feeding is common, found to be a very appreciable advantage. For observation has taught the Germans, rather late in the day, that young stock, to grow up healthily, requires pasturing, were it only for the sake of exercise and air. And high moor pasture provides just what is wanted for the purpose, without encroachment upon other cultivated land.

There is another timely lesson still which German experience teaches. Our learned counsellors in the newspapers have lately admonished us to confine ourselves in the matter of reclamation of moorland to large areas only, and leave the small patches of bog or marsh, distributed over private estates, unconsidered. But in Germany very marked attention has of late been paid more particularly to such patches; they have been improved with care and assiduity, and by such means much valuable cultivated land has been gained. If we are in earnest, we shall have to tithe our mint and anise and cummin as well as obey the weightier behests of the law. And in a national reckoning the small patches total up to a goodly acreage.

There is one more thought which foreign doings suggest with regard to peat moss. Peat moss is not only there to be reclaimed. We have plenty of it. And during the war our supply of coal has been limited and has been menaced with still greater shortage. There is heating power in peat and we have a process at our command for turning it, as the Germans do, into gas, and employing it for the generation of electricity. Why have we not, during the war, drawn to a larger extent upon our resources in peat? The Governments of France and of Italy have been far more on the alert. In Russia, where coal is scarce and peat plentiful, the service of supplying peat for the market is a standing feature in Government organisation. The Government maintains a special college for peat engineers. There are about a million tons of peat raised and put upon the market annually, ordinarily at the price of something under ten shillings the ton. Not a little peat dust is used for cattle food, in conjunction with the refuse of 
sugar beet and other moist feeding-stuffs. In France the digging of peat has long since, for the period of the war, been placed under Government direction, and a special department has been created to supervise it, in order that there may be full production, on correct lines, and no waste. In Italy the Government has by public notice called upon all landowners in possession of peat moss to work such, failing which, within a given time, the authorities threaten to authorise other persons to dig and sell the turf. Bounties of $25^{\circ}$ and 500 lire have been offered to those who make deposits of peat, not hitherto used, available for public use. In time of war-tout sert à menage. And where coal fails, and straw fails for litter, peat is after all worth considering.

In the Scandinavian kingdoms, during the war, in view of the exceptional scarcity of coal, the rich deposits of peat in those countries have been largely drawn upon for the supply of fuel. In Norway the output from the large peat deposits near Stavanger, which in ordinary times is $I, 000$ tons per month, has been raised to I0,000 tons; and there are now 216 steam engines employed in cutting and moving it, in the place of only fifty-five in Igr6. In Denmark the output has increased from 90,000 tons in I9I5 to 200,000 tons in I9I6. In Sweden the output, already grown to I00,000 tons in I9I5, was to be doubled in I9I6.

Enough has probably been said to show that, if we will only take advantage of the precedents set us-fas est $a b$ hoste doceri-there is a good deal of improvement of our paterna rura within our reach in the matter of reclamation of alluvial and bogland.

However, the point in connection with this policy of reclamation which is likely to absorb greatest attention among ourselves, and enlist most interest, is that of the turning of those millions of acres which now lie unprofitably idle in the shape of bare hill-sides and mountain-tops, sometimes covering their nakedness with the euphemistic description of " sheep walks "- - often sparingly spotted with scrub and valueless brushwood, or else with swampy moss and useless marsh herbage and rushes-into good profitable forest. Speaking of such almost methodical neglect of 
vast areas of land, which after all possess not a little productive faculty-for the forester of Dunrobin has given it in evidence that the finest forest that he has seen was grown on soil that was quite unfit for ordinary cultivationAlfred de Musset has sung, bewailing the wasteful destruction going on-

"Notre globe ras, sans barbe et sans cheveux

Comme un gros potiron roulera dans les cieux."

Most attention is due to this kind of land, not only because in it the waste incurred by past neglect is greatest and least excusable, but also because the work of reclamation is in this case bound to take the longest time. There is waste here with a vengeance, waste which the Coast Erosion Commission has estimated at nine million acres. And to this, so it is sad to have to own, must be added large areas of land actually covered with trees, and rejoicing in the name of woodland, but which, owing to neglect and false forestry, really represents little more than absolute waste - with too little timber upon it, and much of that worth very little as timber, though it may be highly useful as cover for game--" gappy woods, stunted growth and short coarse stems far apart," so an expert forester has described it before the Forestry Committee. Look at that woodland-a good part of the three million acres that we actually possess! It looks pretty enough to the untutored eye, picturesque in its wildness, but a large portion of it is worth very little indeed. The timber stands either too thick or too thin. Underwood, which at present is a drug in the market, is plentiful, but good stems are few. The best have been cut down to raise money. In the words of a witness before the Forestry Committee- " On a great many estates in Scotland it is the lawyer in Edinburgh who says, 'you must sell a certain amount of timber or, at any rate, you must fetch me so much money, and you have to get it.' " What few stems there are are either gouty at the foot or spiky at the top, over-ripe, bent, gnarled, whiskered and full of "shakes." Not a little of that neglected land has in the past generations been under trees, and good trees too, 
that famed " British oak," of the quality of which England had a right to be proud. Hand-to-mouth management of entailed estates, and ignorance of the principles of forestry, coupled with the sportman's insonciance for what does not concern his sport, have been the cause of its decline. In Lord Selborne's words, given in evidence before the Forestry Committee, our landlords " prefer rabbits to trees."

Take the two things together, absolute waste and bad forestry, and you arrive at a total of national loss which is appalling. The war has led us to find out our misdeeds. But how can a Nation with very limited territory, with very large wants, a Nation which according to current opinion understands the value of money, and as the Belgian forester quoted by Mr. Rowntree (in his " Land and Labour in Belgium ") put it, goes really foolish lengths in its obsessedness with the idea: "will it pay?" allow things to come to such a pass, national resources allotted by Providence to run so lamentably to waste? Lord Selborne has supplied one answer, already quoted, to that question. But at the bottom of that preference for rabbits spoken of by him lies our old Pandora's gift, which has' so much that is amiss in our land system to answer for : our landowners are for the most part mere life tenants, whose personal interest it is rather to take money out of their property than to put any in. Why should they invest money from which they stand to reap no return? It is a long, long way to the Tipperary of a return from forest trees. Where the owner is full owner and the land is readily saleable without abstract of title and the rest of that heavy taxation imposed upon land by solicitors, growing timber is worth its value at any time and at any stage of its growth, like a bill more or less approaching maturity. If the investment bear no interest in the investor's lifetime, it will increase the selling value of his possession. Beyond that, life tenancy of large areas of land carries with it the pretence, if not in all cases the reality, of great wealth, which, as it is supposed, can afford to neglect remunerative outlay and, in defiance of the national interest, prefer sport to remunerativeness. In Germany, so, in the course of a paper read before the 
Surveyors' Institute, at Plymouth, said Mr. Leese, an experienced forester, who has studied the matter in that country, "there is no rivalry between the forester and the gamekeeper." In truth, the forester and gamekeeper are one and the same person. And the landlord is of the same mind as his officer with the twofold charge. He prefers trees to rabbits. And the consequence is, in Mr. Leese's words, that in Germany " there are no rabbits." There is plenty of sport all the same. But landowners do not throw away the gold of profit for the dross of rabbit shooting. On a forest estate that I know-an estate of about 45 square miles, owned at the time that I am speaking of by a nobleman who had himself, before succeeding to this property, been a forest officer in the service of the Crown-the landlord went so far as to bid his agricultural tenants keep the deer and the wild boars of his forests off their fields by watchmen's cries and trumpetings at night, and lanterns and barking dogs. His battues were rather famous. But he would not allow sport to interfere with agricultural or sylvicultural production.

Whatever be the cause of our present poverty in forest, and however unwilling, according to the Latin proverb, may be the hounds that we have to hunt with, we now seem determined that such mischief as the war has pressingly disclosed shall be put an end to. The limited supply of our land, as observed, makes its ownership a "trust" as well as a possession. And under certain conditions the Nation has a good right to call those who, under its protection, occupy that national heirloom, to account with regard to their administration of it. The mischief, so we appear all agreed, must be set right. The question now to decide is: How? Here we are in a predicamentwithout chart, without guide. For nobody will gainsay Lord Selborne's statement-speaking broadly, of the mass of those concerned-

"I do not think that there is any knowledge of the subject at all. I think that landowners, agents, bailiffs, surveyors and the whole hierarchy of the people who have to do with land, are absolutely ignorant of the very elementary principles of forestry. 
They know how to grow a good tree for ornamental purposes, but of what forestry means as a commercial pursuit they have not the slightest idea."

Naturally, then, we look abroad for that guidance which we do not find at home. We know that abroad-where, as a general rule, the landowner is full owner of his landthey have good forests and good forestry. Our natural inclination tempts us-as it has done since the days of Sterne-to look for instruction first to France, where in Sterne's words, they are supposed to " manage things better."

France, undoubtedly, in spite of the many crimes against good forestry that her own children not without justice lay to her charge, has something to teach us in the matter. If she has sinned, she has also repented, and to some extent set her hand to making good the loss sustained. She has her public Department for Forestry-as quite a special institution applying its scientific régime foresticr in practice. If we want any good done in the way of forestry, we shall have to introduce a special department on the lines of the Eaux ct Forêts, and not be content with tacking on forestry to some other department. The French Government makes an annual grant out of public money towards replanting, which is indeed modest at a million francs a year, but still it is something. In addition the French Government has, in districts in which there is much forest, organised scolaires forestieves, that is, village schools in which instruction is given in the more elementary principles and manipulations of forestry, so as to train up the local youth to a rudimentary knowledge of the craft. In France also landowners have taken up the question of forestry. Of the entire nearly 23,000,000 acres of French forest 67 per cent. are private property-and a goodly part of that the property of private landowners (not communes, municipalities, etc.). Accordingly it bchoves landowners to take an interest in the matter. The three principal Agricultural Societies in France, that is, the Sociéte des Agriculteurs de France (corresponding to our Royal Agricultural Society and numbering at least as many members), the Société Nationale d'Agriculture, which is the oldest institution of 
the kind, and the Société d'Agriculture de la Gironde (specially interested in consideration of the presence of extensive landes within its district) - and probably other local societies besides-have special "Sections of Forestry" in their organisation. There are important private societies, like l'Association Centrale pour l'Aménagement des Montagnes, more particularly in the districts of the Landes and the Alps, for conducting reboisement in the public interest. And in the Sologne my friend Baron de Larnage, one of the most active agricultural reformers in France, and a considerable landowner, has since a few years organised Syndicats forestiers (after the analogy of the well known Syndicats agricoles, whose praise Lord Reay has sung) for the purpose, not only of studying forestal questions, but mainly for enabling owners of forest to proceed conjointly towards a reform of forestal mismanagement and the introduction of scientific forestry. So greatly has this step been felt to meet a present want of the country, that the example set has soon been followed by others, and by the time of the outbreak of the war France already numbered more than a score of syndicates of the order mentioned. In addition to this, of course the high merits of French scientific education in forestry, with the College of Nancy at its head, are well known.

Possibly also what has been done in the Netherlands in the matter of reclaiming waste land, more particularly for the purpose of planting forest, may prove helpful towards our devising an acceptable policy. Thirty years ago the Dutch Crown had only very little forest to call its own, and indeed only very little Crown land altogether. For its accepted policy had been to dispossess itself of all land alienable at law. Some of that land was actually offered for sale at public auctions and got rid of at much less than its genuine value. However Nature provided a reminder. The dune-sand kept blowing over stretches of fruitful arable land and doing much damage. And elsewhere the extensive heath, being steadily robbed of its timber-none of which was replaced-became in its pitiable aspect a standing reproach to the Government. About I8go the latter came 
to the conclusion that something must be done. Shortly after I882 the extensive estates of the late Prince Frederick (known all over Holland as "the rich prince") around Breda had come into its possession by inheritance, and by this means it had become the owner of fairly extensive forests. To devise a scheme of forest management it consulted a society then already formed, which has since done very valuable work in turning barren heathland to profitable account, and, in concert with it, it began in I894 to plant suitable trees on the sand dunes of Schoorl, and the year after at Texel, with a view to fixing such sand. The experiment proved a success, and the Government continued on the newly-trodden path, acquiring bit by bit new land, the extent of which on July I, I9I3, stood at 60,000 acres, 13,000 acres of which had by that time been reclaimed, partly as forest land, a much smaller portion for purposes of tillage. One of the most successful works of reclamation of the sort was that undertaken at Kortwijk in 1897 , where 5,000 acres of blowing sand were reclaimed. To induce the numerous communes (and also private landowners) possessing suitable neglected heath land to plant such with forest--or else to reclaim what was fit to turn into arable land-the Government subsequently made a general offer to persons or corporations (more particularly the latter) possessing suitable land, to advance to them from public funds up to 80 per cent. of the expense actually incurred in reclamation, the loan not to exceed about $£ 4$ per acre, to be advanced free of interest, for the space of fifty years, at the close of which the advance must be repaid. As a matter of course landowners taking advantage of this offer are required to place the land being reclaimed under the Government's control, to manage it according to prescribed rules and not to cut any timber without leave. In this way it looks as if a good deal of dune-sand were to be fixed and heath land to be reclaimed for purposes of tillage or forest. For securing a material benefit to the country the forgoing of interest on loans so secured may be good policy.

The United States likewise have discovered what good forest 
means, and that neglect will spoil even the best forest. The forbears of the present generation have ravaged in the ample woodland assigned to them by Providence to such an extent that lumbermen have declared the best part of the forest to have been clean thrown away. Under President Roosevelt's decidedly bold leading, heartily supported by the expert guidance of MIr. Gifford Pinchot, Forester of the United States, vigorous efforts have been, as they are still being made to repair the mischief done. The United States Government now controls approximately I48,000,000 acres of forest. By far the principal portion of forestry work done in the United States accordingly falls to the share of the Government. The Federal Government has in consequence long since formed a special Section of Forestry, forming part of the Department of Agriculture, and does not stint the means required for setting the forest in order. Particular solicitude is expended upon the rearing of expert scientific foresters. That Section, besides attending carefully to the national forest service, in the words of the present Secretary of the Department of Agriculture, " at the request of the States, makes examinations of their local conditions and conducts other studies needed to frame forest legislation and formulates a State forest policy. The cost of such work is shared by the State and the (Federal) Service. The Service also co-operates with private owners, especially small ones, in States which have no State foresters, by furnishing advice, with or without field examinations, concerning the best methods for managing and protecting their holdings. The cost of such examinations is borne by the owner."

Add to this Germany, of the forestal arrangements in which country I shall still have to speak, and some of the minor countries, in which due attention is paid to forestryfor instance, Finland, where the national importance of forestry (63 per cent. of the area being under forest) has forced the matter upon landowners' notice and special arrangements have been made for forest insurance, partly by Co-operation-and it cannot be said that we have no precedents to guide us. The Netherlands have likewise 
-as well as Belgium, under the guidance of M. Drumeauxprovided a useful precedent for forest insurance, by cooperative means. De Nederlandsche Weidemaatschappij has devised an effective scheme of the sort.

But to return to France-where, by the way, forest insurance is, for the time, still only poorly provided for, since existing practices place hindrances in its way. We see there magnificent forests and observe the methodical course of technical education through which its upgrowing foresters are put. In the matter of hard wood, which up to the present time has specifically interested us, probably there is no country that has more to teach us. In fact France has taught us afresh how to grow oak-which we knew well enough three hundred years ago, but had forgotten in the interval. And on more points than one does France supply a better objective for our learning than any other country, because in the matter of climate, soil, the lie of the country, its wants and habits, and the prevalent taste for hard wood and mixed wood, it comes nearest to our own conditions. We have not got those vast sweeps of sand of Germany, which of necessity make the pine the favourite cultivated tree there, except on those high mountain chains, say, on the Bohemian frontier, for which of course spruce, raised of late to higher favour by the development of the woodpulp industry, coupled with its remarkable readiness to spread out its roots on shallow surface soil, and its fitness for high altitudes, is better suited.

But really, as a craft, forestry stands higher in Germany, and Germany is, among other things, in a position to teach us just what at the present moment we particularly want to know. That is, in the first place, how to cover our bare mountain-sides with timber; and, next, how to manage forest well on private estates. Our bare hills do not resemble the Alps or the Pyrenees, which at the present time constitute the great preoccupation of the French reboiseurs on highly urgent grounds, which do not quite apply to ourselves. That is, that for want of cover, by forest, stemming the sudden downpours from the hill-tops, in times of floods, the soil is being bodily washed down to the destruc- 
tion of much property below, and leaving the rocks bare of scrub or herbage above. Also, where there is an apology for forest, the indiscriminate browsing of cattle prevents its healthy growth, without yielding the cattle an equivalent in food. Nor yet have we land to compare to the sandymoist landes of the Gironde, in which French foresters have of late, following the example of the famous Brémontier and Chambrelent-in whose footsteps now M. Descombes is successfully treading-developed a most vigorous and instructive activity, to the benefit of the country. In Germany, on the other hand, such mountain chains as the Sileso-Bohemian Riesengebirge, the Harz, the Black Forest, the Fichtelgebirge and others may well suggest useful lessons for our Scottish bare rocks.

Then there is the question of private property, which in our case will have to play a conspicuous part in the solution of the waste land problem. For, buy the State-to which hitherto appeals have been exclusively addressed-what it will, it cannot dispossess all our squires owning woodland, and their comparatively small areas, in which the owners will always desire to give as much consideration to picturesque appearance as to financial gain, are scarcely suitable for State administration. In France most of the forests that we admire are the property of the State. And State management of forests is comparatively easy. Germany abounds in State forests-possessing much more than France-wide sweeps that extend from the centre of the empire to the frontier of Russia. But it is also the home of all others, by the side of Switzerland, of well-kept private forests. The country is cut up in the main into what we here must consider very moderate-sized estates--estates corresponding to those which the late Lord Sidney Godolphin Osborne desired to see established in this country, when he pleaded for the substitution of " $£ 2$, 000 a year squires" for our overgrown landlords. And most of those estates have their allowance of forest. There are also very large specifically forest estates-estates ranging up to 40 or 50 square miles. And every owner of an agricultural estate affects to be, and desires to rank as, at any rate an amateur 
forester. That accounts among other things for the wide extension of forestry education, of which we ourselves still possess so very little. Ireland is, once more, a little ahead of us. And it may interest politicians with a memory to learn, that the whilom country seat of Charles Stewart Parnell, Avondale, has now become a forest school. Germany has its Tharand, its Giessen, its Neustadt-Eberswalde, to pit against our nothing and French Nancy. The owning agriculturist wants qua owner to understand forestry, and accordingly lays himself out for respecting its rules, so far as his possessions, down to the smallest areas, permit. That accounts in great part for the fact that, whereas in this country the obsessing passion is to be a sportsman, in Germany forestry holds the first place in popular estimation. That ends all conflict, as Mr. Leese has pointed out, between gamekeeper and forester. Private forest owners are generally careful to practise good forestry. Their forests grow for them into money to be taken in the price of the wood sold or in the valuation put upon the property, if that should be sold while the wood is still growing.

There are, indeed, not a few landowners in Germany who deliberately wreck their little bit of forest for the sake of a little timely cash. Tout comme chez nous. However at this point another factor steps in. For, for any one who is not absolute owner of his land, there is supervision. If his property is entailed, there is an authority to watch over it and see that he does not fell too much, to the loss of his successor. If he is in debt to the landschaft-and that covers a good bit of ground-the landschaft sees that he not only does not fell improvidently, but also that he keeps his forest (as also his fields and buildings) in good condition. In Prussia-which makes up the major portion of Germany - there is also-very necessary-Government supervision for forests belonging to municipal bodies, communes, foundations and the "dead hand" otherwise. In the South of Germany, where there is very much communal forest and forest belonging to Corporations (in the Grandduchy of Baden a full third, not a few of them corporations of 
timber merchants), the legal provisions vary. And, even where they are so strict that, as in Baden, there is a legal interdict upon the selling of forest land apart from the holding, and the Government has the legal right, in cases of gross mismanagement, to seize and sequestrate forest property, those legal provisions are only too often treated as a mere dead letter. And although, in consequence, there is much excellently managed communal forest property, the income from which relieves the burgesses from the necessity of paying rates, and in some cases even gives then a bonus, in other instances there is wretched destruction of forest in communal forests, for instance in parts of the Black Forest. In Prussia the matter is--very judiciously-ordered all the better since the great popular upheaval of the middle of the past century made a thorough revision of things necessary, in connection with the Ablösung or abolition of common rights in the forest-which in Germany was the main "common" for the peasantry. The peasantry, who had browsing rights and also a right to gather wood, and also to claim as their own small timber - on one estate I remember that it was up to three inches thickness-among the timber felled, and who did great mischief, was bought off, and dualism came to an end.

In France things are not quite the same. There is not anything like the same affection for forest and forestry as in Germany. Such as there is has only recently been awakened by the observation that the long continued destruction of forest on mountain chains like the Alps has wrought terrific havoc to the country, more particularly in the matter of inundations. The recent inundation of Paris (in I9Io) has acted us a warning eye-opener. It has been pointed out that that inundation would not have occurred if there had still been the old forests on the mountain-sides, the great value of which Viollet-le-Duc in his day pointed out, to act, as M. Descombes has put it, like a "sponge," retaining the flood-water and letting it run down gently. In Germany the "deutscher Wald," in honour of which Mendelssohn has composed one of his most popular songs, is a tradition that has entered deep 
into the soul of the Nation. People sing about the forest, and delight in the "wearing of the green" of forestry as a popular fashion in dress. Everybody wants to be taken for a "waldmann." It is from the Germans, posing willingly as " foresters," that we have of late adopted-together with many other things - the fashion of wearing grey-green clothes and a favourite shape of soft green felt hats.

In France there is not a little indulgence in a kind of sport. But forestry is not a preoccupation. And private forests, despite their extent, play a more humble part in national economy. As to communes and foundations, they have availed themselves eagerly of the opportunities provided by the two Revolutions of 1789 and of $1848-$ pour leur malheur, says Blanqui-to throw off the régime forestier, under which they had stood and which was extremely strict, giving, among other things, the Navy the right of pre-emption in respect of any stems that they might deem useful for their own purposes. And the results are written in plain features on the deserts left. Some I4,000,000 acres devastated in the brief period of the first revolution, complains M. Descombes, of which more than a hundred years of careful reafforestation have not succeeded in making good more than about a tenth part. That was the first revolution. The second here spoken of extended the mischief. And the present war, according to the same authority, has "massacred" no less than $x, 250,000$ acres of what remained of French forest.

There are two reasons why perhaps German forestry is distinctly deserving of our attention. French teaching for students is every bit as good as German. Nancy will hold its own by the side of all German "Academies." But if you look at the forests, you will find German forestry making the better show. On this point, apart from the admission with regard to certain features, of a late French Inspecteur Général des Forêts, I have the testimony of so thorough a French patriot as the late M. Grad with me, who, having in his native Alsace had the same opportunities for comparing the two systems as myself (among other opportminities), that is, in the Vosges, only over a much 
enlarged area, during an incomparably longer period, and with infinitely more local knowledge, frankly admits: cntrc los dcux systemes (le français ct l'allcmand) le sccona' paraît présenter le plus d'avantage, si non pour le profit immédiat, du moins pour lc remplacemont et la. conscrvation des forêts. He goes on to pronounce the Alsatian forests under the present (German) management les mieux administrés et les plus productifs in Europe. The Germans are, in this matter, as in all others, pure utilitarians. They will mercilessly block up, as I have found in the forests of the Vosges, the most picturesque vistas with a barrier of trees. But their forests show remarkable evcnness of growth, they are duly thinned and not thinned too much. They are "clean" -without underwood. And underwood is, in the present day, certainly mere weeds. You can, as one expert witness stated before the Forestry Committee, in these forests look along their rows between the boles for a long distance. The forest land is well stocked, carefully stocked, but not overstocked. As far as is possible, every foot of land is made to yield its proper return. Mr. Munro Ferguson told the Forestry Committee of forest land in Prince Bismarck's "Sachsenwald "- part of the home of our forbears, who gave it its name-which was by clever management raised in value from 3 s. to 50 s. per acre. That was owing to the development of the wood-pulp industry. The increase is not everywhere as great. But in any case the most that is to be got out of the land is so got. You may trust a German forester for that. You notice the difference between French and German forestry very clearly in a frontier district like that of the Vosges, the loss of the forest treasures on which French patriots and economists plaintively bewailed, as well they might, in $187 \mathrm{r}$. France lost to Germany by that war, according to the testimony of 11. Grad, who knew his native Alsace to the last square inch, one-ninth of its forest property in extent, and onesixth in value-which is now worth a good deal more. On the French side you observe a good deal of insufficient thinning-and it is the same at Brotonne in Normandy as at Le Breuil in Lorraine-and accordingly the lower 
space choked with underwood and faulty growth of trees. And evidently there was-in former times at least-much carelessness in the management. My friend, the late M. Lorenz, son of the founder of the High School of Forestry at Nancy, and himself for some time Inspecteur Général des Forêts de France, with whom I talked much forestry in his native province of Alsace, could not deny this, but put it upon "the Empire, which," as he put it, "always had money for wars, but never for useful purposes." Timber merchants formed "rings," so as to buy the timber dirt cheap at the public sales and, it being part of their contract that they should resow, strewed out carelessly indifferent seed. Very possibly the toleration of such practice was due to a mistaken principle of which M. Lorenz complained, adopted (at that time at least) in the French administration, under which forest officers were kept in one and the same district, which of course they came to know thoroughly well. However, such practice tends, in the first place, to give the officer an incomplete command of his science as a whole; and, in the second, it at any rate planes the way for local personal liaisons, which may work to the detriment of the State. In Germany forestry officers are purposely moved about, from time to time, from one place to another, in order that they may in this way learn more about their craft generally, and also in order that they may not become entangled by local ties. M. Lorenz during his time of office endeavoured to graft the German practice upon the French system, which is otherwise excellent, but failed to convert his superiors to his view.

It is curious, by the way, to observe the changing phases through which the keeping of forests-often enough there was no "forestry" in it at all-has passed in various countries. France has, like ourselves, had its times of wellkept and well-stocked forests. The heights of the Alps were, as Viollet-le-Duc has pointed out, covered with them. There was timber then, there was a softer climate, there was shelter, and there were none of those devastating torrential floods which now annually destroy so much property. The water trickled down gently, doing a minimum of mis- 
chief, and at the same time moistening and fertilising the soil. The changes brought about by the first revolution have altered all that. Freed from the regime forestier, individuals and communes alike have worked their will upon the forests, cutting down timber indiscriminately and increasing the havoc by driving their herds of cattle through what was left of trees-the cowherds in their ignorance persuading themselves that " forest" and "pasture" were natural enemies and incompatibles. In consequence, the land has become impoverished. Torrents sweeping down the mountain-sides unhindered have carried along with them what little soil there was on the tops, bringing down pebbles and even big boulders in unmeasured, destructive avalanches, ruining fields, wrecking entire villages and so indirectly -that is, where the mischief is now mainly and painfully felt-assisting depopulation. The effect has been traced by the inquirer of the Musée Social. France is said to have lost five millions of population through the déboisement. The engineer Surell having called public attention to the fact, in I84I, in I860 a law was passed (since supplemented by other legislation, more notably by the Act of 1882 ) which, in spite of its tentative and experimental form, under present circumstances deserves our attention, providing encouragement for afforestation. And at the same time the rather paltry sum of $f_{60,000}$ a year was made available for such purpose. With such modest aid, up to I878, according to M. Hervé Mangon, about 250,000 acres were planted. By I 900 the figure had grown to about 400,000 acres. C'est peu, commented at the time M. Cardot, seeing that the upper basins of rivers affected by mountain torrents cover between $5,000,000$ and 7,000,000 acres. And in truth legislators and statesmen were, in passing those laws, thinking more of fixing the pebbles and improving the impoverished mountain pasture-most of which is in possession of communes, which ruin it by overstocking and neglect-than of forest proper. However the law of 1860 introduced two new provisions in the interest of afforestation, which it may be worth mentioning. In the first place it gave the Government power 
to compel landowners to plant; and in the second it authorised it to give landowners encouragement to plant, by means of subventions. The result has remained trifling. But of late a more ambitious tone has been struck up. The Administration des Eaux et Forets has taken the matter in hand. The entire population also has been stirred and, in view of public requirements, the cry has been raised and has become general: reboisons les montagnes, défrichons les plaines-which would under existing circumstances be a not inappropriate motto for ourselves. In I9I3 a new law was passed permitting permanent corporations (propriétaires impérissables), which were previously debarred from the practice, to acquire forests as an investment and, subject to the condition of managing them according to the accepted modern rules of forestry, under the supervision of the Administration des Eaux et Forêts. That same law also authorises the said Administration to take under its management forests belonging to private owners, who are willing to submit to the same conditions. At the same time a society was formed having the object of giving back to forest its proper share of the hill-tops, by improving the common pasture and regulating its use. That societywhich is a society working not for profit, but for the common good-has already effected a not inconsiderable change for the better. Both these measures were probably suggested by the fruitful operations of municipal bodies and private individuals working under the guidance of M. Chambrelent in the Landes, which had by their money aid, without State help, brought about the re-afforestation of about I,500 acres of pine forest in that Department. The satisfactory results thus obtained have given rise to the formation of similar societies both in Italy (the Society Pro Montibus) and in Spain (Pro Montibus et Silvis). A similar society for the afforestation, as in the Landes, on level land, exists in Denmark since I866. The recommendation put forward in this country that the State should acquire progressively $6,000,000$ acres to lay down under forest has aroused in French legislators a not unnatural thirst for proceeding in the matter with direct State aid, to be given in the shape 
of State credit or at any rate a State guarantee, to make such credit accessible elsewhere. The latest shape which that idea has taken is to create a Crédit forestier, as there is already a Crédit agricole, which is freely resorted to. The Bill now before Parliament proposes that the Crédit Foncier should be empowered to advance money on forest security in the same way that it does on other real property - which under its constitution of $\mathrm{I}^{8} 5_{2}$ as it stands now it cannot do-and that, to secure such loan, the State should give its guarantee for the advances. M. Méline has been at pains to demonstrate to Parliament that forest property may well be made the object of a long-term loan, with accumulating interest, inasmuch as such accumulating interest will after fifty years represent only the sevenfold value of the first outlay, whereas the value of the pledged object will after the same period amount to the tenfold. It is to be understood that the forest pledged must be insured against fire, and that the State, guaranteeing the loan, must also control the management of the forest.

In Germany the advance to better, modern forestry has followed-in a slightly different way-the same line as among ourselves. Germany has, like ourselves, had its era of neglected forest-forest valued more as a vast game preserve than as a money-producing investment. But that was in the sixteenth and seventeenth centuries. In this case the deterioration was not the result of revolutions, but rather of political advance in the reverse direction. Crown and nobles set the rights of the Nation at naught and, step by step, constituted themselves masters of the forests, which they regarded only as ground for sport, since in those olden days of comparatively sparse population Nature was considered fully equal to the task of producing sufficient timber, however severely forest might be ravaged. However such reckless wastefulness brought about its own nemesis. Timber grew scarce. About r7oo an apprehension became general that there might not be enough. Amendment was resolved upon. Better management was introduced, at first only very hesitatingly. It is really only since the last century that the new principle, which, 
taken as a whole, is excellent, acquired sway. The principle has its peculiarities, one of which has been discovered to be faulty. However there is no occasion to enter here into details. In the course of time improvement asserted itself over the whole of the empire, although in somewhat differing shapes. In the North the growing of conifers and felling in large blocks, producing bare areas, prevails. So advantageous is the cultivation of conifers held to be that in the fifties the kingdom of Saxony-the excellence of whose forestry Sir WV. Schlich remarks upon in his little book-advisedly adopted it as a general rule, methodically replacing deciduous trees by pines and spruce. In the South there is more mixed wood, partial felling and natural regeneration, the coniferae being largely represented by silver fir, for which this method of renewing the forest is particularly congenial. However, whatever the mode of cultivation may be, the management is on the whole admirable-except in the instances already indicated of forests belonging to negligent communes and the peasantry. And cducation is equally good. Very much the same institutions exist in Switzerland, and the forests of the two countries must be allowed, in the matter of management and expert training, to stand at the head of all others.

After considering what has been and what is being done abroad, the question remains to be answered: What are we to do at home?

By the side of France's 23,000,000 acres, Germany's 35,000,000, and Russia's I,372,917,000 acres (taking the whole of the Russian Empire ; there are 480,000,000 acres in European Russia alone), with our about 3,000,000 acres, possibly to be increased, according to Sir John Stirling Maxwell's estimate, to 9,000,000-the Coast Erosion Commission says $\mathrm{I} 2,000,000$ - we can cut only a comparatively modest figure. Also our forest conditions as well as our forest needs are distinctly different from those of other countries. Therefore we can as little hope to reach the desired goal of self-sufficiency by simply copying the pretentious forest machinery of France and Germany, as by obsequiously imitating any of their other practices. We 
shall never have, and we do not want, a large semi-military posse of forest officers like Germany. And as for practice, climate and soil, as well as general conditions, make a material difference. We cannot here talk of the evergreen oak, the cork oak and the Aleppo pine (pinus halipensis) on which French foresters so much rely in the South of their country. Also, as Mr. V. F. Leese has well pointed out, in his lecture already alluded to, French underplanting, which answers so well in France, and which is so much fancied by some of our owners of forests, is altogether out of place in this country of less sunshine and more humidity, resulting in denser canopies and the undergrowth kept short of the necessary light. We should, moreover, remember that, just as we intend to do, other countries are proposing to set their forestal houses in order. We may some time hence look for a considerable increase in yield of timber in Russia. And there is an enormous forest wealth now growing up under very judicious management in India, which will, on its arriving at a felling age, make a perceptible difference to the world's annual output of timber.

Such bettering of other countries must prove all to our advantage. For even if we plant all the $12,000,000$ acres that the Erosion Commission places to our credit, we shall never be able to produce on our native soil all the timber that we bid fair to require. By such planting as we can practise, no doubt we shall gain a great deal. But we camnot make our home forests even an absolutely dependable resource for great emergencies. For the timber maturing to its rotation age will want to be cut. We shall want to get our money in. And allowing the timber to stand to over-ripeness will only reduce its value. No doubt during a great war we shall be able to draw upon the future and fell what is not yet quite ripe. And that will be a help. But in that case by eating our cake we shall cease to have it.

Notwithstanding all this, we shall have to give our attention to our forests, as well as to our waste lands.

The rather pretentious proposals now put forward in favour of big forest blocks of five or ten thousand acres- 
which by means either of irritating expropriation, or else by uneconomic paying through the nose, the State is to acquire and to manage, so as to be able to rival the German Forsten-do not appear to cover the whole ground. Wherever five or ten thousand acres can be got together in a block, and wherever the State can economically acquire the land, by all means let it do so ! But with our limited territory we shall necessarily have to tum those numerous patches of woodland to account, which dot the country all over, picturesquely enough, but unfortunately in the majority of cases not doing economically anything like justice to the soil they occupy, by reason of the encouraged depredations of game, reckless thinning and general bad management. In view, more particularly, of our preference for hard wood and, among conifers, for larch and silver fir, such patches will serve the cause which we have at heart very well, while continuing to beautify the landscape. The propriety of preserving trees will to a great extent have to determine the line which we shall have to select for following.

As in the case of most of the questions here touched upon, a point upon which our policy will in great part have to turn, will, in the first place, evidently have to be one of provision of money for the purpose of planting and paying outgoings whilst the timber crop grows. For such provision of money French and Dutch practices afford us at any rate useful hints, to be supplemented by what is done by the German landschaft and the Finnish Savings Banks. And to that provision will have to be added one of qualified compulsion, so as to produce the forest area that the Nation in its own interest and in self-defence unquestionably requires. Where, in necessaries of State, independent initiative fails, coercive measures become unavoidable. And they cannot, in the present instance, prove injurious, so long as they are kept within reasonable bounds, leaving, more in particular, the actual work to be acconplished, so far as he is willing to perform it, to the owner of the land.

Such pretentious forest service as they have in France, and, even in a higher degree still, in Germany, would in this 
country be quite out of place-let alone that private landowners will prefer as heretofore to appoint their own local men, whom they feel that they can trust, as their foresters, no matter what their preparation for the service may have been. And no one will be able to prevent, or be right even in blaming, them. We want education badly, even in the ranks of such men, as the evidence given before the Forestry Committee made very plain. To state only one instance of prevailing want of knowledge, the fact that an otherwise evidently competent forester, who no doubt has proved a raluable servant to his master, should not know the difference between sessile oak-which is what he ought to have planted-and pedunculated oak - which is what he actually did plant-very plainly demonstrates to what extent present want of tcchnical schooling is apt to affect our forestrywhich accordingly, as witness the evidence given by $\mathrm{Mr}$. Pitcaithley, forester at Scone, "produces an article of inferior quality, that can only be used for certain purposes as a kind of forestal timber, when, under other treatment, it might excel any foreign timber and certainly could be produced in greater bulk on less ground than that on which we grow our inferior timber." It cannot be too often called to mind that forestry is a national interest, as well as an interest of landowning individuals. The care of their own little forests will have to be left to individual landowners. If these gentlemen should have forest enough to warrant the appointment of qualified men of the stamp of the German forster, or the French agent forestier, forestry would be all the better for it. And if we were to start institutions like the German forstschulen, authorised to confer a qualification, probably their instruction would not go a-begging. What strikes the eye more particularly in the German forest service, however, is the very active part in the management taken by the superior class of forest officers, from the Oberförster upward, men of superior technical attainments, and of good social standing, who really direct the entire business. By a curious freak of Prussian organisation, not a few of these higher forestal officials are taken from the dipiomatic service, where they have served as what we should 
call " King's Messengers," forming a special corps, organised on military lines, composed of men with military titles and military rank, but without privates or non-commissioned officers, the corps of Feldjäger being maintained for this particular purpose. For such men there is in Prussia, with its immense forests and its bureaucratic and military habit of mind, ample scope. And that service is popular and petted; and with its large demand it provides a good "career." There are plenty of berths for men of the sort in the gift of the Crown; and a good number more there are available in the employment of very large landowners, generally on entailed and princely estates. Our country could not, at the present time, at any rate, offer anything like the same opening. And we do not care about titles, official precedence and buttons. However, men of this type should be there, to advise and to guide. But they slould be in the service of the State and optionally available for counsel and supervision, such as is freely given abroad, among other countries very notably in the United States, to every one advancing a good claim. That would make them of very great benefit here; for it would practically place our forests, large or small, under the most expert guidance, even the patches belonging to those landowners, who would still prefer to appoint their own Tom, Jick or Harry, but would not be sorry to have an occasional word of counsel from a superior expert. And, in view of the national service rendered, assuredly no one would grudge the expenditure of what would after all be only a moderate amount of public money.

The education which such superior forest officers and those who are to act in this country as teachers of forestry will have to acquire, will, at any rate at the outset, have to be obtained abroad. For we have not the requisite institutions, nor yet, at present, the apparatus of forests well kept for a long time back, to serve as illustrations, for such education. We should probably prefer to go to France, which possesses an admirable educational service, however with visits periodically paid, as part of a settled curriculum, to German and Swiss forests, to compare such 
teaching. For it will be imperative to become acquainted with such forestry also.

As regards more practical steps, the application of the knowledge acquired, whatever the State can do in the acquisition of land for forest purposes in large blocks, without overcharging tax-payers, it would be well that it should do. For in the State's keeping there will be greatest security for good forestry, for permanent forestry, and for forestry to suit national requirements. However, expropriation is rather an extreme measure to resort to, and it is deserving of notice that the French, who really stand nearest to ourselves in the matter of a revival of forestry, have distinctly pronounced against the système étatique. In Germany we have seen how even the staunchest champions of Crown prerogative, the junkers of the eastern provinces of Prussia, have rebelled against the law for expropriating Polish landowners. And we have chimed in lustily in their chorus of condemnation. Under the French law of 1860 the Government has power to expropriate land for forestal purposes and for safeguarding against mountain floods au nom de l'utilité publique. But those powers have been only very sparingly used thus far. Their application is in the law restricted to cases of really imminent danger (danger né et actuel), that is, in case of real danger threatening, say, on mountain-tops, from the neglect of proper tree planting. We are not exposed to anything like the same danger from the same cause. However, as in other respects, as to ourselves, this is perhaps in even a higher degree a matter of national exigency, and it is open to question whether we might not endow our Government with similar powers au nom de l'intérêt commun.

In any case a systematic survey of the country-of a rather more detailed character than that taken in Francebecause our available territory is so much more limitedto discover what areas there are suited for the purpose of planting, and for which planting would be the most advantageous employment-for we cannot sacrifice even our grass to trees-ivill have to precede active measures. And such survey might probably without difficulty be used as a 
means of moral pressure upon private landowners possessing suitable land, to make them understand the necessity of turning it into well-kept forest.

For smaller areas individual ownership will be distinctly preferable to State ownership. For the State will be able to deal directly only with large areas. We have, as it happens, none of those corporate owners of forest which abroad the State, by means of strict supervision, makes serviceable to the common good. But it may be worth while considering whether we could not apply the method of advice and supervision given in France by the Administration des Eaux et Forêts, and in Germany in another form by the landschaften, in consideration of an advance of money. Although we cannot, as observed, expect our private owners, generally speaking, of an only moderate area of forest, to maintain an experienced staff of highly trained foresters, yet the State, as a collective body, can surround itself with the most skilled advisers, and in a matter of so great national importance it can legitimately place such men at the disposal of private landowners desiring to plant land with forest-of course on condition that some security is given that the land will be left under forest, so that at the proper time the Nation may have the benefit. The practice of the "Forest Service" in the United States is a pertinent and good precedent for this. This is what the Administration des Eaux et Forêts does-and it does morc. Under the Law of I909, which authorises public bodies like savings banks and other corporations to invest part of their funds in forest, on condition that the forest so acquired shall be placed under the régime forestier (the management being supervised by the Administration des Eaux et Forêts), private landowners are authorised to apply for and benefit by the same supervision, with a guarantee of the kind spoken of given. Such measure would probably be more largely taken advantage of in this country than it actually is in France.

But where the shoe pinches most in France is in the matter of finance. Forest land is not a very convenient object to accept as a pledge even though it be insured 
against fire. Accordingly the Credit Foncier, which finances so much land in its own country, feels justified in making advances on forest - so far as such are admissible at allonly to the extent of one-third of the ascertained value, whereas in respect of other land it draws the line at onehalf. Accordingly French landowners are now, as already mentioned, agitating for a State-endowed or Stateguaranteed Crédit forestier, to match the Crédit agricole which is so much in request. A Bill is now before Parliament proposing that the Constitution of the Crédit foncier shall be amended to such an extent as to permit advances on forest, the State giving a guarantee in respect of approved schemes. The clamour for some measure of this kind is now so great and so widespread that it may be taken for granted that something of the kind will be sanctioned.

In Germany similar credit-for land, including forestis granted in a different way. The German landschaft, having a lien upon property by reason of money advanced on mortgage, inspects that property from time to time, in order to make sure that its value remains unimpairedin this case by good forestry-and that no more than the proper allowance of timber is cut. Our landowners, who are the greatest stumbling-block in this matter, as not caring to improve their forestry for the benefit of a coming generation, in only too many cases either have not, or else grudge the money required for putting their forest land in proper condition. They might-many of them no doubt would--be found perfectly willing to plant according to rule, if the money required, or a substantial part of it, could be raised in the shape of a mortgage or improvement loan, which it would be in the interest of the State as guardian of the national interest to make, provided that it could secure itself financially against loss, and ensure that in return good forestry, which would have to be under its own supervision, would be practised. The question of insurance ought to occasion no difficulty among ourselves. There are several ways of providing for it. In Finland, so far as the Savings Banks make the advances, in imitation of what is done in Germany, the owner of the forest pledges the growing 
timber, which, up to the moment of its sale, whether felled or still standing, remains as security to the lender. In how far it would be possible and advisable otherwise to apply among ourselves the second power entrusted to the State by the French Act of 1860 - which is rather tentative in character, as being applied on quite untried ground, without any precedent for guidance-the power, that is, of encouraging good forestry by gifts of money or of seed and the like, it will be for our statesmen to consider. If we could ensure an equivalent quidproquo in the shape of regulation forestry, it might be worth trying.

Among our neighbours, both in France and in Germany, in this matter as in others, Co-operation has been found of some little-very little-use. There appears to be no scope for that expedient among ourselves. For the conditions necessary for such organisation are here wholly wanting. We have not that host of small forest owners, who abroad join their little forest areas together for collective management. The associations previously spoken of as existing in various countries-with the exception of the French syndicats forestiers-likewise provide little guidance for ourselves. For with the exception of the Danishwhich has quite dissimilar conditions to deal with-the attention of those associations is above all things directed to the improvement of mountain pasture, which has rudely and ruinously encroached upon the forest standing by its side. The policy pursued is, so to improve the pasture as to make half the area now pastured over to suffice for the needs of the commune-the other half being restored to well-kept forest. Since the State in France under a standing custom provides half the outlay required in such cases-the local body being a party to the work-the financial task of the association is limited to earning out of the improved pasture the interest upon half the outlay which it has generally succeeded in accomplishing.

It may furthermore be mentioned that in France the pupils of what are called scolaires forestières-that is, village forestry classes-have here and there been employed, as part of their schooling, to plant seedlings on intended 
forest land, without charge to any one. Whether it may be possible in largely wooded areas among ourselves to form such classes, in order to teach the young idea how to plant, and whether it would be possible to employ the pupils in the same manner, it must be for others to determine.

What has here been told of practices beneficial to forestry, carried on abroad, ought to provide some material for useful suggestions as to desirable measures to be taken among ourselves. Everybody seems now agreed that something, and something substantial, will have to be done. There is in the shape of forests an immense treasure waiting to be raised in this country. "I do not think," so says Lord Selborne, "that English landowners have the slightest conception of the money they are throwing away, or that the country realises the amount of undeveloped property in this country. "It is time to awaken people out of their sleep. And for that we want an authoritative "lead" from an authorised quarter. For there are too many various elements interested in this matter to be capable of settling the question on a national basis by purely volumtary, spontaneous co-ordination and common action. The huge mass wants stirring up, moving on a common plan, guiding. Evidently there is a call for instructing, inipelling and restricting guidance, to secure singleness of aim, such as is only to be made sure of by the adoption of a wellunderstood "National Land Policy." 


\section{CONCLUSION}

However disappointing may have been the comparative breakdown of our Agriculture in the past, as public opinion now stands, we are not likely to allow such condition to remain unremedied, so far as our powers go, in the future. Awakened as we have been from our lethargy by the harsh lessons of the war-and the threatened possibility of their assuming an even graver shape-our interest in that indispensable calling has, as Mr. Prothero remarked in one of his first public utterances as President of the Board of Agriculture, "come to stay," and come to be turned to account for laying a foundation for better things. The clash of arms being over and the last cannon shot having spent its sound, it is indeed conceivable that, in the matter of preparation for emergencies, we may once more, as we have so often done in the past, relapse into our habitual torpor, allowing our swords to rust, falling back into that lazy trustfulness which, as I remember, made people on the eve of the Crimean War remark mockingly that we had made a verity of the Prayer-book response, "Because there is none other that fighteth for us, but only Thou, oh God!" However, for the moment the whole Nation appears alive to the demands of the newly-created situation at all points.

We have roused ourselves from our long stupor, and profess ourselves as full of good resolutions for amendment as is the proverbial child on New Year's Day. We are not going to allow matters to rest as they are. We are revising our educational apparatus. Let us hope that such revision will extend to the point at which it is most sorely needed, that is, Agriculture. We have discarded our contempt for foreign banking methods, for which there is ample 
room by the side of our own solid and tried ones, which for ordinary purposes suit us far the best. But we have found that more is needed. Along with a Trade Corporation, designed for the very purpose that foreign banks pursue, we are now to have Credit banks to support and develop our home industry and our export trade. What immense amount of benefit those foreign "Export Banks" have brought to their several countries, more particularly to ever pushing Germany, we have, after long continued incredulity, only lately come to realise. While branches of German banks, confidingly welcomed at first by our financial journalists, ferreted out our own trade secrets at home, to profit by them largely, German " Export Banks" enabled their merchants to fasten their hold like an octopus multiplied a thousandfold upon trade, including our own, in all foreign countries, aye, even in our own colonies, and German capitalists to possess themselves of some of our most valuable and necessary " key industries." And to a great extent it was with our money that they were operating. The admission is candidly made in the Jubilee Memorial of the German Reichsbank, ${ }^{1}$ which owns that the great banking crashes in Igoo and the following years were the result of our withdrawal of our money, which we then wanted for the South African war, but with which Germany had been carrying on her trade since I895."

Fifteen years ago Mr. Chamberlain would have it, as an argument in support of his proposed Chinese Wall, which was to keep out foreign goods, that the British " old dog," poor decrepit animal that he was, could not be taught " new tricks." He is learning them now by the score and is taking to them very kindly, with every promise of faring well with them. The " $\operatorname{dog} "$ is not so old as all that yet.

At all points of our economic and political system are we endeavouring to fix new grafts on the inert old stock.

1 "Die Reichsbank I876-I900." Berlin, I904.

"I called attention to this in an article on "Pritish and Foreign Banking," which was published in the October number of the Economic Review, in I9o5. 
And in the general overhauling certainly the Nation's Commissariat is not likely to be forgotten. The German submarines have struck us in a most tender part. The stomach proverbially " has no ears." But it has a most sensitive lining and a penetrating and resonant voice, which will not be stifled. And, having been threatened with an inconveniently prolonged Lent, it is sure to remind us, long after the morrow of the war, of what may conceivably be in store for us in the case of new hostilities. Thus forewarned the Nation will take care that it is also forearmed. Whoever may have been in fault in our past want of preparation, the Nation appears to have thoroughly made up its mind that whatever is amiss shall certainly not be permitted to continue so. The machine which in emergency time is to produce our necessary food must under all conditions be set in order. Altogether the Nation's present temper is of the happiest augury for the future. The war has burdened us with debt beyond what a few years ago we should have conceived to be possible. However, so far from being daunted by the load, we have on the contrary been roused by the sense of it to new energy. The war has held a mirror before our eyes, in which we have seen ourselves-lethargic, overconfident in our greatness acquired in an easy enough way, when we were the only adventurers in the world and had no rival or competitor to contend with, spreading out our commerce, raising up a mighty industry as if by magic, planting our foot and our banner on vantage points all over the globe, founding and acquiring colonies and assuring to ourselves a supreme reign over the sea.

Now that that mirror has been set before us we cannot help owning that the trouble which has come upon us has been brought about mainly by our own remissness. We have been warned often enough. Time after time have our foreign consuls pointed out to us in their reportsmany of them masterly productions of clear minds and keen eyes-what was going on and how Germany was gaining upon us almost everywhere by her readiness to adapt herself to the ways of her new markets, by her study- 
ing the tastes of her foreign customers and, not least, by her consulting their financial requirements and convenience with the help of an easy credit, which her rather riskily built up, but most effective, overscas and home financial organisations for credit purposes-on the one hand through "Export Banks" and ambitious "Trade Corporations," on the other through small " People's Banks" descending down to the very humblest grades of business, but spreading out over an immense territory-permitted her to deal out. The two classes of financial institution referred to between them made unheard-of sums of money available for business purposes. All these things we proudly spurned. Greatness had come to us in our sleep. Why should we stoop to such new-fangled expedients? Overtrustful, confiding too much in the superiority which we had gained by our early start, and for which we gave ourselves excessive credit, we let things slide. And not least so in that Agriculture to which we look, in times of peace, for profit and for employment and happiness for our labouring folk, and for a nursery for our national manhood, and, in time of war, for our necessary food.

Disillusionment has come-fortunately not too late. A little more patience on the German side might have made things very much more troublesome for us. Fortunately the modern Ahab, tempted by his flattering counsellors, stretched out his hand for the coveted Ramoth Gilead a little too soon - to complete the parallel, with an obsequious Jehoshaphat by his side-and so brought about his own discomfiture. Like the fox of the Latin proverb (vulpes non iterum capitur laqueo) we are bestirring ourselves to make sure of not being caught a second time in the same trap.

Among the precautionary measures decided upon under such provocation we appear determined-whatever wisc or else unwise measures we may resort to on other groundafter a long period of fatuous stagnancy, to put a healing touch into our Agriculture, which, under our accepted system, went very near failing us in the hour of trial.

Recent inquiries have, as has been shown, taught us that 
there is very much amiss in the present condition of our Agriculture - as an entire interest, which is of course the aspect under which the Nation has to look at it. For splendid oases scattered over its wide expanse, still leave Sahara only a desert. In speaking of the shortcomings of our premier calling I have advisedly confined myself to quoting the opinions of accepted high authorities and Parliamentary or Departmental Committees. My object was to cite only unexceptionable witnesses. They, as it happens, tell their own tale in remarkable unison, and tell it with unmistakable plainness. And that tale amounts to an admission that the malady from which our husbandry suffers is not a matter of a few local affections, to be cured with plasters and salves, but that it is constitutional, the general system being wrong. We have a goodly structure to show, imposing and pretentious. However, the foundation has grown shaky. The walls are showing cracks, the pillars are giving way. We know that our technical practice is sound. For it has served as a model to all the world, and in truth produced the very weapons with which we ourselves are now being vanquished. But our system of applying that practice lias grown out of date. If good is to be done, we shall have to begin our reconstruction at the bottom. In Lord Selborne's words, what is wanted is a veritable "Revolution," to set matters right. It is the system which is in fault. There is no good in quarrelling with our tools and our materials. We have good enough tools and good enough materials. And we have good enough working power, if we will only properly use it. It is our methods of employing these useful possessions which cause our disappointment. And light and shade in the picture now unrolled before us agree in indicating where the fault lies. Wherever our Agriculture shows up well-and on such spots there is nothing to show up better-it is because landlord and tenant are both in a position to do full justice to their soil and their opportunities, and are agreed among themselves upon the way of doing it. That means, that on such spots there is a unity of interest. There is that "capital and brains" for which Lord Selborne rightly 
stipulates, on both sides. And the "brains" agrec. The landlord is equal to the task entrusted to him, and so is the tenant. The machine works smoothly because its parts work as one. Covenants and restrictions are practically in abeyance. The money required for improvements is forthcoming in adequate quantity. There is consequently output and there is steady improvement.

In the majority of cases, however, unfortunately it is not so. The landlord is crippled-alike in his means and in his freedom of action. For he is after all only a life tenant. And the tenant-whatever be his grade of education, and whatever be his capital-is tied. Covenants are a reality. Money comes forth sparingly. Therc is duality of interest. And, in consequence, there is short output and no improvement.

Under such circumstances, whatever be the quality of our soil, and whatever be the natural advantages dispensed to us by Providence, we cannot look to our Agriculture for the desired and desirable return. Our land, sparingly meted out to us as it is by Providence, is committed to the keeping of two classes of men, neither of whom has, as a class, shown itself quite fit for its business, and whose several interests cannot help clashing. To one of these classes the land is now either an investment only-which they themselves, on the showing of so eminent an authority as $\mathrm{Mr}$. Hall, have never (at any rate not since the days of Coke and Somerville) been able to manage agriculturally with success -or else a pedestal to position. These men are cramped and tied by the duties that they owe to their practically copossessing families. To the other class it is material which they have no earthly interest in either improving or making the most of, since it will perfectly answer their purpose if they only just skim a "living" off it. Each of these two classes naturally pursues its own interest--so far as, under mutual shackling of its power, it can. And the restraints under which the two interests are placed otherwise, of themselves of necessity stand in the way of the production of the best output.

It is from this dualism of interest and from the disabilities 
for each interest concerned, incidental to dualism, that all that noxious crop of abuses and unwholesome excrescences has sprung, which our inquiring Committees have discovered and complain of-deficient education, slovenly farming, systematic exhaustion of the land, bad forestry, restricting covenants, above all things that callous indifference of the really operative factor in the practice of Agriculture, the tenant class, to the science and good practice of their calling. On they move in their torpid, two-centuries-ago way, like animals in a gear, treading over and over again the old beaten track, as if they had blinkers over their eyes and nothing to do but machine-like plodding on.

Under this misuse of the elements of Agriculture it is every interest concerned which suffers. The landlord fails-as we have testimony to show-to receive the full return which his land might yield. The farmer keeps backward and makes less money than he should. The labourer suffers from the faulty handling of their several interests by the classes above him, and is kept landless, prospectless, degraded and dependent. Above all things, the Nation, whose interest must be recognised as paramount and supreme, suffers really a serious loss, the reckoning up of which would yield astonishing figures.

The root of all this evil unfortunately lies so deep down, under a soil grown stubborn and half petrified with long neglect, that it is not easy to reac $h$, not very well possible to reach till after some time - and at such period only, supposing that those interested-that is, the classes directly concerned and the Nation, whose collective interest must necessarily override all other considerations-will pull together to reach and remove it. However, the reaching of such root-cause will have to be kept persistently in sight. For we know that a tree with a bad root cannot bring forth good fruit. And to have good fruit is essential for the Nation. Therefore it is at the root that improvement wants to be effected.

Meanwhile, while such work is in progress, the noisome shoots which have sprung up from the poisoned Upas root now occupying the soil will have to be tackled one by one and clipped away. 
For such formidable task it is obviously necessary that, as observed, all concerned should work together, not aimlessly, but with a clear perception of the goal to be made for, and steadily and perseveringly, under competent leading, the lack of which Mr. Hall makes a special subject of complaint. Lord Selborne, to quote him once more, spoke the right word when at Lincoln he said: "We have no national agricultural policy "- which manifestly implies that, to succeed, we must have one. We have seen, thanks to Mr. Middleton, the advantages of the possession of such policy in the remarkable progress of Agriculture made in Germany. We may see it in the United States, where, under the leadership of the Federal Department of Agriculture, Agriculture is making decided strides forward. We see the result of singleness of aim and concordant action among interested parties in Denmark, in Belgium, in the Netherlands. Everywhere there is a studied watching for the indication which, not the wit of man, but the natural development of things gives us, for new opportunities, new methods, new fields for action, and well thought out, persistent pursuit of the paths deliberately struck out. There is an "air service" at work to direct the agricultural army to the positions to be attacked.

Only among ourselves the old Chaos survives, the chaotic character of which appears the more pronounced by the very gleams of light that are visible within it.

A national agricultural policy, however authoritatively led, as a matter of course cannot mean any restriction of private action, any coercion or limitation of private enterprise. To quote the words of Mr. Herbert C. Hoover, the United States Food Administrator, whose name should by this time be well known in England, on a very similar subject: "The solution of these national difficulties depends entirely upon the co-operation of all those concerned. With our people there can be no force used. There can, however, be intelligent leadership, and there can be a stimulation of patriotism to effect ends for the common good." It is distinctly, the efforts of individuals, entered upon in utter freedom, which have everywhere made for and deter- 


\section{+6.4 THE FUTURE OF OUR AGRICULTURE.}

mined progress. It is the individual who by his insight and discovery strikes out new promising paths. But it is for the community to provide facilities for those for whom the new paths are recommendable, to learn of and follow them. There can be no cast-iron-ness about a living interest. Not even the ultra-absolutist Prussian Government, which has-so far as it could-laid Agricultural Organisation, Agricultural Credit, Agricultural Education, in fetters and put them in Government harness, has attempted so manifestly imbecile a policy. Quite the reverse. It has at all points encouraged individual action, but laid itself out for watching and testing it, and made it its avowed and loyally pursued aim to render its benefits available for Agriculture at large. It lias not, like our Board of Agriculture, grasped perforce the helm of Agricultural Co-operation, interfering with independent action, but has secured the loold which it has eventually secured in quite a different way. That accounts for the more general improvement of German Agriculture, as compared with our own, which is far more chequered with bright light and dark shade-the predominating shade detrimentally reducing the average. In this country, as Mr. Prothero has put it, since I889-that is, since the formation of the Board of Agriculture - it is to that body that the lead in agricultural matters has fallen-from the hands of those enlightened landlords who previously, and up to that time very satisfactorily, exercised it, but whose position has, by modern legislation, by the changes effected in the relations between the various classes connected with the land, and by the dilution of the old landowning stock by the incursion of much new blood, pulsating rather with the beating of the property-loving and position-seeking heart than with the agricultural, has suffered an eclipse, weakening its power of leading. The Board of Agriculture was intended to "lead," to gather the new rays of light breaking through in various quarters, and shed their collected volume as an illuminating and fructifying force, like the electric currents which we now pour stimulatingly upon our growing crops. upon Agriculture as a whole. To do it justice, it has 
laboured very zealously. It has in parts performed excellent work. Its publicist activity is worthy of all praise -if it could only, instead of being a partly barren bombitatio in vacuo, be made to reach all the eyes for which it is intended, and through them the reflecting brain, and in due course the acting hand. But it cannot truthfully be said that the Board has given National Agriculture much of a "lead," that it has detected and clearly indicated the direction in which things agricultural should be made to move, and facilitated, for all, movement along those lines. However, that will have to be its task if it desires fully to justify its existence-the want of which, we may remember, was at the time of its creation challenged by so high an authority as the late Duke of Richmond.

However, the Board of Agriculture can by itself achieve only little-very little. If we want to get our Agriculture into the right groove, it will, as observed, be for all classes concerned to join in a common effort, in which others outside it - since the entire Nation is interested-will have to lend a helping hand. And if that is to be done, there must be some understood, generally marked out, though withal clastic and flexible, plan of progress, along lines such as Nature appears to indicate, pointing to some definite end.

To recapitulate : our first need, in the direction of improvement, so one may lay it down with confidence, after what has been said, is that of more extended, more perfected, and, above all things, more appropriate Education-Education which attunes to rural life and agricultural pursuits, and proclaims Agriculture more emphatically than is done at present a "liberal" calling-Education which teaches, as an American writer has put it, more about Agriculture than about the height of Himalaya and the length of the river Ganges. " It will thus be seen," so lie goes on, " that, while direct teaching of Agriculture is to be deprecated, the giving of an agricultural tinge to education imparted in the higher classes of these rural schools is a great desideratum.' Mr. Sayer, of the Indian Government, puts the case rather well when he says-urging that the teaching given should have morc relation to the environment of the children, 
that textbooks should be brought into concordance with their immediate surroundings and that, for instance, in the teaching of arithmetic, " teaching should relate to the payment of rent, real measurements of ficlds, calculation of fields' produce, etc., all things which will prove useful later on." Wc see this demand put in the forefront of the development of Agriculture in all civilised countries, made a study of, liberally assisted with funds. And we see how it bears fruit. It is not " schoolmaster-governed " Germany alonc which gives proof of the efficacy of such policy. Indeed Germany itself was not so very long ago only a learner in this policy, being taught mainly by Switzerland and Denmark, but to a great extent by ourselves. We see our kinsmen across the Atlantic pushing onward vigorously on this path, Canada in some respects manfully leading the way, the United States sparing no money and no effort, and impregnating the system with the right principle, which is, in agricultural schools to train agriculturists. Elementary schools in country districts there teach Agriculture almost universally, and almost as a matter of course, as a by-subject. But above all things pains are taken in rural schools to maintain and intensify a rural "atmosphere." We see Switzerland educationally thoroughly organised, Denmark-in this respect-raised far above ourselves on the foundation laid by Grundtvig and his collaborators, that is, a basis, not of technical teaching, but of methodically preparing the mind for the reception of every description of knowledge. We see France busy with its Departmental Directors, and its Agricultural Syndicates, of which Lord Reay, surely a good authority, has testified that they "work wonders." IVe ourselves possess shining lights in the matter of Agricultural Science and Education-lights which need fear comparison in brilliancy with no others. We have Cambridge, Oxford, and other centres, pushing on lustily on the path of discovery and teaching. And we have a Board of Agriculture which certainly does not neglect teaching Education so far as its power goes, and whose leaflets are admirable. However, our light for the most part still " shines in darkness," because, among the upper classes, which in Germany 
fill agricultural colleges with students, Agriculture is not a fashionable study, and among those of our operating farmers generally, Education is "not believed in." That wall of unbelief wants to be broken down. "It's dogged as does it." We shall have to make an earnest effort and persist in it. Our educational budget for Agriculture is pitiable by the side of corresponding budgets of other countries. One would think that those who hold our national purse are of a piece with those backward farmers whom Mr. Middleton complains of, who " do not believe in Education." And our voluntary associations have made more than one mistake, both in the selection of teachers and in the devising of plans of action. We have difficulties of our own to contend with, of course. However, these are to be overcome. Among juveniles it is imperative that a new direction should be given to rural teaching. Our rural teachers want to be made to understand that Agriculture is not " yokelism," but an honourable calling, which can hold up its head beside any other. Time was when engineering, commerce, in fact all practical subjects, were held at a discount in comparison with classics. They have fully made good their position. Agriculture will have to do the same. Just as we have discarded Greek in some of our schools in favour of more useful modern subjects, so shall we have to strike some other non-agricultural subjects off our list for schools intended specifically for agriculturists, in favour of agricultural. The calling which Aristotle ranked first among all callings surely need not tolerate its being held in low estimation - even in universities.

Our chief difficulty, however, for the moment lies with the teaching of the adults. It is they who produce the bad farming complained of, they who stand in greatest need of being taught. Mr. Hall would have them "shaken out." But what is to become of them after that? And whom have we at once to put in their place? We shall have to try to carry light into this realm of darkness.

The question is, how to do it, and who are to be the active movers in it.

In respect of a general scheme of liducation, more speci- 
fically for children and young folk, it will of course be for the Government to act. Others may demand; but it is for the Government to give. Let us hope that it will give freely. Dealing with adults is-with possible Government help such as is given, with profit, in the United States and also in European countries, more specifically in Switzerland, Belgium, and the Netherlands-a matter rather for associations of individuals, like the French Syndicats agricoles and their officers, being practical men, who can suit the bait of attractiveness to the trap of designed instruction. Above all things it is more ocular demonstration that we stand in need of. Our agricultural public is in this respect distinctly different from that of the United States. It is not likely that gatherings like the "Farmers' Institutes" would answer among ourselves. But the "demonstration," which is so studiously practised in America, would be likely to make an impression on backward minds. This is not to be done in a hurry. In Ireland Sir Horace Plunkett addressed about fifty farmers' meetings before he succeeded in starting one co-operative society. But in the end his Co-operation proved victorious. L'appétit vient en mangeant. The prize is worth the effort.

Our next, and indeed at the present moment our most pressing need is Organisation-Organisation which, as it happens, contains within it the germs of all other improvements, Education among the number. For nothing educates like Organisation by co-operative means-Organisation which presents matters from their practical side, not as mere classroom subjects, but as matters appealing to that most sensitive organ of the composite human being, the pocket, as well as to the brain and to reason. However little educated country folk may be, they have natural education enough within them to be able to appreciate the value of joining together for an organised service in their calling and to carry through what, however dimly, they after all understand. All round are they faced by organised forces seeking-it may be, in a perfectly natural way, as a consequence of businesslike aims-to prey upon them. It is their sovereign, their shilling, which is coveted 
and laboured for. The best educated country folk, that is, the Danes, have, of course, been the first to realise the necessity of Organisation, as a means of defence, and also as a method of progress and an avenue to profit - just because they were best educated. However raw, untaught settlers on American prairies, moujiks in Sibcria, and peasants in the various Balkan kingdoms, even backward cultivators under the Turkish crescent, and fellaheen in Egypt, and uncultured men down to the aborigines of India, have shown understanding enough to accept organisation, once it was offered to them, and they were shown what advantages it holds in store for them. Alad all alike have benefited by it. Do what we will, on this side of the North Sea, in our unorganised way, the Danish dairyman successfully holds his own even in our own market. The organised Frenchman sends us his flowers, his fruit and his early vegetables by specially provided fast trains and specially chartered boats. The Dutch zuivel co-operator, with the help of his co-operative markets, dominates in his trade, as does also the German organised landwirth with his co-operatively organised sale of live stock. We have beginnings in this country. But we are backward-lamentably backward. The Eastern Counties farmer of large holdings demonstrates to us the value of co-operative organization; so does the Pershore fruitgrower; so does the petty Irish farmer. It is the same all round. Co-operation is a friend and benefactor equally to all. But we do not seem generally able to mend our snail's pace. More than twenty years ago Mr. Jesse Collings wrote in the Contemporary Review about " $£ 35,000,000$ worth of agricultural produce" that we annually imported into our kingdom, which we might just as well have grown at home, if we only would adopt progressive methods, as samples of which he quoted the practice of German Würtembergers, whose ways he had observed on the spot. There is really very much more that we import from abroad and that we might produce ourselves in competition with our Continental rivals. And our doing that would after all be worth more, alike for our Agriculture and for the Nation generally, than a duty clapped upon wheat, to the discourage- 
ment of the cultivation of more paying crops. If we are to make a success of sugar-beet growing, of the cultivation of tobacco, and of that most promising branch of modern Agriculture, the growing of large crops of potatoes for industrial purposes, it is almost indispensable that we should grow those crops and market, or else work them into marketable shape, in a co-operative way. And that multitude of Small Holdings upon which we have set our heart, and which is the hope of our small folk, and the promise of a revival of our country life, repeopling deserted square miles with prosperous and contented folk, cannot possibly be set up upon any other foundation than that of Co-operation, which unites small forces, providing equality for the small holder economically with the large farmer, and knits society together to something like a family, with realised community of interest, of aim, of sentiment.

And Organisation is not difficult, if you will only look at it in a practical, plain and matter-of-fact way. We have specimens to follow all round. But we scarcely need them. Although our national sentiment, more particularly among country folk, appears to predispose us to segregation and individualist aloofness, wherever we do associate, our national bent leads us to associate in a more practical and really more simple way than our Continental neighbours, used as they are to having tout réglé et réglementé for them. There are no societies more simply and yet more efficiently organised than our co-operative societies, consisting mainly of industrial working men-plain, uncultured men that they were at the outset, educated now out of recognition of their former selves, but maintaining their simple, effectively working machinery in its primitive plainness, thougl it has had to be magnified more than a hundredfold. On this ground the Germans are miles behind us. It is for that reason, not least, that, in taking up the matter in I905, at the Birmingham Congress, I have laboured so earnestly for a close connection and dovetailing between industrial Co-operation and agricultural. Our industrial co-operators will prove our best co-operative schoolmasters for agricultural Co-operation, at any rate among small farmers 
and the coming race of labourers endowed with landbetter by far than any that Whitehall Place could send out. And they will teach Co-operation of the right sort, not looking for patronage or help from the outside, but built up by themselves upon the solid foundation of self-help and selfreliance.

It is the perception of the necessity of combined action for organising purposes that is wanting in our case, not the power to effect it. And such perception wants to be infused into our stolid backward folk by teaching. Teaching requires effort; and it requires money. But the money spent upon it will prove well laid out. It is sure to come back " with usury."

Only that Organisation wants to be genuinely co-operative and free, in the service of only onc interest. It is sheer mockery on the part of the Government of Ireland to talk of " non-controversial Co-operation " so ordered as to leave the traders and the gombeen men in possession still, offering the farmers a mere empty name. How on earth cau such a movement be made "non-controversial"? Buying and selling are of the essence of the thing. Trade is competition ; and competition means controversy. And it is admittedly competition which has secured for us more honest trade and cheaper prices than ruled once-all this to the benefit of humanity. The Eastern Swiss farmer has organised to good purpose, and where the trader was fraudulent or overgrasping, he has beaten him and ousted him from his villages. The Danish farmer has had his country stores since 1866 , decidedly "controversial," and has fared the better for having them. His "controversial" Co-operation has taught him that agricultural Organisation which has enabled him to rise superior to Prince Bismarck's twicerepeated protectionist onslaught, issuing all the stronger economically from the contest. The Raiffeisen co-operator in Germany, having his hands full with other business, not yet practised in this country, holds his admitted right to set up "controversial" stores in reserve, to be employed whenever the German "bania" begins to deal unfairly by him. The English and Scotch industrial working man 
has in a decidedly " controversial" spirit set up his stores by the hundred, as a weapon wherewith to fight fraud and overcharge, with the benison of the authorities and the public from Mr. Gladstone downward. And he has made it triumph, to the direct benefit not only of his own more than three million fellow co-operators, but also of the entire Nation, by compelling a radical reform of shop trade, making it more honest and cheaper, and preparing the way for that " universal providing," with prices and qualities open to the knowledge of all, which protects the consumers against fraud. Gombeen men's votes may have their very great value for the maintenance of the "right sort" of politicians in power. But why in the name of common sense is the Irish farmer for their sake to be denied the right so readily accorded to, and so beneficently used by, the English and Scotch industrial working man?

And if Organisation is necessary in a general way, on no ground is it more called for and more urgently wanted than on that of Credit-let us say at present, for working purposes-in spite of the ban pronounced against it by such high economic authorities as Lord Denman and Mr. Leroy Lewis and, on the latter's recommendation, by the Central and Associated Chambers of Agriculture. ${ }^{1}$ Practising farmers, especially of the humbler order, for which we are now actively recruiting, less well endowed with earthly goods, know better at which precise point the shoe of agricultural necessity most painfully pinches. If our soil is to bring forth as it should, if we are to equal and surpass our neighbours in agricultural productiveness, then that soil will have to be liberally fertilised with gold. There is nothing to be done nowadays without money. And it is the money - the nummus of the Latin proverb, which declares it to be-of course, when mixed, as Lord Selborne insists, with "brains" - "supreme king " in the world, which to-day commands success. It is at this point that our Government authorities and those men who should supply a "lead" -and in truth are anxious to supply it, if they only could

1 See Mr. Leroy Lewis's letter in the Agricullural Economist of September, 1895 . 
-have committed the greatest blunders. They can render very valuable services, if they will only be careful to confine themselves to their logical limitations instead of assiduously trying to begin beyond. You cannot from outside creatc Organisation. You cannot from outside create that security upon which Co-operative Credit, like all Credit, can alone be based. The movement wants to be started, led and pushed from within, by those for whose benefit it is designed. Assisted and Government-created Co-operation, whether of Credit or of any other form, blossoms up and withers, bearing no fruit. We have the evidence of this abroadmore specifically in Austria. Authorities may teach-and they should. They may remove barriers. But, as Mr. Gladstone insisted, when the first Friendly Societies Bill was under discussion, they must not provide the money for, and they must not interfere in, the direction and management of, business. It is spontaneous action alone which can make Organisation a success.

Pace Lord Denman and Mr. Leroy Lewis, everybody now recognises the necessity of easy working credit for Agriculture. In France, when the authorities and agricultural organisations set themselves to repair the mischief done to Agriculture during the German occupation in the now "liberated" departments, the first thing that they took in hand was the reconstitution of perished credit societies.

The methods of providing such have long ceased to be a mystery. Some of those adopted in practice are faulty. And nowhere do such faulty practices abound more than in the countries in which co-operative Credit first took its birth. But there are very good ones too, and we see them successful all round, and can indeed test their quality by the degree of their success, not only in providing money, but also in what Mr. Gladstone pronounced to be far more valuable, namely, their function of " manmaking." I have been privileged to reveal such sound methods to the Irish and to determine Lord Curzon in ordering their application in India. My advice has been followed in both countries. And in both countries has 
the result been success. In England authorities are still only groping their way for some new device which is to make the thing easier in the country in which money is really more plentiful and the principles of Credit and business generally are better understood than in any other. This has been going on for more than twenty-four years. And, having vainly attempted to square the circle so long, we still stand precisely where we stood in IS93. The object apparently aimed at is, how to obtain money without giving genuine security, such as would imply risk-such as 'our' people shor tsightedly hope to avoid - which clearly is impossible. Indeed the education impressed by the labour of earning Credit is in truth the best part of the benefit to be secured. It trains men to better ways in other business and in conduct.

There is no necessity for all this seeking and groping. Experience has taught us that, although severe on points of principle, Co-operative Credit is most adaptable in respect of methods, which necessarily have to be suited to every particular country. India has, under the guidance of its resourceful Registrars, discovered and adopted new methods, appropriate to its own conditions, such as neither Schulze nor Raiffeisen dreamt of, and as unquestionably would be out of place alike on the European Continent and in our own country. It is not a question, as some people seem gratuitously to imagine, of unlimited liability quand même, making that form of obligation a sine qua non. Unlimited liability is indispensable in one form of such Credit. Generally speaking it comes natural to Germans, who have grown up in the use of it. Where conditions are different, limited liability is, provided the right sort of organisation be chosen, absolutely as admissible. And it may be so handled as to produce practically the same results, even morally. Only it requires a more liberal provision of share capital, a rather different form of service, and somewhat greater familiarity with business. Even the ideal object of Cooperation, such as that of Raiffeisen-which aims at "brotherhood" and the moral as well as economical uplifting of those who practise it-may be fully as well safeguarded under the share system, for which limited 
liability is preferable, as under the other. There are excellent little societies to testify to this, for instance in Piedmont. In our own country probably the limited liability form will prove more generally acceptable. People are coming round to it at the present time in Ireland-having done very well under unlimited liability, out of which, however, it is thought that now, with more money in their purses and greater familiarity with business, they have "grown." Something more than twenty years ago a similar transformation was adopted before my eyes among some rural credit societies in the Riviera. In Inclia people greatly prefer unlimited liability. And I hold that under their circumstances they are right. Only, when limited liability is adopted, people will do well to avoid blending ordinary trading business with banking and credit-except it be, by way of concession, on the very lowest grade. In a little Raiffeisen society, so long as the rather severe rules are loyally respected, there is no danger in the combination of the two forms. But in a share society there is distinct danger. In both the great agricultural Co-operative Unions in Germany, that of Raiffeisen and that of Haas, a dozen years ago or so, such combination in the Central Departments of the two Unions, that is, at headquarters, led to serious embarrassment and loss. It was against that combination that a rather strongly worded warning from myself, in the second edition of "People's Banks" - which passage appears to have been misunderstood in Upper Merrion Street-was pointed-just as I had spoken strongly against it at our International Congress at Budapest in I904. The desirable correction was subsequently effected in both cases and further loss has thereby been guarded against. Please God, before long we shall see the problem upon which the Board of Agriculture and its advisers have quite unnecessarily bestowed so much barren labour and ingenuity, solved, and Credit provided for our farmers. There is one principle, however, which, it may be laid down, cannot be got away from, and which must be scrupulously held fast by, whatever else ingenuity may suggest, namely, that what under all circumstances must first be provided, 


\section{THE FUTURE OF OUR AGRICUITURE.}

if you would create Credit, is security. That being provided you will have no need to trouble about the money. The money will come in of its own accord.

The means of doing the thing, then, lie ready to our hand. Let us not split hairs, as is being done now, alike in Government and in would-be " organising" quarters, about some new form to give to Organisation, when experience has supplied us with so many trustworthy guides! Surely in this matter the proper stage for discussion is past, and the time for action has come.

As a next point, it is not likely that the question of agricultural Labour will be forgotten under present circumstances. It keeps forcing itself upon public attention every day. Unfortunately town people will look upon the agricultural labour question with town eyes, and prescribe industrial remedies - which is like giving toothache mixture to cure a stomachache. The agricultural labourer does not want all those rigid limitations of hours and work by the stroke of the clock that are asked for on his behalf. But he does want a home of his own, held independently of his employer, a little rural ménage, and the treatment and prospects of a full citizen. He is an Englishman, like all his neighbours. And if you will but give him the " necessary liberties" pertaining to the status of an Englishman, such as his neighbours undisputedly enjoy, he may be relied upon to show-though in some cases it should be only in the next generation-the same intelligence, resource and practical sense of an Englishman, sharpened by acquired practical knowledge and a new sense of responsibility, rendered acute by English sturdiness of character, grit and mettle-as those now more favoured neighbours. And so, by his raising, the Nation will gain a new, valuable class of citizens.

The question of Labour accordingly naturally connects itself, in a complementary manner, with that of Small Holdings, in the substantial multiplication of which not a few intending reformers rightly seek, not only greater agricultural prosperity for the country, but also a more satisfactory organisation of national society, a perfecting 
of its organic structure and increased cconomic well-being and social happiness for the Nation.

Quite half our much-complained-of social troubles may be said to arise from a forcible divorce of our working population from the land. The complaint is often heard, on the one hand, of the incompetency of our present rural labourers; and, on the other, of the revolutionary tendencies revealing themselves among our industrial workmen in over-filled towns, more particularly at times when employment is either scarce, and out-of-works are plentiful, or else, when employment is excessive and increased demand leads Labour to make its own terms rather inconsiderately. These complaints indicate, as Mr. Prothero has rightly pointed out, not a cause, but a result of a faulty condition of things.

For generations the labourer has been denied access to the land, compelled thereby either to take refuge in overfilled industries in towns, where natural discontent as a matter of course has bred revolutionary aspirations, or else to allow himself to be put to one and the same occupation in the country, in a wearying and monotonous round of work, without anything to give a zest to life, anything to look forward to, under conditions necessarily dulling his intellect and depressing his spirits. The consequence is that our society is altogether " out of joint," without its desirable equilibrium or balance. Industrial employment if over-filled, and so are consequently our towns; and the country is depleted. And our people generally have "loved to have it so." The land was supposed to be for the big man, who could fix his own terms for the admission of others to its use, as a matter of grace. The idcal of farming was large wheat breaks, facilitating calculation of rent. It required a farmer with a well-filled purse to hold his own against the landlord and obtain comparative freedom from restrictions; and he must in the bargain be possessed of "nous" and skill to succeed. The moderately endowed tenant must bow to corenants and restrictions and take his chance. The man who had only his labour to depend upon must, dispossessed as he was of his Common rights -the loss of which doomed his cottage to abandonment 
-take what work he could find and devote himself to a treadmill existence.

Evidently these things ought not so to be. Evidently the multiplication of small holdings, the access given, to the small man as well as to the great, to free contact with "Mother Earth" - which is calculated to make him a better-to-do, more contented and happier man-promises, by reasoll of the new interest given in life, the more varied occupation and the sense of responsibility awakened by his farming for his own account, to prove the better workman. Evidently also the opening up of the land to small holders in an ampler measure must tend to thin the population in over-peopled towns and by an Antæus touch with deserted Earth to infuse new health and strength into our population, about the decline of whose physique we have before the war had so many complaints-some of which the war has indeed not altogether borne out.

This is, as already observed, very much more than a purely agricultural question, though the agricultural side does not want to be lost sight of. Experience has shown this elsewhere. It is true that where there are small holdings there are other troubles besetting nations. But those other troubles do not necessarily spring from the absence of the one. The devil has his own gift of finding his way in everywhere. However, because another man, who is free from our dyspepsia, happens to suffer from sciatica, that is no reason why we should not do our best to get rid of our dyspepsia when we have the chance.

Small cultivation, wherever it is practicable-which is not, of course, everywhere-distinctly does produce more value than large farming, although not precisely in the same shape. And it produces it at the most favourable place for turning it to account, that is, in the place where most of it is also consumed, and where, labour not being counted, it is cheapest to produce. We have therefore here the ideal combination of cheapest production with disposal in the most appreciative market. It does not follow that, because the wealthy man, in a town, prefers to buy what produce he wants ready prepared, in the place of producing it for 
himself, that that will likewise be the best economy for the small man in the country. The wealthy man has other occupations to bring him in his income. The small man in the country has not. He raises what he wants by his own labour, which is his goods, just as the industrial working man provides himself, by collective production of his own, through his co-operative society. He buys with his labour.

However, among the arguments used in favour of small holdings those bearing on the social side are by far the weightiest. And that brings us back to the point of Organisation, which is absolutely essential for the maintenance of small holdings. The small holder, as we are thinking of him-even if there is a Prothero to provide a holding for him, in the place of a County Council, as at Mauldencannot possibly stand alone. He needs touch with neighbours for economic purposes. He cannot buy his agricultural requirements of the necessary cheapness and of the necessary quality by himself. It has been shown that he has been benefited even in the obtainment of his small holding by co-operation with others: how societies have been formed to buy or rent the land for him at wholesale prices. We have instances of this, as an arrangement working satisfactorily, in our own country. There are more, and more telling instances to be met with abroad. But once settled, our man wants help which needs to be mutual, consisting of giving and taking. Whether it please Sir Thomas Russell or no, he wants his store, to provide him with cheap and good necessaries of life. Stores ought to cover the face of the country as they do the space of industrial centres. We see the benefit of this in Denmark, and above all countries in Eastern Switzerland. There ought to be stores, for the benefit of the agricultural labourer at any rate, even where there are no small holdings. But where there are sinall holdings, there ought to be stores, not mercly because they provide cheap goods, giving the consumer the value of the profit which now goes to the middleman. Distributive Co-operation is the easiest form of Co-operation to learn, and a form which, humanly speaking, is bound to succeed in almost all cases, yielding an 
overplus wherewith to start new forms of Co-operation, the practice of Co-operation having been learnt, as in an elementary school, at its counters and in the Committee room. Therefore whoever favours Co-operation ought of necessity also to favour stores. That is why it is so very desirable that the two main forms of Co-operation, the distributive and the productively agricultural, should be closely linked together. Beyond that, our small holder needs Co-operation for the supply of his agricultural requirements - seeds, implements, fertilisers, feeding-stuffs, for the use of implements and machinery collectively acquired, which have to serve the members in turn, for marketing, it may be for the supply of electric light and power, for the disposal of his dairy produce, it may be of his fruit, and also other edible produce, and, not least, for the service of expert advice, such as in Germany and in Scandinavian countries "Control Societies " render-being general advisers on everything, whereas in the United States the County Agent and the Organising Section of the Federal Department of Agriculture supply the need. These experts are too costly to serve one small holdings society alone. But once employed by a Union of such societies they are able to furnish all that is required. And they have proved a substantial benefit. For our small holders are not likely to be scientifically trained agriculturists. They are likely to begin with very little scientific knowledge indeed and experience of only one locality. On the other hand, by the very fact of their being small holders they are called upon to practise their agriculture in considerable variety of forms, with an eye ever open to innovations and improvements. But having that small holding, which brings them in pence, they are likely to prove keen and ready to learn.

However, there is a good deal more that lies beyond such economic Co-operation. We want, not only to repeople the countryside: we may be taken to be "out " for the regeneration of a country life, indeed for the creation of a new country life, such as that of which Mr. Roosevelt was, during his Presidency, anxious to lay the foundation -for which reason he appointed his "Country Life Com- 
mission " of Inquiry - and such as we have not known since the big purse bought up small yeomen's properties and annexed the Common. Dull and dreary, anything but cxhilarating and stimulating, as our country life is now, to make it attractive, to tempt people to remain or to settle in the country, we want to make it bright and cheerful, with subjects of interest to keep the mind busy and attention active. That is only to be done by the creation-though it be on old ground-of new communities, bound together by a bond of common interest and a feeling of neighbourliness, with give and take, touch and easy intercourse, the maintaining of something approaching to brotherhood in it. Now, to effect this, and to promote the particular kind of Education which among small folk in the country we require, there is nothing like Co-operation built upon the basis, not of pure commercialism, and not of the pugnacious sort which seeks champions to fight the cause of a political "co-operative" party. It was " the world of brotherhood" which he saw among the co-operative Raiffeisen societics in Germany, which so much enchanted the Hungarian Professor, whom his Government employed to transplant the Rhenish shoot into its Danubian garden, the "happy union of business spirit with the sentiment of a true, a practical philanthropy" ("l'heureuse union de l'esprit d'affaires avec les sentimens d'une véritable, d'une pratique philanthropie"), which delighted the French social economist Eugène Rostand. Whoever has not seen what a remarkable binding together and stimulating effect this form of Cooperation has, and how it excites a desire and readiness to receive and assimilate instruction, technical and general, how it helps to raise the character of people united by it, making for sobriety, strict honesty, good family life and good living generally, finds it difficult to credit it. And the effect has been the same among the comparatively educated peasantry of Germany, the illiterate country folk of Italy, the primitive cultivators of Serbia, and it is beginning to have something of the same effect among the rayats of India, where, as observed, leaders of the movement hope by its means to provide a modern substitute for the lost, 
cherished and typical old Indian "Village Community." Surely to plant sprigs of such beneficent plant on our soil, on which it could send out sets and offshoots freely, must be a benefit to the Nation and is worth taking a little trouble for. However, barring teaching, which may be delivered from outside, such movement must necessarily spring out of its own self. It will not last otherwise. Scarcely even could it grow. Whitehall Place can do nothing in the matter, beyond sending out teachers. Its admonitions and precepts, and that showy modern production which appears to have captured its fancy, of " Boards " consisting of worshipful "Governors" -whose title recalls that of Prussian "Excellencies "- -would be thrown away upon local people. It is the local people themselves who will have to create it. "Vouloir," so wrote Léon d'Andrimont, the "father" of Belgian Co-operation, "voila le grand mot de la Co-opération, sa raison d'êtrc, la garanlie de son succès." You cannot impose Co-operation upon people any more than you can neighbourliness. The one, the same as the other, has to spring up out of their own resolution to practise it.

Once more, the point of the reclamation or else afforestation of waste land - of which, under our improvident national husbandry there is more than enough waiting to be dealt with-links on quite naturally to the question of the settlement of Labour on the land and the creation of small holdings, as does, in truth, also the last point here raised, the aim of which is to make our land, now generally owned, or life-owned, in large areas, more easily divisible and saleable, as a means of unifying the now separated two interests involved in it, and so securing, in the majority of cases, the presence of a single interest only of owner and occupier in one, as a means of ensuring to the tiller the full reward for his pains and outlay.

We are anxious to see our waste land reclaimed and turned to profitable account, whether as arable fields or pastures, or else as forest, in order to provide for the country as a whole an increased output of land produce, and procure for ourselves, more particularly in times of war, a large com- 
mand of foodstuffs and necessary timber-the timber whicls we can best grow (as being most congenial to our soil, climate and the various positions concerned) being also-as has been shown by expert judges, giving evidence before our Forestry Committee-precisely the kind of timber which we most stand in need of, for our practical employment. And we want land made more readily saleable without cxcessive to-do, in great part as a relief to the large landowner. That being done, it will not be difficult to graft upon our land system greater facilities-such as exist and are highly valued abroad-for raising money on the security of territorial possessions at a cheap rate, whatever be the object of such loans. The fact that the form of credit so provided would at the same time bring benefit to capitalists by affording them a handy, readily convertible and safe investment is, of course, an additional recommendation.

However both these measures, or groups of measures, have a decidedly important and direct bearing also upon the question of Labour and Small Holdings Cultivation. The forests to be planted, as it has been repeatedly urged, would provide most welcome employment, so far as it goes, for rural Labour even after the land has been planted-which latter will be a distinct occupation by itself. And methodical, comprehensive reclamation of waste land has, at any rate partly, been advocated on the ground that it will provide employment for small men, whether for the reclamation itself, or for further cultivation, such as would not be practicable for large farmers. There is much land now lying waste which, by reason of its peculiar situation or natural conformation, is cultivable only in small holdings. The facilities for transfer and divisibility of land manifestly tend to assist in the formation of such small holdings, by rendering the separation of small parcels easier from the main block.

It is rather a reproach to us, as establishing the fact of past neglect, that the difficulties in the way of reclamation and afforestation are esteemed so great as of necessity to call for the interference of the State, not with its purse alone, but also with its supreme power of administration and expropriation. Landlords have " preferred rabbits to trees," 
and warrens and moors to fields so long that there is something like an Augean stable left to clear out, to which task only Herculean efforts by the omnipotent State are held to be equal. How far we can follow the example of the Italian Government in respect of the expropriation of terreno assoggettato alla bonifica ma non bonificato, or, again, the example of the French Government, in expropriating-or taking power for doing so, at any rate-land suited for afforestation au nom de l'utilité publique, it will be for others to consider. Certainly some measure of oversight, holding compulsion in reserve, seems called for, and the introduction of an official régime forestier would be not amiss. For all measures aiming at the increase of the value of land, which naturally involve operations of long duration, outside help in money is indispensable. However it remains to be shown that, once title has been made sure, giving scope to credit, and the duty to plant and manage well has been rendered effective, under adequate safeguards, private organisations, laying themselves out for this particular work, might not provide the money required under methods such as the German landschaften have applied and the power or duty to apply which, in a different form, is now in France sought for the Crédit foncier or some similar body. There is so much money in this country; adequate security for good management, such as must be insisted upon, may so well be taken; and the money market would probably be so willing to accept what in Germany and Denmark, and elsewhere, has become a favourite investment in the shape of land bonds, that at any rate it is quite conceivable that private enterprise would be equal to grappling with the matter. The bonds issued by the corporate bodies alluded to are not simple mortgages, secured by one land pledge and withdrawable singly on a debtor's demand, but bonds for which the entire volume of properties pledged answers collectively, in addition to the capital of the shareholders in the financially operating concern and which is repaid according to a fixed plan. One duty which the State will certainly have to charge itself with, however, is a thorough survey of the country, to ascertain what land there is, to either reclaim or afforest. 
It has, I think, been shown that there are more ways than one of usefully reclaiming bog or waste. In the reclamation of bog and peatland Holland and Germany have been particularly active, and, it may be added, successful ; and the methods which they have practised are at any rate varied enough to show that the work of reclamation may readily be adapted to varying conditions. They also show into what very valuable agricultural land unprofitable bog desert may be converted. And, once more, how admirably peat moss lends itself to employment for the purpose of creating small holdings, and whole clusters of small holdings, and communities of small cultivating folk.

Our favourite fancy at present is to employ newly enlisted agricultural labourers in the reclamation of waste, among others by preference discharged soldiers, invalided or otherwise. The demand for turning waste under reclamation to account for the creation of small holdings is very old. Sir James Caird advocated it nearly seventy years ago. And long before him so did Arthur Young. "Every scrap of waste and neglected land," so he urged in I80o, "should be converted into possessions for the poor, and all labourers should be assigned gardens and grass land for the keep of a cow." In I8or he proposed that labourers should beallowed to absorb for themselves the small commons which were situated in the centre of enclosed districts, and that all Acts of Parliament for the reclamation of wastes should attach enough land to every cottage to provide summer and winter keep for a cow, the land to be inalienable and vested in the parish. And afterwards he expressed particular regret that the matter had been left out of sight and a glorious opportunity for providing agricultural labourers with small holdings had been missed.

Those were times when Agriculture was a different thing from what it is now. And Arthur Young was careful to confine the claim for reclamation rights to "agricultural labourers," assumed to be skilled in their intended work. But even then unskil'ed Labour might very well be set to work on the execution of reclamation with a view to obtaining a little property or holding for the worker. Since then, 
however, the science of Agriculture has advanced, and a good deal more has to be looked for in reclamation. Recent experiments in reclamation or cultivation by raw hands have not yielded altogether encouraging results. In the comprehensive labours undertaken in the period of the Unemployed Boards, the employment of men admitted to such in the reclamation of land has not proved entirely successful. And in the English Land Colonisation Society, which was fathered by a noted philanthropist, and supplied with money, apart from subscriptions, by two great capitalists, I remember that we had very curious proofs of the folly of the disregard of the principle of selection of only famiglie abili $e$ attive, as the Italian settlement precepts term it, in allotting holdings to inexperienced and unskilled claimants. Small men reclaiming holdings for themselves-with such assistance as will be necessary-may indeed do very good work and further the national cause to a great extent. But it is absolutely necessary that they should be to the manner bred. And even so, scientific guidance will still in all probability prove advisable. The risk of failure by reason of inexperience and want of skill has become so serious, and Science has discovered so many useful aids to the workby the employment of appropriate fertilisers and decomposers, by suitable drainage and inoculation, and so onthat skilled guidance must appear to have become indispensable. And the work undertaken being, after all, designed for the national benefit, one may well expect that such skilled counsel should be forthcoming at national cost. Settling on land which is cultivated already is a much easier job. But even for that, as has been shown, it is by those who have much experience in the supervision of the work considered imperative that only experienced agriculturists should be employed. Unquestionably there is much profit for the ccmmunity to be gained by reclamation and afforestation, and the credit side of the national balance sheet may be substantially strengthened by careful attention to the matter.

The unification of the two conflicting interests now engaged in Agriculture is a far more difficult matter, requiring 
considerable length of time for its realisation. And it is a work in which the State can assist only inclirectly, since the disposal of a man's property, lawfully acquired, must obviously, so far as there are not compelling reasons to suspend the right, be left to himself. One would not wish to see Henry George's and the most modern Land Reformers' recipe accepted, and landowners taxed into insuperable disgust with the possession of their property and so virtually compelled to dispose of it. But landowners ought to be made to realise, what the war has made abundantly clear, namely, that their property is not altogether so absolutely their own as they have hitherto imagined; that there is in the person of the Nation, an overlord, a feoffor, to whom they are accountable for their stewardship as occupiers of land held under the Nation - a feoffor against whom, in Mr. Prothero's words, "there is no prescription." Quite apart from that, the cumbrous and costly machinery now applied to dealings in landed property, having lived its time-in which it has proved useful, but after the lapse of which it has now become worn out-will be the better for being remodelled. The introduction of compulsory Registration of Title would be a useful first step towards such a consummation. The registering of all burdens resting upon land which on the outside may look an extremely valuable possession, but is possibly honeycombed with charges, would probably in many cases open the eyes of an unsuspecting owner moving on in his old groove, as the calling in of an accountant to draw up a correct balance sheet has often enough opened the eyes of an easy-going encumbered capitalist. The facilities given for selling or dividing might certainly be counted upon, in conjunction with other influences now already in operation, and becoming more and more compelling as time goes on, to dispose landowners, who have thus far clung to their old inherited homes and estates, to exchange troubled splendour for a quiet, secured existence, more particularly when, from having been for centuries back a generally speaking steadily improving and appreciating value, land has, with the modern demands made upon it, become a possession as liable to depreciation as any industrial sharer. In any 
case, being rendered more saleable, land would be more likely to come frecly into the market, and, with suitable credit facilities provided, both for mortgaging and for working purposes, we might expect to see the "tendency " which Mr. Prothero has recently noticed, for tenants to buy their holdings- which already showed itself, on the whole beneficently, a little more than a century ago-gaining in force, and so the way planed for that unification of interests in the same holding, in the place of present dualism, which would promise to secure to the tiller the full reward for his labour, his skill and his outlay, in grist or in meal, in annual income or in disposable capital value.

If that were to come about, the question of placing the land under skilled cultivators, instead of under the unskilled majority of the present day, to whom $\mathrm{Mr}$. Hall has assigned the doom of being "shaken out," would necessarily settle itself. For there would be no more patronage, no more respect for side considerations, in the selection of tenants; there could be no more question as to the political sides or religious opinions, there could also be no trusting to remissions of rent held in reserve, supposing that things were to go badly. Every occupier would farm according to his own free will, but also subject to his own risk. Now risk is a most effective sifter of persons. A man would not take his farm because "father" had done so, and he himself was used to bullocks and the plough. But he would carefully ask himself: Have I the skill, have I the experience, have I the money to embark on a venture which may, under good handling, gain me a fortune, but must, under bad, inevitably mean ruin? Under such rule we might trust to see our land well cultivated.

Our desiderata, then, are these: Above all things Education, extended and made appropriate ; next Organisation ; facilities for assured Credit; appropriate regulation of the question of Labour, ushering in a better era for the labourer ; facilitated access to the land for small cultivators; utilisation, in suitable ways, of land now lying idle; and arrangements with regard to landed property benefiting the landowner and opening the way to a unification of interest, so 
as to assure to the tiller a full return for all that he puts into his cultivation.

Manifestly here is good work to be done, tempting to patriotic reformers, calculated to make our Agriculture very much more productive and to forearm us against a new war, should Providence hold such in reserve for us. Provided that the several interests concerned will work heartily together, and that a good authoritative lead is given them, no doubt the work may be successfully accomplished.

However, of course, as usual, there are supposed to be "lions in the way," obstacles which make achievement difficult, if not impossible. Whenever we come to have others set up as examples for us, we are sure to detect some difference in circumstances, which constitutes a bar to enulation. La moglie degli altri è sempre più bella-it is always the other fellow who has the better-looking wife, that is, some particular favouring circumstances to help him. This argument is in the present instance urged more particularly as applying to Germany, which country one can quite understand that people relish little having set $u p$ to them as a model. Such application, however, ignores the fact that Denmark, a goodly portion of Switzerland, the Netherlands, and poor Belgium, as also the United States, are likewise set up as models with quitc as much to teach us as the country of "Father Thaer" and Liebig. However, let us for the moment stick to Germany! Germany, so it is contended, has for agricultural purposes a more favourable climate than we. And then there is that wonderful German aptitude for organisation! There is, indeed, in Germany more sunshine and more summer warmth than are allowed to us. The holiday maker coming into Lancashire in a rainy season very likely will pronounce the local climate "vile." However the local cotton-spinner knows well how much that grimy moisture is worth to him. It is the same with Agriculture. There is indeed more sun abroad, and that sun will ripen crops which it would be hopeless to expect to arrive at maturity here, under our clouds and murky sky, in a country in which, as Lord Byron has it, though it commands an empire "on which the sun never sets," yet as a matter of 
fact the sun but rarely rises. And as to organisation, German farmers, so it is said, drop automatically into their proper places and perform their proper functions, whereas our farmers could not be got to work together, and if they were to, would work at cross purposes.

Now, never had two popular superstitions less foundation.

To take the first, no doubt our climate is different from that of Germany, Hungary, even of Belgium and the Netherlands; and for some purposes unquestionably it is less kind. IVe cannot compete with Germany and Hungary in the production of Johannisberg or Tokay, nor yet in the raising of wheat of the most bakeable description. No more, once more, have we the sharp, biting, but weathering and disintegrating frost of the German winter, which prepares the soil admirably to make a good seed-bed, and kills vermin and destroys noxious growths. On a balance of distinguishing features, however, the advantage rests altogether with ourselves. There is more that, thanks to our climate, we can do that the Germans cannot, at any rate satisfactorily, than what they can do and we cannot. If we lack sunshine, we have moisture, such as Continentals envy. And we have a far more equable temperature favourable to such crops as roots, spread over a considerably longer period, and therefore we have a much longer working time for our teams and our hands. "It makes nearly a couple of months' difference to me," so complained my friend, the late Mr. Butler, the Duke of Lucca's English agent at Weisstropp in Saxony, not a particularly exposed place, " during which I have to keep my teams and men idle." And if wheat grows up here a little coarse and damp, and grapes will not ripen in the open-even on the sunny South Coast which produces ripe figs-green crops on the other hand grow lustily, indeed better than anywhere else. To come from the Continent back to England after one's summer holiday is, in ordinary years, like moving into another, fresher world. And the luxuriant green which there greets one's eyes does more than look pretty. It means a more pushing and longer continued growth of grass, and clover, and roots. Our superiority in the growtl of potatoes, instanced by Mr. Middleton, is 
mainly due to this cause. The greater equableness of our climate gives to plants a lengthened period of vegetation and greater equableness of growth. German potatoes, planted in England, are apt to grow too big. If in the production of hay and clover we do not, in Mr. Middleton's tables-in spite of our more favourable climate-come up to the measure of our Continental competitors, the fault lies, not with the climate, but with the insufficiency of proper pabulum which we provide for these crops in our soil. We can sow rye in August or September, to give us a bite in the autumn, and it may be, another bite or clip in spring, and yield a ripe crop in summer. To get an autumn bite-a spring bite is out of the question-the Germans have to sow their rye at the end of June-hence the name " Johanniskorn." We sow wheat almost up to Christmas. The Germans begin sowing it on Holy Cross day (September I4), and would not think of sowing it in December, though they sow late rye in that month. When you have had a goodly portion of an exceptionally lieavy potato crop spoilt by an early frost, occurring in the middle of the lifting season, as I did in IS64, and half your rye crop killed in the midst of the blossoming season, on May 26, as liappened to me in I866, you do not feel disposed to sing the praises of the climate over-loudly. Such a thing as "Continuous Cropping" would be out of the question in most parts of Germany. Leaving cattle out in the fields during the winter would simply kill it. Look at our pastures! Look at our orchards and our market gardens! Quite apart from strawberries, in respect of which we appear to enjoy a peculiar monopoly among European countries, Germany cannot produce such fruit as we do in our best orchards. Belgium is far more on a par with us, because it has a climate similar to ours, not to mention its glowing underground shale, which produces something like hothouse temperature. Denmark is decidedly at a disadvantage in comparison with ourselves, in respect both of climate and of soil. And yet, by means of superior knowledge and more careful application and organisation, it outstrips us in the production of its own particular produce, which it wisely selects so as to make it suit its agricultural 
conditions. If it is differences in climatic conditions which stand in our way, in comparison with neighbouring countries, it is because we often enough "bore with the wrong tool," laying ourselves out for producing what is not suitable to our climate. We persist in giving, in Latin phrase, "chaff to the dog, and bones to the donkey."

The second objection, which credits Germans with a gift of organisation that we do not possess, has even less foundation. And I should like to ask the preliminary question: Supposing the Germans possess this monopoly, how comes it that the Danes are even better organised than the Germans? And how about the Belgians and the Dutch, who likewise have a greatly superior organisation to what we can boast of? Germany has indeed shown that it can organise, more particularly in the matter of agricultural Co-operation. But in doing this she has in fact ploughed with our heifer. For it was we, quite undoubtedly, who first set up samples of that Co-operation which, with her usual skill in adapting and improving, Germany has applied to that interest which, in respect of Education, Organisation and General Development, we have for a long time back made our Cinderella. Indeed, all her organisation is more or less copied from ours-organisation in trade, in commerce, in banking, in that high-famed "Social Insurance"-which last-named is a direct outcome from our Friendly Societies' practices, just as is her magnificent Co-operative Credit. It was from us that Schulze Delitzsch avowedly learnt Friendly Society organisation, which he developed into Co-operative Credit. And just like his co-patriarch of such Credit, Raiffeisen, it was with Friendly Society organisation that he began his highly fruitful work. Germany could not have organised an army of five million men, as we have done, nor improvised a huge fighting force, overpoweringly equipped, in practically no time, like our Allies across the Atlantic. She could not organise any army to act together of its own free will from the motive of pure patriotism, also with all avoidance of harshness, as we see ours doing. We have heard to what cruel and truly barbarous treatment soldiers have been exposed in Germany, in order to make them obey 
orders in their machine-like submissiveness. Without that, her "organisation" would have failed. And those tales were not exaggerated. I have heard them in Germany, from German lips, from officers' lips-lips of men who had no occasion whatever to foul their own nest. We know with what abject deference an inferior is compelled to behave to his superior-as a contrast to the good feeling and easy conduct maintained among our own soldiery, without any prejudice to discipline. But we do not know in this country how many thumbs are deliberately mutilated, at the time of conscription, and other bodily injuries inflicted, to get men off service. I have witnessed two mobilisations in Prussia. During one I nearly had my head smashed by a stone which was intended for officers in whose company I happened to be. One does not expect to see such things among ourselves.

And how about organisation in our own and in German Colonies? Germany cannot claim to have made a success of organisation there. How also about organisation of food supply in time of war? Herr von Batocki's organisation is not remembered as a success. We did a good deal better, at any rate.

Such as it is, there are two great helps which Germany has had for her peculiar form of organisation. One is, as already observed, that general penury and severe want of decades following foreign rule and depredations, which made the strictest parsimony and husbanding of all things imperative. That is a powerful stimulus to organisation. And the other is the habit of abject discipline to which, not in the army alone, German citizens are methodically trained, so that, as an ordinary matter, they do at the word of command fall instinctively and automatically into their places and do whatever they are ordered. In matters of agricultural organisation such strictly disciplined organisation is assisted by the prestige of the administrative political officers - who stand for a great deal in the establishment of agricultural organisation turned to account for political purposes -and the " gnädige Herr " of the " big house." Hence the fierce objections raised in Germany by bona-fide co-opera- 
tors to Government influencing of Co-operation, such as our people here cannot be brought quite to understand, even those who have studied its organisation minutely. Distributive Co-operation, in which we lead the world, was not in Germany, or vegetated only in a languid way, until it occurred to some enterprising Germans to visit our great Stores, and, that done, to proclaim what they had seen, in their Report " Unsere Englandreise." It was on the British model that German Co-operation was moulded and grew up.

Do not let us make ourselves out less capable than in reality we are! We have defects enough in all conscience to answer for. Do not let us invent new ones! What is wanting in our case is not the power to do the things wanted, but the perception that they would be to our benefit and accordingly the will. We have not looked at them nor thought them over. Our farmers, even the backward ones, are perfectly equal to accomplishing what the German bauers have done, and the Danish husmänd, the Dutch landbouwers, and the French and Belgian cultivateurs. But it has not yet dawned upon them that they will have to do it, just as in the 'eighties the Germans did not detect the necessity, and the Belgians, when M. Graux bitterly complained in the Chamber that his rural countrymen would not combine and organise. Belgians as well as Germans have learnt since then what organisation, instruction, the judicious use of borrowed money, the employment of new methods and perfected implements, cow-testing, grading and proper packing of produce, careful training of Labour, and a fair wage mean to them. No doubt in due course our country-folk will learn this too. However, time is pressing. The Nation is clamouring for a rightful return from the " talent " entrusted to the guardians of its agricultural interests. If the farmer is content just to eke out a "living," the Nation, which wants to be fed, is of a different mind. And, in the last resort, the Nation will have the power to enforce its will. There is no "prescription," so says Mr. Prothero, against the Nation.

Whatever be the objections raised by one-sided private or class interests, we may be sure that the will of the Nation, 
which is, to make the land produce as it should, will prevail in the end. And whatever passing fancies may divert the national mind for a time from the right path, whether it decide once more to try to prop up bad farming by useless and costly inflation of prices, to the detriment of all the Nation-under the infallible teaching of experience ultimately the right path will have to be struck out, and, instead of paying money gladly, to keep prices above their natural level, the Nation may be counted upon to decide that it must have better farming-farming better in that it raises more produce-and keeping the world at that peace which we all profess to have at heart, that is, a peace in which there will be no sense of just grievance left rankling in the heart of any one nation as against another, such as necessarily must grow up under fiscal differentiation, which means the supposed good of one nation at the cost of another. $\mathrm{We}$ have seen what German insistence upon tariff advantages as against France, exacted under duress in I87I, has brought about. There was war preparing while the enforced terms remained in operation, and the bitter animosity so produced helped to sharpen the weapons with which war was waged when it actually came. If we will show that in advancing the demands that we do upon our Agriculture for improvement and regeneration we are in earnest, if we will with a clear mind and a determined will set ourselves to correct what is now amiss, gradually, if not at once, to secure the full reward for his skill and labour and outlay for the tiller, to educate our farmers as a class up to the proper point, so as to enable them to farm scientifically, and furthermore assist them with the use of the money which unquestionably they require alike for permanent and for passing purposes; if we will take care that whatever land there is, is turned to proper account, be it under crops or under trees, to ensurc that Labour is treated as it should be and the great gulf which now severs the large host of rural workers from the rest of the community is bridged over, and if we will see that the land is without stint, according to the clemand made, placed at the command of Agricultural Labour-we shall have, with our peculiar advantages, climatic, economic and 
political, a prospect of agricultural revival before us such as no other country can surpass. The practical sense, which, as an element of value for successful business, excels all other favouring conditions, is in us probably in greater forcc than in any of our Continental neighbours. It is national inertia, a disposition to be satisfied with what is-heightened rather than mitigated by our national proneness to grumbling - and a disinclination to accept anything that is new, that stands in the way of progress. That wants, under the influence of a National Agricultural Policy, in which all interests concerned must join together, to be overcome by will power. We have excellent men at work, excellent material for them to work upon. What we stand in need of is a cement to bring the two into closer contact and bind them to one another, so as to enable the good to make their influence effectively felt upon the backward and carry them away by their example. Please God, such cement will be found. We are not setting out for a new position to conquer. All that we need to do is, under altered circumstances, to which due consideration will have to be paid, to recover a position which we held easily fifty and sixty years ago, and thus to make the United Kingdom once more the world's leader in Agriculture, and to make it provide for the Nation that which the Nation needs and rightly asks for: A maximum agricultural output in time of peace, and a fully assured supply of foodstuffs in time of war, from a broad acreage nursed up to good " heart " by the cultivation of remunerative crops, congenial to our climate, serving as an incomparable preparation for a plentiful growth of corn, when the time of trial comes, enabling us to rely with confidence upon our own production of it. 


\section{INDEX}

Abuse of Agricultural OrganiSATION for Political Purposes, $27,29,5$ I $166,263,264,372,379$ Ackerbauschulen, 109, I14

A Cow to the Acre, 63

Administration des Eaux et Forêts, 432,452

Affittanze Collettive, 92, 344

Afforestation, 429, 431

Afforestation in Italy and Spain, 444

Agricultural Associations, 174

Agricultural "Atmosphere," 106

Agricultural Banks Association, 229

Agricultural Bank of Egypt, I52, 226

Agricultural Colleges, I I I, I 50, I53, 154

Agricultural Co-operation the Refuge of distressed Nations, I60

Agricultural curriculum in Germany, 116

Agricultural Departments in Universities, 104

Agricultural Depression, 3 mitigated by Small Farming, 316

Agricultural Development intensified by Small Farming in the United States, I 53

Agricultural Education for Women in Ontario, $141,1.46$

in Belgium, ${ }^{1} 46$

in Denmark, 143

in France, 143

in Germany, 148

in Russian Poland, I 45

in Scandinavia, I 43

in Switzerland, I 48

in the United States, $14 \mathrm{I}, 145$, I 46

Agricultural High Schools, 57, I I 3

Agricultural Holdings Acts, 3,136 Agricultural Labour, 277,280

Africultural Labourer's Home, 291
Agricultural Organisation Society, 2 I, 26

Agricultural Organisation in America, 8I

Agricultural Society of Dublin, 12

Agricultural Syndicates, 105, 158,266

Agriculture a "Business," 72, I 73

Agriculture in America, $8 \mathrm{I}$

Agronomes de l'Etat, 130

Agro Romano (Reclamation of), 342,421

Alberta, United Farmers of, 59

Allmend (Swiss), 320

Allotments Association, I 72

Alluvial Deposits awaiting Reclamation, $4{ }^{1} 4,4{ }^{1} 8$

Alpage, I 89

Analytical Tables, 25, I 35

Anglo-German Customs Treaty and its Effects upon German Husbandry, 18

Arch, Joseph, 276, 302, 356

Argentina, 68

Assington, 92

Association Centrale pour l'Aménagement des Montagnes, 433

Associations Syndicales, 197

Austria's Bad Example, 264

Average Yields of Crops, 6, 8

BAD Farmers to BE "Shaken Out," 89

Banca Popolare of Milan, 239

Bankers' Association in the United States, 2 I 8,238

Bankers' Attitude towards Cooperative Credit Movement, 223 , 229, 232, 233

"Banker-Farmer " (United States), 239

Barnard, Lord, 98

Belgium, 6, 53, 80

Blairgowrie Fruit-growers, I 87

Board of Agriculture, 5, 42, 50, $78,99,100,157,159,133,213$. $2: 27,456$

k. $\mathrm{k}$ 
Board of Agriculture's Credit $\Lambda \mathrm{r}$ rangement, 237

Boerenbond, 147

Bogland Reclamation, 424, 427

Bones, 22

British Agricultural Organisation Socicty, 26

British Breeds, 23

Brooke Hunt, Mr., of the Board of Agriculture, 118,137

Bund der Landwirtle, 27

Bureau of Soils (in United States), 150

Caird, Sir James, 15, 50, 57, 66, $86,96,302$

Campbell, Professor, 100, 101, I I 3

Canada, 8I, I 13

Canadian Bankers' Credit Arrangement, 239

Cane Farming, 73

"Catholic" Banks, 264

Cattedre Ambulanti, 1.1

Central Banks, 244, 253, 255

State Bank (Prussian), 260

Central Chamber of Agriculture, $26,229,234,238,472$

Cercles de Fermières, I 4 I, I 45

Chambers of Agriculture (German), 32

Chambrelent, $\Lambda$ fforestor of the "Landes," 444

Channing of Wellingborough, Lord, 234

Chaplin, Lord, 42, 305, 325

Chemistry, 21, 24, 89, 135

"Club" Work (in America), 123

Coast Erosion Commission, $44^{6}$, 447

“Coke of Norfolk," 12, 22, 54, 57, $61,82,370,388,411$

Collecting Banks, 232

Collective Farming, 91, 92

Collective Land-renting, 193, 319, $341,3+2,343$

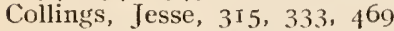

Committee on Elucation, 97, 100

Common Forests, 39

Common Rights, 477

Commons (Enclosure of), yo

Congressional Schools (in United States), I I3

Conrad's Tables of Corn Prices, $6 \mathrm{r}$

Conservatism of French Propriétaires, 383

Continuous Croppin: $G_{3}, G_{4}$
Control Societies, $130, \mathrm{IS}_{7}$

Co-operation commands the services of Expcrts, 178,186

Co-operation in America, I 59-1 Gy

in Belgium, I 59

in Bulgaria, 159

in Canada, $159,183,188$

in Denmark, 158,178

in Germany, 159-169

in Hungary, 159

in India, 160

in Ireland, I 62

in Italy, 159

in the Netherlands, 179

in Norway, 159

in Roumania, 159

ii Russia, 160

in Serbia, 159

Co-operation (Industrial), 203

Co-operation, Uses of, 26, 34, 40,42, $46,92, \quad 167, \quad 177,202,388$

Co-operative Credit, $14,34,153$, 256, 257, 294

Co-operative Dairying, 177

Co-operative Fruit Farming, I 8 I

Co-operative Insurance, I93

Co-operative Irrigation, 197, 417

Co-operatively owned Machinery, 173

Co-operative Marketing, 179, I 8 I

Co-operative Mortgage Credit, 397 . 401

Co-operative Stores, 171, I72, 208

Co-operative Union, I68, I 73, 214

Co-operative Wholesale Society (of England), 70, 91, 213

Corn Laws, 22, 55, 57, 388

Country Life Commission (Mr. Roosevelt's), 407, 480

County Agricultural Agents (in United States)

County Agricultural Representatives (in Canada)

County Councils, 100, 156, 227 , $345,406,470$

Cow Testing, 187,188

"Craftsman Farming," 78,89

Crawford, Lord, 73,76

Credit, $388,464,472,+74$

Crédit Agricole (the Emperor's), 237

Crédit Agricole (present day), 261

Crédit foncier, 381,391

Crédit forestier, 445,453

Credits by Bankers, 218

Curzon of Kedleston, Lord, 210,266, 267,473 
DANISH DAIRY'ING, 460

Dealers' Credit, 224

Dease, Colonel, 24.4

Decline of Agriculture, 3, 4, 12, $49,56,78$

Demani cellettivi, 32 I

Demonstration Plots, 136

Demonstration Stations, 135

Denman, Lord, on Co-operative Credit, 235,472

Denmark, 6, 27, 53, 80

Department of Agriculture (Irish), 101,207

(United States), 273

Depurtmental Committee on Education, 116,128

Departmental Food Committer, 5

Depoprilated Villages, 82, 313

Descombes, MI., Frencli Authority on Afforestation, 437

Deterrents to Remaining on the Land, 107

Development Fund Commissioners, 2 II

Difficulties in the way of Organisation, 222, 226

Directems Departementanx, 105. I 30

"Dislike to Learn," 15

Disraeli's "' 'Three Livings from the Land," $85,331,368$

Distress, $55,56,57$

Diversified Farming, 138

Dresdner Bank's Services to Cooperation, 233

Durand, L., the "Raiffeisen " of France, 39I, 395

Dutch Crown Land Afforestation, 433

Eastern Farmers' Co-operative Association, 469

Eastern Swiss Farmers' Co-operative Association, 479

Ecoles Agricoles, 12 I

Ecoles d'Agriculture pratique, I I5

Fcoles Ménagères, 141, 145, 147

Fducation " a difficult tling," IO2

Fducation (agricultural) to be distinctively Organised), I IO, 465

Fiducation in Belgium, I15, 120, 288

in Canada, I 16

in Denmark, 105, I09, I19, I20, I 21,139

in France, 105

in Germany, I 15,120

in India, 112
Fducation in Ireland, IOO

in the Netherlands, I I 5, I 2 , 288

in Prussia, 99, I 15,156

in Sweden, I06

in Switzerland, IOO, 102,105 , I06, 108 , I I 5

in the United States, 116

Education, insufficiently equipped, 99, IOO, I 53,467

Education (our need of it), 20, 33 , $94,95,4+9,464$

Education to be separated from Practice, 101

Education worth its Money, I 55

Education, its Three Crades, I03, 113,114 , I 6

Educative Effects of Co-operation, I 84, I98, 199. 200, 204

Egg Demonstration Train, I33, I 48

Eilevators, 34,183

English Land Colonisation Society, 416,487

Expropriation " an nom de l'utilité publique," 420, 451

Expropriation of "Terreno assoggettato alla bonificà e 1 Ion bonificato," 185

Extended Limited Liability, 248

Extensive Farning, 79

FARMers' Alliance, 3, 82, 276

"Farmers' Institutes" (American), I 33 , I 57

"Farmers" Educational and Cooperative Union" (American), 163

"Farm Loans" in the United States, 403

Farm Schools, 109, I I 5, 138

Faulty Education, 97

Faulty Farming, 41 6

Faunce de Laune, of Sharsted Court, 76

Fédération Nationale de la Mutualité et Coopération Agricoles, I 3 I

Fellenberg, Emmanuel von, 12, 108 , 109

Fiermes Ecoles, 109

Field Gardens, 339

Fixing Dune Sand, 4 I9

Fokking Consulenten, I 30

Folks Hoejskoler, Iog, I 2 I

Food Production Committee, 70

Forestry, Board of, 429

Forestry College at Nancy, 423

Forestry Committee, 429, 44 I, 483

Forest Wealth of the World, $44^{6}$

Forstschulen, 449 
France, 12, 52, 60, 81, 91, 107

Free Trade, 18,53

first suggested by Prussia, i 8

French Forestry, 432, 436, 443

French Railways Favouring Agriculture, 20

Friedenthal, Prussian Minister of Agriculture, 25

Full Ownership, 432

Fumigating Societies, 197

GAIIE, II

German Farming, 4, 6, 7, 8, II, 13 , I 6, I $8,19,23,38,50,52,72,79,80$

German Forestry, 435

German Forestry Colleges, $43^{8}$

Germany Learning from England, 19,20

"Give me back my Crutch," 50

Gladstone, IV. E., on "Thrift" and "Man-making" 209, 473

"Golden Age of British Agriculture, 3, 19, 22, 49

Government Bungling, 207, 209

Grading, I $8 \mathrm{I}$

Greening, E. O., 26, $22 j$

Grundtvig, Bishop, 109

Guano, 2 I

Guaranteed Prices, 5t

HAAS, DR. 33, 35, 258, 260

Hall, A. D., $4,5,66,73,76,77,79$, $81,83,86,89,94,134,176,224$, $278,37 \mathrm{I}, 373,3^{85}, 4^{6 \mathrm{I}}, 4^{88}$,

Hanbury, Mr., 42

Hares and Rabbits Act, 373

Havenstein, Dr., on German Financial Preparation for the War, 30

Hawaii Islands, 228

Healthiness of Farm Labour, 285

Heiligenstadt, President, 34

High Farming, I 6, 23, 57

High Mloor, 424

High Rents, 54

Holding, The Labourer's 295

Home Colonisation in Prussia (economic) $306,307,318,336$

(political, depolonising), 333 . $34 \mathrm{I}$

Home Trade benefited by Small Holdings, 326

Houston, D. B., United States Secretary of Agriculture, 38, I 40, 149

How we financed Germany, 457

Humus Theory, 22

Huskisson, IV., on "Mutual Facili ties," I 8
Hybrid System of Co-operative Credit, 250

ILKESTON, LORD, 33I

Imperial Union (German), 33, 259

Independence of Food Imports, 60

India, I $53,160,210,227,257,266$, 327,475

Indian Registrars' Resourcefulness, 474

Industrial Farming, 38 , 140

"Industrialising" Agriculture, 286

Institut National Agronomique to be opened to Women Students, I 44

Intensive Farming, 79, 221

Interlinking Co-operative Movements, $47^{\circ}, 4^{80}$

International Co-operative Alliance, 46,264

Ireland, 10, 82, 85, 93, $185,207,210$

Irish Agricultural Organisation

Society, 2 II

Irish Farmers, I 40

Irish Grain Stores, 185

Italy, 53

JARDINS OUVRIERS, 339

Jessop, Canon, on "Accady" 314

Joint Stock Banks, 35

"Junkers," 5, 27, 28, 33, 294

Justification of Peasant Proprietorship, $4^{\circ}$

" KNowledgeable" Farier, What he may do, 76,77

LABOUR: ITS altered Position, 274,476

Labour, Impolicy of discarding it, 276

Labour Troubles, 108

Labour Unrest, 376

Labourers' Holdings, 295

Labourers' Own Homes, 122, 310

" Ladder," The, 105, 305, 306, 329

Land agents, 87

Land Army, The, 284

Land Bank, The (in Germany), 34 $\mathrm{r}$

Land Credit, 392

Land Nationalisation, 91, 377, 382

Land Reclamation requires slikll, 4I $5,4^{\mathrm{I}} 7$

Land Registry, 390, 402, 403,405, $4^{87}$

Land Settlement, 345

(in India), 347

Land System, Our, 106, 364, 419 
Land Transfer Act of 1897,403 Landed Property a " Trust," 6, $42 \mathrm{I}$, 487

"Landes," + 19

Ländliche Haushaltungsscluulen, $I+I, 1+3, I+8$

Ländliche Mittelschulen, is 3

Landlords, $50,82,8_{3}, 8_{4}, 8_{5}, 8_{7}$

Landlords' Embarrassments, 372

Landlords' Crotchets, 372, 373

Landschaften, 392, 393, 399, 401, $44^{8}, 452$

Large Farms, 380

Latifundia, $39,51,3+2$

"Lead " to the Country, 465

Leese, V. F, on Forestry, 431, 447

"Legalised Usury," 335

Liebig, J. von, 2 I, 24, I I I, 489

Lightfoot, Gerald, Report on United States Agricultural Education, 112

Lincolnshire, Marquess of, 42

Live Stock Improvement, 188

Lloyd George, D., 62, 65, 99

Lorenz, French Inspecteur Général des Forêts, 440, $44^{2}$

Lothian Farmers, 82

Low Noor, 424

Luzzatti, L, 199, 244, 254, 255, 265

Mackénna, J. 138 , I 5 I

Madison University, 47

Manitoba, 68

Manitoba Grain Growers' Association, 59

Marketing, I 60, 161

Maulden, $41,305,307,325,346$, 349,479

Mersey, Lord, 237

"Mlettle," Farmers put upon their, $22,5^{8}$

Middleton, T. H., 7, I3, I6, 40, 4I, $46,50,53,79,103,104,113$, I 6 , I $48,156,383,467$

Milk, 65

Mineral Theory, 21

\Iöglin, I09, I 36

Montgomery, H. de F., 394

Morier, Sir R., 229, 293

Mortgage Banks, 392, 400, 401

Mortgage Credit, 4OI Modernised, 396

Mortgage Debt of United Kingdom, 394

Motor wagons, 197

National Agricultural Policy, $4 \mathrm{I}, 43$
National Agricultural Union, 26

National Interest favours Ownership, 369

“Necessary Liberties," 28I, 290, 305,476

Nederlandsche Weidemaatschappij, 436

Negro Settler (Mr. Booker Washington's), 33 I

Nelthorpe, Capt, Sutton, 229

Netherlands, Thr., 53, 80

New Spirit, Our 456

Newly Reclaimed Land to enjoy temporary Exemption from Taxation, 4 I 2

Nitrogen Theory, 2.4

"Non-controversial" Co-operation, 471

Oak Growing in France, 436

Office of Farm Management (in America), I 49

One-crop Farming, I 39

Ontario Institute for Women, I 4 I

Orbiston, 92

Organisation, $7,14,33,40,42,95$, ${ }_{15} 8, I_{5}, 464,468,470,479$

Organisation of Co-operative Sales, I87 ; sce also "Marketing"

Organising Section of United States Department of Agriculture, $4^{80}$

Overdrafts, 2.40

Overmortgaging, 391

Ownership, 352, 355 361, 385, 387

Pacte de Fanine, 56

Parker, Sir Gilbert, 355

Passy, F., 109

Pasture, 6, 8, 73, i 89

Patronage (injurious), $26_{4}$

Peasants' Unions, I 55

Peat, its Use in War-time, 422, 428

Peat as Generator of Electric Power, 423

Personal Credit, 243

Personal Interest conflicting with National, 78

"Pilgrimage of British Farming," 5

Pliny's Warning, to care for Men more than for Wheat, 319

Plunkett, H. C., 26, 46

Polish Settlements (successful), $337,34^{8}$

Possession vaut tître, 404

Potash, 25

Potatoes, 8, 10, 14, 20, 38, 41, 72, $91,124,140$

Profit Sharing, 298, 300 
Progress Abroad during our Depression, 79

Proportional Fattening Qualities of Feeding-stuffs, 376

Protection, 49, 50, $5 \mathrm{I}$

Protection does not steady Prices, $6 \mathrm{I}$

Protection, Canadian Protest against it, 59,60

Protection, Effects of, 17, 19, 20

Protection, History of, in England, 55 in Canada, 59

in France, 52

in Germany, $20,2 \mathrm{~S}$

in Italy, 53

Prothero, R. E., 35, II, 19, 22, 57 , $60,65,68,77,82,93,277,287$, $288,361,362,370,3^{85}, 3^{87}, 388$, $456,477,479$.

Prout, J., of Sawbridgeworth, 62

Prussian Jand Settlement, Its Principles, 345

RABBITS PREFERRED TO TREES, 430

Radbourne, 92

Raiffeisen, F. W., 25. 26, 35, I 75 , I99, 233, 474

Raiffeisen Societies, 129, 195, 254, $257,25^{8}$

Ralahine, 92

Reay, Lord, I00, I 16,433

Reboisons les Montagnes, Défrichons les Plaines, 444

Reclaimable Land: $12,000,000$ acres, 447

Reclamation requires skill, $4^{\text {I } 5 \text {, }}$ 417

Régime forestier, 440,443

Reîtres, 15

Relations between Employers and Employed, 289

Rent, I I

Rentenbank of Prussia, 334, 337

Rents raised on Improvements, $37^{\circ}$

Return for Outlay, II

"Revolution in Agriculture," 9.3, $3^{5} 3$

Riclımond, late Duke of, 42,465

Rimpan's System of Reclaiming Bogland, 426

Roosevelt, late President, I 45, I99, 407

Roots, 24 ; see also "Potatoes" and "Sugar-beet"

Rothamsted, 23, 137
Routine, 78,89

Royal Commission on Argiculture, 219

on Raiffeisen System, 26

Rural "Atmosphere" in Schools, I 8 , 465,466

Rural Elementary Schools, I16, 287,288

Rural Mentality, 287

"Tural Prosperity in France," 389

Rural Settlement means Progress, 314

Russell, Sir. T. W., 6.5, 471, 479

Russia, 27, 80

Ryan, Prof. J. A., on Co-operation, 205

Rye, 9, I I

SAMpson, Colonel, 22

Sand, 25

Saskatchewan Grain Growers' Association, 59

Saussure, I 2

Sawbridgeworth Wheat Growing, 62

Say, Léon, 93

Sayer, IVynne, I I 2

Scandinavia, 80

Scawby Credit Socicty, 229

Schulze Delitzsch, H., 25, 35, 265 , 474

Scolaires forestières, $432,45+$

Scotch Cash Credit, $246,247,248$, 249,250

Sections of Forestry in French great Agricultural Societies, 433

Security, $S_{3}$

Seed Breeding, 23, I $S_{5}$

Selborne, Lord, 7, 4I, 94, 32I, 33I, $363,431,455,472$

Self-help, 207, 48I

Settlers to be selected, $308,34^{6}$

Seven million acres available for Wheat Growing, 66

“ S. G. O.," I07, 292, 378, $38 \mathrm{I}$

Shaftesbury, Lord, 236

Sharsted Court, 76

Singleness of Purpose, 99

Small Farms, their power of resisting Depression, 35 I

Small Farming, 96, 213, 350, 35I, 368,478

Small Holders are all-round men, 295, 321

" Small Holders' Library," 362

Small Holdings a Social Question, 352 
Small Holdings Movenent, 213 , $229,295,363,476$

False Inference drawn, 325

Faulty Legislation on, 324 , 376

Società Umanitaria (of Milan), $34^{2}$

Société Nationale d'Agriculture de France, 108

Society for Bettering the Condition of the Poor, 339

Soils and Climates Inquiry Station in Belgium, I. 40

Soldiers' Settlements, 328

Soldiers' Settlements projected in South Africa, 329

Somerville, Lord, 12

Spedding, Miss, 52, 380

"Sport " lieeps Land Waste, 4 I I

State Action (commendable) 129 , I $46,148,156,157,164,210,266$, $305,306,346,+28,452$

State Aid, 35, 99, 209, 260, 267

State Supervision of Forestry, 452

Stein's Land Legislation, 39

Stöckhardt, J. A., 24, 58

Subdivision of Land, 39, 357, 391

Sugar-beet, If, 20, 72, $1_{4} 0$

Superphosphate, 22

Sussex Association for the Improvement of Agriculture, I37. 173

Swiss Breeding Societies, I8S, I 89

Swiss Forestry, 437

Switzerland, I 2

Syndicats forestiers, 433,454

Système étatique condemned, 451

TARIFF (German), I 6

Teachers, 482

Teaching the Teachers, 150

"Tenant Co-operators," 335, 344

Tenant Farming, II, $83,85,352$, $369,3^{8} 4$

Tenants, Selection of, 85,86

Terminable Rent-charge, 347

Thaer, A., 20, 108, 109

"Thaler de Narie Thérèse, le," I 75

Three Field Shift, 24

Tillage Farming, 8

"Torrens' System," 402, 403, 404

Townshend, Lord, 12, 22, 54, 82, $37^{\circ}$

Tractors, 197
Transfer Facilities, 392

Tull, Jethro, 2 I

"Two Thousand a Year Squires," $107,378,381$

UNDER-RENTING, 82

Unequal Farming, 5

United States Afforestation, 434

United States Bankers help Farmers, 2 i 8

United States Department of Agriculture, 26, 47, 8I

United States Farming, SI, I 12

Universities, I 13 , I I 4

Unlimited Liability, $2.48,249,251$

VALUE OF WOHEN'S WORK, I 42

Valuation of Land, 392

Vansittart Neale, E., 225

Vermuyden, our Teacher of Warping, 418

Village Communities, 353

Ville, M., 22

Viollet-le-Duc on Forestry; 429

Voelcker, Dr. A., 26, 376

von Thünen, 71,298

WAGES, 283

Wage Boards, $2 s_{4}$

Want of Capital, 79

Wastefulness of "Waste," 409

Wehrlischulen (Swiss), 109, I 15

Wenlock, late Lord, 26

Wheat, 9, 10, 60, 62, 64, 67, 68, 69, 72,350

Wibberley, T., 62, 64, 295, 35 I

Wilkins, Mrs. Rowland, 355, 362

Wilson, J., late United States Secretary of Agriculture, 38, 8I, I 33,20 I

IVinter Courses, 1 i 5

Winter Occupation, 288

Winter Schools, I I 5

Winterslow Settlement, 3.40

Women's and Girls' Schools, I 4 I

Women's Labour, 274, 285

Wool, Co-operative Sale of, 179

YTELD OF CROPS, 72

Young, Arthur, $386,+13,485$

ZiEMIANSKI, I 45

Zuivelconsulenten, I 30 


\section{BY THE SAME AUTHOR \\ Co-Operation in Agriculture}

Second Impression. I9I4. P. S. King \& Son, Lid. 6s. net.

People's Banks : A Record of Social and Economic Success

Fourth Edition in Preparation.

P. S. King \& Son, Ltd. 6s. net.

Co-Operative Banking : Its Principles and Practice

With a Chapter on Co-Operative Mortgage Credit I907. P. S. King \& Son, LTD. 7s. $6 d$. net.

A Co-Operative Credit Bank HandBook, with Rules

(OUT OF PRINT)

A New Edition in Preparation.

I908. P. S. King \& Son, LTD. Is. net.

Co-Operative Credit for the United States

I9I7. Sturgis \& Walton Co., New York. \$1.50 net. 



\section{UNIVERSITY OF CALIFORNIA LIBRARY}

Los Angeles

This book is DUE on the last date stamped below.

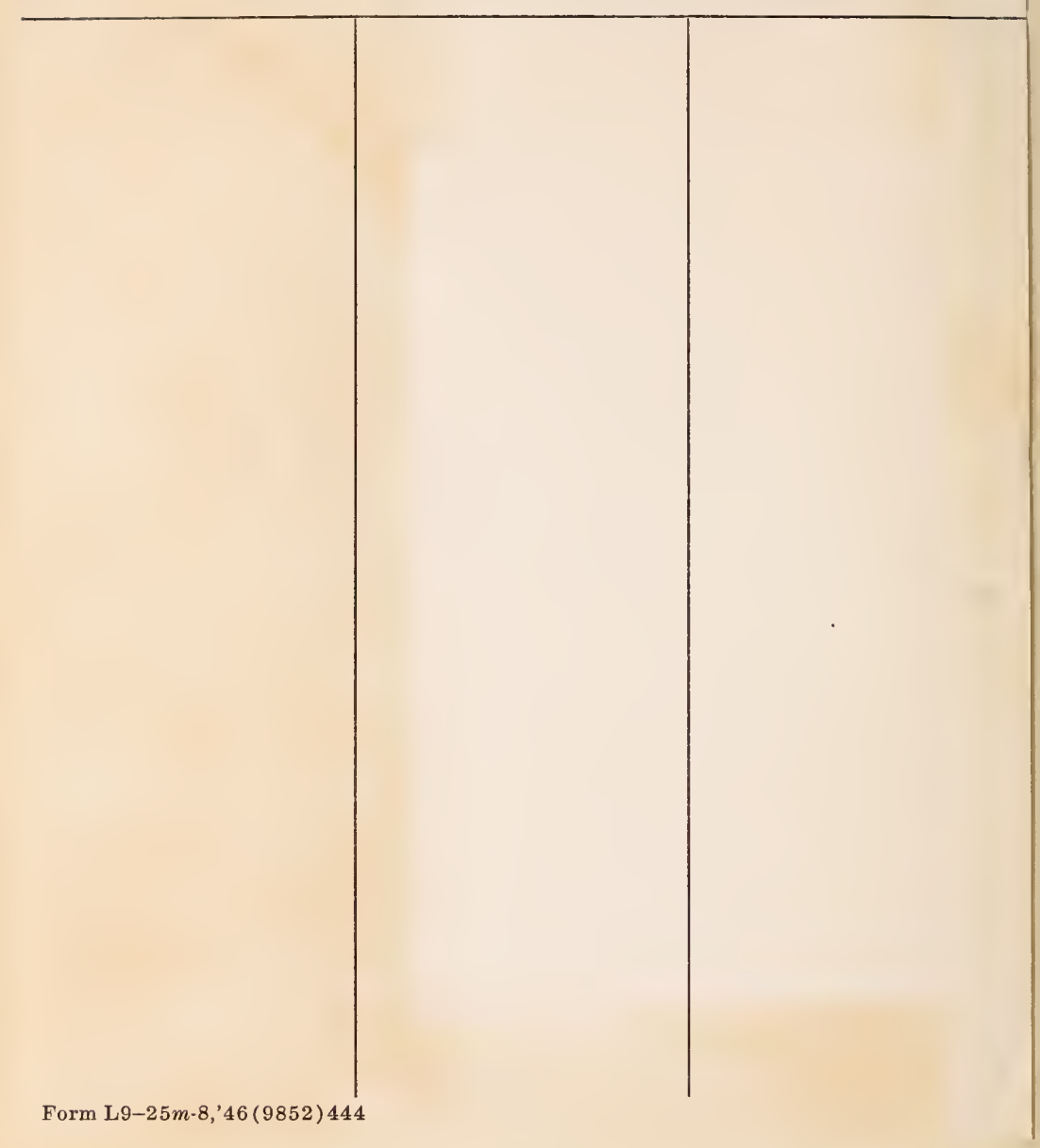

Form L9-25m-8,'46 (9852) 444 
UC SOUTHERN REGIONAL LIBRARY FACILITY

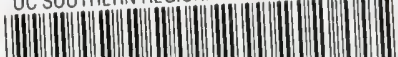

AA $000278153 \quad 2$

HD

1925

W83f 
